\title{
Cisalhamento entre viga e laje pré-moldadas ligadas mediante nichos preenchidos com concreto de alto desempenho
}

\section{Daniel de Lima Araújo}

\begin{abstract}
Tese apresentada à Escola de Engenharia de São Carlos da Universidade de São Paulo como parte dos requisitos para obtenção do título de Doutor em Engenharia de
\end{abstract} Estruturas.

Orientador: Prof ${ }^{\circ}$. Dr. Mounir Khalil El Debs

São Carlos

2002 
FOLHA DE JULGAMENTO

Candidato: Engenheiro DANIEL DE LIMA ARAÚJO

Tese defendida e julgada em 25-03-2002 perante a Comissão Julgadora:

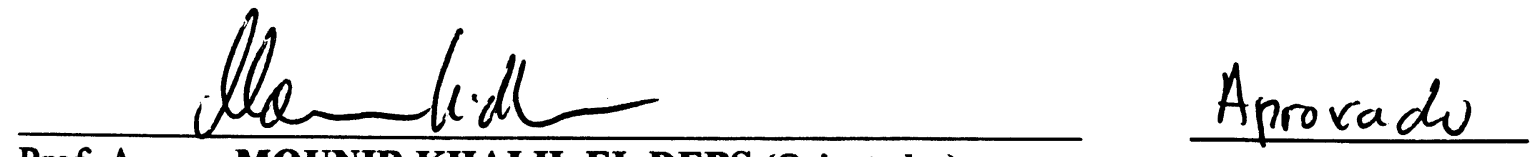

Prof. Assoc. MOUNIR KHALIL EL DEBS (Orientador)

(Escola de Engenharia de São Carlos/USP)

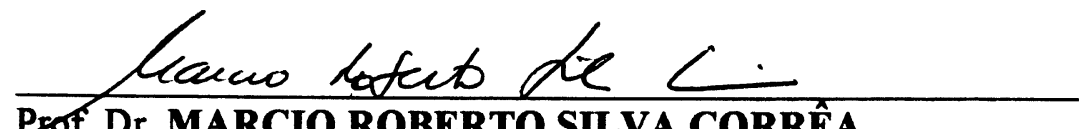

AProvAsO

(Escola de Engenharia de São Carlos/USP)

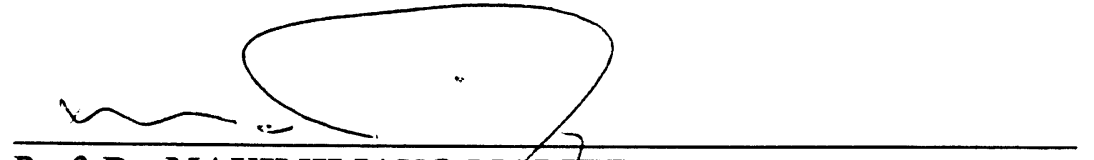

ApROUAOO

Prof. Dr. MAXIMILIANO MALITE

(Escola de Engenharia de Sao Carlos/USP)

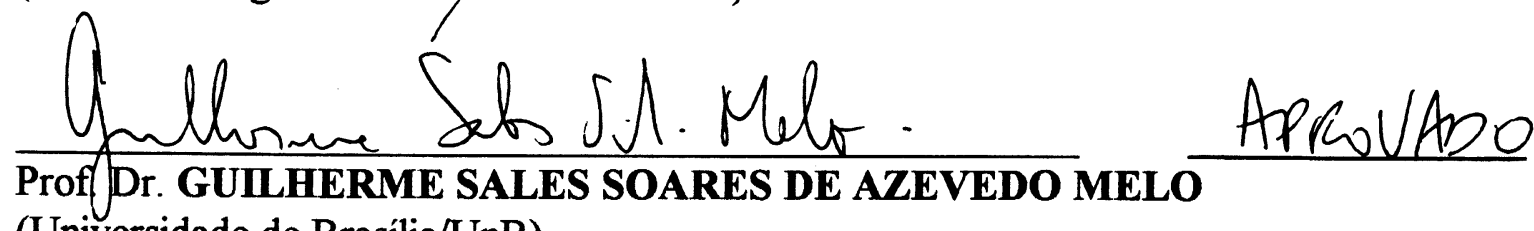

(Universidade de Brasília/UnB)

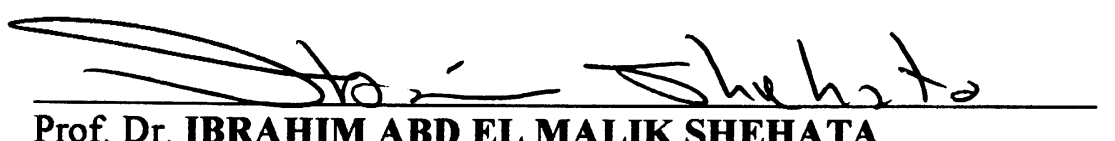

Apranade

Prof. Dr. IBRAHIM ABD EL MALIK SHEHATA

(Universidade Federal do Rio de Janeiro/UFRJ)

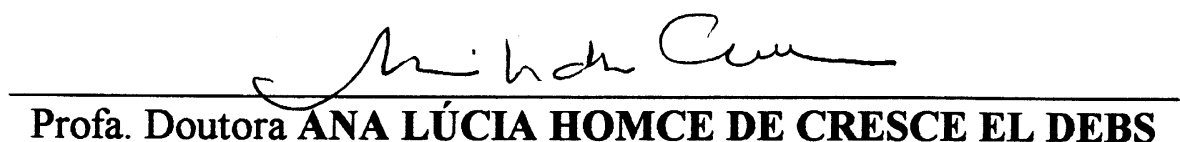

Coordenadora do Programa de Pós-Graduação em

Engenharia Civil (Engenharia de Estruturas)

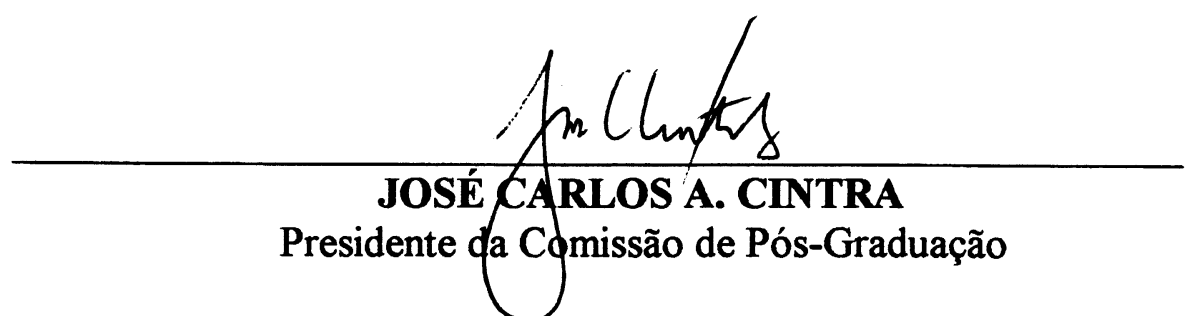


Para Roberta,

amada esposa, a quem pertenceram muitas das horas necessárias para a realização deste trabalho. Sem o seu apoio, não teria conseguido chegar ao final da jornada. 


\section{AGRADECIMENTOS}

Ao Prof ${ }^{\circ}$. Mounir Khalil El Debs pela orientação segura e incentivo, sem os quais este trabalho não existiria.

Aos colegas da Escola de Engenharia Civil da Universidade Federal de Goiás por possibilitarem que eu me dedicasse à conclusão deste trabalho.

À CAPES (Coordenação de Aperfeiçoamento de Pessoal de Nível Superior) pela concessão de bolsa de estudo, e à FAPESP (Fundação de Amparo a Pesquisa do Estado de São Paulo) pelo apoio financeiro, sem as quais este trabalho não poderia ter sido realizado.

Às empresas Camargo Corrêa Cimentos S.A. e Belgo-Mineira Bekaert Arames S.A. pela doação de materiais empregados nos ensaios.

À Maria Nadir Minatel pela orientação no trabalho de referências bibliográficas.

Ao amigo Richard Sarzi Oliveira por ter estado ao meu lado nesses últimos anos, o que ajudou a tornar menos árdua a jornada.

Às amigas Aline e Vanessa pela amizade e atenção dispensadas durante a realização deste trabalho.

Ao amigo Jorge Luis Rodrigues Brabo pela ajuda dispensada durante a realização do trabalho experimental.

Aos técnicos do laboratório de estruturas e do departamento de geotecnia da Escola de Engenharia de São Carlos pela dedicação na realização dos ensaios.

Aos funcionários do departamento de engenharia de estruturas da Escola de Engenharia de São Carlos que contribuíram para que este trabalho se tornasse uma realidade. 
"A ciência é a medida do poder do homem" Bacon, Fr.

“Ninguém está tão errado como aquele que sabe todas as soluções"

Chuang Tzu

"Há duas formas de conhecimento: ou dominamos o assunto, ou sabemos onde encontrá-lo."

Samuel Johnson (1709 - 1784)

"Eu sei que nada sei de tudo quanto sei"

Sócrates (470 a.C. - 399 a.C.) 


\section{RESUMO}

ARAÚJO, D.L. (2002). Cisalhamento entre viga e laje pré-moldadas ligadas mediante nichos preenchidos com concreto de alto desempenho. São Carlos. Tese (Doutorado). Escola de Engenharia de São Carlos, Universidade de São Paulo.

Neste trabalho, foram estudadas as vigas compostas formadas por viga e laje prémoldadas de concreto. A ligação empregada na interface era constituída por conectores metálicos associados com concreto moldado no local. Os conectores eram formados por vergalhões de aço dobrados em forma de laço, que eram inseridos em nichos existentes na laje pré-moldada. A ligação era realizada preenchendo os nichos com concreto de alto desempenho. $O$ objetivo foi caracterizar a ligação viga-laje e analisar o comportamento à flexão das vigas compostas com laje pré-moldada. Foram realizados ensaios de cisalhamento direto sob carregamento monotônico, tendo sido observados aumentos de $250 \%$ na resistência da ligação devido à substituição da ligação plana e lisa por outra com chave de cisalhamento. A partir desses ensaios, foi proposto um modelo analítico para representar o comportamento das ligações com chave de cisalhamento, considerando a influência da resistência do concreto, do diâmetro do conector e da adição de fibras metálicas à ligação. Foram realizados ensaios de cisalhamento direto com carregamento cíclico não reversível, tendo sido observado menores perdas de rigidez na ligação devido à adição de fibras. Os resultados de ensaios em vigas mostraram que a resistência à flexão da viga composta está diretamente relacionada com a resistência ao cisalhamento da interface. O dimensionamento adequado da interface garantiu à viga composta com laje pré-moldada um comportamento semelhante ao das vigas com laje moldada no local. Dessa forma, esse sistema apresenta-se como uma alternativa viável ao sistema com laje moldada no local.

Palavras-chave: vigas compostas, ligação de cisalhamento, concreto pré-moldado, concreto reforçado com fibras metálicas. 


\begin{abstract}
ARAÚJO, D.L. (2002). Shear between precast beam and precast slab joined by pockets filled with high performance concrete. São Carlos. Ph.D. Thesis. Escola de Engenharia de São Carlos, Universidade de São Paulo.

Composite beams formed by precast beam and precast deck were studied in this work. The connection used in the interface was constituted by steel connectors associated with cast-in-place concrete. Steel bars bent in hoop form constituted the connectors, which were inserted in shear pockets in the precast deck. The connection was carried out filling the shear pockets with high performance concrete. The objective was to characterize the beamdeck connection and to analyze the flexural behavior of the composite beams with precast deck. Push-out tests with monotonic loading were carried out, and it was observed an increase of $250 \%$ in the shear strength of the connection due to the substitution of the plane smooth surface for other with shear-key. Based on these tests, an analytic model to represent the behavior of the connections with shear-key was proposed, considering the influence of the strength of the cast-in-place concrete, the diameter of the connector and the addition of steel fibers to the connection. Push-out tests with no reversible cyclic loading were carried out, and it was observed lower shear stiffness degradation in the connection due to the addition of fibers. The results of beam tests showed that the flexural strength of the composite beam is directly related to the shear strength of the interface. The appropriate design of the interface guaranteed to the composite beam with precast deck a flexural behavior similar to the beams with cast-in-place deck. In that way, the system with precast deck is a viable alternative to the system with cast-in-pace deck.
\end{abstract}

Keywords: composite beams, shear connection, precast concrete, concrete with steel Fibers. 


\section{SUMÁRIO}

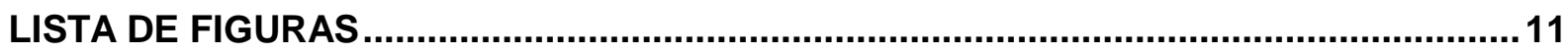

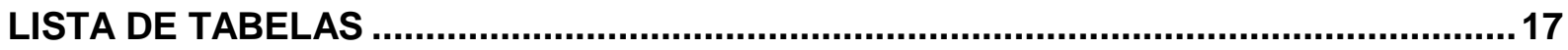

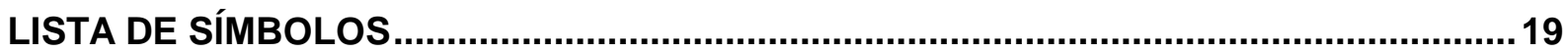

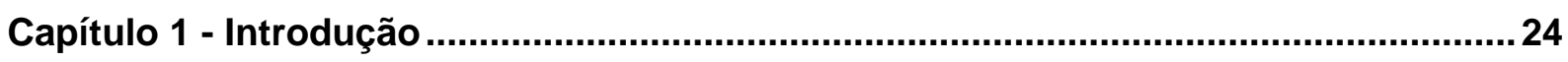

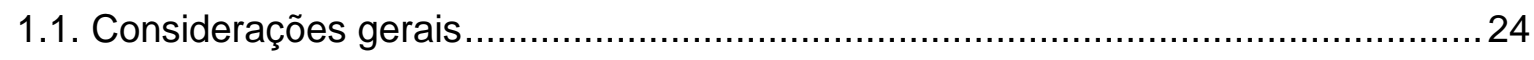

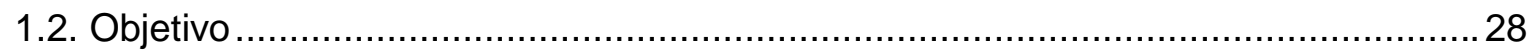

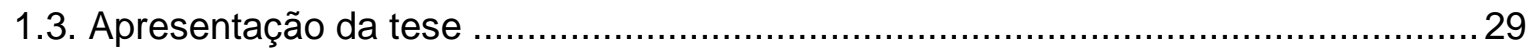

Capítulo 2 - Alguns Aspectos sobre o Comportamento dos Concretos Simples e Reforçados com Fibras ............................................................................................31

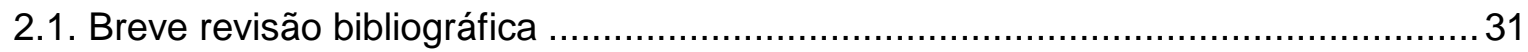

2.1.1. Resistência ao cisalhamento em interfaces de concreto ..............................31

2.1.2. Concreto reforçado com fibras ........................................................ 40

2.1.2.1. Resistência à compressão ......................................................... 43

2.1.2.2. Curva tensão-deformação na compressão ..................................... 44

2.1.2.3. Resistência à tração ................................................................. 49

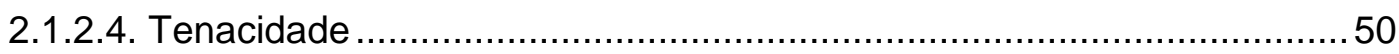

2.1.2.5. Concreto reforçado com fibras submetido à fadiga e ao impacto ...........51

2.1.2.6. As fibras e o cisalhamento ......................................................... 51

2.2. Modelos mecânicos de transferência de esforços de cisalhamento ........................55

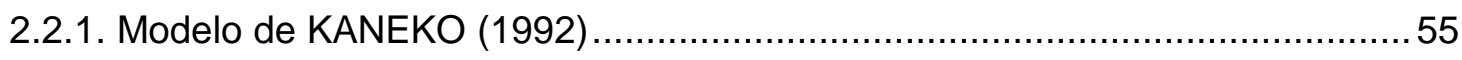

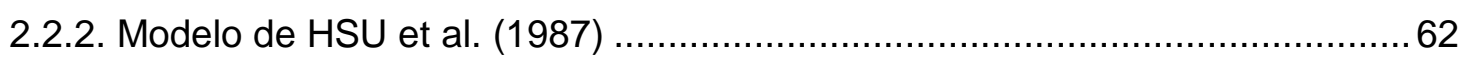

2.2.2.1. Equações básicas.................................................................... 62

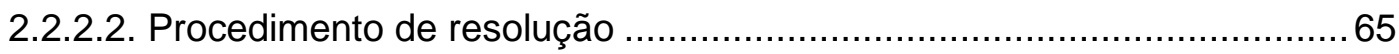

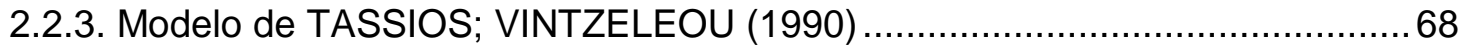

Capítulo 3 - Ensaios de Caracterização do Concreto Reforçado com Fibras Metálicas71

3.1. Resistências à compressão e à tração .......................................................... 71

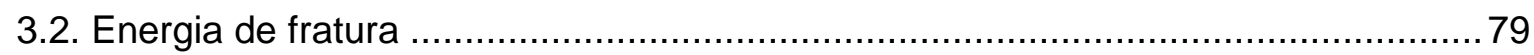

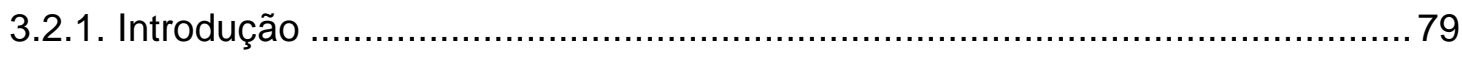

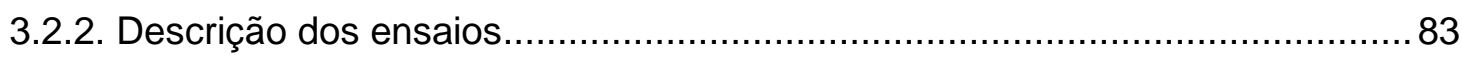

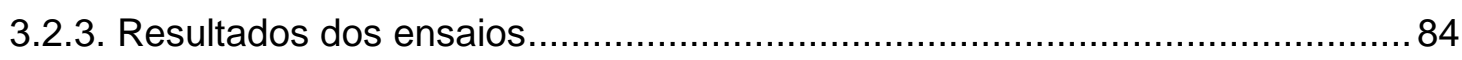


3.3. Ensaios de compressão uniaxial com deformação controlada ............................. 91

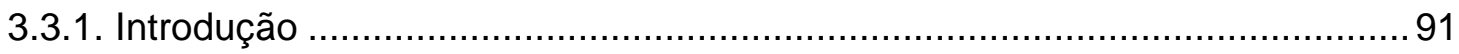

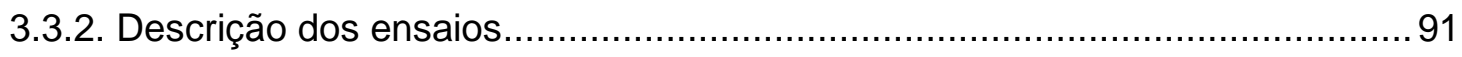

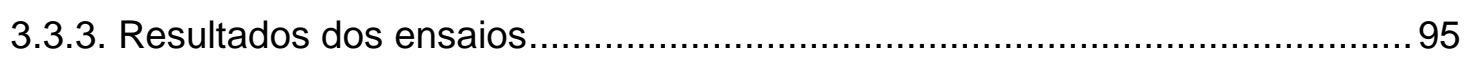

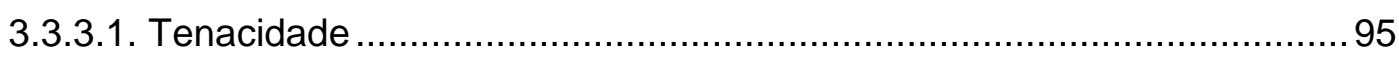

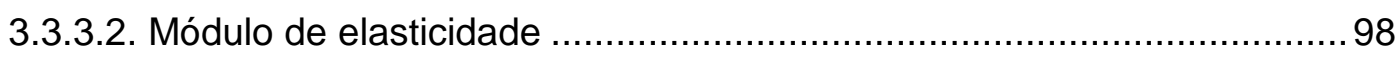

3.3.3.3. Deformação correspondente à tensão máxima......................................99

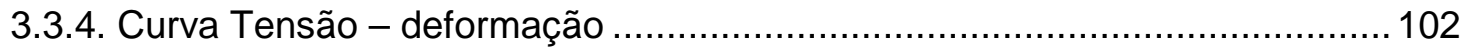

3.4. Síntese e considerações finais ................................................................... 111

Capítulo 4 - Ensaios de Cisalhamento Direto ...........................................................112

4.1. Descrição dos ensaios de cisalhamento direto .................................................. 112

4.1.1. Confecção dos corpos-de-prova ...................................................... 114

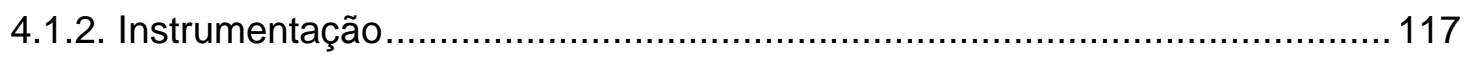

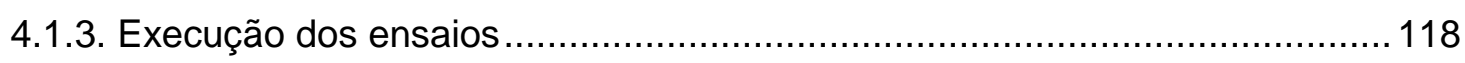

4.2. Resultados dos ensaios de cisalhamento direto ................................................. 120

4.2.1. Influência da forma da superfície da ligação............................................. 123

4.2.2. Influência da resistência do concreto na ligação com chave ........................ 125

4.2.3. Influência do diâmetro do conector na ligação com chave ............................ 127

4.2.4. Influência do volume de fibras na ligação com chave .................................. 130

4.2.5. Rigidez da ligação com chave sob carregamento cíclico ............................. 133

4.3. Avaliação da ligação com superfície plana e rugosa por modelos analíticos ......... 140

4.4. Avaliação numérica dos ensaios de cisalhamento direto........................................ 142

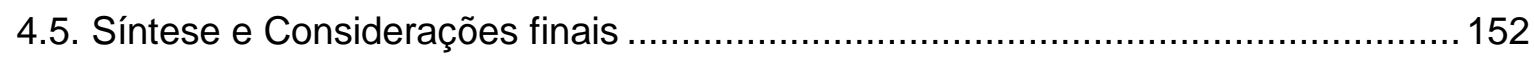

Capítulo 5 - Análise da ligação com Chave de Cisalhamento e Conector .................... 154

5.1. Proposta de uma expressão para a representação da ligação com chave de

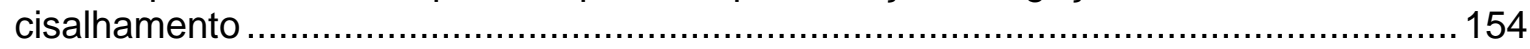

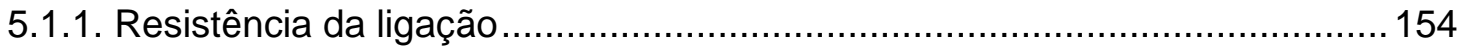

5.1.2. Deslizamento da ligação na ruptura..................................................... 156

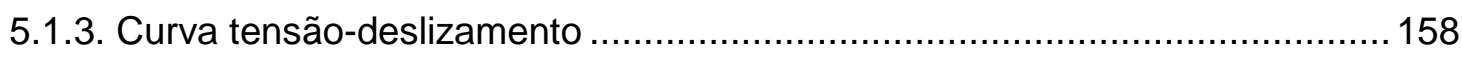

5.2. Avaliação pelo modelo de KANEKO (1992) ...................................................... 166

5.3. Avaliação pelo modelo de KANEKO (1992) modificado para incluir o conector..... 171

5.3.1. Análise paramétrica do modelo de KANEKO (1992) modificado ................... 175

5.4. Avaliação pelo modelo de HSU et al. (1987) …................................................. 177

5.5. Alguns comentários sobre a aplicação dos modelos mecânicos ............................ 180

5.6. Proposta de um modelo analítico para as chaves de cisalhamento com conector 186

5.6.1. Ação de pino do conector .................................................................. 186

5.6.2. Curva força-deslizamento para o concreto ............................................. 188 


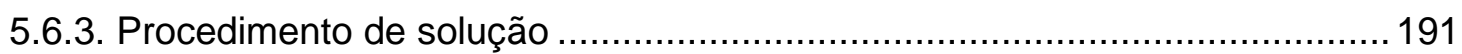

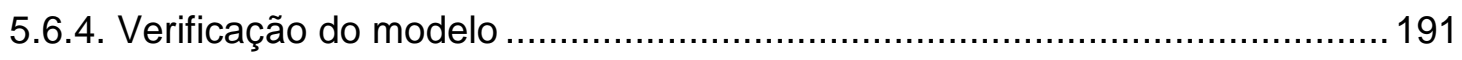

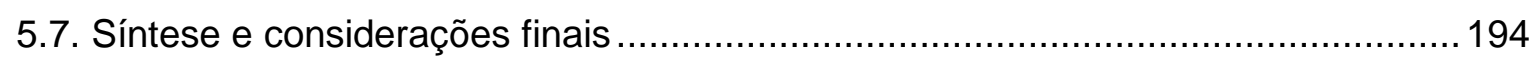

Capítulo 6 - Vigas Compotas com Laje Pré-moldada ...................................................197

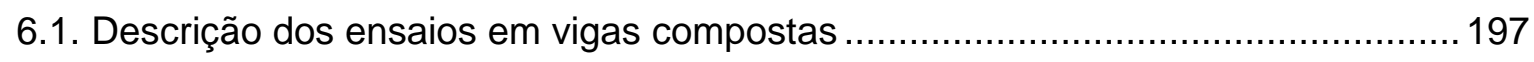

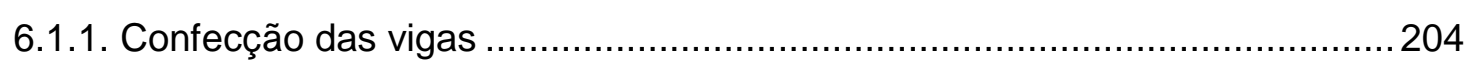

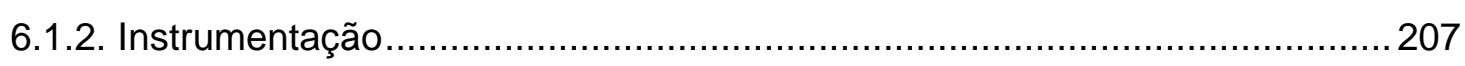

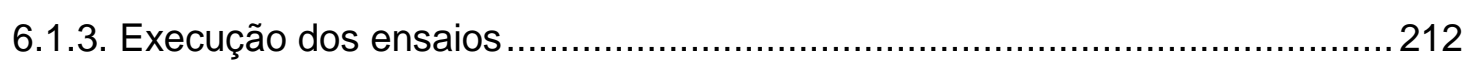

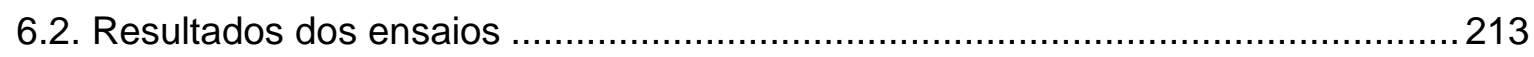

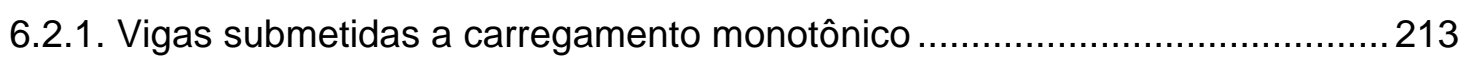

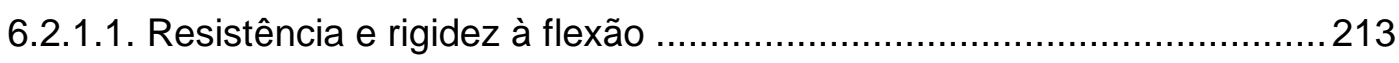

6.2.1.2. Configuração das fissuras e forma de ruptura das vigas .....................216

6.2.1.3. Deslizamento relativo na interface e deformação dos conectores.........222

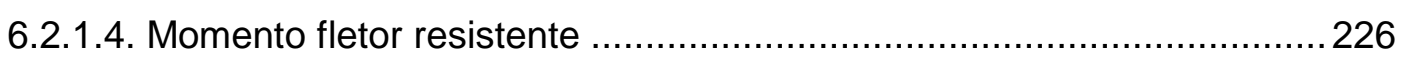

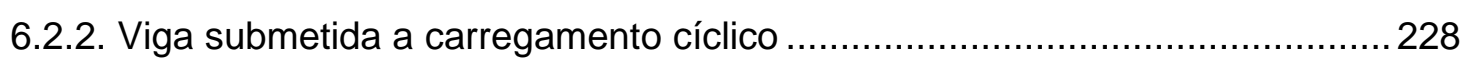

6.3. Análise numérica das vigas compostas com laje pré-moldada...............................231

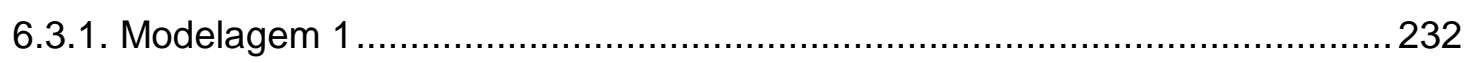

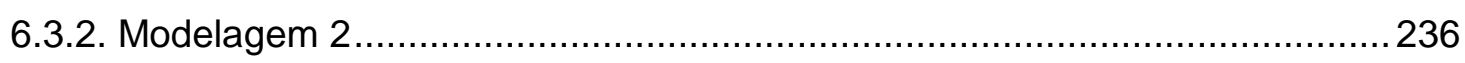

6.3.3. Influência do tipo de ligação na interface entre a viga e a laje pré-moldadas 241

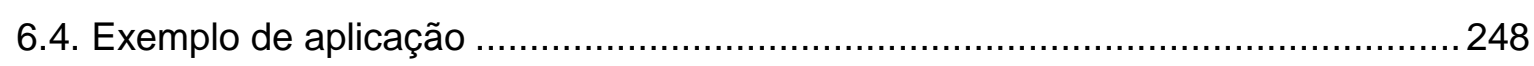

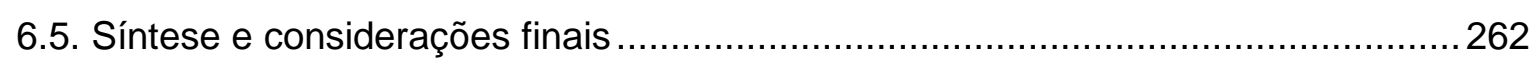

Capítulo 7 - Considerações Finais e Conclusão..........................................................267

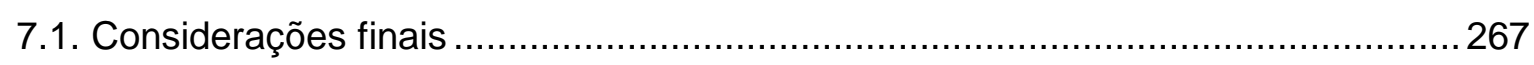

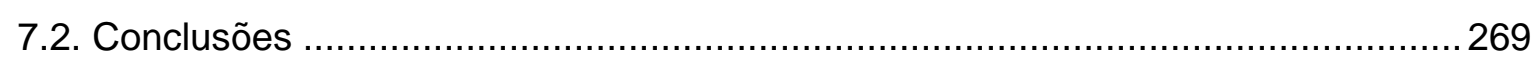

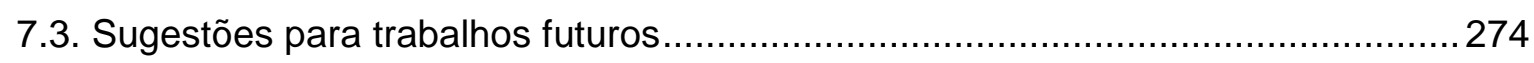

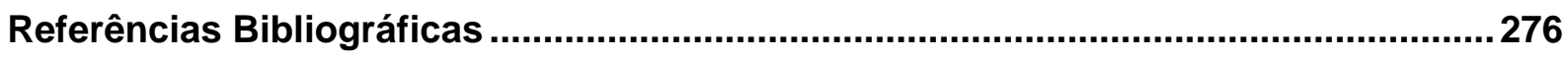

Apêndice A - Resultados dos Ensaios de Cisalhamento Direto.....................................286

Apêndice B - Comparação da Expressão Analítica com os Resultados dos Ensaios de

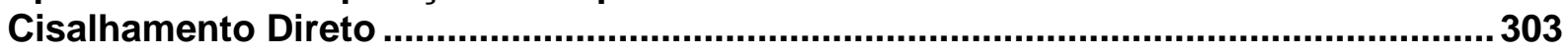

Apêndice C - Comparação do Modelo Mecânico de KANEKO (1992) com os

Resultados dos Ensaios de Cisalhamento Direto .........................................................306

Apêndice D - Resultados dos Ensaios nas Vigas Compostas ......................................310 


\section{LISTA DE FIGURAS}

Figura 1.1 - Tipos de associações utilizadas em vigas compostas.

Figura 1.2 - Desenvolvimento de tensões de cisalhamento horizontal na interface de vigas compostas.

Figura 1.3 - Transferência de tensões de cisalhamento entre viga e laje pré-moldadas

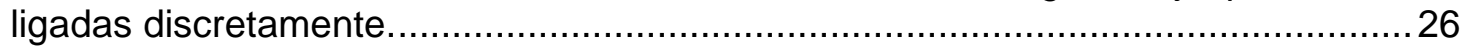

Figura 1.4 - Proposta de modificação na ligação entre viga e laje pré-moldadas. ...............27

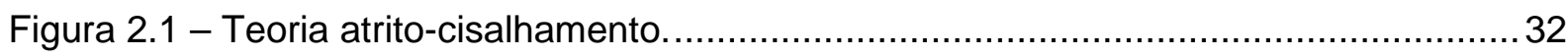

Figura 2.2 - Formas de ruptura em interfaces de concreto............................................. 34

Figura 2.3 - Relações de equilíbrio e de compatibilidade no modelo de VECCHIO (2000).. 36

Figura 2.4 - Relações de compatibilidade no modelo de CHO; LEE (2000) ..........................37

Figura 2.5 - Modos de ruptura das chaves de cisalhamento. ........................................... 39

Figura 2.6 - Curva tensão-deformação na compressão uniaxial para concretos com fibras

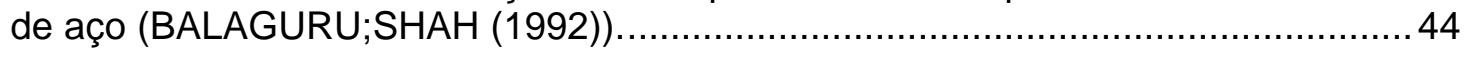

Figura 2.7 - Aspecto geral da curva tensão-deformação para ensaios de tração direta em concreto com e sem adição de fibras. ........................................................... 50

Figura 2.8 - Transferência de forças transversais em vigas de concreto reforçado com

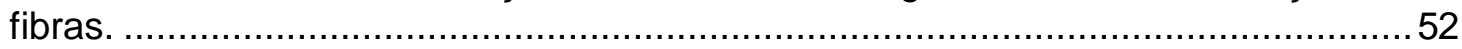

Figura 2.9 - Seqüência de fissuração em chaves de cisalhamento idealizada por KANEKO (1992).

Figura 2.10 - Corpo-de-prova empregado por BAKHOUM (1991) para solicitar uma chave de cisalhamento (dimensões em polegadas) - obtida de BAKHOUM (1991)...........56

Figura 2.11 - Modelagem da fissura discreta pela mecânica da fratura elástica linear para concreto simples e concreto com fibras (KANEKO (1992)) . ..................................5 57

Figura 2.12 - Fase de fissuração múltipla na chave. .......................................................... 58

Figura 2.13 - Modelo constitutivo para o concreto simples - KANEKO (1992).....................59

Figura 2.14 - Modelo constitutivo para o concreto reforçado com fibras- KANEKO (1992). .60

Figura 2.15 - Transição esquemática entre a fissuração discreta e a fissuração múltipla na chave de cisalhamento - KANEKO (1992) ......................................................... 61

Figura 2.16 - Tensões em um elemento de concreto armado ......................................... 63

Figura 2.17 - Modelo para ensaio de cisalhamento direto ................................................66

Figura 2.18 - Tensões de aderência em uma barra tracionada imersa em região de concreto

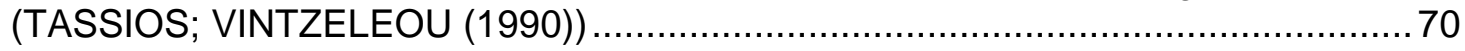

Figura 3.1 - Influência da adição de fibras na resistência à tração indireta do concreto ....... 74

Figura 3.2 - Relação entre a resistência à tração e a resistência à compressão do concreto75

Figura 3.3 - Comparação da resistência à tração indireta deste trabalho com o ACl 363R-92 (1994), com a FIB (1999) e com a FIP (1999) ................................................... 75

Figura 3.4 - Influência do volume de fibras na resistência do concreto à tração na flexão .. 77

Figura 3.5 - Ruptura dos corpos-de-prova prismáticos no ensaio de flexão (CATELLI JR.

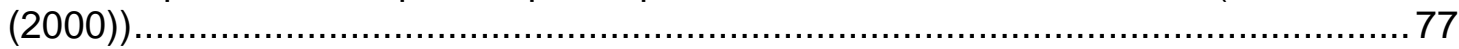


Figura 3.6 - Índice de tenacidade segundo o ASTM-C1018 (CATELLI JR. (2000)) .............78

Figura 3.7 - Curvas Força-deslocamento obtidas dos ensaios de flexão em prismas ......... 79

Figura 3.8 - Ensaio de flexão sob três pontos de carga para quantificação da energia de

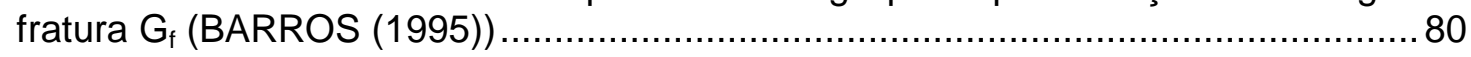

Figura 3.9 - Quantificação da energia de fratura segundo o RILEM (1985)......................... 82

Figura 3.10 - Corpo-de-prova posicionado para ensaio de flexão sob três pontos de carga84

Figura 3.11 - Resposta dos corpos-de-prova ensaiados à flexão e influência das fibras na

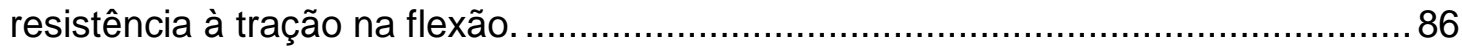

Figura 3.12 - Panorama de fissuração nos corpos-de-prova ensaiados à flexão ................. 88

Figura 3.13 - Forma da superfície de ruptura nos corpos-de-prova ensaiados à flexão com

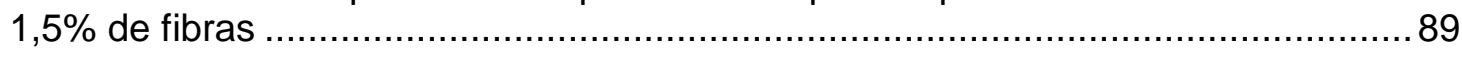

Figura 3.14 - Superfície de fratura dos corpos-de-prova com $0,75 \%$ de fibras ................... 89

Figura 3.15 - Relação entre a energia de fratura nos corpos-de-prova com e sem fibras ...90

Figura 3.16 - Fotografia do equipamento empregado nos ensaios de compressão uniaxial92

Figura 3.17 - Curvas médias dos ensaios de compressão com deformação controlada ..... 96

Figura 3.18 - Índice de tenacidade relativa em função do volume de fibras ........................98

Figura 3.19 - Influência das fibras no módulo de elasticidade inicial do concreto ................99

Figura 3.20 - Deformação $\varepsilon_{c, \text { lim }}$ dos corpos-de-prova em função da resistência à compressão

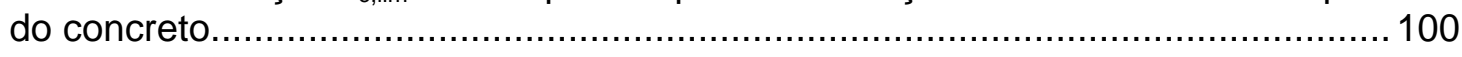

Figura 3.21 - Influência da adição de fibras no valor médio de $\varepsilon_{\text {c,lim }}$ nos ensaios de

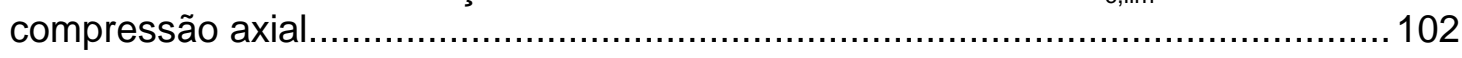

Figura 3.22 - Determinação da relação de $\varepsilon_{c, \text { lim }}$ com $V_{f}$ e $f_{c m}$ nos ensaios de compressão

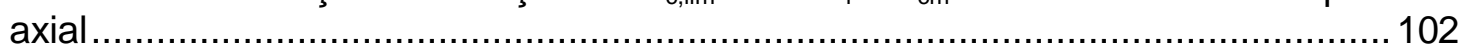

Figura 3.23 - Comparação entre algumas expressões para traçado da curva tensãodeformação e os resultados experimentais deste trabalho ...................................103

Figura 3.24 - Curvas médias normalizadas ............................................................. 105

Figura 3.25 - Regressão na parte ascendente da curva tensão-deformação do concreto. 106

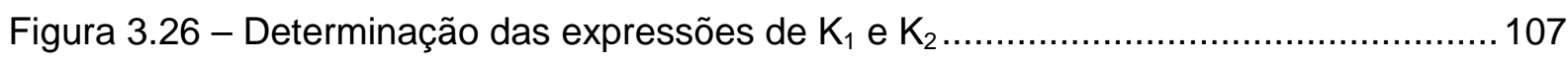

Figura 3.27 - Comparação das curvas experimentais com as previstas pela curva proposta108

Figura 4.1 - Dimensões dos corpos-de-prova de cisalhamento direto ensaiados................ 114

Figura 4.2 - Armadura dos corpos-de-prova de cisalhamento direto................................ 115

Figura 4.3- Detalhe das peças centrais dos corpos-de-prova de cisalhamento direto........116

Figura 4.4 - Detalhe da peça lateral e realização da ligação. ......................................... 116

Figura 4.5 - Corpo-de-prova com superfície plana e rugosa ( $5 \mathrm{~mm}$ x $20 \mathrm{~mm}$ ) ….............116

Figura 4.6 - Posição dos transdutores no ensaio de cisalhamento direto...........................117

Figura 4.7 - Numeração dos extensômetros da armadura para o ensaio de cisalhamento

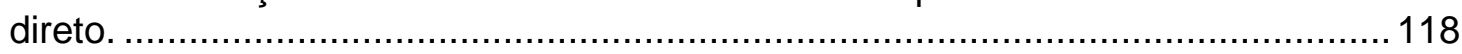

Figura 4.8 - Possível fissuração do bloco central no ensaio de cisalhamento direto. ........ 118

Figura 4.9- Realização do ensaio de cisalhamento direto. ............................................... 119

Figura 4.10 - Esquema do carregamento nos ensaios cíclicos......................................120 
Figura 4.11 - Deslizamento da ligação com conector de $10 \mathrm{~mm}$ 123

Figura 4.12 - Influência da resistência do concreto moldado no nicho na ligação com superfície lisa

Figura 4.13- Influência da resistência do concreto empregado na ligação sobre a forma de ruptura dos corpos-de-prova com superfície rugosa. 126

Figura 4.14 - Relação entre a tensão de cisalhamento e a resistência à compressão do concreto da ligação nos corpos-de-prova com chave de cisalhamento ..... 126

Figura 4.15 - Relação entre a tensão de cisalhamento e a tensão normal ao plano de cisalhamento nos corpos-de-prova com chave de cisalhamento .....

Figura 4.16 - Comparação da resistência dos ensaios de cisalhamento direto com expressões baseadas na teoria atrito-cisalhamento

Figura 4.17 - Comparação dos resultados experimentais com as expressões empíricas propostas por BAKHOUM (1991) e pelo CEB-90 129

Figura 4.18 - Influência da resistência do concreto empregado na ligação sobre a forma de ruptura dos corpos-de-prova com chave de cisalhamento e 1,50\% de fibras ......... 131

Figura 4.19 - Influência das fibras na energia absorvida pela ligação 133

Figura 4.20 - Curvas típicas do ensaio de cisalhamento direto sob carregamento cíclico 134

Figura 4.21 - Influência das fibras na perda de rigidez da ligação sob carregamento cíclico primeiro nível de carregamento

Figura 4.22 - Influência do conector na perda de rigidez da ligação sob carregamento cíclico - primeiro nível de carregamento.

Figura 4.23 - Influência das fibras na perda de rigidez da ligação sob carregamento cíclico segundo nível de carregamento 138

Figura 4.24 - Influência das fibras na perda de rigidez da ligação sob carregamento cíclico terceiro nível de carregamento.

Figura 4.25 - Aplicação do modelo de TASSIOS; VINTZELEOU (1990) aos corpos-de-prova com superfície plana e rugosa...

Figura 4.26 - Relação entre força e deslocamento no elemento COMBIN40 do ANSYS ..143

Figura 4.27 - Curva de resistência versus deslizamento da interface para o elemento COMBIN39 do ANSYS.

Figura 4.28 - Substituição de uma fissura discreta por fissuras distribuídas em uma região de largura $h$. 145

Figura 4.29 - Discretização dos corpos-de-prova de cisalhamento direto com superfície plana e lisa..... 146

Figura 4.30 - Resultado da simulação do corpo-de-prova com superfície plana e lisa 147

Figura 4.31 - Discretização dos corpos-de-prova de cisalhamento direto com superfície plana e rugosa.

Figura 4.32 - Resultados da simulação dos corpos-de-prova com superfície plana e rugosa148

Figura 4.33 - Discretização dos corpos-de-prova de cisalhamento direto ensaiados 149

Figura 4.34 - Comparação dos resultados da simulação numérica com os resultados experimentais da ligação com chave de cisalhamento (deslizamentos sem correção)150

Figura 5.1 - Expressão para avaliação da resistência da ligação com chave de cisalhamento sem fibras...... 
Figura 5.2 - Expressão para avaliação da resistência da ligação com chave de cisalhamento e fibras

Figura 5.3 - Expressão para avaliação do deslizamento médio da ligação com chave de cisalhamento sem fibras

Figura 5.4 - Expressão para avaliação do deslizamento médio da ligação com chave de cisalhamento e fibras.

Figura 5.5 - Determinação do parâmetro $\beta$ para a parte ascendente das curvas de deslizamento dos corpos-de-prova sem fibra

Figura 5.6 - Determinação do parâmetro $\beta$ para a parte ascendente da curva tensãodeslizamento da ligação com chave de cisalhamento 160

Figura 5.7 - Determinação do parâmetro $\beta$ para a parte descendente das curvas de deslizamento dos corpos-de-prova .................................................................. 162

Figura 5.8 - Comparação do modelo analítico com as curvas experimentais. 162

Figura 5.9 - Comparação do modelo de KANEKO (1992) com os resultados experimentais dos corpos-de-prova com chave de cisalhamento. 169

Figura 5.10 - Comparação entre o modelo de KANEKO (1992), com controle da deformação principal de compressão, e os resultados experimentais .................... 173

Figura 5.11 - Análise paramétrica do modelo de KANEKO (1992) modificado ....................176

Figura 5.12 - Panorama de fissuração nas chaves de cisalhamento ensaiadas.................178

Figura 5.13 - Avaliação do coeficiente $K$ do modelo de HSU et al. (1987) através da simulação numérica.

Figura 5.14 - Comparação entre o modelo de HSU et al. (1987) e os resultados experimentais 179

Figura 5.15 - Comparação entre a força última experimental e a obtida segundo o modelo de KANEKO (1992) modificado..... 181

Figura 5.16 - Comparação entre a resistência experimental e a obtida segundo o modelo de HSU et al. (1987) nos corpos-de-prova sem fibras.

Figura 5.17 - Deslizamento por ruptura da aderência entre a chave de cisalhamento e a peça pré-moldada.

Figura 5.18 - Deslizamento devido à deformação da peça pré-moldada na região da ligação184

Figura 5.19 - Resultados do corpo-de-prova CP15 ensaiado sem conector. 185

Figura 5.20 - Influência do conector no comportamento da ligação com chave de cisalhamento .

Figura 5.21 - Resistência do conector, por ação de pino da armadura, obtida dos ensaios de cisalhamento direto

Figura 5.22 - Curva trilinear para representação do concreto à tração 190

Figura 6.1 - Principais dimensões das vigas ensaiadas por ARAUJO (1997). 198

Figura 6.2 - Dimensões da viga com espaçamento entre chaves de $28 \mathrm{~cm}$ (V2). 199

Figura 6.3 - Dimensões da viga com espaçamento entre chaves de 42 cm (V3 e V5)....... 200

Figura 6.4 - Dimensões da viga com espaçamento entre chaves de $56 \mathrm{~cm}$ (V4)..............200

Figura 6.5 - Armadura da viga com espaçamento entre nichos de $28 \mathrm{~cm}$ (V2) ..................201

Figura 6.6 - Armadura da viga com espaçamento entre nichos de 42 cm (V3 e V5)..........202 
Figura 6.7 - Armadura da viga com espaçamento entre nichos de $56 \mathrm{~cm}$ (V4) ................. 203

Figura 6.8 - Armadura da viga monolítica (V1) ....................................................... 204

Figura 6.9 - Confecção das vigas compostas.......................................................... 205

Figura 6.10 - Cronograma de moldagem das vigas compostas. ...................................206

Figura 6.11 - Instrumentação da viga V2 com nichos espaçados de $28 \mathrm{~cm}$. .................... 208

Figura 6.12 - Instrumentação das vigas V3 e V5 com nichos espaçados de $42 \mathrm{~cm}$..........209

Figura 6.13 - Instrumentação da viga V4 com nichos espaçados de $56 \mathrm{~cm}$......................210

Figura 6.14 - Instrumentação da viga V1 monolítica......................................................211

Figura 6.15 - Ensaio das vigas compostas submetidas a carregamento monotônico. .......213

Figura 6.16 - Ensaio da viga composta submetida a carregamento cíclico ......................213

Figura 6.17 - Relação entre a força máxima resistida pela viga e a área de transferência de

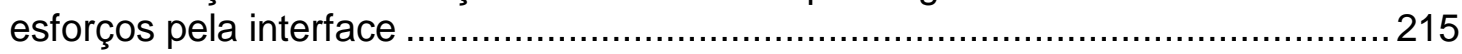

Figura 6.18 - Curva força versus deslocamento vertical nas vigas compostas..................215

Figura 6.19 - Comparação entre os comportamentos à flexão das vigas monolítica - V1 - e

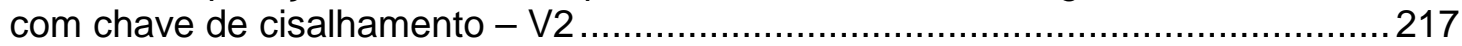

Figura 6.20 - Panorama de fissuração de uma viga composta com laje moldada no local (ARAUJO (1997)) ..................................................................................217

Figura 6.21 - Forma de ruptura das vigas compostas V3 e V4 .....................................219

Figura 6.22 - Comparação entre os comportamentos à flexão das vigas compostas V3 e V4220

Figura 6.23 - Avaliação da tensão na interface por equilíbrio de forças ........................... 221

Figura 6.24 - Deslizamento relativo na interface das vigas compostas ...........................223

Figura 6.25 - Deformação nos conectores das vigas compostas ....................................224

Figura 6.26 - Comparação do comportamento da ligação nas vigas compostas V3 e V5 com

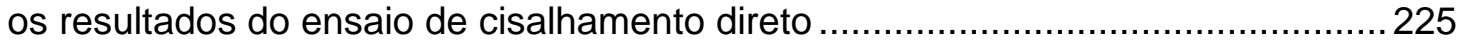

Figura 6.27 - Deformação na seção do meio do vão das vigas compostas ........................226

Figura 6.28 - Variação da rigidez à flexão da viga V5 submetida a carregamento cíclico .229

Figura 6.29 - Variação da rigidez da ligação da viga V5 submetida a carregamento cíclico230

Figura 6.30 - Panorama de fissuração da V5 após a ruptura ..........................................231

Figura 6.31 - Discretização das vigas compostas V2, V3 e V4 ......................................234

Figura 6.32 - Comparação entre os deslocamentos verticais no meio do vão obtidos da simulação numérica e os resultados experimentais.............................................. 235

Figura 6.33 - Panorama de fissuração das vigas compostas segundo análise numérica .. 237

Figura 6.34 - Deformação principal de tração nas vigas pré-moldadas segundo a análise

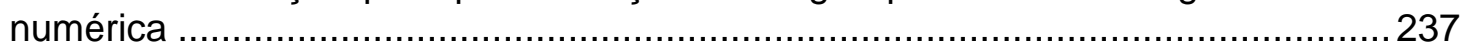

Figura 6.35 - Discretização das vigas compostas com laje pré-moldada. ..........................238

Figura 6.36 - Modelagem da transferência de esforços pela interface da viga composta com

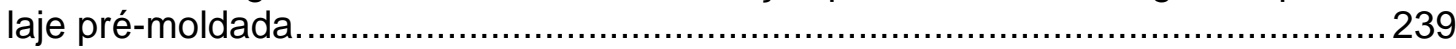

Figura 6.37 - Comparação entre o deslocamento vertical no meio do vão obtido da simulação numérica e o deslocamento experimental ............................................240 
Figura 6.38 - Curvas força versus deslocamento do elemento COMBIN39 nos casos de ligação plana com superfícies lisa e rugosa, e ligaçao com chave sem fibra...........242

Figura 6.39 - Deslocamento vertical no meio do vão das vigas compostas para vários tipos de ligação na interface (obtido da simulação numérica) . 245

Figura 6.40 - Influência do espaçamento dos nichos na resistência da viga composta

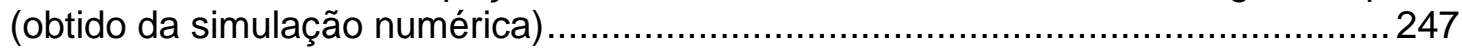

Figura 6.41 - Estrutura típica de ponte rodoviária com tabuleiro em grelha formada por vigas

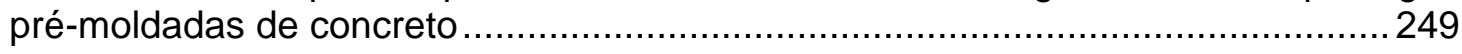

Figura 6.42 - Posição das seções de cálculo nas longarinas. ........................................252

Figura 6.43 - Disposição da armadura protendida nas longarinas..................................... 253

Figura 6.44 - Curva normal de distribuição de freqüências. ............................................255

Figura 6.45 - Resistência da ligação com chave de cisalhamento e fibras por equações

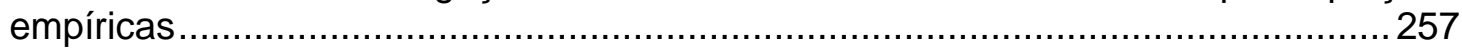

Figura 6.46 - Resistência da ligação com chave de cisalhamento em função da taxa de

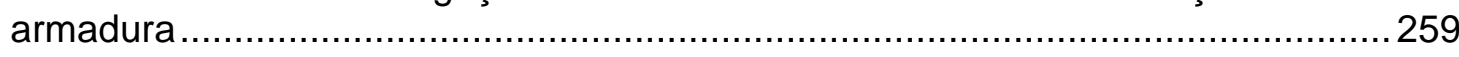

Figura 6.47 - Tabuleiro de ponte com viga e laje pré-moldadas ....................................261 


\section{LISTA DE TABELAS}

Tabela 2.1 - Principais características das fibras (BENTUR;MINDESS (1990)) . ................ 43

Tabela 3.1 - Relação de materiais para confecção de $1 \mathrm{~m}^{3}$ de concreto .............................. 72

Tabela 3.2 - Quantidade de superplastificante e abatimento em função do volume de fibras

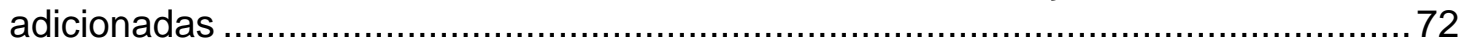

Tabela 3.3 - Resistência média do concreto em função do volume de fibras adicionadas .. 73

Tabela 3.4 - Forças máximas suportadas pelos corpos-de-prova prismáticos e resistência do concreto à tração na flexão ........................................................................ 76

Tabela 3.5 - Índices de tenacidade dos ensaios de flexão em corpos-de-prova prismáticos78

Tabela 3.6 - Dimensões dos corpos-de-prova para ensaio de flexão sob três pontos de

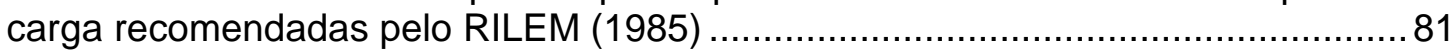

Tabela 3.7 - Resultados dos ensaios de flexão sob três pontos de carga ........................... 85

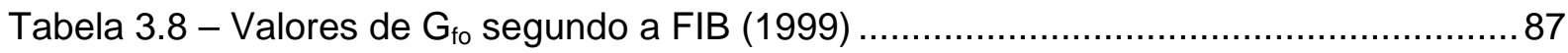

Tabela 3.9 - Tenacidade relativa dos corpos-de-prova ensaiados à compressão axial .......97

Tabela 3.10 - Influência da relação de forma das fibras na tenacidade relativa do concreto98

Tabela 3.11 - Deformação média $\varepsilon_{\mathrm{c}, \text { lim }}$ dos corpos-de-prova ensaiados à compressão axial101

Tabela 4.1 - Ensaios de cisalhamento direto realizados................................................ 113

Tabela 4.2 - Resistência média do concreto e força última da ligação nos ensaios de

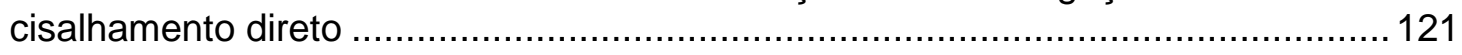

Tabela 4.3 - Deslizamento e energia absorvida pela ligação.......................................... 122

Tabela 4.4 - Comparação entre os resultados da análise numérica e os resultados experimentais dos ensaios de cisalhamento direto com chave............................. 151

Tabela 5.1 - Comparação entre a força última experimental e a obtida segundo a curva

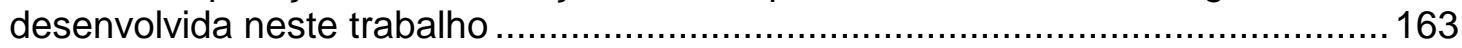

Tabela 5.2 - Comparação entre o deslizamento experimental e o obtido pela aplicação da

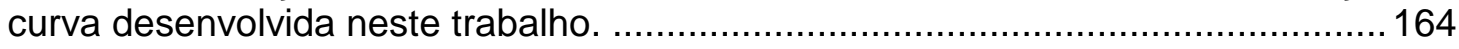

Tabela 5.3 - Comparação entre a energia absorvida pela ligação e a obtida pela aplicação

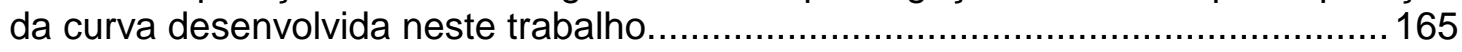

Tabela 5.4 - Comparação entre a força última obtida pela aplicação do modelo de KANEKO

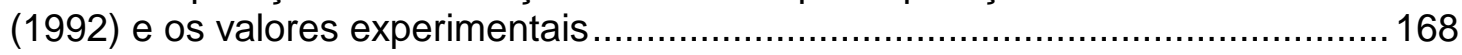

Tabela 5.5 - Comparação entre o deslizamento experimental e o obtido pela aplicação do

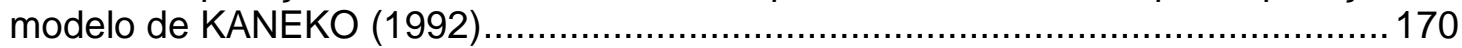

Tabela 5.6 - Comparação entre a força última obtida pela aplicação do modelo de KANEKO (1992) modificado para incluir a armadura e os valores experimentais

Tabela 5.7 - Comparação entre a força última experimental e a obtida aplicando o modelo de HSU et al. (1987)....

Tabela 5.8 - Comparação entre os resultados obtidos pela aplicação do modelo analítico proposto e os valores experimentais ................................................................ 192

Tabela 6.1 - Relação de ensaios em vigas compostas ................................................. 198

Tabela 6.2 - Resistência e módulo de elasticidade do concreto empregado nas vigas ......207 
Tabela 6.3 - Força máxima resistida pelas vigas ensaiadas.......................................... 214

Tabela 6.4 - Avaliação do momento resistente das vigas compostas...............................228

Tabela 6.5 - Força máxima alcançada pelas vigas compostas em função do tipo de ligação na interface (obtido da simulação numérica) ........................................................243

Tabela 6.6 - Momento fletor nas longarinas (kN.m) ................................................... 251

Tabela 6.7 - Esforço cortante nas longarinas (kN). .................................................... 251

Tabela 6.8 - Tensão de cisalhamento na interface da viga de extremidade .....................253

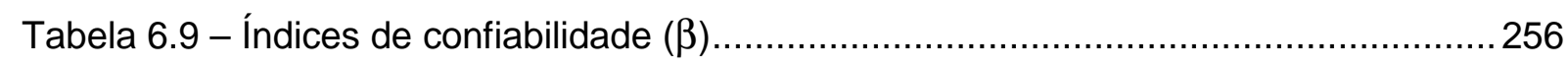

Tabela 6.10 - Resistência de vários tipos de ligação viga-laje.......................................258 


\section{LISTA DE SÍMBOLOS}

\section{- Letras maiúsculas}

$\mathrm{A}_{\mathrm{c}} \quad$ - área comprimida da seção transversal

$\mathrm{A}_{\mathrm{s}} \quad$ - área da seção transversal da armadura passiva

$A_{\text {lig }} \quad$ - área da superfície de fratura

$A_{n} \quad$ - área do nicho

$A_{p} \quad$ - área da seção transversal da armadura ativa

D - dimensão da chave de cisalhamento na direção da solicitação tangencial (comprimento)

E - energia

$\mathrm{E}_{\mathrm{c}} \quad$ - módulo de elasticidade inicial do concreto

$\mathrm{E}_{\mathrm{s}} \quad$ - módulo de elasticidade do aço

F $\quad$ - força

$F_{c} \quad$ - resultante de compressão no concreto em uma seção fletida

$F_{d} \quad$ - força resistida por ação de pino da armadura

$\mathrm{F}_{\mathrm{d}, \mathrm{u}} \quad$ - força última resistida por ação de pino da armadura

$F_{\text {int }} \quad$ - força resistida pela interface em vigas compostas

$F_{\text {lig }} \quad$ - força aplicada em cada ligação na interface entre viga e laje pré-moldadas

- força resistida por cada ligação na interface entre viga e laje pré-moldadas

$F_{t} \quad$ - resultante de tração na armadura de flexão em uma seção fletida

$\mathrm{F}_{\mathrm{u}} \quad$ - força máxima resistida ou força última

$\mathrm{G}_{f} \quad$ - energia de fratura

K - coeficiente

$\mathrm{K}_{\mathrm{IC}}$ - fator crítico de intensidade de tensão no modo I de ruptura

L $\quad$ - comprimento

- dimensão da chave de cisalhamento na direção normal à solicitação tangencial (altura)

$\mathrm{M}_{\text {comp }} \quad$ - momento fletor resistente da seção composta

$M_{d} \quad$ - momento fletor de cálculo

R - índice de correlação 
TR - tenacidade relativa na compressão

V - esforço cortante

$V_{f} \quad$ - volume de fibras, em porcentagem

$\mathrm{W}_{0} \quad$ - trabalho exercido por uma força externa

$W_{f} \quad$ - fração em peso de fibras

\section{- Letras minúsculas}

a $\quad$ - altura do entalhe em um corpo-de-prova prismático

$a_{v}$ : - distância sobre a qual são transferidas tensões pela interface

b $\quad$ - largura de um corpo-de-prova prismático

- largura da interface nas vigas compostas

$b_{f} \quad$ - largura colaborante da laje na resistência à flexão da seção composta

d : $\quad$ - altura útil de uma viga

- diâmetro equivalente da fibra

- altura de um corpo-de-prova prismático

d' - distância do centro de gravidade da armadura principal de flexão ao bordo inferior da viga

$d_{1} \quad$ - distância do centro de gravidade da armadura de flexão à interface da viga composta

$\mathrm{d}_{\max } \quad$ - dimensão máxima do agregado graúdo

$\mathrm{f}_{\mathrm{c}} \quad$ - resistência à compressão do concreto

$f_{c d}$ : - resistência de cálculo à compressão do concreto

$\mathrm{f}_{\mathrm{ck}} \quad$ - resistência característica à compressão do concreto

$\mathrm{f}_{\mathrm{cm}} \quad$ - resistência média do concreto à compressão medida em corpos-de-prova cilíndricos

$\mathrm{f}_{\mathrm{ct}} \quad-$ resistência do concreto à tração direta

$\mathrm{f}_{\mathrm{ctm}, \mathrm{f}} \quad$ - resistência média do concreto à tração na flexão

$\mathrm{f}_{\mathrm{ctm}, \mathrm{sp}}$ - resistência média do concreto à tração indireta obtida por compressão diametral em corpos-de-prova cilíndricos

$\mathrm{f}_{\mathrm{y}} \quad$ - resistência de escoamento do aço à tração

$\mathrm{f}_{\mathrm{yd}} \quad$ - resistência de cálculo do aço à tração

$\mathrm{f}_{\mathrm{yk}} \quad$ - resistência característica de escoamento do aço à tração

$\mathrm{f}_{\mathrm{s}} \quad$ - resistência do aço

$\mathrm{f}_{\mathrm{tu}} \quad$ - resistência ao arrancamento das fibras da matriz 


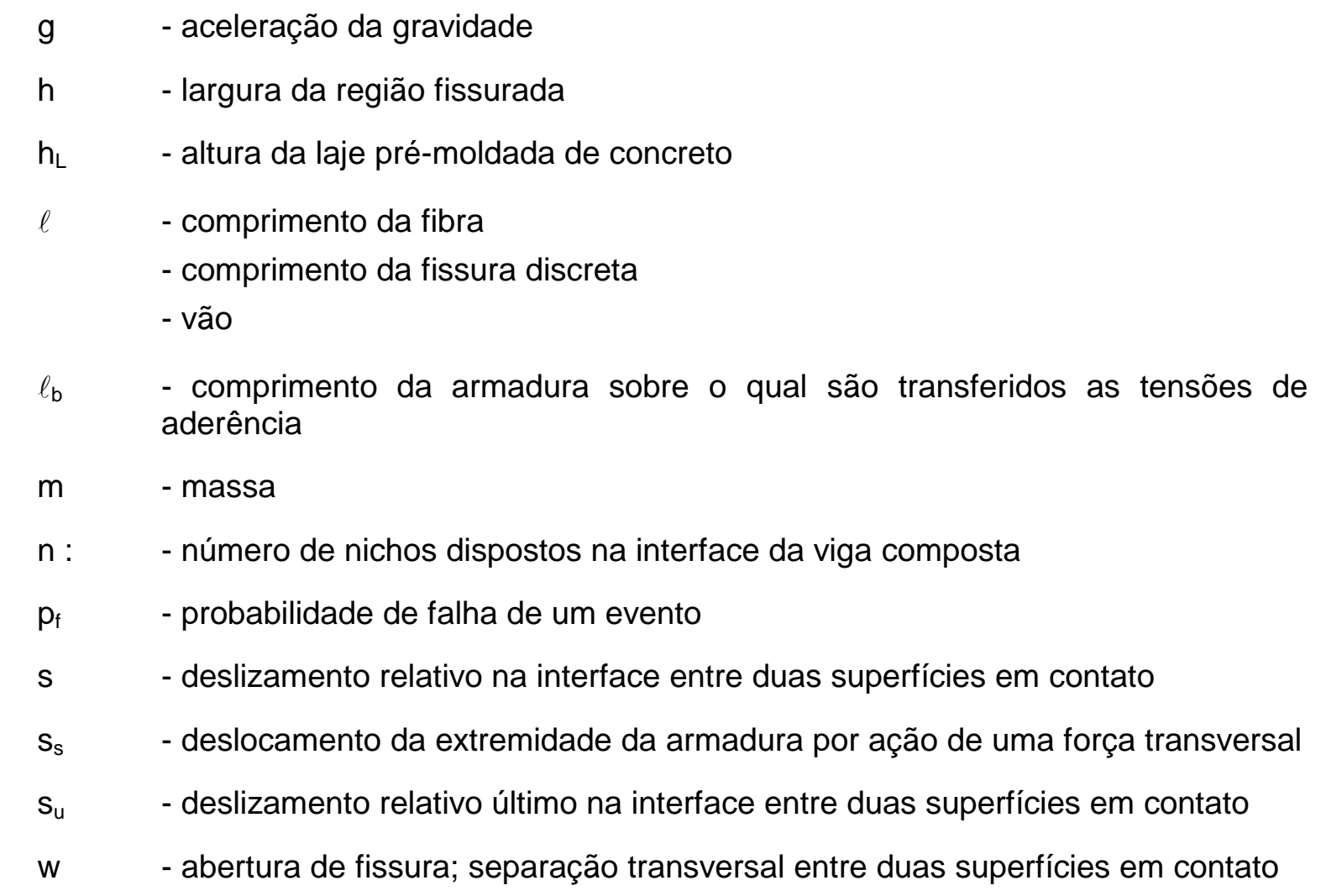

- Letras gregas

$\alpha \quad$ - ângulo

$\beta \quad$ - relação entre a área de transferência de esforços de cisalhamento e a área total da interface em uma viga composta

- coeficiente

- índice de confiabilidade

$\delta \quad$ - deslocamento

- coeficiente de variação

$\delta_{0} \quad$ - deslocamento máximo

$\delta_{\mathrm{m}} \quad$ - deslizamento médio correspondente à resistência da ligação nos ensaios de cisalhamento direto

$\delta_{d} \quad$ - deslocamento por ação de pino da armadura

$\delta_{\mathrm{d}, \mathrm{u}} \quad$ - deslocamento último por ação de pino da armadura

$\varepsilon \quad$ - deformação específica

$\varepsilon_{\mathrm{c}} \quad$ - deformação específica uniaxial de compressão no concreto

- deformação principal de compressão no estado plano de tensões

$\varepsilon_{\mathrm{c}, \mathrm{lim}} \quad$ - deformação à compressão do concreto correspondente à resistência $\mathrm{f}_{\mathrm{c}}$ 


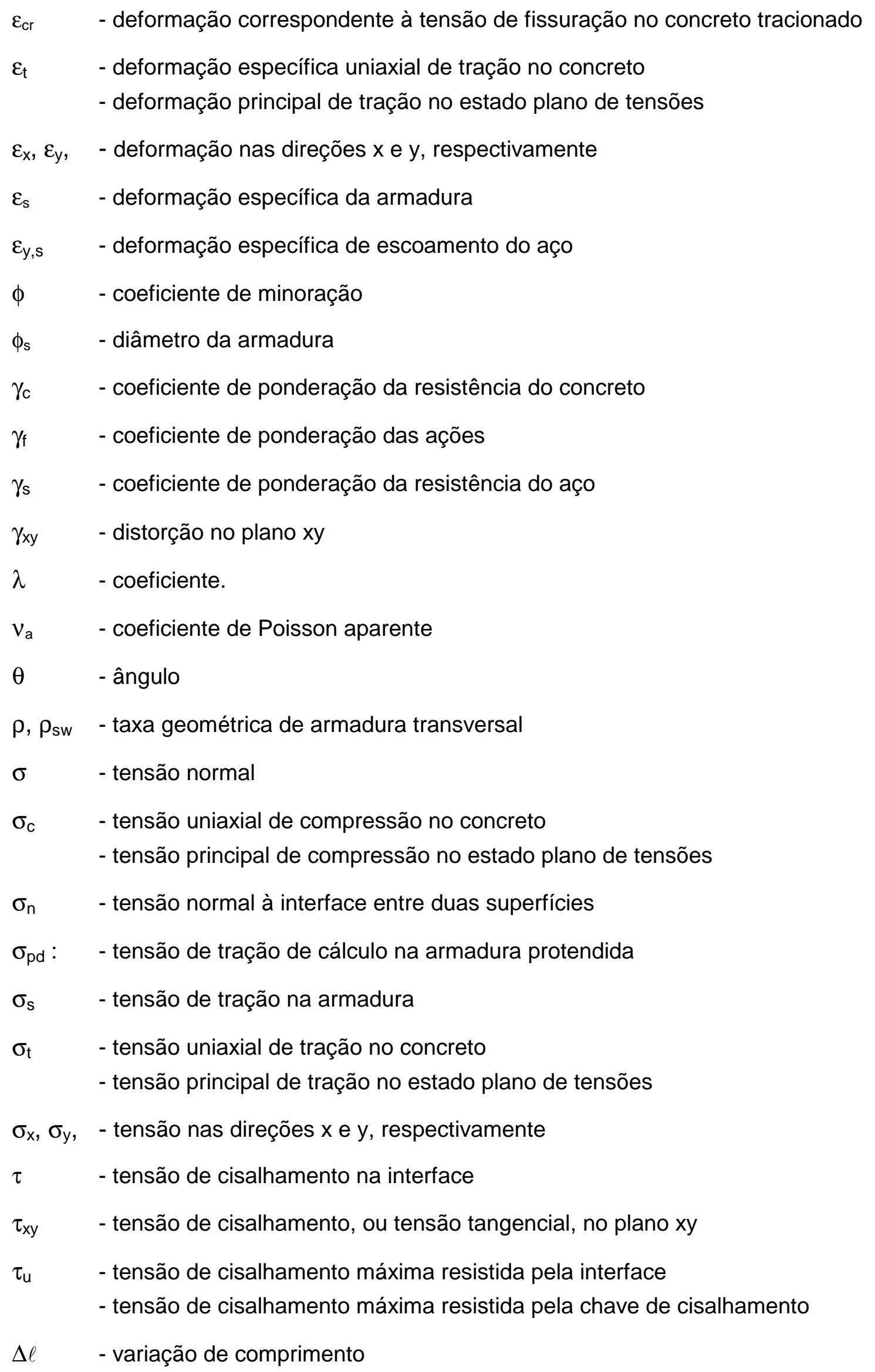


- sub-índices gerais

$\begin{array}{ll}\text { c } & \text { - concreto; compressão } \\ \text { d } & \text { - de cálculo } \\ \text { k } & \text { - característico } \\ \text { lim } & \text { - limite } \\ \max & \text { - máximo } \\ \text { min } & \text { - mínimo } \\ \text { s } & \text { - aço; barra da armadura } \\ \text { t } & \text { - tração } \\ \text { u } & \text { - último }\end{array}$




\section{Capítulo 1 - Introdução}

\subsection{Considerações gerais}

A associação de elementos pré-moldados com concreto moldado no local é uma das aplicações mais comuns da pré-moldagem, recebendo a denominação de peças compostas. Essa associação tem sido utilizada com sucesso na construção de pontes, onde as vigas longitudinais do tabuleiro são pré-moldadas e a laje é moldada no local. Associação semelhante com viga metálica e laje de concreto também tem sido utilizada com sucesso há vários anos. Algumas das principais vantagens do emprego das peças compostas sobre os sistemas unicamente em concreto moldado no local são a maior rapidez na execução da obra e a redução de fôrmas e cimbramentos. Estas vantagens podem ser maximizadas se a laje também for pré-moldada (Figura 1.1).

Na Figura 1.2 é ilustrada a transferência de tensões de cisalhamento horizontal entre duas peças em contato e submetidas à flexão por uma força concentrada no meio do vão. Em função do nível de transferência de esforços entre as peças (integral ou parcial), podese ter uma viga composta com comportamento monolítico ou não. A avaliação da resistência da interface entre a viga e a laje é importante para que se possa garantir, ou não, a contribuição da laje na resistência ao momento fletor. A distribuição de tensões ilustrada na Figura 1.2 é típica da associação de viga pré-moldada com concreto moldado no local, na qual a aderência entre as duas superfícies de concreto representa parcela importante da resistência da interface. Estudos recentes sobre a transferência de esforços pela interface desse tipo de viga foram realizados por PATNAIK (1992), ARAUJO (1997) e PATNAIK (2001). Na associação de viga pré-moldada com laje também pré-moldada, contudo, o simples contato entre as peças não é suficiente para garantir a transferência das tensões de cisalhamento horizontais pela interface, havendo a necessidade da execução de ligações discretas ao longo do vão. 

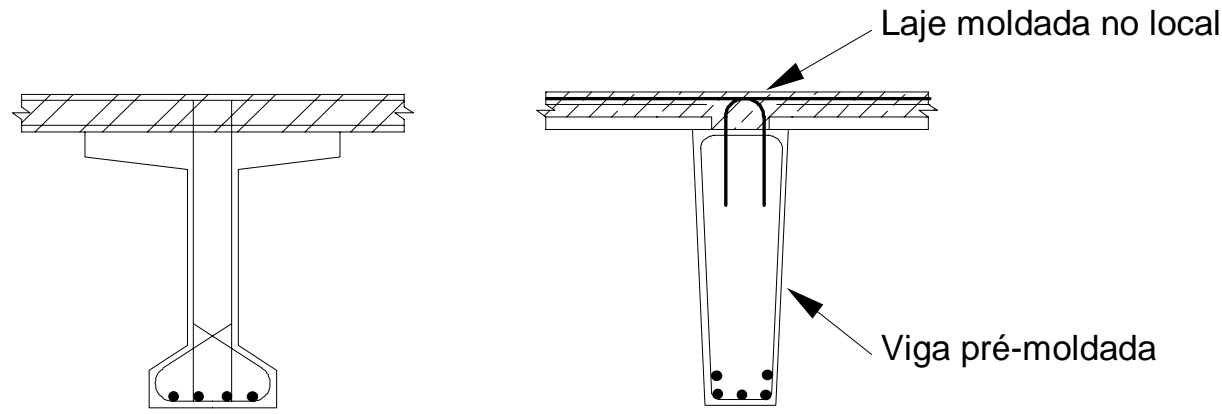

(a) Viga pré-moldada com laje moldada no local

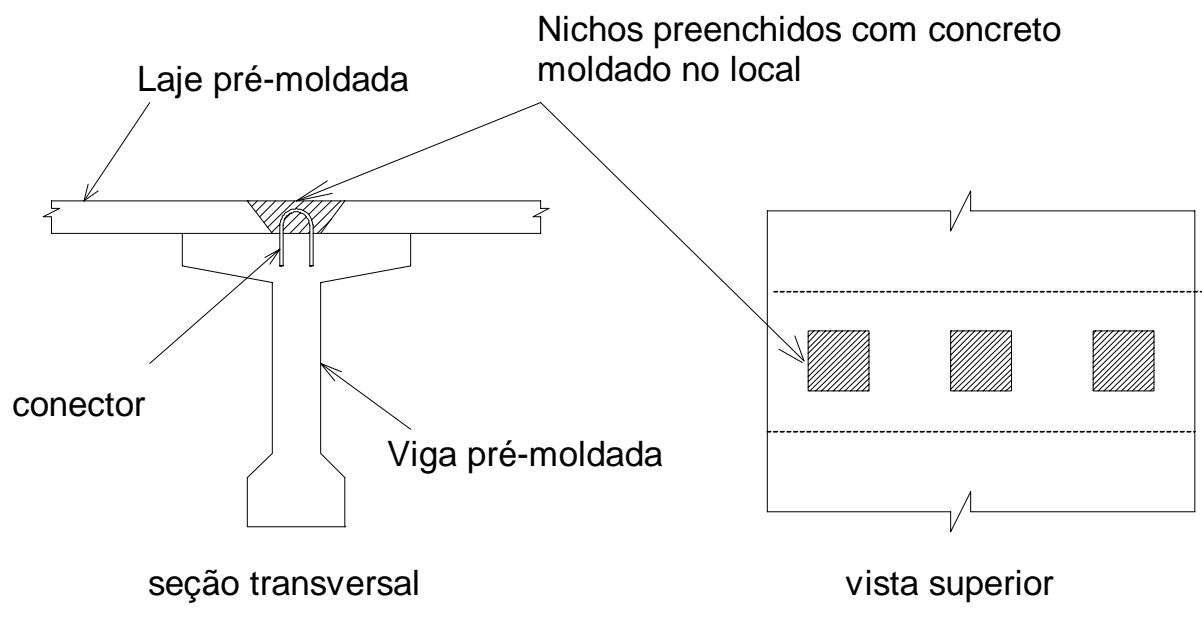

b) Viga e laje pré-moldadas

Figura 1.1 - Tipos de associações utilizadas em vigas compostas.

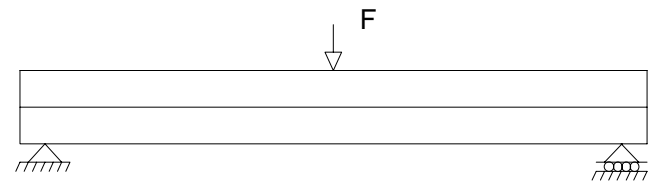

(a) viga composta formada por duas barras solicitadas por uma força concentrada
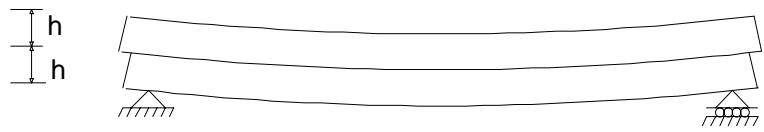

(b) interface sem transferência de tensões de cisalhamento: flexão independente das barras

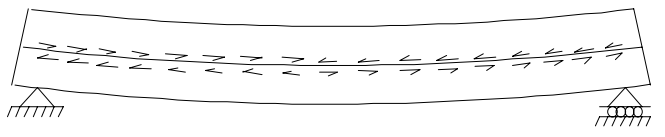

(c) interface com transferência integral de tensões de cisalhamento: peça monolítica

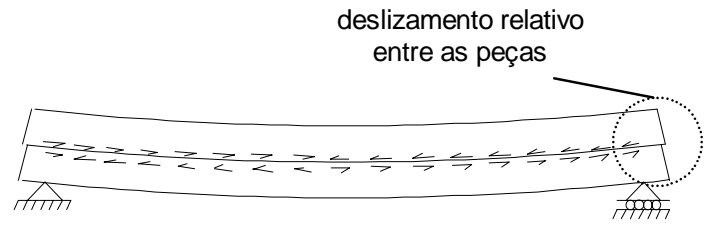

(d) interface com transferência parcial de tensões de cisalhamento: peça composta

Figura 1.2 - Desenvolvimento de tensões de cisalhamento horizontal na interface de vigas compostas. 
Nas estruturas pré-moldadas existem vários modos e se utilizam diversos materiais para efetuar as ligações entre as peças. Contudo, o emprego de concreto moldado no local é uma das formas mais simples. Um tipo de ligação, que pode ser utilizado entre viga e laje pré-moldadas, consiste na associação de conectores metálicos com concreto moldado no local. Os conectores, formados por vergalhões de aço dobrados em forma de laço, são deixados na viga pré-moldada durante sua moldagem, e durante a montagem da estrutura eles são inseridos em furos (ou nichos) existentes na laje pré-moldada. Posteriormente, a ligação é realizada pelo preenchimento dos nichos com concreto moldado no local. Nessa ligação, a transferência de esforços pela interface é feita de forma discreta através dos conectores e da superfície de contato entre o concreto pré-moldado da viga e o concreto moldado nos nichos da laje (Figura 1.3). A resistência por atrito que surge na superfície de contato entre a viga e a laje pré-moldadas pode ser desprezada por ser pouco confiável.

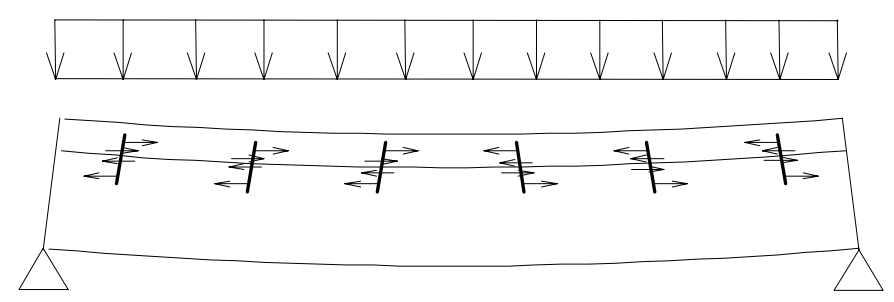

Figura 1.3 - Transferência de tensões de cisalhamento entre viga e laje pré-moldadas ligadas discretamente.

A transferência de esforços de cisalhamento pela interface entre duas peças de concreto moldadas em idades diferentes é garantida pela aderência entre as duas superfícies em contato e pela ação de pino da armadura transversal à interface. Se a superfície da interface se torna rugosa, por exemplo, pela exposição dos agregados graúdos durante a concretagem ou pela escarificação da superfície após o endurecimento do concreto, haverá também uma contribuição do engrenamento mecânico dos agregados na resistência ao cisalhamento. Existem na literatura diversos modelos mecânicos que podem ser empregados para avaliar a resistência ao cisalhamento da interface de peças compostas de concreto. No caso das vigas compostas com laje pré-moldada, esses modelos podem ser empregados na superfície de contato entre a viga pré-moldada e o concreto moldado nos nichos para avaliar a resistência da interface ao cisalhamento (MALITE et al. (1997)).

Neste trabalho é proposta uma modificação na ligação correntemente empregada entre viga e laje pré-moldadas que consiste na execução de uma pequena cavidade na viga 
pré-moldada (ou chave de cisalhamento), conforme mostrado na Figura 1.4. Neste caso, uma possível forma de ruptura da ligação é por cisalhamento do concreto da chave ao nível da superfície da viga pré-moldada. A resistência da ligação pode ainda ser aumentada pelo aumento da resistência ao cisalhamento do concreto moldado no nicho. Nesse sentido, é proposto o emprego de concreto de alta resistência associado com fibras metálicas. Além do mais, para a utilização dessa ligação em estruturas de pontes, a adição de fibras ao concreto também melhora seu comportamento quando submetida a esforços cíclicos.

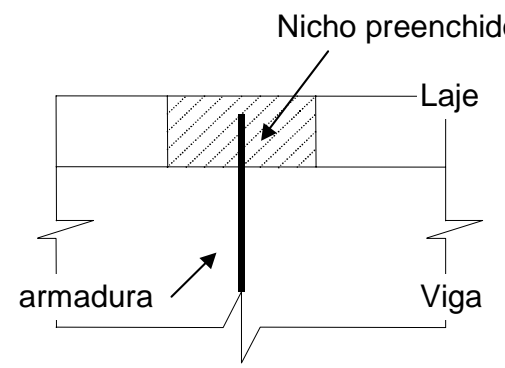

Corte longitudinal

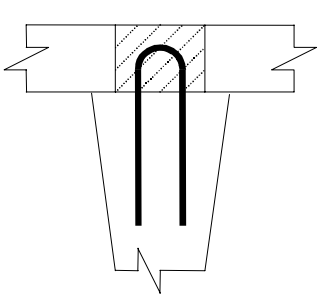

Corte transversal

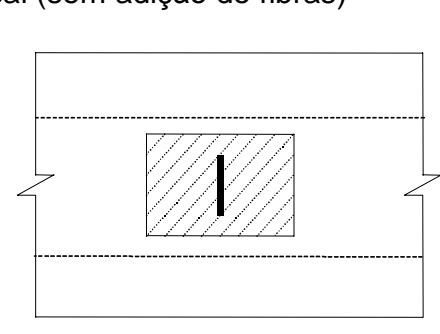

Vista superior

a) superfície de contato plana

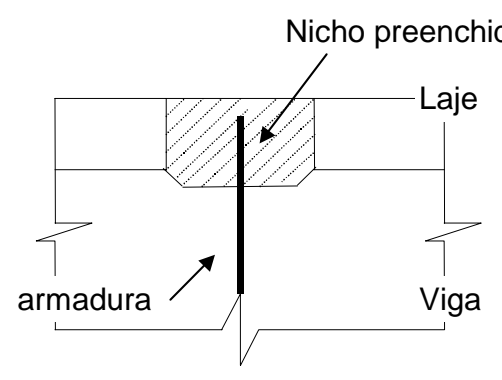

Corte longitudinal

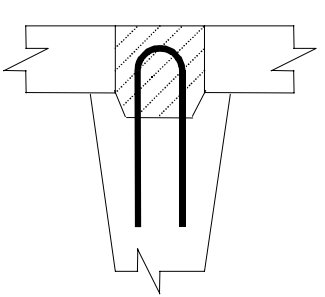

Corte transversal

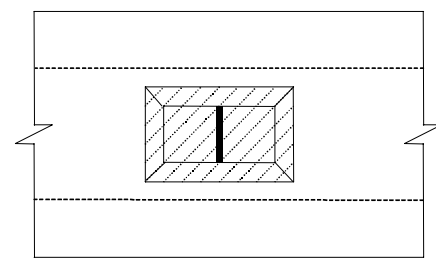

Vista superior

b) Proposta de superfície de contato com chave de cisalhamento

Figura 1.4 - Proposta de modificação na ligação entre viga e laje pré-moldadas.

A associação de viga e laje pré-moldadas tem sido empregada com alguma freqüência na construção de pontes. Contudo, não existem indicações seguras para o dimensionamento da ligação entre elas. Uma das formas de dimensioná-la seria fazer uma analogia com as vigas compostas formadas por viga metálica e laje de concreto moldada no local, uma vez que neste tipo de viga a transferência de esforços pela interface também é feita de forma discreta por conectores de cisalhamento. Além disso, elas têm sido empregadas há alguns anos e, por essa razão, existe vasta literatura sobre o assunto. 
Apenas para ficar em um exemplo, cita-se o trabalho de MALITE (1993). Outra forma de dimensionar a ligação entre viga e laje pré-moldadas seria por meio de avaliações experimentais. Neste sentido, recentemente foi realizado um trabalho na Escola de Engenharia de São Carlos com o objetivo de avaliar a resistência da ligação empregada na construção de uma ponte sobre o rio Paraná (MALITE; TAKEYA (1996)). Os resultados obtidos neste trabalho, contudo, não são extensivos a todos os tipos de ligação possíveis, tendo sido aplicados apenas àquela ponte. Poderiam, ainda, ser empregados os resultados obtidos de trabalhos que estudaram a associação de viga metálica com laje de concreto pré-moldada (SHIM et al. (2001), LAM et al. (2000)a , LAM et al. (2000) ${ }^{\mathrm{b}}$, LAM et al. (2000) ${ }^{\mathrm{c}}$, ISSA et al. (2000), YAMANE et al. (1998), ISSA et al. (1998) e LAM et al. (1998)). Esses trabalhos confirmam a eficiência do emprego das lajes de concreto pré-moldadas, contudo eles não são suficientes para estabelecer um critério definitivo para o dimensionamento da ligação. Além disso, o tipo de ligação empregada nesses trabalhos, que consistia de pinos soldados à viga metálica, não pode ser aplicado à associação entre viga e laje prémoldadas de concreto. Por essas razões, o presente trabalho foi idealizado com o objetivo de fornecer uma contribuição para melhor compreender a ligação entre as vigas e as lajes pré-moldadas. Acredita-se que esse tipo de associação possa ser ainda mais empregado na construção civil, principalmente naqueles casos onde a rapidez de execução da obra seja um fator determinante na escolha do projeto.

\subsection{Objetivo}

O objetivo deste trabalho foi caracterizar a ligação viga-laje pré-moldadas e analisar o comportamento à flexão das vigas compostas com laje pré-moldada, comparando-as com as vigas compostas com laje moldada no local. Foi empregada uma metodologia baseada em investigação experimental associada com análises numéricas e comparação com modelos mecânicos. Buscou-se, assim, obter indicações que auxiliassem no projeto da ligação entre viga e laje pré-moldadas de concreto.

Dentro deste objetivo, os principais aspectos analisados foram:

- Estudo da ligação viga-laje quando submetida a carregamento monotônico. Para tanto, foram empregados ensaios de cisalhamento direto, a partir dos quais foi analisada a influência sobre a resistência da ligação do tipo de superfície empregada na viga pré-moldada. Foi analisada, também, a influência da resistência do concreto moldado no nicho, do diâmetro do conector e da adição de fibras metálicas na resistência da ligação com chave de cisalhamento. 
- Estudo da ligação viga-laje com chave de cisalhamento quando submetida a carregamento cíclico não reversível. Para tanto, foram realizados ensaios de cisalhamento direto, a partir dos quais foi analisada a influência da adição de fibras metálicas ao concreto moldado no nicho sobre a perda de rigidez da ligação.

- Comparação do comportamento à flexão de vigas compostas formadas por viga e laje pré-moldadas, ligadas mediante nichos com chave de cisalhamento, com as vigas compostas formadas por viga pré-moldada e laje moldada no local.

\subsection{Apresentação da tese}

O capítulo dois é reservado à revisão bibliográfica. Não existem trabalhos e normas específicas sobre a ligação aqui proposta, de modo que ao longo desse capítulo são apresentados assuntos relacionados com o tema deste trabalho que posteriormente são empregados nos demais capítulos. Dessa forma, é apresentada uma breve revisão acerca de algumas propriedades mecânicas dos concretos simples e reforçados com fibras. No caso dos concretos simples, é enfocada a análise da transferência de tensões de cisalhamento em interfaces de concreto. Em seguida, são apresentadas algumas propriedades mecânicas dos concretos reforçados com fibras. Ao final, são apresentados alguns modelos mecânicos disponíveis na literatura empregados na avaliação da resistência ao cisalhamento dos concretos simples e reforçados com fibras e das interfaces de concreto.

No terceiro capítulo é apresentado o programa experimental desenvolvido para a determinação de algumas propriedades mecânicas do concreto reforçado com fibras metálicas. Foi estudada a influência das fibras nas resistências à compressão e à tração, na energia de fratura e no modulo de elasticidade do concreto. Também foram realizados ensaios de compressão com deformação controlada a partir dos quais foi proposta uma expressão para o traçado da curva tensão-deformação do concreto com fibras.

Os resultados dos ensaios de cisalhamento direto sob carregamento monotônico e sob carregamento cíclico não reversível são apresentados no capítulo quatro. São apresentados, também, alguns resultados da simulação numérica dos ensaios com carregamento monotônico, empregando o programa comercial ANSYS baseado no método dos elementos finitos.

No capítulo cinco, os resultados dos ensaios de cisalhamento direto com carregamento monotônico são empregados na elaboração de uma expressão para a 
representação da ligação com chave de cisalhamento e conector. Os mesmos resultados também são analisados empregando modelos mecânicos disponíveis na literatura, que são modificados para melhor representarem os resultados experimentais.

No capítulo seis são mostrados os resultados dos ensaios realizados nas vigas compostas formadas por viga e laje pré-moldadas. A partir desses resultados, é analisada a influência do espaçamento dos nichos na resistência e na rigidez das vigas. Na seqüência, são mostrados os resultados obtidos da análise numérica realizada no programa ANSYS, que ampliaram a compreensão do comportamento das vigas compostas com laje prémoldada. Também é mostrado um exemplo de dimensionamento da ligação entre viga e laje pré-moldadas em uma estrutura típica de ponte rodoviária.

Finalmente, as considerações finais e as conclusões deste trabalho são apresentadas no capítulo sete, sendo propostos alguns temas para trabalhos futuros.

No Apêndice A, são mostrados os resultados dos ensaios de cisalhamento direto realizados. No Apêndice $B$, esses resultados são empregados para validar o modelo analítico desenvolvido para a ligação com chave de cisalhamento. No Apêndice C, são apresentados os resultados da aplicação de um modelo mecânico, obtido da literatura, à ligação com chave de cisalhamento. Finalmente, os resultados dos ensaios nas vigas compostas com laje pré-moldada são mostrados no Apêndice D. 


\title{
Capítulo 2 - Alguns Aspectos sobre o Comportamento dos Concretos Simples e Reforçados com Fibras
}

\begin{abstract}
Neste capítulo é apresentada uma breve revisão bibliográfica acerca de algumas propriedades mecânicas dos concretos simples e reforçados com fibras. No caso dos concretos simples, é enfocada a análise da transferência de tensões de cisalhamento em interfaces de concreto. Em seguida, são apresentadas algumas propriedades mecânicas dos concretos reforçados com fibras. Ao final, são apresentados alguns modelos mecânicos disponíveis na literatura empregados na avaliação da resistência ao cisalhamento dos concretos simples e reforçados com fibras e das interfaces de concreto. Posteriormente, esses modelos serão comparados com os resultados dos ensaios de cisalhamento direto.
\end{abstract}

\subsection{Breve revisão bibliográfica}

\subsubsection{Resistência ao cisalhamento em interfaces de concreto}

Os primeiros estudos de que se tem notícia sobre a transferência de tensões de cisalhamento em interfaces de concreto datam da década de 1960. BIRKELAND; BIRKELAND (1966) e MAST (1968) propuseram um modelo simplificado para avaliação da resistência por atrito em interfaces rugosas de concreto atravessadas por armadura. Nesse modelo, a interface rugosa era substituída por uma série de pequenos dentes inclinados sem atrito. Ao se aplicar uma força paralela à interface, uma das partes deslizava sobre a outra, afastando-se e tracionando a armadura transversal à interface que reagia aplicando uma força normal. A resistência da interface era avaliada pelo produto dessa força normal por um coeficiente de atrito aparente (Figura 2.1). Esse modelo não é diretamente aplicado no dimensionamento de estruturas de concreto submetidas aos esforços de cisalhamento, porém está incorporado em modelos mais refinados para avaliar a contribuição devido ao atrito entre duas superfícies de concreto em uma fissura. Por outro lado, em estruturas que possuem um plano de cisalhamento pré-definido como, por exemplo, nas estruturas compostas formadas por concretos moldados em idades diferentes, esse modelo é utilizado 
para dimensionar a armadura transversal ao plano de cisalhamento, sendo indicado por diversas instituições normativas (FIP (1982), NBR-9062 (1985), ACI 318 (1989), VALLUVAN et al. (1999)). Dentre as várias aplicações deste modelo, merece destaque o dimensionamento da interface das vigas compostas formadas por viga pré-moldada e laje de concreto moldada no local. Uma abordagem completa desse assunto pode ser encontrada em ARAUJO (1997) e EL DEBS (2000).

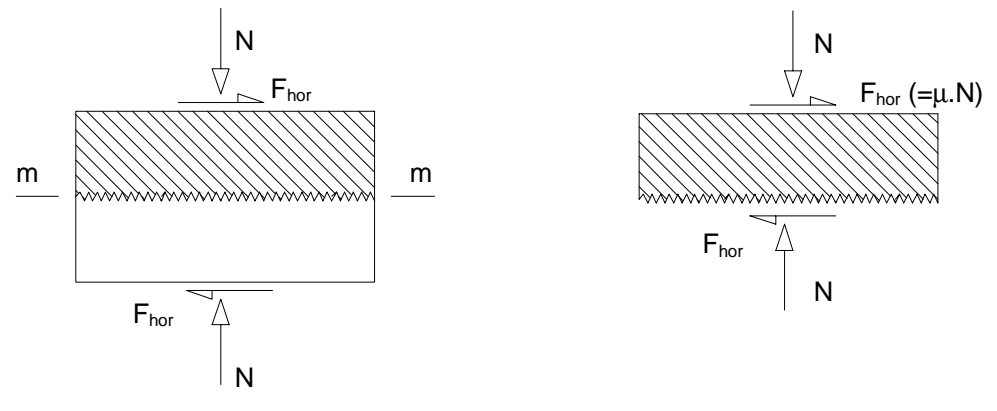

(a) força de atrito entre duas superfícies em contato

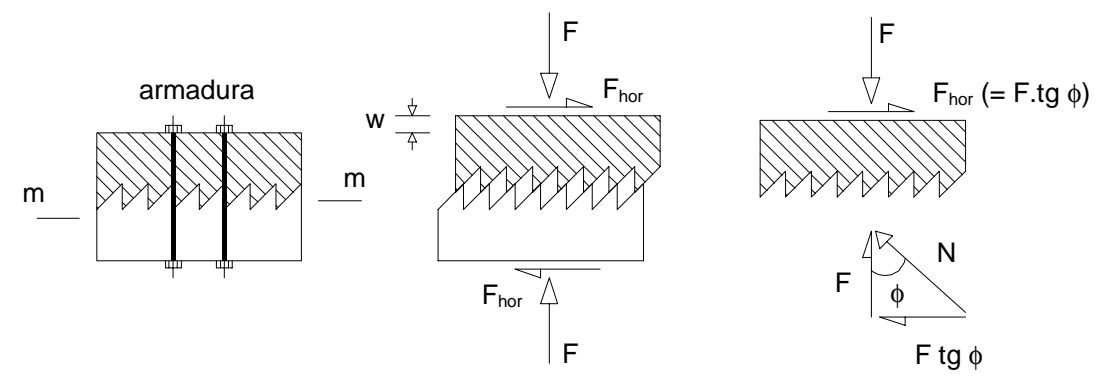

(b) aplicação pela armadura de força normal à interface

Figura 2.1 - Teoria atrito-cisalhamento.

A partir da década de 1970, inúmeras pesquisas foram realizadas e diversas formulações foram apresentadas para avaliar a resistência ao cisalhamento da interface de peças de concreto. De forma geral, em todas as formulações propostas o mecanismo resistente era composto de duas parcelas: resistência ao deslizamento da superfície de contato e resistência por ação de pino da armadura transversal à interface. A primeira parcela, por sua vez, era dividida em outras três parcelas: aderência, atrito e engrenamento mecânico dos agregados. Esse modelo de transferência de tensões pressupõe a existência de um plano de cisalhamento previamente definido no qual será formado o mecanismo resistente descrito. Ao solicitar a interface, a primeira parcela de resistência mobilizada é a aderência entre as superfícies. Essa parcela é fortemente influenciada pelo tratamento da 
superfície de contato antes do lançamento do concreto novo e apresenta grande dispersão no seu valor. Depois de rompida a aderência, as parcelas de atrito e engrenamento mecânico passam a resistir aos esforços, sendo responsáveis por grande parte da resistência da interface. Essas parcelas são influenciadas pelo nível de rugosidade da interface. A ruptura ocorre ao longo do plano de cisalhamento definido com pequeno ou nenhum aumento da abertura, exceto quando há grande porcentagem de armadura atravessando a interface. Entre os inúmeros trabalhos publicados sobre esse assunto, pode-se citar os de FENWICK; PAULAY (1968), MILLARD; JOHNSON (1984), TASSIOS; VINTZELEOU (1987), PRUIJSSERS (1988), BASS et al. (1989) e TASSIOS; VINTZELEOU (1990). Merece destaque o trabalho de WALRAVEN; REINHARDT (1981) que apresenta uma abordagem completa sobre a influência do engrenamento dos agregados na resistência ao cisalhamento em interfaces de concreto.

A resistência por ação de pino da amadura foi estudada por SOROUSHIAN et al. (1986), SOROUSHIAN et al. (1987), SOROUSHIAN et al. (1988), VINTZELEOU; TASSIOS (1990) e DEI POLI et al. (1992), entre outros. Geralmente, essa parcela de resistência apresenta valor muito inferior ao das outras parcelas, de modo que a principal função da armadura acaba sendo a de garantir uma força normal à interface que aumente a resistência por atrito entre as superfícies. A título de exemplo, cita-se o trabalho de JELIC et al. (1999) que ensaiaram vigas com taxa de armadura longitudinal constante e sem armadura transversal. Eles observaram que o aumento do diâmetro da armadura longitudinal não influenciou na resistência ao cisalhamento da viga e concluíram que apenas a parcela de resistência proporcionada pelo concreto deveria ser considerada no cálculo da resistência da viga. Este assunto ainda não está totalmente explicado e gera controvérsias.

Nas peças de concreto com altas taxas de armadura normal ao plano de cisalhamento e submetidas a esforços tangenciais, se não houver uma interface claramente definida, são formadas inúmeras fissuras inclinadas com relação ao plano de cisalhamento. A ruptura ocorre, então, pelo esmagamento das bielas comprimidas de concreto formadas, aproximadamente, paralelas às fissuras (Figura 2.2). A compressão nas bielas e a tração nas armaduras paralelas e normais ao plano de cisalhamento formam uma treliça que constitui o mecanismo resistente às tensões de cisalhamento. Esse modelo foi apresentado por HSU et al. (1987) e foi empregado para avaliar a resistência de corpos-de-prova de cisalhamento direto monolíticos. Ele é baseado na chamada teoria de campo de compressão modificada (Modified Compression Field Theory - MCFT) proposta por VECCHIO; COLLINS (1986) para representar o comportamento de painéis de concreto armado. Apesar desse modelo ter sido desenvolvido para peças monolíticas, ele também 
pode ser empregado para avaliar a resistência ao cisalhamento em peças pré-fissuradas e com interface definida. Um exemplo de aplicação desse modelo às vigas compostas de concreto com laje moldada no local pode ser encontrado em ARAUJO (1997). Outro exemplo de aplicação dos modelos de biela e tirante em interfaces de concreto é encontrado em HWANG et al. (2000). Nesse trabalho, os autores apresentaram um modelo capaz de avaliar a resistência de corpos-de-prova de cisalhamento direto, semelhantes aos da Figura 2.2, tanto com plano de cisalhamento pré-fissurado quanto monolíticos.

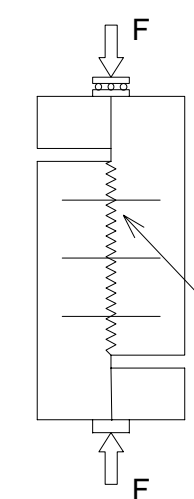

(a) modelo pré-fissurado (ruptura por deslizamento na interface)

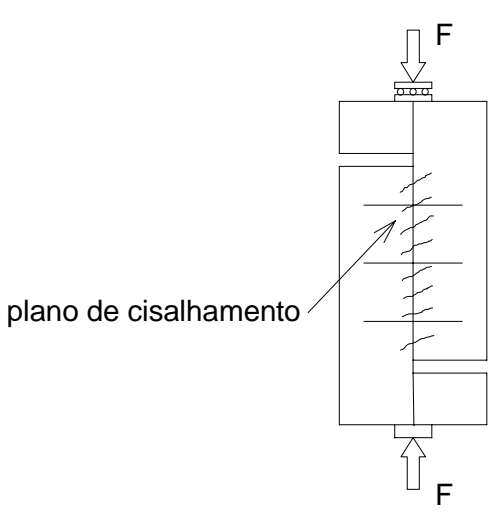

(b) modelo monolítico (ruptura por esmagamento das bielas de concreto)

Figura 2.2 - Formas de ruptura em interfaces de concreto.

Recentemente, alguns modelos baseados no conceito de bielas e tirantes foram modificados para representar o comportamento de estruturas com baixa taxa de armadura normal ao plano de cisalhamento. Destaca-se, principalmente o trabalho de VECCHIO (2000). Nesse trabalho, o autor modificou a teoria de campo de compressão modificado ("Modified Compression Field Theory - MCFT"), apresentado por VECCHIO; COLLINS (1986), e apresentou um novo modelo chamado campo de tensões perturbadas ("Disturbed Stress Field Model - DSFM'). Em linhas gerais, o modelo MCFT é baseado em relações obtidas do equilíbrio de forças, da compatibilidade de deformações e de equações constitutivas para os materiais. Esse modelo, desenvolvido originalmente para representar o comportamento de painéis de concreto armado sob estado plano de tensões, também emprega conceitos da teoria de fissuras distribuídas em banda. Após a fissuração do concreto, este é tratado como um material ortótropo, sendo a capacidade de transferência de esforços de tração normais à fissura considerada devido à existência das armaduras ("tension stiffening"). Além do equilíbrio das forças externas atuantes no elemento de concreto armado, também é considerado o equilíbrio local de forças no plano da fissura. 
Esse equilíbrio é necessário devido à introdução de tensões de cisalhamento no plano da fissura proporcionadas pelo engrenamento dos agregados. Ao se efetuar o equilíbrio, surgem tensões normais ao plano da fissura que são transferidas para a armadura, acarretando um acréscimo de tensão na armadura.

O modelo MCFT foi amplamente aplicado em painéis de concreto armado e em outros tipos de estruturas como, por exemplo, em vigas de concreto armado para avaliação da sua resistência ao cisalhamento. No caso de painéis armados em apenas uma direção ou em vigas com baixa ou nenhuma armadura transversal, contudo, esse modelo apresentou divergências com relação aos resultados experimentais. Nesses casos, normalmente, o modelo superestima a resistência e a rigidez da estrutura. Isto se deve, principalmente, ao fato do modelo permitir que durante o carregamento apareçam novas fissuras com orientações diferentes, o que permite uma distribuição de tensões nem sempre real. Para solucionar esse problema, VECCHIO (2000) apresentou o modelo DSFM que é um modelo híbrido entre os que permitem a rotação das fissuras e os que consideram a fissura com inclinação fixa durante toda a história de carregamento. Esse modelo se diferencia do modelo MCFT, principalmente, pela inclusão nas equações de compatibilidade do elemento de uma parcela devido ao deslizamento no plano da fissura (Figura 2.3). Em função disso, surgem outras diferenças com relação ao modelo anterior: (i) os ângulos de inclinação das tensões e deformações principais não necessitam mais serem iguais; (ii) o comportamento de estruturas nas quais o deslizamento na fissura define a ruptura pode ser mais bem representado (por exemplo, vigas de concreto sem armadura transversal); (iii) o grau de redução da resistência à compressão do concreto das bielas, devido às tensões principais de tração, é menor. Essas modificações fazem com que o modelo DSFM, aplicado em estruturas com baixa taxa de armadura transversal, forneça valores de resistência até $10 \%$ inferior ao valor previsto pelo modelo MCFT (VECCHIO (2001) e VECCHIO et al. (2001)). Além disso, as deformações angulares previstas por este modelo são significativamente maiores que as previstas pelo modelo MCFT.

Outro trabalho que mostra a importância da consideração do deslizamento na fissura no caso de peças de concreto sem armadura, foi desenvolvido por CHO; LEE (2000). Nesse trabalho, os autores modificaram a teoria de campo de compressão modificado (MCFT) considerando também o deslizamento relativo no plano da fissura. Além disso, eles admitiram que uma vez formada a fissura, sua inclinação mantinha-se fixa durante todo o carregamento. Os autores aplicaram esse modelo aos resultados experimentais de vigas de concreto sem armadura transversal e observaram que os resultados eram dependentes do valor adotado para o ângulo de inclinação das fissuras. Adotando um ângulo de $45^{\circ}$, ocorreu 
a melhor concordância entre a resistência prevista pelo modelo e a resistência experimental. O mais interessante, porém, era que, nesse modelo, as deformações previstas para as vigas eram muito superiores às previstas pelo modelo MCFT. Apesar disso, com o ângulo devidamente escolhido, as resistências previstas pelos dois modelos eram muito próximas, mostrando que a inclusão do deslizamento na fissura influencia muito mais as deformações que a resistência. As deformações médias do elemento de concreto eram obtidas pela soma das deformações calculadas na região entre fissuras (região contínua) com as deformações resultantes da abertura da fissura (w) e do deslizamento no seu plano $(\delta)$, as quais eram decompostas nas direções x e y, como mostrado na Figura 2.4 . Como a fissura era considerada de forma indireta (a abertura da fissura era definida pela multiplicação da deformação principal de tração da região não fissurada pelo espaçamento fictício entre fissuras), pode-se considerar essas deformações como deformações médias do concreto fissurado.

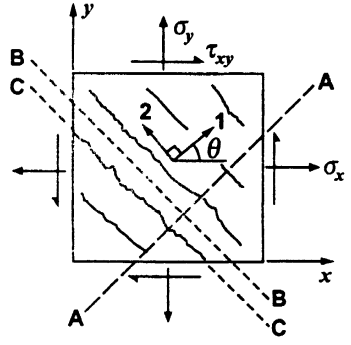

(a)

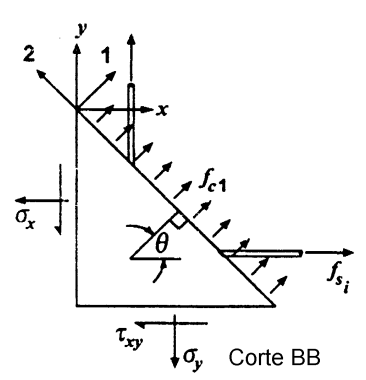

(c)

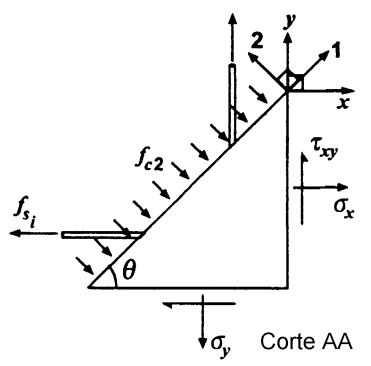

(b)

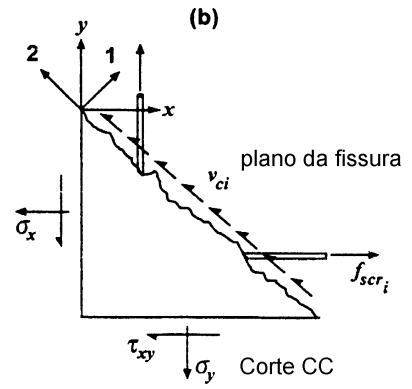

(d)
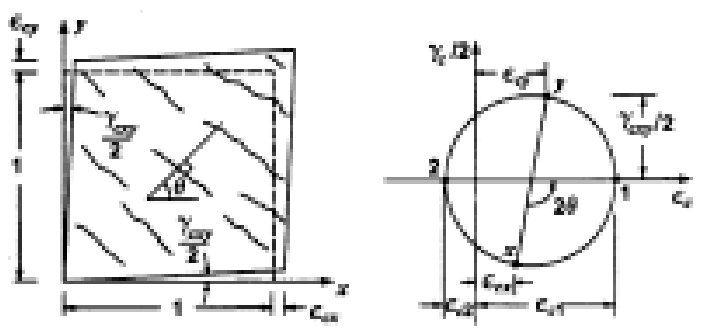

(e)
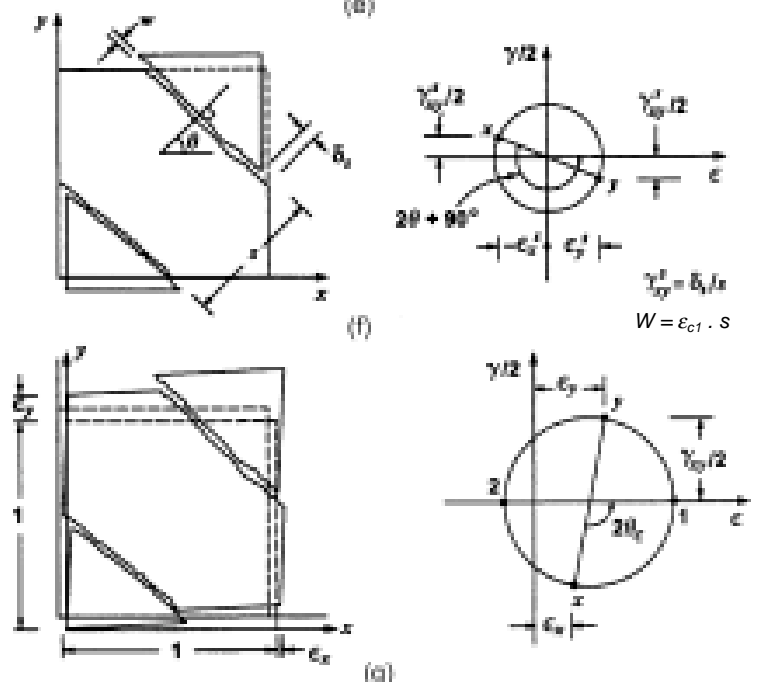

(g)

Equilíbrio em um elemento de concreto armado: Compatibilidade de deformações em um elemento (a) tensões externas; (b) tensões em um plano normal à fissura; (c) tensões em um plano paralelo à fissura; (d) tensões de cisalhamento no plano da fissura.

de concreto: (e) deformações no meio contínuo entre fissuras; (f) deformações devido ao deslizamento no plano da fissura; (g) deformação final.

Figura 2.3 - Relações de equilíbrio e de compatibilidade no modelo de VECCHIO (2000) 


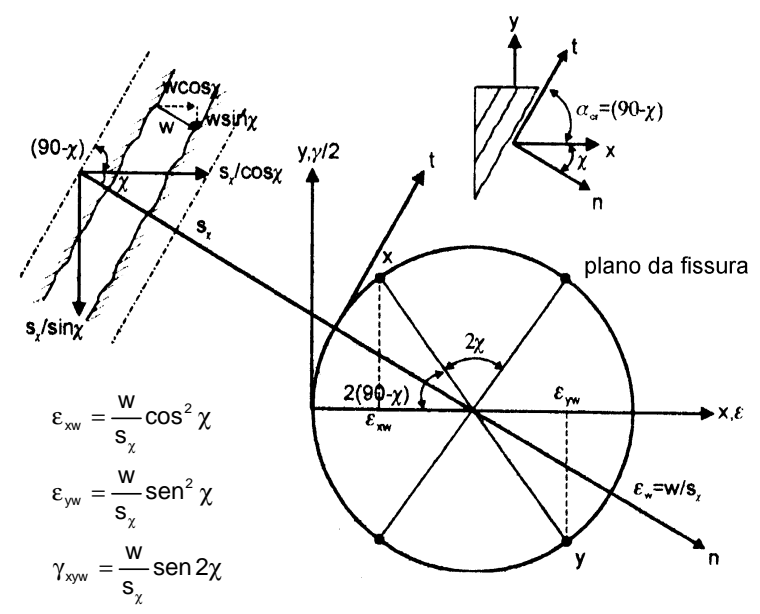

(a) deformações médias no elemento de concreto devido à abertura da fissura $(w)$

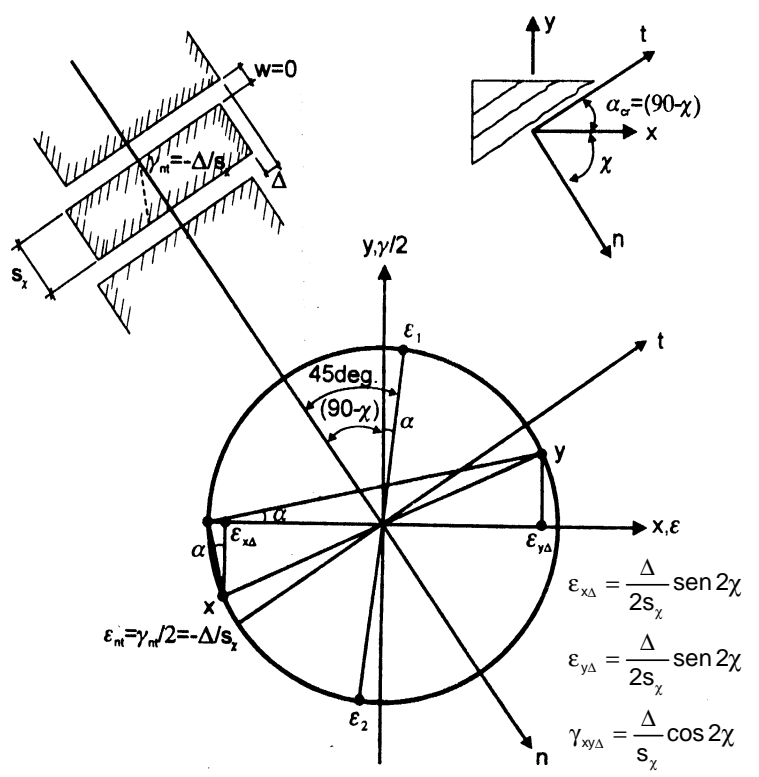

(b) deformações médias no elemento de concreto devido ao deslizamento no plano da fissura $(\Delta)$

Figura 2.4 - Relações de compatibilidade no modelo de CHO; LEE (2000)

As expressões para avaliação da resistência ao cisalhamento da interface de peças de concreto foram propostas inicialmente a partir de resultados obtidos de ensaios com carregamento monotônico. Mais tarde, elas foram modificadas a partir de resultados de ensaios de cisalhamento direto com carregamento cíclico reversível de modo a avaliarem o comportamento das ligações de estruturas pré-moldadas submetidas a sismos. Entre os diversos trabalhos publicados sobre o assunto, cita-se os trabalhos de MATTOCK (1981), JIMENEZ et al. (1982), PRUIJSSERS (1988), TSOUKANTAS; TASSIOS (1989) e DAVIES et al. (1990). A principal modificação foi a consideração da perda de resistência por atrito e pela ação de pino da armadura a cada ciclo de carregamento. Poucos ensaios foram realizados com carregamento cíclico não reversível, situação que ocorre com freqüência nas estruturas submetidas à carga móvel. VINTZELEOU; TASSIOS (1987) realizaram ensaios de cisalhamento em barras de aço ancoradas em blocos de concreto submetidas a carregamento cíclico reversível e não reversível. Os autores observaram que quando não havia inversão no sentido do carregamento, a perda de resistência por ação de pino da armadura, em função do número de ciclos, era menor do que quando havia inversão no sentido do carregamento.

Paralelamente, os modelos baseados na chamada teoria de campo de compressão modificada (MCFT) foram sendo refinados de modo a representarem o comportamento das peças quando submetidas a carregamento cíclico. Nessa linha, cita-se os trabalhos de 
RULE; ROWLANDS (1992) e ELMORSI et al. (1998), entre outros. Neste último trabalho, os autores realizaram uma refinada modelagem do comportamento do concreto considerando o amolecimento do concreto na tração e na compressão, a transferência de esforços pelo plano da fissura em função da sua abertura, e a degradação da resistência e da rigidez do concreto na direção paralela às fissuras em função do número de ciclos de carregamento. Esse modelo foi implementado em um programa computacional baseado no método dos elementos finitos com elementos planos que foi aplicado a painéis de concreto submetidos a carregamento cíclico reversível. Os resultados obtidos para a resistência e para a degradação da rigidez dos painéis em função do número de ciclos apresentaram boa concordância com os resultados experimentais.

$\mathrm{Na}$ interface entre peças pré-moldadas de concreto submetidas a tensões de cisalhamento é comum a confecção de chaves de cisalhamento. Essas chaves aumentam a resistência ao cisalhamento da interface, uma vez que além das parcelas de resistência proporcionadas pela armadura transversal e pelo atrito na superfície de contato, elas proporcionam uma parcela adicional devido à resistência ao cisalhamento do concreto da chave. Elas têm sido muito utilizadas nas ligações horizontais de painéis pré-moldados de concreto empregados na construção de edifícios. Os primeiros estudos de que se tem notícia sobre o comportamento das chaves de cisalhamento submetidas a esforços horizontais foram realizados por FAUCHART; CORTINI (1972) e LACOMBE; POMMERET (1974). Nesses estudos os autores mostraram que o modo de ruptura das chaves de cisalhamento é função das suas dimensões (Figura 2.5). Estudos mais recentes em painéis pré-moldados foram realizados por FROSCH (1999), ABDUL-WAHAB (1986), CHAKRABARTI et al. (1988), FOERSTER et al. (1989) e SERRETTE et al. (1989), e em corpos-de-prova de cisalhamento direto por ANNAMALAI; BROWN JR. (1990). A principal conclusão desses trabalhos foi que a presença das chaves de cisalhamento aumentou significativamente a resistência da ligação aos esforços de cisalhamento quando comparado com painéis com superfície de ligação plana. O comportamento das chaves de cisalhamento, empregadas na ligação de aduelas de concreto pré-moldado no processo de construção de pontes por balanços sucessivos, foi estudado por KANEKO (1992), KANEKO et al. (1993 $\left.{ }^{\mathrm{a}}\right)$, KANEKO et al. (1993 ${ }^{\mathrm{b}}$ ) e KANEKO; MIHASHI (1999). Nesses trabalhos, os autores desenvolveram um modelo mecânico baseado na mecânica da fratura que apresentou bons resultados quando comparados com resultados experimentais (BAKHOUM (1991)). Vale ressaltar também o trabalho realizado por ALMEIDA (1982) no laboratório da EESC-USP. Nesse trabalho, o autor ensaiou ligações de parabolóides elípticos prémoldados com chave de cisalhamento, tendo obtido resultados semelhantes aos de outros autores. 


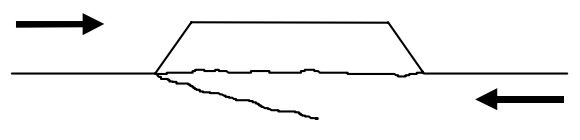

a) cisalhamento da base

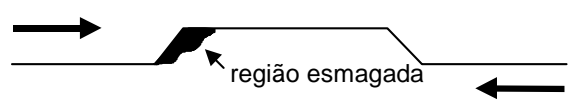

b) esmagamento do concreto

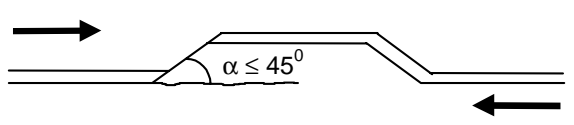

c) deslizamento

Figura 2.5 - Modos de ruptura das chaves de cisalhamento.

SOUDKI et al. (1995) e SOUDKI et al. (1996) realizaram ensaios em painéis prémoldados com chave de cisalhamento submetidos a carregamento cíclico. Eles observaram que a presença das chaves de cisalhamento reduziu o deslizamento entre os painéis ao final do ensaio quando comparado aos painéis sem chaves de cisalhamento. Além disso, concluíram que não havia grande degradação na ligação com chave de cisalhamento quando submetida a carregamento cíclico, sendo sua resistência avaliada pelas mesmas expressões formuladas a partir de carregamento estático.

Recentemente, tem aumentado a aplicação de concretos de alta resistência em estruturas, contudo ainda existem dúvidas sobre seu comportamento quando submetido tanto a solicitações provenientes de flexão quanto a solicitações tangenciais. Aliás, as dificuldades começam na diferenciação entre concreto de resistência normal e concreto de alta resistência. Alguns autores sugerem que a partir de $45 \mathrm{MPa}$ de resistência à compressão já se pode falar em alta resistência. Essa discussão, contudo, não é relevante, uma vez que esse limite varia em função da tecnologia disponível em cada região, e tende a aumentar na medida em que há uma maior industrialização da construção civil e uma maior difusão do emprego de materiais como, por exemplo, a sílica ativa.

Inúmeras pesquisas foram realizadas nos últimos anos e diversas formulações foram propostas para representar a relação entre a tensão e a deformação do concreto de alta resistência, tanto à compressão quanto à tração. São tantas expressões que seria praticamente impossível listar todas elas em único texto. Limita-se aqui, portanto, a analisar a influência do aumento da resistência à compressão do concreto sobre sua resistência ao cisalhamento. Nesse sentido, merece destaque o trabalho de WALRAVEN; STROBAND 
(1994) que estudou corpos-de-prova de cisalhamento direto com resistência à compressão de $100 \mathrm{MPa}$. Eles observaram que quando a fissuração da matriz de cimento era acompanhada pela ruptura dos agregados, a resistência ao cisalhamento do concreto simples valia aproximadamente $35 \%$ da resistência avaliada pelas expressões usuais da teoria atrito-cisalhamento. Quando havia armadura atravessando a interface, a ruptura dos agregados proporcionava uma redução menor, e a resistência ao cisalhamento valia de $55 \%$ a $75 \%$ da resistência admitindo não haver a ruptura dos agregados. Esse fenômeno ocorre quando a matriz torna-se mais resistente que o agregado, o qual não é mais capaz de desviar a direção da fissura e termina rompendo por cisalhamento. Isto deixa claro que o aumento na resistência à compressão não é necessariamente acompanhado por um aumento na resistência ao cisalhamento da mesma proporção. Para contornar esse problema, é necessário impedir que a fissuração da matriz de cimento seja acompanhada pela ruptura dos agregados, o que pode ser feito, por exemplo, empregando agregados mais resistentes ou acrescentando materiais que limitem a abertura das fissuras como, por exemplo, as fibras.

Ainda existem poucos trabalhos analisando a interface de peças de concreto de alta resistência. No caso da interface formada pela fissuração de uma peça monolítica, pode-se citar o trabalho de GUPTA; RANGAN (1998), onde os autores incorporaram na teoria de campo de compressão modificada (MCFT) uma relação tensão - deformação para o concreto representando o comportamento de concretos de alta resistência. Esse modelo modificado foi utilizado para avaliar a resistência de painéis de concreto com resistência a compressão variando de $60 \mathrm{MPa}$ a $80 \mathrm{MPa}$, tendo sido obtida boa concordância com os resultados experimentais. No caso da interface formada por duas peças de concreto moldadas em idades diferentes, pode-se citar o trabalho de ZILCH; REINECKE (2000), que observaram um aumento na resistência da interface quando um dos concretos era de alta resistência. Também se deve citar o trabalho de MATTOCK (2001) que propõe algumas modificações nas equações da teoria atrito-cisalhamento para considerar os concretos de alta resistência. Finalmente, tem-se o trabalho de ALI; WHITE (1999) que propõem um modelo mecânico para avaliar a resistência ao cisalhamento de concretos de média e alta resistência.

\subsubsection{Concreto reforçado com fibras}

A idéia de se reforçar a matriz frágil de concreto para torná-la mais homogênea e mais dúctil data de longo tempo. A introdução de fibras curtas ao concreto melhora a 
ductilidade, a resistência ao impacto, a resistência à fadiga, o controle da fissuração, o comportamento pós-fissuração e, em alguns casos, a resistência à tração. Algumas dessas vantagens são sensíveis à quantidade e ao tipo de fibra adicionada. As fibras, em quantidade, comprimento e formato adequado, podem incorporar deformações plásticas significativas à matriz, melhorando seu emprego na construção civil, já que se pode alterar o comportamento pós-fissuração e tornar menos brusca a ruptura do material. Esta última característica, aliás, é fundamental para a aplicação prática de concretos de alta resistência. Para se ter uma idéia, a adição de $60 \mathrm{~kg} / \mathrm{m}^{3}$ de fibras a um concreto de alta resistência, o que corresponde a um volume de aproximadamente $0,75 \%$, já é suficiente para que o comportamento do ramo descendente da curva tensão-deformação na compressão seja semelhante ao comportamento de um concreto de resistência normal sem adição de fibras. (TAERWE (1992)).

Por ser descontínua, a fibra é menos eficiente que a armadura contínua de fios e barras na função de resistir aos esforços de tração e de cisalhamento. Contudo, devido ao espaçamento reduzido entre elas, sua atuação como obstáculo ao desenvolvimento das fissuras é superior. Ao interceptar as microfissuras que surgem durante o endurecimento da pasta, as fibras impedem sua progressão e evitam o aparecimento prematuro das microfissuras. Na mistura endurecida, a abertura e o comprimento das fissuras também se tornam menores.

Quando as fibras são combinadas com armadura contínua, ambas se tornam mais eficientes. As fibras melhoram a aderência do concreto com a armadura, quando corrugada, inibindo a fissuração na região de transferência de esforços da armadura para o concreto (HARAJLI; SALLOUKH (1997)). Além disso, elas "costuram" as fissuras, constituindo-se em um reforço adicional.

A quantidade máxima de fibras que pode ser adicionada ao concreto é influenciada pela dimensão máxima dos agregados. Em misturas com presença predominante de partículas graúdas, há uma maior dificuldade na uniformização das fibras. Isto explica a maior facilidade de se adicionar fibras em argamassas do que em concretos. A dificuldade de uniformizar a distribuição das fibras na matriz, devido ao embolamento e agrupamento das fibras, é comum a quase todos os tipos de fibra, embora em níveis diferentes. Outro problema relacionado com a utilização das fibras é a tendência de diminuição da fluidez do concreto, embora isso possa ser solucionado realizando uma melhor vibração da mistura. São alternativas usuais para melhorar a trabalhabilidade do concreto o uso de aditivos superplastificantes e a substituição de parte do cimento por pozolanas. O aumento da 
relação água/cimento também pode ajudar, em detrimento da resistência, mas acima de um determinado valor torna-se ineficiente.

Segundo BENTUR; MINDESS (1990), a utilização recente das fibras como reforço para o concreto ocorreu em duas frentes distintas: nas peças delgadas, visando a busca de compósitos substitutivos do cimento-amianto (com volumes acima de 5\% para melhorar a tenacidade, a durabilidade e a resistência da matriz de cimento), e em peças de concreto como armadura secundária (com volumes reduzidos de até $2 \%$ ) para melhorar a tenacidade, o controle da fissuração induzida e o desempenho sob forças dinâmicas.

Nos compósitos produzidos a partir de técnicas convencionais de mistura, com volumes reduzidos, a primeira evidência da influência das fibras no concreto tracionado ocorre somente após a ruptura da matriz. O comportamento pós-pico do material é expressa em função da força de costura das fibras e da abertura das fissuras, as quais podem ser determinadas experimentalmente ou por análises micromecânicas. Nos compósitos produzidos com técnicas especiais, com volumes de até $15 \%$, ao contrário, altera-se a natureza da matriz, aumentando muito os valores do módulo de deformação longitudinal e da resistência à tração. Seria uma nova classe de materiais, cujo comportamento à flexão se aproxima do comportamento do aço.

O mecanismo básico do reforço das fibras deve-se à diferença na capacidade de deformação das fibras e da matriz. Inicialmente, ambas se deformam conjuntamente até a ruptura da matriz quando a força resistida pela matriz é transferida para as fibras. A idealização deste comportamento está baseada na transferência de tensões de aderência entre a fibra e a matriz junto às fissuras. Portanto, ele depende das propriedades da fibra e da matriz e, principalmente, da tensão de aderência na interface entre elas.

A microestrutura do concreto é das mais complexas dentre os materiais estruturais. A microestrutura da interface pasta-agregado (zona de transição) é diferente da microestrutura da pasta. $\mathrm{Na}$ interface, onde se desenvolve a microfissuração, o fator água/cimento é maior devido à exsudação interna. Isto resulta em uma morfologia cristalina diferente e em menor resistência mecânica. À zona de transição é atribuída a causa da ruptura do concreto a um nível de tensão mais baixo do que a resistência dos seus dois materiais constituintes principais. A aderência entre a fibra e a matriz pode ser melhorada reduzindo o volume de vazios na zona de transição, o que pode ser conseguido através do uso de sílica ativa, superplastificante ou do aumento do consumo de cimento. Com a melhoria da aderência há um acréscimo na resistência à tração e na ductilidade. 
A aderência entre a fibra e a matriz é medida em ensaios de arrancamento. Destes ensaios, observa-se que as fibras lisas e retas perdem a aderência rapidamente com o início do escorregamento da fibra. Nas fibras com ganchos nas extremidades há uma tendência de retificação do gancho antes de ocorrer o escorregamento. Desta forma, o acréscimo de resistência é significativo, chegando a ser 3 a 4 vezes maior que a resistência da fibra reta. Estas fibras também proporcionam um aumento muito grande na energia dissipada durante o ensaio de arrancamento.

Diversos tipos de fibras podem ser adicionados ao concreto, sendo a escolha feita em função das propriedades que se deseja modificar. Na Tabela 2.1 são apresentadas as características de algumas fibras utilizadas como reforço no concreto, incluindo, para comparação, as características da matriz de cimento.

Tabela 2.1 - Principais características das fibras (BENTUR;MINDESS (1990)).

\begin{tabular}{|c|c|c|c|c|c|}
\hline Tipo de fibra & $\begin{array}{c}\text { Diâmetro } \\
(\mu \mathrm{m})\end{array}$ & $\begin{array}{c}\text { Peso } \\
\text { específico } \\
\left(\mathrm{g} / \mathrm{cm}^{3}\right)\end{array}$ & $\begin{array}{c}\text { Módulo de } \\
\text { deformação } \\
\text { longitudinal } \\
(\mathrm{GPa})\end{array}$ & $\begin{array}{c}\text { Resistência } \\
\text { à tração } \\
(\mathrm{GPa})\end{array}$ & $\begin{array}{c}\text { Alongamento } \\
\text { na ruptura } \\
(\%)\end{array}$ \\
\hline aço & $5-500$ & 7,84 & 200 & $0,5-2,0$ & $0,5-3,5$ \\
\hline $\begin{array}{c}\text { Polipropileno } \\
\text { fibrilada }\end{array}$ & $20-200$ & 0,9 & $5-77$ & $0,5-0,75$ & 8 \\
\hline vidro & $9-15$ & $2-60$ & $70-80$ & $2-4$ & $2-3,5$ \\
\hline amianto & $0,02-0,4$ & $2,6-3,4$ & $164-196$ & $3,1-3,5$ & $2-3$ \\
\hline Polietileno & - & 0,95 & 0,3 & 0,0007 & 10 \\
\hline sisal & $10-50$ & 1,5 & - & 0,8 & 3,0 \\
\hline $\begin{array}{c}\text { matriz de } \\
\text { cimento }\end{array}$ & - & 2,5 & $10-45$ & 0,0004 & 0,02 \\
\hline
\end{tabular}

\subsubsection{Resistência à compressão}

O aumento proporcionado pelas fibras na resistência à compressão raramente excede $25 \%$. Nas aplicações usuais, a quantia de fibras adicionadas ao concreto é limitada a $60 \mathrm{~kg} / \mathrm{m}^{3}$ ou $0,75 \%$. Para essa quantia de fibras, o aumento da resistência à compressão pode ser desprezado. Apenas quando a quantidade de fibras é maior que $120 \mathrm{~kg} / \mathrm{m}^{3}$ espera-se um aumento na resistência. Em muitos casos, a resistência pode até ser menor 
do que a do concreto sem adição de fibras, uma vez que ocorre a incorporação de vazios ao concreto quando as fibras são adicionadas.

A contribuição mais significativa das fibras está no aumento da ductilidade do concreto, sendo mais pronunciado quando a quantidade de fibras varia de 0 a $0,7 \%$ do que quando são empregadas grandes quantidades de fibras. Para concretos convencionais, a adição de $60 \mathrm{~kg} / \mathrm{m}^{3}$ de fibras de aço com ganchos nas extremidades é suficiente para proporcionar uma boa ductilidade do material, enquanto para concretos de alta resistência é necessário a adição de $120 \mathrm{~kg} / \mathrm{m}^{3}$ para proporcionar ductilidade semelhante (Figura 2.6).

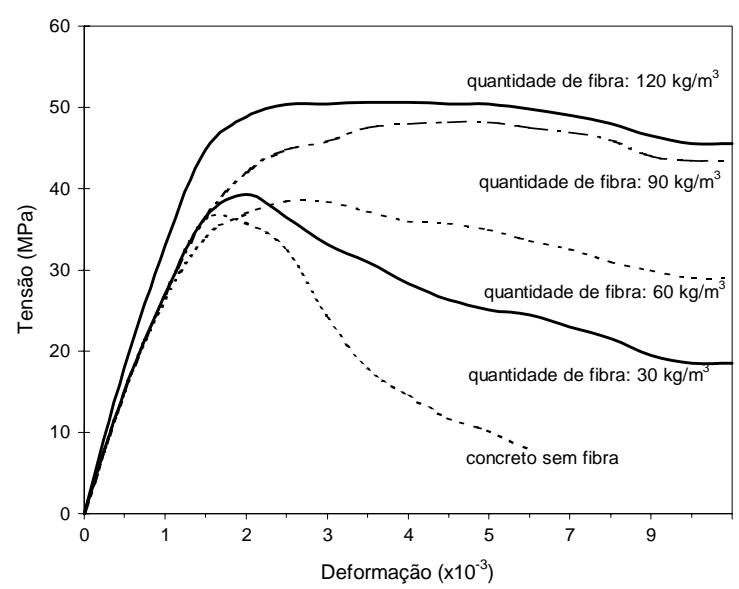

(a) concreto normal com fibras de aço de $50 \mathrm{~mm}$

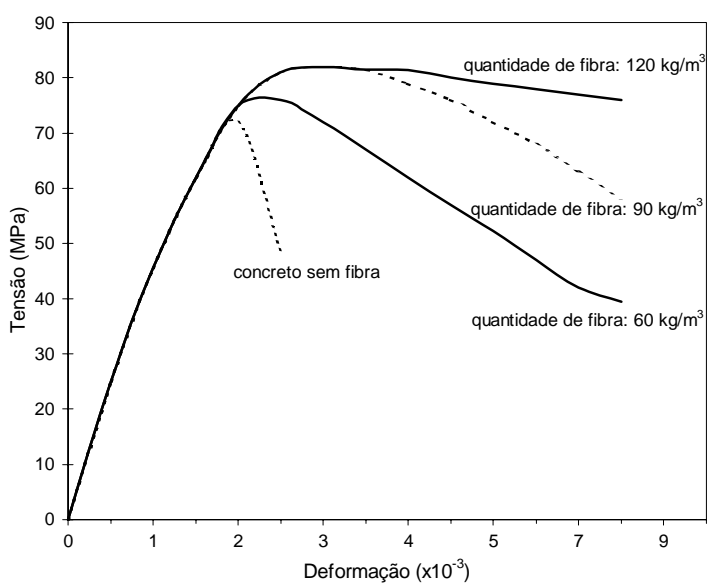

(b) concreto de alta resistência com fibras de aço de $30 \mathrm{~mm}$

Figura 2.6 - Curva tensão-deformação na compressão uniaxial para concretos com fibras de aço (BALAGURU;SHAH (1992)).

A geometria das fibras, a qual é definida pelo fator de forma, ou seja, a relação entre o comprimento da fibra e seu diâmetro equivalente, influi na ductilidade do concreto à compressão. Para as fibras lisas, o aumento do fator de forma resulta em um aumento da ductilidade do concreto, sendo seu limite definido pela capacidade de mistura-las ao concreto. As fibras com ganchos nas extremidades proporcionam maior capacidade de absorção de energia ao concreto que as fibras lisas. O fator de forma também é um fator importante, entretanto não é tão significativo quanto nas fibras lisas.

\subsubsection{Curva tensão-deformação na compressão}

Existem na literatura diversas expressões desenvolvidas com o objetivo de representar o comportamento à compressão dos concretos reforçados com fibras, incluindo o ramo de amolecimento do concreto ("strain softening"). Nessas expressões, a relação 
entre a tensão aplicada e a respectiva deformação do material é obtida a partir das características das fibras empregadas. A seguir são mostradas, de forma resumida, algumas expressões que serão empregadas no capítulo seguinte.

\section{- EZELDIN; BALAGURU (1992)}

Nesse trabalho os autores estudaram concretos com resistência à compressão variando de $35 \mathrm{MPa}$ a $85 \mathrm{MPa}$. Foram empregadas fibras metálicas com ganchos nas extremidades e fatores de forma de 60, 75 e 100. O volume máximo de fibras adicionadas foi de $0,75 \%\left(60 \mathrm{~kg} / \mathrm{m}^{3}\right)$. A expressão que fornece a tensão no material em função de sua deformação foi definida como:

$$
\frac{\sigma_{\mathrm{c}}}{\mathrm{f}_{\mathrm{c}}}=\frac{\beta \frac{\varepsilon_{\mathrm{c}}}{\varepsilon_{\mathrm{c}, \mathrm{lim}}}}{\beta-1+\left(\frac{\varepsilon_{\mathrm{c}}}{\varepsilon_{\mathrm{c}, \mathrm{lim}}}\right)^{\beta}}
$$

onde

$$
\begin{aligned}
& \beta=\left(\frac{f_{c}}{32,4}\right)^{3}+1,55 \quad \text { para } V_{f}=0 \% \\
& \beta=1,093+0,7132(R I)^{-0,926} \quad \text { para } V_{f}<0,75 \% \\
& \varepsilon_{c, \lim }=0,002+0,000446 \mathrm{RI} \\
& \mathrm{RI}=\mathrm{W}_{\mathrm{f}} \frac{\ell}{\mathrm{d}} \text { é o índice de reforço de fibras. }
\end{aligned}
$$

Nessas expressões, $f_{c}$ é a resistência do concreto em $M P a, \varepsilon_{c, l i m}$ a deformação correspondente à tensão $f_{c}, V_{f}$ é o volume de fibras adicionadas, $\ell$ é o comprimento e $d o$ diâmetro equivalente das fibras, respectivamente. $O$ parâmetro $W_{f}$ é a fração, em peso, de fibras adicionadas, que pode ser relacionada, de forma aproximada, com o volume de fibras por $W_{f} \cong 3,27 V_{f}$.

\section{- $\quad \underline{H S U} ; \underline{H S U} \underline{(1994)}$}

Nesse trabalho os autores estudaram concretos com resistência à compressão variando de $62 \mathrm{MPa}$ a $88 \mathrm{MPa}$. Foram empregadas fibras metálicas com ganchos nas extremidades e fator de forma de 60 . O volume máximo de fibras adicionadas foi de 1,0\% $\left(80 \mathrm{~kg} / \mathrm{m}^{3}\right)$. A expressão que fornece a tensão no material em função de sua deformação foi definida como: 


$$
\begin{aligned}
& \frac{\sigma_{c}}{f_{c}}=\frac{n \beta x}{n \beta-1+x^{n \beta}} \quad \text { para } 0 \leq x \leq x_{d} \\
& \frac{\sigma_{c}}{f_{c}}=0,6 e^{\left(-0,7\left(x-x_{d}\right)^{0,8}\right)} \quad \text { para } \quad x>x_{d} \\
& \text { onde } \\
& x=\frac{\varepsilon_{c}}{\varepsilon_{c, l i m}} \\
& \beta=\frac{1}{1-\frac{f_{c}}{\varepsilon_{c, l i m} E_{c}}} \text { para concreto sem fibra } \\
& \beta=\left(\frac{f_{c}}{A}\right)^{3}+C \quad \text { para concreto com fibra } \\
& A=1,717\left(V_{f}\right)^{3}+8,501 \quad \text { e } C=-0,26 V_{f}+2,742 \\
& \varepsilon_{c, l i m}=a_{1} f_{c}+C \quad \text { para concreto com fibra } \\
& E_{c}=a_{2} f_{c}+C_{2} \quad \text { para concreto com fibra } \\
& \varepsilon_{c, l i m}=0,002 \quad \text { e } E_{c}=4700 \sqrt{f_{c}} \quad \text { para concreto sem fibra }
\end{aligned}
$$

Nessas expressões, $x_{d}$ é a deformação, no ramo descendente, correspondente à tensão de $0,6 f_{c}, f_{c}$ a resistência do concreto em MPa, $\varepsilon_{c, l i m}$ a deformação correspondente à tensão $f_{c}, E_{c} \circ$ módulo de elasticidade tangente inicial em MPa, e $V_{f} O$ volume de fibras adicionadas. Os parâmetros $n, a_{1}, a_{2}, C_{1}$ e $C_{2}$ são definidos pelos autores em função da resistência do concreto e do volume de fibras adicionadas.

\section{- $\quad$ MANSUR et al. $\underline{\text { (1999) }}$}

Nesse trabalho os autores estudaram concretos com resistência à compressão variando de $70 \mathrm{MPa}$ a $120 \mathrm{MPa}$. Foram empregadas fibras metálicas com ganchos nas extremidades e fator de forma de 60 . O volume máximo de fibras adicionadas foi de $1,5 \%$ $\left(120 \mathrm{~kg} / \mathrm{m}^{3}\right)$. A expressão que fornece a tensão no material em função de sua deformação foi definida como: 


$$
\begin{array}{ll}
\frac{\sigma_{\mathrm{c}}}{\mathrm{f}_{\mathrm{c}}}=\frac{\beta \frac{\varepsilon_{\mathrm{c}}}{\varepsilon_{\mathrm{c}, \mathrm{lim}}}}{\beta-1+\left(\frac{\varepsilon_{\mathrm{c}}}{\varepsilon_{\mathrm{c}, \mathrm{lim}}}\right)^{\beta}} & \text { para } \varepsilon_{\mathrm{c}} \leq \varepsilon_{\mathrm{c}, \mathrm{lim}} \\
\frac{\sigma_{\mathrm{c}}}{\mathrm{f}_{\mathrm{c}}}=\frac{\mathrm{k}_{1} \beta \frac{\varepsilon_{\mathrm{c}}}{\varepsilon_{\mathrm{c}, \mathrm{lim}}}}{\mathrm{k}_{1} \beta-1+\left(\frac{\varepsilon_{\mathrm{c}}}{\varepsilon_{\mathrm{c}, \mathrm{lim}}}\right)^{\mathrm{k}_{2} \beta}} & \text { para } \varepsilon_{\mathrm{c}}>\varepsilon_{\mathrm{c}, \mathrm{lim}}
\end{array}
$$

onde

$$
\begin{aligned}
& \beta=\frac{1}{1-\frac{f_{c}}{\varepsilon_{c, l i m} E_{c}}} \\
& k_{1}=\left(\frac{50}{f_{c}}\right)^{3}\left[1+2,5\left(\frac{V_{f} \ell}{d}\right)^{2,5}\right] \\
& k_{2}=\left(\frac{50}{f_{c}}\right)^{1,3}\left[1-0,11\left(\frac{V_{f} \ell}{d}\right)^{-1,1}\right] \\
& \varepsilon_{c, \lim }=\left[0,00050+0,00000072\left(\frac{V_{f} \ell}{d}\right)\right] f_{c}^{0,35} \\
& E_{c}=\left(10300-400 V_{f}\right) f_{c}^{1 / 3}(M P a)
\end{aligned}
$$

Nessas expressões, $\mathrm{f}_{\mathrm{c}}$ é a resistência do concreto em $\mathrm{MPa}, \varepsilon_{\mathrm{c}, \text { lim }}$ a deformação correspondente à tensão $\mathrm{f}_{\mathrm{c}}, \mathrm{E}_{\mathrm{c}} \mathrm{O}$ módulo de elasticidade tangente inicial em MPa, $\mathrm{V}_{\mathrm{f}}$ é o volume de fibras adicionadas, $\ell$ é o comprimento e $d$ o diâmetro equivalente das fibras, respectivamente.

- NATARAJA et al. $\underline{\text { (1999) }}$

Nesse trabalho os autores estudaram concretos com resistência à compressão variando de $30 \mathrm{MPa}$ a $50 \mathrm{MPa}$. Foram empregadas fibras metálicas onduladas com fatores de forma de 55 e 82 . O volume máximo de fibras adicionadas foi de 1,0\%. A expressão que fornece a tensão no material em função de sua deformação foi definida como: 


$$
\frac{\sigma_{\mathrm{c}}}{\mathrm{f}_{\mathrm{c}}}=\frac{\beta \frac{\varepsilon_{\mathrm{c}}}{\varepsilon_{\mathrm{c}, \mathrm{im}}}}{\beta-1+\left(\frac{\varepsilon_{\mathrm{c}}}{\varepsilon_{\mathrm{c}, \mathrm{lim}}}\right)^{\beta}}
$$

onde

$$
\begin{aligned}
& \beta=\left(\frac{f_{c}}{32,4}\right)^{3}+1,55 \quad \text { para } V_{f}=0 \% \\
& \beta=0,5811+1,93(R I)^{-0,7406} \quad \text { para } V_{f}<1,0 \% \\
& \varepsilon_{c, \text { lim }}=0,002+0,0006 R I \\
& R I=W_{f} \frac{\ell}{d} \text { é o índice de reforço de fibras. }
\end{aligned}
$$

Nessas expressões, $f_{c}$ é a resistência do concreto em $\mathrm{MPa}, \varepsilon_{\mathrm{c}, \text { lim }}$ a deformação correspondente à tensão $\mathrm{f}_{\mathrm{c}}, \mathrm{V}_{\mathrm{f}}$ é o volume de fibras adicionadas, $\ell$ é o comprimento e $d \mathrm{o}$ diâmetro equivalente das fibras, respectivamente. O parâmetro $W_{f}$ é a fração, em peso, de fibras adicionadas, que pode ser relacionada, de forma aproximada, com o volume de fibras por $W_{f} \cong 3,27 V_{f}$

\section{- BARROS; FIGUEIRAS $\underline{(1999)}$}

Nesse trabalho os autores estudaram concretos com resistência à compressão variando de $30 \mathrm{MPa}$ a $60 \mathrm{MPa}$. Foram empregadas fibras metálicas com ganchos nas extremidades e fatores de forma de 60 e 75. O volume máximo de fibras adicionadas foi de $0,75 \%\left(60 \mathrm{~kg} / \mathrm{m}^{3}\right)$. A expressão que fornece a tensão no material em função de sua deformação foi definida como:

$$
\frac{\sigma_{c}}{f_{c}}=\frac{\frac{\varepsilon_{c}}{\varepsilon_{c, \text { lim }}}}{(1-p-q)+q\left(\frac{\varepsilon_{c}}{\varepsilon_{c, \text { lim }}}\right)+p\left(\frac{\varepsilon_{c}}{\varepsilon_{c, \text { lim }}}\right)^{(1-q) / p}}
$$

onde

$$
\begin{aligned}
& q=1-p-\frac{E_{c s}}{E_{c}}, \quad 0<p+q<1, \quad \frac{1-q}{p}>0 \\
& \varepsilon_{c, \lim }=0,0022+0,0002 W_{f} \quad \text { para } \ell / d=60
\end{aligned}
$$




$$
\begin{array}{ll}
\varepsilon_{c, \lim }=0,0022+0,00026 \mathrm{~W}_{\mathrm{f}} & \text { para } \ell / d=75 \\
p=1-0,919 \mathrm{e}^{-0,394 \mathrm{~W}_{\mathrm{f}}} & \text { para } \ell / d=60 \\
\mathrm{p}=1-0,722 \mathrm{e}^{-0,144 \mathrm{~W}_{\mathrm{f}}} & \text { para } \ell / d=75
\end{array}
$$

Nessas expressões, $f_{c}$ é a resistência do concreto em $M P a, \varepsilon_{c, l i m}$ a deformação correspondente à tensão $f_{c}, \ell$ é o comprimento e $d$ o diâmetro equivalente das fibras, respectivamente. $O$ parâmetro $W_{f}$ é a fração, em peso, de fibras adicionadas, que pode ser relacionada, de forma aproximada, com o volume de fibras por $W_{f} \cong 3,27 V_{f}$.

\subsubsection{Resistência à tração}

Nas aplicações usuais, a porcentagem de fibras é inferior a 3\%, o que não proporciona grande aumento na resistência à tração. Em concretos de alta resistência, contudo, a melhor aderência entre a fibra e a matriz pode proporcionar aumentos de até $200 \%$ na resistência à tração, como observado em ensaios realizados com concreto leve (BALAGURU; SHAH (1992)).

As fibras contribuirão de forma significativa na resistência à tração apenas quando $V_{f}>V_{f, \text { crit }} \approx 2 \cdot \frac{\sigma_{m}}{\tau_{f u}} \cdot \frac{1}{\ell / d}$, onde $V_{f, \text { crit }}$ é o volume crítico de fibras, $\tau_{f u}$ é a máxima tensão de aderência entre a fibra e a matriz, $\ell$ é o comprimento da fibra, d é o diâmetro da fibra, e $\sigma_{\mathrm{m}}$ é a resistência à tração da matriz. Neste caso, o modo de fratura do compósito é caracterizado pela fissuração múltipla da matriz. Após o surgimento da primeira fissura, a força aplicada na matriz é transferida para as fibras que estão em quantidade suficiente para resistir à força sem atingir a ruptura. Acréscimos na força provocarão o surgimento de novas fissuras na matriz, os quais serão resistidos pelas fibras até ser atingida a força de arrancamento das mesmas. Por outro lado, quando $V_{f}<V_{f, \text { crit, }}$ o modo de ruptura é caracterizado pela propagação de uma única fissura principal que surge na matriz quando a solicitação é igual à $\sigma_{\mathrm{m}}$. Neste caso, em virtude do volume de fibras ser insuficiente para provocar a fissuração múltipla da matriz, a ruptura é frágil e a resistência do compósito é menor. O volume crítico é função do fator de forma da fibra e da aderência entre a fibra e a matriz. A partir de ensaios experimentais, determinou-se que os valores de $\tau_{\mathrm{fu}}$ variam de $1 \mathrm{a}$ $10 \mathrm{MPa}$. Admitindo uma matriz com resistência à tração de $3 \mathrm{MPa}$ e considerando que o fator de forma das fibras encontra-se entre 50 e 100, o volume crítico varia de $1 \%$ a $3 \%$. Em muitos casos, não é possível adicionar fibras ao concreto em quantidade superior ao volume 
crítico. Neste caso, a presença das fibras proporciona maior ductilidade após a fissuração, mas não aumenta significativamente a resistência final à tração. (Figura 2.7).

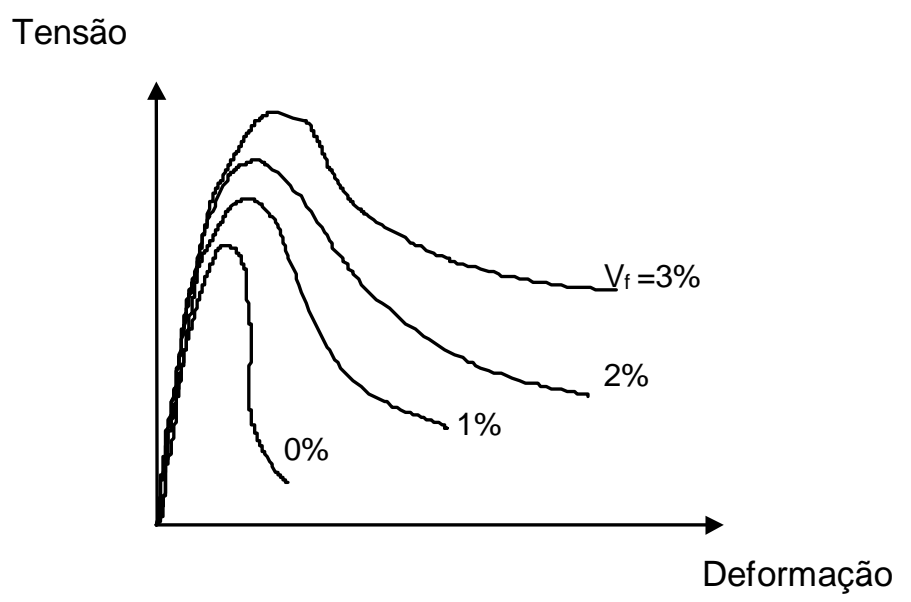

Figura 2.7 - Aspecto geral da curva tensão-deformação para ensaios de tração direta em concreto com e sem adição de fibras.

Existem alguns modelos constitutivos consistentes para o concreto reforçado com fibras relatados na literatura. Esses modelos apresentam relações tensão-deformação, na compressão e na tração, quase sempre baseadas em resultados experimentais. Quando inseridos em programas computacionais baseados no método dos elementos finitos, eles podem representar com boa precisão o comportamento de peças de concreto reforçadas com fibras submetidas a esforços de flexão (AL-TAAN; EZZADEEN (1995), SIMÕES (1998)).

\subsubsection{Tenacidade}

Um dos principais motivos para a adição de fibras ao concreto é proporcionar um aumento da capacidade de absorção de energia pela matriz. Essa energia pode ser avaliada pela área sob a curva tensão-deformação em ensaios de compressão ou pela área sob a curva força-deslocamento em ensaios de corpo-de-prova prismáticos submetidos a forças concentradas nos terços do vão. A partir dessa área, calcula-se o índice de tenacidade, o qual mede a capacidade de absorção de energia pelo material antes da ruptura. $O$ aumento da tenacidade implica também em um melhor comportamento do material à fadiga e ao impacto. 
Para um determinado tipo de fibra, o aumento no volume das fibras proporciona um aumento na capacidade de absorção de energia pelo compósito. Para uma determinada geometria de fibra, fibras longas proporcionam maior tenacidade. Esse efeito é mais significativo no caso de fibras lisas. As fibras onduladas apresentam melhor ancoragem e o fator de forma influencia menos do que nas fibras lisas. Para um determinado volume e comprimento de fibra, as fibras onduladas proporcionam maior tenacidade. As fibras com ganchos nas extremidades proporcionam os melhores resultados.

As fibras poliméricas possuem módulo de elasticidade menor que o das fibras de aço. Logo, as vigas reforçadas com essas fibras apresentam deslocamentos maiores antes que as fibras sejam solicitadas. A energia absorvida pelo compósito com fibras de aço é maior que a energia absorvida pelo compósito com fibras poliméricas.

\subsubsection{Concreto reforçado com fibras submetido à fadiga e ao impacto}

As fibras proporcionam substancial aumento na resistência à fadiga e ao impacto. Essa é umas das principais razões para a utilização do concreto reforçado com fibras em pavimentos e tabuleiros de pontes. Nestas estruturas, o material está submetido a milhões de ciclos de carregamento e descarregamento durante sua vida útil, além de estar sujeito a algumas solicitações de impacto. Basicamente, o bom desempenho do concreto reforçado com fibras deve-se ao aumento da capacidade de absorção de energia pelo material antes da ruptura. Em especial no caso de solicitações de impacto, a fissuração múltipla na tração garante maior desempenho desse material quando comparado ao concreto sem fibra.

\subsubsection{As fibras e o cisalhamento}

A melhoria no desempenho de elementos de concreto submetidos a solicitações tangenciais devido à introdução de fibras foi registrada por diversos pesquisadores pelo aumento da capacidade resistente e, eventualmente, pela alteração da forma de ruptura. A substituição parcial dos estribos por um volume conveniente de fibras é vantajosa sob vários aspectos: obtenção de resistência igual em todas as direções devido à distribuição aleatória das fibras, maior resistência à fissuração, melhor propagação das fissuras, facilidade de produção e outros.

Ensaios experimentais em vigas com estribos e em vigas sem estribos com $1 \%$ de fibras registraram similaridade de comportamento. Isto significa que para valores compatíveis de taxa de armadura transversal $\left(\rho_{\text {sw }}\right)$ e volume de fibras $\left(V_{f}\right)$, pode-se manter a 
capacidade resistente da viga substituindo-se os estribos pelas fibras, sem alterações na parcela de resistência adicional após o aparecimento da fissura diagonal e na configuração das fissuras. Além disso, para volumes crescentes de fibra, a ruptura por cisalhamento pode ser substituída pela ruptura por flexão-cisalhamento ou por flexão, o que confirma a contribuição das fibras na resistência ao cisalhamento (FURLAN JR. (1995)).

A consideração das fibras na resistência ao cisalhamento normalmente é feita de forma empírica através de uma parcela resistente adicional. No entanto, existem alguns modelos mecânicos consistentes sobre a atuação das fibras que são baseados em modelos convencionalmente aplicados para peças de concreto armado ou protendido. Por exemplo, SWAMY et al. (1993) realizaram ensaios em vigas de concreto leve reforçadas com fibras e sem armadura de cisalhamento, e, baseados na analogia da treliça como mecanismo resistente, propuseram uma expressão para a resistência proporcionada pelas fibras. Basicamente, eles idealizaram uma fissura inclinada de $45^{\circ}$, conforme mostrado na Figura 2.8. Devido à existência das fibras atravessando a fissura, para que ela continue abrindo é necessário haver a ruptura ou o arrancamento das fibras, o que proporciona uma força resistente adicional normal ao plano da fissura. A componente vertical dessa força representa a contribuição das fibras na resistência ao cisalhamento, sendo adicionada às parcelas de resistência do concreto e por ação de pino da armadura longitudinal. Outro modelo foi proposto por TAN; MANSUR (1990) e TAN et al. (1993) a partir de ensaios em vigas de concreto reforçadas com fibras e sem armadura de cisalhamento. Este modelo foi obtido pela modificação do modelo de HSU et al. (1987) através da incorporação de uma nova relação tensão-deformação para o concreto com fibras tanto na tração quanto na compressão. Nesses trabalhos, foram observados aumentos significativos na resistência da viga aos esforços de cisalhamento devido à adição de fibras. Diversos outros trabalhos foram realizados em vigas de concreto de alta resistência e, em praticamente todos eles, a adição de fibras também aumentou a resistência da viga ao cisalhamento (LI et al. (1992), ASHOUR et al. (1992), FANG; WU (1994), IMAM et al. (1994), IMAM et al. (1995)).

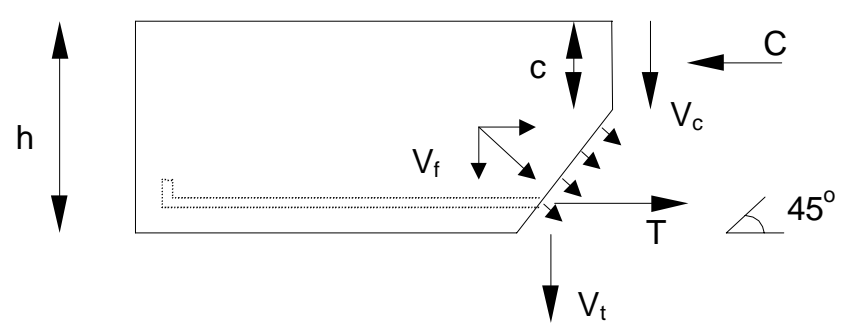

$\mathrm{V}=\mathrm{V}_{\mathrm{c}}+\mathrm{V}_{\mathrm{t}}+\mathrm{V}_{\mathrm{f}}$

$\mathrm{V}_{\mathrm{c}}$ : parcela resistente do concreto

$\mathrm{V}_{\mathrm{t}}$ : parcela resistente da armadura longitudinal

$\mathrm{V}_{\mathrm{f}}$ : parcela resistente das fibras

Figura 2.8 - Transferência de forças transversais em vigas de concreto reforçado com fibras. 
PARAMASIVAM et al. (1995) apresentaram uma formulação, empregada em programas de elementos finitos, para avaliação do comportamento de vigas de concreto reforçadas com fibras e parcialmente protendidas. Essa formulação era baseada na teoria de campo de compressão modificada (MCFT), e os resultados obtidos apresentaram boa concordância com os ensaios experimentais.

Outros pesquisadores estudaram a influência das fibras na resistência ao cisalhamento a partir de ensaios em consolos curtos. FATTUHI (1987) e ABDUL-WAHAB (1989) observaram um aumento na resistência e a modificação da forma de ruptura de consolos curtos devido à adição de fibras. Baseados nessas observações, eles propuseram uma modificação na teoria atrito-cisalhamento de forma a levar em consideração a influência das fibras. MANGAT; HALABI (1996) também realizaram ensaios em consolos curtos e propuseram uma expressão baseada no volume e no fator de forma das fibras adicionadas para avaliar a parcela adicional de resistência ao cisalhamento.

Também são encontrados estudos sobre a influência das fibras na resistência ao cisalhamento realizados a partir de ensaios de cisalhamento direto, como, por exemplo, ALLOS (1989) e VALLE; BÜYÜKÖZTÜRK (1993). Neste último trabalho, os autores estudaram também o efeito das fibras quando adicionadas ao concreto de alta resistência e propuseram uma alteração no modelo de HSU et al. (1987) para levar em consideração a influência das fibras. KHALOO; KIM (1997) também realizaram ensaios em corpos-de-prova de cisalhamento direto com a resistência do concreto variando de $28 \mathrm{MPa}$ a $72 \mathrm{MPa}$ e o volume de fibras variando de 0 a 1,5\%. Eles observaram que a adição de $1 \%$ de fibras de aço com fator de forma igual a 58 ( $\ell=32 \mathrm{~mm}$ e $\mathrm{d}=0,55 \mathrm{~mm}$ ) aumentou em $84 \%$ a resistência ao cisalhamento do corpo-de-prova com concreto de $70 \mathrm{MPa}$ de resistência quando comparado ao mesmo corpo-de-prova sem adição de fibras. Quando a este mesmo concreto foi adicionado $1 \%$ de fibras com fator de forma igual a 29 ( $\ell=16 \mathrm{~mm}$ e $\mathrm{d}=0,55$ $\mathrm{mm}$ ), a resistência ao cisalhamento aumentou em 38\%. Esse aumento foi ainda maior quando o volume de fibras adicionado foi de 1,5\% (105\% para $\ell / d=58$ e $62 \%$ para $\ell / d=29)$. Os autores também observaram que quanto menor a resistência à compressão do concreto, menor era o aumento da resistência ao cisalhamento dos corpos-de-prova. Esse comportamento deve-se ao aumento da aderência entre a fibra e a matriz na medida em que a resistência à compressão é aumentada. Eles também concluíram que, para melhorar o comportamento do concreto de alta resistência ao cisalhamento, deveriam ser empregadas fibras, de elevado fator de forma, em quantidades maiores que no concreto convencional. 
ABDUL-WAHAB (1992) realizou ensaios de cisalhamento direto em painéis prémoldados ligados mediante concreto moldado no local e com superfície de contato plana ou com chave de cisalhamento. Ele observou que a adição de fibras ao concreto da ligação $\left(\mathrm{V}_{\mathrm{f}} \leq 1,5 \%\right)$ proporcionou um aumento na resistência da ligação, principalmente quando ela era realizada com chave de cisalhamento. A partir desses resultados, propôs uma expressão para avaliação da resistência da ligação baseada na resistência ao cisalhamento do concreto com fibras e na resistência por ação de pino da armadura transversal à interface. Aliás, vale ressaltar que a resistência por ação de pino da armadura também é aumentada quando são adicionadas fibras, tanto em carregamento estático quanto em carregamento cíclico (SWAMY; BAHIA (1979), SOROUSHIAN; MIRZA (1991), NAAMAN; BACCOUCHE (1995)).

Diversos ensaios com carregamento cíclico mostraram que a interface entre duas superfícies de concreto apresentava elevada perda de resistência nos primeiros ciclos de carregamento, mantendo-se constante até próximo à ruptura. A adição de fibras, neste caso, poderia melhorar a transferência dos esforços de cisalhamento pela fissura, como observado nas estruturas submetidas a carregamento estático. Contudo, poucos estudos existem sobre a aplicação de fibras em peças submetidas a esforços cíclicos de cisalhamento.

Atualmente, a aplicação mais usual das fibras em estruturas submetidas a carregamento cíclico reversível é na ligação entre viga e pilar pré-moldados. JIURI et al. (1992) realizaram ensaios em doze ligações e observaram que a adição de fibras aumentou a resistência à primeira fissura e a resistência última, bem como a ductilidade e a energia absorvida durante os ciclos de carregamento. SOUBRA et al. (1993) realizaram ensaios em quatro corpos-de-prova formados por duas peças pré-moldadas ligadas por meio de concreto moldado no local, simulando a ligação entre viga e pilar pré-moldados. Eles observaram que a adição de fibras à ligação proporcionava uma menor perda de resistência da ligação nos primeiros ciclos e também um aumento no número de ciclos que provocava a ruptura. VASCONEZ et al. (1998) realizaram ensaios em treze ligações e obtiveram resultados semelhantes. A adição de $2 \%$ de fibras à ligação com concreto de $39 \mathrm{MPa}$ de resistência à compressão aumentou a resistência da ligação em $30 \%$ e a energia dissipada em $350 \%$. Além disso, as fibras diminuíram a concentração de armadura transversal na ligação. Os autores também concluíram que as fibras metálicas eram mais eficientes na melhoria do comportamento da ligação que as fibras de PVA. 


\subsection{Modelos mecânicos de transferência de esforços de cisalhamento}

\subsubsection{Modelo de KANEKO (1992)}

KANEKO (1992) desenvolveu um modelo mecânico para análise e dimensionamento de chaves de cisalhamento em concreto simples ou em concreto reforçado com fibras. Esse modelo foi desenvolvido empregando a teoria da mecânica da fratura elástica linear (LEFM) em conjunto com a teoria de bielas e tirantes conforme apresentado em HSU et al. (1987).

Na Figura 2.9 é mostrada a seqüência de fissuração idealizada para uma chave de cisalhamento quando solicitada até a ruptura. Essa seqüência foi observada por BAKHOUM (1991) que realizou uma série de ensaios em corpos-de-prova de cisalhamento direto com chave de cisalhamento na ligação (Figura 2.10). Nas primeiras etapas de carregamento, há uma forte concentração de tensões de tração no canto inferior da chave. Quando essas tensões ultrapassam a resistência à tração do concreto, ocorre a formação de uma fissura inclinada e curvilínea que se propaga ao longo da chave com o aumento do carregamento. Para um certo valor de carregamento, ela penetra em uma região de baixas tensões e pára de se propagar. Essa fissura, para fins de modelagem, é assumida retilínea e inclinada de um certo ângulo $\theta$.
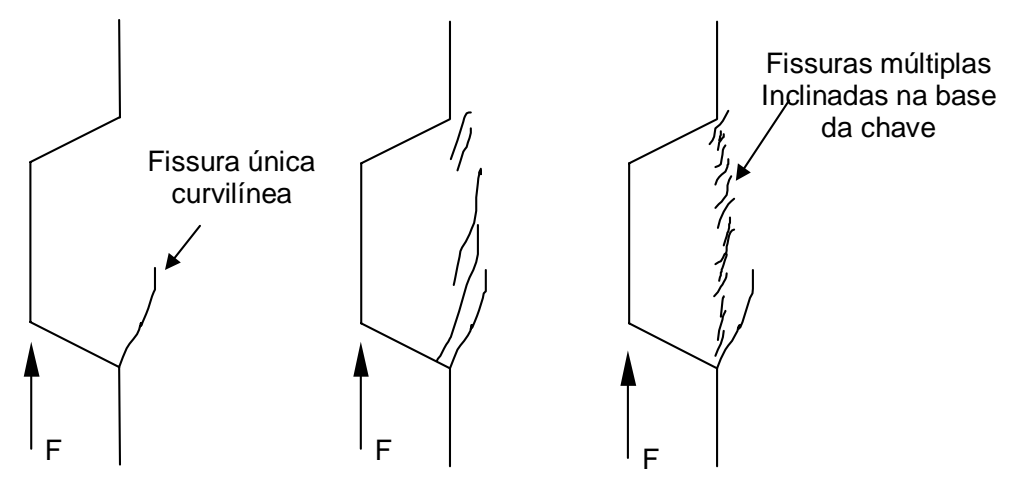

Figura 2.9 - Seqüência de fissuração em chaves de cisalhamento idealizada por KANEKO (1992).

A chave, durante a propagação da fissura discreta, sofre uma rotação que muda o comportamento das tensões ao longo da sua base. Esse fenômeno provoca a rotação dos eixos principais de tensão e forma um campo de tensões elevadas que provoca a formação de fissuras normais à direção da tensão principal de tração. Com o aumento da força aplicada, os eixos principais de tensão sofrem rotações para garantir o equilíbrio de forças 
na chave. As fissuras, seguindo a direção da tensão principal de tração, também rotacionam, e são formadas bielas de compressão situadas entre duas fissuras paralelas. A resistência da chave passa então a ser garantida por estas bielas uniformemente distribuídas ao longo da sua base. Na estrutura real, as fissuras não são uniformemente distribuídas, porém alguns pesquisadores observaram que é possível definir uma região de largura $h$ onde elas podem ser admitidas uniformes (HSU et al. (1987)). Admite-se, também, que não haja transferência de esforços de cisalhamento pela superfície das fissuras. A ruptura da chave ocorre, então, pelo esmagamento das bielas de compressão à medida que o carregamento aumenta.

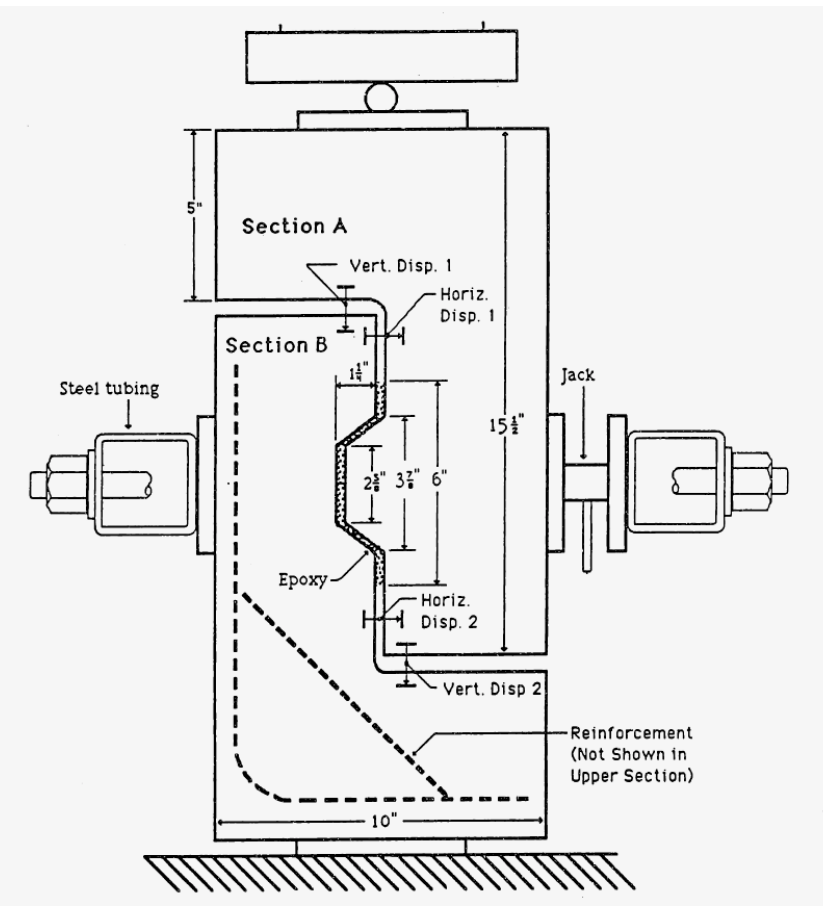

Figura 2.10 - Corpo-de-prova empregado por BAKHOUM (1991) para solicitar uma chave de cisalhamento (dimensões em polegadas) - obtida de BAKHOUM (1991).

A primeira parte desse modelo, que idealiza a fissura discreta, está representada na Figura 2.11. Nessa figura, conhecido o comprimento da fissura $(\ell)$ e a tensão normal aplicada à chave $\left(\sigma_{p}\right)$, é possível calcular a resistência da chave $(F)$ e o deslocamento na direção da solicitação tangencial $(\delta)$. No caso do concreto reforçado com fibras, surge uma tensão normal à direção da fissura $\left(\mathfrak{f}_{\mathrm{tu}}\right)$ devido à resistência das fibras ao arrancamento da matriz. Baseado em diversos outros trabalhos, KANEKO (1992) sugeriu para o ângulo de inclinação da fissura $(\theta)$ o valor de $45^{\circ}$. 


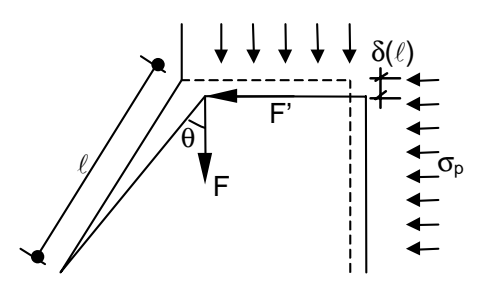

(a) Concreto simples

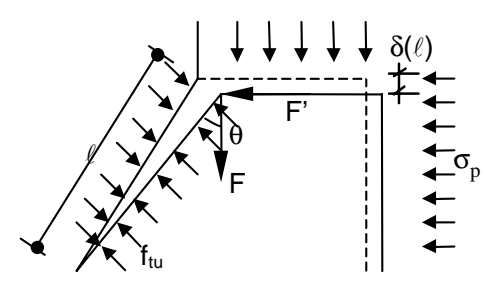

(b) Concreto reforçado com fibras

$$
\begin{aligned}
& \mathrm{F}=\frac{\frac{\mathrm{K}_{\mathrm{IC}} \sqrt{\left(\pi^{2}-4\right) \ell}}{2 \sqrt{\pi}}+\sigma_{\mathrm{p}} \ell \cos ^{2} \theta}{\sin \theta} \\
& \delta(\ell)=\sin 45^{0} \frac{8 \pi}{\mathrm{E}_{\mathrm{c}}\left(\pi^{2}-4\right)}\left(\mathrm{F} \sin 45^{\circ}-\sigma_{\mathrm{p}} \ell \cos ^{2} 45^{\circ}\right) \ln \ell
\end{aligned}
$$

$$
\begin{aligned}
& \mathrm{F}=\frac{\frac{\left(\mathrm{K}_{\mathrm{IC}}+1,1215 \mathrm{f}_{\mathrm{tu}} \sqrt{\pi \ell}\right) \sqrt{\left(\pi^{2}-4\right) \ell}}{2 \sqrt{\pi}}+\sigma_{\mathrm{p}} \ell \cos ^{2} \theta}{\sin \theta} \\
& \delta(\ell)=\sin 45^{0}\left[\frac{8 \pi}{\mathrm{E}_{\mathrm{c}}\left(\pi^{2}-4\right)}\left(\mathrm{F} \sin 45^{0}-\sigma_{\mathrm{p}} \ell \cos ^{2} 45^{0}\right) \ln \ell-\mathrm{f}_{\mathrm{tu}}\left(\frac{4,486 \pi}{\mathrm{E}_{\mathrm{c}} \sqrt{\pi^{2}-4}}\right)\right]
\end{aligned}
$$

Figura 2.11 - Modelagem da fissura discreta pela mecânica da fratura elástica linear para concreto simples e concreto com fibras (KANEKO (1992)).

O coeficiente $K_{I C}$ que aparece na formulação, denominado fator crítico de intensidade de tensão no modo I de ruptura (tensão de tração perpendicular à fissura), pode ser avaliado como $\sqrt{E_{c} G_{f}}$, sendo $E_{c} \circ$ módulo de elasticidade tangente inicial do concreto e $G_{f}$ a energia de fratura. $O$ módulo de elasticidade do concreto pode ser avaliado de acordo com o ACl-318M-89 como $4733 \sqrt{f_{c}}$, sendo a resistência à compressão $\left(f_{c}\right)$ medida em MPa. A energia de fratura pode ser estimada pelo CEB-90, ou pode ser adotado um valor constante médio igual a 0,1 N/mm (KANEKO et al. (1993)).

A segunda parte desse modelo, que representa a fase de fissuração múltipla do concreto, foi desenvolvida satisfazendo duas condições, ou seja, equilíbrio de forças e compatibilidade de deformações, e empregando uma lei constitutiva que representasse 0 comportamento dos materiais. Pelo equilíbrio de forças na chave obtêm-se as seguintes expressões (Figura 2.12):

$$
\begin{aligned}
& \sigma_{x}=\sigma_{c} \cdot \cos ^{2} \theta+\sigma_{t} \cdot \operatorname{sen}^{2} \theta \\
& \sigma_{y}=\sigma_{c} \cdot \operatorname{sen}^{2} \theta+\sigma_{t} \cdot \cos ^{2} \theta \\
& \tau_{x y}=\left(\sigma_{c}-\sigma_{t}\right) \cdot \operatorname{sen} \theta \cdot \cos \theta
\end{aligned}
$$


sendo $\sigma_{\mathrm{c}}$ a tensão principal de compressão, $\sigma_{\mathrm{t}}$ a tensão principal de tração, $\sigma_{\mathrm{x}}$ a tensão na direção $x, \sigma_{y}$ a tensão na direção $y, \tau_{x y}$ a tensão de cisalhamento, e $\theta$ o ângulo de inclinação das fissuras.

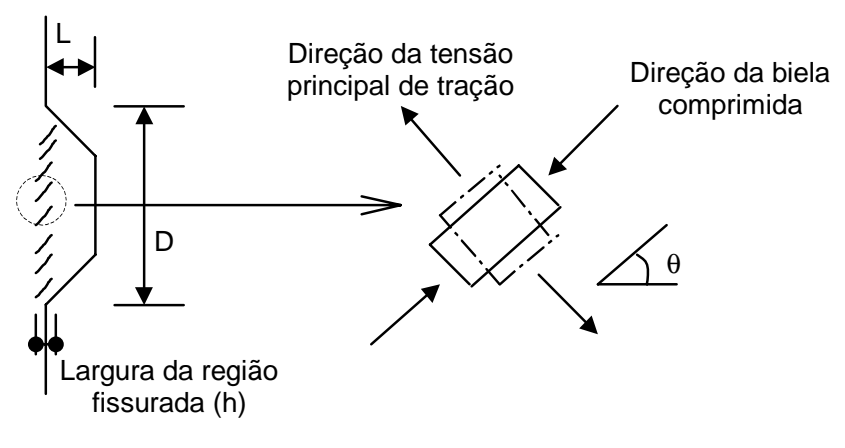

(a) formação da biela de compressão na fase de fissuração
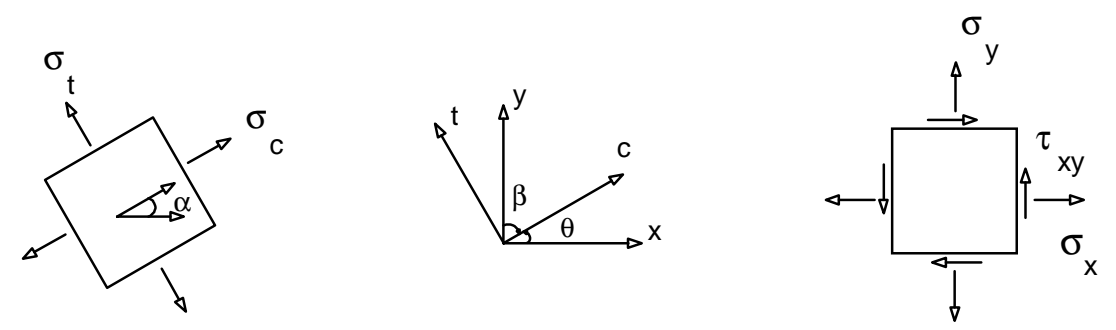

(b) transformação de coordenadas

Figura 2.12 - Fase de fissuração múltipla na chave.

Admitindo que as direções das deformações principais coincidam com as direções das tensões principais, pode-se chegar a expressões similares às anteriores para representar a compatibilidade de deformações na chave:

$$
\begin{aligned}
& \varepsilon_{x}=\varepsilon_{c} \cdot \cos ^{2} \theta+\varepsilon_{t} \cdot \operatorname{sen}^{2} \theta \\
& \varepsilon_{y}=\varepsilon_{c} \cdot \operatorname{sen}^{2} \theta+\varepsilon_{t} \cdot \cos ^{2} \theta \\
& \gamma_{x y}=2\left(\varepsilon_{c}-\varepsilon_{t}\right) \cdot \operatorname{sen} \theta \cdot \cos \theta
\end{aligned}
$$

sendo $\varepsilon_{\mathrm{c}}$ a deformação principal de compressão, $\varepsilon_{\mathrm{t}}$ a deformação principal de tração, $\varepsilon_{\mathrm{x}} \mathrm{a}$ deformação na direção $x, \varepsilon_{y}$ a deformação na direção $y, \gamma_{x y}$ a distorção, e $\theta$ o ângulo de inclinação das fissuras.

Os modelos constitutivos uniaxiais para o concreto simples e para o concreto reforçado com fibras utilizados por KANEKO (1992) são mostrados na Figura 2.13 e na 
Figura 2.14. Nessas figuras, a resistência à tração direta do concreto $\left(\mathrm{f}_{\mathrm{ct}}\right)$ é avaliada segundo o ACl-318M-89 como $0,332 \sqrt{f_{c}}$.

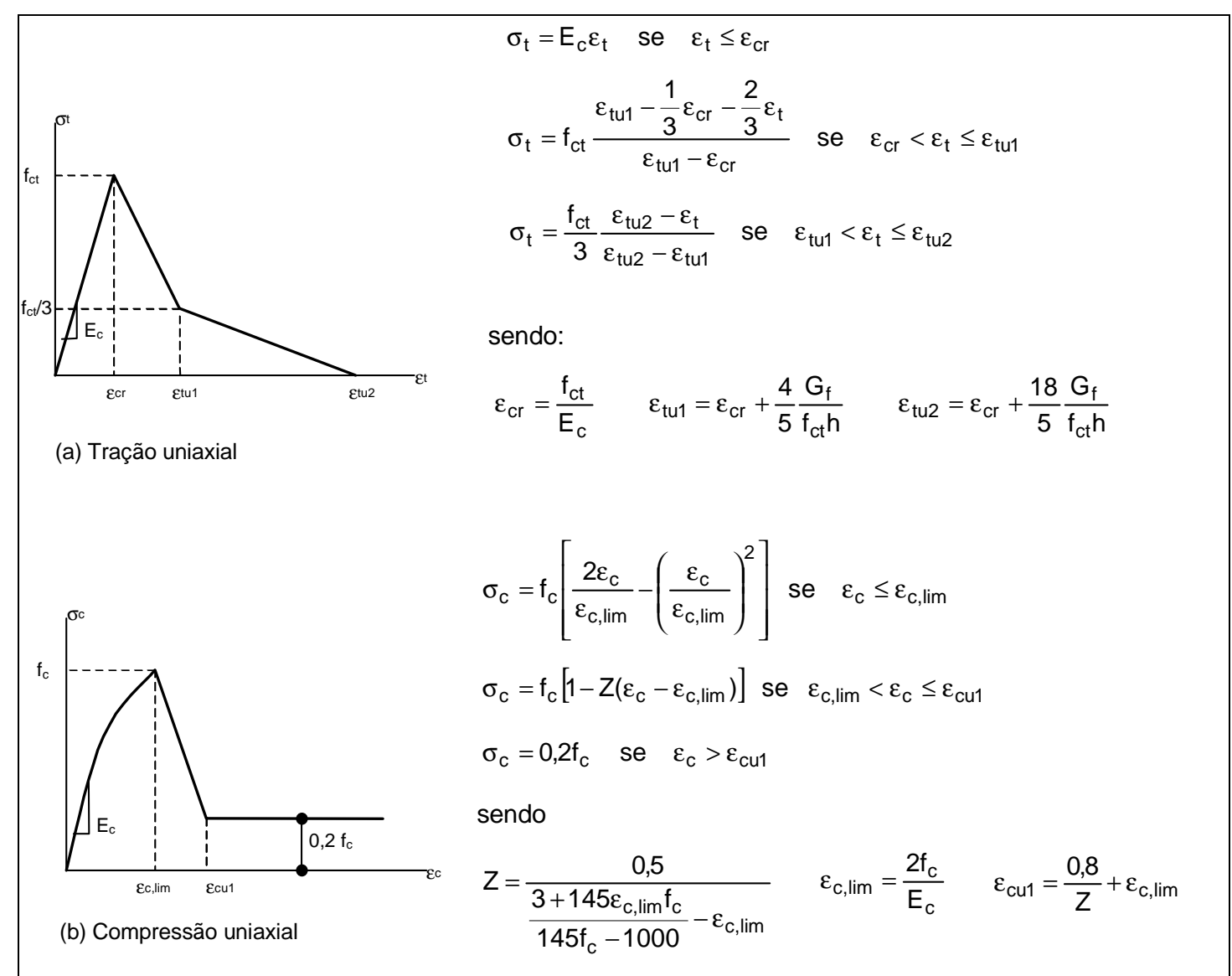

Figura 2.13 - Modelo constitutivo para o concreto simples - KANEKO (1992).

Complementando o modelo, a relação entre a tensão principal de tração e a tensão principal de compressão do concreto nas bielas comprimidas é avaliada pelo coeficiente de Poisson aparente $v_{\mathrm{a}}=\varepsilon_{\mathrm{c}} / \varepsilon_{\mathrm{t}}$, o qual tem a seguinte lei de variação:

$$
\begin{aligned}
& v_{\mathrm{a}}=0,2 \text { (comportamento elástico; variação de volume) se } \varepsilon_{\mathrm{c}} \leq \varepsilon_{\mathrm{c} 1} \\
& v_{\mathrm{a}}=0,2 \text { a } 0,5 \text { (transição linear) se } \varepsilon_{\mathrm{c} 1}<\varepsilon_{\mathrm{c}} \leq \varepsilon_{\mathrm{c} 2} \\
& v_{\mathrm{a}}=0,5 \text { (comportamento plástico; sem variação de volume) se } \varepsilon_{\mathrm{c}}>\varepsilon_{\mathrm{c} 2}
\end{aligned}
$$

sendo $\varepsilon_{\mathrm{c} 1}$ e $\varepsilon_{\mathrm{c} 2}$ as deformações para $\sigma_{\mathrm{c}}=0,8 \mathrm{f}_{\mathrm{c}}$ e $\sigma_{\mathrm{c}}=\mathrm{f}_{\mathrm{c}}$, respectivamente. 


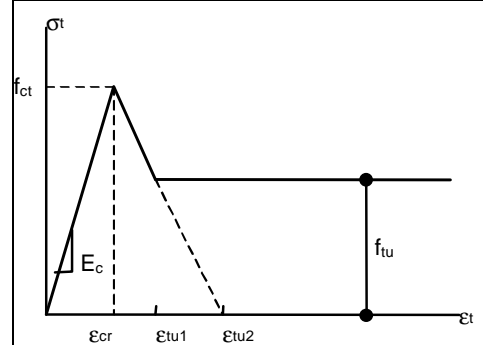

(a) Tração uniaxial

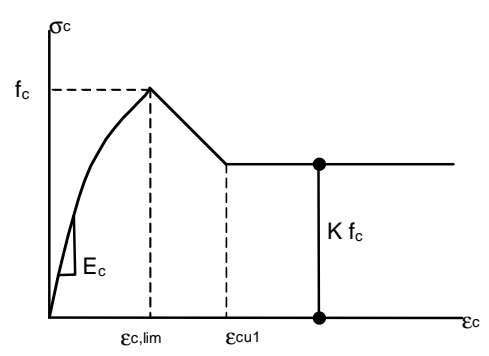

(b) Compressão uniaxial

$$
\begin{aligned}
& \sigma_{\mathrm{t}}=\mathrm{E}_{\mathrm{c}} \varepsilon_{\mathrm{t}} \text { se } \varepsilon_{\mathrm{t}} \leq \varepsilon_{\mathrm{cr}} \\
& \sigma_{\mathrm{t}}=\mathrm{f}_{\mathrm{ct}} \frac{\varepsilon_{\mathrm{tu} 2}-\varepsilon_{\mathrm{t}}}{\varepsilon_{\mathrm{tu} 2}-\varepsilon_{\mathrm{cr}}} \text { se } \varepsilon_{\mathrm{cr}}<\varepsilon_{\mathrm{t}} \leq \varepsilon_{\mathrm{tu} 1} \\
& \sigma_{\mathrm{t}}=\mathrm{f}_{\mathrm{tu}} \text { se } \varepsilon_{\mathrm{t}}>\varepsilon_{\mathrm{tu} 1}
\end{aligned}
$$

sendo:

$$
\varepsilon_{\mathrm{cr}}=\frac{\mathrm{f}_{\mathrm{ct}}}{\mathrm{E}_{\mathrm{c}}} \quad \varepsilon_{\mathrm{tu} 1}=\varepsilon_{\mathrm{tu} 2}-\frac{\mathrm{f}_{\mathrm{tu}}}{\mathrm{f}_{\mathrm{ct}}}\left(\varepsilon_{\mathrm{tu} 2}-\varepsilon_{\mathrm{cr}}\right) \quad \varepsilon_{\mathrm{tu} 2}=\varepsilon_{\mathrm{cr}}+\frac{18}{5} \frac{\mathrm{G}_{\mathrm{f}}}{\mathrm{f}_{\mathrm{ct}} \mathrm{h}}
$$$$
\sigma_{\mathrm{c}}=\mathrm{f}_{\mathrm{c}}\left[\frac{2 \varepsilon_{\mathrm{c}}}{\varepsilon_{\mathrm{c}, \mathrm{lim}}}-\left(\frac{\varepsilon_{\mathrm{c}}}{\varepsilon_{\mathrm{c}, \mathrm{lim}}}\right)^{2}\right] \text { se } \varepsilon_{\mathrm{c}} \leq \varepsilon_{\mathrm{c}, \mathrm{lim}}
$$$$
\sigma_{\mathrm{c}}=\mathrm{Kf}_{\mathrm{c}}+\frac{(1-\mathrm{K}) \mathrm{f}_{\mathrm{c}}\left(\varepsilon_{\mathrm{cu} 1}-\varepsilon_{\mathrm{c}}\right)}{\varepsilon_{\mathrm{cu} 1}-\varepsilon_{\mathrm{c}, \mathrm{lim}}} \text { se } \varepsilon_{\mathrm{c}, \mathrm{lim}}<\varepsilon_{\mathrm{c}} \leq \varepsilon_{\mathrm{cu} 1}
$$$$
\sigma_{\mathrm{c}}=\mathrm{Kf}_{\mathrm{c}} \quad \text { se } \quad \varepsilon_{\mathrm{c}}>\varepsilon_{\mathrm{cu} 1}
$$

sendo

$$
\mathrm{K}=0,38 \mathrm{~V}_{\mathrm{f}} \frac{\ell_{\mathrm{f}}}{\phi_{\mathrm{f}}} \quad \varepsilon_{\mathrm{c}, \lim }=\frac{2 \mathrm{f}_{\mathrm{c}}}{\mathrm{E}_{\mathrm{c}}} \quad \varepsilon_{\mathrm{cu1}}=\frac{0,041-2 \varepsilon_{\mathrm{c}, \lim } \mathrm{f}_{\mathrm{c}}}{\mathrm{f}_{\mathrm{c}}-6,896}+\varepsilon_{\mathrm{c}, \lim }
$$

Figura 2.14 - Modelo constitutivo para o concreto reforçado com fibras- KANEKO (1992).

O procedimento de solução consiste em resolver um sistema de oito equações (três de equilíbrio, três de compatibilidade e duas da lei constitutiva do material) com onze incógnitas $\left(\sigma_{x}, \sigma_{y}, \tau_{x y}, \varepsilon_{x}, \varepsilon_{y}, \gamma_{x y}, \sigma_{t}, \sigma_{c}, \varepsilon_{c}, \varepsilon_{t}\right.$ e $\left.\theta\right)$.Usando o coeficiente de Poisson aparente e especificando o valor de $\sigma_{x}$, o sistema fica reduzido a nove incógnitas. Adota-se, então, 0 seguinte procedimento: (1) escolher um valor para $\varepsilon_{\mathrm{t}}$; (2) calcular $v_{\mathrm{a}}$ a partir do valor de $\varepsilon_{\mathrm{c}}$ calculado no passo anterior ou assumir $v_{\mathrm{a}}=0,2$ no primeiro passo de cálculo; (3) calcular $\varepsilon_{\mathrm{c}}$ de $v_{\mathrm{a}}=\varepsilon_{\mathrm{c}} / \varepsilon_{\mathrm{t}}$; (4) calcular $\sigma_{\mathrm{t}}$ e $\sigma_{\mathrm{c}}$ a partir do modelo constitutivo do material; (5) obter $\theta$ a partir da primeira das equações de equlíbrio com $\sigma_{x}$ (tensão de compressão na chave) conhecida; (6) calcular $\tau_{x y}, \varepsilon_{y}, \gamma_{x y}$ a partir das outras equações de equilíbrio e das equações de compatibilidade de deformações.

O deslocamento da face externa da chave na direção da solicitação tangencial é calculado somando-se a contribuição da deformação na direção y com a deformação angular, o que resulta em:

$$
\delta=\varepsilon_{y} D+\gamma_{x y} L
$$


onde $D$ é a dimensão da chave na direção y (comprimento) e $L$ é a dimensão na direção $x$ (altura), conforme mostrado na Figura 2.12.

Definidos os modelos parciais que representam o comportamento da chave em cada fase de carregamento, o modelo completo é definido pela associação desses dois modelos. Apesar de aparentemente simples, não é fácil definir quando o comportamento da chave deixa de ser regido pela fissuração discreta e passa a ser regido pela fissuração múltipla (ponto de interseção mostrado na Figura 2.15). Uma das formas de definir este limite é através da observação em ensaios experimentais. Porém, como nem sempre existem resultados de ensaios disponíveis, pode-se defini-lo como o ponto onde as duas curvas tem a mesma tangente ou, então, quando a interseção entre elas é feita de forma suave. Em ambos os casos, aos deslocamentos calculados na fase de fissuração múltipla devem ser somados os deslocamentos calculados na fase de fissuração discreta.

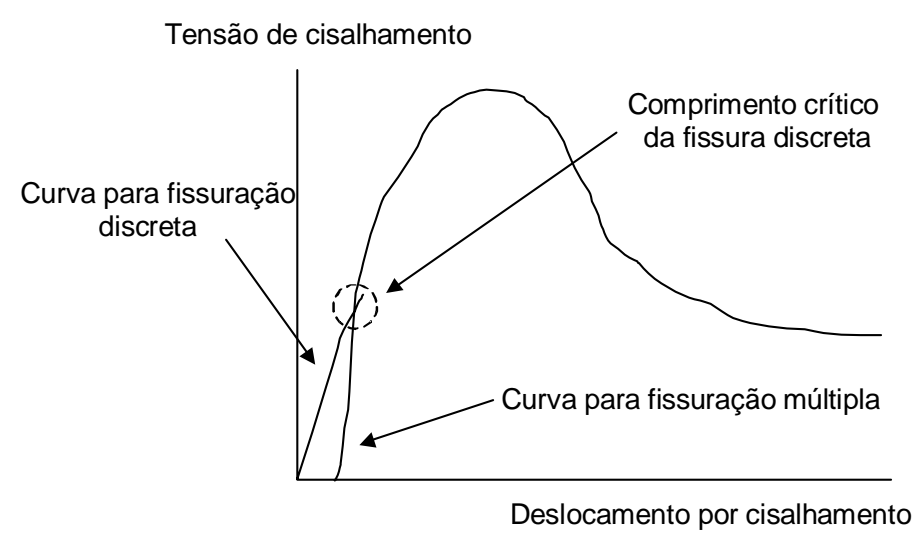

Figura 2.15 - Transição esquemática entre a fissuração discreta e a fissuração múltipla na chave de cisalhamento - KANEKO (1992)

A resistência máxima da chave é sempre obtida da fase de fissuração múltipla. Admitindo no modelo correspondente a esta fase que a resistência da chave é alcançada quando a tensão principal de compressão nas bielas atinge a resistência à compressão do concreto, é possível obter uma expressão para calcular diretamente a resistência da chave:

$$
\begin{aligned}
& \tau_{\max }=\frac{f_{c}-C}{2} \sin 2\left\{\cos ^{-1} \sqrt{\frac{\sigma_{x}-C}{f_{c}-C}}\right\} \quad(M P a) \\
& C=\frac{f_{C} h}{568.000 G_{f}}\left(\frac{1}{3}-4 \sqrt{f_{c}}\right)+\frac{\sqrt{f_{c}}}{11} \quad(M P a)-\text { concreto simples }
\end{aligned}
$$




$$
\mathrm{C}=2 \eta_{\ell} \eta_{0} \tau_{\mathrm{uf}} \mathrm{V}_{\mathrm{f}} \frac{\ell}{\mathrm{d}} \quad(\mathrm{MPa}) \text { - concreto reforçado com fibras }
$$

Nessas expressões, $f_{c}$ e $\sigma_{x}$ devem ser usados com valor negativo quando a tensão for de compressão. Para a largura da região fissurada (h), pode-se usar o valor de $10 \mathrm{~mm}$ observado nos ensaios experimentais de chaves de cisalhamento. Ainda nessas expressões, $V_{f}$ é o volume de fibras, $\ell$ é o comprimento das fibras, $d$ é o diâmetro equivalente das fibras, $\tau_{\text {uf }}$ é a tensão de aderência entre a fibra e a matriz, $\eta_{\ell}$ é o fator de eficiência do comprimento das fibras e $\eta_{0}$ é o fator de eficiência da orientação das fibras, adotados iguais a 0,5 e 0,45 , respectivamente.

\subsubsection{Modelo de HSU et al. (1987)}

HSU et al. (1987) apresentaram um modelo, baseado na teoria de biela e tirante, para avaliação da resistência de corpos-de-prova de cisalhamento direto. Esse modelo foi desenvolvido satisfazendo duas condições, ou seja, equilíbrio de forças e compatibilidade de deformações, e empregando uma lei constitutiva que representasse o comportamento dos materiais. Diferentemente do modelo de KANEKO (1992), ele incorpora a influência das armaduras paralela e normal ao plano de cisalhamento, entretanto, as leis constitutivas são definidas apenas para o concreto simples.

\subsubsection{Equações básicas}

- Equação de equilíbrio

Seja um elemento de concreto com armadura nas duas direções ortogonais $x$ e $y$ (Figura 2.16). Ele está submetido às tensões normais $\left(\sigma_{x}\right.$ e $\left.\sigma_{y}\right)$ e tensões de cisalhamento $\left(\tau_{x y}\right)$ constantes ao longo de cada plano. Após a fissuração, surgem várias bielas comprimidas e inclinadas de um ângulo $\alpha$ que, junto com a armadura, formam uma treliça resistente aos esforços de cisalhamento. Esta direção é assumida como a direção da tensão principal de compressão no concreto $\left(\sigma_{c}\right)$, sendo a direção da tensão principal de tração $\left(\sigma_{t}\right)$ ortogonal a ela. As tensões $\sigma_{x}, \sigma_{y}$ e $\tau_{x y}$, atuantes no elemento de concreto armado, são resistidas pelo concreto e pela armadura, sendo que as tensões resistidas apenas pelo concreto são designadas por $\sigma_{x, c}, \sigma_{y, c}$ e $\tau_{x y, c}$. Elas podem ser escritas em função das tensões principais através de uma transformação de coordenadas, ou seja:

$$
\sigma_{x, \mathrm{c}}=\sigma_{\mathrm{c}} \cdot \cos ^{2} \alpha+\sigma_{\mathrm{t}} \cdot \operatorname{sen}^{2} \alpha
$$




$$
\begin{aligned}
& \sigma_{y, c}=\sigma_{c} \cdot \operatorname{sen}^{2} \alpha+\sigma_{t} \cdot \cos ^{2} \alpha \\
& \tau_{x y, c}=\left(\sigma_{c}-\sigma_{t}\right) \cdot \operatorname{sen} \alpha \cdot \cos \alpha
\end{aligned}
$$

A armadura resiste apenas às tensões normais e sua contribuição pode ser avaliada como:

$$
\begin{aligned}
& \sigma_{x, s}=\rho_{x} \cdot f_{s, x} \\
& \sigma_{y, s}=\rho_{y} \cdot f_{s, y}
\end{aligned}
$$

sendo $f_{s, x}$ e $f_{s, y}$ a resistência da armadura nas direções $x$ e $y$, respectivamente.

A tensão total no elemento de concreto armado é obtida pela soma da parcela resistida pelo concreto com a parcela resistida pela armadura.

$$
\begin{aligned}
& \sigma_{x}=\sigma_{c} \cdot \cos ^{2} \alpha+\sigma_{t} \cdot \operatorname{sen}^{2} \alpha+\rho_{x} \cdot f_{s, x} \\
& \sigma_{y}=\sigma_{c} \cdot \operatorname{sen}^{2} \alpha+\sigma_{t} \cdot \cos ^{2} \alpha+\rho_{y} \cdot f_{s, y} \\
& \tau_{x y}=\left(\sigma_{c}-\sigma_{t}\right) \cdot \operatorname{sen} \alpha \cdot \cos \alpha
\end{aligned}
$$

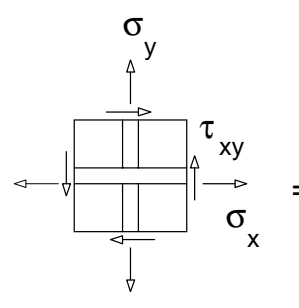

concreto armado

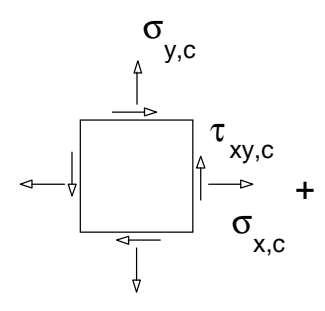

concreto

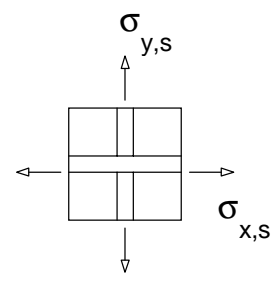

armadura

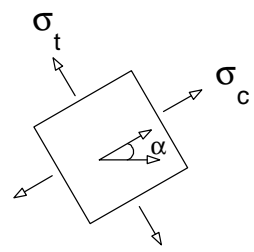

concreto

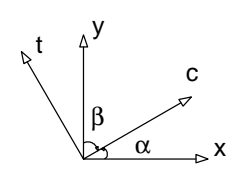

Figura 2.16 - Tensões em um elemento de concreto armado 
- Equação de compatibilidade

Assumindo que as deformações são uniformemente distribuídas no elemento de concreto e que a direção das deformações principais é coincidente com a direção das tensões principais, as seguintes expressões podem ser escritas:

$$
\begin{aligned}
& \varepsilon_{x}=\varepsilon_{c} \cdot \cos ^{2} \alpha+\varepsilon_{t} \cdot \operatorname{sen}^{2} \alpha \\
& \varepsilon_{y}=\varepsilon_{c} \cdot \operatorname{sen}^{2} \alpha+\varepsilon_{t} \cdot \cos ^{2} \alpha \\
& \gamma_{x y}=2\left(\varepsilon_{c}-\varepsilon_{t}\right) \cdot \operatorname{sen} \alpha \cdot \cos \alpha
\end{aligned}
$$

sendo $\varepsilon_{\mathrm{x}}$ e $\varepsilon_{\mathrm{y}}$ as deformações normais nas direções $\mathrm{x}$ e $\mathrm{y}$, respectivamente, $\gamma_{\mathrm{xy}}$ a deformação angular, e $\varepsilon_{\mathrm{c}}$ e $\varepsilon_{\mathrm{t}}$ as deformações principais de compressão e tração, respectivamente.

\section{- Equação constitutiva}

A relação tensão-deformação nas bielas comprimidas de concreto é representada pelas seguintes expressões:

$$
\text { ramo ascendente }: \sigma_{\mathrm{c}}=-\mathrm{f}_{\mathrm{c}} \cdot\left[2 \frac{\varepsilon_{\mathrm{c}}}{\varepsilon_{\mathrm{c}, \mathrm{lim}}}-\lambda \cdot\left(\frac{\varepsilon_{\mathrm{c}}}{\varepsilon_{\mathrm{c}, \mathrm{lim}}}\right)^{2}\right] \quad \text { se }\left|\varepsilon_{\mathrm{c}}\right| \leq\left|\frac{\varepsilon_{\mathrm{c}, \text { lim }}}{\lambda}\right|
$$

$$
\text { ramo descendente }: \sigma_{\mathrm{c}}=-\frac{\mathrm{f}_{\mathrm{c}}}{\lambda} \cdot\left[1-\left(\frac{\frac{\varepsilon_{\mathrm{c}}}{\varepsilon_{\mathrm{c}, \mathrm{lim}}}-\frac{1}{\lambda}}{2-\frac{1}{\lambda}}\right)^{2}\right] \quad \text { se }\left|\varepsilon_{\mathrm{c}}\right|>\left|\frac{\varepsilon_{\mathrm{c}, \mathrm{lim}}}{\lambda}\right|
$$

sendo $\frac{\varepsilon_{\mathrm{c}, \mathrm{im}}}{\lambda}$ a deformação correspondente à máxima tensão de compressão na biela de concreto e $\varepsilon_{\mathrm{c}, \text { lim }}=-0,002$ a deformação correspondente à resistência do concreto $\left(\mathrm{f}_{\mathrm{c}}\right)$ medida em corpos-de-prova cilíndricos. O coeficiente $\lambda$ é definido para avaliar o fenômeno de diminuição da resistência do concreto das bielas comprimidas devido às tensões de tração ("softening truss model"), sendo expresso por:

$$
\lambda=\sqrt{0,7-\frac{\varepsilon_{\mathrm{t}}}{\varepsilon_{\mathrm{c}}}}
$$

A relação tensão-deformação do concreto submetido à tração uniaxial é representada pelas seguintes expressões: 


$$
\begin{aligned}
& \sigma_{\mathrm{t}}=\mathrm{E}_{\mathrm{c}} \cdot \varepsilon_{\mathrm{t}} \text { se } \varepsilon_{\mathrm{t}} \leq \varepsilon_{\mathrm{cr}} \\
& \sigma_{\mathrm{t}}=\frac{\mathrm{f}_{\mathrm{t}}}{1+\sqrt{\frac{\varepsilon_{\mathrm{t}}-\varepsilon_{\mathrm{cr}}}{0,005}}} \text { se } \varepsilon_{\mathrm{t}}>\varepsilon_{\mathrm{cr}}
\end{aligned}
$$

$E_{c}=-\frac{2 . f_{c}}{\varepsilon_{0}}:$ módulo de elasticidade do concreto

$\mathrm{f}_{\mathrm{ct}}=0,331 \cdot \sqrt{\mathrm{f}_{\mathrm{c}}}$ : tensão de tração do concreto $(\mathrm{MPa})$

$\varepsilon_{\mathrm{cr}}=\frac{\mathrm{f}_{\mathrm{ct}}}{\mathrm{E}_{\mathrm{c}}}:$ deformação correspondente à tensão que inicia a fissuração do concreto

\subsubsection{Procedimento de resolução}

Seja o corpo-de-prova monolítico para ensaio de cisalhamento direto mostrado na Figura 2.17, o qual foi empregado por HOFBECK et al. (1969). Assumindo que as tensões normais ao plano de cisalhamento devido às ações externas sejam conhecidas, as outras tensões podem ser obtidas em função da força $F$ por:

$$
\begin{aligned}
\sigma_{y} & =K_{\sigma} \frac{F}{b \cdot h} \\
\tau_{x y} & =K_{\tau} \frac{F}{b \cdot \ell}
\end{aligned}
$$

$\mathrm{K}_{\sigma}$ : coeficiente para avaliação da distribuição não uniforme de $\sigma_{\mathrm{y}}$

$\mathrm{K}_{\tau}$ : coeficiente para avaliação da distribuição não uniforme de $\tau_{x y}$;

Se as tensões forem uniformemente distribuídas ao longo da peça, os coeficientes $\mathrm{K}_{\sigma}$ e $\mathrm{K}_{\tau}$ são iguais à unidade. Combinando a eq.(2.17a) e a eq.(2.17b), obtêm-se uma relação entre $\sigma_{y}$ e $\tau_{x y}$ :

$$
\sigma_{y}=K . \tau_{x y} \quad, \quad K=\frac{\ell}{h}
$$

Segundo a teoria da elasticidade, as tensões não são uniformes no plano de cisalhamento do modelo da Figura 2.17. Antes da fissuração do concreto, a tensão de cisalhamento $\tau_{x y}$ é maior próxima às extremidades onde há uma concentração de tensões devido à aplicação da força concentrada. Com o aumento do carregamento, ocorre a 
formação de fissuras inclinadas na região próxima ao plano de cisalhamento. Essa região é chamada de região crítica e está hachurada na Figura 2.17. Em ensaios realizados em modelos com largura $(h)$ de $254 \mathrm{~mm}$, observou-se que a região crítica possuía largura $\left(\mathrm{h}_{\mathrm{cr}}\right)$ de 50,8 mm a 76,2 mm. Nessa região, a intensa fissuração do concreto possibilita a redistribuição das tensões $\sigma_{x}, \sigma_{y}$ e $\tau_{x y}$ ao longo do plano de cisalhamento, diminuindo a rigidez dessa região em comparação com outras partes da peça. Dessa forma, as tensões podem ser consideradas uniformes na região crítica e a teoria exposta pode ser aplicada. No modelo apresentado na Figura 2.17, $\tau_{x y}$ foi tomado como a tensão média no plano de cisalhamento, $\sigma_{y}$ como a tensão média paralela ao plano de cisalhamento e $\sigma_{x}$ igual a zero, uma vez que não há tensões externas na direção $x$.

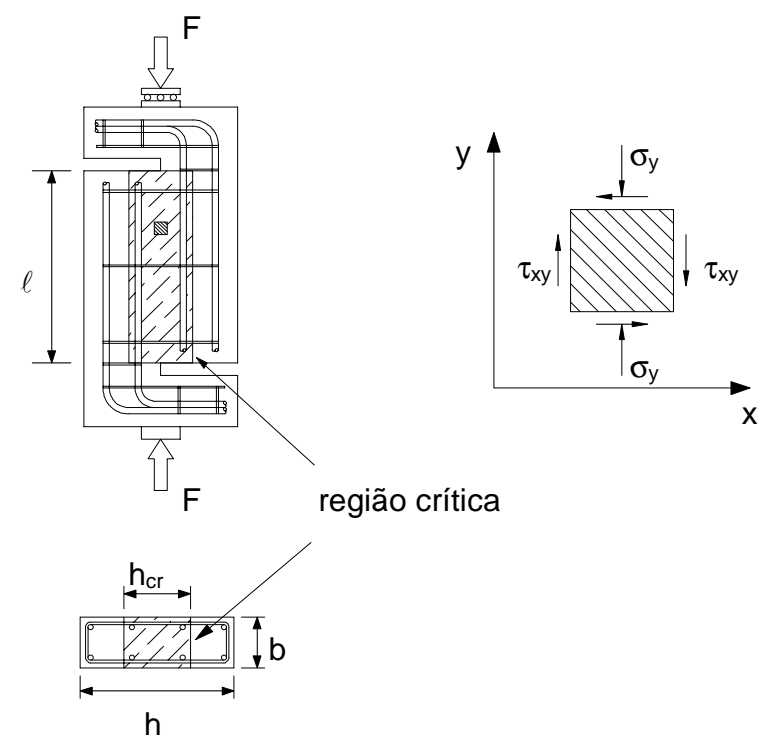

Figura 2.17 - Modelo para ensaio de cisalhamento direto

A taxa de armadura $\rho_{x}$ foi obtida dividindo a área total de armadura na direção x pela área do plano de cisalhamento e $\rho_{y}$ foi obtida dividindo a área total de armadura na direção y pela seção transversal do modelo. A avaliação de $\rho_{y}$ desta forma é válida para o modelo da figura, uma vez que a armadura está distribuída de forma simétrica na seção transversal.

Combinando as equações já definidas e lembrando que $f_{s, x}$ e $f_{s, y}$ são iguais à $f_{y}$ quando a armadura atinge a deformação de escoamento $\left(\varepsilon_{y, s}\right)$, obtém-se das eq.(2.12) e eq.(2.13):

$$
\varepsilon_{x} \geq \varepsilon_{y, s} \quad \sigma_{x}=\sigma_{c} \cdot \cos ^{2} \alpha+\sigma_{t} \cdot \operatorname{sen}^{2} \alpha+\rho_{x} \cdot f_{y}
$$




$$
\begin{aligned}
\varepsilon_{x}<\varepsilon_{y, s} \quad \sigma_{x}= & \sigma_{c} \cdot \cos ^{2} \alpha+\sigma_{t} \cdot \operatorname{sen}^{2} \alpha+ \\
& \rho_{x} \cdot E_{s} \cdot\left(\varepsilon_{c} \cdot \cos ^{2} \alpha+\varepsilon_{t} \cdot \operatorname{sen}^{2} \alpha\right)
\end{aligned}
$$

Combinando a eq.(2.12b) e eq.(2.12c) com a eq.(2.18), obtém-se:

$$
\mathrm{K} \cdot\left(\sigma_{\mathrm{c}}-\sigma_{\mathrm{t}}\right) \cdot \operatorname{sen} \alpha \cdot \cos \alpha=\sigma_{\mathrm{c}} \cdot \operatorname{sen}^{2} \alpha+\sigma_{\mathrm{t}} \cdot \cos ^{2} \alpha+\rho_{\mathrm{y}} \cdot \mathrm{f}_{\mathrm{s}, \mathrm{y}}
$$

Substituindo o valor de $\mathrm{f}_{\mathrm{s}, \mathrm{y}}$ e utilizando a eq.(2.13b), tem-se:

$$
\begin{aligned}
& \begin{aligned}
& \varepsilon_{y} \geq \varepsilon_{y, s} \quad K \cdot\left(\sigma_{c}-\sigma_{t}\right) \cdot \operatorname{sen} \alpha \cdot \cos \alpha= \\
&= \sigma_{c} \cdot \operatorname{sen}^{2} \alpha+\sigma_{t} \cdot \cos ^{2} \alpha+\rho_{y} \cdot f_{y}
\end{aligned} \\
& \begin{aligned}
& \varepsilon_{y}<\varepsilon_{y, s} \quad K \cdot\left(\sigma_{c}-\sigma_{t}\right) \cdot \operatorname{sen} \alpha \cdot \cos \alpha= \\
&= \sigma_{c} \cdot \operatorname{sen}^{2} \alpha+\sigma_{t} \cdot \cos ^{2} \alpha+\rho_{y} \cdot E_{s} \cdot\left(\varepsilon_{c} \cdot \operatorname{sen}^{2} \alpha+\varepsilon_{t} \cdot \cos ^{2} \alpha\right)
\end{aligned}
\end{aligned}
$$

A eq.(2.19a), a eq.(2.19b), a eq.(2.21a) e a eq.(2.21b) são escritas em função de seis variáveis. Adotando um valor para $\varepsilon_{c}$, as outras variáveis $\sigma_{c}, \sigma_{t}, \varepsilon_{t}, \alpha$ e $\lambda$ podem ser facilmente obtidas. A variável $\varepsilon_{c}$ foi escolhida porque se espera que a deformação das bielas aumente com o acréscimo do carregamento. Um procedimento iterativo para resolução simultânea das cinco equações não lineares é o seguinte: (1) adotar um valor (negativo) para $\varepsilon_{c} ;(2)$ adotar um valor (positivo) para $\sigma_{t} ;(3)$ calcular $\varepsilon_{t}$ pela curva tensão-deformação do concreto; (4) calcular $\lambda$; (5) calcular $\sigma_{c}$; (6) calcular $\alpha ;(7)$ calcular $\sigma_{t}$; (8) se o valor calculado para $\sigma_{\mathrm{t}}$ estiver próximo do valor inicialmente adotado, $\sigma_{\mathrm{c}}, \sigma_{\mathrm{t}}, \varepsilon_{\mathrm{t}}, \alpha$ e $\lambda$ são a solução para o valor de $\varepsilon_{\mathrm{c}}$ adotado; caso contrário, deve-se adotar outro valor para $\sigma_{\mathrm{t}} \mathrm{e}$ repetir os passos de 2 a 7 ; (9) adotar um novo valor para $\varepsilon_{c}$ e repetir os passos de 1 a 8 . A tensão de cisalhamento última resistente $\left(\tau_{u}\right)$ pode ser obtida do ponto de máximo absoluto da curva que relaciona $\tau_{x y} \operatorname{com} \gamma_{x y}$.

O modelo proposto por HSU et al. (1987) foi comparado com os resultados dos ensaios em corpos-de-prova de cisalhamento direto, monolíticos, realizados por HOFBECK et al. (1969), tendo fornecido bons resultados. Os autores concluíram que a redução da resistência à compressão do concreto das bielas após a fissuração é um importante fator que influencia a resistência aos esforços de cisalhamento. Tanto a quantidade de armadura normal ao plano de cisalhamento quanto de armadura paralela a ele são importantes fatores que também influenciam na resistência ao cisalhamento. A armadura normal ao plano de cisalhamento influencia mais na resistência que a armadura paralela ao mesmo. Contudo, o 
emprego de baixas porcentagens de armadura paralela ao plano de cisalhamento acarreta em uma redução significativa da resistência do corpo-de-prova.

\subsubsection{Modelo de TASSIOS; VINTZELEOU (1990)}

Os modelos apresentados anteriormente são aplicáveis nas situações em que não há uma interface claramente definida. Nesses casos, à medida que a estrutura é solicitada, surgem tensões de cisalhamento em regiões específicas que resultarão na formação de um plano de cisalhamento. Por outro lado, nas situações em que existe uma interface claramente definida, a resistência é definida pela capacidade de transferência de esforços de cisalhamento por essa interface. Nesse sentido, TASSIOS; VINTZELEOU (1990) propuseram um modelo para avaliação da resistência ao cisalhamento de interfaces de concreto, com superfície plana, baseado na teoria atrito-cisalhamento e na contribuição do efeito de pino da armadura transversal à interface. A equação que representa a resistência ao cisalhamento $(\tau)$ em função do deslizamento (s) é:

$$
\tau=0,5 \cdot \sqrt[3]{f_{\mathrm{c}}{ }^{2} \cdot \sigma_{\mathrm{n}} \cdot \frac{\mathrm{s}}{\mathrm{s}_{\mathrm{u}}}} \leq \tau_{\mathrm{u}}=0,44 \cdot \sqrt[3]{\mathrm{f}_{\mathrm{c}}{ }^{2} \cdot \sigma_{\mathrm{n}}} \quad(\mathrm{MPa}) \quad, \mathrm{s}_{\mathrm{u}} \cong 2 \mathrm{~mm}
$$

onde $\mathrm{f}_{\mathrm{c}}$ é a resistência à compressão do concreto e $\sigma_{\mathrm{n}}$ é a tensão normal a interface.

A força resistida pelo efeito de pino da armadura transversal à interface pode ser avaliada, em função do deslizamento $\left(\mathrm{s}_{\mathrm{s}}\right)$, por:

$$
\begin{aligned}
& \text { para } s_{s} \leq 0,1 s_{s, u}, F_{d}=5 \cdot \frac{F_{d, u}}{s_{s, u}} \cdot s_{s} \quad(N) \\
& \text { para } 0,1 s_{s, u} \leq s_{s} \leq s_{s, u}, s_{s}=0,10+1,15 \cdot\left[\left(\frac{F_{d}}{F_{d, u}}\right)^{4}-0,5 \cdot\left(\frac{F_{d}}{F_{d, u}}\right)^{3}\right] \cdot s_{s, u}
\end{aligned}
$$

sendo:

$$
\begin{aligned}
& \mathrm{s}_{\mathrm{s}, \mathrm{u}}=0,05 \phi_{\mathrm{s}} \quad(\mathrm{mm}) ; \\
& \mathrm{F}_{\mathrm{d}, \mathrm{u}}=1,3 \cdot \phi_{\mathrm{s}}^{2} \cdot \sqrt{\mathrm{f}_{\mathrm{c}} \cdot \mathrm{f}_{\mathrm{y}} \cdot\left(1-\xi^{2}\right)} \quad(\mathrm{N}) \\
& \xi=\sigma_{\mathrm{s}} / \mathrm{f}_{\mathrm{y}} \\
& \sigma_{\mathrm{s}}: \text { tensão de tração atuante na armadura; }
\end{aligned}
$$




$$
\begin{aligned}
& \phi_{s} \text { :diâmetro da armadura }(\mathrm{mm}) \\
& \mathrm{f}_{\mathrm{y}} \text { : resistência de escoamento do aço. }
\end{aligned}
$$

A relação entre a força de arrancamento e o deslocamento de uma barra imersa em uma região de concreto com resistência à tração $f_{c t}$ pode ser obtida a partir da distribuição das tensões axiais e das tensões de aderência nesta barra, conforme ilustrado na Figura 2.18a. Nesta figura, a barra possui comprimento insuficiente para que a tensão axial alcance a resistência de escoamento do aço. Neste caso, a barra é arrancada do bloco de concreto com tensão axial $\sigma_{\mathrm{s}}$ inferior à resistência de escoamento $\mathrm{f}_{\mathrm{y}}$. Do equilíbrio entre forças externas e tensões de aderência obtêm-se:

$$
\sigma_{\mathrm{s}}=7 \cdot \frac{\ell_{\mathrm{b}}}{\phi_{\mathrm{s}}} \cdot \mathrm{f}_{\mathrm{ct}} \leq \mathrm{f}_{\mathrm{y}} \quad \text { e } \quad \Delta \ell=3,5 \cdot \frac{\mathrm{f}_{\mathrm{ct}}}{\mathrm{E}_{\mathrm{s}}} \cdot \frac{\ell_{\mathrm{b}}{ }^{2}}{\phi_{\mathrm{s}}}=\frac{\mathrm{w}}{2}
$$

sendo as unidades em $\mathrm{mm}$ e MPa, $\ell_{\mathrm{b}}$ o comprimento sobre o qual são desenvolvidas as tensões de aderência na barra e $\Delta \ell$ a variação de comprimento da barra. Admitindo que a barra esteja atravessando a interface entre duas peças de concreto, a variação de comprimento total da barra pode ser admitida igual à abertura da interface $(w)$, que pode ser avaliada como $w=0,05 . s$, para superfície lisa, e como $w=0,6 . \mathrm{s}^{2 / 3} \leq 1,4 \mathrm{~mm}$ para superfície rugosa. Assim sendo, definido o deslizamento da interface é possível determinar a variação de comprimento da barra e, consequentemente, sua tensão de tração. A partir daí pode-se determinar a resistência da armadura pela ação de pino. Dessas equações também é possível determinar o mínimo comprimento de ancoragem de uma barra para que ela seja arrancada com $\sigma_{s}=f_{y}$, ou seja:

$$
\ell_{\min }=\frac{1}{7} \cdot \frac{\phi_{\mathrm{s}} \cdot \mathrm{f}_{\mathrm{y}}}{\mathrm{f}_{\mathrm{ct}}} \quad(\mathrm{mm})
$$

Se a barra possuir comprimento de ancoragem maior que $\ell_{\min }$, ela alcançará a resistência de escoamento $\left(\sigma_{\mathrm{s}}=\mathrm{f}_{\mathrm{y}}\right)$, e a sua variação de comprimento será dada por:

$$
\Delta \ell=\left(\ell-\frac{1}{7} \cdot \frac{f_{y}}{f_{c t}} \cdot \phi_{s}\right) \cdot\left(\frac{f_{y}}{E_{s}}+0,029\right)+\frac{1}{14} \cdot \frac{f_{y}}{E_{s}} \cdot \frac{f_{y}}{f_{c t}} \cdot \phi_{s}
$$

Este valor deve ser inferior ao correspondente à deformação de ruptura do aço empregado. 


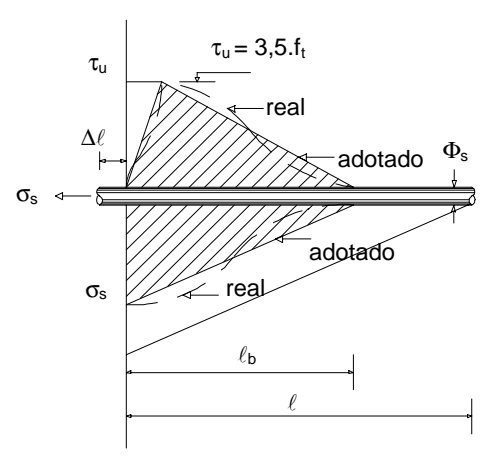

(a) comprimento de ancoragem insuficiente

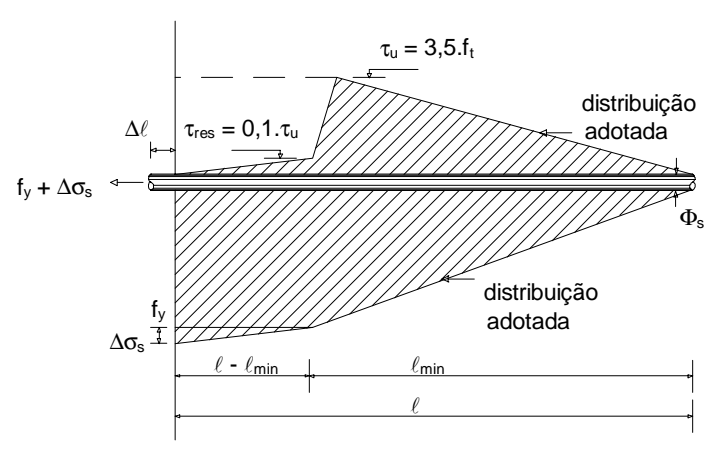

(b) comprimento de ancoragem maior que 0 mínimo para a barra atingir a tensão de escoamento

Figura 2.18 - Tensões de aderência em uma barra tracionada imersa em região de concreto (TASSIOS; VINTZELEOU (1990))

Apesar desse modelo ter sido desenvolvido a partir de resultados de ensaios em ligações de pilares pré-moldados, ele mostrou-se adequado na avaliação da resistência da interface de vigas compostas com laje moldada no local (ARAUJO (1997) e ARAUJO; EL DEBS (2000)). Ele também foi aplicado na avaliação da resistência ao cisalhamento da ligação viga-laje estudada por MALITE; TAKEYA (1996). Neste caso, entretanto, os resultados obtidos divergiram dos resultados experimentais. Isto ocorreu por que nestes ensaios a aderência apresentou parcela importante da resistência da ligação, fato que não é considerado nesse modelo (ARAUJO (1997)).

Posteriormente, esse modelo será utilizado na simulação numérica para modelar a resistência da ligação com superfície plana e lisa. Ele também será comparado com os resultados dos ensaios da ligação com superfície plana e rugosa. 


\section{Capítulo 3 - Ensaios de Caracterização do Concreto Reforçado com Fibras Metálicas}

Neste capítulo são mostrados os resultados do estudo realizado para determinação de algumas propriedades mecânicas do concreto reforçado com fibras metálicas. Foi estudada a influência das fibras nas resistências à compressão e à tração, na energia de fratura e no modulo de elasticidade inicial do concreto. Também foram realizados ensaios de compressão com deformação controlada, a partir dos quais foi determinada uma expressão para o traçado da curva tensão-deformação do concreto com fibras.

\subsection{Resistências à compressão e à tração}

Inicialmente foi realizado o estudo para definição dos traços de concreto empregados ao longo de todo o programa experimental. Foi obtido um traço para a confecção das peças pré-moldadas e três traços, com resistência à compressão variando de $50 \mathrm{MPa}$ a $100 \mathrm{MPa}$, para a confecção da ligação entre as peças pré-moldadas. Na definição desses traços contou-se com a ajuda de um aluno de iniciação científica (CATELLI JR. (2000)). Na Tabela 3.1 é mostrada a relação de material necessária para a confecção de um metro cúbico de concreto para os quatro traços. Nesta tabela, os traços de 1 a 3 foram empregados nas ligações nos ensaios de cisalhamento direto e nos ensaios em vigas compostas, enquanto o traço 4 foi utilizado para confeccionar as peças pré-moldadas. Foi empregado o cimento CP V-ARI, especificado pela NBR 5733 (1991), o que proporcionou a realização dos ensaios sete dias após a moldagem dos corpos-de-prova. Segundo o fabricante do cimento, ele apresentava uma resistência à compressão de $29 \mathrm{MPa}$ na idade de 1 dia e $47 \mathrm{MPa}$ na idade de 7 dias. Ao concreto empregado na ligação foi adicionada sílica ativa na proporção de $10 \%$ do peso do cimento. A areia e a brita foram obtidas na região, sendo que a brita apresentava um diâmetro máximo de $19 \mathrm{~mm}$. Também foi adicionado superplastificante de modo a melhorar a trabalhabilidade da mistura. No caso do concreto empregado na ligação, sua quantidade foi definida de modo a se obter um concreto com trabalhabilidade adequada para a execução da ligação entre as peças pré- 
moldadas. Sendo assim, a quantidade de superplastificante mostrada na Tabela 3.1 foi aumentada na medida em que foram adicionadas fibras à mistura. Na Tabela 3.2 são mostrados os valores obtidos do ensaio de abatimento de cone nas misturas com e sem fibras.

Tabela 3.1 - Relação de materiais para confecção de $1 \mathrm{~m}^{3}$ de concreto

\begin{tabular}{|c|c|c|c|c|c|c|}
\hline Traço & $\begin{array}{c}\text { Cimento } \\
(\mathrm{kg})\end{array}$ & $\begin{array}{c}\text { Sílica Ativa } \\
(\mathrm{kg})\end{array}$ & $\begin{array}{c}\text { Areia } \\
(\mathrm{kg})\end{array}$ & $\begin{array}{c}\text { Brita } \\
(\mathrm{kg})\end{array}$ & $\begin{array}{c}\text { Fator } \\
\mathrm{a} / \mathrm{c}\end{array}$ & $\begin{array}{c}\text { Superplastificante } \\
(\%)\end{array}$ \\
\hline 1 & 380 & 38 & 631 & 1132 & 0,56 & 1,50 \\
\hline 2 & 460 & 46 & 616 & 1104 & 0,42 & 1,80 \\
\hline 3 & 640 & 64 & 563 & 1011 & 0,32 & 2,20 \\
\hline 4 & 345 & - & 759 & 1173 & 0,55 & 0,37 \\
\hline
\end{tabular}

Tabela 3.2 - Quantidade de superplastificante e abatimento em função do volume de fibras adicionadas

\begin{tabular}{|c|c|c|c|}
\hline Traço & Volume de fibras (\%) & Superplastificante (\%) & Abatimento (cm) \\
\hline \multirow{3}{*}{1} & 0,00 & 1,5 & 25,7 \\
\cline { 2 - 4 } & 0,75 & 1,5 & 19,0 \\
\cline { 2 - 4 } & 1,50 & 1,7 & 23,3 \\
\hline \multirow{3}{*}{2} & 0,00 & 1,8 & 20,0 \\
\cline { 2 - 4 } & 0,75 & 1,8 & 16,0 \\
\cline { 2 - 4 } & 1,50 & 2,0 & 11,3 \\
\hline \multirow{3}{*}{3} & 0,00 & 2,2 & 20,3 \\
\cline { 2 - 4 } & 0,75 & 2,3 & 19,4 \\
\cline { 2 - 4 } & 1,50 & 2,3 & 9,8 \\
\hline
\end{tabular}

As fibras metálicas, empregadas neste trabalho, eram do tipo DRAMIX RL-45/30 BN com ganchos na extremidade. Segundo o fabricante, elas apresentavam um comprimento de $30 \mathrm{~mm}$ e um diâmetro de 0,62 $\mathrm{mm}$, resultando em um fator de forma igual a 48, e uma resistência à tração mínima de $1250 \mathrm{MPa}$. Foram definidos dois volumes de fibras, 0,75\% e $1,50 \%$, que correspondem a uma quantidade de, aproximadamente, $60 \mathrm{~kg}$ e $120 \mathrm{~kg}$ de fibras por metro cúbico de concreto, respectivamente. As fibras foram adicionadas no final do processo de mistura dos materiais, sendo a mistura homogeneizada por mais 1 minuto. O concreto empregado na confecção das peças pré-moldadas foi misturado em uma betoneira de eixo inclinado, enquanto o concreto empregado na ligação foi misturado em uma betoneira de eixo vertical com pás giratórias. 
$\mathrm{Na}$ Tabela 3.3 são mostradas as resistências à compressão e à tração indireta, determinada por compressão diametral, obtidas a partir de corpos-de-prova cilíndricos de $100 \mathrm{~mm} \times 200 \mathrm{~mm}$. Na Figura 3.1 é mostrada a influência das fibras na resistência à tração indireta do concreto. Observa-se que a adição de fibras ao concreto não alterou a resistência à compressão, entretanto proporcionou um aumento da resistência à tração. $\mathrm{A}$ partir desses resultados confirma-se, como relatado na literatura, que a adição de um volume de fibras abaixo de $120 \mathrm{~kg} / \mathrm{m}^{3}$ não influencia a resistência à compressão, principalmente quando as fibras são curtas (BALAGURU; SHAH (1992)). No caso da resistência à tração, contudo, as fibras proporcionaram um aumento superior ao que era esperado para uma fibra com fator de forma relativamente baixo, o que pode ser explicado pela melhor aderência entre a fibra e a matriz proporcionada pela redução dos vazios do concreto devida à adição de sílica.

Tabela 3.3 - Resistência média do concreto em função do volume de fibras adicionadas

\begin{tabular}{|c|c|c|c|}
\hline Traço & Volume de fibras $(\%)$ & Compressão $\left(f_{\mathrm{cm}}\right)-\mathrm{MPa}$ & Tração $\left(\mathrm{f}_{\mathrm{ctm}, \mathrm{sp}}\right)-\mathrm{MPa}$ \\
\hline \multirow{3}{*}{1} & 0,00 & 45,0 & 3,2 \\
\cline { 2 - 4 } & 0,75 & 52,2 & 5,1 \\
\cline { 2 - 4 } & 1,50 & 48,9 & 6,0 \\
\hline \multirow{3}{*}{2} & 0,00 & 73,3 & 3,5 \\
\cline { 2 - 4 } & 0,75 & 73,1 & 5,0 \\
\cline { 2 - 4 } & 1,50 & 73,1 & 8,1 \\
\hline \multirow{3}{*}{3} & 0,00 & 93,7 & 4,7 \\
\cline { 2 - 4 } & 0,75 & 99,3 & 6,2 \\
\cline { 2 - 4 } & 1,50 & 101,5 & 8,9 \\
\hline
\end{tabular}

Na Figura 3.2 é mostrada a relação entre a resistência à tração indireta e a resistência à compressão nos traços 1 a 3. Realizando uma regressão não-linear, obtêm-se as seguintes expressões para o cálculo da resistência à tração indireta do concreto:

$$
\begin{array}{ll}
f_{c t m, s p}=(0,52 \pm 0,01) f_{c m}^{1 / 2}(R=0,86) & \text { para } V_{f}=0 \% \\
f_{c t m, s p}=(0,78 \pm 0,02) f_{c m}^{1 / 2}(R=0,79) & \text { para } V_{f}=0,75 \% \\
f_{c t m, s p}=(1,02 \pm 0,01) f_{c m}^{1 / 2}(R=0,94) & \text { para } V_{f}=1,50 \%
\end{array}
$$


sendo R o índice de correlação entre os dados experimentais e os previstos pela expressão proposta. Quanto mais próximo da unidade for esse valor, mais a expressão proposta se aproxima dos dados experimentais.

É possível ainda correlacionar os coeficientes que multiplicam a raiz quadrada da resistência à compressão nas expressões anteriores com o volume de fibras adicionadas. Dessa forma, chega-se a uma expressão única que fornece a resistência à tração indireta do concreto em função da resistência à compressão e do volume de fibras adicionadas:

$$
f_{c t m, s p}=\left(0,52+0,31 V_{f}\right) f_{c m}^{1 / 2} \text { com } V_{f} \text { em porcentagem }
$$

Da Figura 3.2 observa-se que a adição de 1,5\% de fibras metálicas, com ganchos na extremidade e fator de forma igual a 48, aumentou a resistência à tração indireta do concreto em 99\%. Esta análise é válida para concretos com resistência à compressão variando de $50 \mathrm{MPa}$ a $100 \mathrm{MPa}$. Na Figura 3.3 é feita a comparação da expressão obtida neste trabalho para concretos sem fibra com as expressões do ACI 363R-92 (1994), da FIB (1999) e da FIP (1999). Observa-se que os resultados aqui obtidos estão próximos dos valores indicados por essas normas.

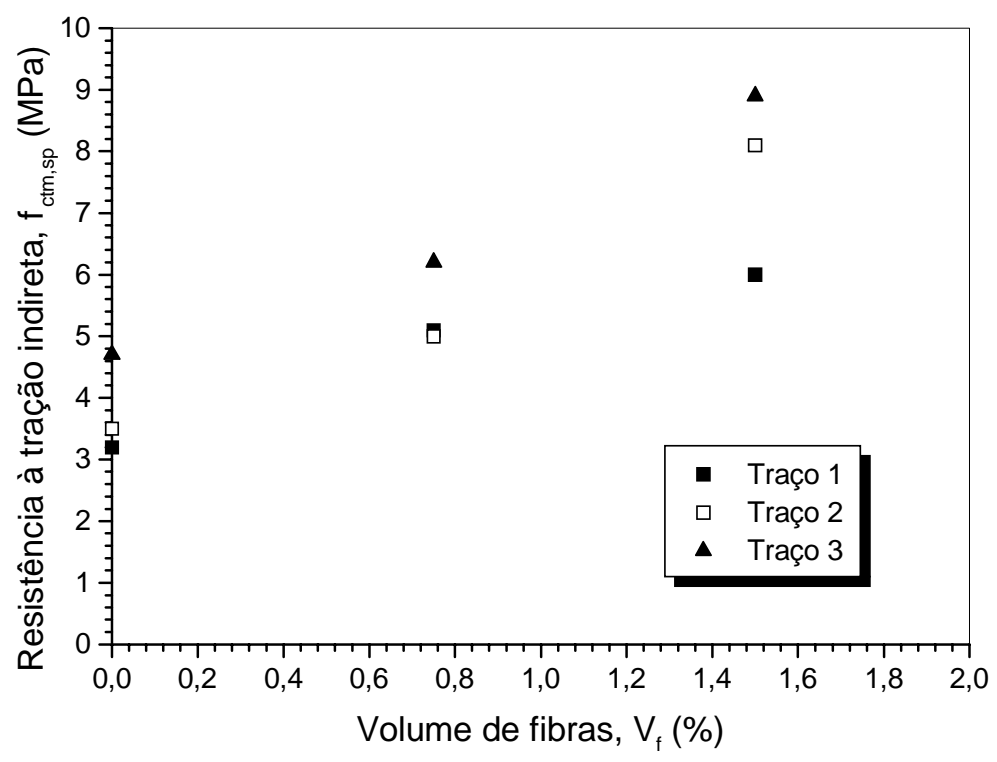

Figura 3.1 - Influência da adição de fibras na resistência à tração indireta do concreto 


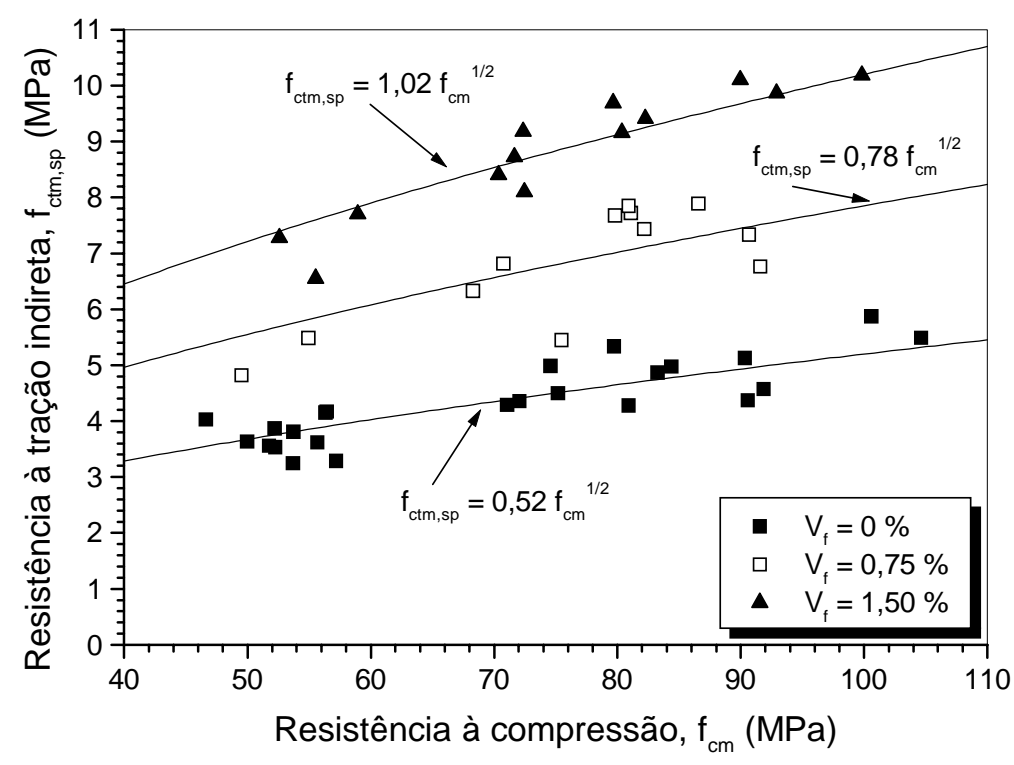

Figura 3.2 - Relação entre a resistência à tração e a resistência à compressão do concreto

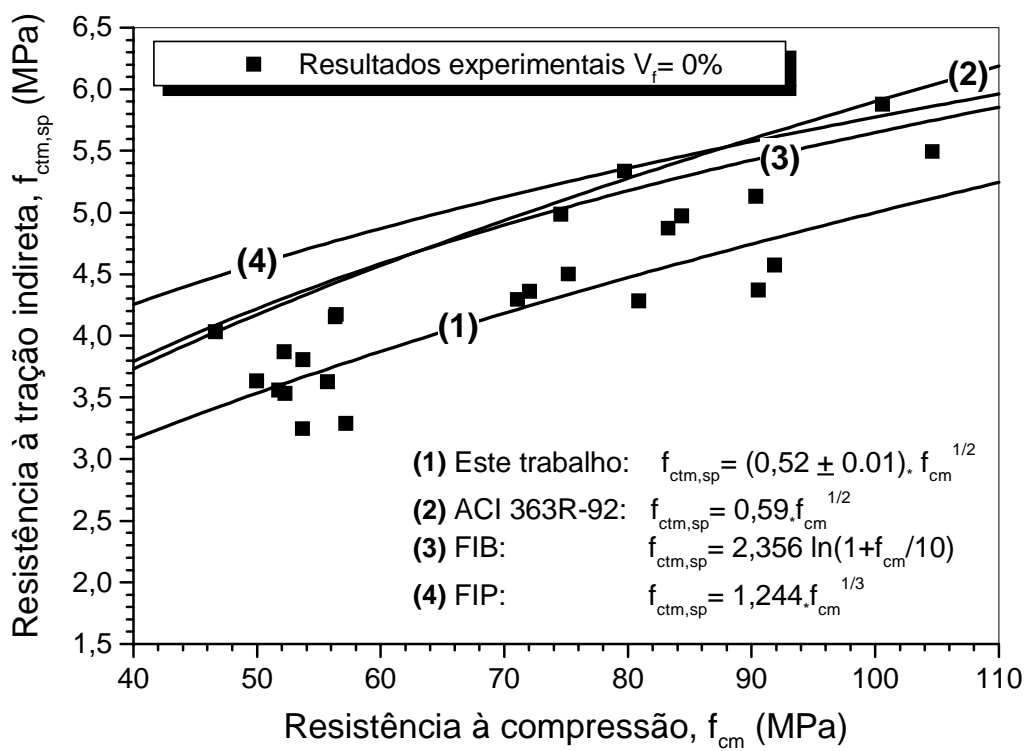

Figura 3.3 - Comparação da resistência à tração indireta deste trabalho com o ACI 363R-92 (1994), com a FIB (1999) e com a FIP (1999)

Foram realizados, também, ensaios de flexão em corpos-de-prova prismáticos com dimensões de $150 \mathrm{~mm}$ x $150 \mathrm{~mm}$ × $500 \mathrm{~mm}$ e carregados com duas forças concentradas nos terços do vão (CATELLI JR. (2000)). Os ensaios foram realizados com controle de deslocamento em uma prensa servo-controlada INSTRON com o objetivo de obter a curva força-deslocamento depois do pico de resistência. Na Tabela 3.4 estão mostradas as forças 
máximas obtidas e a resistência à tração na flexão de cada traço. Observa-se que, de modo geral, a adição de fibras aumentou a resistência à tração na flexão do concreto (Figura 3.4). No traço 1, contudo, praticamente não houve alteração da resistência, enquanto nos traços 2 e 3 a adição de 1,5\% de fibras proporcionou um ganho de resistência de até 34\%. Novamente, este comportamento pode ser explicado pelo fato da melhoria da aderência entre a fibra e a matriz nos traços de resistência mais elevada, o que resulta em um ganho de resistência devido à tendência de arrancamento das fibras da matriz. É interessante notar que nos traços 2 e 3, a adição de 0,75\% de fibras não alterou a resistência do concreto, que somente foi aumentada devido à adição de $1,5 \%$ de fibras. Isto talvez tenha ocorrido porque nestes traços o volume crítico de fibras, a partir do qual as fibras passam a influenciar na resistência à tração da matriz, esteja entre $0,75 \%$ e 1,50\%. Contudo, não é possível afirmar com certeza que o volume crítico realmente esteja neste intervalo, uma vez que durante o ensaio não observou-se uma fissuração múltipla no meio do vão, mas sim uma fissura única que prolongava-se até a face superior do corpo-de-prova (Figura 3.5).

Tabela 3.4 - Forças máximas suportadas pelos corpos-de-prova prismáticos e resistência do concreto à tração na flexão

\begin{tabular}{|c|c|c|c|}
\hline \multirow{2}{*}{ Traço } & Volume de fibras (\%) & Força $(\mathrm{kN})$ & $\begin{array}{c}\text { Resistência à tração na } \\
\text { flexão }\left(\mathrm{f}_{\mathrm{ctm}, \mathrm{f}}\right)-\mathrm{MPa}\end{array}$ \\
\hline \multirow{3}{*}{1} & 0,00 & 29,7 & 3,96 \\
\cline { 2 - 4 } & 0,75 & 30,3 & 4,04 \\
\cline { 2 - 4 } & 1,50 & 30,1 & 4,01 \\
\hline \multirow{3}{*}{2} & 0,00 & 43,7 & 5,83 \\
\cline { 2 - 4 } & 0,75 & 44,9 & 5,99 \\
\hline \multirow{3}{*}{3} & 1,50 & 58,5 & 7,8 \\
\cline { 2 - 4 } & 0,00 & 51,0 & 6,8 \\
\cline { 2 - 4 } & 0,75 & 52,0 & 6,93 \\
\hline
\end{tabular}

A medida de tenacidade nos ensaios de flexão foi obtida de acordo com as recomendações do ASTM-C1018 (1992). Primeiramente determinou-se o deslocamento correspondente à primeira fissura (ponto $A$ da Figura 3.6). Foi admitido que a primeira fissura aconteceu quando a curva força-deslocamento desviou-se do trecho linear. Em seguida, as áreas sob a curva força-deslocamento compreendidas entre a origem e os pontos $3 \delta, 5,5 \delta, 10,5 \delta$ e $15,5 \delta$ foram determinadas, sendo $\delta$ o deslocamento relativo à 
primeira fissura. A divisão dessas áreas pela área compreendida entre os pontos OAM fornece os índices de tenacidade $I_{5}, I_{10}, I_{20}$ e $I_{30}$ respectivamente.

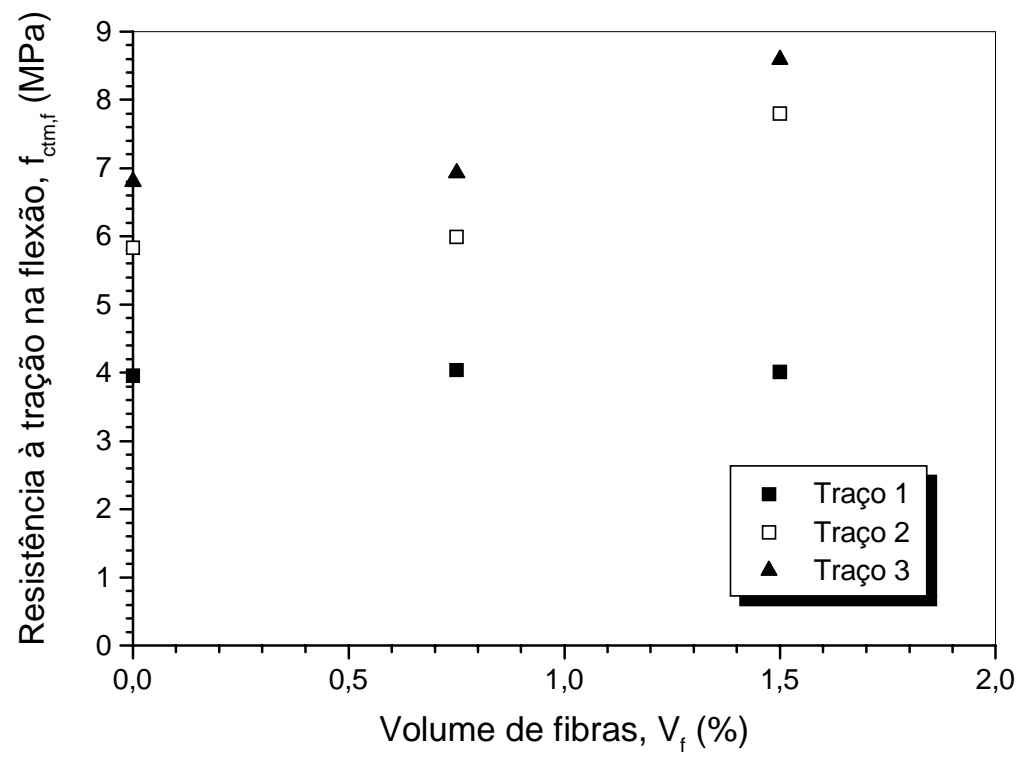

Figura 3.4 - Influência do volume de fibras na resistência do concreto à tração na flexão

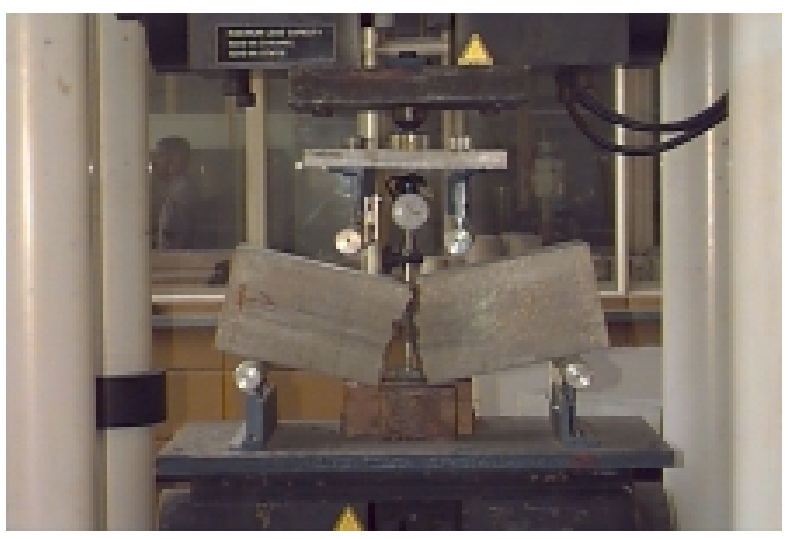

(a) Corpo-de-prova sem fibras

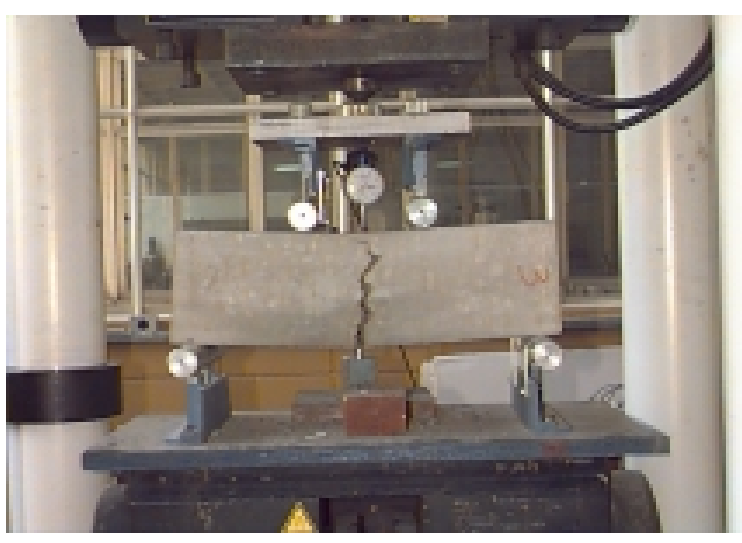

(b) Corpo-de-prova com $1,5 \%$ de fibras

Figura 3.5 - Ruptura dos corpos-de-prova prismáticos no ensaio de flexão (CATELLI JR. (2000)) 


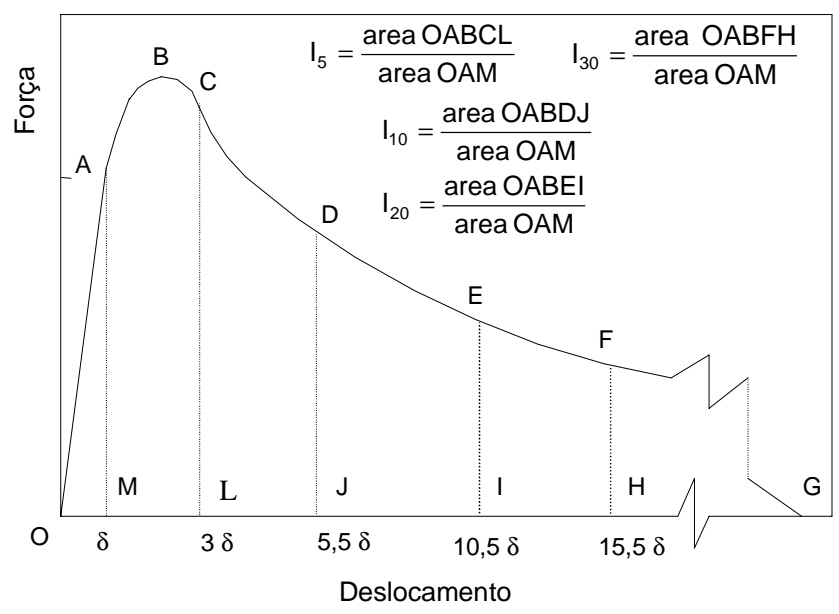

Figura 3.6 - Índice de tenacidade segundo o ASTM-C1018 (CATELLI JR. (2000))

Na Tabela 3.5 são mostrados os índices de tenacidade calculados para os traços 1 a 3 com dois volumes diferentes de fibras. Na Figura 3.7 são mostradas as curvas força contra deslocamento obtidas do ensaio. Observa-se que a medida em que se aumenta o volume de fibras, o índice de tenacidade nos três traços também aumenta. No traço 3 , entretanto, o aumento da tenacidade proporcionado pela adição de $1,5 \%$ de fibras é significativamente maior que nos demais traços. Analisando a relação entre os índices $I_{5} \mathrm{e}$ $\mathrm{I}_{10}$ para um volume de fibras de $0,75 \%$, observa-se que o traço 3 possui um valor inferior ao dos demais traços. Contudo, quando o volume de fibras é aumentado para 1,5\%, o traço 3 apresenta a maior relação entre os índices $I_{5}$ e $I_{10}$. Comportamento semelhante é observado quando se analisa a relação entre os índices $I_{10}$ e $I_{20}$. Este resultado sugere que a adição de 0,75\% de fibras ao traço 3 não é suficiente para melhorar a ductilidade do concreto ao mesmo nível que nos traços 1 e 2.

Tabela 3.5 - Índices de tenacidade dos ensaios de flexão em corpos-de-prova prismáticos

\begin{tabular}{|c|c|c|c|c|c|}
\hline \multirow{2}{*}{ Traço } & \multirow{2}{*}{$\begin{array}{c}\text { Volume de } \\
\text { fibras (\%) }\end{array}$} & \multicolumn{4}{|c|}{ Índices de tenacidade } \\
\cline { 3 - 6 } & & $\mathrm{I}_{5}$ & $\mathrm{I}_{10}$ & $\mathrm{I}_{20}$ & $\mathrm{I}_{30}$ \\
\hline \multirow{3}{*}{1} & 0,75 & 4,56 & 6,40 & 7,89 & 8,39 \\
\cline { 2 - 6 } & 1,50 & 4,77 & 7,37 & 9,40 & 10,05 \\
\hline \multirow{3}{*}{2} & 0,75 & 5,04 & 7,38 & 9,06 & 9,66 \\
\cline { 2 - 6 } & 1,50 & 5,32 & 8,25 & 10,66 & 11,65 \\
\hline \multirow{3}{*}{3} & 0,75 & 5,39 & 6,75 & 7,46 & 7,60 \\
\cline { 2 - 6 } & 1,50 & 6,12 & 10,01 & 13,27 & 14,63 \\
\hline
\end{tabular}



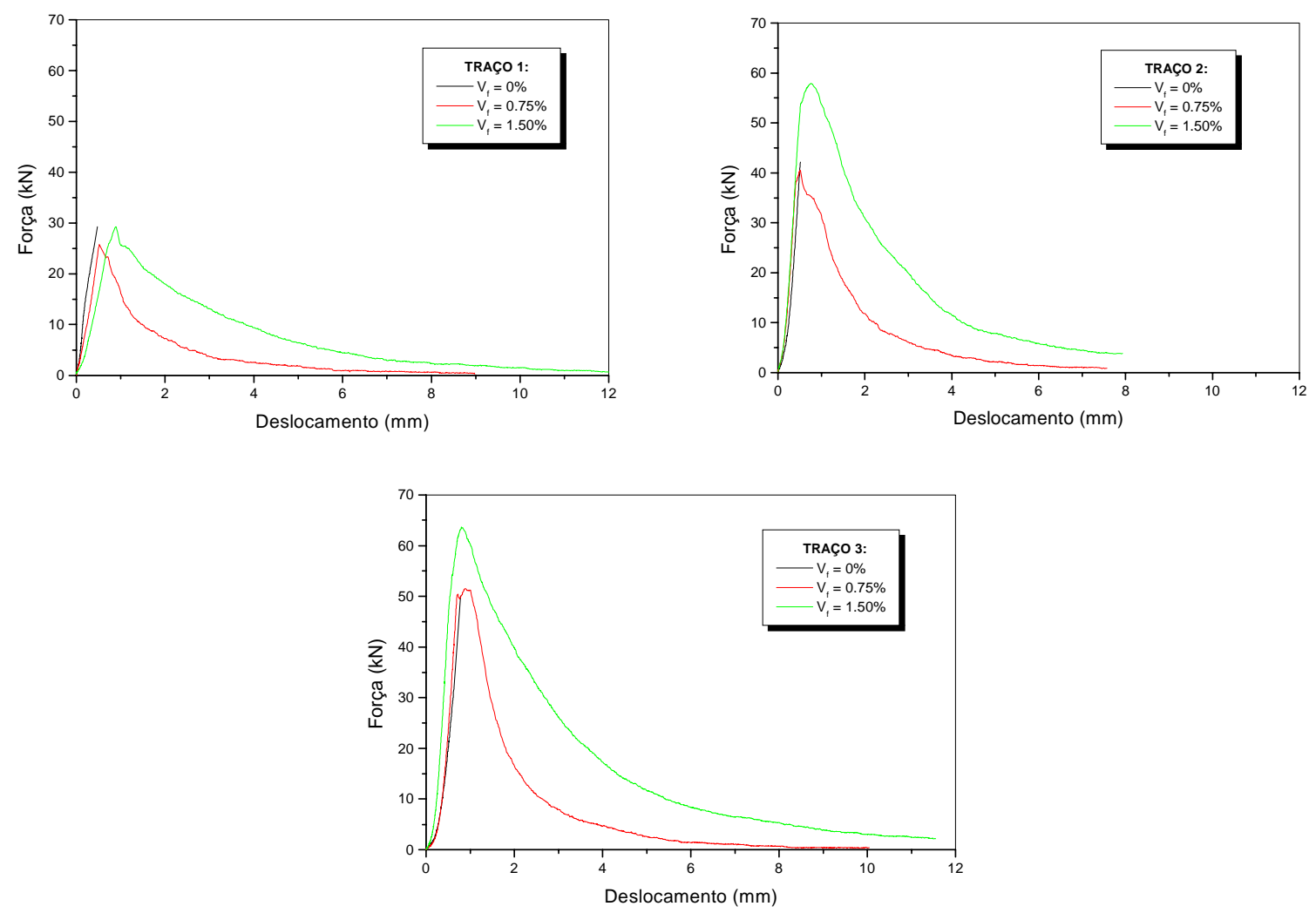

Figura 3.7 - Curvas Força-deslocamento obtidas dos ensaios de flexão em prismas

\subsection{Energia de fratura}

\subsubsection{Introdução}

A capacidade de absorção de energia de um material à tração normalmente é avaliada por intermédio do conceito de energia de fratura, $G_{f}$, definido como a energia despendida na formação de uma fissura de área unitária. A energia de fratura pode ser quantificada por meio de ensaios de tração uniaxial ou de flexão, ambos sob controle de deslocamentos. Para que não de dissipe energia fora da zona de fratura, os corpos-deprova devem ser entalhados.

O ensaio de tração uniaxial sob controle de deslocamentos é o teste mais adequado para quantificar a energia de fratura. Contudo, a estabilidade destes ensaios exige equipamentos bastante rígidos (BARROS (1995)). Como nem sempre este tipo de equipamento está disponível na maior parte dos laboratórios, os ensaios de flexão em viga com entalhe no meio do vão, submetida a três pontos de carga, são mais adequados para quantificar a energia de fratura do material (Figura 3.8). 


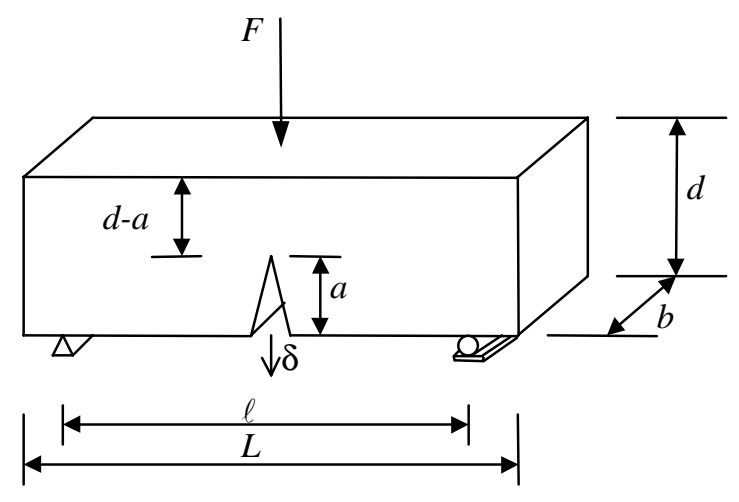

Figura 3.8 - Ensaio de flexão sob três pontos de carga para quantificação da energia de fratura $\mathrm{G}_{\mathrm{f}}(\mathrm{BARROS}(1995)$ )

Para que $G_{f}$ seja uma propriedade do material, é necessário que as três condições seguintes sejam verificadas:

a) A energia consumida fora da zona de fratura tem que ser suficientemente pequena para que possa ser desprezada em comparação com a energia dissipada na zona de fratura. Isto significa que a relação $a / d$ não deve ser muito pequena;

b) A energia de fratura deve ser independente das dimensões do corpo-de-prova e do entalhe;

c) O processo de fratura deve ser estável. Isto implica no emprego de equipamentos suficientemente rígidos.

Por outro lado, a dimensão da superfície de fratura não deve ser muito pequena comparada com a maior dimensão do agregado, uma vez que se tal condição não for respeitada aumenta a dispersão dos valores de $G_{f}$ e aumenta a influência do peso próprio do corpo-de-prova na quantificação de $\mathrm{G}_{\mathrm{f}}$. O RILEM (1985) para satisfazer tanto a condição anterior quanto à das alíneas a) e c), recomenda $a / d=0,5$.

A rigidez exigida do equipamento de ensaio depende das propriedades mecânicas do corpo-de-prova e das suas dimensões. Se durante a fase de amolecimento ocorrerem quedas bruscas de força, é porque a rigidez do equipamento não é suficiente face à rigidez do corpo-de-prova. Para não ser necessário o emprego de equipamentos demasiadamente rígidos, é aconselhável a realização de ensaios sob três pontos de carga em vez de ensaios sob quatro pontos de carga. Para facilitar o seu manuseio, os corpos-de-prova devem ser pequenos, mas o parâmetro $\ell / d$ não deve ser muito baixo (Figura 3.8). Tendo em conta 
estas considerações, o RILEM (1985) propõe, para dimensões dos corpos-de-prova, os valores mostrados na Tabela 3.6, que são função da dimensão máxima do agregado graúdo $\left(d_{\max }\right)$. Para misturas com $d_{\max }>64 \mathrm{~mm}$, os valores de $d$ e $b$ devem aumentar de modo proporcional com $d_{\max }$, enquanto os valores de $L$ e $\ell$ devem aumentar em proporção com a raiz quadrada de $\mathrm{d}_{\max }$.

Tabela 3.6 - Dimensões dos corpos-de-prova para ensaio de flexão sob três pontos de carga recomendadas pelo RILEM (1985)

\begin{tabular}{|c|c|c|c|c|}
\hline$d_{\max }(\mathrm{mm})$ & $d(\mathrm{~mm})$ & $b(\mathrm{~mm})$ & $L(\mathrm{~mm})$ & $\ell(\mathrm{mm})$ \\
\hline $1-16$ & $100 \pm 5$ & $100 \pm 5$ & $840 \pm 10$ & $800 \pm 5$ \\
\hline $16,1-32$ & $200 \pm 5$ & $100 \pm 5$ & $1190 \pm 10$ & $1130 \pm 5$ \\
\hline $32,1-48$ & $300 \pm 5$ & $150 \pm 5$ & $1450 \pm 10$ & $1385 \pm 5$ \\
\hline $48,1-64$ & $400 \pm 5$ & $200 \pm 5$ & $1640 \pm 10$ & $1600 \pm 5$ \\
\hline
\end{tabular}

A curva força contra deslocamento no meio do vão do corpo-de-prova deve ser obtida até o instante em que a força resistida pelo corpo-de-prova torna-se nula $(F=0)$. A energia de fratura do material pode ser calculada empregando a expressão recomendada pelo RILEM (1985):

$$
G_{f}=\frac{W_{0}+\left(m_{1}+2 m_{2}\right) g \delta_{0}}{A_{\text {lig }}}
$$

em que $W_{0}$ é o trabalho produzido pela Força $F$ exercida pelo atuador durante a deformação do corpo-de-prova (área sob a curva $F-\delta$ da Figura 3.9 ), $\mathrm{m}_{1}$ é a massa do corpo-de-prova entre apoios, calculada como a massa do corpo-de-prova multiplicada por $\ell / L, \mathrm{~m}_{2}$ é a massa do equipamento que acompanha a deformação do corpo-de-prova durante o ensaio e que não está acoplada ao atuador, $g$ é a aceleração da gravidade (admitida igual a 9,81 $\left.\mathrm{m} / \mathrm{s}^{2}\right), \delta_{0}$ é a flecha última, isto é, o deslocamento registrado no fim do ensaio quando $F=0$, e $A_{\text {lig }}=b(d-a)$ é a área da superfície de fratura acima do entalhe projetada no plano ortogonal ao eixo longitudinal do corpo-de-prova. Nos primeiros ensaios experimentais, a quantificação da energia de fratura era realizada computando apenas a área sob a curva $F$ $-\delta$. Contudo, a influência do peso próprio do corpo-de-prova e de outros equipamentos não acoplados ao atuador é apreciável podendo representar de $40 \%$ a $60 \%$ da energia total computada no cálculo de $G_{f}($ HILLERBORG (1985)). 


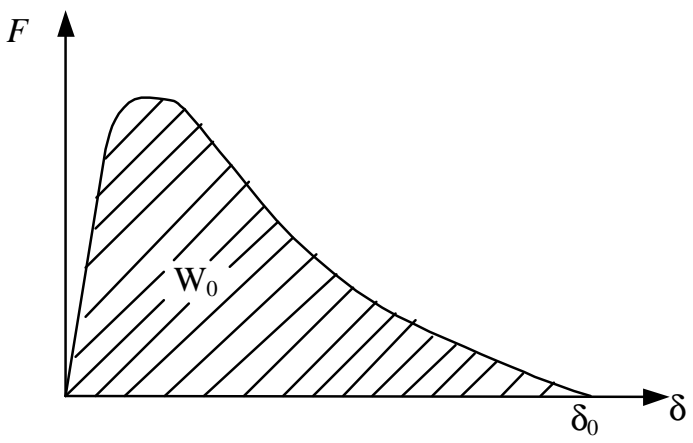

Figura 3.9 - Quantificação da energia de fratura segundo o RILEM (1985)

Aumentando-se o tamanho dos agregados até um limite máximo que não prejudique demasiadamente a trabalhabilidade da mistura, a energia de fratura aumenta, uma vez que aumenta a rugosidade da superfície de fratura. Aumentando a resistência dos agregados graúdos, da matriz e da zona de interface matriz-agregado, aumenta-se a resistência do material, resultando em maiores energias de fratura. Nos concretos de alta resistência a matriz e os agregados possuem resistências semelhantes, de modo que a superfície de fratura atravessa também os agregados, sendo por isso menos rugosa que nos concretos de mais baixa resistência. Assim, a energia de fratura, ainda que maior nos concretos de alta resistência, não é proporcional ao aumento registrado na resistência à compressão, dado que se por um lado a energia de fratura aumenta com o aumento da resistência da matriz, por outro lado este aumento é atenuado pela diminuição do engrenamento dos agregados devido o plano de fraturamento atravessar os agregados graúdos. Por este motivo, a adição de fibras à matriz torna-se importante de modo a se obter compósitos com elevada resistência e adequada ductilidade.

Diversos trabalhos demonstraram que quando $G_{f}$ é avaliada empregando ensaios de flexão sob três pontos de carga, a energia de fratura não é de toda independente das dimensões do corpo-de-prova e do entalhe. Deste modo, a hipótese de que a energia de fratura é uma propriedade do material tem sido posta em dúvida por alguns pesquisadores (DE BORST (1989)).

Os ensaios de flexão sob três pontos de carga também podem ser utilizados para determinar a resistência do concreto à tração na flexão. Levando em conta a ação do peso próprio do corpo-de-prova e de possíveis massas de equipamentos não acopladas ao atuador, a resistência à flexão pode ser obtida pela seguinte expressão (BARROS (1995)): 


$$
f_{c t, f}=C_{1} \frac{\left[F_{\max }+C_{2} m_{1} g\left(1-\alpha^{2}\right)+m_{2} g\right] \ell}{b(d-a)^{2}}
$$

em que $F_{\max }$ é a máxima força transmitida pelo atuador, $m_{1}$ é a massa do corpo-de-prova entre os apoios, $\mathrm{m}_{2}$ é a massa do equipamento que acompanha a deformação do corpo-deprova durante o ensaio e que não está acoplada ao atuador, $\alpha=L / \ell-1$ é o parâmetro que atende ao fato do comprimento do corpo-de-prova, $L$, poder ser diferente do seu vão, $\ell, g$ é a aceleração da gravidade $\left(9,81 \mathrm{~m} / \mathrm{s}^{2}\right)$, b e $d$ são a largura e a altura do corpo-de-prova, respectivamente, e a é a altura do entalhe. No ensaio de flexão sob três pontos de carga, $\mathrm{C}_{1}$ $=1,5$ e $C_{2}=0,5$, enquanto no ensaio de flexão sob quatro pontos de carga, $C_{1}=1,0$ e $C_{2}=$ $3 / 4$.

\subsubsection{Descrição dos ensaios}

Para se obter a curva completa força-deslocamento no meio do vão, os ensaios de flexão foram realizadas sob controle de deslocamentos em uma prensa servo-controlada INSTRON. A célula de carga deste equipamento possuía uma capacidade máxima de 2500 kN e uma tensão de saída de $10 \mathrm{~V}$, resultando em uma sensibilidade de $0,25 \mathrm{kN}$. O atuador possuía um transdutor interno que registrava os deslocamentos verticais do pistão. Estes valores, entretanto, não foram empregados para o traçado da curva força-deslocamento. Foram posicionados dois transdutores, com $20 \mathrm{~mm}$ de curso e sensibilidade de $0,01 \mathrm{~mm}$, de cada lado do corpo-de-prova, os quais eram fixados a um dispositivo que se ligava ao corpo-de-prova na interseção do eixo longitudinal médio do prisma com os alinhamentos verticais dos apoios. Desta forma, pretendia-se evitar a leitura de deslocamentos parasitas provenientes de acomodações nos apoios. O deslocamento no meio do vão foi avaliado pelo valor médio da leitura dos transdutores. Na Figura 3.10 é mostrado um corpo-de-prova posicionado para ensaio.

A velocidade de carregamento adotada foi de $0,002 \mathrm{~mm} / \mathrm{s}$ para os corpos-de-prova confeccionados sem adição de fibras, e de $0,004 \mathrm{~mm} / \mathrm{s}$ para os corpos-de-prova com fibras. Neste último caso, a velocidade de carregamento foi aumentada para $0,015 \mathrm{~mm} / \mathrm{s}$ quando 0 deslocamento medido pelos transdutores de $20 \mathrm{~mm}$ atingiu $2 \mathrm{~mm}$. O aumento da velocidade de carregamento tende a introduzir uma resistência adicional ao corpo-de-prova. Contudo, como nesta fase eles já se encontravam com elevado grau de fissuração, não foram observadas alterações significativas na leitura da força aplicada pelo atuador. Esta velocidade foi mantida constante até o final do ensaio, que, em alguns casos, atingiu flechas superiores a $20 \mathrm{~mm}$. 

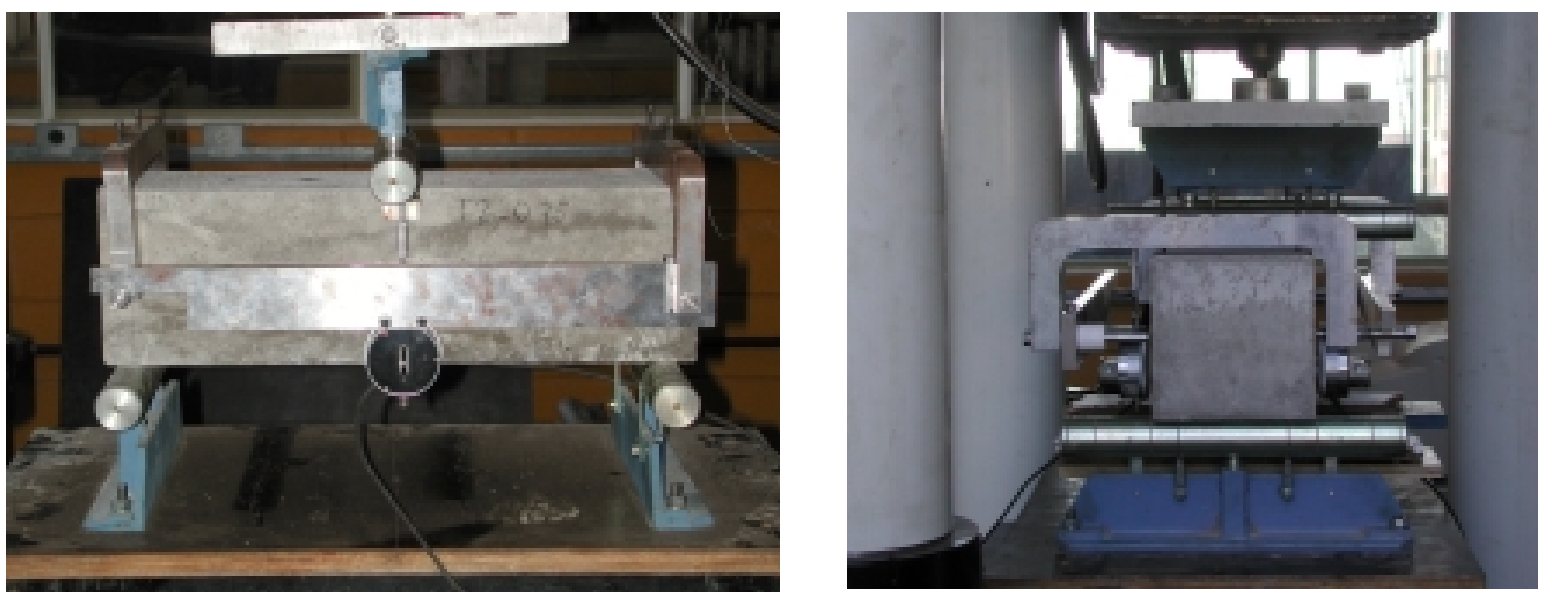

Figura 3.10 - Corpo-de-prova posicionado para ensaio de flexão sob três pontos de carga

Para confecção dos corpos-de-prova, foram utilizados moldes prismáticos de aço existentes no laboratório, que apresentavam dimensões de $150 \mathrm{~mm} \times 150 \mathrm{~mm} \times 500 \mathrm{~mm}$. Assim sendo, os corpos-de-prova ensaiados possuíam dimensões de $150 \mathrm{~mm}$ x $150 \mathrm{~mm}$ x $450 \mathrm{~mm}$.

Os corpos-de-prova foram confeccionados apenas com o traço 2. Foram analisados quatro volumes diferentes de fibra: 0,75\% $\left(60 \mathrm{~kg} / \mathrm{m}^{3}\right), 1,0 \%\left(80 \mathrm{~kg} / \mathrm{m}^{3}\right), 1,50 \%\left(120 \mathrm{~kg} / \mathrm{m}^{3}\right)$ e $2,0 \%\left(160 \mathrm{~kg} / \mathrm{m}^{3}\right)$. A mistura dos materiais foi realizada em betoneira de eixo vertical, e a concretagem realizada em mesa vibratória. Os corpos-de-prova foram desmoldados após 24 horas de cura e mantidos em câmara úmida até a data do ensaio, que foi realizado oito dias após a concretagem. O ensaio após uma data tão reduzida de cura foi possível graças ao emprego de cimento de alta resistência inicial.

Um dia antes do ensaio, os corpos-de-prova foram serrados até a metade de sua altura conforme recomendação do RILEM (1985). A largura do entalhe era de aproximadamente $5 \mathrm{~mm}$. Em seguida eles foram pesados e medidos com precisão de milímetro.

\subsubsection{Resultados dos ensaios}

$\mathrm{Na}$ Tabela 3.7 são mostrados a resistência à tração na flexão, a resistência à compressão e a energia de fratura nos corpo-de-prova ensaiados. Esses valores representam o valor médio obtido do ensaio de três exemplares. A primeira vista, nota-se que o aumento do volume de fibras adicionadas aumenta tanto a energia de fratura quanto a resistência à tração na flexão. Esses resultados estão de acordo com outros trabalhos que 
mostram a eficiência das fibras na melhoria do comportamento do concreto à tração (BARROS (1995)).

Tabela 3.7 - Resultados dos ensaios de flexão sob três pontos de carga

\begin{tabular}{|c|c|c|c|}
\hline Volume de fibras $(\%)$ & $\mathrm{f}_{\mathrm{cm}}(\mathrm{MPa})$ & $\mathrm{f}_{\mathrm{ctm}, \mathrm{f}}(\mathrm{MPa})$ & $\mathrm{G}_{\mathrm{f}}(\mathrm{N} / \mathrm{mm})$ \\
\hline 0 & 71,05 & 6,96 & 0,152 \\
\hline 0,75 & 68,27 & 5,15 & 0,509 \\
\hline 1,0 & 74,10 & 9,62 & 4,330 \\
\hline 1,5 & 80,34 & 9,35 & 5,177 \\
\hline 2,0 & 79,60 & 12,79 & 8,029 \\
\hline
\end{tabular}

Nos corpos-de-prova sem fibras, a força máxima foi alcançada quando surgiu a primeira fissura logo acima do entalhe. Nos corpos-de-prova com fibras, mesmo após o aparecimento da primeira fissura ainda houve acréscimo na força aplicada. Este acréscimo foi tanto maior quanto maior o volume de fibras adicionadas. No caso da adição de $0,75 \%$ de fibras, praticamente não houve alteração na resistência à flexão. Surgida a primeira fissura, houve uma queda na força aplicada seguida de um ramo descendente menos acentuado que no caso dos ensaios sem fibras. Isto confirma que este volume de fibras é ineficiente para influenciar a resistência à tração do compósito. Estes resultados são semelhantes aos obtidos dos ensaios de flexão sob quatro pontos de carga. Naqueles ensaios, foi observado um aumento de $34 \%$ na resistência à flexão quando foi adicionado $1,50 \%$ de fibras, valor muito próximo ao obtido nos ensaios sob três pontos de carga. $\mathrm{Na}$ Figura 3.11 são mostradas as curvas de força versus deslocamento no meio do vão referentes aos corpos-de-prova ensaiados.

A energia de fratura do concreto pode ser estimada pela seguinte expressão recomendada pelo código modelo CEB-FIP MC90 (FIB (1999)):

$$
\begin{array}{ll}
G_{f}=G_{f 0}\left(\frac{f_{c m}}{f_{c m 0}}\right)^{0,7} & \text { para } f_{c m} \leq 80 \mathrm{MPa} \\
G_{f}=4,30 G_{f 0} & \text { para } f_{c m}>80 \mathrm{MPa}
\end{array}
$$

sendo $G_{f 0}$ estimado em função do diâmetro máximo do agregado pela Tabela 3.8 ,e $f_{\mathrm{cm} 0}=$ $10 \mathrm{MPa}$. 


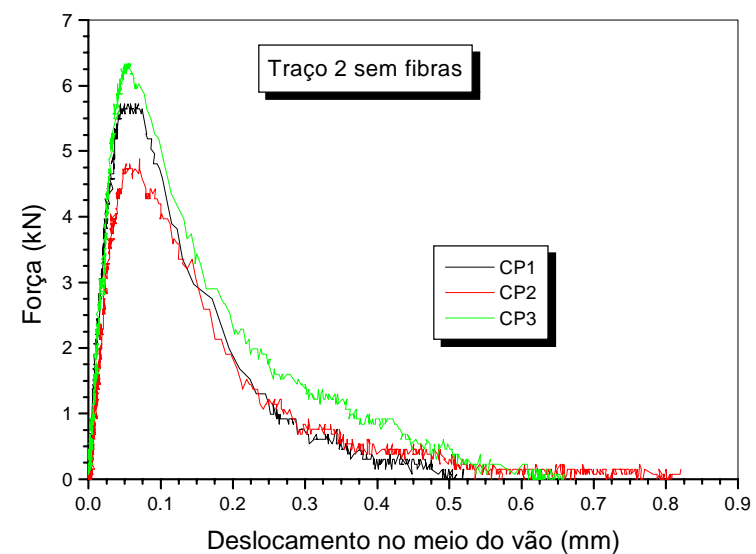

(a) $V_{f}=0 \%$

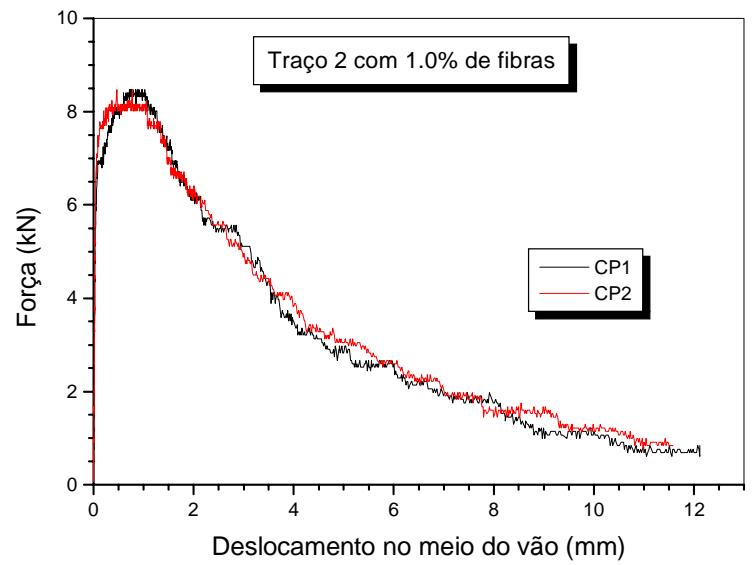

(a) $V_{f}=1,0 \%$

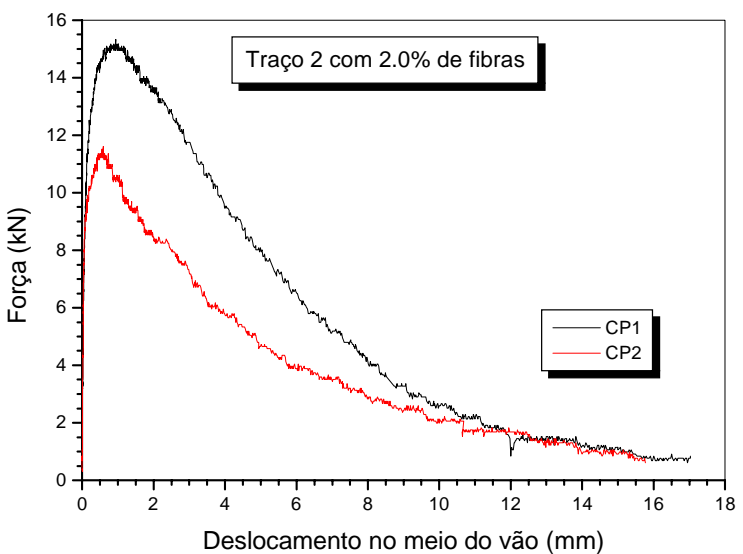

(a) $V_{f}=2,0 \%$

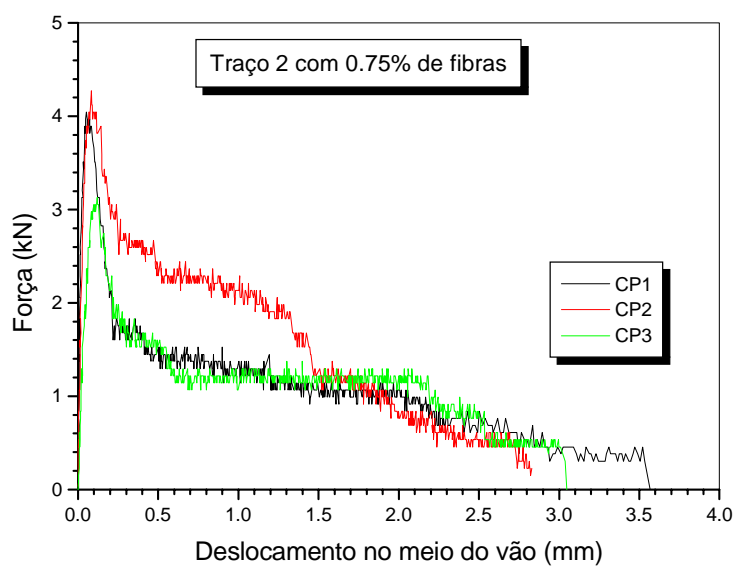

(b) $V_{f}=0,75 \%$

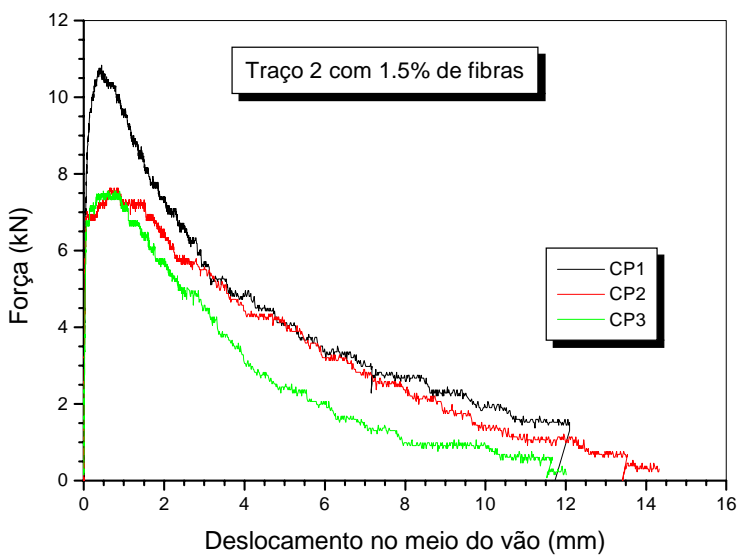

(b) $V_{f}=1,5 \%$

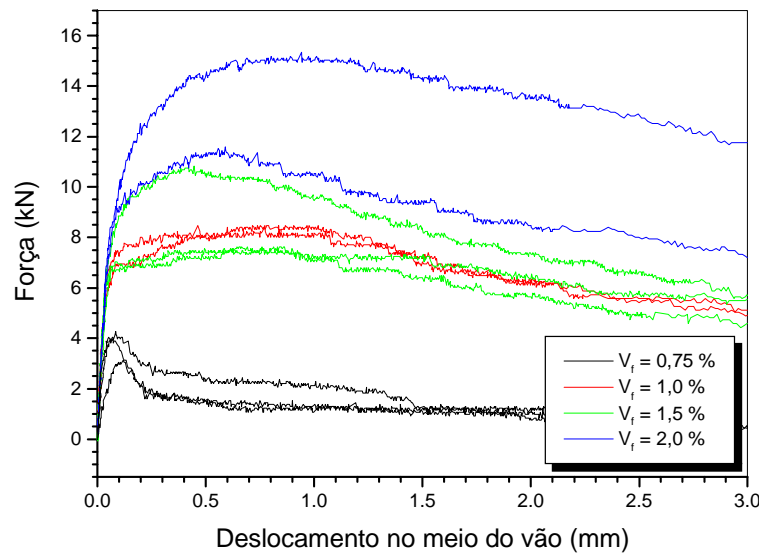

(b) Influência das fibras

Figura 3.11 - Resposta dos corpos-de-prova ensaiados à flexão e influência das fibras na resistência à tração na flexão. 
Tabela 3.8 - Valores de $\mathrm{G}_{\mathrm{fo}}$ segundo a FIB (1999)

\begin{tabular}{|c|c|c|c|}
\hline $\mathrm{d}_{\max }(\mathrm{mm})$ & 8 & 16 & 32 \\
\hline $\mathrm{G}_{\mathrm{f} 0}(\mathrm{~N} / \mathrm{mm})$ & 0,025 & 0,03 & 0,058 \\
\hline
\end{tabular}

Aplicando a eq.(3.5) ao corpo-de-prova ensaiado sem fibras, chega-se a uma energia de fratura de $0,12 \mathrm{~N} / \mathrm{mm}$, o que representa um valor $20 \%$ inferior ao obtido experimentalmente. O código modelo CEB-FIP MC 90, contudo, admite uma dispersão de $30 \%$ em torno dos valores calculados pela eq.(3.5), de modo que se pode admitir que o ensaio de flexão realizado foi adequado para avaliar a energia de fratura do concreto.

Nos corpos-de-prova sem fibras, desenvolveu-se uma única superfície de fratura localizada em uma banda estreita logo acima do entalhe. Nos corpos-de-prova com fibras, desenvolveu-se uma macrofissura em uma banda estreita acima do entalhe, surgindo por vezes algumas ramificações superficiais, tanto mais significativas quanto maior o volume de fibras. Na Figura 3.12 são mostrados os panoramas de fissuração dos corpos-de-prova ensaiados.

A forma da superfície de fratura também está associada às propriedades de resistência e de capacidade de absorção de energia do material. Na Figura 3.13 comparase a forma da superfície de fratura na superfície frontal dos corpos-de-prova com 1,50\% de fibras. Dessa figura constata-se que o corpo-de-prova 1 apresenta uma superfície de fratura com maior desenvolvimento, o que contribuiu para a maior resistência e a maior capacidade de absorção de energia quando comparado com o corpo-de-prova 3.

No que se refere ao modo de ruptura das fibras, houve o seu arrancamento da matriz, sem que houvesse uma retificação das suas extremidades. Isto evidencia a pouca utilização dessas fibras e explica porque foi necessário um volume tão alto de fibras para conseguir comportamento semelhante ao de outras fibras mais longas e com maior fator de forma, porém com volumes inferiores. A superfície de fratura apresentava-se pouco rugosa devido ao fraturamento dos agregados, que é uma situação típica dos concretos de alta resistência (Figura 3.14). 


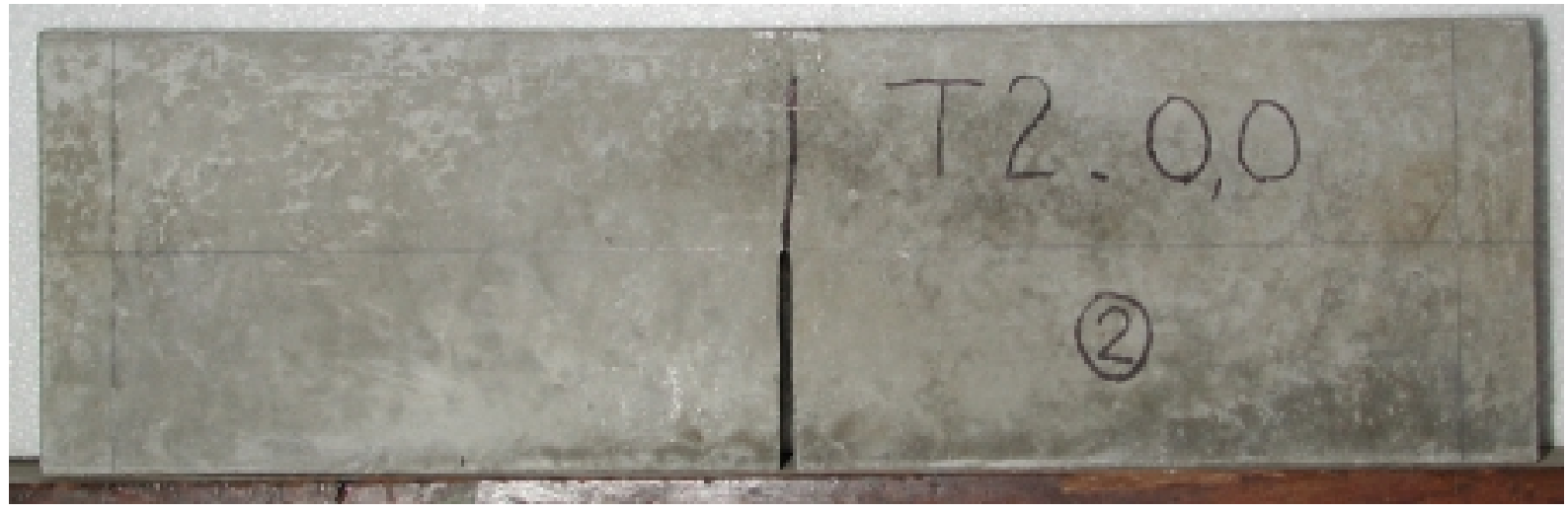

(a) corpo-de-prova sem fibras

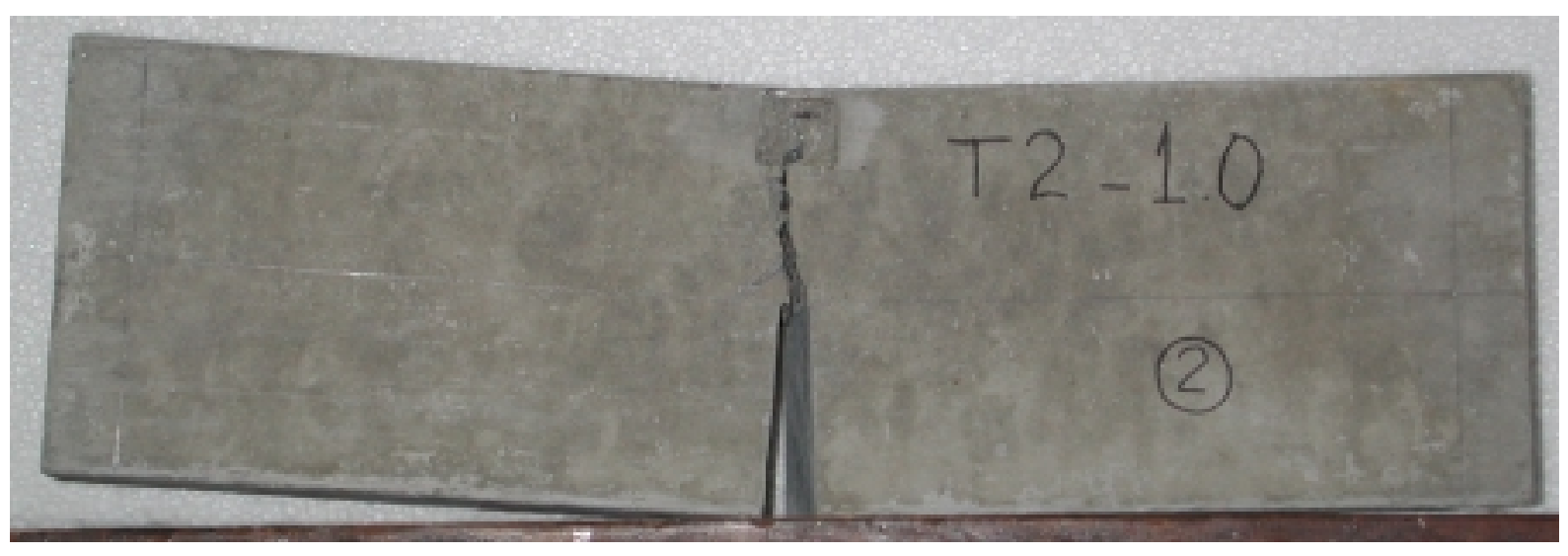

(b) corpo-de-prova com 1,0\% de fibras

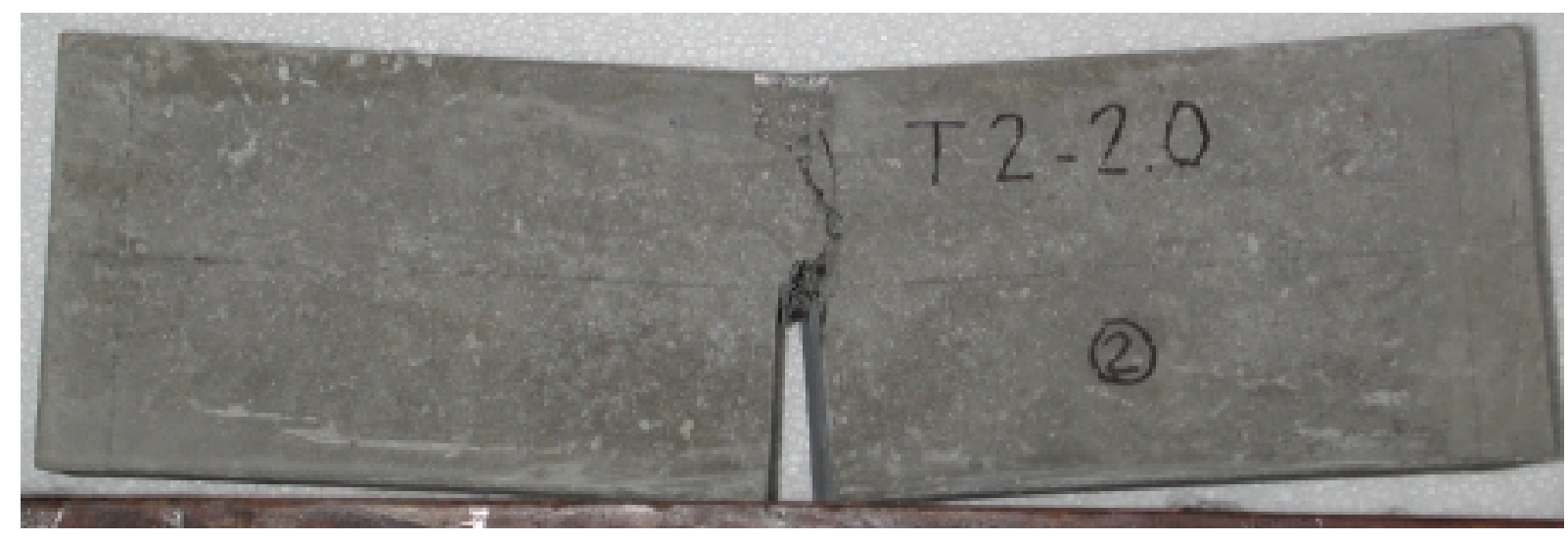

(c) corpo-de-prova com 2,0\% de fibras

Figura 3.12 - Panorama de fissuração nos corpos-de-prova ensaiados à flexão 


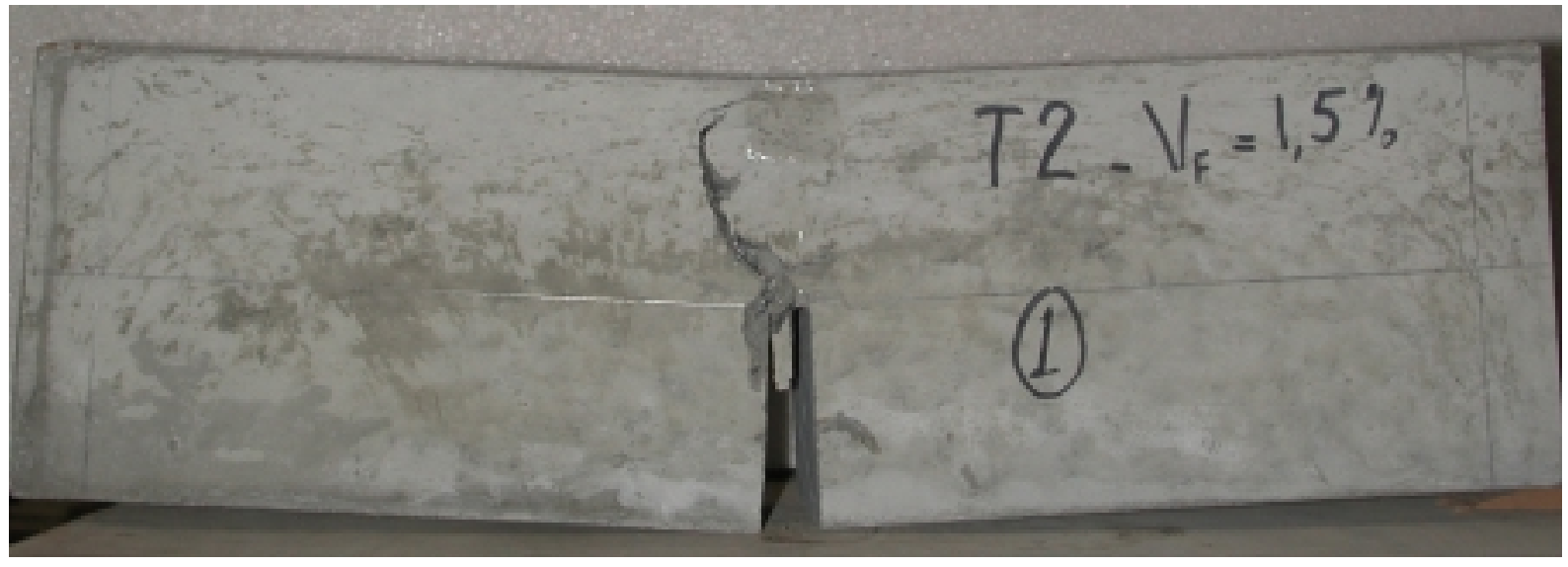

(a) corpo-de-prova 1

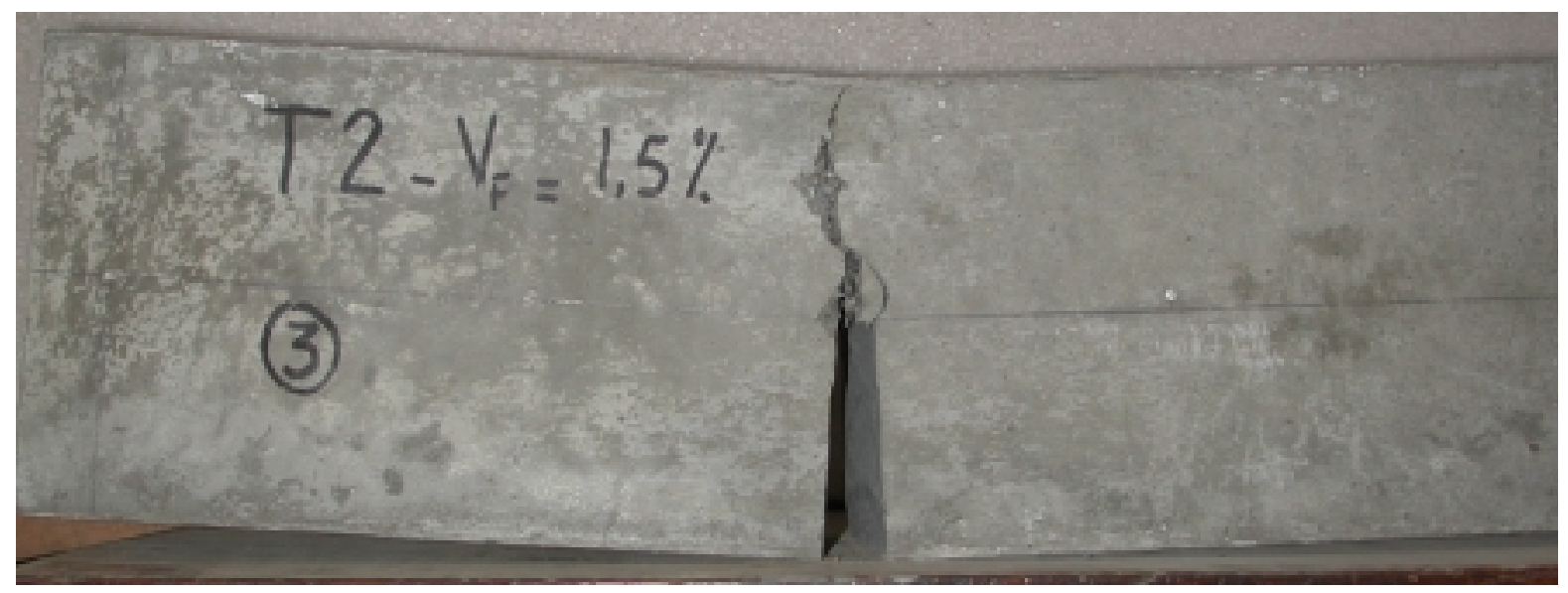

(b) corpo-de-prova 3

Figura 3.13 - Forma da superfície de ruptura nos corpos-de-prova ensaiados à flexão com $1,5 \%$ de fibras
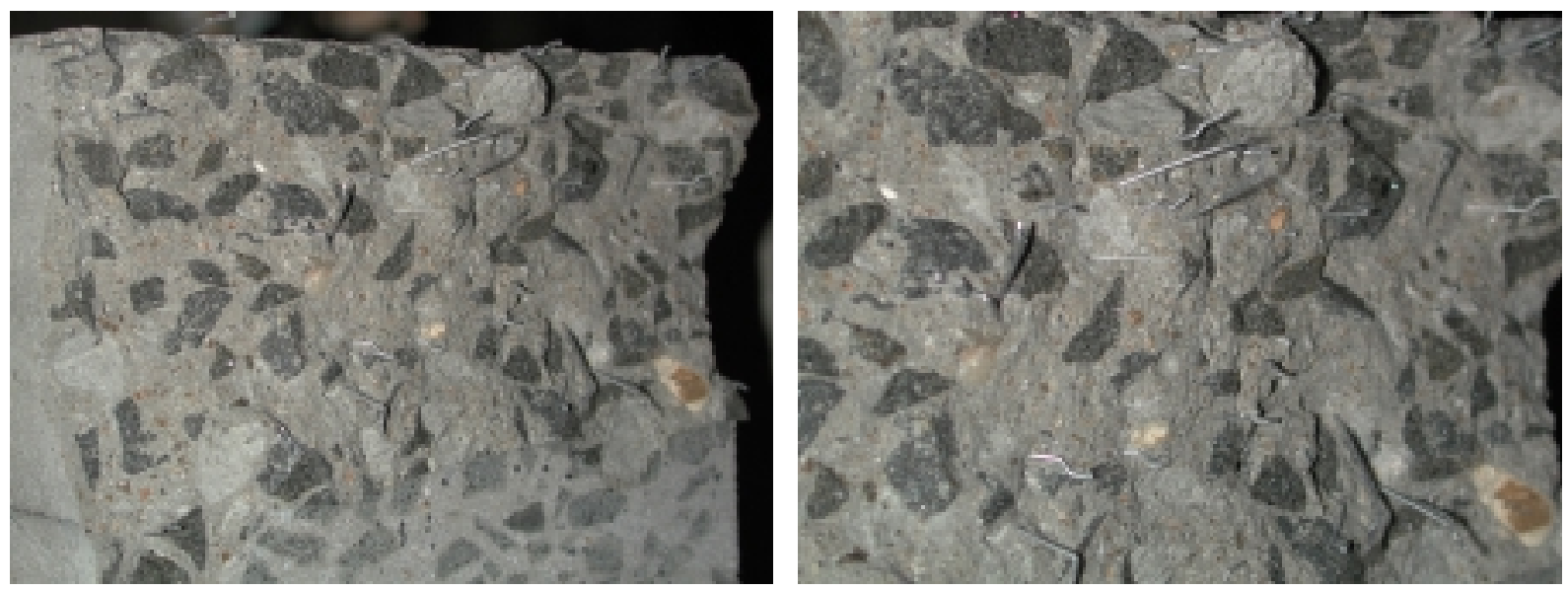

Figura 3.14 - Superfície de fratura dos corpos-de-prova com 0,75\% de fibras 
A partir desses resultados, é possível estabelecer uma relação entre a energia de fratura dos corpos-de-prova com fibras $\left(G_{f}{ }^{F}\right)$ e a energia de fratura dos corpos-de-prova sem fibras $\left(G_{f}{ }^{0}\right)$. Para tanto, a parcela de energia devida ao peso próprio do corpo-de-prova e dos equipamentos não acoplados ao atuador foram desconsiderados, uma vez que ela depende da geometria do corpo-de-prova e do máximo deslocamento observado no ensaio. De modo a obter uma expressão para a energia de fratura em função do volume de fibras adicionadas, é mostrada na Figura 3.15 a relação entre a razão $\mathrm{G}_{\mathrm{f}}{ }^{\mathrm{F}} / \mathrm{G}_{\mathrm{f}}{ }^{0}$ e o volume de fibras. Aplicando o método dos mínimos quadrados, é possível estabelecer a seguinte relação:

$$
\frac{G_{f}^{F}}{G_{f}^{0}}=1+27,41 V_{f} \quad(R=0,94) \text { com } V_{f} \text { em porcentagem }
$$

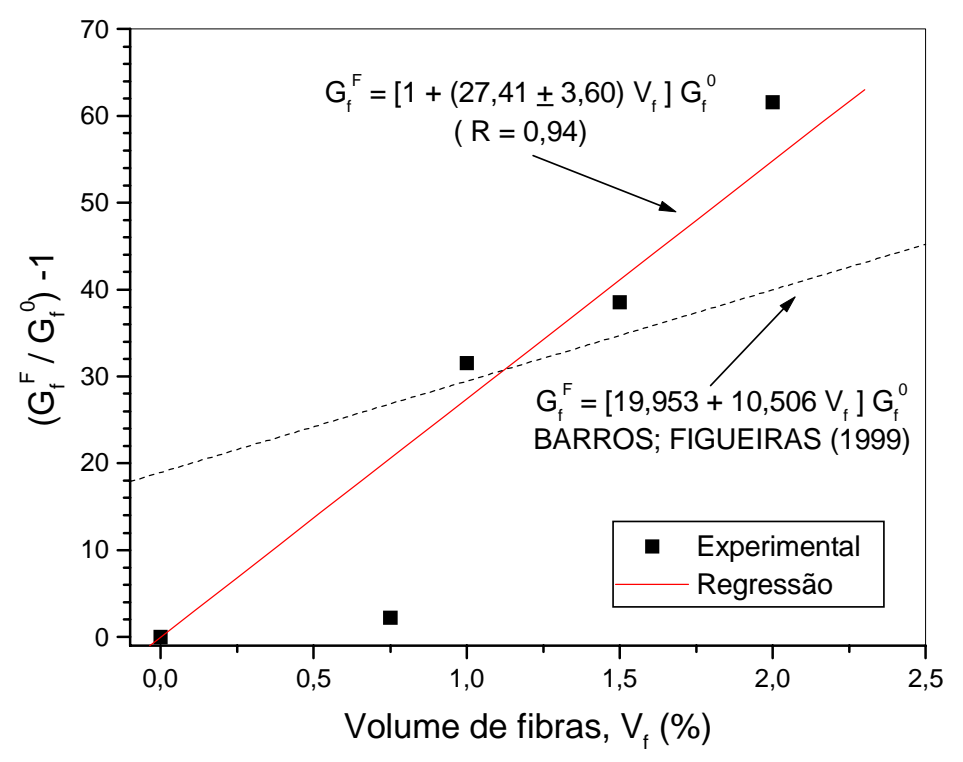

Figura 3.15 - Relação entre a energia de fratura nos corpos-de-prova com e sem fibras

BARROS; FIGUEIRAS (1999) obtiveram relação semelhante para o caso de fibras DRAMIX ZP30/.50 com ganchos nas extremidades adicionadas em matrizes com resistência à compressão de $30 \mathrm{MPa}$. Neste caso, os autores obtiveram $\mathrm{G}_{\mathrm{f}}^{\mathrm{F}} / \mathrm{G}_{\mathrm{f}}^{0}=19,953+10,506 \mathrm{~V}_{\mathrm{f}}$, para um volume máximo de fibras igual a $0,75 \%$. Comparando essa expressão com a obtida neste trabalho, observa-se que em baixos volumes 0 acréscimo de energia é menor que o medido por BARROS; FIGUEIRAS (1999). Isto pode ser explicado pelo fato das fibras empregadas no referido trabalho possuírem uma relação de forma maior que a empregada neste trabalho. Cabe observar que na regressão mostrada na Figura 3.15, a energia de fratura para o caso de $0,75 \%$ de fibras é bem inferior 
ao valor calculado pela eq.(3.6). Recomenda-se, portanto, o emprego da eq.(3.6) com cautela e, de preferência, para volumes superiores ao volume crítico da matriz.

\subsection{Ensaios de compressão uniaxial com deformação controlada}

\subsubsection{Introdução}

A capacidade de absorção de energia é umas das propriedades mais beneficiadas pela introdução de fibras à matriz de cimento. Para a sua quantificação, é necessário que os ensaios sejam conduzidos até que o material apresente desprezível capacidade de carga. Dessa forma, os ensaios devem ser realizados sob controle de deformações para que seja possível obter a relação força-deformação não somente até a força máxima, mas também após o pico de resistência (ramo de amolecimento do material ou "strain softening").

Nesta seção são descritos e apresentados os resultados dos ensaios de compressão uniaxial em corpos-de-prova cilíndricos de $100 \mathrm{~mm}$ x $200 \mathrm{~mm}$ com deformação controlada. Foram empregados os traços 1 a 3, já apresentados na seção 3.1, e foram estudados quatro volumes diferentes de fibras: 0,75\% $\left(60 \mathrm{~kg} / \mathrm{m}^{3}\right), 1,0 \%\left(80 \mathrm{~kg} / \mathrm{m}^{3}\right), 1,50 \%$ $\left(120 \mathrm{~kg} / \mathrm{m}^{3}\right)$ e $2,0 \%\left(160 \mathrm{~kg} / \mathrm{m}^{3}\right)$. Ao final é mostrada a metodologia empregada para obtenção de uma expressão representativa do comportamento à compressão de concretos reforçados com fibras.

\subsubsection{Descrição dos ensaios}

Os ensaios foram realizados empregando uma prensa servo-controlada MTS 815. Na Figura 3.16 é mostrada uma fotografia na qual aparecem a prensa, o painel de controle dos sinais e o computador responsável pela aquisição dos dados.

Os corpos-de-prova foram moldados em fôrmas metálicas com auxílio de uma mesa vibratória. Após o início da pega do concreto, a superfície superior dos corpos-de-prova foi uniformizada e alisada. Terminada a pega do concreto, foi iniciada a cura em câmara úmida, sendo os corpos-de-prova desmoldados depois de 24 horas de cura. Eles foram mantidos em câmara úmida até a data do ensaio, que se realizou, em média, sete dias após a concretagem. O ensaio só foi possível nesta data devido ao emprego de cimento de alta resistência inicial. No dia do ensaio, os corpos-de-prova foram retirados da câmara úmida na parte da manhã e deixados para secar. Em seguida foram capeados para evitar qualquer 
irregularidade no contato com os pratos da prensa, sendo ensaiados no período da tarde. Este procedimento foi adotado na maior parte dos traços ensaiados. Em alguns traços, entretanto, os corpos-de-prova foram ensaiados após 28 dias devido a dificuldades de disponibilidade do equipamento. Neste caso, alguns corpos-de-prova foram rompidos aos sete dias para verificar a resistência à compressão do concreto. Quando do ensaio com deformação controlada, observou-se um aumento médio de $15 \%$ na resistência à compressão destes traços.

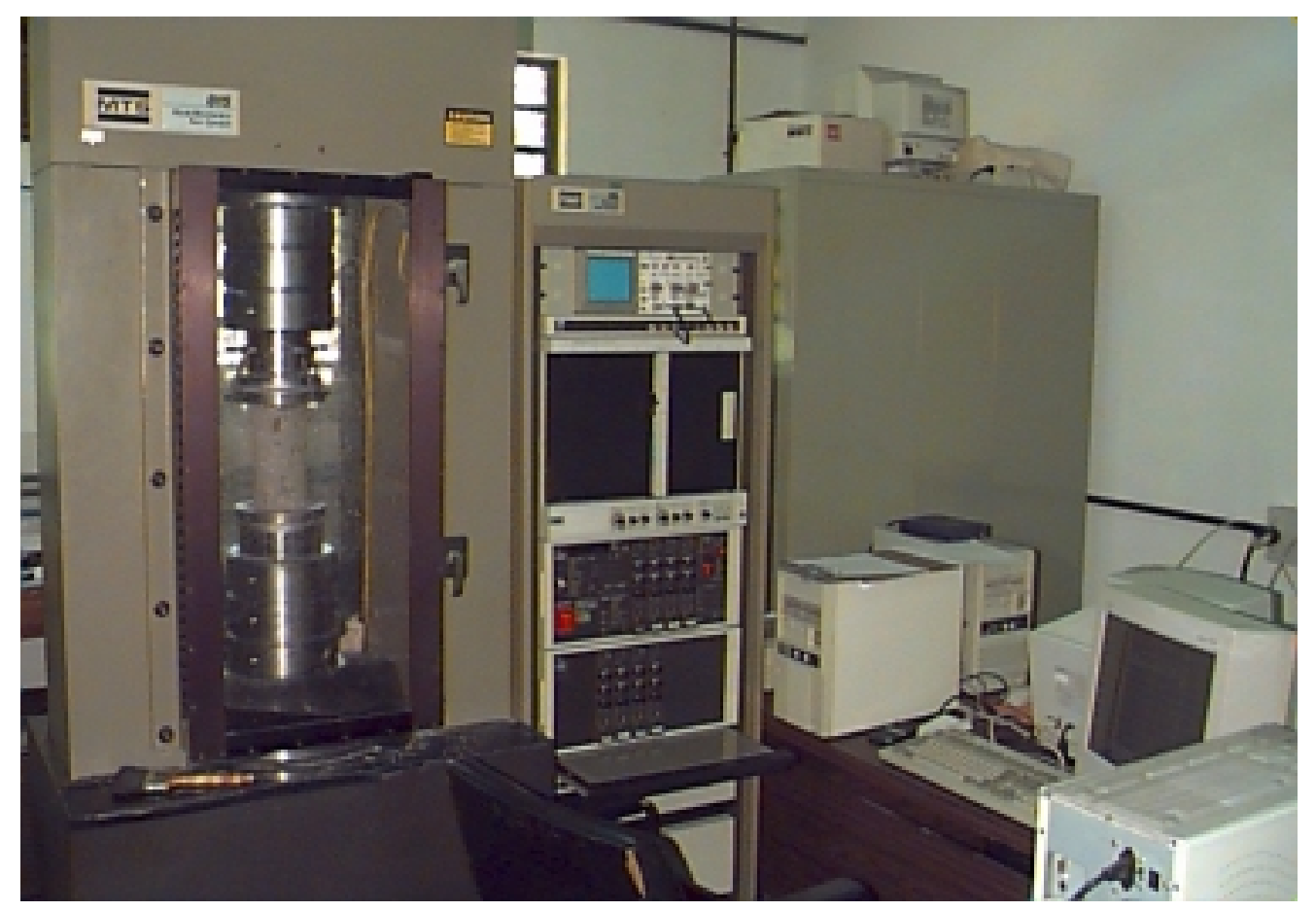

Figura 3.16 - Fotografia do equipamento empregado nos ensaios de compressão uniaxial

Em cada betonagem foram confeccionados 10 corpos-de-prova, sendo três usados para determinar a resistência à compressão, três para determinar a resistência à tração indireta e quatro para o ensaio de compressão com deformação controlada. $O$ tratamento da face superior do corpo-de-prova mostrou ter uma influência significativa nos resultados com deformação controlada. Em alguns casos, quando se demorou muito para iniciar a cura do concreto, surgiram microfissuras na face superior do corpo-de-prova que resultaram em uma resistência à compressão inferior à obtida dos ensaios com controle de força. Os resultados destes corpos-de-prova foram descartados, não sendo, portanto, usados na determinação da curva tensão-deformação do concreto. Também foi verificado que nos ensaios dos corpos-de-prova com as superfícies planas, porém sem capeamento, próximo à resistência do concreto ocorria uma ruptura localizada nas extremidades do corpo-de-prova 
sem aparente fissuração em outras regiões. Esse problema foi minimizado com o capeamento dos corpos-de-prova antes do ensaio. Tal comportamento está relacionado com o aparecimento de forças de atrito entre a superfície do corpo-de-prova e os pratos da prensa, tendo também sido observado por outros autores (BARROS (1995)). Em RILEM TC 148-SSC (2000) são apresentadas algumas recomendações para a determinação experimental da curva tensão-deformação do concreto. Entre elas, está a sugestão da colocação de bases adequadas entre o corpo-de-prova e os pratos da prensa de modo a diminuir o atrito nessa região.

Os valores da tensão de compressão foram obtidos dividindo a força axial registrada pelo equipamento pela área da seção transversal do corpo-de-prova. Para a medida de deformação axial foram realizadas duas leituras de deslocamentos axiais. Segundo o RILEM TC 148-SSC (2000), a deformação axial medida entre os pratos do equipamento não pode ser empregada na avaliação do módulo de elasticidade do concreto. Isto porque, nesta medida, estão incluídas além da deformação do material a deformação dos pratos do equipamento, que não são perfeitamente rígidos, e as deformações localizadas nas extremidades do corpo-de-prova devido a uma maior concentração de tensão nessas regiões. Sendo assim, foram fixados dois extensômetros, de $100 \mathrm{~mm}$ cada, ao longo de duas geratrizes opostas do corpo-de-prova. Dispunha-se, então, de duas leituras, isto é, uma fornecida pelo transdutor interno da prensa, que media o deslocamento do prato, e outra fornecida pela média dos deslocamentos dos extensômetros. A leitura dos extensômetros, contudo, somente podia ser realizada antes do pico de resistência, uma vez que no regime pós-pico o corpo-de-prova apresentava grande expansão. Lançou-se mão, então, de um coeficiente de correção definido por MANSUR et al. (1995). Esses autores definiram um coeficiente, aplicado à deformação axial obtida da leitura do transdutor interno do equipamento, que corrigia os efeitos de deformações concentradas e de deformação do equipamento. Dessa forma a deformação corrigida era calculada por:

$$
\varepsilon_{\mathrm{c}}=\varepsilon_{\mathrm{tp}}-\left(\frac{1}{\mathrm{E}_{\mathrm{tp}}}-\frac{1}{\mathrm{E}_{\mathrm{c}}}\right) \sigma
$$

onde $\varepsilon_{\mathrm{c}}$ é a deformação axial de compressão do concreto corrigida, $\varepsilon_{\mathrm{tp}}$ é a deformação medida pelo transdutor interno da prensa, $E_{t p}$ e $E_{C}$ são o módulo de elasticidade tangente inicial do concreto medido pelo transdutor interno e pelos transdutores externos, respectivamente, e $\sigma$ é a tensão de compressão axial.

Realizada a correção, foi possível traçar toda a curva tensão-deformação do concreto a partir apenas da deformação axial medida pelo deslocamento dos pratos da 
prensa. Sendo assim, os ensaios foram realizados em duas etapas. Na primeira etapa, os extensômetros foram afixados no corpo-de-prova e foi aplicado um deslocamento até que a tensão atuante no corpo-de-prova fosse, aproximadamente, igual a 30\% de sua resistência. A resistência à compressão do concreto era previamente conhecida pela ruptura de corposde-prova em uma prensa com controle de força. Em seguida, o carregamento foi retirado e os extensômetros desmontados. O ensaio foi então reiniciado e o carregamento aplicado de modo contínuo até que o corpo-de-prova apresentasse quase nenhuma resistência. $O$ valor de $E_{t p}$ foi obtido graficamente a partir da leitura do transdutor interno e o valor de $E_{c}$, também graficamente, a partir das leituras dos transdutores externos. Conhecidos esses valores, foi calculada a deformação corrigida em toda a curva tensão-deformação do corpode-prova. $O$ valor de $E_{t p}$ apresentava, geralmente, um valor próximo a $50 \%$ do valor de $E_{c}$.

A se carregar o corpo-de-prova pela segunda vez, apareciam pequenas deformações residuais. Estas, porém, foram desconsideradas por serem muito inferiores à deformação correspondente ao pico de resistência.

O ramo de amolecimento da curva tensão-deformação do concreto em um ensaio de compressão tem tanto maior desenvolvimento quanto mais baixa for a resistência do concreto. O desenvolvimento desse ramo é ainda mais significativo nos concretos reforçados com fibras. A velocidade de carregamento foi definida de modo que não fosse muito alta e nem demasiadamente baixa para evitar que o tempo de ensaio fosse excessivamente alto. Para atender a estes requisitos, os ensaios foram realizados com velocidades de deformação variando entre $0,0017 \mathrm{~mm} / \mathrm{s}$ e $0,0067 \mathrm{~mm} / \mathrm{s}$. O primeiro valor foi empregado nos ensaios dos corpos-de-prova sem fibra, e é um pouco superior ao recomendado pelo RILEM TC 148-SSC (2000) - 0,001 mm/s. No ensaio dos corpos-deprova do traço 3 sem fibras, contudo, a velocidade adotada foi diminuída pela metade, ou seja, $0,0008 \mathrm{~mm} / \mathrm{s}$. O segundo valor foi empregado nos ensaios dos corpos-de-prova reforçados com fibras. Nestes ensaios, a velocidade foi ainda aumentada para $0,013 \mathrm{~mm} / \mathrm{s}$ depois de grande parte do amolecimento do material ter ocorrido. Desta forma, o tempo de ensaio foi diminuído sem alteração significativa no ramo descendente da curva tensãodeformação.

Nestes ensaios, apenas o sinal do transdutor interno que media o deslocamento vertical do prato foi usado para controlar a força aplicada pelo pistão. Segundo o RILEM TC 148-SSC (2000), para concretos com resistência superiores a $70 \mathrm{MPa}$ devem ser usados além da deformação axial também a deformação lateral de modo a se obter um ramo descendente estável. Apesar desse procedimento não ser empregado neste trabalho, foi possível obter um ramo descendente estável em todos os ensaios realizados. A única 
exceção foi o traço 3 sem fibras, no qual em apenas um dos corpos-de-prova obteve-se o ramo descendente. Nos demais, atingida a resistência do concreto, houve uma ruptura brusca sem que fosse possível registrar os deslocamentos. Isto evidencia a necessidade do controle das deformações laterais para se obter a curva tensão-deformação em concretos de alta resistência. A adição de fibras, entretanto, torna o material mais dúctil e o controle apenas da deformação axial do corpo-de-prova mostrou-se suficiente para o traçado da curva tensão-deformação.

\subsubsection{Resultados dos ensaios}

\subsubsection{Tenacidade}

O aumento de ductilidade do concreto proporcionado pelas fibras também pode ser analisado através dos resultados dos ensaios de compressão com deformação controlada. Para tanto, pode-se utilizar o conceito de tenacidade relativa, definida como a relação entre a energia consumida pelo corpo-de-prova durante o ensaio e a energia admitindo o material plástico perfeito (EZELDIN; BALAGURU (1992)). Dessa forma, têm-se:

$$
T R=\frac{E}{f_{c} 0,015}
$$

onde $\mathrm{E}$ representa a área sob a curva tensão-deformação e $\mathrm{f}_{\mathrm{c}}$ é a resistência à compressão do concreto. Nessa expressão, a deformação axial máxima é limitada em 1,5\%. Nos corposde-prova sem fibras, a deformação máxima atingida foi sempre inferior a este valor, enquanto nos corpo-de-prova com fibras a deformação máxima foi maior. Sendo assim, essa medida não representa a totalidade de energia absorvida pelo corpo-de-prova durante o ensaio, que é função da resistência do concreto e da deformação máxima alcançada no final do ensaio. Nos corpos-de-prova com fibras, o aumento do volume de fibras implica no aumento da deformação máxima resultando no aumento da energia. A tenacidade relativa, entretanto, fornece uma boa base de comparação para analisar a influência das fibras sobre a energia absorvida, uma vez que a deformação máxima é limitada a um valor constante.

Na Figura 3.17 são mostradas as curvas médias obtidas do ensaio de compressão nos três traços estudados com os quatro volumes de fibras adicionadas. Cada curva média foi obtida a partir de, pelo menos, três corpos-de-prova. A primeira vista, observa-se que o ramo descendente das curvas é menos acentuado à medida que se aumenta o volume de fibras adicionadas. Isto evidencia o aumento da energia absorvida quando o volume de 
fibras é aumentado. Comparando os três traços para um mesmo volume de fibras, observase que diminui a influência da fibra sobre a capacidade de absorção de energia a medida que a resistência do concreto aumenta (Figura 3.17(d)). Esse comportamento é semelhante ao relatado na literatura que mostra que com aumento da resistência da matriz, é necessário um maior volume de fibras para proporcionar a mesma ductilidade.

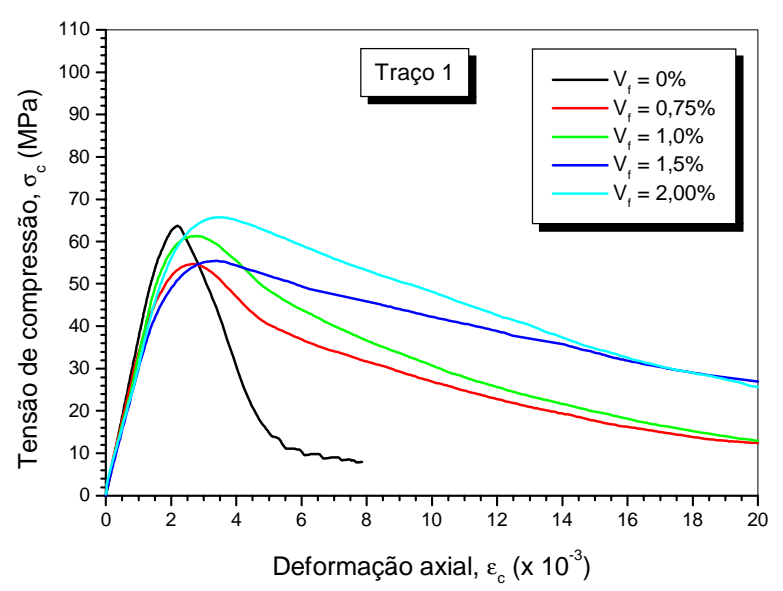

(a) Traço 1

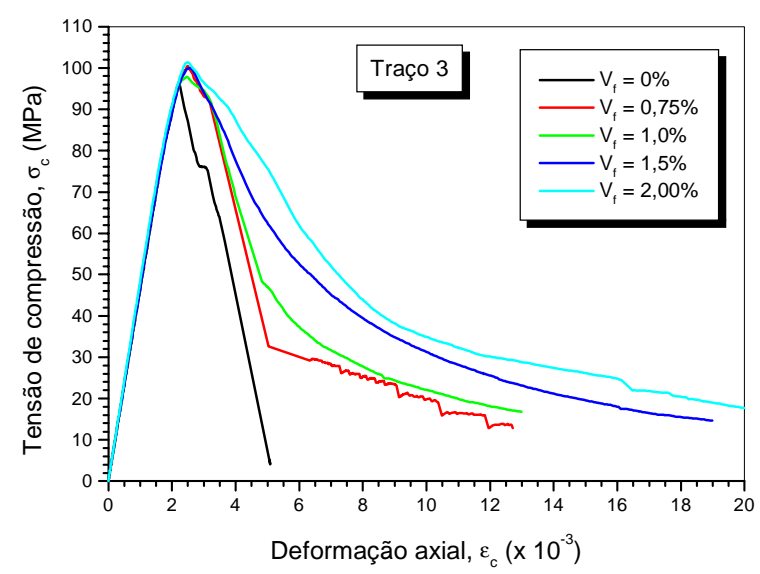

(c) Traço 3

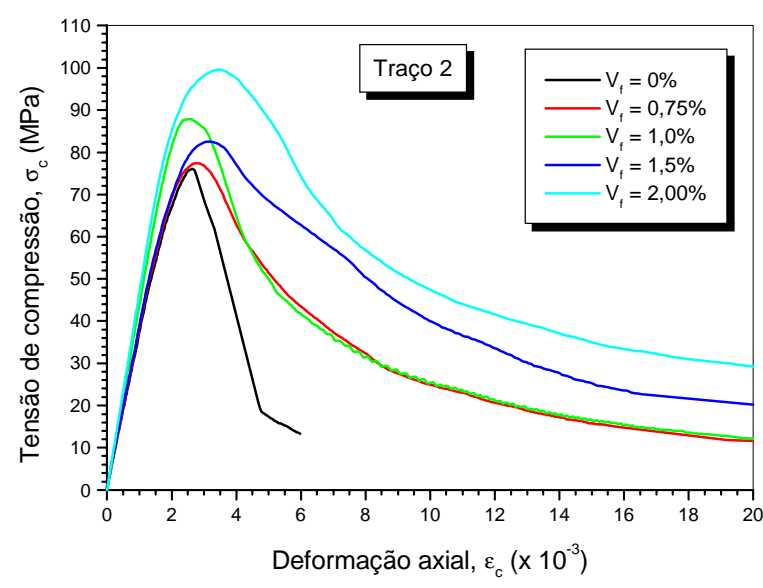

(b) Traço 2

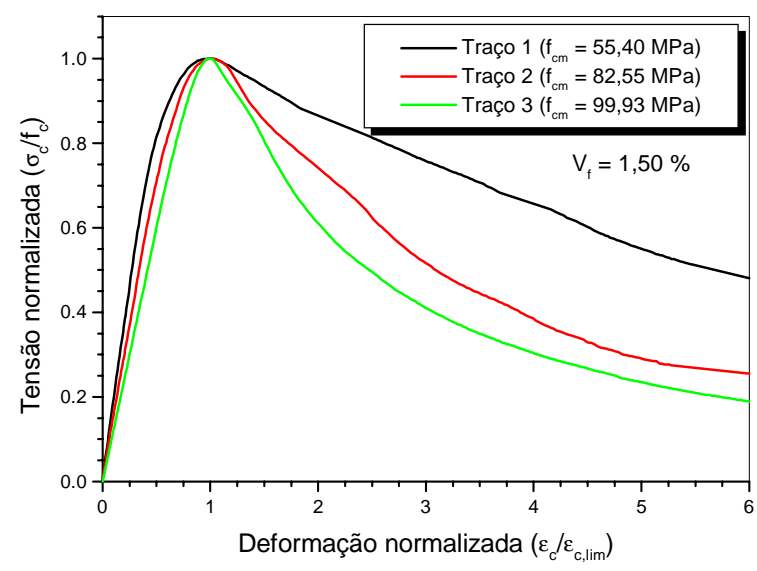

(d) Curva normalizada para $V_{f}=1,5 \%$

Figura 3.17 - Curvas médias dos ensaios de compressão com deformação controlada

$\mathrm{Na}$ Tabela 3.9 são mostrados os valores da tenacidade relativa nos traços de 1 a 3 com os quatro volumes de fibras. Também são mostradas as resistências médias à compressão alcançadas pelos corpos-de-prova no ensaio com deformação controlada. Desses resultados, nota-se que a tenacidade relativa aumenta de modo significativo devido à adição de $0,75 \%$ de fibras. Nota-se, também, um aumento da tenacidade relativa com o aumento do volume de fibras o que mostra a influência das fibras na ductilidade do 
concreto. Percebe-se nitidamente, entretanto, uma redução da eficiência das fibras com o aumento da resistência do concreto. Por exemplo, adicionando $1,50 \%$ de fibras ao concreto de $50 \mathrm{MPa}$, resulta em uma tenacidade relativa de 0,772 , enquanto este mesmo volume de fibras no concreto de $100 \mathrm{MPa}$ resulta em uma tenacidade de apenas 0,459. Esse comportamento fica mais evidente na Figura 3.18 na qual é mostrada a relação entre o índice de tenacidade relativa e o volume de fibras para os três traços. Para um determinado volume de fibras, a tenacidade é tanto menor quanto maior for a resistência do concreto.

Tabela 3.9 - Tenacidade relativa dos corpos-de-prova ensaiados à compressão axial

\begin{tabular}{|c|c|c|c|}
\hline Traço & Volume de fibras (\%) & $\mathrm{f}_{\mathrm{cm}}(\mathrm{MPa})$ & Tenacidade relativa \\
\hline \multirow{5}{*}{1} & 0 & 63,70 & 0,232 \\
\hline & 0,75 & 54,68 & 0,593 \\
\hline & 1,0 & 61,29 & 0,604 \\
\hline & 1,5 & 55,40 & 0,772 \\
\hline & 2,0 & 65,72 & 0,745 \\
\hline \multirow{5}{*}{2} & 0 & 76,07 & 0,213 \\
\hline & 0,75 & 77,43 & 0,479 \\
\hline & 1,0 & 87,82 & 0,442 \\
\hline & 1,50 & 82,55 & 0,595 \\
\hline & 2,0 & 99,51 & 0,599 \\
\hline \multirow{5}{*}{3} & 0 & 95,95 & 0,186 \\
\hline & 0,75 & 100,49 & 0,330 \\
\hline & 1,0 & 97,79 & 0,369 \\
\hline & 1,5 & 99,93 & 0,459 \\
\hline & 2,0 & 101,36 & 0,505 \\
\hline
\end{tabular}

Baseado na Figura 3.18 é possível obter uma relação explícita entre o índice de tenacidade e o volume de fibras. Como a tenacidade é influenciada pela resistência do concreto, este parâmetro deve estar presente na relação. Realizando uma regressão linear nessa figura chega-se a seguinte expressão para TR:

$$
\mathrm{TR}=\mathrm{TR}_{0}+\frac{1,2826 \mathrm{~V}_{\mathrm{f}}}{\mathrm{f}_{\mathrm{c}}^{0,34}} \quad(\mathrm{R}=0,945)
$$

onde $\mathrm{TR}_{0}$ é o índice de tenacidade do concreto sem fibra. Nessa expressão, o expoente da resistência do concreto, medida em $\mathrm{MPa}$, foi obtido de modo a minimizar o resíduo dos 
mínimos quadrados e assim melhorar o índice de correlação. Observa-se que a contribuição das fibras será tanto menor quanto maior for a resistência do concreto.
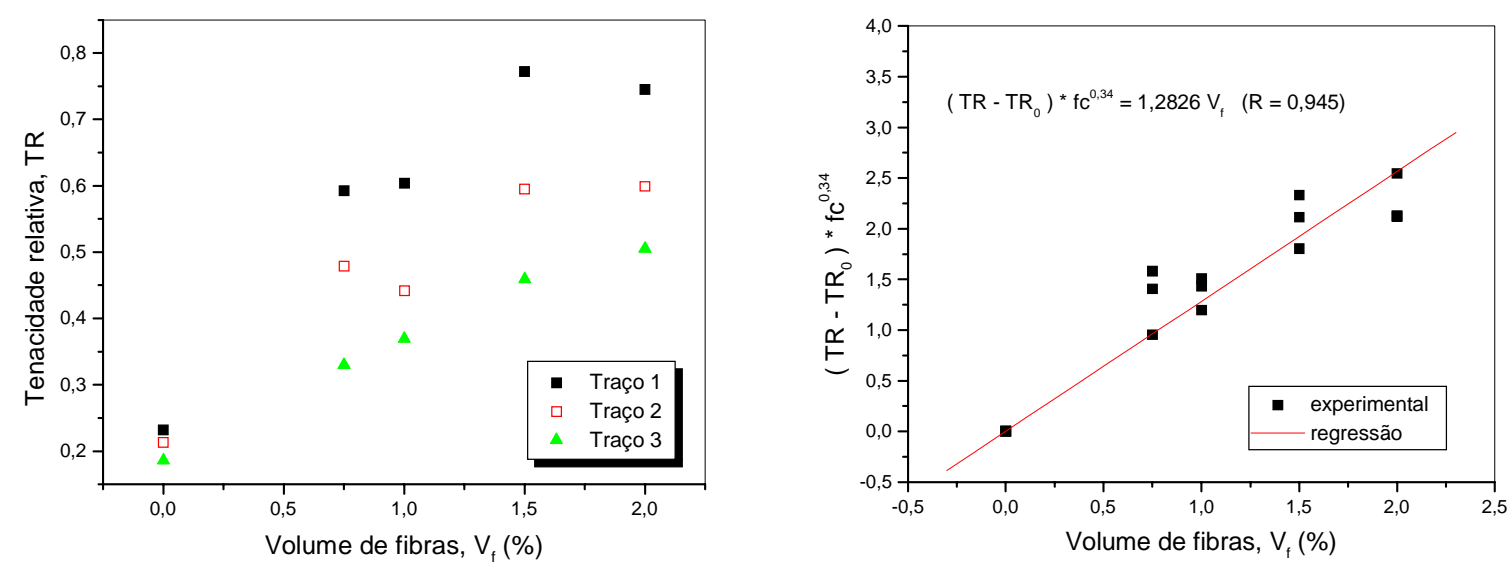

Figura 3.18 - Índice de tenacidade relativa em função do volume de fibras

$\mathrm{Na}$ Tabela 3.10 é mostrado, a título de comparação, o índice de tenacidade relativa obtida do traço 2 com $0,75 \%$ de fibras e os índices de tenacidade de dois exemplares ensaiados por EZELDIN; BALAGURU (1992). Os dois últimos valores foram obtidos de corpos-de-prova reforçados com fibras metálicas com fator de forma maior que a da fibra empregada neste trabalho. Como todos os exemplares possuem resistência à compressão semelhante, é possível fazer uma comparação direta entre eles. Observa-se que o índice de tenacidade obtido pelos autores foi maior que os valores obtidos neste trabalho, devido ao emprego de fibras com fator de forma maior que o das fibras aqui empregadas. Isto, contudo, não diminui o efeito positivo das fibras estudas neste trabalho.

Tabela 3.10 - Influência da relação de forma das fibras na tenacidade relativa do concreto

\begin{tabular}{|c|c|c|c|c|}
\cline { 2 - 5 } \multicolumn{1}{c|}{} & $\mathrm{f}_{\mathrm{c}}(\mathrm{MPa})$ & $\mathrm{V}_{\mathrm{f}}(\%)$ & $\ell / \mathrm{d}$ & $\mathrm{TR}$ \\
\hline Este Trabalho & 77,43 & 0,75 & $\begin{array}{c}48(\ell=30 \mathrm{~mm} \mathrm{e} \\
=0,625 \mathrm{~mm})\end{array}$ & 0,479 \\
\hline $\begin{array}{c}\text { EZELDIN; } \\
\text { BALAGURU } \\
(1992)\end{array}$ & 73,78 & 0,75 & $\begin{array}{c}75(\ell=60 \mathrm{~mm} \mathrm{e} \quad \mathrm{d} \\
=0,8 \mathrm{~mm})\end{array}$ & 0,620 \\
\cline { 2 - 5 } & 81,36 & 0,75 & $\begin{array}{c}100(\ell=50 \mathrm{~mm} \mathrm{e} \\
\mathrm{d}=0,5 \mathrm{~mm})\end{array}$ & 0,700 \\
\hline
\end{tabular}

\subsubsection{Módulo de elasticidade}

O módulo de elasticidade inicial do concreto foi determinado graficamente a partir das leituras dos extensômetros externos fixados no corpo-de-prova. Na Figura 3.19 são 
mostrados os valores obtidos em todos os corpos-de-prova ensaiados. Nessa figura, observa-se uma grande dispersão dos resultados, contudo é possível verificar que a adição das fibras pouco influenciou o valor do módulo de elasticidade. Apenas quando foram adicionadas $2,0 \%$ de fibras percebe-se uma pequena redução, que pode ter ocorrido pela introdução de vazios no corpo-de-prova devido à elevada quantidade de fibras introduzidas na mistura.

Realizando uma regressão linear no gráfico que relaciona o módulo de elasticidade com a raiz quadrada da resistência à compressão, obteve-se a expressão seguinte:

$$
\mathrm{E}_{\mathrm{c}}=4576 \sqrt{\mathrm{f}_{\mathrm{cm}}} \quad(\mathrm{MPa})
$$

Apesar da dispersão apresentada pelos resultados (Figura 3.19), essa relação é coerente com a expressão recomendada pelo $A C l 318$ (1989) de $E_{c}=4733 \sqrt{f_{c m}}$.
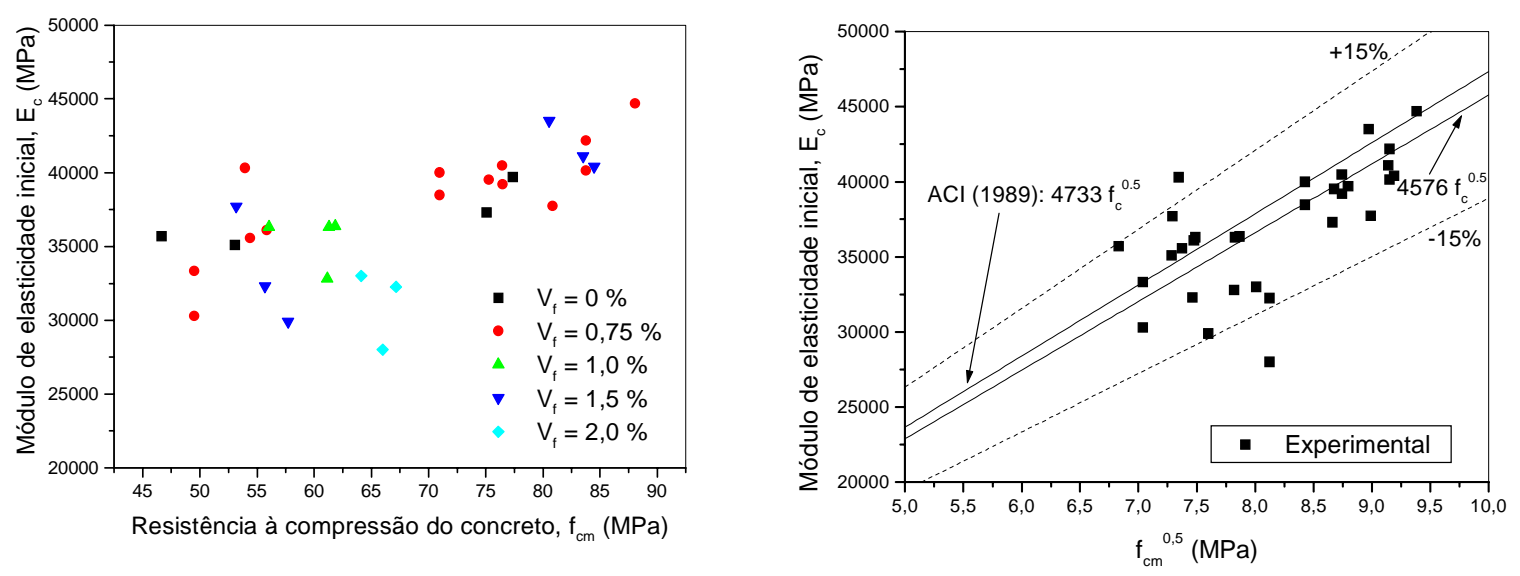

Figura 3.19 - Influência das fibras no módulo de elasticidade inicial do concreto

\subsubsection{Deformação correspondente à tensão máxima}

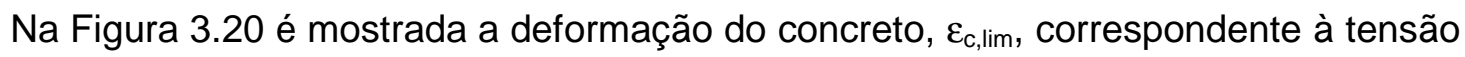
máxima $f_{c m}$, em função da resistência do concreto. Observa-se dessa figura uma grande dispersão nos resultados, contudo é possível observar uma tendência de diminuição no valor de $\varepsilon_{c, \text { lim }}$ a medida que se aumenta a resistência à compressão do concreto. Isto ocorreu devido ao comportamento registrado nos corpos-de-prova confeccionados com o traço 3. Durante os ensaios, observou-se que nos corpos-de-prova confeccionados com o traço 1 a curva força-deslocamento apresentava um trecho nitidamente não-linear antes da força máxima ser atingida. No caso dos corpos-de-prova com o traço 3 , essa curva era 
praticamente linear até a ruptura. Também pode ter influído no resultado o fato da série executada com o traço 3 ter sido ensaiada após 28 dias, enquanto as outras séries foram ensaiadas com idades em torno de 12 dias. Além disso, nesses ensaios pode ter ocorrido um deslizamento do extensômetro mecânico preso ao corpo-de-prova, o que prejudicaria a determinação do valor de $\varepsilon_{c, l i m}$.

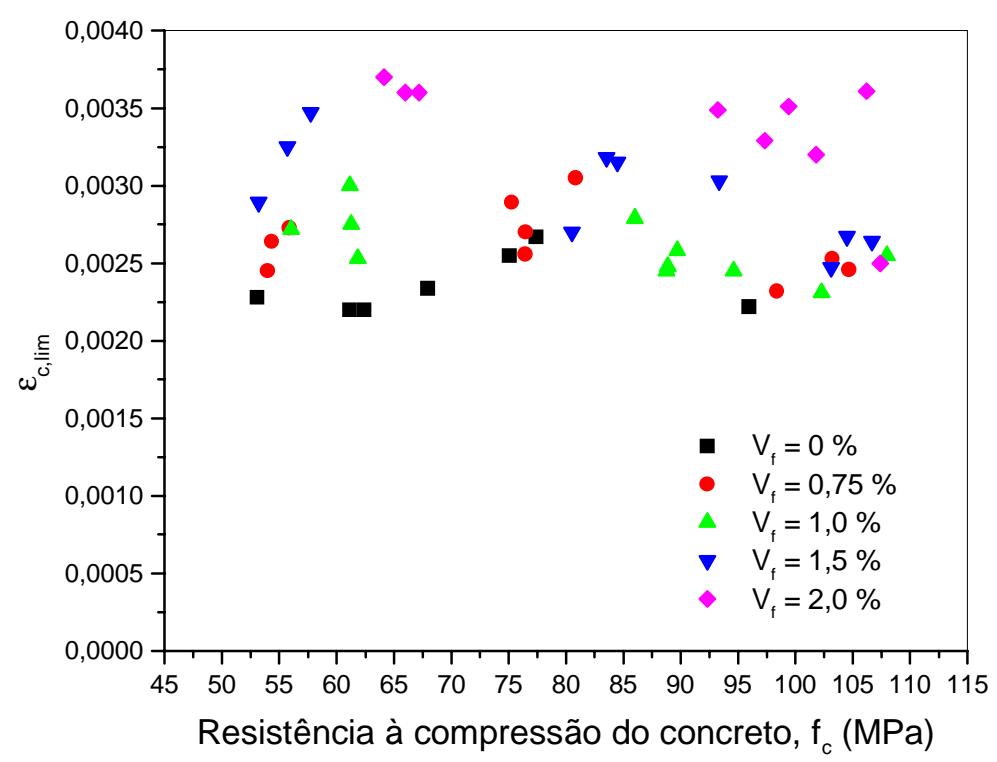

Figura 3.20 - Deformação $\varepsilon_{c, \text { lim }}$ dos corpos-de-prova em função da resistência à compressão do concreto

$\mathrm{Na}$ Tabela 3.11 são mostrados os valores médios de $\varepsilon_{c, \text { lim }}$ e da resistência à compressão do concreto para cada série ensaiada. A partir desses resultados, procurou-se uma correlação entre os valores de $\varepsilon_{c, \text { lim }}$ com a resistência à compressão do concreto e o volume de fibras adicionadas.

Na Figura 3.21 é mostrada a influência das fibras no valor de $\varepsilon_{\mathrm{c}, \text { lim. }}$. A partir desta figura, observa-se que a deformação $\varepsilon_{\mathrm{c}, \text { lim }}$ aumentou com o aumento do volume de fibras nos três traços estudados. Observa-se, também, que a medida em que se aumentou a resistência do concreto, o ganho de deformação proporcionado pelas fibras foi menor. Isto parece coerente, uma vez que os concretos de alta resistência exigem um volume maior de fibras que os concretos convencionais para proporcionarem melhorias semelhantes em suas propriedades. Além disso, a fibra empregada neste trabalho possuía um fator de forma relativamente baixo, o que diminuiu sua eficiência. Nessa figura também é mostrada a expressão obtida por BARROS; FIGUEIRAS (1999) para fibras metálicas com relação de 
forma igual a 75. Observa-se que, neste caso, a fibra proporciona um aumento mais significativo no valor de $\varepsilon_{\mathrm{c}, \mathrm{lim}}$.

Tabela 3.11 - Deformação média $\varepsilon_{\mathrm{c}, \text { lim }}$ dos corpos-de-prova ensaiados à compressão axial

\begin{tabular}{|c|c|c|c|}
\hline Traço & Volume de fibras $(\%)$ & $\mathrm{f}_{\mathrm{cm}}(\mathrm{MPa})$ & $\varepsilon_{\mathrm{c}, \mathrm{lim}}\left(\times 10^{-3}\right)$ \\
\hline \multirow{4}{*}{1} & 0 & 63,70 & 2,20 \\
\cline { 2 - 4 } & 0,75 & 54,68 & 2,71 \\
\cline { 2 - 4 } & 1,0 & 61,29 & 2,73 \\
\cline { 2 - 4 } & 1,5 & 55,40 & 3,38 \\
\hline \multirow{5}{*}{2} & 2,0 & 65,72 & 3,45 \\
\cline { 2 - 4 } & 0 & 76,07 & 2,64 \\
\cline { 2 - 4 } & 0,75 & 77,43 & 2,78 \\
\cline { 2 - 4 } & 1,0 & 87,82 & 2,58 \\
\cline { 2 - 4 } & 1,50 & 82,55 & 3,14 \\
\hline \multirow{5}{*}{3} & 2,0 & 99,51 & 3,44 \\
\cline { 2 - 4 } & 0 & 95,95 & 2,23 \\
\cline { 2 - 4 } & 0,75 & 100,49 & 2,50 \\
\cline { 2 - 4 } & 1,0 & 97,79 & 2,45 \\
\cline { 2 - 4 } & 1,5 & 99,93 & 2,57 \\
\cline { 2 - 4 } & 2,0 & 101,36 & 2,50 \\
\hline
\end{tabular}

Na Figura 3.22 é mostrada a relação de $\varepsilon_{c, l i m}$ com a resistência à compressão e com o volume de fibras adicionadas. A expressão da deformação do concreto simples foi obtida analisando apenas os resultados obtidos dos ensaios dos corpos-de-prova sem adição de fibras. O acréscimo de deformação proporcionado pelas fibras foi obtido subtraindo da deformação medida nos corpos-de-prova com fibras o valor da deformação do concreto simples. Os resultados obtidos foram, então, divididos pela resistência à compressão do concreto com o objetivo de levar em consideração a redução observada no valor de $\varepsilon_{c, \text { lim }}$ com o aumento da resistência. A deformação final do concreto reforçado com fibras foi escrita como a soma da deformação do concreto simples com o acréscimo de deformação proporcionado pelas fibras. Dessa forma, chegou-se à seguinte expressão para avaliação de $\varepsilon_{\mathrm{c}, \mathrm{lim}}$ :

$$
\varepsilon_{c, \lim }=0,001446 f_{c m}^{0,114}+\frac{0,0271 V_{f}^{1,5269}}{f_{c m}} \quad \text { com } V_{f} \text { em \% e f } f_{c m} \text { em MPa }
$$


A expressão acima é válida para concretos com resistência à compressão variando entre $50 \mathrm{MPa}$ e $100 \mathrm{MPa}$ reforçados com fibras metálicas $(\ell / \mathrm{d}=48)$ em um volume máximo de $2,0 \%$. Contudo, ela deve ser empregada com cuidado, uma vez que nas regressões efetuadas nem sempre foram obtidas boas correlações.

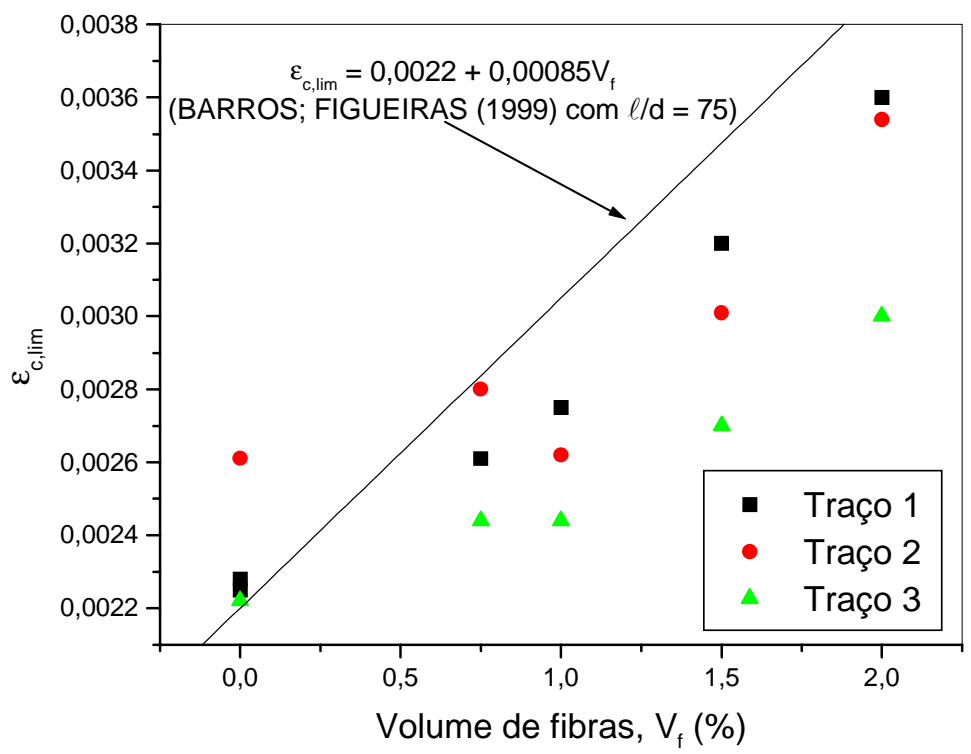

Figura 3.21 - Influência da adição de fibras no valor médio de $\varepsilon_{c, l i m}$ nos ensaios de compressão axial
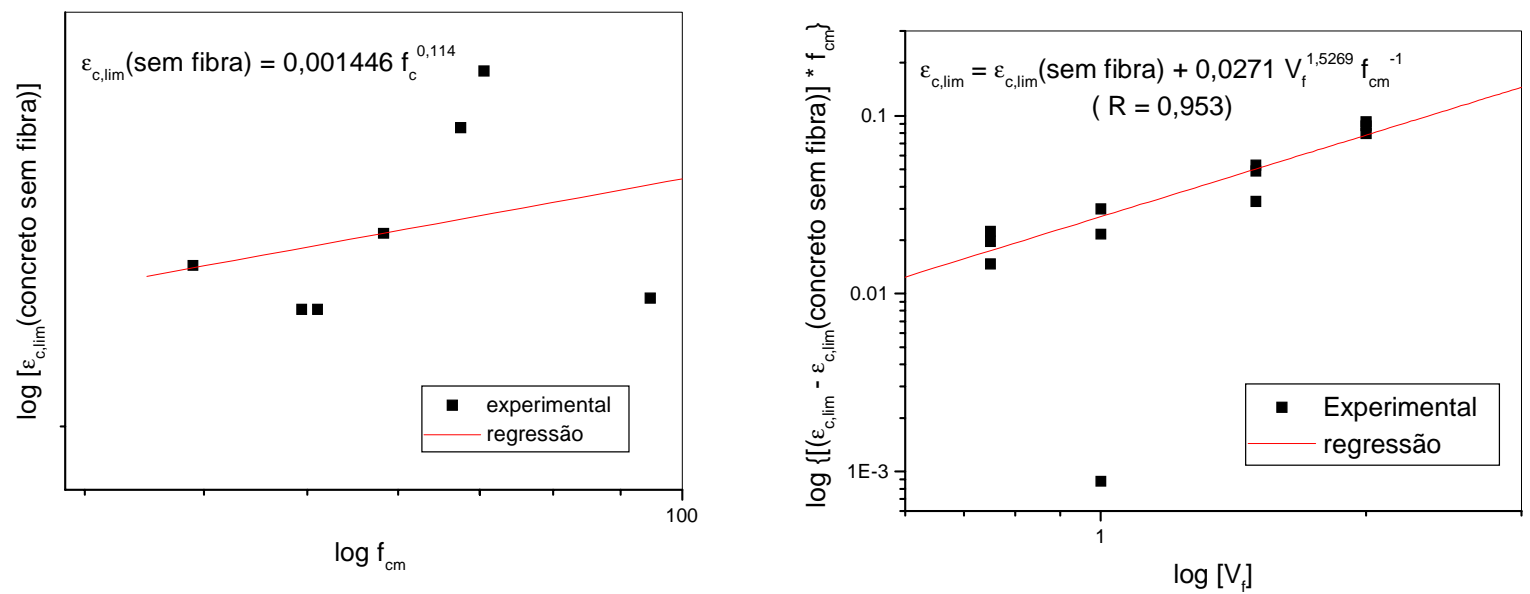

Figura 3.22 - Determinação da relação de $\varepsilon_{c, \text { lim }}$ com $\bigvee_{f}$ e $f_{c m}$ nos ensaios de compressão axial

\subsubsection{Curva Tensão - deformação}

Neste item é apresentada a metodologia empregada na determinação de uma expressão representativa do comportamento do concreto à compressão axial. Essa 
expressão deve ser função das principais propriedades do concreto, isto é, da resistência à compressão, do módulo de elasticidade inicial e da deformação na ruptura. Nela também devem constar parâmetros referentes às fibras. Como neste trabalho foi empregado apenas um tipo de fibra, a influência do fator de forma não pode ser explicitada. Dessa forma, o único parâmetro relacionado às fibras é o volume de fibras adicionadas.

Na Figura 3.23 são comparadas algumas expressões disponíveis na literatura para o traçado da curva tensão-deformação do concreto de alta resistência com os resultados experimentais deste trabalho. Essas expressões foram apresentadas no item 2.1.2.2. No traçado dessas curvas, foi empregado o fator de forma das fibras utilizadas neste trabalho. Os demais parâmetros foram os mesmos admitidos pelos autores em seus respectivos trabalhos. Pode-se notar que nenhuma das curvas representou de modo adequado o comportamento experimental.
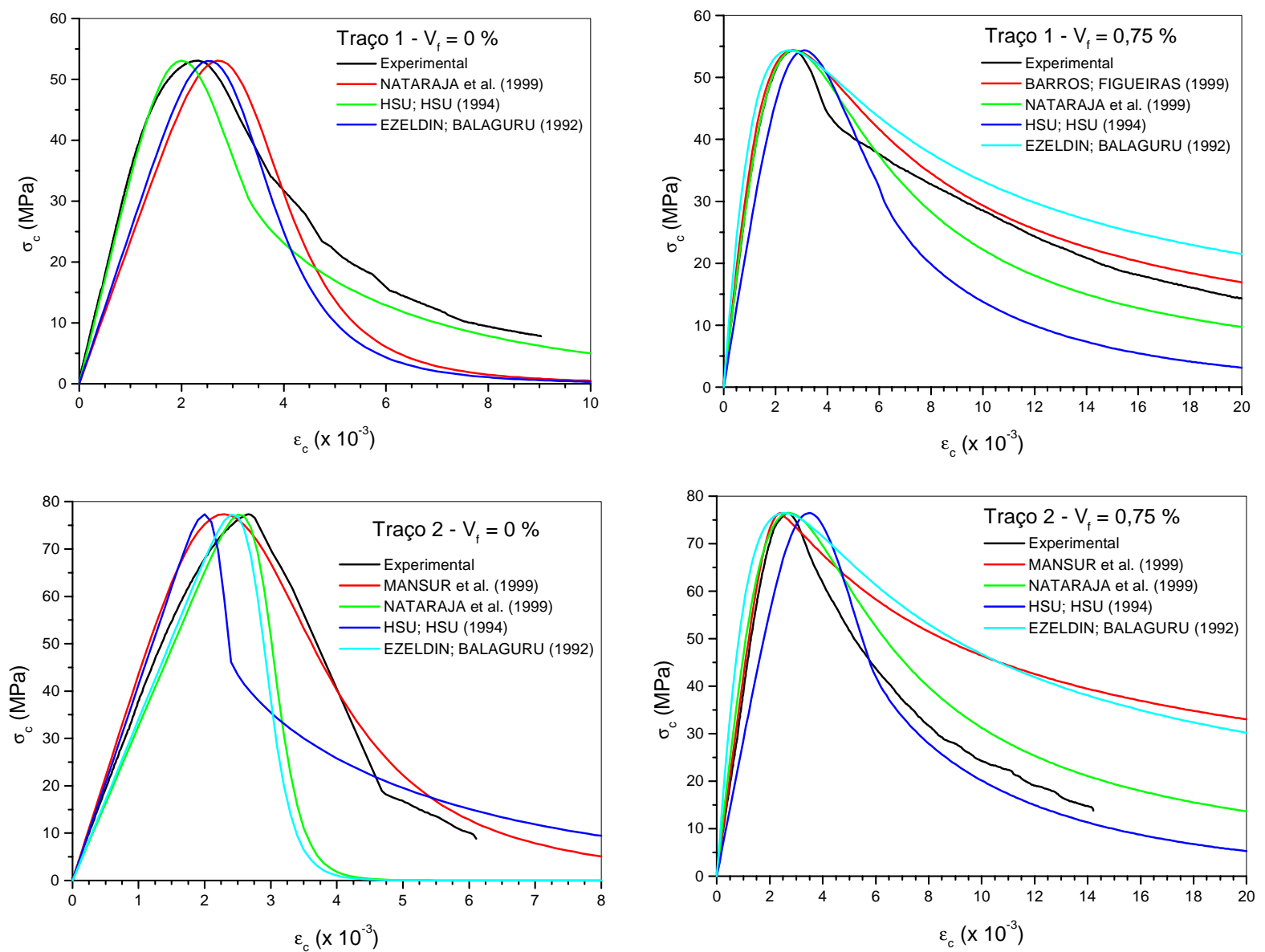

Figura 3.23 - Comparação entre algumas expressões para traçado da curva tensãodeformação e os resultados experimentais deste trabalho 
Para a determinação de uma curva tensão deformação adequada aos resultados deste trabalho, inicialmente é necessário definir uma expressão analítica. Foi escolhida, então, a seguinte expressão, adotada por MANSUR et al. (1999):

$$
\frac{\sigma_{c}}{f_{c}}=\frac{k_{1} \beta \frac{\varepsilon_{c}}{\varepsilon_{c, \text { lim }}}}{k_{1} \beta-1+\left(\frac{\varepsilon_{c}}{\varepsilon_{c, l i m}}\right)^{k_{2} \beta}}
$$

Essa expressão é uma modificação da curva original proposta por CARREIRA; CHU (1985). A alteração na expressão, realizada pela introdução dos coeficientes $K_{1}$ e $K_{2}$, possibilita uma melhor aproximação com os resultados experimentais. MANSUR et al. (1999) introduziram esses coeficientes apenas na região pós-pico, pois eles observaram que a expressão original, sem os coeficientes, era suficientemente adequada para representar os resultados experimentais que eles possuíam antes de atingida a resistência do concreto.

Para que a eq.(3.12) possa representar o comportamento à compressão do concerto, ela deve satisfazer às seguintes condições básicas:

$$
\begin{aligned}
& \left.\frac{d \sigma_{c}}{d \varepsilon_{c}}\right|_{\varepsilon_{c}=0}=E_{c} \\
& \frac{d \sigma_{c}}{d \varepsilon_{c}}>0 \text { para } \varepsilon_{c}<\varepsilon_{c, l i m} \\
& \frac{d \sigma_{c}}{d \varepsilon_{c}}=0 \text { para } \varepsilon_{c}=\varepsilon_{c, l i m} \\
& \frac{d \sigma_{c}}{d \varepsilon_{c}}<0 \text { para } \varepsilon_{c}>\varepsilon_{c, \text { lim }}
\end{aligned}
$$

Para que a primeira das condições anteriores seja satisfeita, é necessário que:

$$
\beta=\frac{1}{1-\frac{f_{c}}{\varepsilon_{c, l i m} E_{c}}} \quad \text { e } K_{1}=K_{2}=1
$$

Esta expressão para $\beta$ foi inicialmente apresentada por CARREIRA; CHU (1985). É facilmente verificado que a eq.(3.12) satisfaz as demais condições anteriores para quaisquer valores de $\mathrm{K}_{1}$ e $\mathrm{K}_{2}$. 
Conhecidos os valores de $\varepsilon_{c, \text { lim }}$ e $E_{c}$, o parâmetro $\beta$ fica definido. Empregando a eq.(3.12) e a eq.(3.14), têm-se definida uma expressão para a curva tensão-deformação. Pode-se verificar que essa expressão representa com boa aproximação a parte ascendente da curva tensão-deformação experimental. Para tanto, foram tomadas as curvas médias de cada série ensaiada. Dessa forma, fica-se com uma única curva representativa de cada série, com um total de 15 curvas ( 3 traços e 5 volumes de fibras). Em seguida, as curvas médias foram normalizadas, isto é, a tensão foi dividida por $\mathrm{f}_{\mathrm{cm}}$ e a deformação por $\varepsilon_{\mathrm{cm} \text {,lim }}$ (Figura 3.24). Em cada curva normalizada foi realizada uma regressão não-linear, apenas na parte ascendente, empregando a eq.(3.12) com $\mathrm{K}_{1}=\mathrm{K}_{2}=1$. A regressão foi realizada fazendo variar os valores de $\beta$ até que a diferença entre os valores da função e os valores experimentais fosse o menor possível. Foram obtidos, assim, os valores de $\beta$ que melhor representavam as curvas experimentais. Na Figura 3.25 é mostrada a regressão em umas das curvas médias e a comparação entre os valores experimentais de $\beta$ e os calculados pela eq.(3.14), empregando os valores médios experimentais de $\varepsilon_{c, l i m}$ e $E_{c}$ de cada série (Tabela 3.11). Verifica-se, assim, que a curva tensão-deformação dos corpos-de-prova ensaiados, na sua parte ascendente, pode ser representada pela eq.(3.12), com $\mathrm{K}_{1}$ e $\mathrm{K}_{2}$ iguais a 1 e $\beta$ definido pela eq.(3.14).
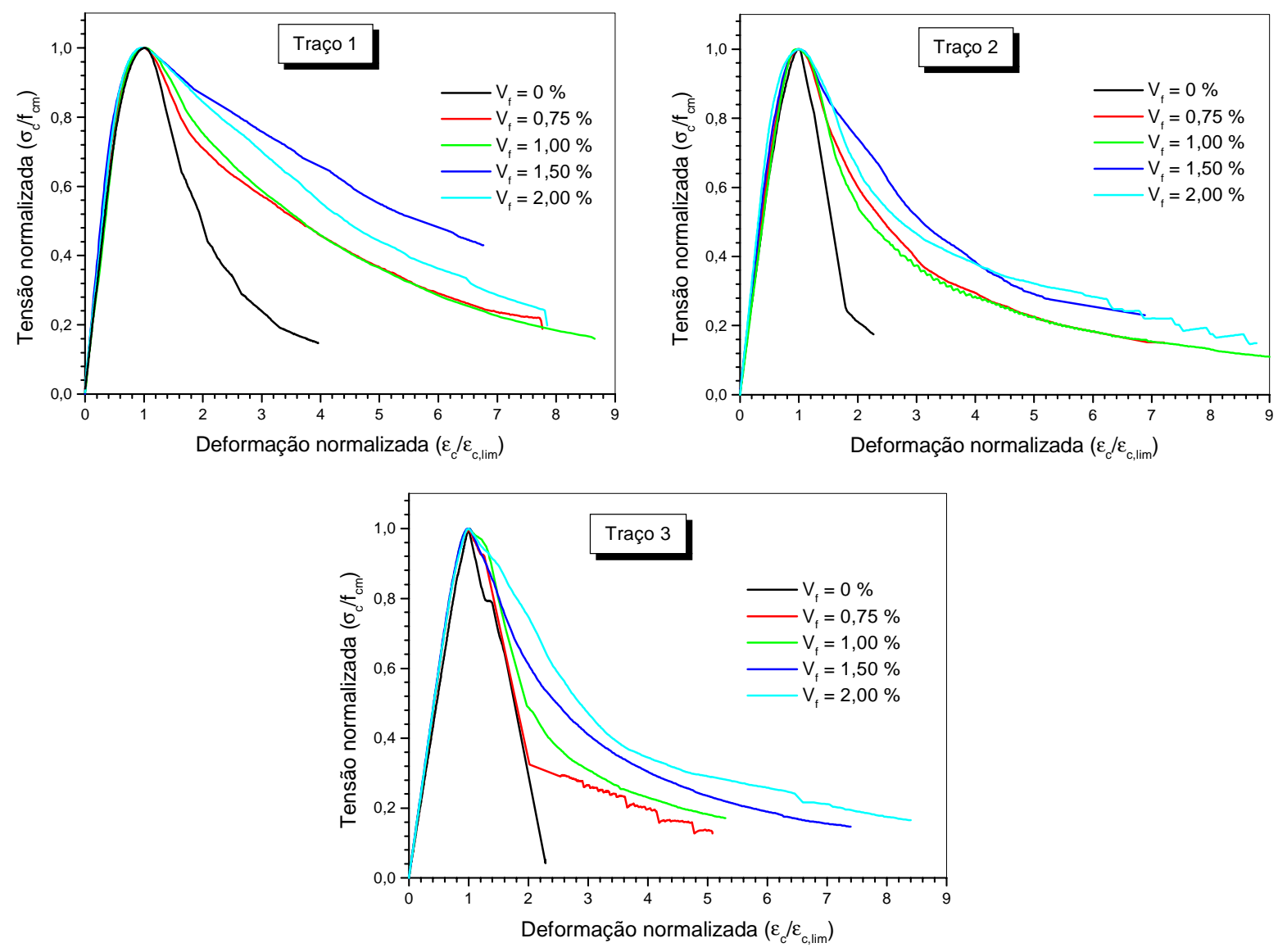

Figura 3.24 - Curvas médias normalizadas 


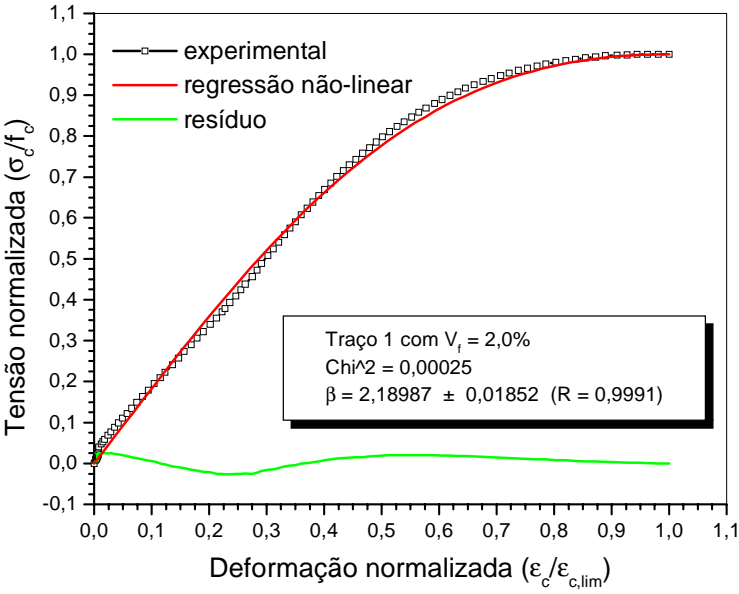

(a) Determinação de $\beta$ pela regressão na curva média experimental

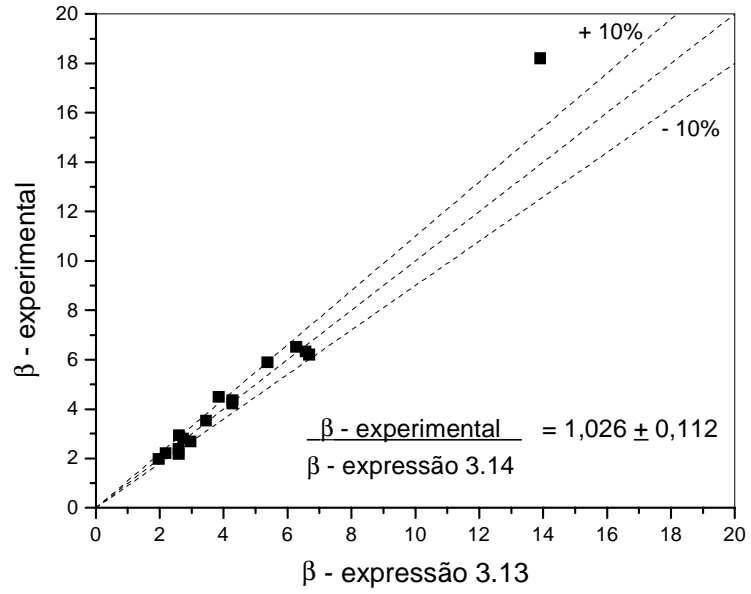

(b) Comparação entre os valores de $\beta$ obtidos por regressão e pela eq.(3.14)

Figura 3.25 - Regressão na parte ascendente da curva tensão-deformação do concreto

Para definir a parte descendente da curva tensão-deformação, é necessário definir expressões para os coeficientes $\mathrm{K}_{1}$ e $\mathrm{K}_{2}$ da eq.(3.12). Para tanto, foram realizadas regressões não-lineares na parte descendente das curvas médias de cada série empregando a eq.(3.12). Com essas regressões, foram obtidos valores para $k_{1} \beta$ e $K_{2} \beta$ que passaram a ser admitidos como sendo valores experimentais. Os valores de $\mathrm{K}_{1}$ e $\mathrm{K}_{2}$ foram obtidos dividindo os valores experimentais de $k_{1} \beta$ e $\mathrm{K}_{2} \beta$ pelos valores de $\beta$ fornecidos pela eq.(3.14). O problema residia, portanto, em tentar encontrar uma correlação entre os valores de $K_{1}$ e $K_{2}$ e as variáveis $f_{c m}$ e $V_{f}$. Efetuou-se, em um primeiro passo, uma regressão entre os valores de $K_{1}$ e $f_{c m}$ apenas para as séries sem fibras. Foi obtida, assim, uma relação entre estas duas variáveis. O passo seguinte foi tentar introduzir o efeito das fibras. Isto foi possível dividindo os valores experimentais de $K_{1}$ das séries com fibras pela expressão já obtida das séries sem fibra. Efetuando-se uma nova regressão, foi obtida uma expressão que correlaciona $\mathrm{K}_{1}$ com $\mathrm{f}_{\mathrm{cm}}$ e $\mathrm{V}_{\mathrm{f}}$. Neste último passo, os valores de $\mathrm{K}_{1}$ foram multiplicados por $\mathrm{f}_{\mathrm{cm}}$ para melhorar a correlação, o que significa admitir que a influência das fibras na parte descendente também é função direta da resistência do concreto. A expressão que correlaciona $\mathrm{K}_{2}$ com $\mathrm{f}_{\mathrm{cm}}$ e $\mathrm{V}_{\mathrm{f}}$ foi obtida repetindo a mesma metodologia. $\mathrm{Na}$ Figura 3.26 são mostradas as regressões efetuadas, passo a passo, para a determinação das expressões de $\mathrm{K}_{1}$ e $\mathrm{K}_{2}$. As expressões finais obtidas foram:

$$
\begin{array}{lll}
\mathrm{K}_{1}=8,241 \mathrm{f}_{\mathrm{c}}^{-0,593} & (\mathrm{R}=0,82) & \text { para } \mathrm{V}_{\mathrm{f}}=0 \\
\mathrm{~K}_{1}=478,608 \mathrm{f}_{\mathrm{c}}^{-1,593} \mathrm{~V}_{\mathrm{f}}^{0,6577} & (\mathrm{R}=0,92) & \text { para } 0<\mathrm{V}_{\mathrm{f}} \leq 2 \% \\
\mathrm{~K}_{2}=22,500 \mathrm{f}_{\mathrm{c}}^{-0,775} & (\mathrm{R}=0,80) & \text { para } \mathrm{V}_{\mathrm{f}}=0
\end{array}
$$




$$
K_{2}=34,513 f_{c}{ }^{-0,925} V_{f}^{0,368}
$$

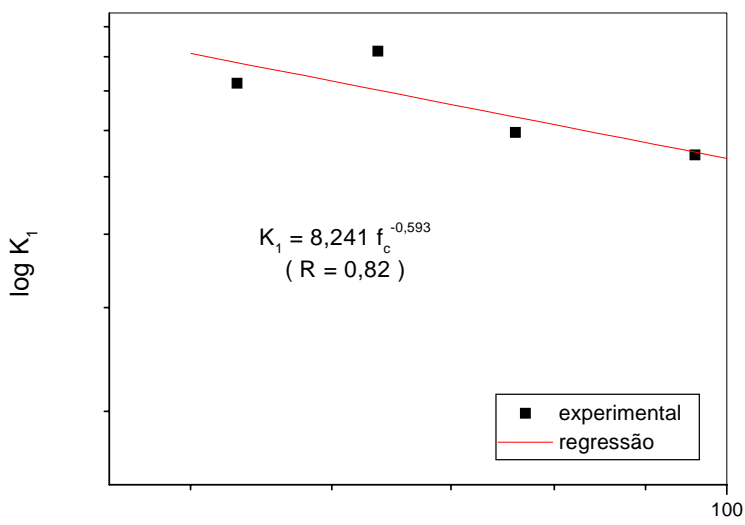

$\log \mathrm{f}_{\mathrm{c}}(\mathrm{MPa})$

(a) Relação entre $\mathrm{K}_{1}$ e $\mathrm{f}_{\mathrm{c}}$ para concreto sem fibra

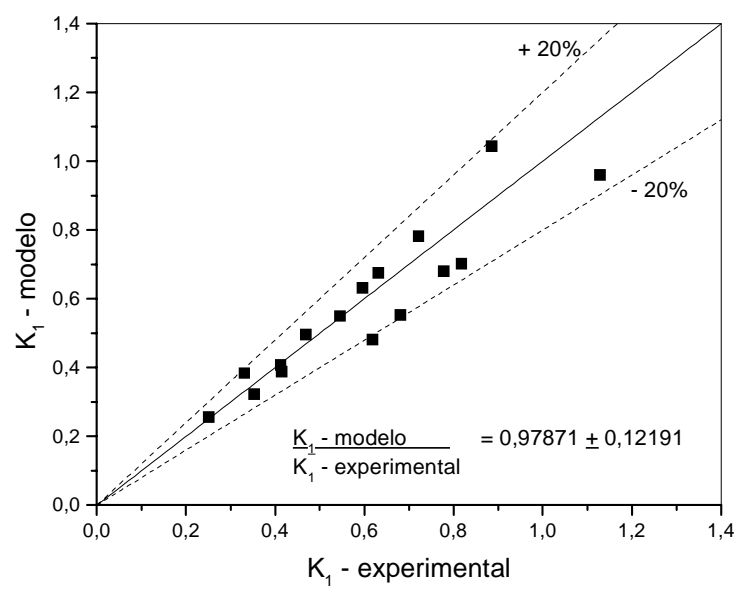

(c) Comparação de $\mathrm{K}_{1}$ do modelo com os valores experimentais

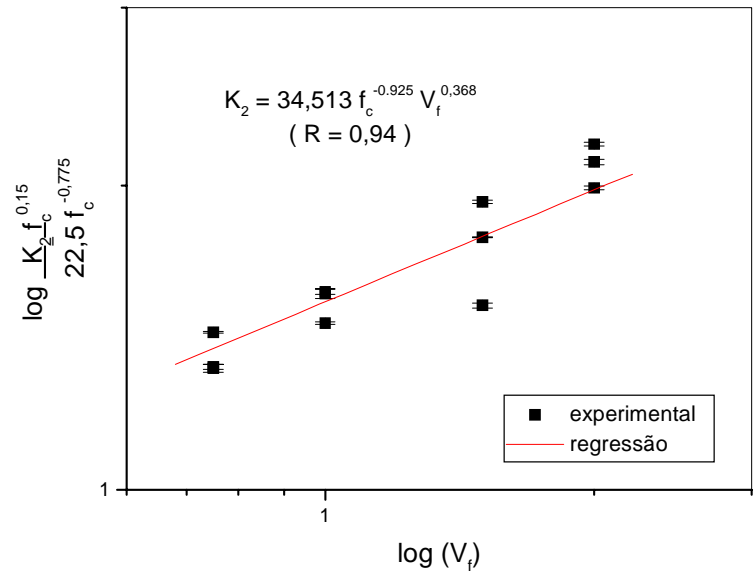

(e) Relação entre $\mathrm{K}_{2}$ e $\mathrm{V}_{\mathrm{f}}$ para concreto com fibra
$(\mathrm{R}=0,94) \quad$ para $0<\mathrm{V}_{\mathrm{f}} \leq 2 \%$

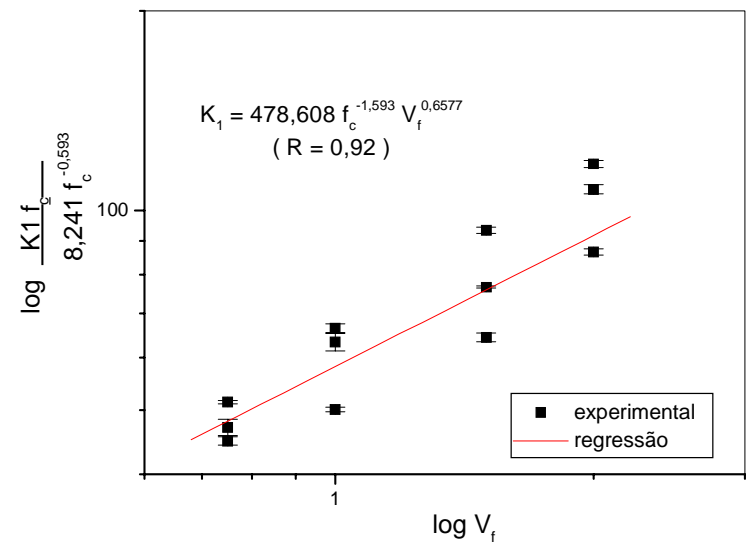

(b) Relação entre $K_{1}$ e $V_{f}$ para concreto com fibra

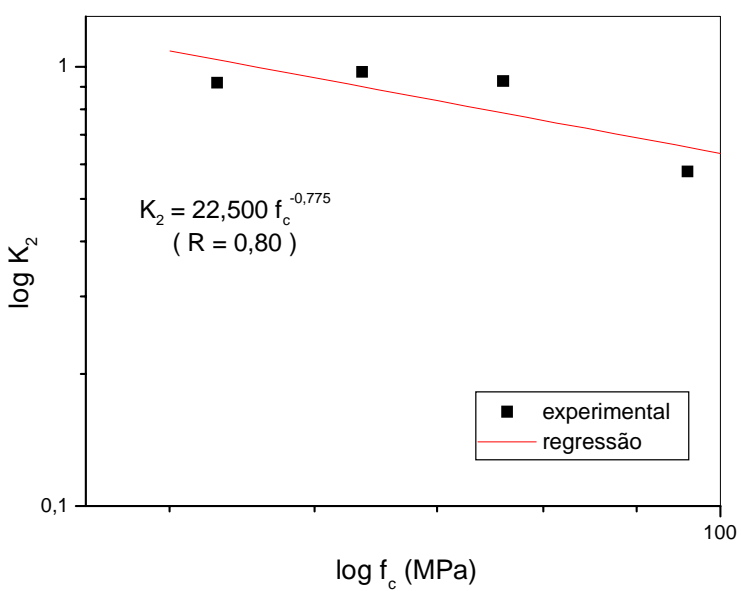

(d) Relação entre $\mathrm{K}_{2}$ e $\mathrm{f}_{c}$ para concreto sem fibra

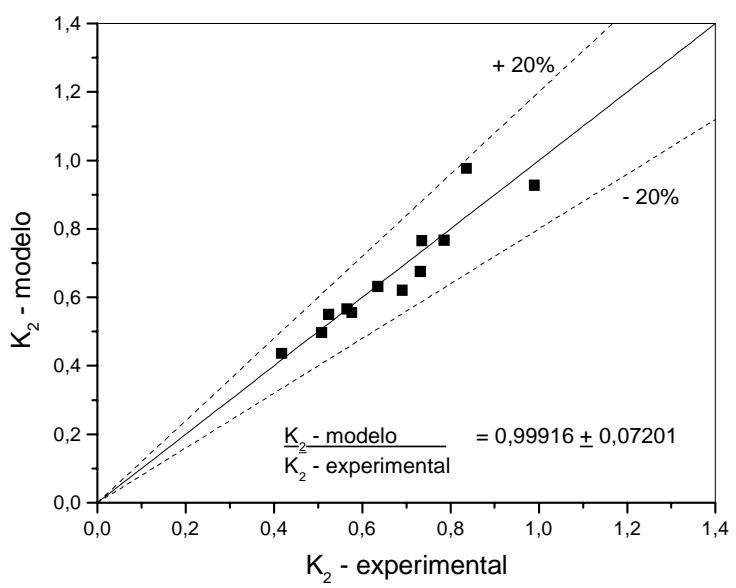

(f) Comparação de $K_{2}$ do modelo com os valores experimentais

Figura 3.26 - Determinação das expressões de $\mathrm{K}_{1}$ e $\mathrm{K}_{2}$ 
A curva tensão-deformação do concreto pode, então, ser traçada empregando a eq.(3.12) em conjunto com a eq.(3.14) e a eq.(3.15). Na parte ascendente da curva, ou seja, para $\varepsilon_{\mathrm{c}} \leq \varepsilon_{\mathrm{c} \text {,lim }}$, deve-se fazer $\mathrm{K}_{1}=\mathrm{K}_{2}=1$. Na parte descendente, ou seja, quando $\varepsilon_{\mathrm{c}}>\varepsilon_{\mathrm{c} \text {,lim, }}$, $\mathrm{K}_{1}$ e $\mathrm{K}_{2}$ são definidos pela eq.(3.15), não tomando, entretanto, valores maiores que a unidade. Os valores de $E_{c}$ e $\varepsilon_{c, l i m}$ são definidos pela eq.(3.10) e pela eq.(3.11), respectivamente. Na Figura 3.27, a curva proposta é comparada com as curvas médias experimentais de todas as séries ensaiadas. Como pode ser observado, a curva proposta representou de modo adequado o comportamento obtido dos ensaios.
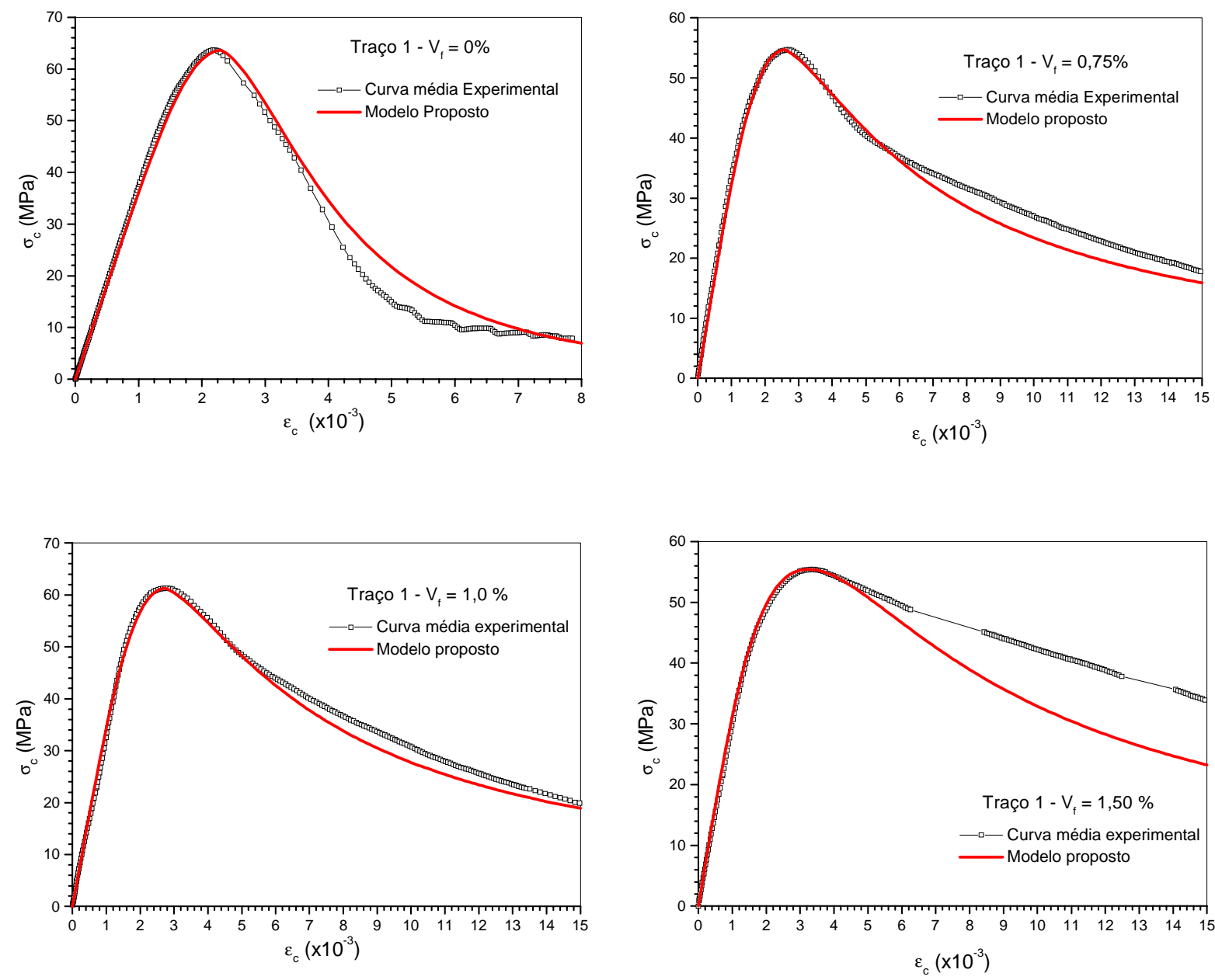

Figura 3.27 - Comparação das curvas experimentais com as previstas pela curva proposta 

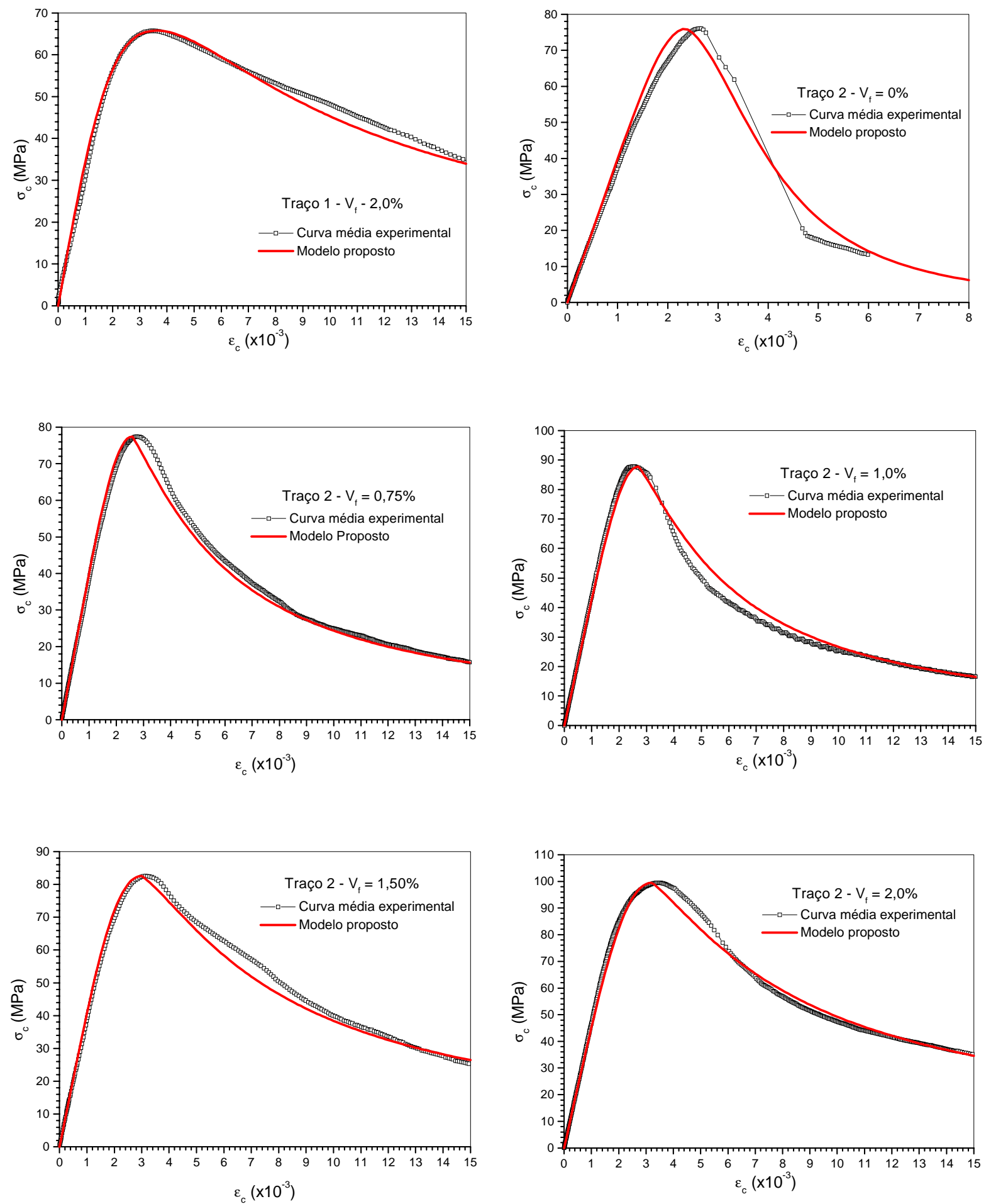

Figura 3.27 - Comparação das curvas experimentais com as previstas pela curva proposta (continuação) 

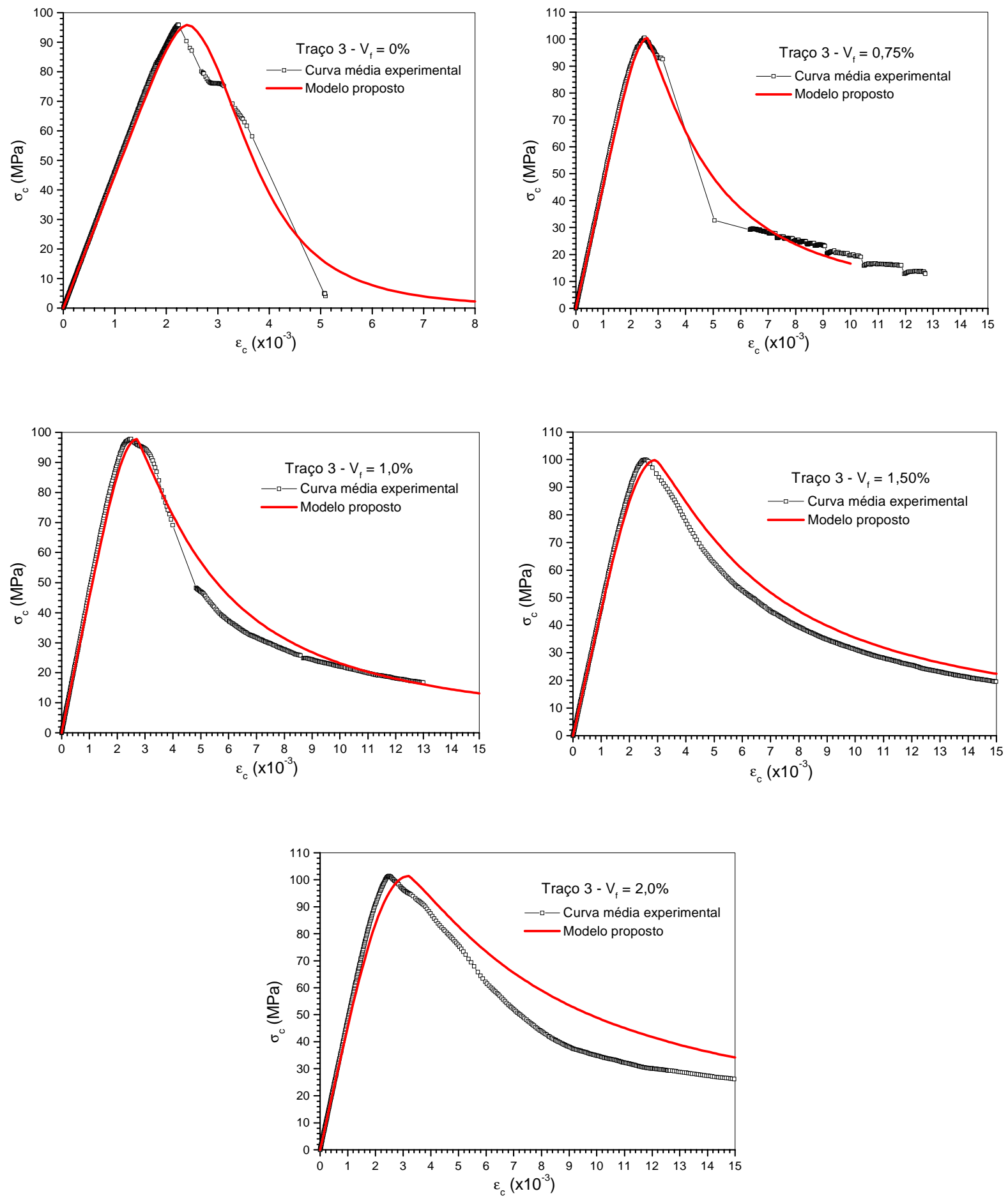

Figura 3.27 - Comparação das curvas experimentais com as previstas pela curva proposta (continuação) 


\subsection{Síntese e considerações finais}

Neste capítulo foi apresentado o estudo realizado para a caracterização do concreto reforçado com fibras. Foram estudados três traços, com resistência à compressão variando de $50 \mathrm{MPa}$ a $100 \mathrm{MPa}$, e quatro volumes de fibras metálicas. As fibras empregadas apresentavam $30 \mathrm{~mm}$ de comprimento e fator de forma igual a 48 . Verificou-se que a adição de até $2,0 \%$ de fibras não alterou a resistência à compressão do concreto. Com relação à resistência à tração na flexão, foi verificado um aumento de até $80 \%$ devido à adição de $2,0 \%$ de fibras. Também foi verificado um aumento nos índices de tenacidade devido à adição de fibras. A energia de fratura para o concreto simples, medida a partir de ensaios de flexão sob três pontos de carga, apresentou um valor muito próximo do recomendado pelo CEB-FIP MC90 (FIB (1999)). A adição de fibras ao concreto em um volume superior a $0,75 \%$ aumentou de forma significativa a energia de fratura do material. Os corpos-de-prova com 2,0\% de fibras, por exemplo, apresentaram uma energia mais de cinqüenta vezes maior que a energia dos corpos-de-prova sem fibras. Foram realizados também ensaios de compressão axial com deformação controlada. A partir desses ensaios, foi possível verificar a influência das fibras na energia absorvida pelo material empregando o conceito de tenacidade relativa. Novamente, foi verificado um aumento na energia devido à adição das fibras. Ao final, foi proposta uma expressão para o traçado da curva tensão-deformação do concreto comprimido, que se mostrou coerente com os resultados experimentais.

Os resultados do estudo de caracterização do material mostraram que a adição de fibras metálicas com fator de forma igual a 48 melhorou o comportamento do concreto tanto na tração quanto na compressão, sendo que a principal contribuição foi o aumento da ductilidade do concreto. Essas fibras proporcionaram ganhos de energia e ductilidade inferiores aos observados com fibras de maiores fatores de forma, contudo os resultados indicam que o emprego de um volume de fibras maior que o usual é capaz de melhorar o comportamento do concreto de alta resistência de forma satisfatória. 


\section{Capítulo 4 - Ensaios de Cisalhamento Direto}

Neste capítulo são apresentados os ensaios de cisalhamento direto realizados sob carregamento monotônico e sob carregamento cíclico não reversível. Nos ensaios sob carregamento monotônico, o comportamento das ligações com superfície plana foi comparado com o comportamento das ligações com chave de cisalhamento. Desses ensaios também foi analisada a influência da resistência do concreto, do diâmetro do conector e do volume de fibras sobre a resistência da ligação com chave de cisalhamento. Dos ensaios sob carregamento cíclico foi mostrada a influência do diâmetro do conector e do volume de fibras na perda de rigidez da ligação com chave de cisalhamento. Em seguida, as ligações com superfície plana e rugosa foram analisadas empregando modelos analíticos disponíveis na literatura. Ao final, são apresentados alguns resultados da simulação numérica dos ensaios com carregamento monotônico, empregando o programa comercial ANSYS baseado no método dos elementos finitos.

\subsection{Descrição dos ensaios de cisalhamento direto}

Foram realizados vinte e oito ensaios de cisalhamento direto, seis com superfície de contato plana e vinte e dois com chave de cisalhamento. Nove modelos com chave de cisalhamento foram submetidos a carregamento cíclico não reversível, enquanto os demais modelos com chave, bem como os modelos com superfície plana, foram submetidos a carregamento monotônico. As variáveis analisadas nos ensaios foram: forma da superfície de contato, tipo de carregamento, resistência e volume de fibras do concreto moldado nos nichos, e diâmetro do conector. Na Tabela 4.1 está detalhado o programa experimental realizado. Foi dada maior ênfase ao estudo da ligação com chave de cisalhamento, sendo os ensaios com ligação plana realizados apenas para efeito de comparação. A numeração dos corpos-de-prova nessa tabela não aparece de modo seqüencial, uma vez que a tabela original de ensaios foi aqui reorganizada para melhor visualização das variáveis estudadas. 
Tabela 4.1 - Ensaios de cisalhamento direto realizados

\begin{tabular}{|c|c|c|c|c|c|}
\hline Carregamento & Superfície & $\begin{array}{l}\text { Traço empregado } \\
\text { na ligação* }\end{array}$ & $\begin{array}{l}\text { Diâmetro do } \\
\text { conector }(\mathrm{mm})\end{array}$ & $\begin{array}{l}\text { Volume de } \\
\text { fibras (\%) }\end{array}$ & $\begin{array}{l}\text { Corpo-de- } \\
\text { prova }\end{array}$ \\
\hline \multirow{19}{*}{ Monotônico } & \multirow{3}{*}{ Plana e lisa } & \multirow{2}{*}{ Traço 1} & 10 & - & CP6 \\
\hline & & & 12,5 & - & CP2 \\
\hline & & Traço 3 & 12,5 & - & CP4 \\
\hline & \multirow{3}{*}{$\begin{array}{l}\text { Plana e } \\
\text { rugosa }\end{array}$} & \multirow{2}{*}{ Traço 1} & 8 & - & CP1 \\
\hline & & & 10 & - & CP5 \\
\hline & & Traço 3 & 8 & - & CP3 \\
\hline & \multirow{13}{*}{$\begin{array}{c}\text { Chave de } \\
\text { cisalhamento }\end{array}$} & \multirow{7}{*}{ Traço 1} & ** & - & CP15 \\
\hline & & & 8 & - & CP14 \\
\hline & & & 10 & - & CP13 \\
\hline & & & 12,5 & - & CP7 \\
\hline & & & 12,5 & - & CP7A \\
\hline & & & 12,5 & - & CP22 \\
\hline & & & 12,5 & 1,50 & CP8 \\
\hline & & \multirow{2}{*}{ Traço 2} & 12,5 & 0,75 & CP11 \\
\hline & & & 12,5 & 0,75 & CP12 \\
\hline & & \multirow{4}{*}{ Traço 3} & 8 & - & CP24 \\
\hline & & & 10 & - & CP25 \\
\hline & & & 12,5 & - & CP9 \\
\hline & & & 12,5 & 1,50 & CP10 \\
\hline \multirow{9}{*}{$\begin{array}{l}\text { Cíclico não } \\
\text { reversível }\end{array}$} & \multirow{9}{*}{$\begin{array}{l}\text { Chave de } \\
\text { cisalhamento }\end{array}$} & \multirow{9}{*}{ Traço 2} & 8 & - & CP16 \\
\hline & & & 8 & 0,75 & CP18 \\
\hline & & & 8 & 1,50 & CP20 \\
\hline & & & 10 & - & CP23 \\
\hline & & & 10 & 0,75 & CP26 \\
\hline & & & 10 & 1,50 & CP27 \\
\hline & & & 12,5 & - & CP17 \\
\hline & & & 12,5 & 0,75 & CP19 \\
\hline & & & 12,5 & 1,50 & CP21 \\
\hline
\end{tabular}

* Os traços 1, 2 e 3 empregados na ligação das peças pré-moldadas foi definido no capítulo 3.

** Ensaio realizado sem conector na ligação 
O corpo-de-prova utilizado para solicitar a ligação apenas a esforços de cisalhamento consistia de três peças pré-moldadas: uma peça central, simulando a viga prémoldada, e duas peças laterais, simulando a laje pré-moldada. O conector era formado por um vergalhão de aço dobrado em forma de laço. A ligação entre as peças laterais e a peça central era feita através da concretagem dos nichos existentes nas peças laterais. Na Figura 4.1 são mostradas as dimensões do corpo-de-prova utilizado no ensaio. Essas dimensões foram definidas a partir das recomendações da BS 5400 (1979) e das dimensões internas do equipamento disponível no laboratório para ensaio. A armadura das peças pré-moldadas é mostrada na Figura 4.2.

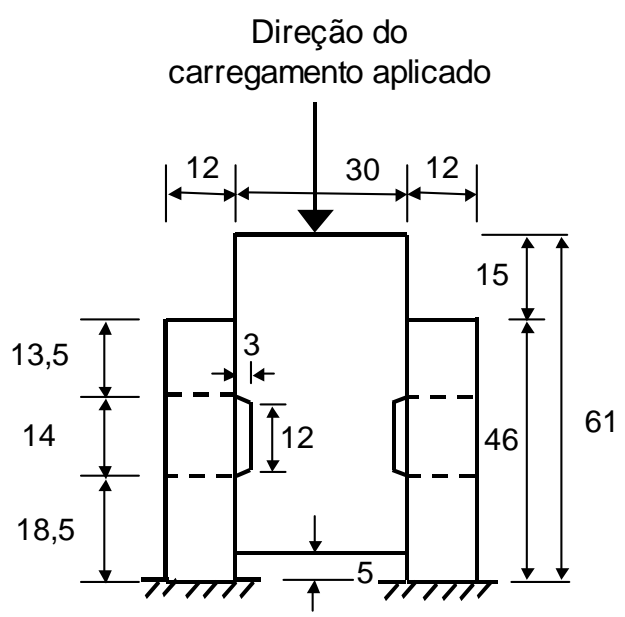

Vista frontal

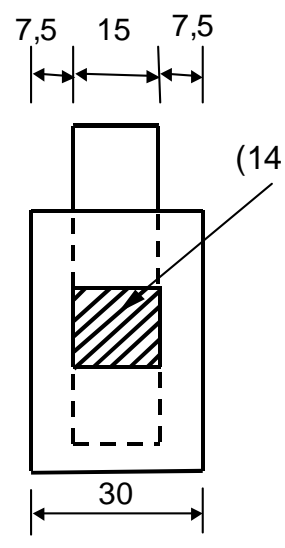

Vista lateral
Dimensões em cm

Nicho $(14 \mathrm{~cm} \times 15 \mathrm{~cm})$

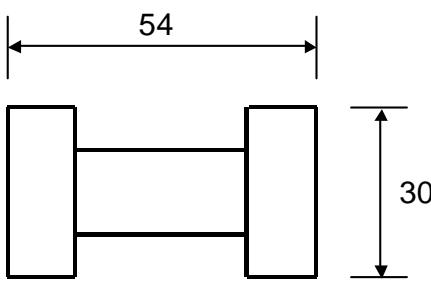

Vista superior

Figura 4.1 - Dimensões dos corpos-de-prova de cisalhamento direto ensaiados.

\subsubsection{Confecção dos corpos-de-prova}

Os corpos-de-prova foram moldados em duas etapas. Na primeira etapa foram moldadas as peças laterais, com os nichos, e as peças centrais, deixando-se exposto parte do conector (Figura 4.3). Após dois dias, as peças foram desmoldadas e uma das peças laterais foi posicionada sobre a peça central. Antes disso, porém, foi passada uma fina camada de graxa sobre a superfície da peça central para retirar o atrito entre as peças prémoldadas. Depois de posicionada a peça lateral, o nicho foi calafetado de modo a evitar a fuga de nata para fora da região da ligação, o que poderia alterar os resultados de resistência da ligação. Em seguida, a superfície de contato entre os dois concretos foi limpa com ar comprimido para retirar impurezas e partículas soltas. O nicho foi, então, umedecido, evitando que ficasse água livre, o que provocaria redução da resistência do concreto moldado no nicho. A ligação entre as peças pré-moldadas foi finalmente realizada através 
da concretagem do nicho, sendo mantida sob cura durante 24 horas (Figura 4.4). Depois desse período, o corpo-de-prova foi virado, sendo a ligação da segunda peça lateral realizada seguindo a mesma metodologia.

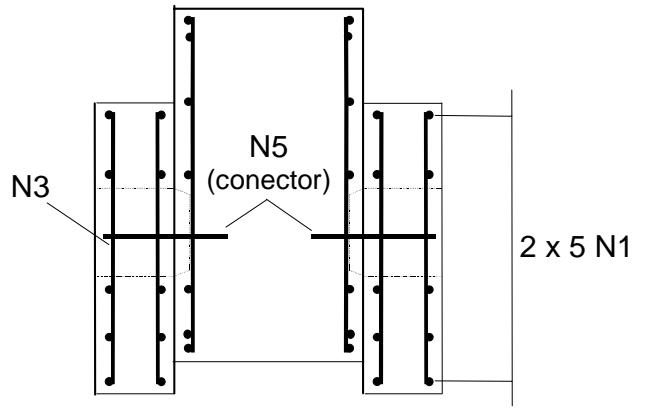

Corte AA

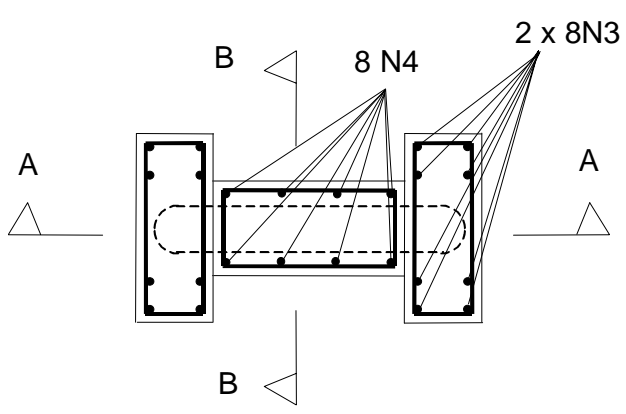

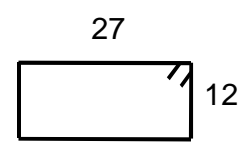

$\mathrm{N} 1-10 \phi 8 \mathrm{~mm}-78 \mathrm{~cm} \quad \mathrm{~N} 2-7 \phi 8 \mathrm{~mm}-84 \mathrm{~cm}$

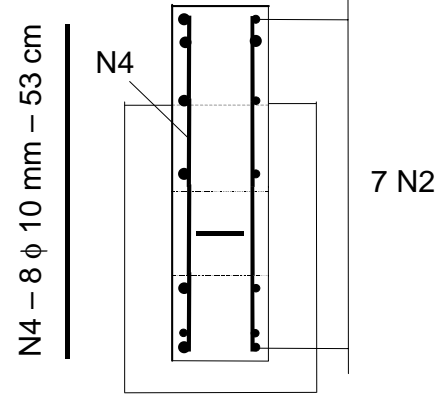

Corte BB
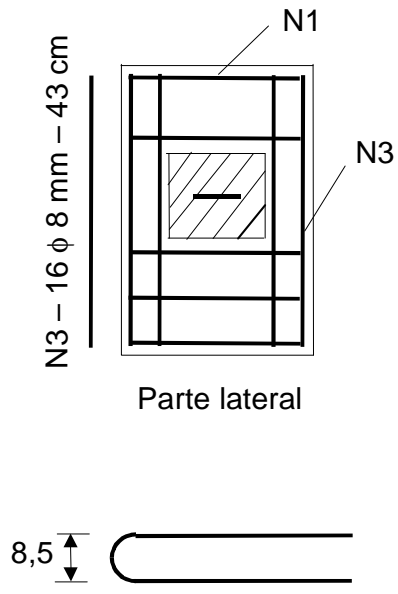

$\mathrm{N} 5-2 \phi-73 \mathrm{~cm}$

Figura 4.2 - Armadura dos corpos-de-prova de cisalhamento direto.

Nos corpos-de-prova CP2, CP4 e CP6 a superfície da ligação era plana e lisa, isto é, não foi feito nenhum tratamento na superfície da peça central de modo a torná-la rugosa, enquanto nos corpos-de-prova CP1, CP3 e CP5 a superfície da ligação era plana e rugosa. Nestes corpos-de-prova, a rugosidade foi garantida pela colagem de pequenas tiras de isopor com $5 \mathrm{~mm}$ de espessura por $20 \mathrm{~mm}$ de largura e espaçadas de $20 \mathrm{~mm}$ (Figura 4.5). Dessa forma, foi garantida a rugosidade mínima recomendada pela NBR 9062 (1985) de 5 $\mathrm{mm}$ a cada $30 \mathrm{~mm}$. 


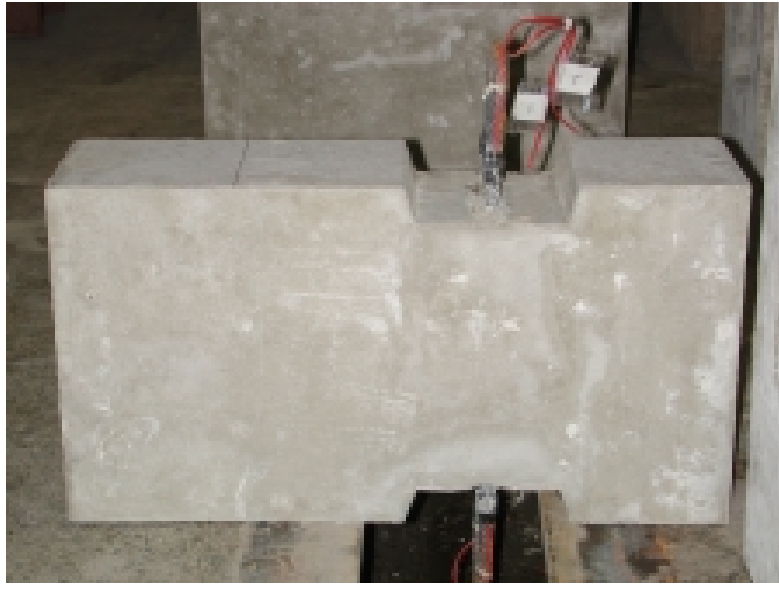

(a) Peça central com chave de cisalhamento

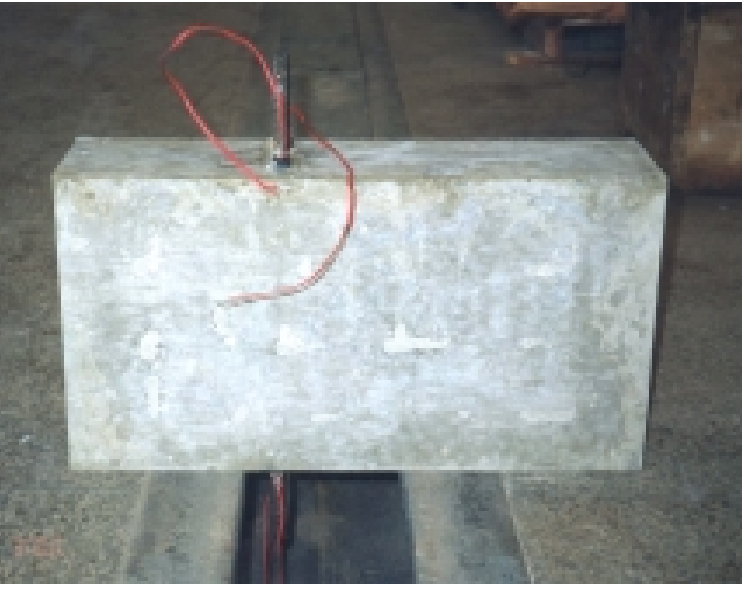

(b) Peça central com superfície plana

Figura 4.3- Detalhe das peças centrais dos corpos-de-prova de cisalhamento direto.

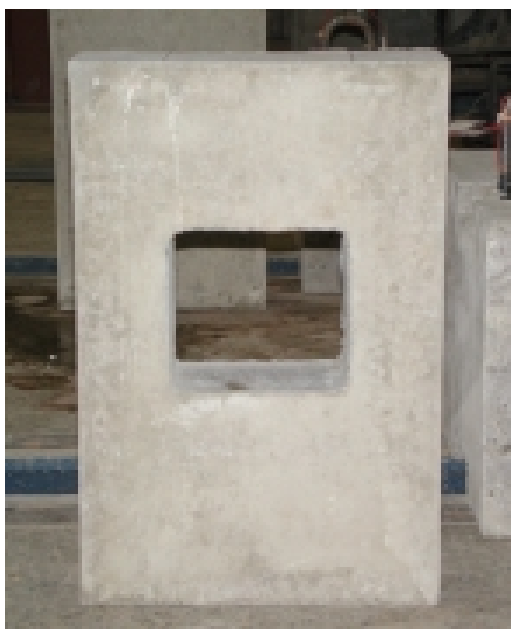

(a) Peça lateral com nicho

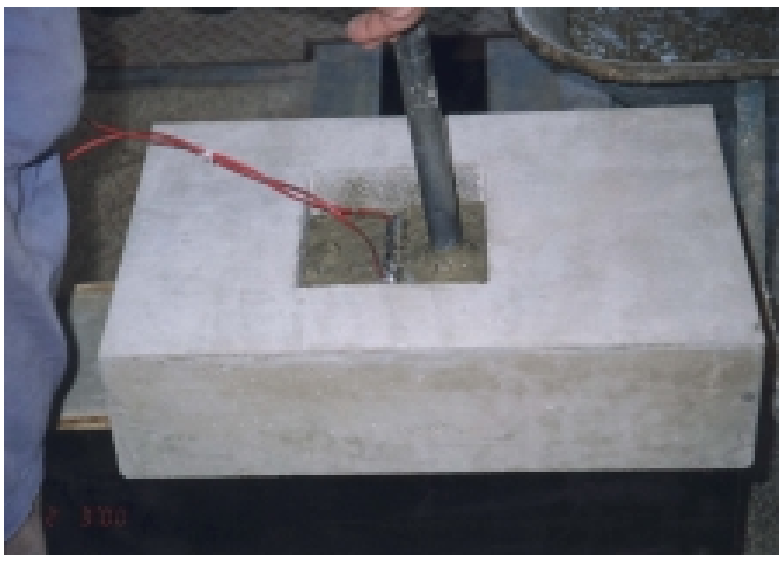

(b) Realização da ligação

Figura 4.4 - Detalhe da peça lateral e realização da ligação.
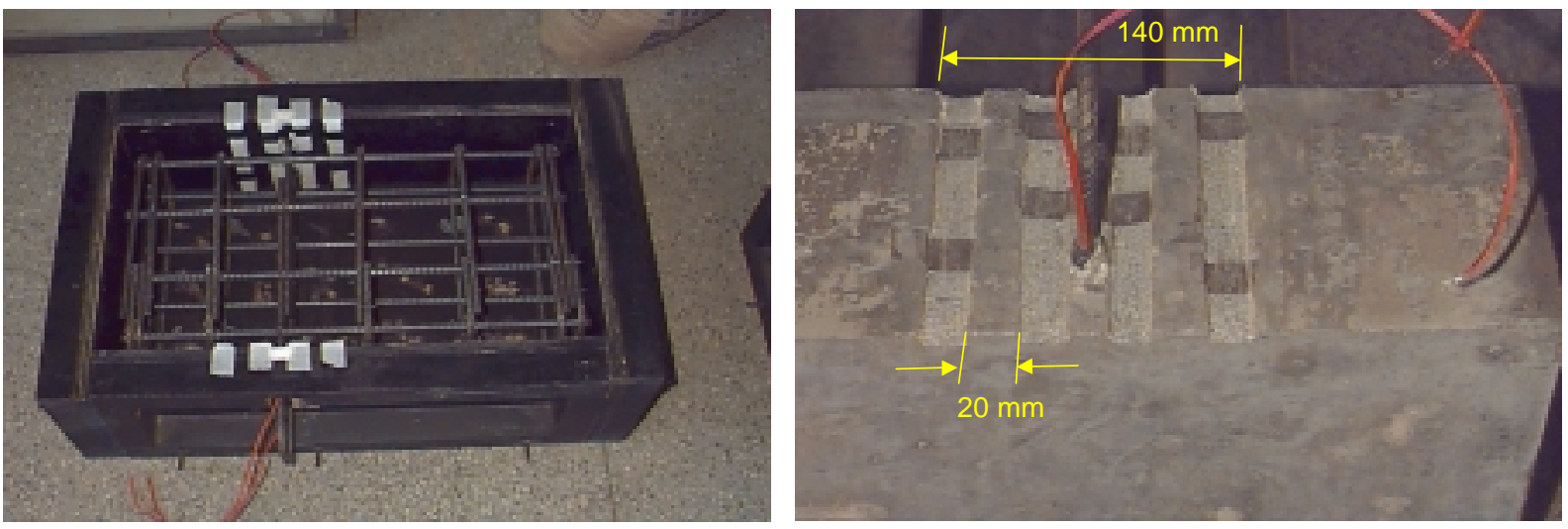

Figura 4.5 - Corpo-de-prova com superfície plana e rugosa ( $5 \mathrm{~mm}$ x $20 \mathrm{~mm}$ ) 
O corpo-de-prova CP15 foi confeccionado sem o conector na ligação. O objetivo desse ensaio era quantificar a contribuição do concreto na resistência da ligação. Foi aplicado um adesivo epóxi na superfície da peça pré-moldada antes da concretagem do nicho de modo a garantir a aderência entre a chave de cisalhamento e a peça central prémoldada (Nitobond EPD da FOSROC). Dessa forma, foi possível garantir que a ruptura ocorresse por cisalhamento na chave e não pelo descolamento entre o concreto moldado no nicho e o concreto pré-moldado. Como não havia conector na ligação, se este descolamento ocorresse haveria a separação entre as peças pré-moldadas.

\subsubsection{Instrumentação}

Os corpos-de-prova foram instrumentados com oito transdutores, com $10 \mathrm{~mm}$ de curso e 0,003 $\mathrm{mm}$ de sensibilidade, fixados na peça central e com a haste apoiada em cantoneiras coladas nas peças laterais. Na Figura 4.6 é mostrado o posicionamento e a numeração dos transdutores. Os transdutores de 5 a 8 foram empregados para medir 0 deslizamento relativo entre as peças pré-moldadas na região da ligação, enquanto os transdutores de 9 a 12 foram empregados para medir a abertura entre as peças prémoldadas proporcionada por uma eventual rotação da peça lateral.

Vista superior

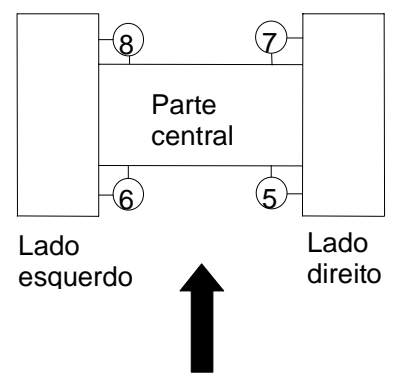

Frente
Vista de frente

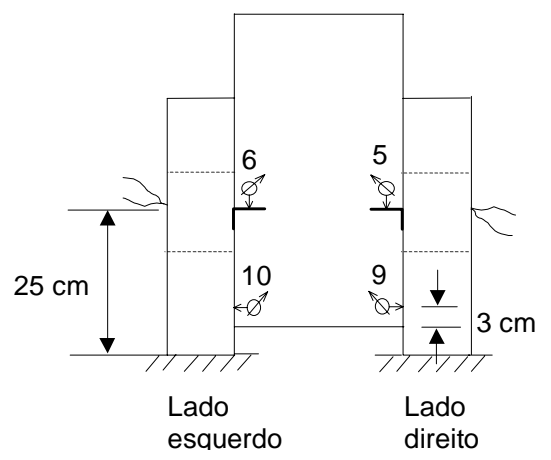

Vista de trás

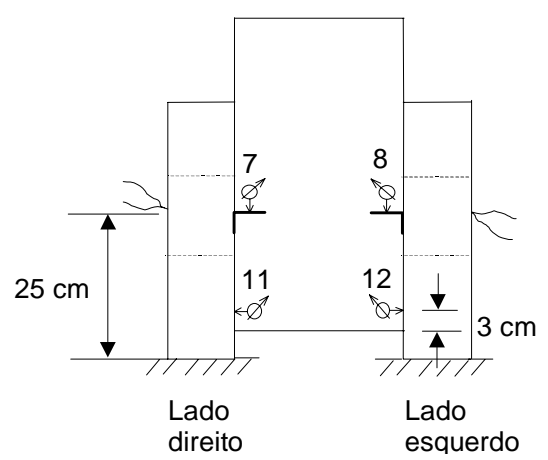

Figura 4.6 - Posição dos transdutores no ensaio de cisalhamento direto.

A armadura foi instrumentada com extensômetros elétricos uniaxiais, modelo KFG-5 da KYOWA, sendo seu posicionamento mostrado na Figura 4.7. Os extensômetros de 1 a 4 foram colados nos conectores, na altura do plano de cisalhamento, para medir a deformação da armadura durante o deslizamento da ligação. Em alguns corpos-de-prova, o estribo N2 (ver Figura 4.2) foi instrumentado junto à suas extremidades de modo a verificar 
a influência desta armadura em uma possível ruptura da peça central por cisalhamento (Figura 4.8). O estribo N1 também foi instrumentado em alguns corpos-de-prova para verificar as tensões que surgiram na armadura da peça lateral pré-moldada durante o processo de carregamento.

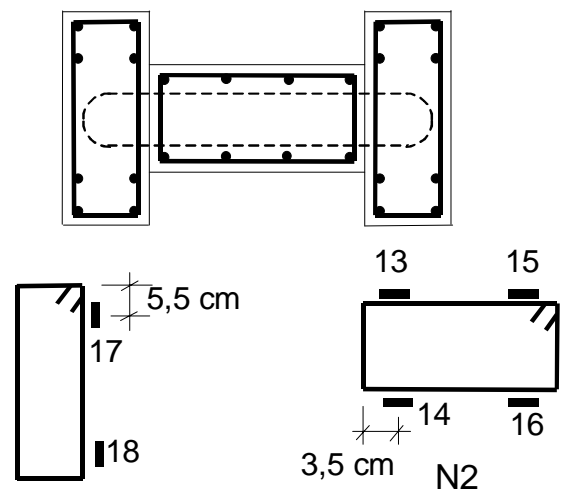

N1

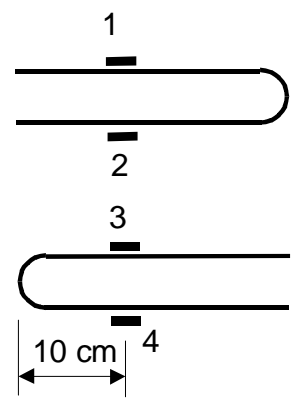

N5

Figura 4.7 - Numeração dos extensômetros da armadura para o ensaio de cisalhamento direto.

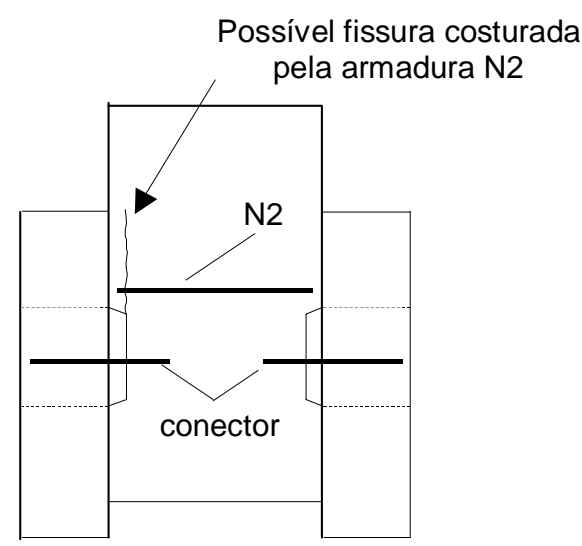

Figura 4.8 - Possível fissuração do bloco central no ensaio de cisalhamento direto.

\subsubsection{Execução dos ensaios}

O ensaio, com controle de deslocamento, foi realizado sete dias após a concretagem da segunda ligação, empregando-se uma prensa servo-controlada INSTRON com capacidade de $\pm 3000 \mathrm{kN}$ em carregamento estático e \pm 2500 kN em carregamento dinâmico (Figura 4.9). Nos ensaios sob carregamento monotônico, o carregamento foi aplicado de forma contínua até o final do ensaio. A velocidade de carregamento empregada, antes de atingida a resistência da ligação, variou de $0,001 \mathrm{~mm} / \mathrm{s}$ a $0,006 \mathrm{~mm} / \mathrm{s}$. A velocidade mais baixa foi empregada nos corpos-de-prova com a ligação confeccionada sem fibras, 
enquanto a segunda velocidade foi empregada nos corpos-de-prova com fibras. Depois de caracterizada a ruptura da ligação, a velocidade de carregamento foi gradualmente aumentada até o final do ensaio.

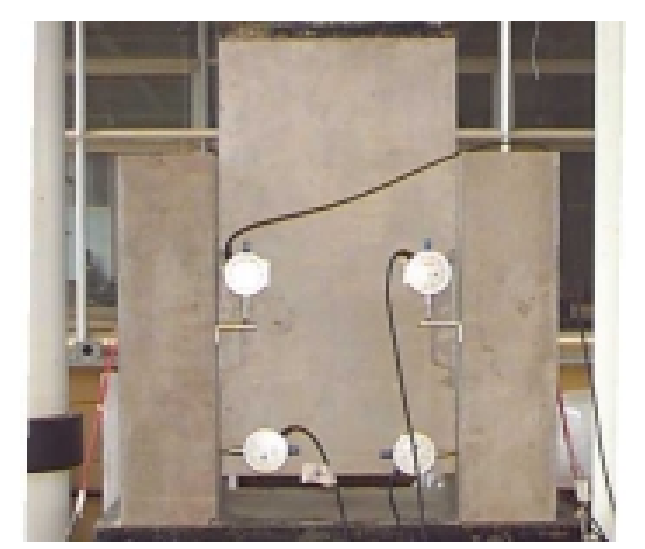

(a) Corpo-de-prova posicionado para ensaio

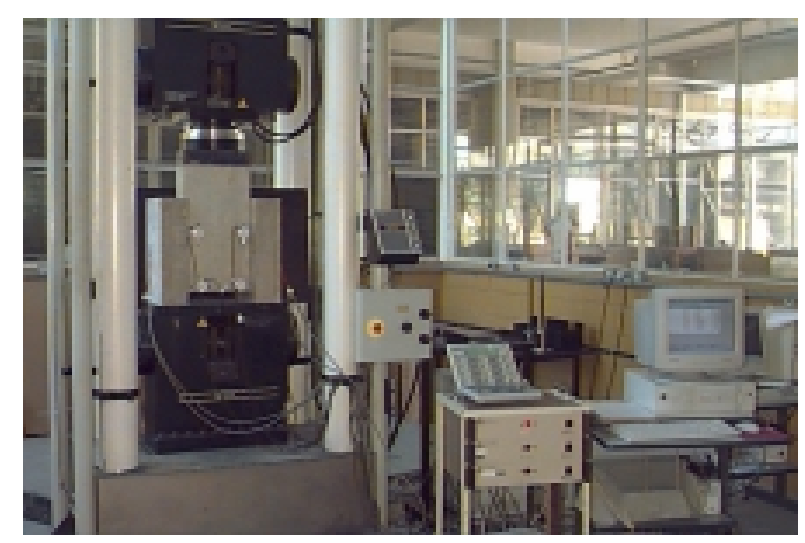

(b) Vista geral do ensaio

Figura 4.9- Realização do ensaio de cisalhamento direto.

Nos ensaios sob carregamento cíclico foram adotadas duas velocidades. Na etapa de carregamento, a velocidade adotada foi de $0,006 \mathrm{~mm} / \mathrm{s}$, enquanto no descarregamento a velocidade foi de $0,03 \mathrm{~mm} / \mathrm{s}$. Os corpos-de-prova foram descarregados sem, contudo, solicitar a ligação no outro sentido. O objetivo principal desses ensaios era avaliar a rigidez da ligação quando submetida a carregamentos sucessivos Dessa forma, as amplitudes adotadas para o carregamento foram inferiores à resistência da ligação. Foram adotadas três amplitudes: $40 \%$, 65\% e $80 \%$ da resistência da ligação que foi admitida conhecida antes da execução dos ensaios. Por esta razão, as amplitudes reais foram ligeiramente diferentes desses valores.

Para cada amplitude definida no ensaio cíclico, foram realizados vinte ciclos completos de carga e descarga. Após o termino do carregamento cíclico, a ligação foi levada à ruptura aplicando o carregamento de modo contínuo. Para que a resistência da ligação pudesse ser obtida, era fundamental que ela não rompesse por fadiga durante o ensaio cíclico. BAKHOUM (1991) observou que se uma chave de cisalhamento, sem fibras, fosse submetida a carregamento cíclico com amplitude inferior a $85 \%$ de sua resistência, até 30 ciclos de carga não ocorria ruptura por fadiga. Dessa forma, a resistência da ligação obtida desses ensaios também poderia ser empregada para a caracterização da ligação. 
Na Figura 4.10 é mostrado o esquema do carregamento cíclico adotado. O período de cada ciclo dependia da amplitude do carregamento. No primeiro nível de carregamento, cada ciclo durava, em média, 150 segundos. Este período era maior nos níveis seguintes de carregamento e nos corpos-de-prova com fibras na ligação.

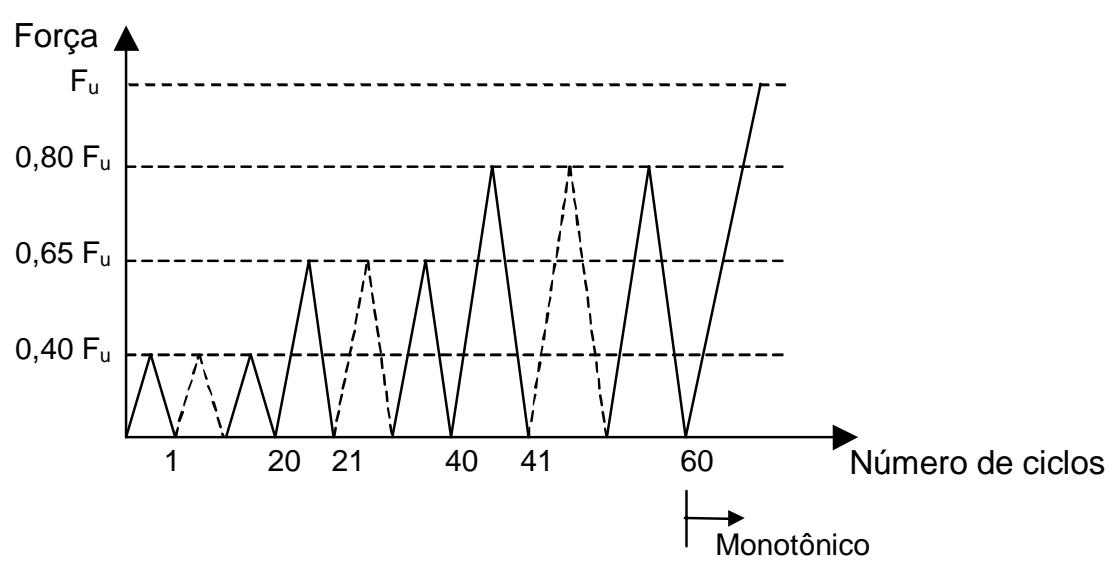

Figura 4.10 - Esquema do carregamento nos ensaios cíclicos

\subsection{Resultados dos ensaios de cisalhamento direto}

$\mathrm{Na}$ Figura 4.11 são mostradas curvas da força na ligação em função do deslizamento médio relativo entre as peças pré-moldadas para os casos de ligação com chave de cisalhamento e ligação plana com superfícies lisa e rugosa. O deslizamento médio da ligação foi obtido pela média das leituras dos transdutores verticais, sendo as suas leituras corrigidas em função dos deslocamentos medidos pelos transdutores horizontais, conforme mostrado no Apêndice A. Analisando essa figura, observa-se um aumento da resistência da ligação ao ser garantida a rugosidade na superfície de contato, e um aumento ainda maior quando a chave de cisalhamento foi executada. Na Tabela 4.2 é mostrada a força última resistida pela ligação em todos os ensaios. Nessa tabela também são mostradas a deformação do conector e a tensão normal ao plano de cisalhamento no momento da ruptura da ligação. Na Tabela 4.3 são mostrados o deslizamento médio, $\delta_{\mathrm{m}}$, referente ao pico de resistência e a energia absorvida pela ligação. Nos itens seguintes é feita uma análise mais detalhada dos resultados dos ensaios de cisalhamento direto. 
Tabela 4.2 - Resistência média do concreto e força última da ligação nos ensaios de cisalhamento direto

\begin{tabular}{|c|c|c|c|c|c|c|c|}
\hline \multirow{2}{*}{$\begin{array}{l}\text { Corpo- } \\
\text { de-prova }\end{array}$} & \multicolumn{2}{|c|}{ Blocos pré-moldados } & \multicolumn{2}{|c|}{ Nichos } & \multirow{2}{*}{$\begin{array}{c}\varepsilon_{\mathrm{s}}\left(\times 10^{-3}\right) \\
(1)\end{array}$} & \multirow{2}{*}{$\begin{array}{c}\sigma_{\mathrm{n}}(\mathrm{MPa}) \\
(2)\end{array}$} & \multirow{2}{*}{$\begin{array}{c}\text { Força } \\
\text { última (kN }\end{array}$} \\
\hline & $\mathrm{f}_{\mathrm{cm}}(\mathrm{MPa})$ & $\mathrm{f}_{\mathrm{ctm}, \mathrm{sp}}(\mathrm{MPa})$ & $\mathrm{f}_{\mathrm{cm}}(\mathrm{MPa})$ & $\mathrm{f}_{\mathrm{ctm}, \mathrm{sp}}(\mathrm{MPa})$ & & & \\
\hline CP1 & 55,30 & 3,10 & 53,75 & 3,85 & 1,487 & 1,49 & 192,65 \\
\hline $\mathrm{CP} 2$ & 58,50 & 4,00 & 75,45 & 4,45 & 0,223 & 0,55 & $109,50^{(3)}$ \\
\hline CP3 & 55,30 & 3,10 & 91,20 & 4,85 & 1,853 & 1,86 & 215,45 \\
\hline CP4 & 51,50 & 4,15 & 97,60 & 5,40 & 1,038 & 2,55 & $129,50^{(3)}$ \\
\hline CP5 & 52,30 & 4,30 & 54,75 & 3,45 & 0,975 & 1,53 & 190,45 \\
\hline CP6 & 52,30 & 4,30 & 54,75 & 3,45 & 0,304 & 0,48 & $71,70^{(3)}$ \\
\hline CP7 & 53,58 & 4,39 & 55,10 & 4,17 & - & - & 395,60 \\
\hline CP7A & 58,50 & 4,00 & 75,45 & 4,45 & 1,861 & 4,57 & 390,50 \\
\hline CP8 & 51,60 & 4,00 & 55,75 & 7,50 & 1,893 & 4,66 & 358,30 \\
\hline CP9 & 51,50 & 4,15 & 97,60 & 5,40 & 1,745 & 4,28 & 476,00 \\
\hline CP10 & 51,60 & 4,00 & 96,35 & 10,05 & 2,998 & 6,46 & 421,75 \\
\hline CP11 & 53,58 & 4,39 & 80,92 & 7,68 & - & - & 461,90 \\
\hline CP12 & 53,58 & 4,39 & 80,92 & 7,68 & - & - & 453,40 \\
\hline CP13 & 47,40 & 3,90 & 54,00 & 3,90 & 1,971 & 3,09 & 250,10 \\
\hline CP14 & 47,40 & 3,90 & 54,00 & 3,90 & 1,878 & 1,89 & 230,70 \\
\hline CP15 & 53,58 & 4,39 & 55,10 & 4,17 & - & 0 & 196,05 \\
\hline CP16 & 73,49 & 4,58 & 83,80 & 4,92 & 2,729 & 2,65 & 286,15 \\
\hline CP17 & 73,49 & 4,58 & 83,80 & 4,92 & 2,577 & 6,34 & 349,40 \\
\hline CP18 & 84,61 & 5,11 & 88,60 & 7,61 & 3,708 & 2,65 & 320,10 \\
\hline CP19 & 84,61 & 5,11 & 88,60 & 7,61 & 2,332 & 5,74 & 519,50 \\
\hline CP20 & 73,08 & 4,23 & 80,00 & 9,42 & 2,939 & 2,65 & 345,30 \\
\hline CP21 & 67,63 & 4,04 & 71,35 & 8,79 & 2,535 & 6,24 & 459,55 \\
\hline CP22 & 51,06 & 3,83 & 48,01 & 3,49 & 2,043 & 5,03 & 259,95 \\
\hline CP23 & 67,63 & 4,04 & 72,81 & 4,65 & 2,327 & 3,65 & 316,55 \\
\hline CP24 & 51,06 & 3,83 & 96,76 & 5,45 & 2,730 & 2,65 & 310,00 \\
\hline CP25 & 51,06 & 3,83 & 96,76 & 5,45 & 2,767 & 4,13 & 345,75 \\
\hline CP26 & 66,79 & 3,52 & 71,87 & 5,89 & 2,553 & 4,01 & 363,10 \\
\hline CP27 & 66,79 & 3,52 & 72,07 & 8,41 & 2,942 & 4,13 & 383,85 \\
\hline
\end{tabular}

Obs.:

(1) $\varepsilon_{s}$ : Deformação média do conector no instante da ruptura da ligação.

(2) $\sigma_{n}$ : Tensão normal ao plano de cisalhamento da ligação, devido ao conector, no instante da ruptura da ligação.

(3) No caso de superfície lisa, a força última foi tomada no instante da ruptura da aderência entre o concreto moldado no nicho e o concreto pré-moldado.

Conector: $f_{y}=553 \mathrm{MPa}$ e $E_{s}=210000 \mathrm{MPa}$ 
Tabela 4.3 - Deslizamento e energia absorvida pela ligação

\begin{tabular}{|c|c|c|c|}
\hline $\begin{array}{l}\text { Corpo- } \\
\text { de-prova }\end{array}$ & $\delta_{m}(\mathrm{~mm})^{(1)}$ & $\begin{array}{l}\text { Energia absorvida }{ }^{(2)} \\
\quad(\mathrm{kN} . \mathrm{mm})\end{array}$ & $\begin{array}{c}\text { Energia absorvida }{ }^{(3)} \\
(\mathrm{kN} . \mathrm{mm})\end{array}$ \\
\hline CP1 & 0,46 & 70,58 & 372,04 \\
\hline CP2 & 0,05 & 3,39 & 237,25 \\
\hline CP3 & 0,47 & 72,15 & 381,65 \\
\hline CP4 & 0,08 & 5,58 & 266,82 \\
\hline CP5 & 0,44 & 65,84 & 379,44 \\
\hline CP6 & 0,06 & 2,89 & 156,54 \\
\hline CP7 & 1,39 & 413,19 & 833,43 \\
\hline CP7A & 0,73 & 186,05 & 738,54 \\
\hline CP8 & 1,81 & 520,68 & 750,04 \\
\hline CP9 & 1,28 & 437,12 & 955,42 \\
\hline CP10 & 2,21 & 723,86 & 843,93 \\
\hline CP11 & 1,43 & 457,75 & 893,97 \\
\hline CP12 & 2,40 & 845,01 & 891,75 \\
\hline CP13 & 0,75 & 136,43 & 485,87 \\
\hline CP14 & 0,62 & 103,80 & 429,69 \\
\hline CP15 & 0,57 & 77,23 & 283,47 \\
\hline CP16 & 0,76 & 128,22 & 519,26 \\
\hline CP17 & 0,99 & 223,02 & 658,11 \\
\hline CP18 & 0,96 & 181,58 & 504,58 \\
\hline CP19 & 1,19 & 406,76 & 893,11 \\
\hline CP20 & 1,15 & 260,77 & 580,20 \\
\hline CP21 & 1,32 & 392,18 & 816,72 \\
\hline CP22 & 0,90 & 168,43 & 547,44 \\
\hline CP23 & 0,89 & 178,00 & 566,54 \\
\hline CP24 & 0,96 & 193,41 & 491,37 \\
\hline CP25 & 1,08 & 255,79 & 628,92 \\
\hline CP26 & 0,93 & 232,99 & 689,89 \\
\hline CP27 & 1,12 & 297,00 & 674,03 \\
\hline
\end{tabular}

(1) $\delta_{m}$ : deslizamento médio corrigido na ruptura da ligação

(2) Energia absorvida até o deslizamento médio $\delta_{m}$

(3) Energia absorvida até o deslizamento médio de $2,5 \mathrm{~mm}$ 


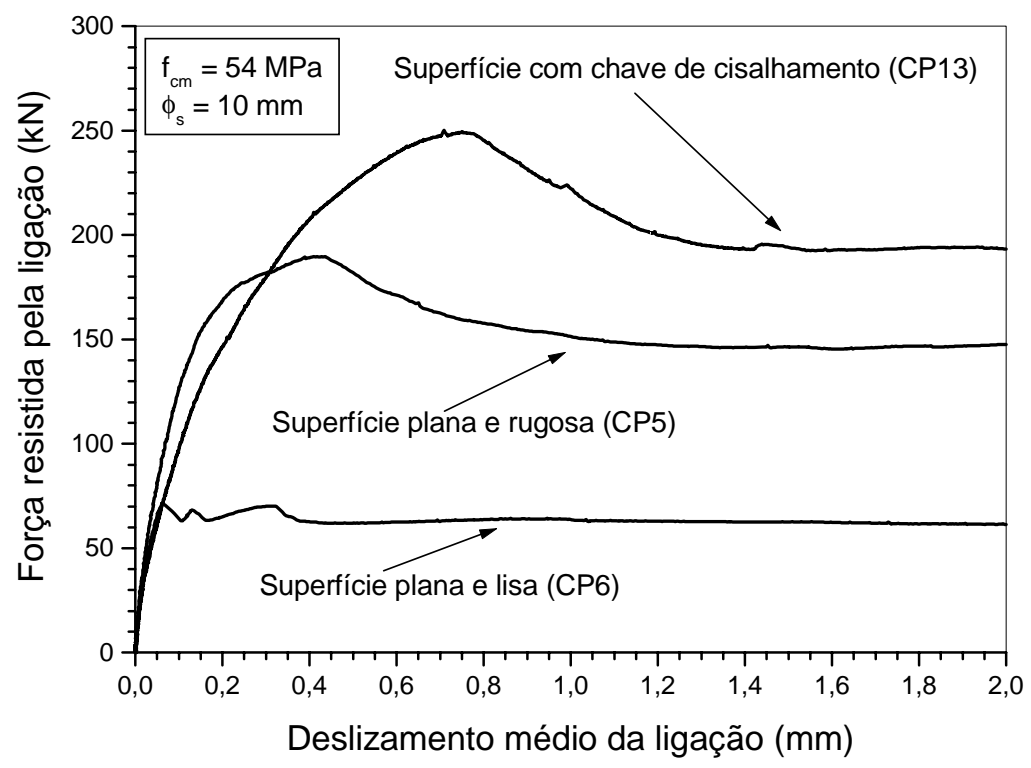

Figura 4.11 - Deslizamento da ligação com conector de $10 \mathrm{~mm}$

Após o ensaio dos corpos-de-prova CP7, CP7A e CP9, percebeu-se que havia ocorrido fuga de nata durante a concretagem da ligação, o que alterou os resultados devido à maior área de contato entre as peças laterais e a peça central. Assim sendo, estes corpos-de-prova não foram considerados na análise dos resultados.

\subsubsection{Influência da forma da superfície da ligação}

Analisando a ligação com conector de $10 \mathrm{~mm}$, observou-se que a execução da chave de cisalhamento aumentou em $250 \%$ a sua resistência quando comparada com a ligação com superfície plana e lisa. A garantia de rugosidade na superfície de contato da ligação proporcionou um aumento de $165 \%$ na resistência da ligação e uma energia absorvida até o pico de resistência 22 vezes maior quando comparada com a superfície lisa (Figura 4.11).

Quando a ligação com chave de cisalhamento e a ligação com superfície rugosa foram comparadas entre si, ambas confeccionadas com o traço 1 , verificou-se que a confecção das chaves de cisalhamento aumentou em 30\% a resistência da ligação. Quando foi empregado o traço 3 , a chave de cisalhamento aumentou a resistência da ligação em $44 \%$. Além disso, a ligação com chave de cisalhamento absorveu muito mais energia que a superfície rugosa, uma vez que ela atingiu deslizamentos maiores antes da ruptura da ligação. 
Analisando os corpos-de-prova com superfície plana e lisa, a aderência foi o principal mecanismo resistente. No momento em que ela foi vencida, apenas a ação de pino do conector foi responsável pela resistência da ligação. Para valores elevados de deslizamento, a ligação chegou a apresentar uma resistência até $70 \%$ maior que a obtida no momento da ruptura da aderência, contudo acompanhado do esmagamento do concreto pré-moldado. Observou-se, também, que com o aumento da resistência do concreto moldado no nicho, ocorreu um aumento da resistência da ligação, aqui definida pela ruptura da aderência (Figura 4.12). Esse aumento, provavelmente, foi devido apenas à melhoria da aderência entre o concreto moldado no nicho e o concreto pré-moldado. A aderência, contudo, é pouco confiável, sendo muito influenciada pelas condições de execução da superfície da ligação. Dessa forma, muitas vezes ela é desconsiderada, tanto nas recomendações das instituições normativas quanto nos ensaios de cisalhamento direto relatados na literatura.

Comparando os corpos-de-prova CP6 e CP2, ambos confeccionados com o traço 1, observou-se um aumento na resistência da ligação ao se aumentar o diâmetro do conector de $10 \mathrm{~mm}$ para $12,5 \mathrm{~mm}$. Esse aumento, contudo, não deve ter ocorrido pela alteração do conector, mas sim pela maior resistência do concreto no corpo-de-prova CP2. Isto ocorreu por que este corpo-de-prova foi ensaiado com uma idade superior à dos outros corpos-deprova devido a problemas com o equipamento na época do ensaio, o que proporcionou um aumento na resistência do concreto.

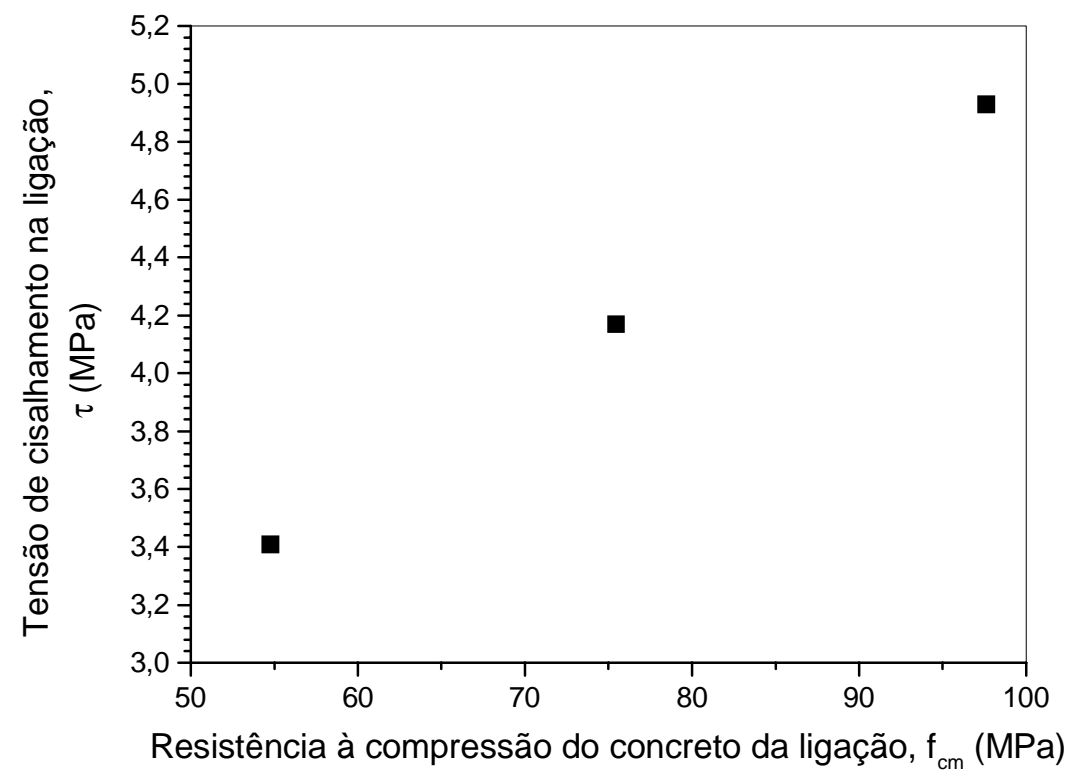

Figura 4.12 - Influência da resistência do concreto moldado no nicho na ligação com superfície lisa 
Analisando os corpos-de-prova com superfície rugosa e conector de $8 \mathrm{~mm}$ (CP1 e CP3), observou-se que o aumento da resistência à compressão do concreto da ligação de $50 \mathrm{MPa}$ para $90 \mathrm{MPa}$ aumentou a resistência da ligação em 12\%. Esse aumento foi devido à maior deformação do conector no instante do pico de resistência da ligação. No corpo-deprova onde a resistência à compressão do concreto da ligação era muito superior à do concreto pré-moldado, a ruptura ocorreu no concreto pré-moldado. Por outro lado, no corpode-prova onde o concreto da ligação e o concreto das peças pré-moldadas apresentavam a mesma resistência, ocorreu a ruptura tanto do concreto pré-moldado quanto do concreto moldado no nicho (Figura 4.13). Isto mostra que o aumento excessivo da resistência à compressão do concreto moldado no nicho não aumenta de modo significativo a resistência da ligação, mas transfere a ruptura para a peça pré-moldada. No caso da energia absorvida, praticamente não houve alteração.

Dos ensaios com ligação plana e rugosa, também foi possível avaliar a influência do diâmetro do conector sobre o comportamento da ligação (CP1 e CP5). Ao se aumentar o diâmetro do conector de $8 \mathrm{~mm}$ para $10 \mathrm{~mm}$, mantendo a resistência à compressão do concreto da ligação constante em $50 \mathrm{MPa}$, não foi observado aumento na resistência da ligação. Isto ocorreu por que neste último corpo-de-prova a deformação do conector no momento da ruptura da ligação diminuiu, o que anulou a influência do aumento da área de aço do conector. Foram realizados, porém, poucos ensaios, de modo que não foi possível obter conclusões sobre o comportamento dessa ligação.

\subsubsection{Influência da resistência do concreto na ligação com chave}

A execução da chave de cisalhamento na peça pré-moldada aumentou de modo significativo a resistência da ligação. Nesse tipo de ligação, a ruptura ocorreu pelo cisalhamento do concreto moldado no nicho. Dessa forma, a resistência da ligação é influenciada pela resistência do concreto empregado nos nichos. De fato, analisando os corpos-de-prova sem adição de fibras, observou-se que aumentando a resistência do concreto moldado no nicho de $50 \mathrm{MPa}$ para $100 \mathrm{MPa}$, a resistência da ligação aumentou, em média, 35\%. Este aumento parece estar relacionado com o aumento da resistência à tração do concreto, que ficou em torno de $40 \%$.

Analisando a tensão de cisalhamento na ligação, observou-se que o seu aumento foi menor que o aumento da resistência à compressão do concreto moldado no nicho (Figura 4.14). Tal comportamento também foi observado em outros trabalhos (WALRAVEN; STROBAND (1994)). Isto acontece por que nos concretos de alta resistência o plano de 
ruptura intercepta os agregados graúdos, enquanto nos concretos convencionais este plano contorna os agregados, o que o torna mais rugoso. Dessa forma, para que os concretos de alta resistência apresentem resistência ao cisalhamento proporcional aos concretos convencionais, é necessário o emprego de agregados mais resistentes.

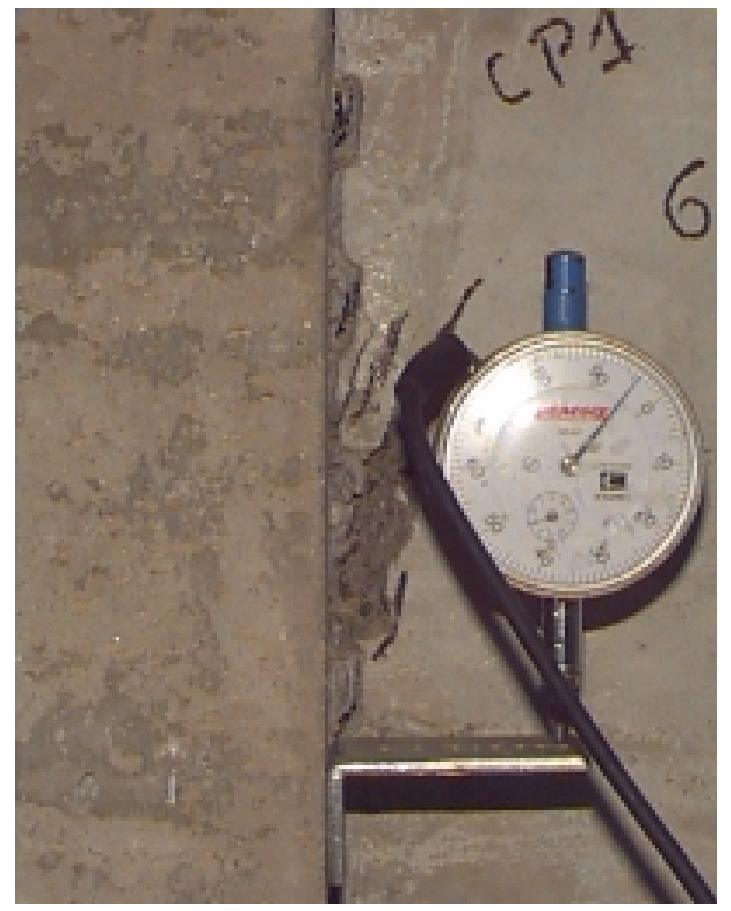

$\mathrm{CP} 1-\mathrm{f}_{\mathrm{cm}}=53,75 \mathrm{MPa}$

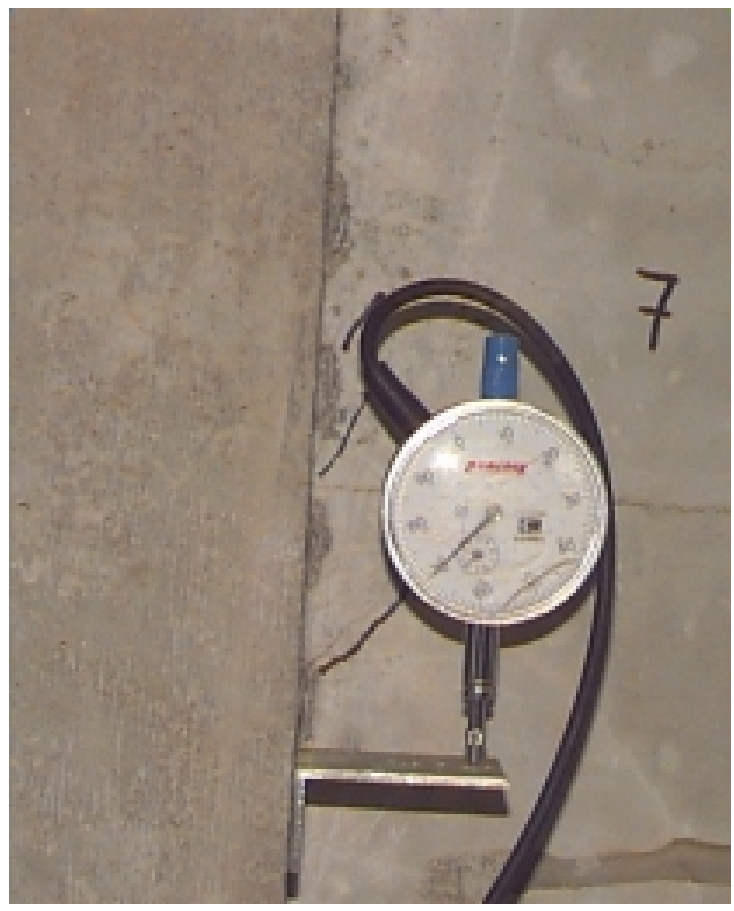

$\mathrm{CP} 3-\mathrm{f}_{\mathrm{cm}}=91,20 \mathrm{MPa}$

Figura 4.13- Influência da resistência do concreto empregado na ligação sobre a forma de ruptura dos corpos-de-prova com superfície rugosa

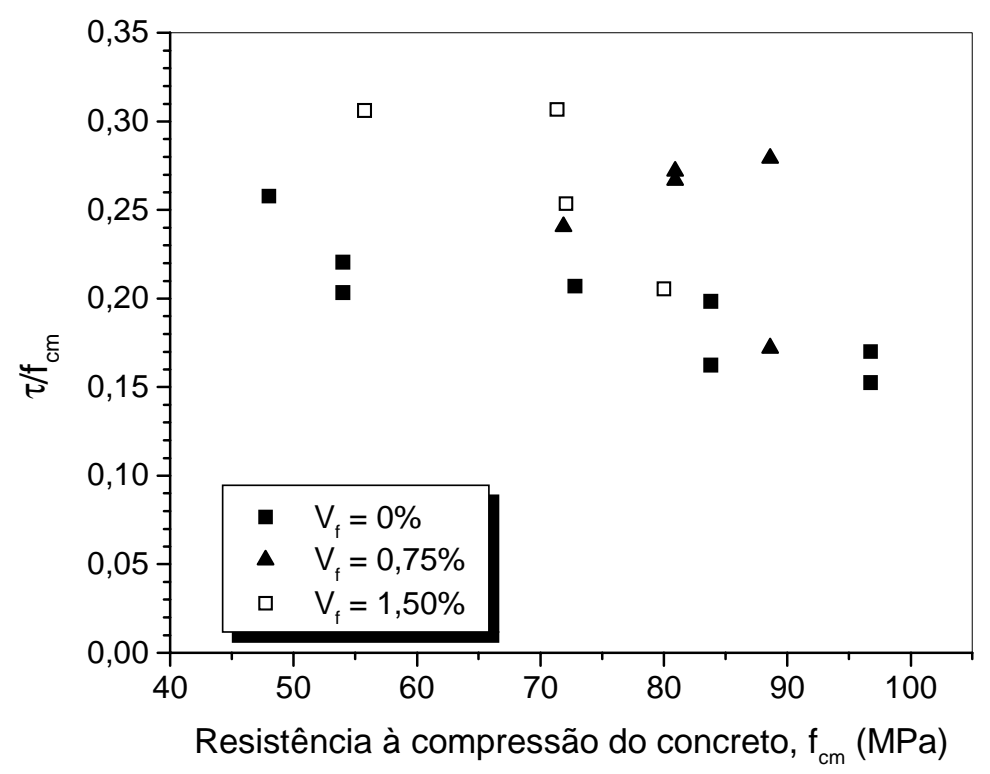

Figura 4.14 - Relação entre a tensão de cisalhamento e a resistência à compressão do concreto da ligação nos corpos-de-prova com chave de cisalhamento 
$\mathrm{Na}$ Figura 4.14 também estão mostrados os resultados dos corpos-de-prova com fibras. Observa-se que mesmo com a adição de fibras, a resistência ao cisalhamento não aumenta na mesma proporção em que a resistência à compressão aumenta.

Com relação à energia absorvida até a ruptura da ligação, o aumento da resistência do concreto implicou em um aumento médio de $85 \%$ no valor dessa energia. Isto está relacionado, principalmente, ao aumento da resistência da ligação.

\subsubsection{Influência do diâmetro do conector na ligação com chave}

O aumento no diâmetro do conector resultou no aumento da resistência da ligação. Esse aumento foi mais significativo nos corpos-de-prova com a ligação efetuada com o traço 3. Neste caso, o aumento foi de $22 \%$, enquanto nos corpos-de-prova com a ligação efetuada com o traço 10 aumento foi de apenas 13\%. A adição de fibras à ligação parece aumentar a influência do conector. No caso dos corpos-de-prova com a ligação efetuada com o traço 2, o aumento no diâmetro do conector de $8 \mathrm{~mm}$ para 12,5 mm proporcionou um aumento de $62 \%$ e $33 \%$ nas ligações com $0,75 \%$ e $1,5 \%$ de fibras, respectivamente. A adição de $1,5 \%$ de fibras proporcionou uma menor contribuição do conector. Isto pode estar relacionado às falhas de concretagem que ocorreram na ligação quando foi empregado o maior volume de fibras. Apesar da mistura apresentar-se com boa trabalhabilidade, percebeu-se uma certa dificuldade em adensar o concreto, com auxílio do vibrador de agulha, durante a concretagem do nicho.

Na Figura 4.15 é mostrada a relação entre a resistência ao cisalhamento da ligação e a tensão normal ao plano de cisalhamento. A tensão normal foi definida como sendo a tensão proporcionada pelo conector no momento da ruptura. Conhecidas a deformação do conector a partir dos extensômetros elétricos e o módulo de elasticidade do aço, a tensão normal foi facilmente obtida. Na Tabela 4.2 estão mostrados os valores de $\sigma_{\mathrm{n}}$ em todos os ensaios realizados. Pela Figura 4.15 é possível confirmar a afirmação anterior de que a resistência da ligação aumentou com o aumento do diâmetro do conector. Também é possível visualizar um aumento mais pronunciado da resistência nos modelos reforçados com fibras.

Existem na literatura diversas expressões empíricas, baseadas na teoria atritocisalhamento, empregadas para avaliar a resistência de interfaces de concreto. Na Figura 4.16 é mostrada a comparação dos resultados experimentais, obtidos dos corpos-de-prova com chave de cisalhamento sem fibra, com algumas expressões empíricas extraídas da 
literatura. Observa-se que essas expressões não avaliam satisfatoriamente os resultados experimentais. Elas atribuem para a parcela resistente proporcionada pela armadura um valor maior que o observado experimentalmente. Analisando a expressão proposta por MATTOCK (1994), nota-se que a tensão de cisalhamento resistente é função apenas da tensão normal à interface, enquanto nas expressões propostas por MATTOCK (1988) e MATTOCK (2001) há uma parcela resistente proporcionada pelo concreto. Esta parcela, contudo, é muito inferior à observada experimentalmente no ensaio do corpo-de-prova CP15. Observando a forma de ruptura dos corpos-de-prova, observou-se um plano de cisalhamento definido na base da chave somente após a ligação atingir sua capacidade resistente máxima. Antes da ruptura da ligação, observou-se a formação de algumas fissuras inclinadas na região da base da chave que definiam uma região fissurada. Dessa forma, modelos baseados na teoria de biela e tirante devem ser mais adequados para representar a ligação com chave de cisalhamento.

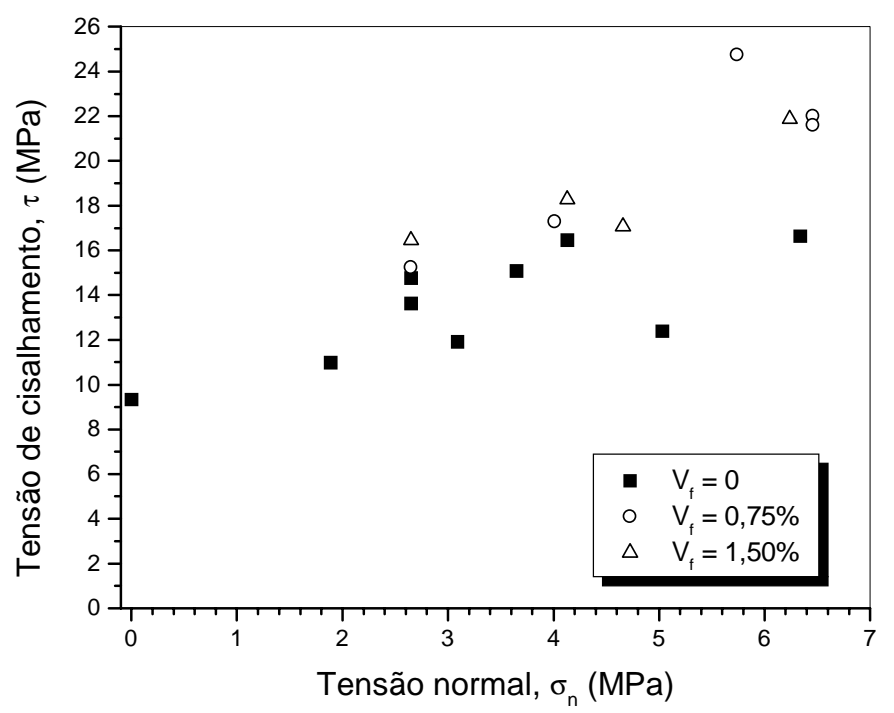

Figura 4.15 - Relação entre a tensão de cisalhamento e a tensão normal ao plano de cisalhamento nos corpos-de-prova com chave de cisalhamento

BAKHOUM (1991) realizou ensaios em chaves de cisalhamento empregadas na ligação de aduelas pré-moldadas. Na Figura 4.17 é mostrada a comparação entre as expressões propostas por este autor e os resultados obtidos neste trabalho. São mostradas duas expressões: uma obtida a partir de ensaios com junta seca e outra a partir de ensaios com epóxi na ligação, semelhante ao realizado no corpo-de-prova CP15. No caso da junta seca, uma das peças pré-moldadas era simplesmente apoiada sobre a outra. Observa-se que as resistências obtidas neste trabalho são superiores às avaliadas pelas expressões de BAKHOUM (1991), sendo que o caso de junta com epóxi é o que mais se aproxima. Essas 
expressões melhor representam os resultados experimentais que a expressão de MATTOCK (1988), principalmente porque elas consideram uma maior contribuição do concreto na resistência. Contudo, parece que elas superestimam a contribuição da tensão normal, o que pode ser justificado pelo fato de que nos ensaios de BAKHOUM (1991) a tensão normal ao plano de cisalhamento foi garantida por tensões externas que simulavam o efeito de uma protensão normal à ligação. Por outro lado, nos ensaios realizados neste trabalho a tensão normal foi garantida apenas pela deformação do conector. No próximo capítulo será apresentada uma metodologia para a determinação da curva forçadeslizamento das ligações com chave de cisalhamento. Nesta ocasião será sugerida uma expressão similar à de BAKHOUM (1991) para avaliação da resistência da ligação.

Com relação à energia absorvida até a ruptura da ligação, o aumento do diâmetro do conector de $8 \mathrm{~mm}$ para $12,5 \mathrm{~mm}$ resultou em um aumento médio de $70 \%$. Isto está relacionado, principalmente, ao aumento da resistência da ligação.
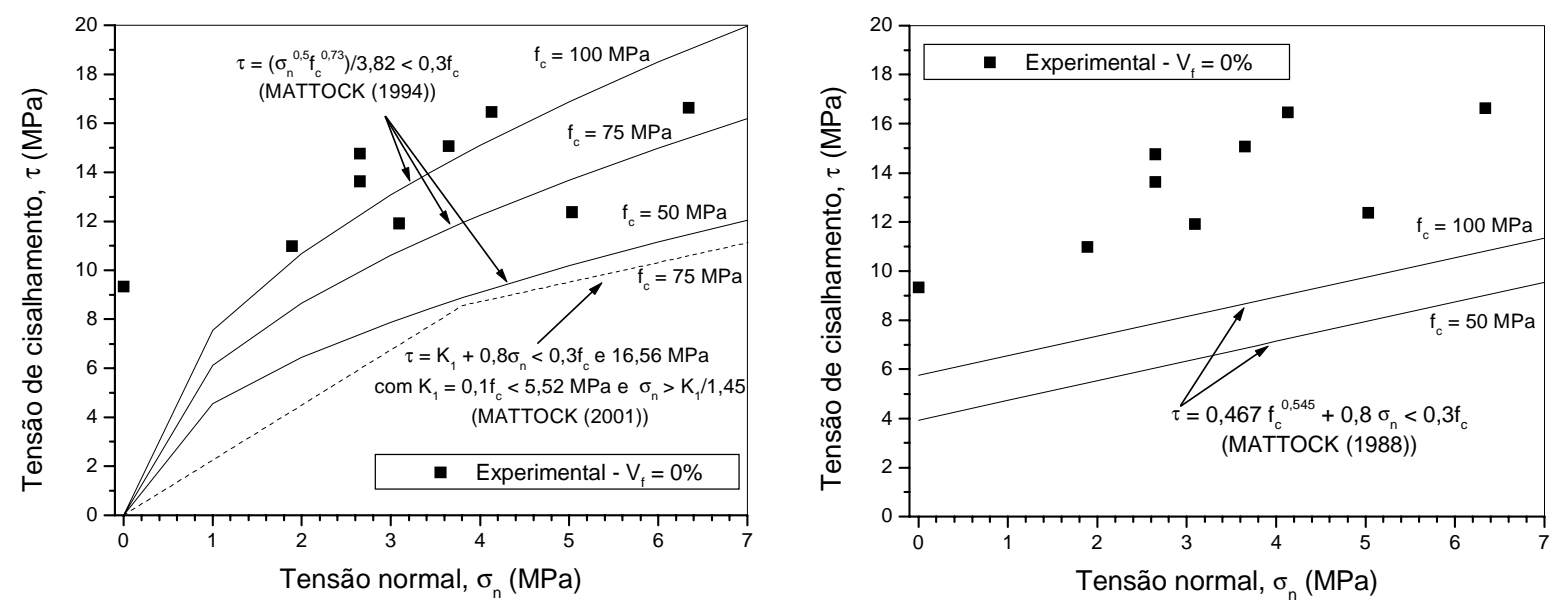

Figura 4.16 - Comparação da resistência dos ensaios de cisalhamento direto com expressões baseadas na teoria atrito-cisalhamento
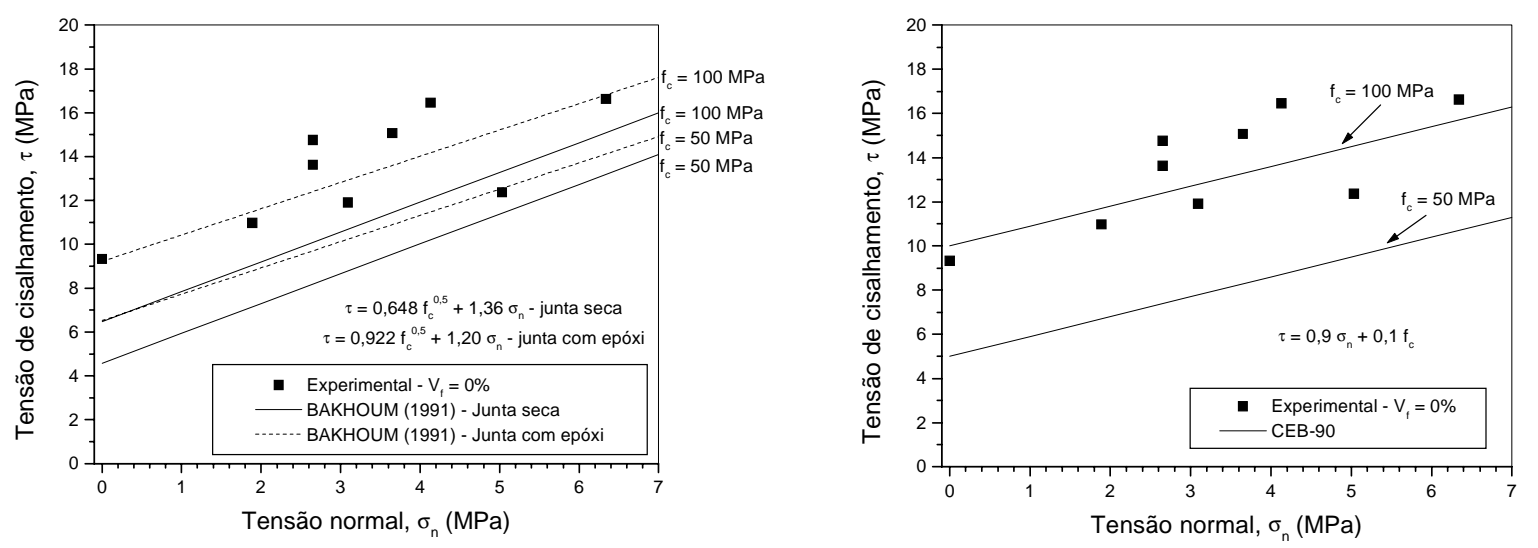

Figura 4.17 - Comparação dos resultados experimentais com as expressões empíricas propostas por BAKHOUM (1991) e pelo CEB-90 


\subsubsection{Influência do volume de fibras na ligação com chave}

A adição de fibras metálicas ao concreto durante o estudo de traço melhorou algumas de suas propriedades, entre elas sua resistência à tração. Sendo assim, era esperado um aumento da resistência da ligação devido à adição das fibras ao concreto moldado no nicho. No caso dos corpos-de-prova com a ligação efetuada com o traço 1 , observou-se que a adição de $1,50 \%$ de fibras aumentou em $38 \%$ a resistência da ligação.

$\mathrm{Na}$ ligação efetuada com o traço 2, a adição de 0,75\% de fibras aumentou a resistência da ligação em, aproximadamente, 13\%, e a adição de 1,50\% de fibras aumentou a resistência da ligação em, aproximadamente, $21 \%$. Esses valores foram observados nos corpos-de-prova com conector de $8 \mathrm{~mm}$ e $10 \mathrm{~mm}$. No caso do conector com diâmetro de $12,5 \mathrm{~mm}$, houve um aumento mais significativo. A adição de $0,75 \%$ de fibras proporcionou um aumento médio de $37 \%$ e a adição de 1,50\% um aumento médio de 32\%. Aparentemente, o maior volume de fibras proporcionou um aumento menor da resistência. Provavelmente contribuiu para isso o fato da resistência à compressão do concreto da ligação, neste corpo-de-prova, ser ligeiramente inferior ao dos outros corpos-de-prova. $O$ aumento mais significativo da resistência no caso do conector de maior diâmetro pode ser justificado se a sua contribuição for considerada pela ação de pino da armadura. Nesse caso, próximo à ruptura, a região de concreto em torno do conector fica submetida a elevadas tensões de compressão e tração. A ruptura da ligação ocorre devido ao esmagamento da região de concreto que serve de suporte ao conector. Esse fenômeno é mais pronunciado para armaduras com diâmetros maiores que $12,5 \mathrm{~mm}$, por exemplo. A adição das fibras melhora o comportamento do concreto submetido a altas solicitações de compressão, o que faz com que a resistência por ação de pino da armadura aumente. Tal comportamento foi observado por outros pesquisadores que perceberam o aumento da resistência de pino da armadura devido à adição de fibras (SOROUSHIAN; MIRZA (1991)).

Comparando os corpos-de-prova CP8 e CP10, é possível verificar a influência do aumento da resistência do concreto moldado no nicho quando o diâmetro e o volume de fibras são tomados com seus valores máximos. Nesse caso, o aumento da resistência da ligação foi inferior ao observado nos ensaios com o traço 2, o que se deve ao fato da ruptura ter ocorrido pelo esmagamento da peça pré-moldada e não mais na chave de cisalhamento (Figura 4.18). Isto mostra que o aumento excessivo da resistência da chave de cisalhamento transfere a ruptura para a peça pré-moldada. Em primeira análise, pode-se admitir que a partir de uma relação entre as resistências à tração indireta do concreto da ligação e do concreto pré-moldado igual a 2,5, a ruptura não ocorre mais na chave de cisalhamento, e sim na viga pré-moldada. 


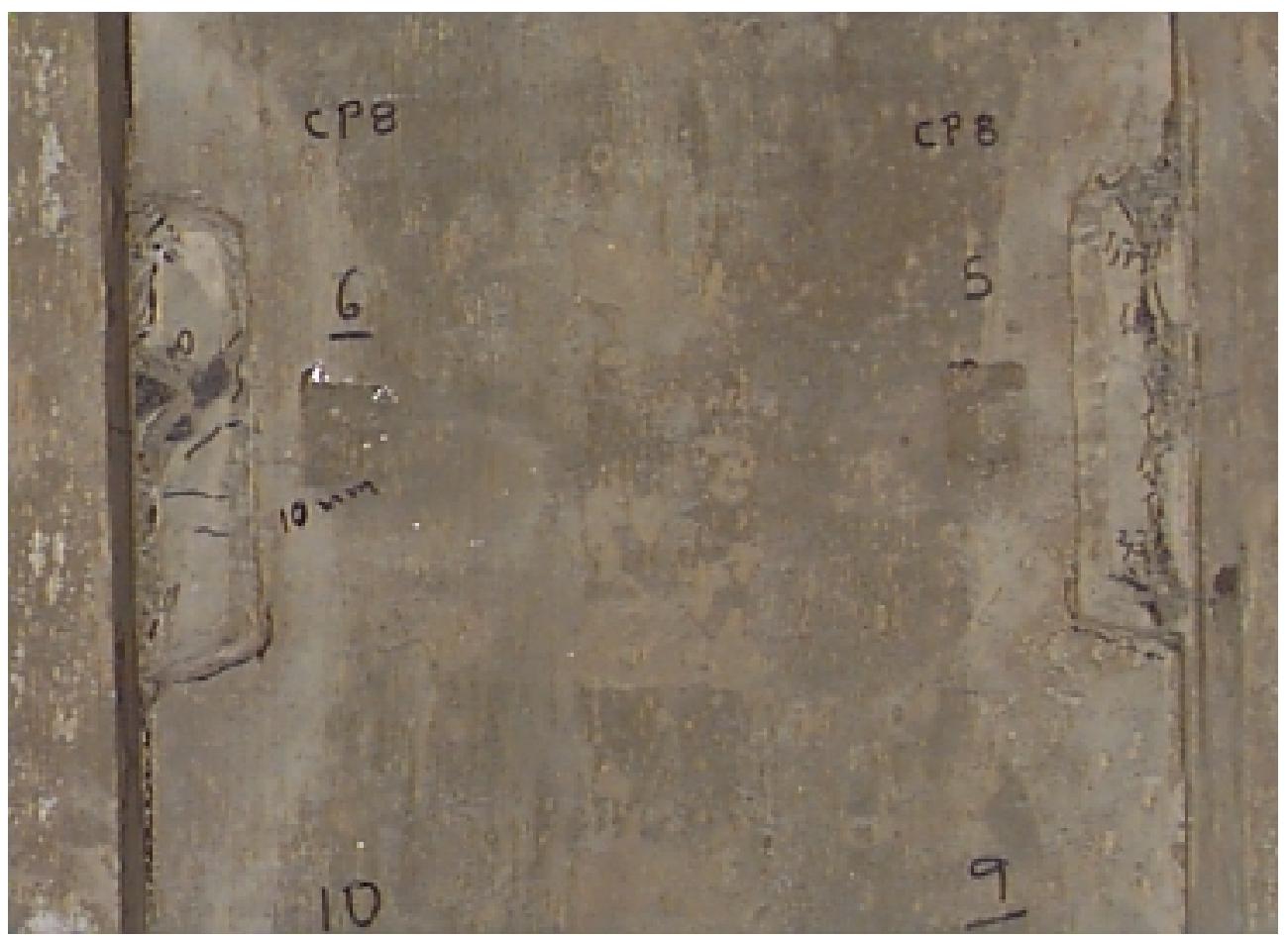

$\mathrm{CP} 8-\mathrm{f}_{\mathrm{cm}}=55,75 \mathrm{MPa}$

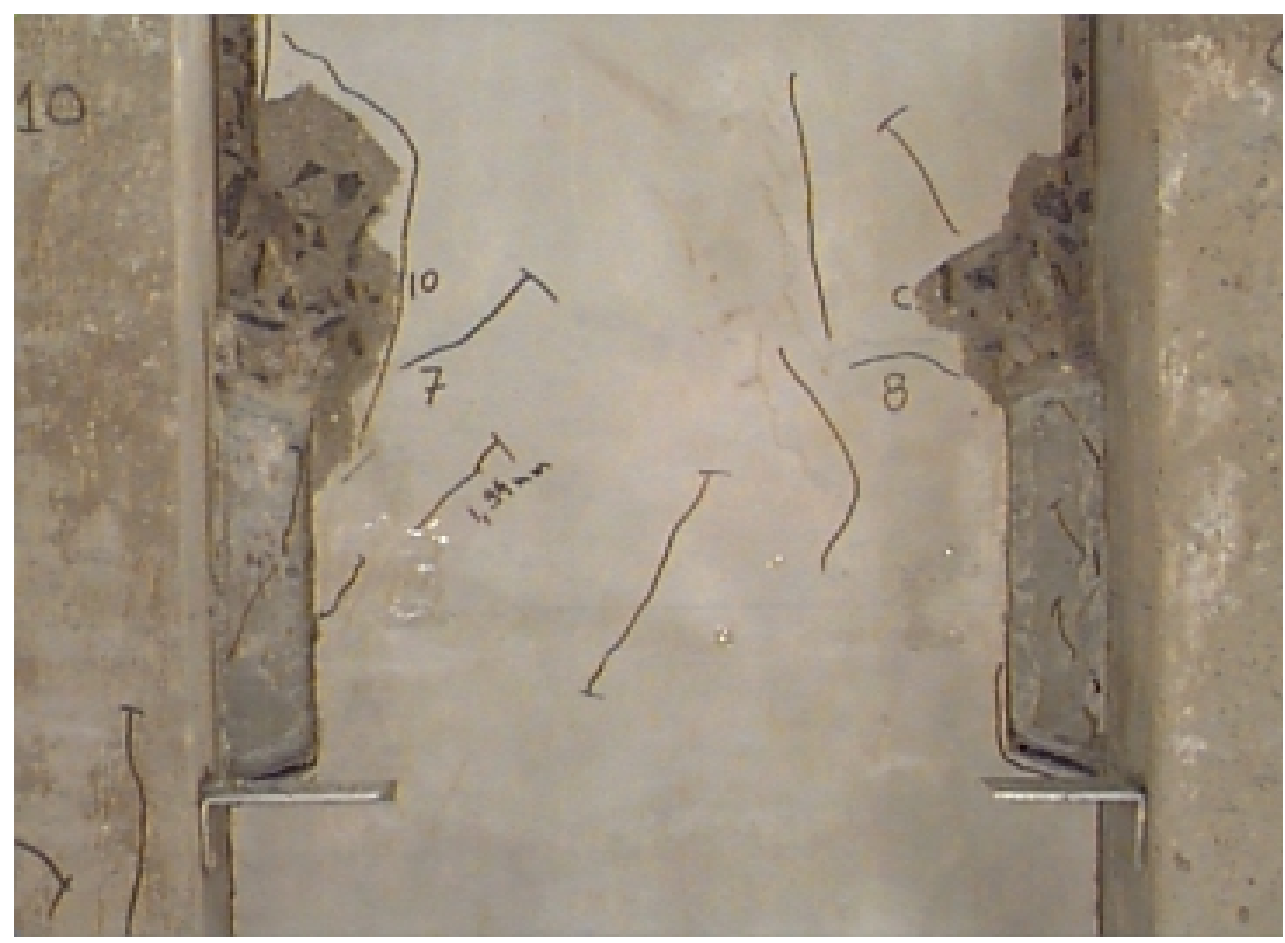

$\mathrm{CP} 10-\mathrm{f}_{\mathrm{cm}}=96,35 \mathrm{MPa}$

Figura 4.18 - Influência da resistência do concreto empregado na ligação sobre a forma de ruptura dos corpos-de-prova com chave de cisalhamento e $1,50 \%$ de fibras 
No capítulo três foi observado que a adição de 1,50\% de fibras aumentou a resistência à tração indireta do concreto em, aproximadamente, $80 \%$, e a resistência à tração na flexão em, aproximadamente, 34\%. Enquanto isso, a resistência da ligação aumentou em no máximo $37 \%$ com a adição de $1,50 \%$ de fibras. Este valor foi obtido do ensaio no qual tanto as peças pré-moldadas quanto a ligação foram confeccionadas com o traço 2. Comparando esses percentuais, nota-se que o aumento da resistência da ligação ficou próximo do aumento da resistência à tração na flexão, contudo foi bem inferior ao aumento da resistência à tração indireta. Apesar de não ser possível estabelecer uma relação direta entre esses percentuais, é possível afirmar que o aumento da resistência à tração do concreto da chave contribuiu para o aumento da resistência da ligação.

Com relação à energia absorvida até a ruptura da ligação, ela geralmente aumentou com o aumento no volume de fibras. No caso da ligação confeccionada com o traço 1 e com o conector de $12,5 \mathrm{~mm}$, esse aumento foi de $200 \%$. Na ligação confeccionada com o traço 2 e conector de $12,5 \mathrm{~mm}$, o aumento da energia absorvida foi de $77 \%$, e na ligação com o mesmo traço, mas com conector de $8 \mathrm{~mm}$, o aumento foi de 106\%. Esses dois últimos resultados foram inferiores ao obtido na ligação com o traço 1 , o que sugere que a capacidade das fibras em aumentar a energia diminui com o aumento da resistência do concreto. Pode-se admitir, portanto, que seria necessário um volume de fibras maior para que a ligação confeccionada com concreto de alta resistência apresentasse comportamento semelhante ao de uma ligação com concreto de resistência mais baixa.

Na Figura 4.19 é mostrada a influência das fibras na energia absorvida pela ligação até a ruptura. Nessa figura, a energia está dividida pela resistência à compressão do concreto e pelo diâmetro do conector para eliminar a influência dessas variáveis. Apesar da dispersão dos resultados, é possível notar claramente o aumento da energia com o aumento do volume de fibras. Esse aumento está relacionado com o aumento da resistência da ligação, mas, principalmente, com o aumento do seu deslizamento no momento da ruptura.

Depois de atingida a resistência da ligação, sua integridade é mantida apenas pelo conector. Desse modo, os ramos descendentes das curvas em todos os modelos apresentaram comportamento semelhante, bem como a energia absorvida. 


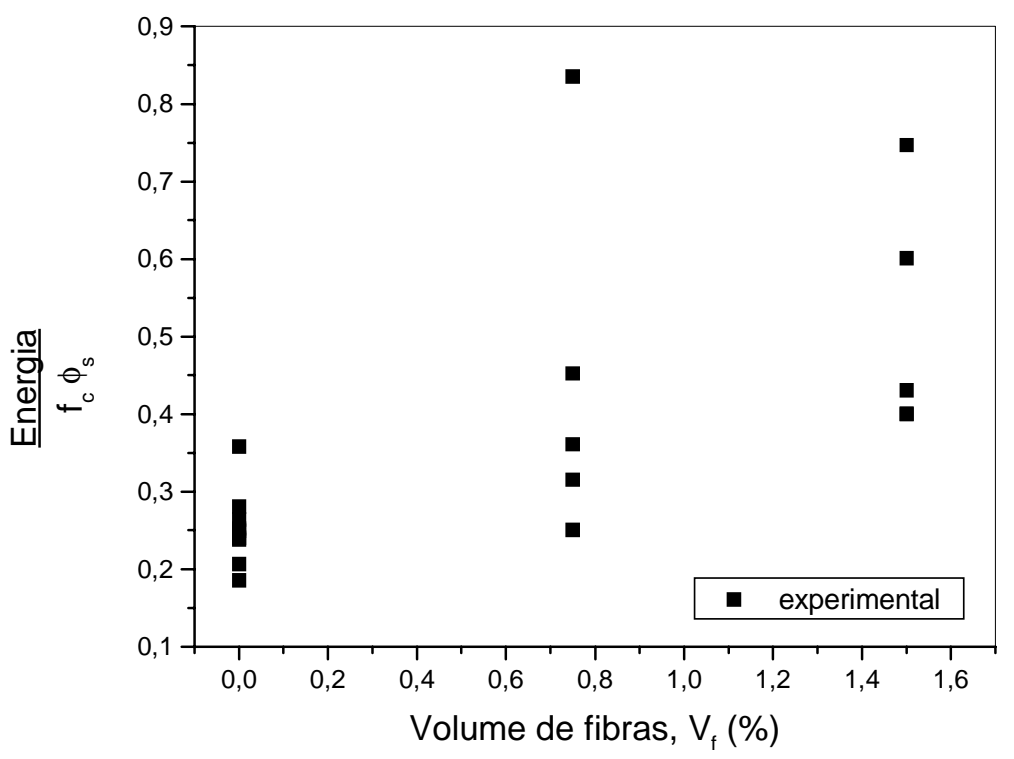

Figura 4.19 - Influência das fibras na energia absorvida pela ligação

\subsubsection{Rigidez da ligação com chave sob carregamento cíclico}

O objetivo dos ensaios sob carregamento cíclico foi avaliar a rigidez da ligação quando submetida a carregamentos sucessivos. As variáveis analisadas foram o volume de fibras adicionadas à ligação e o diâmetro do conector. A resistência do concreto moldado no nicho foi mantida constante, sendo empregado o traço 2. A superfície analisada foi apenas com chave de cisalhamento.

Para efetuar as análises, foi calculada a rigidez secante em cada ciclo de carga, a qual foi definida como sendo a razão da força no final da etapa de carregamento pelo deslizamento médio medido também no final da etapa de carregamento. Na Figura 4.20 são mostradas duas curvas típicas obtidas experimentalmente a partir de corpos-de-prova, com conector de $8 \mathrm{~mm}$, submetidos a carregamento cíclico. A diferença entre elas está no volume de fibras. Observa-se claramente que a adição de $1,50 \%$ de fibras reduziu a perda de rigidez da ligação com a repetição do carregamento.

Na Figura 4.21 é mostrada a variação da rigidez secante relativa em função do número de ciclos de carregamento. A rigidez relativa foi obtida dividindo a rigidez absoluta de cada ciclo de carregamento pela rigidez absoluta do primeiro ciclo. Dessa forma, foi possível comparar os resultados dos ensaios entre si apesar das diferenças na resistência do concreto. Nessa figura é mostrada a influência das fibras no primeiro nível de carregamento, que correspondia, aproximadamente, a $40 \%$ da resistência da ligação. Observa-se que nas ligações com conector de $8 \mathrm{~mm}$ e $10 \mathrm{~mm}$, a adição de fibras reduziu a 
perda de rigidez sob carregamento cíclico. Nas ligações sem fibras houve uma perda média de $25 \%$ na rigidez da ligação após vinte ciclos de carga, enquanto nas ligações com fibras esta perda foi reduzida para 15\%. A rigidez relativa, contudo, não foi influenciada pela quantidade de fibras adicionadas. Isto pode ter acontecido pelo fato da adição de $1,50 \%$ de fibras ter introduzido elevado número de vazios à ligação. De fato, foram observadas pequenas falhas de concretagem na chave de cisalhamento destes corpos-de-prova.

Cabe ressaltar que a intensidade do carregamento nas ligações sem fibras foi inferior à solicitação nas ligações com fibras. Apesar disso, as observações anteriores continuam válidas. Deve-se, apenas, levar em consideração que a perda de rigidez na ligação sem fibras pode ser maior que $25 \%$.
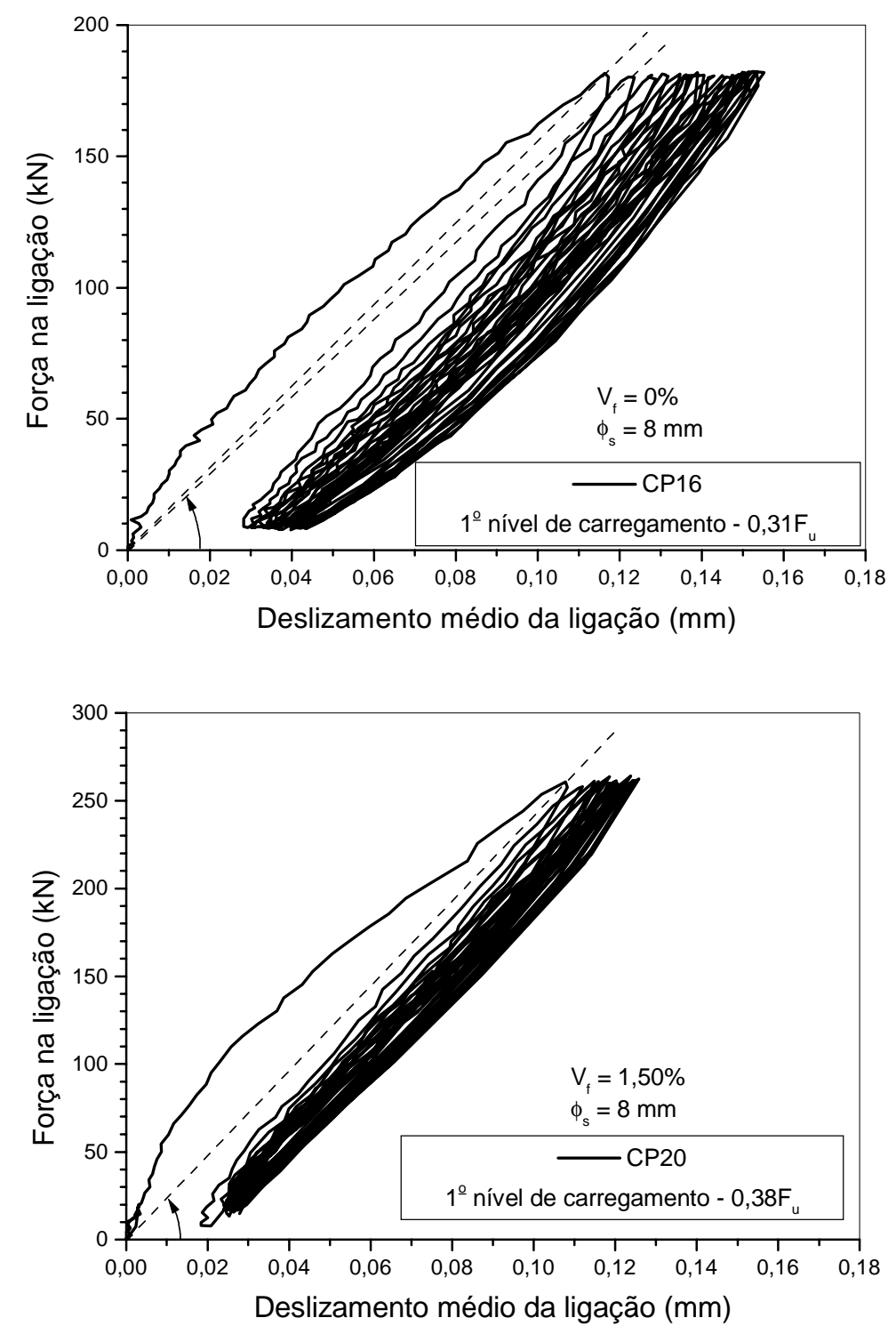

Figura 4.20 - Curvas típicas do ensaio de cisalhamento direto sob carregamento cíclico 

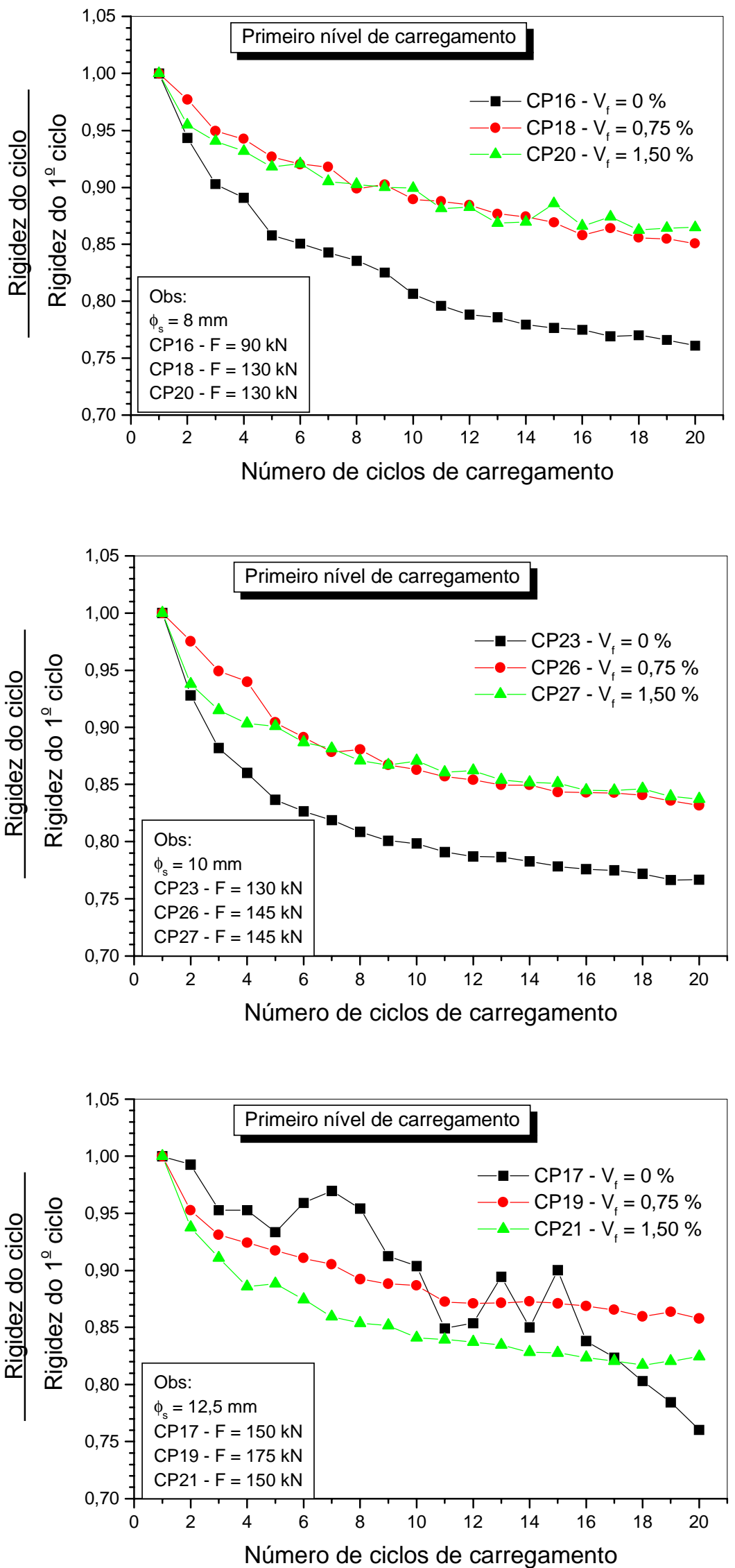

Figura 4.21 - Influência das fibras na perda de rigidez da ligação sob carregamento cíclico primeiro nível de carregamento 
No caso dos corpos-de-prova com conector de $12,5 \mathrm{~mm}$, houve grande perturbação na resposta do ensaio sem fibras, de modo que não é possível afirmar se as fibras alteraram o comportamento da ligação sob carregamento cíclico.

A influência do diâmetro do conector na perda de rigidez secante da ligação é mostrada na Figura 4.22. A primeira vista, observa-se dessa figura que o diâmetro do conector têm pouca influência sobre a perda de rigidez da ligação, independente da existência ou não de fibras. Comportamento semelhante foi observado por VINTZELEOU; TASSIOS (1987). Nesse trabalho, os autores mostraram que a diminuição da resistência por ação de pino da armadura devido ao carregamento cíclico era independente do recobrimento de concreto, da resistência do concreto e do diâmetro da barra. Deve-se levar em consideração, entretanto, que as intensidades do carregamento em cada diâmetro eram diferentes, sendo maiores para os maiores diâmetros. Dessa forma, sob mesma intensidade de carregamento, não é possível concluir sobre a influência do diâmetro do conector sobre a perda de rigidez da ligação.

Partindo do princípio de que a perda de rigidez da armadura, quando submetida a carregamento cíclico, seja desprezível (SOROUSHIAN et al. (1988)), a perda de rigidez da ligação é devida apenas ao concreto. Dessa forma, as fibras contribuem de modo significativo na preservação da integridade da ligação, uma vez que elas "costuram" as fissuras que surgem no concreto e impedem a sua propagação com a repetição do carregamento. Em primeira aproximação, pode-se admitir que após vinte ciclos de carga, a ligação com fibras mantém $85 \%$ de sua rigidez secante inicial, enquanto a ligação sem fibras apresenta $75 \%$ de sua rigidez secante inicial. Estes valores foram para uma solicitação na ligação igual a, aproximadamente, $40 \%$ de sua resistência.

Na Figura 4.23 e na Figura 4.24 é mostrada a influência das fibras na perda da rigidez secante quando a ligação foi submetida ao segundo e ao terceiro nível de carregamento, respectivamente. A primeira vista, percebe-se que a adição de fibras pouco influenciou a perda de rigidez da ligação. Aparentemente, houve até uma maior perda com a adição de fibras. Contudo, o valor absoluto da força aplicada nos corpos-de-prova sem fibra era menor, o que justifica a menor perda de rigidez neste caso. Observando os corposde-prova com conector de 12,5 mm submetidos ao segundo nível de carregamento, onde as ligações com fibra e sem fibra foram submetidas à solicitações de mesma intensidade, verifica-se que as fibras efetivamente contribuíram para diminuir a perda de rigidez da ligação. 

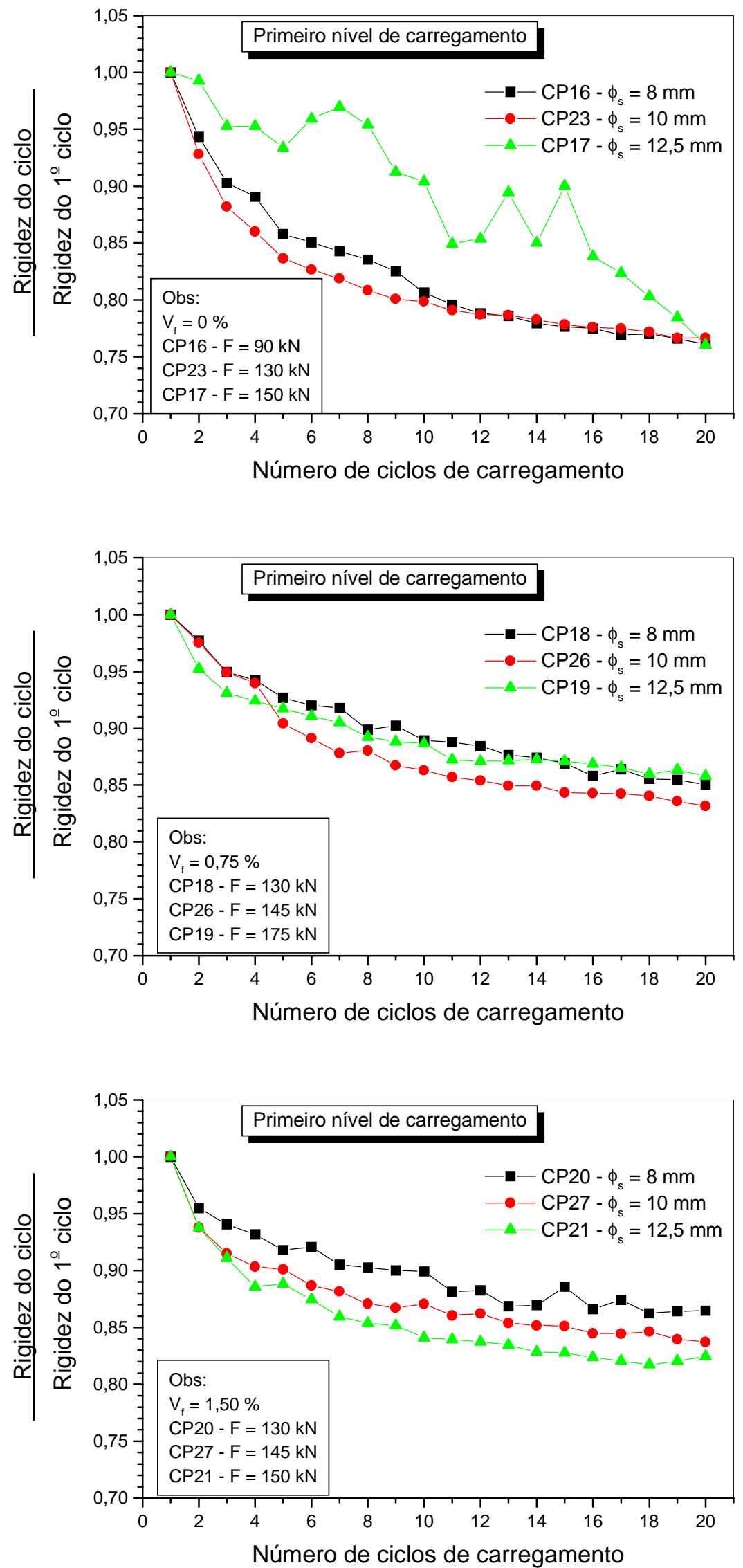

Figura 4.22 - Influência do conector na perda de rigidez da ligação sob carregamento cíclico - primeiro nível de carregamento 

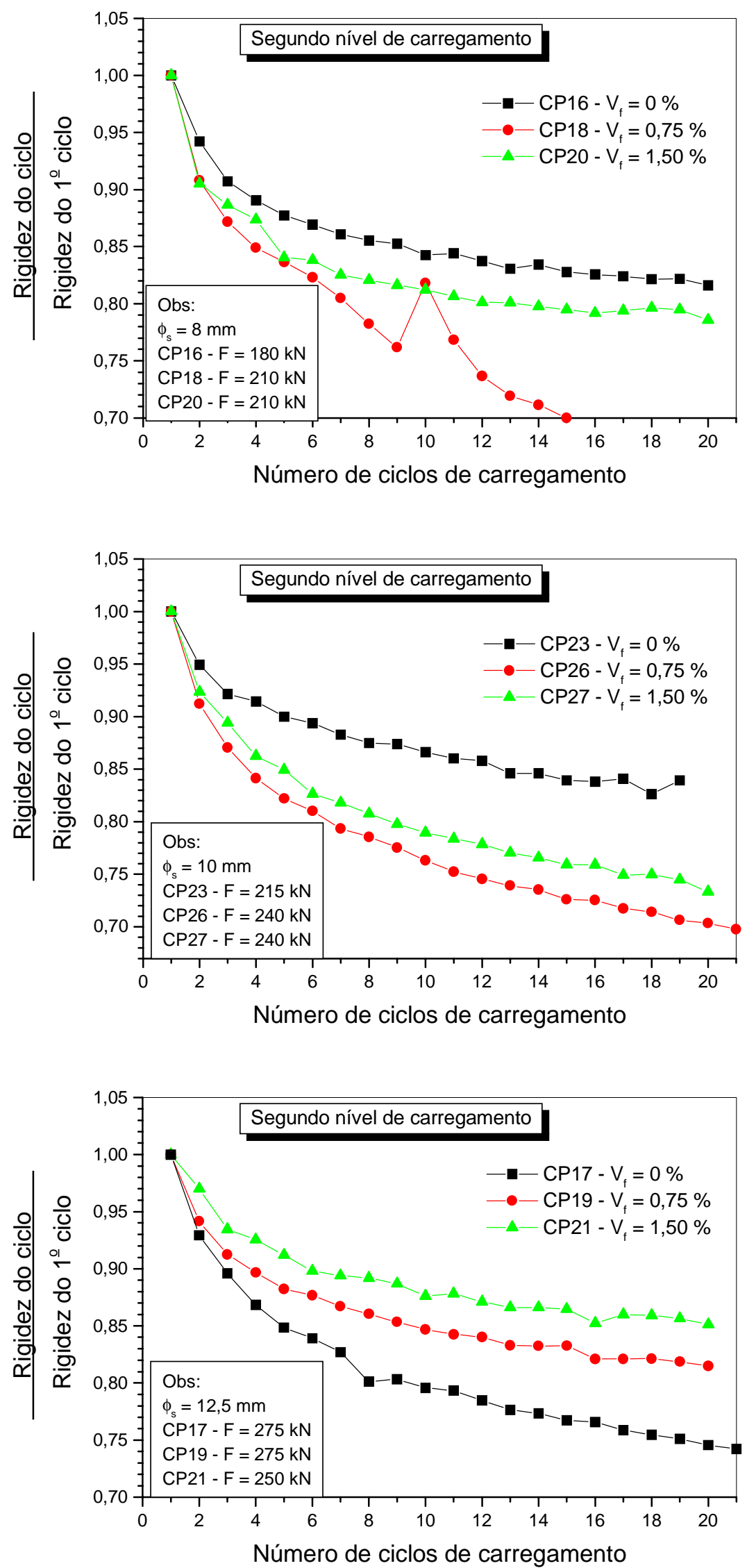

Figura 4.23 - Influência das fibras na perda de rigidez da ligação sob carregamento cíclico segundo nível de carregamento 

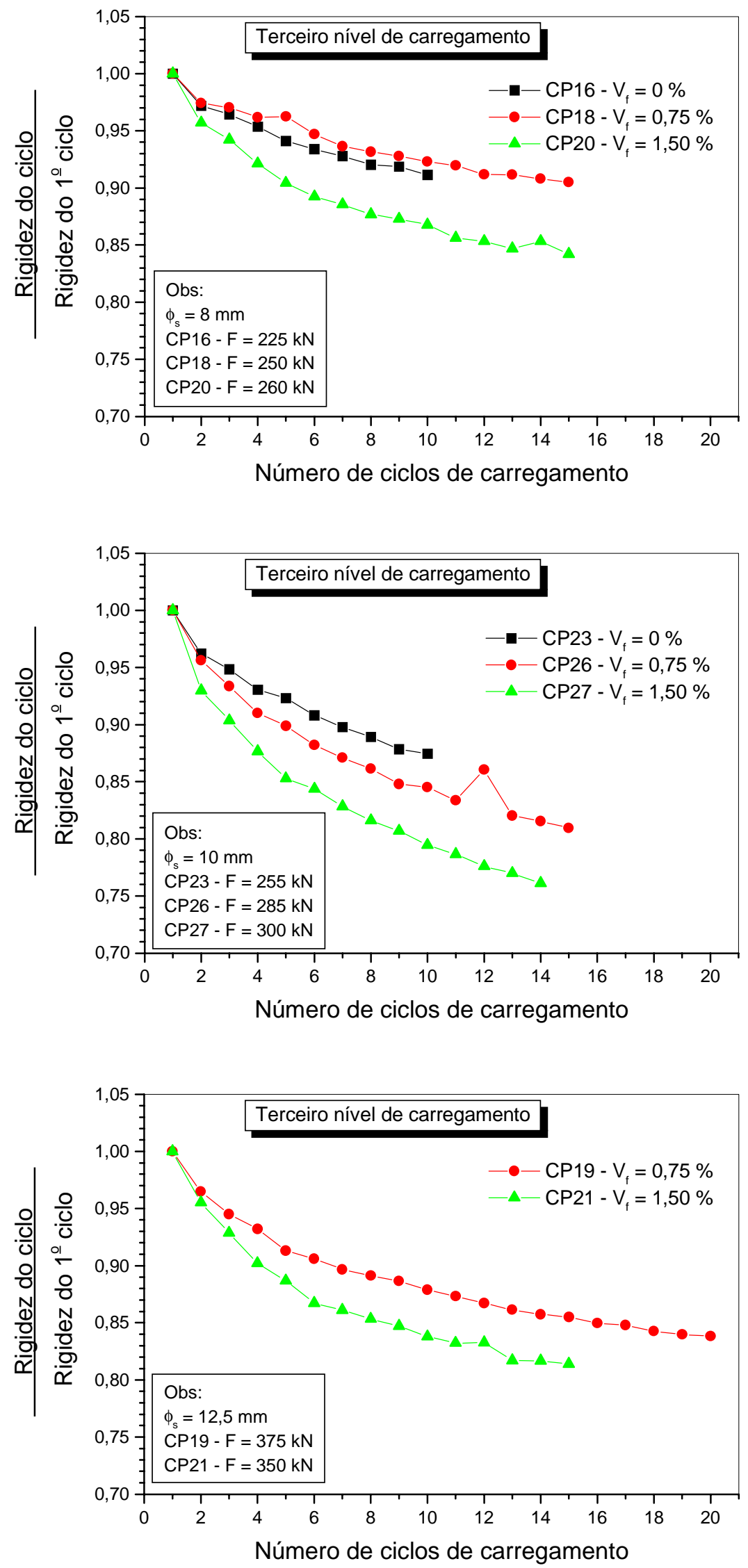

Figura 4.24 - Influência das fibras na perda de rigidez da ligação sob carregamento cíclico terceiro nível de carregamento 
Em termos quantitativos, após vinte ciclos de carregamento com uma solicitação máxima em torno de $65 \%$ da resistência da ligação, esta ainda mantinha, em média, 70\% de sua rigidez secante inicial. No caso da ligação com conector de $12,5 \mathrm{~mm}$ e 1,50\% de fibras, a rigidez secante após vinte ciclos ainda representava $85 \%$ da rigidez inicial.

Quando da definição do número de ciclos de carregamento a serem aplicados no ensaio cíclico, escolheu-se 20 ciclos. Era esperado que após essa quantidade de ciclos a perda de rigidez da ligação estivesse estabilizada. Dos resultados obtidos, entretanto, notase que nem sempre houve uma tendência de estabilização da rigidez da ligação. Dessa forma, as perdas de rigidez aqui registradas podem ser maiores se uma quantidade maior de ciclos for aplicada à ligação.

Existem na literatura diversos modelos mecânicos desenvolvidos para avaliar o comportamento do concreto quando submetido a solicitações cíclicas de cisalhamento. Citam-se, por exemplo, os trabalhos de MARTíN-PÉREZ; PANTAZOPOULOU (2001) e MARTÍN-PÉREZ (1995) que desenvolveram um modelo mecânico para o caso de carregamento cíclico reversível explicitando as contribuições do engrenamento dos agregados e da ação de pino da armadura. Poucos modelos, contudo, existem para o caso de carregamento cíclico não reversível. Além disso, eles somente são aplicáveis através de programas computacionais baseados no método dos elementos finitos, por exemplo. Como esse tipo de análise foge ao escopo deste trabalho, fica a sugestão para trabalhos futuros.

\subsection{Avaliação da ligação com superfície plana e rugosa por modelos analíticos}

Os resultados dos ensaios de cisalhamento direto, com a superfície da ligação plana e rugosa, foram comparados com o modelo analítico de TASSIOS; VINTZELEOU (1990). Procurou-se, assim, uma forma de avaliar o comportamento da ligação sem a necessidade de ensaios experimentais. Evidentemente, não é possível tirar conclusões de um número tão pequeno de ensaios, porém pode-se estimar se esse modelo analítico é capaz ou não de representar o comportamento experimental da ligação.

Na Figura 4.25 são comparados os resultados experimentais com os resultados da aplicação do modelo analítico de TASSIOS; VINTZELEOU (1990) aos corpos-de-prova CP1, CP3 e CP5. Para a obtenção desses resultados, foi feita uma pequena modificação nas equações do modelo apresentadas no capítulo 2. No modelo original, é sugerido o valor de $2 \mathrm{~mm}$ para o deslizamento no qual a resistência por atrito atinge seu valor máximo (eq.(2.22)). Observando os resultados dos ensaios, entretanto, verificou-se que a ligação atingia a resistência muito antes desse valor. Dessa forma, foi adotado o valor de $0,5 \mathrm{~mm}$ 
para o deslizamento máximo $\mathrm{s}_{\mathrm{u}}$. Com essa modificação, a curva prevista pelo modelo de TASSIOS; VINTZELEOU (1990) apresentou boa concordância com a curva experimental. Com relação à resistência da ligação, também houve boa concordância entre os resultados previstos pelo modelo e os experimentais. Na ligação com o traço 1 e conector de $8 \mathrm{~mm}$ (CP1), o resultado previsto pelo modelo praticamente coincidiu com o valor experimental. $\mathrm{Na}$ ligação com o traço 3 e conector de $8 \mathrm{~mm}$ (CP3), o valor previsto pelo modelo foi $10 \%$ inferior ao experimental ao se empregar na avaliação o concreto de menor resistência. Quando foi empregado o concreto de maior resistência, o valor previsto pelo modelo foi $24 \%$ superior ao experimental. Neste caso, a curva prevista pelo modelo ficou mais rígida que a experimental, confirmando que o comportamento da ligação foi definido pelo concreto de menor resistência. Na ligação com o traço 1 e conector de 10 mm (CP5), a resistência prevista pelo modelo foi $17 \%$ superior ao experimental. Isto sugere que neste ensaio o conector contribui menos na resistência final se comparado com o ensaio da ligação com conector de $8 \mathrm{~mm}$, o que já havia sido observado quando da análise da deformação do conector. Fica a dúvida se foi um resultado isolado ou se neste tipo de ligação as deformações da armadura transversal à interface diminuem com o aumento do diâmetro do conector.

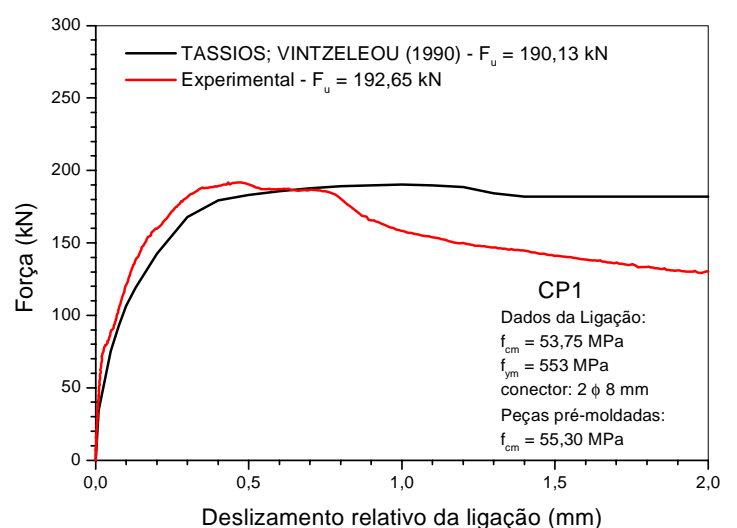

(a) CP1

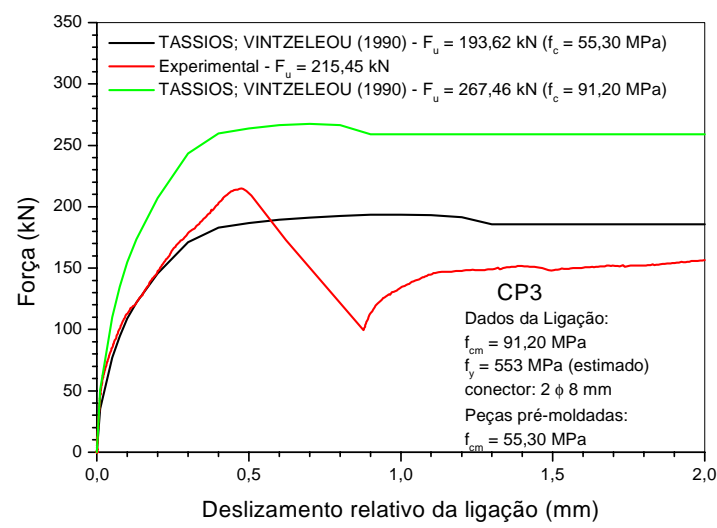

(b) CP3

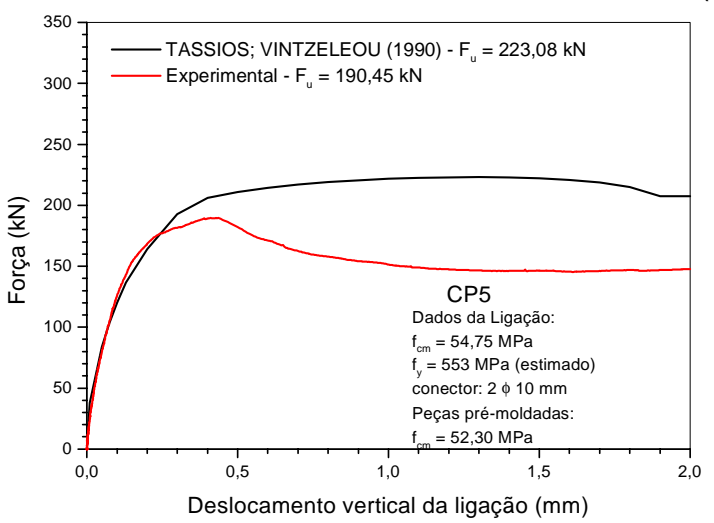

(c) CP5

Figura 4.25 - Aplicação do modelo de TASSIOS; VINTZELEOU (1990) aos corpos-de-prova com superfície plana e rugosa 
Desses resultados, é possível concluir que o modelo analítico de TASSIOS; VINTZELEOU (1990), apesar de obtido de ensaios em ligações de pilares pré-moldados, pode ser capaz de avaliar o comportamento das ligações de cisalhamento com superfície plana e rugosa. Novos ensaios, contudo, necessitam serem realizados para confirmar essa afirmação.

\subsection{Avaliação numérica dos ensaios de cisalhamento direto}

Os ensaios de cisalhamento direto foram simulados através do programa comercial ANSYS, baseado no método dos elementos finitos. O objetivo dessas simulações foi verificar se uma modelagem numérica seria capaz de representar com fidelidade os resultados obtidos experimentalmente. Não foi possível simular no ANSYS o comportamento da ligação quando submetida a carregamento cíclico. Isto se deve ao fato desse programa não possuir um modelo constitutivo adequado para representar o comportamento do concreto nessa condição. O efeito da adição de fibras ao concreto moldado no nicho foi considerado de modo indireto na modelagem, isto é, as propriedades das fibras não foram empregadas de modo explícito. Procedeu-se dessa forma pelo fato de não existir um modelo constitutivo específico para concreto com fibras no ANSYS. Sendo assim, a influência das fibras foi considerada apenas pelo aumento da resistência à tração indireta do concreto.

A simulação foi realizada empregando um modelo tridimensional, uma vez que o modelo disponível no ANSYS para a representação do concreto não podia ser aplicado em elementos planos. Devido à simetria, foi analisado apenas um quarto do corpo-de-prova.

Inicialmente foi modelado o corpo-de-prova CP4 que possuía ligação com superfície plana e lisa. Para modelar a transferência de esforços pela interface entre o concreto moldado no nicho e o concreto da peça central, foram empregados os elementos CONBIN39 e CONBIN40 disponíveis na biblioteca de elementos do ANSYS. O elemento COMBIN40 foi utilizado para simular a transferência por aderência. Esse elemento é formado por uma mola linear que, após atingida um certa força, permite o deslocamento entre dois nós sob força constante (Figura 4.26). Essa força foi obtida a partir das recomendações de MATTOCK (1988). Segundo esse autor, a resistência por aderência entre duas superfícies de concreto submetidas a cisalhamento direto pode ser estimada pela primeira parcela da seguinte expressão:

$$
\tau_{u}=0,467 f_{c}^{0,545}+0,8 \cdot\left(\rho \cdot f_{y}+\sigma_{n}\right) \leq 0,3 \cdot f_{c} \quad(M P a)
$$




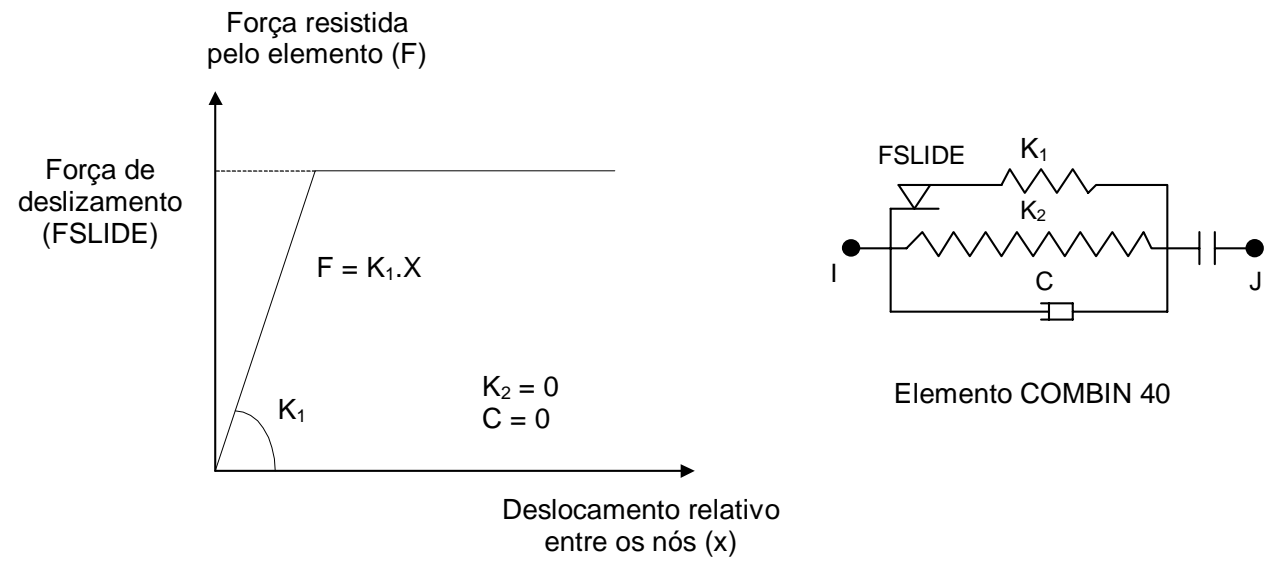

Figura 4.26 - Relação entre força e deslocamento no elemento COMBIN40 do ANSYS

A tensão de aderência, calculada para o concreto de maior resistência (no caso, o concreto do nicho), foi admitida constante em toda a interface e a força resultante foi dividida pelo número de elementos da interface.

O elemento COMBIN39 foi utilizado para simular a resistência por atrito da interface. Esse elemento é formado por uma mola com comportamento não-linear, que foi calibrada de acordo com o modelo de TASSIOS; VINTZELEOU (1990). Na Figura 4.27 é mostrada a curva obtida pela aplicação desse modelo à interface do corpo-de-prova.

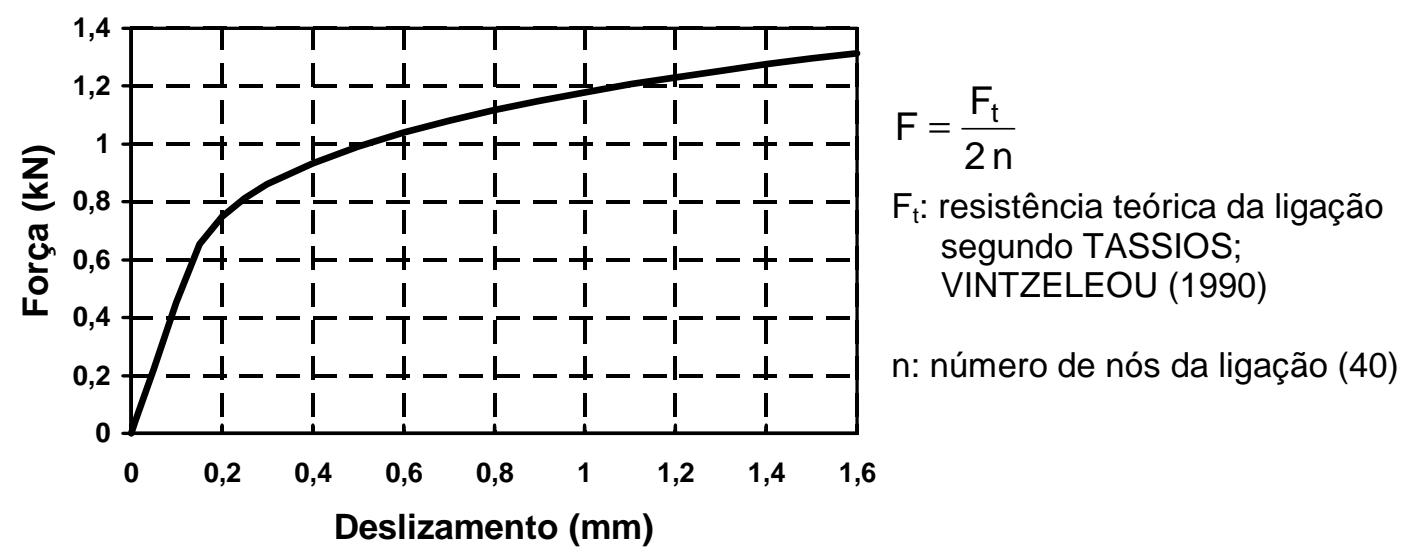

Figura 4.27 - Curva de resistência versus deslizamento da interface para o elemento COMBIN39 do ANSYS. 
O conector foi modelado com um elemento de viga de seção circular maciça (elemento BEAM23), e o concreto foi modelado com o auxílio de um elemento sólido com três graus de liberdade por nó (SOLID65).

Para o aço foi admitido um comportamento elastoplástico perfeito, e para o concreto foi adotado o modelo CONCRETE disponível no ANSYS. Este modelo emprega conceitos da mecânica da fratura com fissuração distribuída, cujo princípio reside na substituição da fissura discreta por um meio contínuo com propriedades físicas alteradas. Na Figura 4.28 é mostrada uma ilustração desse conceito. Nessa figura, a largura da região fissurada $h$ deve ser maior que a maior partícula constituinte do material que, no caso do concreto, é representado pelo agregado graúdo. Alguns autores sugerem adotar para $h$ um valor aproximadamente igual a três vezes o diâmetro máximo do agregado (KARIHALOO (1995)). As propriedades médias do material na região fissurada são modificadas considerando um material ortótropo definido em função da orientação das fissuras. Algumas das razões para a implementação de um modelo de fissuração distribuída em detrimento da consideração de uma fissura discreta são: não há a necessidade de refazer a malha em função do crescimento da fissura; em estruturas de concreto tem sido observada a existência de fissuras distribuídas; as fissuras reais normalmente não são retilíneas, sendo mais fácil representar essa tortuosidade por uma série de pequenas fissuras distribuídas. A principal desvantagem, contudo, é a influência que a dimensão da malha tem sobre o resultado final, o que provoca a falta de objetividade da solução. Uma das formas de evitar esse problema é a consideração da energia de fratura como sendo uma propriedade do material. A transferência de esforços de cisalhamento pela fissura, devido ao engrenamento dos agregados, também pode ser considerada na fissuração distribuída através de um coeficiente $\beta(0<\beta<1)$ que altera as propriedades elásticas do material relacionadas com a tensão de cisalhamento. Quando $\beta$ é igual a 1, há transferência integral de tensões de cisalhamento pela fissura e o material se comporta como íntegro, e quando $\beta$ é igual a 0 nenhuma tensão de cisalhamento é transferida pela fissura. Maiores detalhes sobre a mecânica da fratura podem ser encontrados em KARIHALLOO (1995) e SHAH et al. (1995), entre outros. 


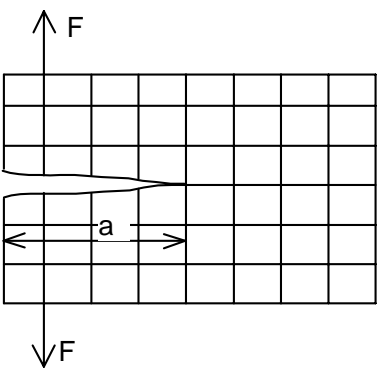

Fissura discreta

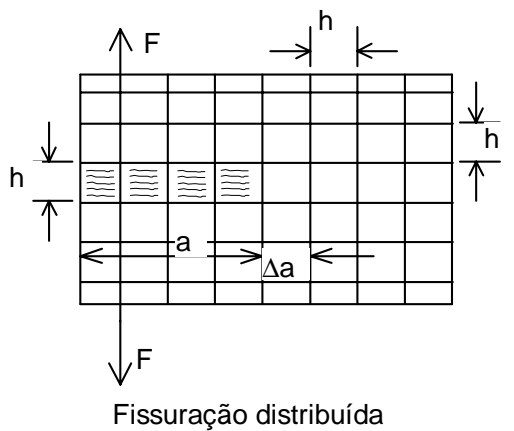

Fissuração distribuída

Figura 4.28 - Substituição de uma fissura discreta por fissuras distribuídas em uma região de largura $h$.

No modelo CONCRETE do ANSYS, é usada como superfície de ruptura a superfície definida por WILLAN; WARNKE (1975) ${ }^{1}$.O critério de ruptura no estado multiaxial de tensão é escrito como:

$$
\frac{F}{f_{c}}-S \geq 0
$$

onde $F$ é uma função das tensões principais, $S$ é a superfície de falha definida por cinco parâmetros, função das propriedades do material, e $\mathrm{f}_{\mathrm{c}}$ é a resistência à compressão uniaxial do material. Se a eq.(4.2) não for satisfeita, não há ruptura do material nem por compressão e nem por tração. Por outro lado, se ela for atendida e qualquer uma das tensões principais for de tração, haverá a formação de uma fissura na direção normal à tensão principal de tração. Entretanto, se todas as tensões principais forem de compressão, haverá o esmagamento do material. Neste caso, o programa torna desprezível a contribuição do elemento rompido na matriz de rigidez da estrutura.

O elemento SOLID65 é o único elemento do ANSYS que aceita a aplicação do modelo CONCRETE. Esse elemento é composto por oito nós com três graus de liberdade em cada nó. Durante o processamento, o programa verifica se as tensões principais violam o critério de falha do material. Caso ele seja violado, em qualquer nó, por uma tensão de tração, é definida uma fissura no ponto de integração do respectivo elemento. A fissura é modelada modificando as propriedades do material na matriz de rigidez referente àquele ponto de integração. Na direção normal ao plano da fissura não são mais transmitidas tensões de tração, enquanto no plano da fissura podem ser transmitidas tensões de cisalhamento dependendo do valor de $\beta$ adotado. Em cada ponto de integração podem 
surgir até três planos de fissuração ortogonais. É importante salientar que o programa ANSYS não admite nenhuma transferência de tensões de tração normal ao plano de fissuração. Isto significa dizer que ele não incorpora o conceito de amolecimento do material em tração ("tension softening"). Dessa forma, não é possível definir a energia de fratura como uma característica do material. A principal conseqüência dessa limitação é que o resultado da simulação numérica fica dependente da malha adotada. Todos os resultados aqui apresentados foram obtidos a partir de uma mesma malha, que foi escolhida de modo a melhor representar os resultados experimentais. Na Figura 4.29 é mostrada a malha empregada na simulação dos corpos-de-prova com superfície plana e lisa.

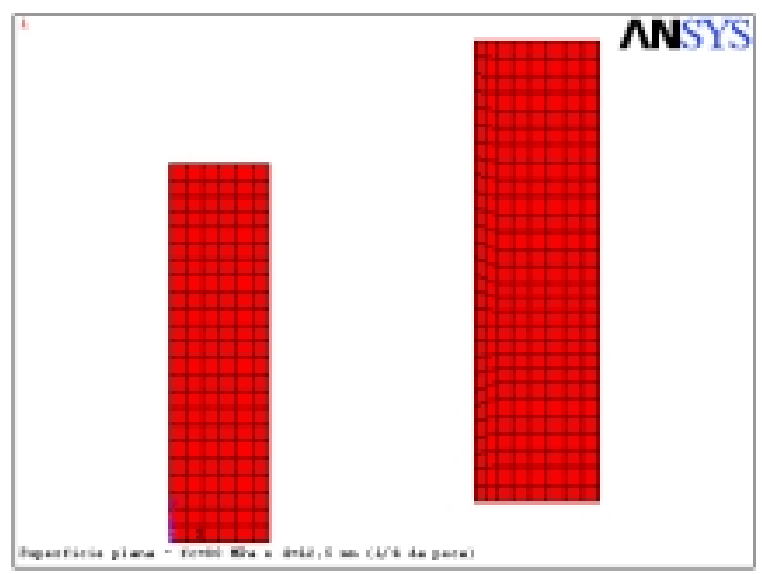

(a) Vista frontal das peças pré-moldadas

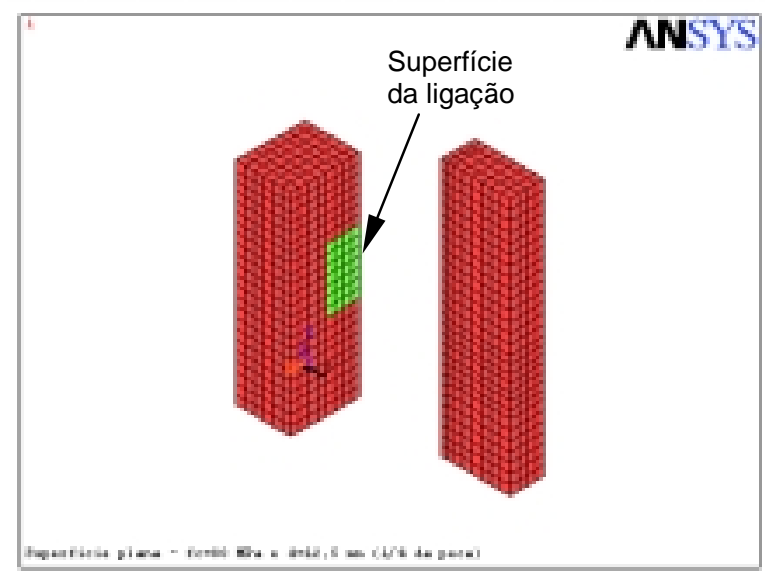

(b) Perspectiva das peças pré-moldadas com nicho

Figura 4.29 - Discretização dos corpos-de-prova de cisalhamento direto com superfície plana e lisa

Na Figura 4.30 é mostrado o deslizamento na ligação do corpo-de-prova CP4 obtido do ensaio e da simulação numérica. Observa-se que a resistência da ligação obtida da simulação numérica, aqui definida como a máxima força para a qual houve convergência do processo numérico, foi apenas $4 \%$ superior à resistência experimental. Pode-se, portanto, admitir que a modelagem empregada foi adequada para representar a ligação com superfície plana e lisa. Modelagem semelhante foi realizada por ARAUJO; EL DEBS (2000) para representar a transferência de esforços pela interface entre o concreto pré-moldado e o concreto moldado no local em vigas compostas. Nesse trabalho, os autores também observaram boa concordância entre os resultados da simulação numérica e os resultados experimentais.

\footnotetext{
${ }^{1}$ WILLAN, K.J. ; WARNEK, E.D. (1975). Constitutive model for the triaxial behavior of concrete. Proceedings, International Association for Bridge and Structural Engineering. V.19, ISMES, Bergamo, Italy, p.174 apud ANSYS RELEASE 5.5.1 (1998). Basic Analysis Procedures Guide. $3^{\text {rd }}$ Edition. SAS IP, Inc.
} 


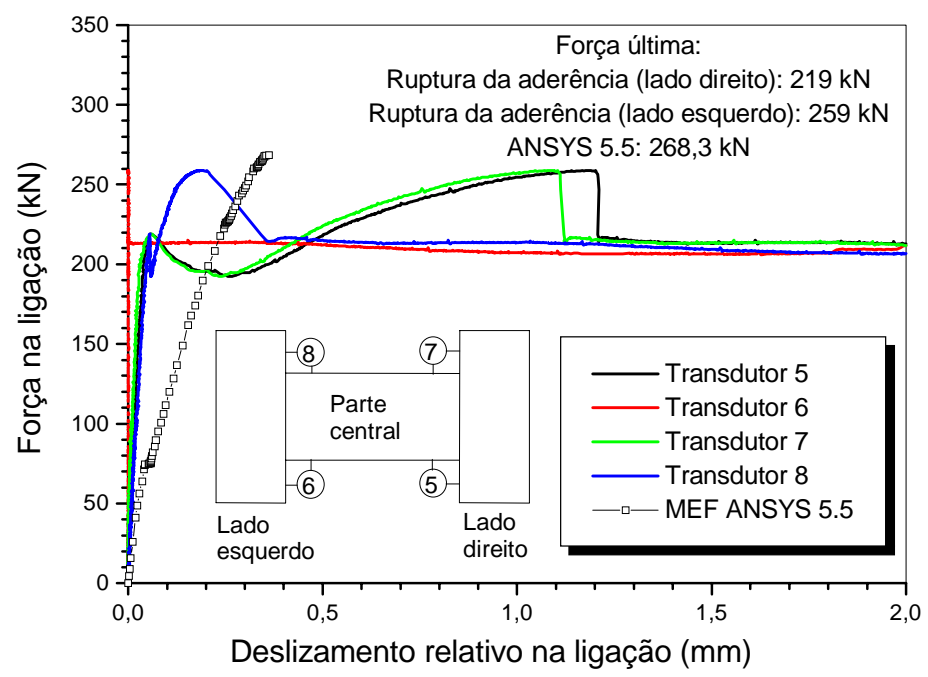

Figura 4.30 - Resultado da simulação do corpo-de-prova com superfície plana e lisa

Os corpos-de-prova com superfície plana e rugosa foram modelados de forma semelhante. A diferença era apenas na modelagem da ligação. Neste caso, não foram usados os elementos CONBIN39 e CONBIN40 para garantir a transferência de esforços pela ligação, uma vez que os pequenos dentes que garantiam a rugosidade da superfície foram incluídos na modelagem (Figura 4.31). Também não foram empregados elementos de contato na ligação, sendo os nós referentes aos dentes do nicho ligados aos nós referentes aos dentes da peça central pré-moldada.

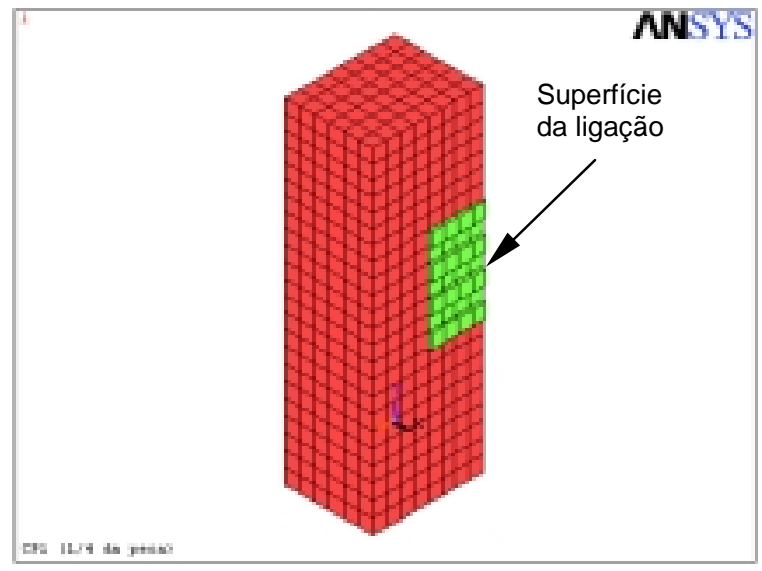

(a) Perspectiva da peça lateral e do nicho

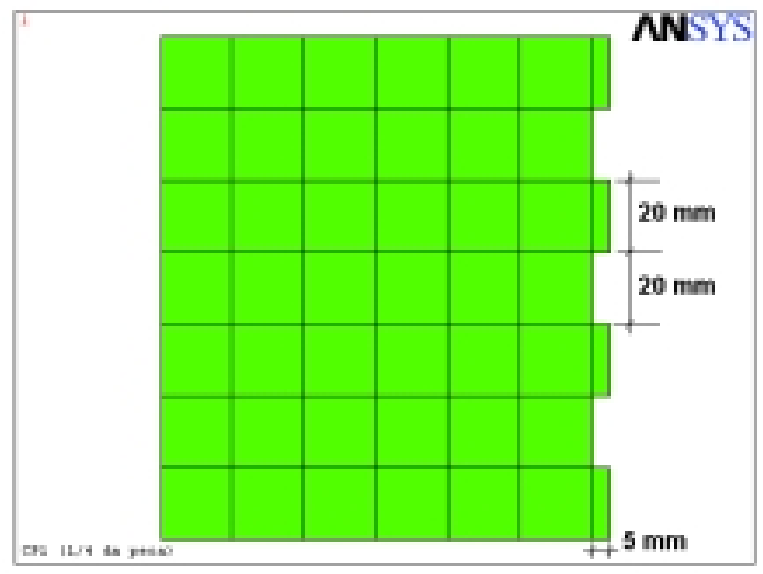

(b) Dimensões dos dentes na ligação

Figura 4.31 - Discretização dos corpos-de-prova de cisalhamento direto com superfície plana e rugosa 
$\mathrm{Na}$ Figura 4.32 é feita a comparação dos resultados experimentais com os da simulação numérica nos corpos-de-prova com superfície rugosa. Observa-se que no caso do corpo-de-prova CP1, com a ligação efetuada com o traço 1, a resposta numérica está próxima da experimental. No corpo-de-prova CP3, entretanto, a força última da simulação numérica é bem superior à experimental. Isto talvez tenha ocorrido pela mudança da forma de ruptura da ligação. No corpo-de-prova CP1, a ruptura ocorreu no concreto do nicho, enquanto no corpo-de-prova CP3, onde a resistência do concreto da ligação era muito superior à resistência do concreto pré-moldado, a ruptura ocorreu na peça pré-moldada. $\mathrm{Na}$ simulação numérica, entretanto, a máxima força de convergência foi definida pela resistência do concreto do nicho. Os deslocamentos referentes à força última na simulação numérica estão relativamente próximos dos valores experimentais.

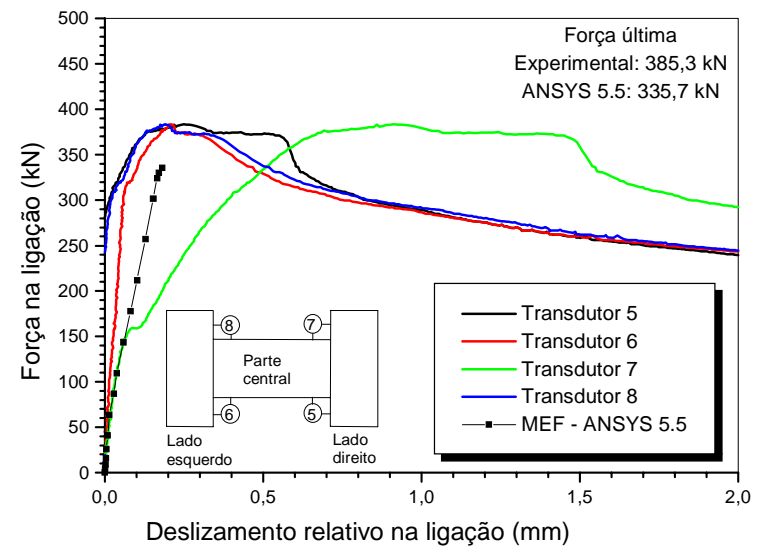

(a) CP1

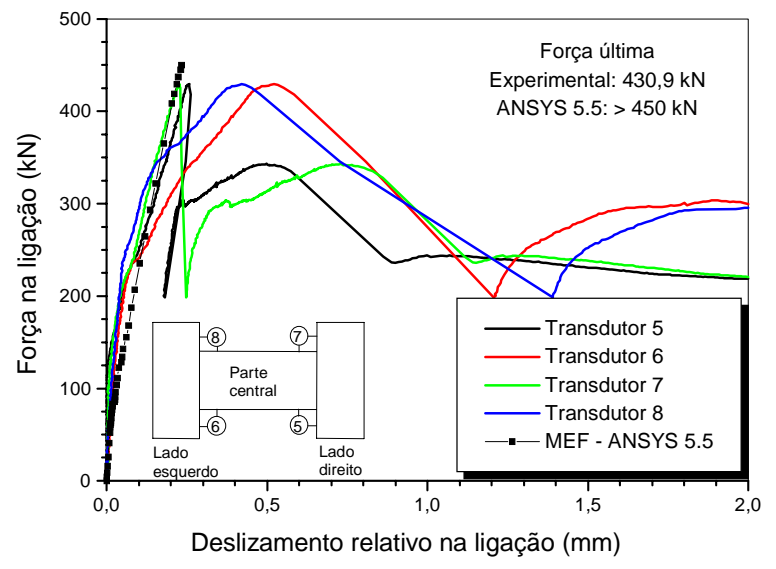

(b) $\mathrm{CP} 3$

Figura 4.32 - Resultados da simulação dos corpos-de-prova com superfície plana e rugosa

A malha empregada na modelagem dos corpos-de-prova com chave de cisalhamento na ligação é mostrada na Figura 4.33. Nesses corpos-de-prova, a transferência de esforços entre as peças pré-moldadas era garantida pela chave de cisalhamento e pelo conector. Nessas simulações, o conector foi modelado com o elemento SOLID65 e não mais com o BEAM23. Foram colocados elementos de contato na superfície entre as peças pré-moldadas e na superfície entre a chave de cisalhamento e a peça central para evitar a penetração de uma superfície sobre a outra. Para tanto, foram empregados os elementos CONTA173 e TARGE170 disponíveis na biblioteca de elementos do ANSYS. Nesses elementos a capacidade de transferência de esforços por atrito foi desabilitada. A aderência inicial que surge entre o concreto moldado no nicho e o concreto da peça central foi considerada empregando o elemento CONBIN40, e seu valor foi estimado a partir dos ensaios dos corpos-de-prova com superfície plana e lisa. Para a armadura foi admitido um 
comportamento elastoplástico perfeito, e para o concreto foi empregado o modelo CONCRETE associado com o modelo de Drucker Prager. O elemento SOLID65 permite associar ao modelo de fissuração um modelo elastoplástico. Nesse caso, antes de verificar a superfície do modelo CONCRETE o programa verifica a superfície de plastificação. $\mathrm{Na}$ Figura 4.34 são comparadas curvas típicas obtidas da simulação numérica com os resultados experimentais. As demais curvas estão mostradas no apêndice $A$.

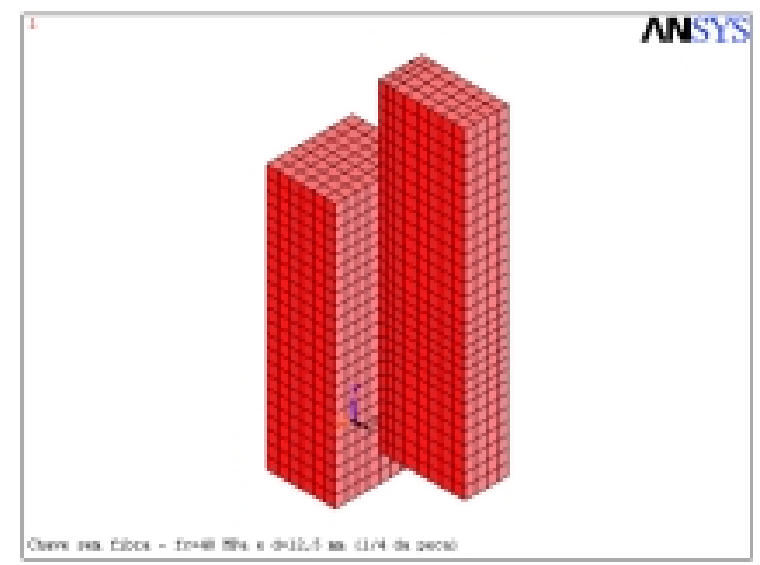

Perspectiva de $1 / 4$ do corpo-de-prova

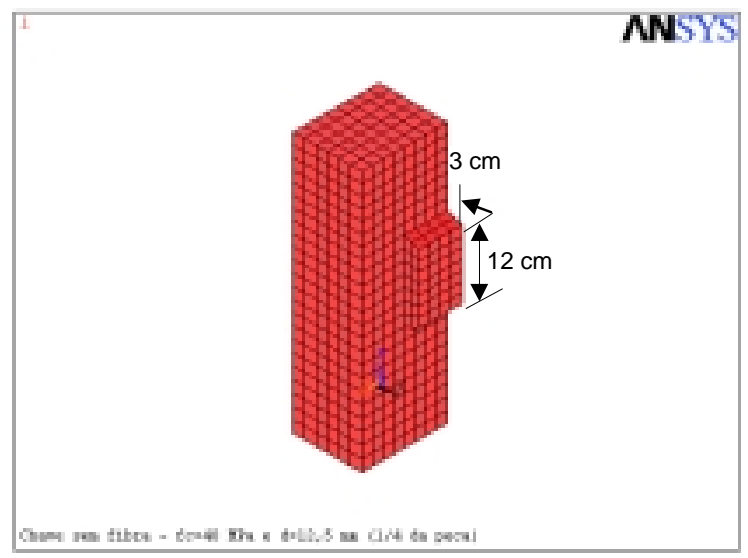

Dimensões da chave de cisalhamento

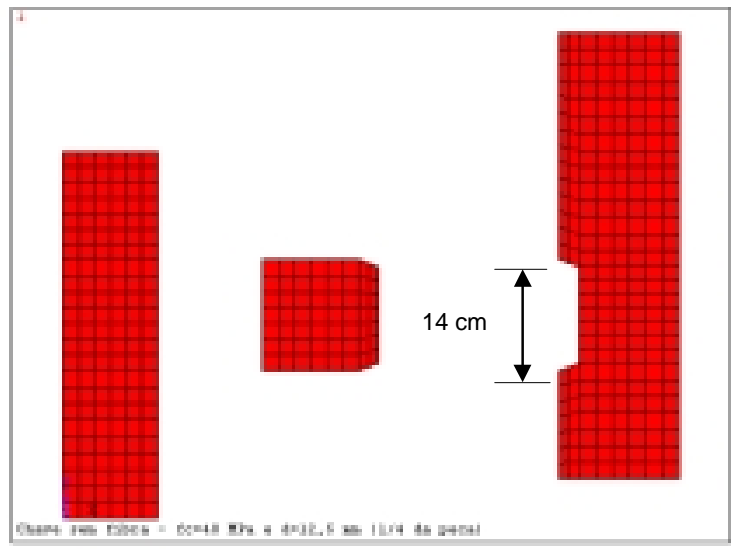

Vista frontal

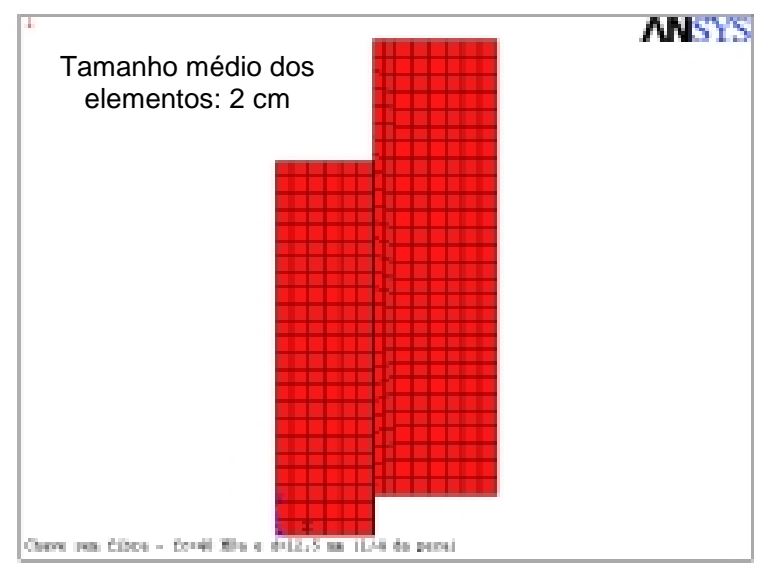

Vista frontal do corpo-de-prova

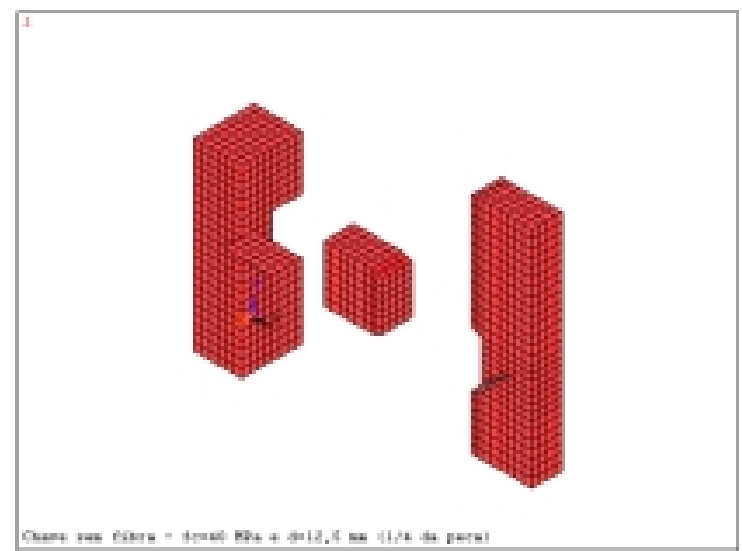

Perspectiva expandida

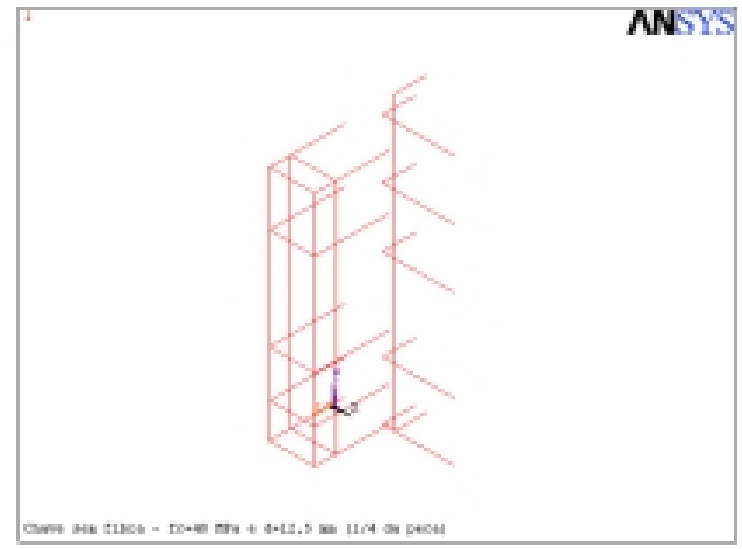

Armadura de reforço nos blocos central e lateral

Figura 4.33 - Discretização dos corpos-de-prova de cisalhamento direto ensaiados 


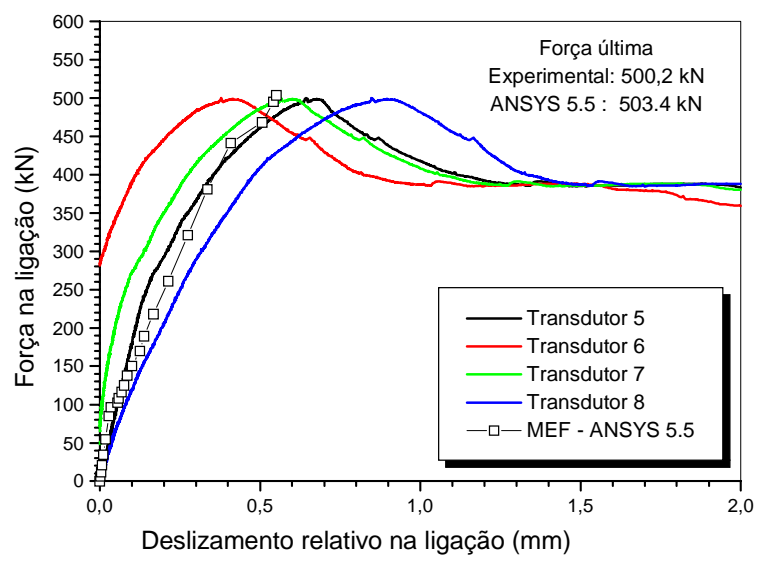

(a) CP13

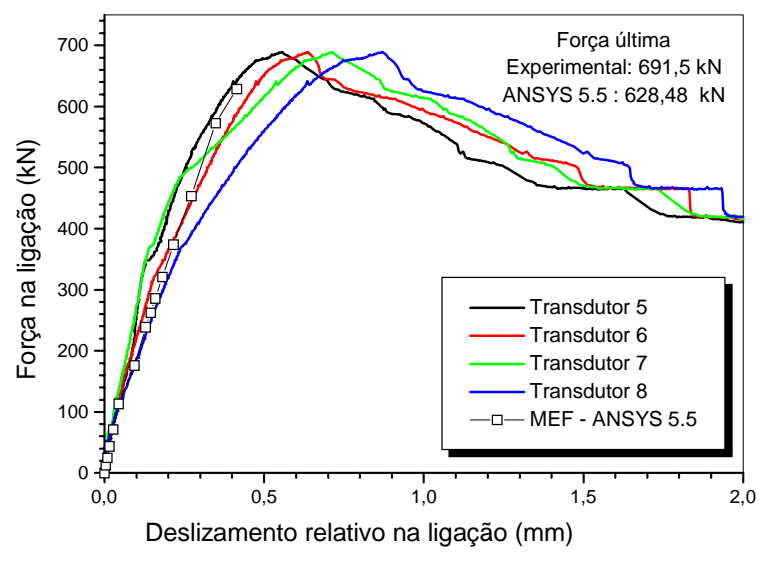

(b) CP25

Figura 4.34 - Comparação dos resultados da simulação numérica com os resultados experimentais da ligação com chave de cisalhamento (deslizamentos sem correção)

A simulação numérica representou com relativa precisão a resistência da ligação obtida do ensaio dos corpos-de-prova com chave de cisalhamento. Novamente, a resistência numérica foi definida como a máxima força para a qual houve convergência do processo numérico. O valor do deslizamento último, contudo, ficou bem abaixo dos valores experimentais. Na Tabela 4.4 são mostrados os valores obtidos da simulação em todos os corpos-de-prova com chave de cisalhamento.

Analisando mais detalhadamente os resultados da simulação numérica, observa-se que em alguns corpos-de-prova há uma diferença significativa entre os resultados numérico e experimental. Por exemplo, no corpo-de-prova CP15 a força última obtida da simulação numérica é significativamente maior que a experimental. Outro resultado interessante é que a variação do diâmetro do conector na ligação com o traço 1 não alterou a força última numérica. Isto induz à conclusão que o conector não tem influência sobre a resistência da ligação, o que não está de acordo com o observado nos ensaios. Tal comportamento pode ser explicado pela forma de ruptura observada na simulação numérica, que ocorreu pelo esmagamento do concreto na região logo abaixo do conector. Quando a resistência do concreto da ligação era elevada (corpos-de-prova CP24 e CP25), o aumento do diâmetro do conector aumentou a resistência da ligação na mesma proporção observada nos ensaios. Daí pode-se deduzir que a influência do conector na resistência da ligação é diretamente relacionada com a resistência do concreto.

A influência da adição de fibras foi considerada na simulação numérica pelo aumento da resistência à tração do concreto. Os resultados mostraram um aumento na força última numérica ao se aumentar a resistência à tração do concreto. Contudo, esse aumento foi inferior ao observado nos ensaios. Isto sugere que a resistência à tração do 
concreto não é o único parâmetro que influencia o mecanismo de ruptura da ligação. Provavelmente, a maior influência das fibras foi na modificação do ramo descendente da curva de tração uniaxial do material. Contudo, não é possível analisar esta influência com o programa ANSYS.

Tabela 4.4 - Comparação entre os resultados da análise numérica e os resultados experimentais dos ensaios de cisalhamento direto com chave

\begin{tabular}{|c|c|c|c|c|c|c|}
\hline $\begin{array}{c}\text { Corpo-de- } \\
\text { prova }\end{array}$ & $F_{\exp }(k N)^{(1)}$ & $\mathrm{F}_{\text {ANSYS }}(\mathrm{kN}){ }^{(2)}$ & $\frac{\underline{F}_{\text {ANSYS }}}{F_{\text {exp }}}$ & $\delta_{\exp }(\mathrm{mm}){ }^{(3)}$ & $\delta_{\text {ANSYS }}(m m)^{(4)}$ & $\frac{\underline{\delta}_{\text {ANSYS }}}{\delta_{\text {exp }}}$ \\
\hline CP8 & 358,30 & 296,7 & 0,83 & 1,81 & 0,44 & 0,24 \\
\hline CP11 & 461,90 & 317,34 & 0,69 & 1,43 & 0,48 & 0,34 \\
\hline CP12 & 453,40 & 317,34 & 0,70 & 2,40 & 0,48 & 0,20 \\
\hline CP13 & 250,10 & 251,70 & 1,01 & 0,75 & 0,55 & 0,73 \\
\hline CP14 & 230,70 & 252,80 & 1,10 & 0,62 & 0,48 & 0,77 \\
\hline CP15 & 196,05 & 241,36 & 1,23 & 0,57 & 0,47 & 0,82 \\
\hline CP16 & 286,15 & 341,12 & 1,19 & 0,76 & 0,50 & 0,66 \\
\hline CP17 & 349,40 & 385,52 & 1,1 & 0,99 & 0,57 & 0,58 \\
\hline CP18 & 320,10 & 411,54 & 1,29 & 0,96 & 0,54 & 0,56 \\
\hline CP19 & 519,50 & 454,68 & 0,88 & 1,19 & 0,53 & 0,45 \\
\hline CP20 & 345,30 & 382,22 & 1,11 & 1,15 & 0,5 & 0,43 \\
\hline CP21 & 459,55 & 407,94 & 0,89 & 1,32 & 0,51 & 0,39 \\
\hline CP22 & 259,95 & 251,68 & 0,97 & 0,90 & 0,51 & 0,57 \\
\hline CP23 & 316,55 & 341,66 & 1,08 & 0,89 & 0,50 & 0,56 \\
\hline CP24 & 310,00 & 284,24 & 0,92 & 0,96 & 0,38 & 0,40 \\
\hline CP25 & 345,75 & 314,24 & 0,91 & 1,08 & 0,41 & 0,38 \\
\hline CP26 & 363,10 & 332,28 & 0,92 & 0,93 & 0,47 & 0,51 \\
\hline CP27 & 383,85 & 376,06 & 0,98 & 1,12 & 0,51 & 0,46 \\
\hline \multicolumn{3}{|c|}{ Média } & 0,989 & \multicolumn{2}{|c|}{ Média } & 0,502 \\
\hline \multicolumn{3}{|c|}{ Desvio Padrão } & 0,167 & \multicolumn{2}{|c|}{ Desvio Padrão } & 0,172 \\
\hline
\end{tabular}

(1) $F_{\text {exp }}$ : Resistência da ligação obtida dos ensaios

(2) $F_{\text {ANSYS }}$ : Resistência da ligação obtida da simulação numérica no ANSYS 5.5

(3) $\delta_{m}$ : deslizamento médio correspondente ao pico de resistência da ligação obtido dos ensaios

(4) $\delta_{\text {ANSYS }}$ : deslizamento correspondente à máxima força de convergência da simulação numérica

O deslizamento máximo relativo da ligação, obtido da simulação numérica, foi significativamente inferior ao observado nos ensaios. Isto aconteceu por que na simulação numérica a contribuição do conector foi subestimada, o que pode ser comprovado pelo fato 
da melhor aproximação entre os resultados ter ocorrido no corpo-de-prova CP15 sem conector. Além disso, essa divergência de resultados pode ser justificada também pelo modelo empregado para representar o concreto, o qual apresentava um comportamento, na compressão, linear até a ruptura. Dessa forma, ele não é capaz de representar as nãolinearidades físicas que ocorrem no material comprimido e que influenciam no deslizamento relativo da ligação. Essa discrepância de resultados poderia ser minimizada se o programa ANSYS possuísse um modelo constitutivo baseado em tensões e deformações, definidas pelo usuário, e que pudesse ser aplicado ao concreto, como em outros programas comerciais. Também sente-se falta da representação do ramo descendente da ligação, que não foi possível ser realizada por limitações do programa.

A partir do que foi exposto até aqui, conclui-se que a simulação numérica realizada no ANSYS não representou de modo adequado o comportamento observado nos ensaios dos corpos-de-prova com chave de cisalhamento, apesar da força última numérica estar, em média, próxima da resistência da ligação medida nos ensaios. Contudo, foi possível analisar o modo de ruptura da ligação, o que servirá de base para a proposição de um modelo analítico no próximo capítulo. No caso dos corpos-de-prova com superfície plana, lisa ou rugosa, a simulação numérica parece adequada.

\subsection{Síntese e Considerações finais}

Os resultados apresentados neste capítulo mostram que a confecção da chave de cisalhamento na ligação melhora significativamente a resistência e a energia absorvida pela ligação quando comparadas às ligações com superfície plana e lisa. A garantia de rugosidade na superfície da peça pré-moldada também melhora significativamente seu comportamento quando comparado com a superfície lisa. A principal vantagem da ligação com chave sobre a ligação plana e rugosa é a possibilidade do emprego de fibras, que contribuem para uma menor perda de rigidez da ligação sob carregamento cíclico e uma maior absorção de energia.

Os resultados dos ensaios sob carregamento monotônico mostraram que a execução da chave de cisalhamento na ligação aumentou em $250 \%$ a sua resistência quando comparada com a ligação com superfície plana e lisa. A garantia de rugosidade na superfície de contato aumentou em 165\% a resistência da ligação, também comparada com a superfície lisa. No caso da ligação com chave de cisalhamento, o aumento da resistência do concreto moldado no nicho de $50 \mathrm{MPa}$ para $100 \mathrm{MPa}$ aumentou a resistência da ligação em 35\%, em média. Nesse tipo de ligação, o aumento do diâmetro do conector também 
aumentou a resistência da ligação, principalmente nas ligações com fibras. Foi observado um aumento de $62 \%$ na resistência quando o diâmetro do conector passou de $8 \mathrm{~mm}$ para $12,5 \mathrm{~mm}$, referente à ligação confeccionada com o traço 2 e $0,75 \%$ de fibras. A adição de fibras ao concreto moldado nos nichos, também aumentou a resistência da ligação com chave de cisalhamento. Foi observado um aumento de 37\% devido à adição de $0,75 \%$ de fibras na ligação confeccionada com o traço 2 e conector de $12,5 \mathrm{~mm}$. A maior contribuição das fibras, contudo, foi no aumento da energia absorvida até a ruptura da ligação, devido ao aumento do deslizamento relativo da ligação na ruptura. A quantidade de energia absorvida pela ligação é um parâmetro importante, principalmente, nas situações em que a estrutura é submetida a carregamento cíclico reversível, como, por exemplo, quando submetida à ação de sismos.

Dos ensaios de cisalhamento direto sob carregamento cíclico não reversível observou-se que as ligações sem fibras apresentaram uma perda de rigidez, ao final de vinte ciclos, de $25 \%$. A adição de fibras ao concreto moldado no nicho reduziu essa perda para $15 \%$. Esses resultados foram obtidos para um nível de solicitação correspondente a $40 \%$ da resistência da ligação. Em níveis mais altos de solicitação, também foi observada uma menor perda de rigidez da ligação devido à adição de fibras.

A ligação com superfície plana e rugosa foi avaliada pelo modelo analítico de TASSIOS; VINTZELEOU (1990), modificado pela proposição de um novo limite para o deslizamento relativo da interface. Os resultados mostraram-se coerentes com os obtidos experimentalmente, o que indica que esse modelo pode ser capaz de avaliar o comportamento desse tipo de ligação. Novos ensaios, porém, necessitam serem realizados para confirmar essa afirmação.

A simulação numérica dos corpos-de-prova com chave de cisalhamento, realizada no programa ANSYS, não representou de modo adequado o comportamento observado nos ensaios, apesar da força última numérica estar, em média, próxima da resistência da ligação medida nos ensaios. A maior discrepância entre os resultados foi verificada na avaliação do deslizamento último da ligação. A pouca representatividade do deslizamento da ligação pode ser devido ao modelo constitutivo empregado na representação do concreto. Nesse modelo, não foi possível a inclusão da energia de fratura como um parâmetro do material, de modo que a resposta ficou dependente da malha empregada. $O$ emprego de uma malha mais refinada aumentou os deslizamentos relativos na ligação, porém a máxima força de convergência foi reduzida. Por outro lado, nos corpos-de-prova com superfície plana, lisa ou rugosa, a simulação numérica mostrou-se adequada na representação do comportamento da ligação. 


\title{
Capítulo 5 - Análise da ligação com Chave de Cisalhamento e Conector
}

\begin{abstract}
Neste capítulo, os resultados dos ensaios de cisalhamento direto com chave de cisalhamento, apresentados no capítulo anterior, foram empregados na determinação de uma expressão para a representação da curva força-deslizamento da ligação. Em seguida, os mesmos resultados foram comparados com os resultados de modelos mecânicos disponíveis na literatura. Dessa comparação, foi sugerida uma modificação no modelo apresentado por KANEKO (1992) de modo a se obter uma melhor representação da resistência da ligação.
\end{abstract}

\subsection{Proposta de uma expressão para a representação da ligação com chave de cisalhamento}

Neste item, é mostrada a metodologia empregada na determinação de uma expressão para a representação dos resultados dos ensaios de cisalhamento direto. Essa expressão é válida apenas para ligação com chave de cisalhamento e submetida a carregamento monotônico. Os resultados dos ensaios com carregamento cíclico também foram usados na construção do modelo, tomando, neste caso, a envoltória da curva forçadeslizamento da ligação.

\subsubsection{Resistência da ligação}

As forças últimas alcançadas pelos corpos-de-prova foram mostradas na Tabela 4.2. Na Figura 4.16 e na Figura 4.17 foi mostrada a relação entre a resistência da ligação, nos corpos-de-prova sem fibra, e a tensão normal ao plano de cisalhamento proporcionada pelo conector, $\sigma_{n}$. Nessas figuras, também foram indicados os valores obtidos de equações empíricas baseadas na teoria atrito-cisalhamento e da equação empírica proposta por BAKHOUM (1991). Foi observado que todas elas forneceram resultados inferiores aos obtidos experimentalmente. Com o objetivo de conseguir uma correlação semelhante à de 
BAKHOUM (1991), a resistência da ligação e a tensão normal, $\sigma_{\mathrm{n}}$, foram dividas pela raiz quadrada da resistência à compressão do concreto moldado no nicho. Na Figura 5.1 são mostrados os resultados obtidos. Nessa mesma figura também são mostrados os resultados admitindo que o conector sempre atinja a deformação de escoamento do aço antes da ligação atingir a ruptura, o que significa fazer $\sigma_{n}=\rho f_{y}$. Realizando uma regressão linear, chega-se às seguintes expressões:

$$
\begin{aligned}
& \tau_{\mathrm{u}}=1,302 \sqrt{f_{\mathrm{cm}}}+0,767 \sigma_{\mathrm{n}} \leq 1,8 \sqrt{\mathrm{f}_{\mathrm{cm}}}(\mathrm{MPa}) \text { para } \mathrm{V}_{\mathrm{f}}=0 \%(\mathrm{R}=0,94) \\
& \tau_{\mathrm{u}}=1,270 \sqrt{\mathrm{f}_{\mathrm{cm}}}+0,798 \rho \mathrm{f}_{\mathrm{y}} \leq 1,8 \sqrt{\mathrm{f}_{\mathrm{cm}}}(\mathrm{MPa}) \text { para } \mathrm{V}_{\mathrm{f}}=0 \%(\mathrm{R}=0,93)
\end{aligned}
$$

sendo $f_{\mathrm{cm}}$ a resistência média à compressão do concreto moldado no nicho.
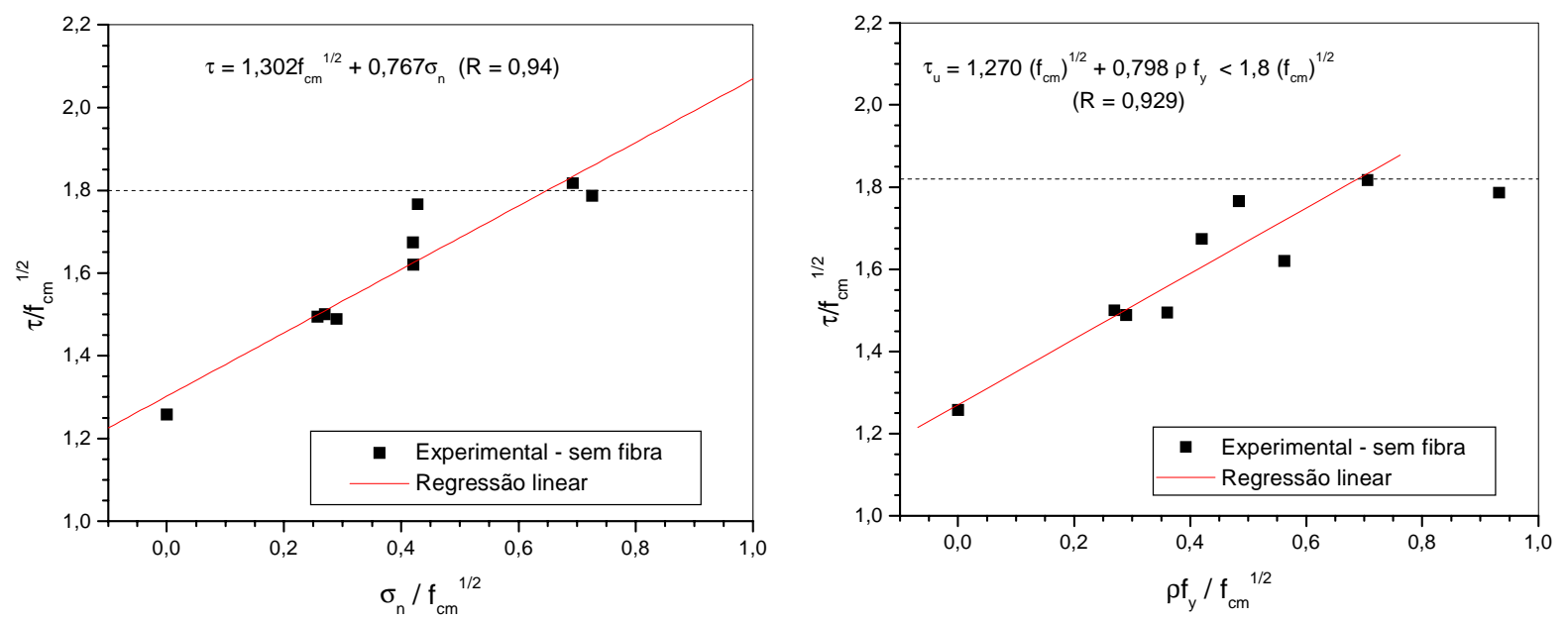

Figura 5.1 - Expressão para avaliação da resistência da ligação com chave de cisalhamento sem fibras

Comparando as expressões anteriores com a de BAKHOUM (1991), mostrada na Figura 4.17, nota-se que nas expressões aqui obtidas há uma maior contribuição do concreto na resistência da ligação, enquanto o acréscimo de resistência proporcionado pela tensão normal ao plano de cisalhamento é menor. A partir da observação dos resultados, foi proposto um limite superior para a resistência da ligação em função da resistência do concreto moldado no nicho. No restante do trabalho será empregada a eq.(5.1b) por ser de mais fácil aplicação.

Procedendo de modo semelhante com os resultados dos ensaios dos corpos-deprova com fibras adicionadas à ligação, chega-se às seguintes expressões para a avaliação da resistência da ligação (Figura 5.2): 


$$
\begin{aligned}
& \tau_{\mathrm{u}}=1,238 \sqrt{\mathrm{f}_{\mathrm{cm}}}+1,791 \sigma_{\mathrm{n}} \leq 2,6 \sqrt{\mathrm{f}_{\mathrm{cm}}}, 0,75 \% \leq \mathrm{V}_{\mathrm{f}} \leq 1,50 \% \quad(R=0,92) \\
& \tau_{\mathrm{u}}=1,730 \mathrm{f}_{\mathrm{cm}}{ }^{0,708}\left(\rho \sqrt{\mathrm{f}_{\mathrm{y}}}\right)^{0,415} \leq 2,6 \sqrt{\mathrm{f}_{\mathrm{cm}}} \quad 0,75 \% \leq V_{\mathrm{f}} \leq 1,50 \% \quad(R=0,95)
\end{aligned}
$$

sendo $f_{c m}$ a resistência média à compressão do concreto moldado no nicho. A eq.(5.2b) deve ser empregada apenas para $\rho>0,005$, uma vez que não foram realizados ensaios com fibras e sem conector. Caso esse limite não seja satisfeito, empregar a eq.(5.1b).

Das expressões anteriores, observa-se uma maior contribuição da tensão normal na resistência da ligação que no caso da ligação sem fibras. Também foi sugerido um limite máximo para a resistência da ligação em função da resistência do concreto moldado no nicho. Não foi observado, contudo, um limite máximo nítido, talvez por que a resistência da ligação seja também definida pela resistência da peça pré-moldada, isto é, com o aumento da resistência da chave de cisalhamento, a ruptura passa a ocorrer não mais na chave e sim no concreto pré-moldado. Não foi possível correlacionar a resistência da ligação com o volume de fibras, uma vez que se dispunha de poucos resultados experimentais com 1,5\% de fibras adicionadas. No restante do trabalho será empregada a eq.(5.2b) por ser de mais fácil aplicação.
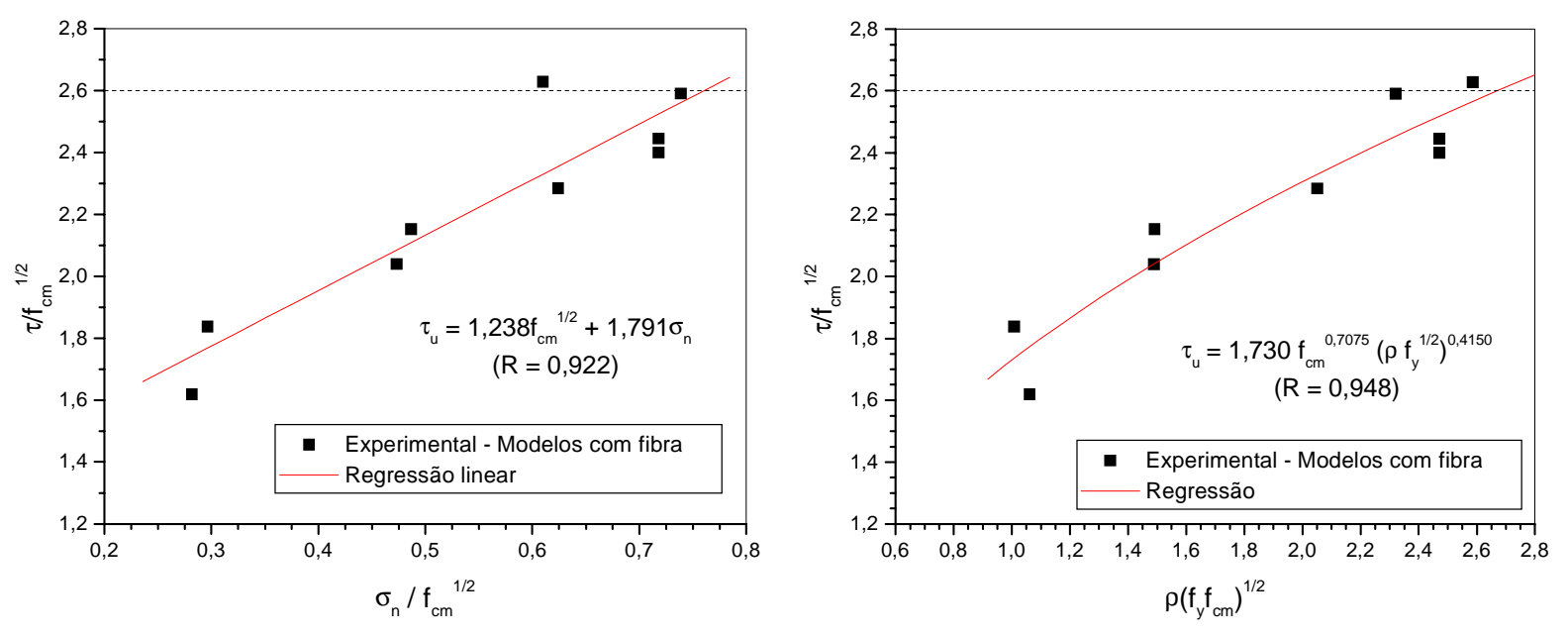

Figura 5.2 - Expressão para avaliação da resistência da ligação com chave de cisalhamento e fibras

\subsubsection{Deslizamento da ligação na ruptura}

Os deslizamentos médios da ligação na ruptura - $\delta_{m}$ - foram mostrados na Tabela 4.3. A partir desses valores, é possível obter uma expressão que relacione $\delta_{\mathrm{m}}$ com a resistência do concreto moldado no nicho, com o diâmetro do conector e com o volume de 
fibras, de modo semelhante ao realizado no item anterior. Após várias tentativas de correlacionar os resultados dos ensaios, com diversas expressões, o melhor resultado foi obtido com a metodologia descrita a seguir.

Inicialmente foi obtida uma correlação entre o deslizamento médio, $\delta_{\mathrm{m}}$, e a resistência à compressão do concreto moldado no nicho, para cada diâmetro de conector, empregando apenas os resultados dos ensaios sem adição de fibras (Figura 5.3). O objetivo era identificar a influência da resistência à compressão do concreto - $f_{c m}$. Foi calculado o valor médio do expoente de $\mathrm{f}_{\mathrm{cm}}$ de cada uma das expressões obtidas, que foi empregado para determinar a relação entre $\delta_{\mathrm{m}}$ e o diâmetro do conector. Para tanto, os resultados de deslizamentos de todos os corpos de prova sem fibra foram divididos por $\mathrm{f}_{\mathrm{cm}}{ }^{0,572}$. Realizando uma regressão não linear entre esses resultados e o diâmetro do conector, foi obtida a expressão final para o cálculo de $\delta_{\mathrm{m}}$ :

$$
\delta_{m}=0,014 f_{c m}^{0,572} \phi_{s}^{0,737} \text { para } V_{f}=0 \% \text { e } \phi_{s} \neq 0(R=0,89)
$$

sendo $f_{\mathrm{cm}}$ em MPa, $\phi_{\mathrm{s}}$ em $\mathrm{mm}$, e $\delta_{\mathrm{m}}$ em $\mathrm{mm}$.
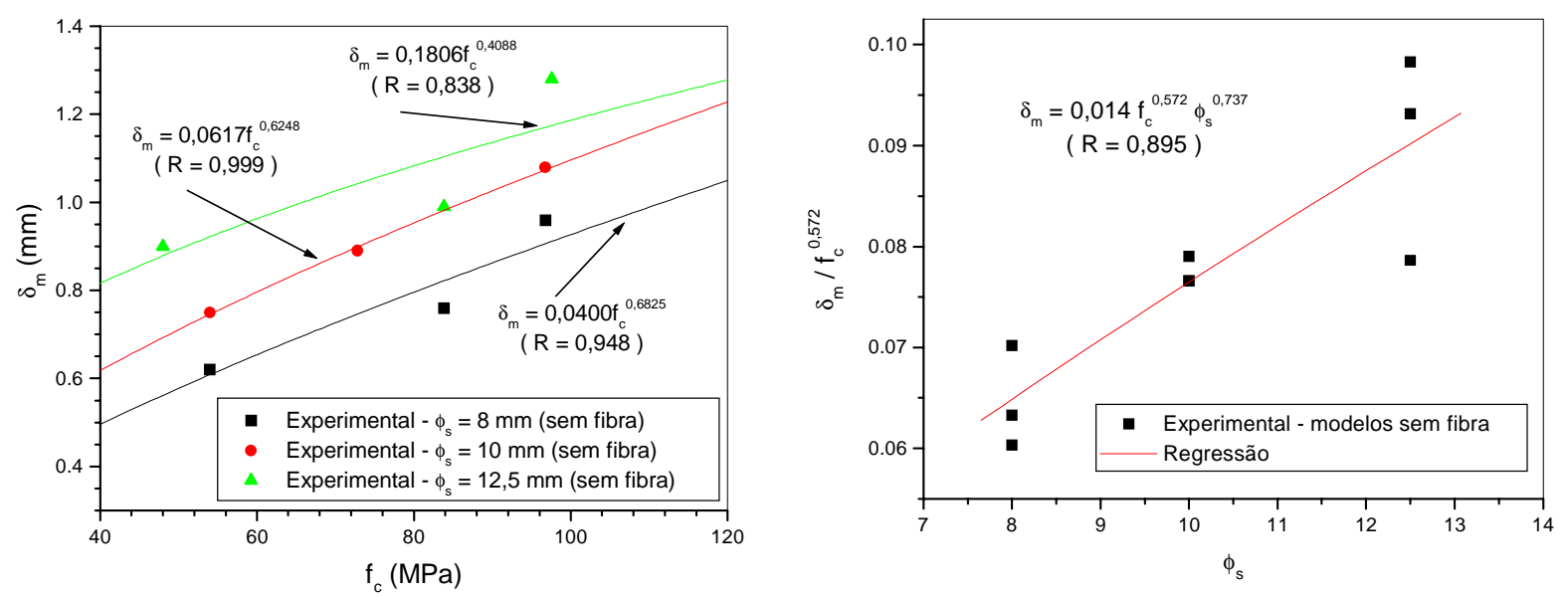

Figura 5.3 - Expressão para avaliação do deslizamento médio da ligação com chave de cisalhamento sem fibras

Foi adotado procedimento semelhante para obter a expressão de $\delta_{\mathrm{m}}$ no caso da ligação com fibras (Figura 5.4). Primeiramente, os resultados de deslizamento dos corposde-prova com fibras foram divididos por $\mathrm{f}_{\mathrm{cm}}{ }^{0,572}$. Em seguida, regressões não lineares foram realizadas correlacionando estes resultados com o diâmetro do conector. Obtido o expoente para $\phi_{s}$, por último foi feita a correlação com o volume de fibras. A expressão final obtida foi:

$$
\delta_{m}=0,0304 f_{c m}{ }^{0,572} \phi_{s}{ }^{0,468} V_{f}^{0,313}, 0,75 \% \leq V_{f} \leq 1,50 \% \text { e } \phi_{s} \neq 0(R=0,98)
$$


sendo $f_{c m}$ em MPa, $\phi_{s}$ em $m m, V_{f}$ em porcentagem, e $\delta_{m}$ em mm.
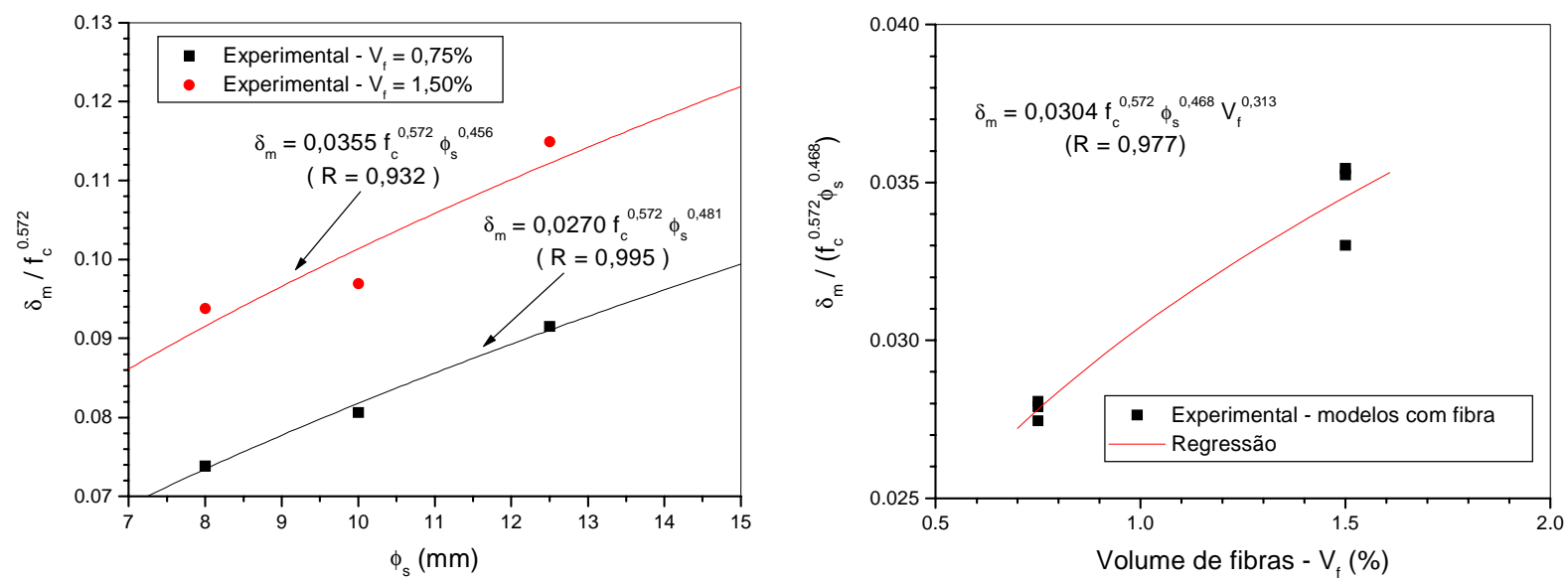

Figura 5.4 - Expressão para avaliação do deslizamento médio da ligação com chave de cisalhamento e fibras

\subsubsection{Curva tensão-deslizamento}

Definidas as expressões para o cálculo da resistência da ligação e do deslizamento na ruptura, $\delta_{m}$, o próximo passo foi definir uma expressão analítica para a representação da curva tensão-deslizamento da ligação. Foi escolhida uma função semelhante à empregada no traçado da curva tensão-deformação do concreto na compressão, porém com apenas um parâmetro:

$$
\frac{\tau}{\tau_{\mathrm{u}}}=\frac{\beta \frac{\delta}{\delta_{\mathrm{m}}}}{\beta-1+\left(\frac{\delta}{\delta_{\mathrm{m}}}\right)^{\beta}}
$$

A metodologia empregada na determinação da expressão do parâmetro $\beta$ consistiu em realizar regressões não lineares nas curvas médias obtidas dos ensaios, tanto na parte ascendente quanto na parte descendente das curvas. Foram empregadas as curvas normalizadas, isto é, a tensão de cisalhamento, $\tau$, foi dividida pela resistência da ligação, $\tau_{u}$, e o deslizamento, $\delta$, dividido pelo deslizamento médio na ruptura, $\delta_{\mathrm{m}}$. Em seguida, procurouse correlacionar os valores obtidos de $\beta$ com a resistência à compressão do concreto moldado no nicho, $f_{c m}$, com a taxa de armadura normal ao plano de cisalhamento, $\rho$, e com $\mathrm{o}$ volume de fibras adicionadas, $\mathrm{V}_{\mathrm{f}}$.

$\mathrm{Na}$ primeira etapa, foram realizadas as regressões apenas na parte ascendente das curvas obtidas do ensaio dos corpos-de-prova sem adição de fibras à ligação. Na Figura 
5.5a é mostrada a regressão efetuada no corpo-de-prova CP13. Após várias tentativas, a melhor correlação entre os valores de $\beta$ e as variáveis consideradas foi (Figura 5.5b):

$$
\beta=266,50 \rho \sqrt{f_{c m} f_{y}} \phi_{s}^{-2,324} \text { para } V_{f}=0 \% \text { e } \phi_{s} \neq 0(R=0,95)
$$

sendo $f_{c m}$ e $f_{y}$ em MPa e $\phi_{s}$ em mm.

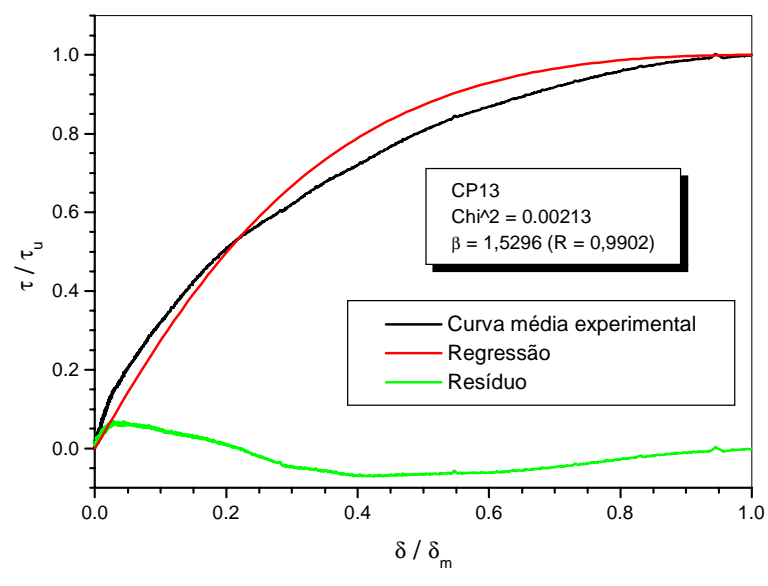

(a)

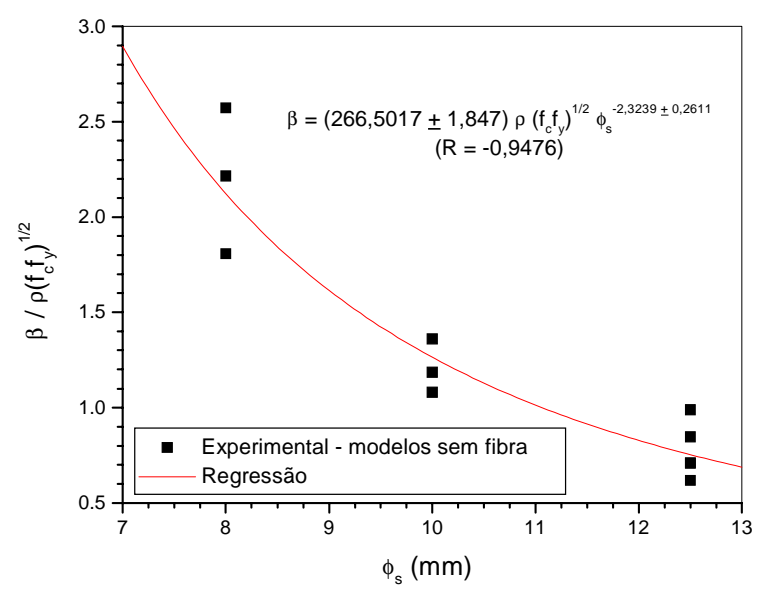

(b)

Figura 5.5 - Determinação do parâmetro $\beta$ para a parte ascendente das curvas de deslizamento dos corpos-de-prova sem fibra

Procedendo de forma semelhante nos corpos-de-prova com fibras adicionadas à ligação, chega-se à seguinte expressão para $\beta$ (Figura 5.6a):

$$
\beta=239,28 \rho \sqrt{f_{c m} f_{y}} \phi_{s}{ }^{-2,298}, 0,75 \% \leq V_{f} \leq 1,50 \% \text { e } \phi_{s} \neq 0(R=0,93)
$$

sendo $f_{c m}$ e $f_{y}$ em MPa e $\phi_{s}$ em mm.

Comparando a eq.(5.7) com a eq.(5.6), observa-se pequena diferença entre elas. Sendo assim, a consideração de que as fibras não influenciam a forma da curva tensãodeslizamento antes da ruptura parece ser razoável, o que justificaria a falta de correlação com o volume de fibras. Procedendo uma nova regressão nos valores de $\beta$, porém considerando todos os corpos-de-prova, chega-se à seguinte expressão (Figura 5.6b):

$$
\beta=257,87 \rho \sqrt{f_{c m} f_{y}} \phi_{s}{ }^{-2,318}, 0 \% \leq V_{f} \leq 1,50 \% \text { e } \phi_{s} \neq 0(R=0,94)
$$

sendo $f_{c m}$ e $f_{y}$ em MPa e $\phi_{s}$ em mm. 
Ao se efetuar a correlação entre a eq.(5.8) e o volume de fibras obteve-se um coeficiente muito pequeno para a parcela que representava as fibras. Desse modo, a consideração anterior de que as fibras não influenciavam a forma da curva mostrou-se verdadeira.

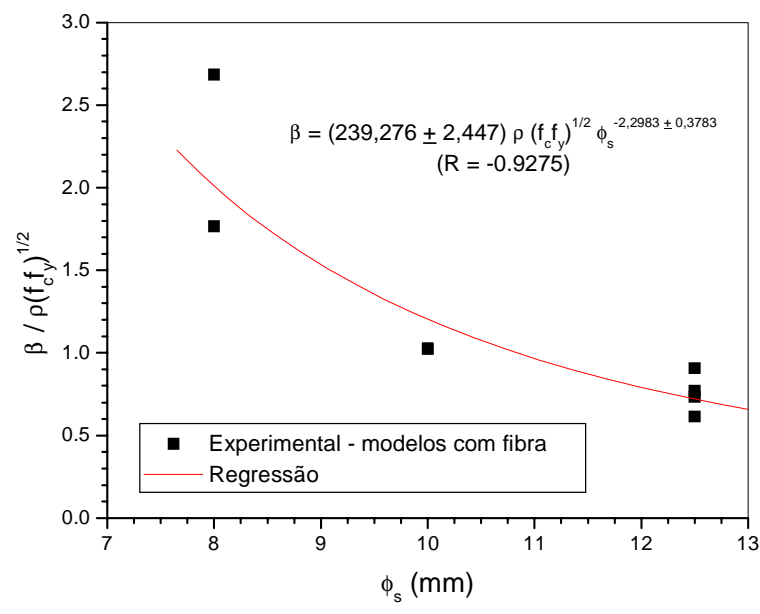

(a) corpos-de-prova com fibra

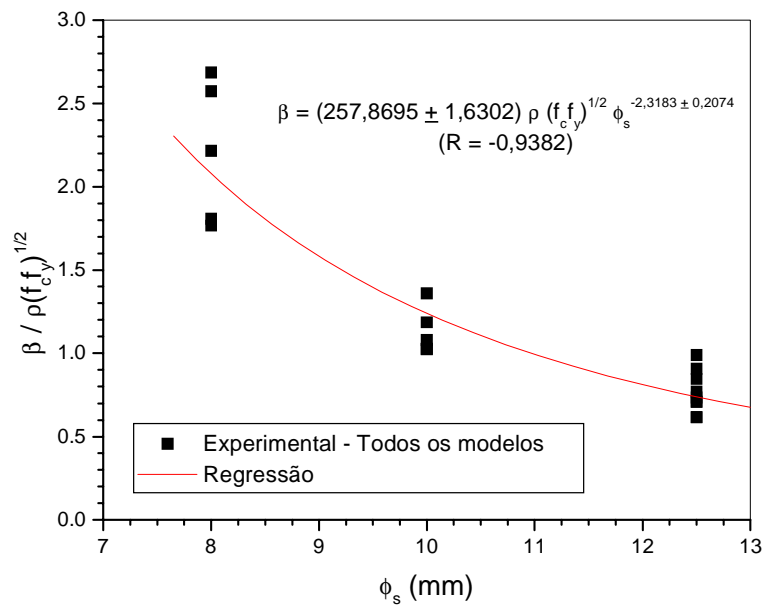

(b) todos os corpos-de-prova

Figura 5.6 - Determinação do parâmetro $\beta$ para a parte ascendente da curva tensãodeslizamento da ligação com chave de cisalhamento

A segunda etapa consistiu em determinar uma expressão para $\beta$ de modo que a eq.(5.5) representasse a parte descendente da curvas experimentais. Procedendo de modo idêntico ao exposto anteriormente, chegou-se à seguinte expressão, válida tanto para os corpos-de-prova com fibras na ligação quanto para aqueles sem fibra (Figura 5.7):

$$
\beta=196,45 \rho \sqrt{f_{c m} f_{y}} \phi_{s}^{-2,123}, 0 \% \leq V_{f} \leq 1,50 \% \text { e } \phi_{s} \neq 0(R=0,83)
$$

sendo $f_{c m}$ e $f_{y}$ em MPa e $\phi_{s}$ em mm.

As eq.(5.1), eq.(5.2), eq.(5.3), eq.(5.4), eq.(5.5), eq.(5.8) e eq.(5.9) definem a expressão para o traçado da curva tensão-deslizamento da ligação com chave de cisalhamento associada com conector.

Esta curva foi aplicada aos corpos-de-prova ensaiados, sendo os resultados mostrados na Tabela 5.1, na Tabela 5.2 e na Tabela 5.3.

A razão entre as resistências obtidas pela eq.(5.1) e pela eq.(5.2) e os valores experimentais apresentou valor médio de 1,002 com desvio padrão de 0,046. Considerando apenas os ensaios dos corpos-de-prova sem adição de fibras à ligação, a razão entre os 
valores obtidos pela eq.(5.1) e os valores experimentais apresentou valor médio de 0,999 com desvio padrão de 0,040. No caso dos ensaios com adição de fibras à ligação, esta mesma razão apresentou valor médio de 1,004 com desvio padrão de 0,052.

A razão entre os deslizamentos $\delta_{m}$ obtidos pela eq.(5.3) e pela eq.(5.4) e os valores experimentais apresentou valor médio de 0,936 com desvio padrão de 0,168. Considerando apenas os ensaios dos corpos-de-prova sem adição de fibras à ligação, a razão entre os valores obtidos pela eq.(5.3) e os valores experimentais apresentou valor médio de 1,005 com desvio padrão de 0,076 . No caso dos ensaios com adição de fibras à ligação, esta mesma razão apresentou valor médio de 0,925 com desvio padrão de 0,147.

A razão entre a energia absorvida até o pico de resistência obtida pela eq.(5.5) e o valor experimental apresentou valor médio de 0,984 com desvio padrão de 0,212. Considerando apenas os ensaios dos corpos-de-prova sem adição de fibras à ligação, a razão entre os valores obtidos pela eq.(5.5) e os valores experimentais apresentou valor médio de 1,064 com desvio padrão de 0,131. No caso dos ensaios com adição de fibras à ligação, esta mesma razão apresentou valor médio de 0,972 com desvio padrão de 0,193.

A razão entre a energia absorvida até o deslizamento de $2,5 \mathrm{~mm}$ e os valores experimentais apresentou valor médio de 1,056 com desvio padrão de 0,071. Considerando apenas os ensaios dos corpos-de-prova sem adição de fibras à ligação, a razão entre os valores obtidos pelo modelo e os valores experimentais apresentou valor médio de 1,018 com desvio padrão de 0,041 . No caso dos ensaios com adição de fibras à ligação, esta mesma razão apresentou valor médio de 1,089 com desvio padrão de 0,077.

De forma geral, a eq.(5.5) descreveu com boa precisão os resultados experimentais. A pequena divergência, observada nos resultados de deslizamento e energia absorvida nos corpos-de-prova com fibras, deve-se a pouca precisão do modelo em avaliar os deslizamentos dos corpos-de-prova CP8, CP11 e CP12. Na Figura 5.8 a expressão desenvolvida neste trabalho é comparada com as curvas experimentais dos corpos-deprova CP17 e CP25. As demais curvas são mostradas no Apêndice B. Novos ensaios devem ser realizados para dar mais confiabilidade a essa expressão, bem como para verificar algumas divergências. 


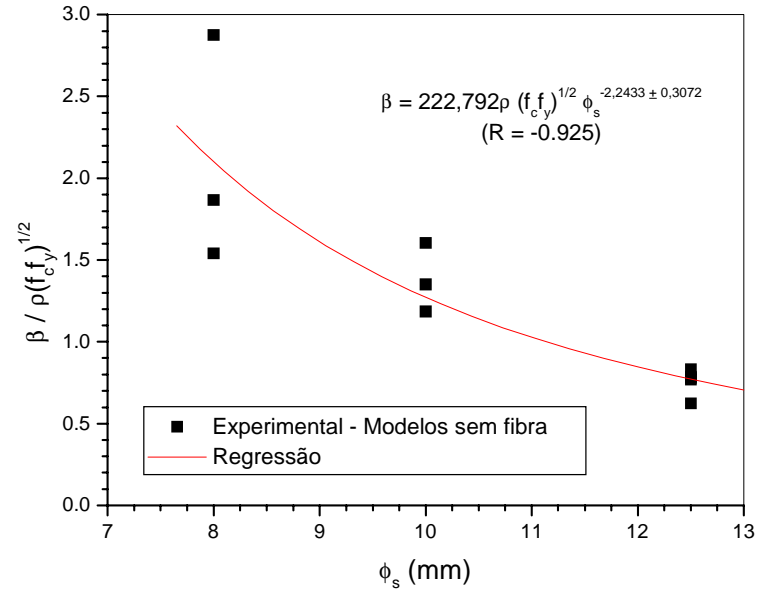

(a) corpos-de-prova sem fibra

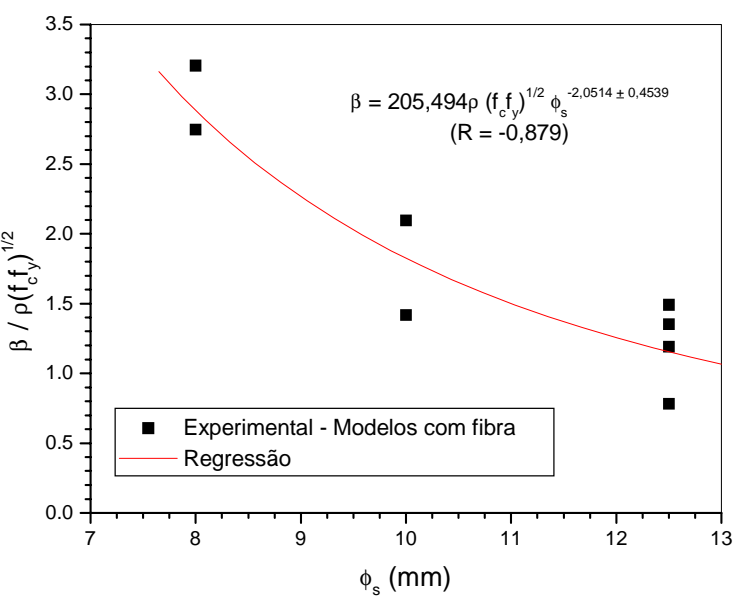

(b) corpos-de-prova com fibra

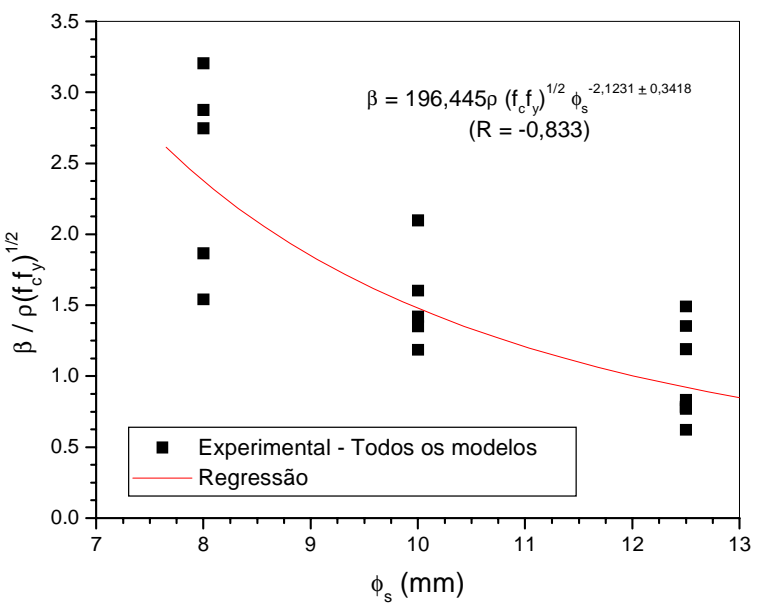

(c) todos os corpos-de-prova

Figura 5.7 - Determinação do parâmetro $\beta$ para a parte descendente das curvas de deslizamento dos corpos-de-prova

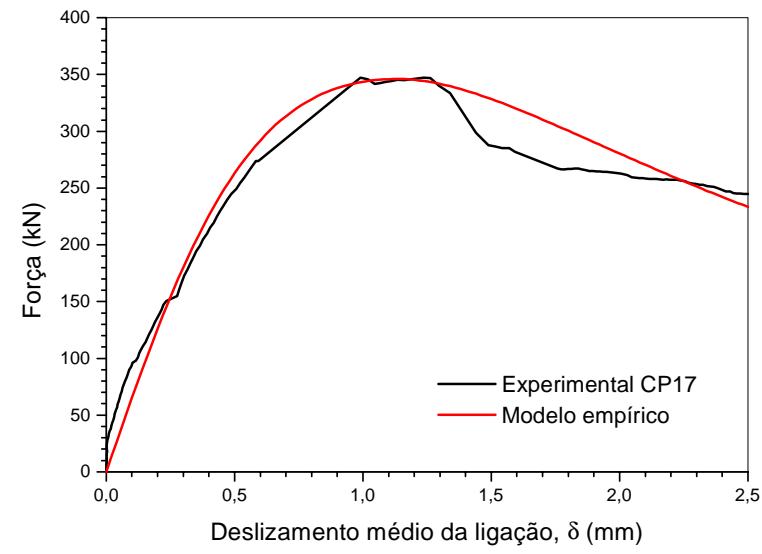

(a) corpos-de-prova CP17

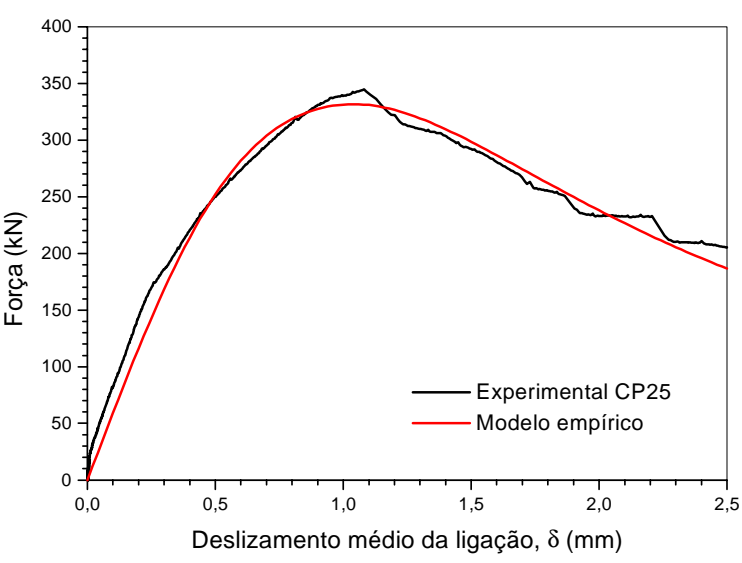

(b) corpos-de-prova CP25

Figura 5.8 - Comparação do modelo analítico com as curvas experimentais. 
Tabela 5.1 - Comparação entre a força última experimental e a obtida segundo a curva desenvolvida neste trabalho

\begin{tabular}{|c|c|c|c|}
\hline Corpo-de-prova & $\mathrm{F}_{\exp }(\mathrm{kN})^{(1)}$ & $\mathrm{F}_{\mathrm{t}}(\mathrm{kN})^{(2)}$ & $\frac{F_{t}}{F_{\text {exp }}}$ \\
\hline CP7 & 395,60 & 280,59 & $0,709^{*}$ \\
\hline CP7A & 390,50 & 328,34 & $0,841^{*}$ \\
\hline CP8 & 358,30 & 366,58 & 1,023 \\
\hline CP9 & 476,00 & 372,00 & $0,782^{*}$ \\
\hline CP10 & 421,75 & 540,01 & $1,280^{\star \star}$ \\
\hline CP11 & 461,90 & 477,24 & 1,033 \\
\hline CP12 & 453,40 & 477,24 & 1,052 \\
\hline CP13 & 250,10 & 265,30 & 1,061 \\
\hline CP14 & 230,70 & 240,37 & 1,042 \\
\hline CP16 & 286,15 & 288,53 & 1,008 \\
\hline CP17 & 349,40 & 346,03 & 0,990 \\
\hline CP18 & 320,10 & 350,85 & 1,096 \\
\hline CP19 & 519,50 & 508,88 & 0,980 \\
\hline CP20 & 345,30 & 326,38 & 0,945 \\
\hline CP21 & 459,55 & 436,55 & 0,950 \\
\hline CP22 & 259,95 & 261,91 & 1,008 \\
\hline CP23 & 316,55 & 296,89 & 0,938 \\
\hline CP24 & 310,00 & 306,73 & 0,989 \\
\hline CP25 & 345,75 & 331,66 & 0,959 \\
\hline CP26 & 363,10 & 364,32 & 1,003 \\
\hline CP27 & 383,85 & 365,04 & 0,951 \\
\hline \multicolumn{3}{|c|}{ Média } & 1,002 \\
\hline \multicolumn{3}{|c|}{ Desvio Padrão } & 0,046 \\
\hline \multicolumn{3}{|c|}{ Coeficiente de variação } & $4,5 \%$ \\
\hline
\end{tabular}

(1) $F_{\text {exp }}$ : Força última da ligação obtida dos ensaios

(2) $F_{t}$ : Força última da ligação obtida pela aplicação da eq.(5.1) e da eq.(5.2) desenvolvidas neste trabalho.

* Valor não considerado no cálculo da média devido às falhas durante a execução do modelo

** Valor não considerado no cálculo da média devido à ruptura ter ocorrido na peça pré-moldada 
Tabela 5.2 - Comparação entre o deslizamento experimental e o obtido pela aplicação da curva desenvolvida neste trabalho.

\begin{tabular}{|c|c|c|c|}
\hline Corpo-de-prova & $\delta_{\mathrm{m}, \exp }(\mathrm{kN})$ & $\delta_{\mathrm{m}, \mathrm{t}}(\mathrm{kN})^{(2)}$ & $\begin{array}{c}\underline{\delta}_{\mathrm{m}, \mathrm{t}} \\
\delta_{\mathrm{m}, \exp }\end{array}$ \\
\hline CP7 & 1,39 & 0,89 & $0,640^{*}$ \\
\hline CP7A & 0,73 & 1,07 & $1,466^{*}$ \\
\hline CP8 & 1,81 & 1,12 & 0,619 \\
\hline CP9 & 1,28 & 1,24 & $0,969^{*}$ \\
\hline CP10 & 2,21 & 1,53 & $0,692^{* \star}$ \\
\hline CP11 & 1,43 & 1,12 & 0,783 \\
\hline CP12 & 2,40 & 1,12 & 0,467 \\
\hline CP13 & 0,75 & 0,75 & 1,000 \\
\hline CP14 & 0,62 & 0,63 & 1,016 \\
\hline CP16 & 0,76 & 0,82 & 1,079 \\
\hline CP17 & 0,99 & 1,13 & 1,141 \\
\hline CP18 & 0,96 & 0,96 & 1,000 \\
\hline CP19 & 1,19 & 1,18 & 0,992 \\
\hline CP20 & 1,15 & 1,12 & 0,974 \\
\hline CP21 & 1,32 & 1,29 & 0,977 \\
\hline CP22 & 0,90 & 0,82 & 0,911 \\
\hline CP23 & 0,89 & 0,89 & 1,000 \\
\hline CP24 & 0,96 & 0,89 & 0,927 \\
\hline CP25 & 1,08 & 1,04 & 0,963 \\
\hline CP26 & 0,93 & 0,94 & 1,011 \\
\hline CP27 & 1,12 & 1,17 & 1,045 \\
\hline \multicolumn{3}{|c|}{ Média } & 0,936 \\
\hline \multicolumn{3}{|c|}{ Desvio Padrão } & 0,168 \\
\hline \multicolumn{3}{|c|}{ Coeficiente de variação } & $17,9 \%$ \\
\hline
\end{tabular}

(1) $\delta_{\text {m,exp }}$ : deslizamento da ligação na ruptura obtida dos ensaios

(2) $\delta_{m, t}$ : deslizamento da ligação na ruptura obtido pela aplicação da eq.(5.3) e da eq.(5.4) desenvolvidas neste trabalho.

* Valor não considerado no cálculo da média devido às falhas durante a execução do modelo

** Valor não considerado no cálculo da média devido à ruptura ter ocorrido na peça pré-moldada 
Tabela 5.3 - Comparação entre a energia absorvida pela ligação e a obtida pela aplicação da curva desenvolvida neste trabalho.

\begin{tabular}{|c|c|c|c|c|c|c|}
\hline $\begin{array}{c}\text { Corpo-de- } \\
\text { prova }\end{array}$ & $\begin{array}{c}\mathrm{E}_{\text {exp }, 1} \\
(\mathrm{kN} \cdot \mathrm{mm})\end{array}$ & $\begin{array}{c}E_{t, 1} \\
(k N \cdot m m)\end{array}$ & $\underset{E_{t, 1}}{E_{\text {exp }, 1}}$ & $\begin{array}{c}E_{\text {exp,2 }} \\
(k N \cdot m m)\end{array}$ & $\begin{array}{c}\mathrm{E}_{\mathrm{t}, 2} \\
(\mathrm{kN} \cdot \mathrm{mm})\end{array}$ & $\begin{array}{c}\underline{E}_{t, 2} \\
E_{\text {exp }, 2}\end{array}$ \\
\hline CP7 & 413,19 & 190,78 & $0,462^{*}$ & 833,43 & 570,13 & $0,684^{*}$ \\
\hline CP7A & 186,05 & 248,70 & $1,337^{\star}$ & 738,54 & 651,60 & $0,882^{*}$ \\
\hline CP8 & 520,68 & 308,52 & 0,593 & 750,04 & 764,82 & 1,020 \\
\hline CP9 & 437,12 & 319,55 & $0,731^{*}$ & 955,42 & 726,34 & $0,760^{*}$ \\
\hline CP10 & $723,86^{\star \star}$ & - & - & $843,93^{* *}$ & - & - \\
\hline CP11 & 457,75 & 379,62 & 0,829 & 893,97 & 943,61 & 1,055 \\
\hline CP12 & 845,01 & 379,62 & 0,449 & 891,75 & 943,61 & 1,058 \\
\hline CP13 & 136,43 & 144,41 & 1,058 & 485,87 & 513,84 & 1,057 \\
\hline CP14 & 103,80 & 111,45 & 1,074 & 429,69 & 436,10 & 1,015 \\
\hline CP16 & 128,22 & 161,50 & 1,260 & 519,26 & 507,48 & 0,977 \\
\hline CP17 & 223,02 & 279,18 & 1,252 & 658,11 & 682,13 & 1,036 \\
\hline CP18 & 181,58 & 228,54 & 1,259 & 504,58 & 643,08 & 1,274 \\
\hline CP19 & 406,76 & 421,31 & 1,036 & 893,11 & 1000,40 & 1,120 \\
\hline CP20 & 260,77 & 250,59 & 0,961 & 580,20 & 631,10 & 1,088 \\
\hline CP21 & 392,18 & 402,35 & 1,026 & 816,72 & 888,82 & 1,088 \\
\hline CP22 & 168,43 & 165,69 & 0,984 & 547,44 & 539,25 & 0,985 \\
\hline CP23 & 178,00 & 183,88 & 1,033 & 566,54 & 562,62 & 0,993 \\
\hline CP24 & 193,41 & 180,16 & 0,931 & 491,37 & 537,46 & 1,094 \\
\hline CP25 & 255,79 & 234,44 & 0,916 & 628,92 & 621,08 & 0,987 \\
\hline CP26 & 232,99 & 242,26 & 1,040 & 689,89 & 702,07 & 1,018 \\
\hline CP27 & 297,00 & 305,73 & 1,029 & 674,03 & 728,87 & 1,081 \\
\hline \multicolumn{3}{|c|}{ Média } & 0,984 & - & - & 1,056 \\
\hline \multicolumn{3}{|c|}{ Desvio Padrão } & 0,212 & - & - & 0,071 \\
\hline \multicolumn{3}{|c|}{ Coeficiente de variação } & $21,6 \%$ & - & - & $6,7 \%$ \\
\hline
\end{tabular}

(1) Energia absorvida até o deslizamento médio $\delta_{m}$

(2) Energia absorvida até o deslizamento médio $\delta_{m}$ obtida pela aplicação da eq.(5.5) desenvolvida neste trabalho

(3) Energia absorvida até o deslizamento médio $2,5 \mathrm{~mm}$

(4) Energia absorvida até o deslizamento médio de $2,5 \mathrm{~mm}$ obtida pela aplicação da eq.(5.5) desenvolvida neste trabalho.

* Valor não considerado no cálculo da média devido às falhas durante a execução do modelo

** Valor não considerado no cálculo da média devido à ruptura ter ocorrido na peça pré-moldada 


\subsection{Avaliação pelo modelo de KANEKO (1992)}

O modelo mecânico desenvolvido por KANEKO (1992), apresentado no capítulo 2, foi utilizado para avaliar o comportamento da ligação com chave de cisalhamento e conector. Esse modelo é composto de duas fases de fissuração distintas: uma primeira fase caracterizada pela formação de uma fissura discreta e uma segunda fase caracterizada pela formação de inúmeras fissuras localizadas na base da chave. Esse modelo foi baseado nos resultados experimentais de BAKHOUM (1991) que realizou uma série de ensaios em chaves de cisalhamento, cujo corpo-de-prova foi mostrado no item 2.2.1.

Para aplicação do modelo de KANEKO (1992) aos ensaios de cisalhamento realizados neste trabalho, foram necessárias algumas considerações. A primeira delas diz respeito à tensão normal ao plano de cisalhamento $\left(\sigma_{x}\right)$. No referido modelo, ela é um valor conhecido e age externamente. De fato, na aplicação para a qual o modelo foi desenvolvido, ou seja, ligação de aduelas pré-moldadas de concreto, essa tensão é conhecida a partir da força de protensão aplicada às aduelas. Nos ensaios realizados por BAKHOUM (1991) a tensão normal à chave era garantida por atuadores hidráulicos. Nos ensaios realizados neste trabalho, contudo, não havia nenhuma força externa atuando na direção normal ao plano de cisalhamento. Dessa forma, a primeira análise consistiu em aplicar o modelo de KANEKO (1992) com $\sigma_{\mathrm{x}}=0$. Os resultados obtidos, porém, foram bastante inferiores aos experimentais. Sendo assim, partiu-se para a definição de uma força normal ao plano de cisalhamento, que foi obtida considerando a deformação do conector no instante em que a ligação atingia sua máxima resistência. Conhecidas a deformação do conector, a tensão de escoamento do aço e o seu módulo de elasticidade, a força axial nas barras que formavam o conector foi facilmente obtida. Essa força foi, então, dividida pela área do nicho, e a tensão resultante foi considerada como uma tensão externa ao plano de cisalhamento da chave.

A segunda consideração necessária diz respeito à transição da fase de fissuração discreta para a fase de fissuração distribuída. A melhor forma de definir essa passagem é conhecendo o comprimento máximo da fissura discreta na chave de cisalhamento. Atingido o valor máximo da fissura discreta, passa-se para a fissuração distribuída. Nos ensaios realizados neste trabalho, contudo, não foi possível visualizar a formação da fissura discreta, uma vez que ela encontrava-se dentro da peça lateral pré-moldada. Sendo assim, para a solução do problema foi admitido um comprimento máximo de $140 \mathrm{~mm}$ para a fissura, referente à altura do nicho. Se a fissura for inclinada de $45^{\circ}$, isto significa dizer que ela termina logo após ter alcançado o conector no interior do nicho. A transição entre as 
duas fases de fissuração foi feita graficamente, procurando o ponto no qual a transição entre as duas curvas fosse suave.

Com essas duas considerações, foi possível aplicar o modelo de KANEKO (1992) às chaves de cisalhamento ensaiadas. Na Tabela 5.4 são mostrados os valores de força última obtidos pela aplicação desse modelo. A razão entre os valores obtidos pelo modelo e os valores experimentais apresentou valor médio de 1,083 com desvio padrão de 0,104. Considerando apenas os ensaios dos corpos-de-prova sem adição de fibras à ligação, a razão entre os valores obtidos pelo modelo e os valores experimentais apresentou valor médio de 1,10 com desvio padrão de 0,138 . No caso dos ensaios com adição de fibras à ligação, esta mesma razão apresentou valor médio de 1,066 com desvio padrão de 0,057. Esses resultados mostram que o modelo de KANEKO (1992), com estas considerações, foi capaz de representar com relativa precisão a resistência da ligação. Porém, ele tende a fornecer valores ligeiramente superiores aos reais.

$\mathrm{Na}$ Tabela 5.4 também são mostrados os valores de força última obtidos pela aplicação do modelo de KANEKO (1992) admitindo que o conector sempre atinja a tensão de escoamento do aço no instante da ruptura. Procedeu-se assim pelo fato de no projeto ser difícil saber que valor de tensão normal usar se não existirem resultados experimentais. O mais fácil seria admitir a armadura escoando e a partir daí calcular a tensão normal a ser utilizada no modelo. Nesse caso, a razão entre os valores obtidos pelo modelo e os valores experimentais apresentou valor médio de 1,121 com desvio padrão de 0,120. Considerando apenas os ensaios dos corpos-de-prova sem adição de fibras à ligação, a razão entre os valores obtidos pelo modelo e os valores experimentais apresentou valor médio de 1,153 com desvio padrão de 0,156 . No caso dos ensaios com adição de fibras à ligação, esta mesma razão apresentou valor médio de 1,088 com desvio padrão de 0,060. Novamente, o modelo forneceu resultados superiores aos reais e contrários à segurança. Contudo, é interessante notar que no caso dos modelos com fibras, a média obtida está muito próxima da média calculada anteriormente com os valores reais da deformação do conector. Isto mostra que, geralmente, a adição de fibras torna a ligação mais dúctil, permitindo que o conector atinja a deformação de escoamento do aço antes de atingida a ruptura da ligação. 
Tabela 5.4 - Comparação entre a força última obtida pela aplicação do modelo de KANEKO (1992) e os valores experimentais

\begin{tabular}{|c|c|c|c|c|c|}
\hline Corpo-de-prova & $F_{\exp }(k N)^{(1)}$ & $\mathrm{F}_{\mathrm{t}, 1}(\mathrm{kN})^{(2)}$ & $\frac{\mathrm{F}_{\mathrm{t}, 1}}{\mathrm{~F}_{\mathrm{exp}}}$ & $\mathrm{F}_{\mathrm{t}, 2}(\mathrm{kN})^{(3)}$ & $\frac{F_{t, 2}}{F_{\text {exp }}}$ \\
\hline CP7 & 395,60 & 384,36 & $0,97^{*}$ & 384,36 & $0,97^{*}$ \\
\hline CP7A & 390,50 & 386,10 & $0,99^{*}$ & 448,33 & $1,15^{\star}$ \\
\hline CP8 & 358,30 & 379,40 & 1,06 & 424,83 & 1,19 \\
\hline CP9 & 476,00 & 418,60 & $0,88^{*}$ & 508,18 & $1,07^{*}$ \\
\hline CP10 & 421,75 & 570,10 & $1,35^{\star *}$ & 570,10 & $1,35^{\star *}$ \\
\hline CP11 & 461,90 & 486,15 & 1,05 & 486,15 & 1,05 \\
\hline CP12 & 453,40 & 486,15 & 1,07 & 486,15 & 1,07 \\
\hline CP13 & 250,10 & 278,30 & 1,11 & 313,38 & 1,25 \\
\hline CP14 & 230,70 & 228,82 & 0,99 & 261,56 & 1,13 \\
\hline CP15 & 196,05 & 163,95 & 0,84 & 163,95 & 0,84 \\
\hline CP16 & 286,15 & 310,25 & 1,08 & 310,25 & 1,08 \\
\hline CP17 & 349,40 & 462,11 & 1,32 & 465,99 & 1,33 \\
\hline CP18 & 320,10 & 368,61 & 1,15 & 368,61 & 1,15 \\
\hline CP19 & 519,50 & 493,42 & 0,95 & 517,04 & 0,99 \\
\hline CP20 & 345,30 & 388,29 & 1,12 & 388,29 & 1,12 \\
\hline CP21 & 459,55 & 479,70 & 1,04 & 485,31 & 1,06 \\
\hline CP22 & 259,95 & 320,23 & 1,23 & 353,26 & 1,36 \\
\hline CP23 & 316,55 & 342,24 & 1,08 & 361,33 & 1,14 \\
\hline CP24 & 310,00 & 330,50 & 1,07 & 330,50 & 1,07 \\
\hline CP25 & 345,75 & 409,31 & 1,18 & 409,31 & 1,18 \\
\hline CP26 & 363,10 & 380,77 & 1,05 & 385,01 & 1,06 \\
\hline CP27 & 383,85 & 422,29 & 1,10 & 422,29 & 1,10 \\
\hline \multicolumn{3}{|c|}{ Média } & 1,083 & - & 1,121 \\
\hline \multicolumn{3}{|c|}{ Desvio Padrão } & 0,104 & - & 0,120 \\
\hline \multicolumn{3}{|c|}{ Coeficiente de variação } & $9,6 \%$ & - & $10,7 \%$ \\
\hline
\end{tabular}

(1) $F_{\text {exp: }}$ : Força última da ligação obtida dos ensaios

(2) $\mathrm{F}_{\mathrm{t}, 1}$ : Força última da ligação obtida por KANEKO (1992)

(3) $F_{t, 2}$ : Força última da ligação obtida segundo KANEKO (1992) admitindo que o conector sempre atinja a tensão de escoamento do aço antes da ruptura da ligação $\left(\sigma_{x}=2,65 \mathrm{MPa}\right.$ para $\phi=8$ $\mathrm{mm}, \sigma_{\mathrm{x}}=4,13 \mathrm{MPa}$ para $\phi=10 \mathrm{~mm}$ e $\sigma_{\mathrm{x}}=6,46 \mathrm{MPa}$ para $\phi=12,5 \mathrm{~mm}$ )

* Valor não considerado no cálculo da média devido às falhas durante a execução do modelo

** Valor não considerado no cálculo da média devido à ruptura ter ocorrido na peça pré-moldada 
O deslizamento relativo da ligação na ruptura, calculado pelo modelo de KANEKO (1992) e obtido experimentalmente, é mostrado na Tabela 5.5. Observa-se que os valores previstos pelo modelo são, em média, 30\% inferiores aos experimentais. Na Figura 5.9 são mostradas duas curvas típicas obtidas pelo modelo de KANEKO (1992). É possível notar que a curva prevista pelo modelo se aproxima relativamente bem da experimental antes da ligação atingir a resistência máxima. Após o pico de resistência, a curva prevista pelo modelo apresenta uma perda de resistência bem superior à observada nos ensaios. Isto se deve ao fato que nos ensaios usados para definição do modelo não havia armadura atravessando o plano de fissuração. Sendo assim, havia uma ruptura brusca da ligação depois de atingida sua resistência. A presença do conector impede essa ruptura brusca, mantendo boa parte da resistência da ligação na região pós-pico. Cabe observar, ainda, que a forma da curva prevista pelo modelo na região pós pico dos corpos-de-prova sem fibras é fisicamente impossível, o que demonstra deficiências na formulação desse modelo.

No Apêndice C são mostradas as curvas obtidas da aplicação do modelo de KANEKO (1992) a todos os ensaios de cisalhamento com chave na ligação.

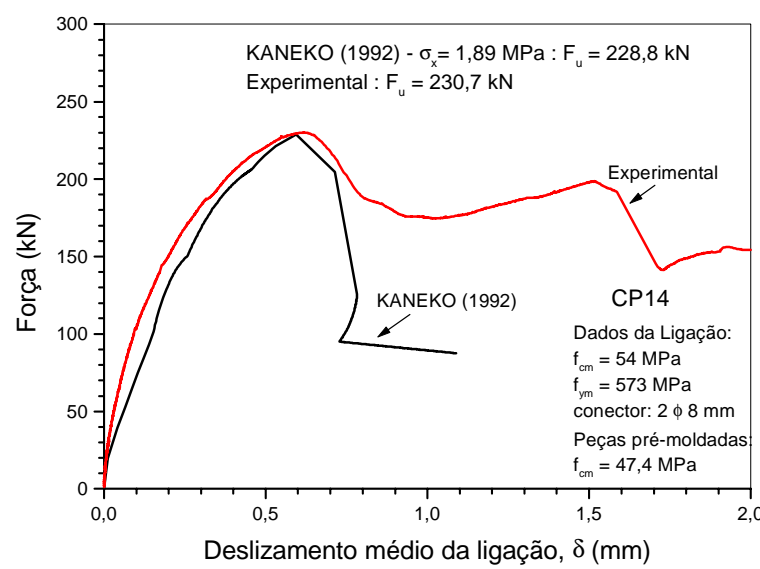

$\mathrm{CP} 14-\mathrm{V}_{\mathrm{f}}=0 \%$

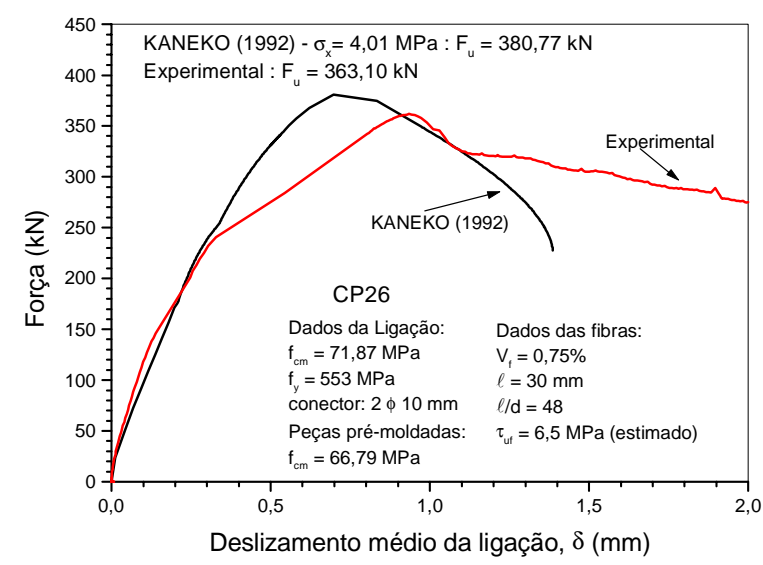

$C P 26-V_{f}=0,75 \%$

Figura 5.9 - Comparação do modelo de KANEKO (1992) com os resultados experimentais dos corpos-de-prova com chave de cisalhamento 
Tabela 5.5 - Comparação entre o deslizamento experimental e o obtido pela aplicação do modelo de KANEKO (1992)

\begin{tabular}{|c|c|c|c|}
\hline Corpo-de-prova & $\delta_{\exp }(k N)^{(1)}$ & $\delta_{\mathrm{t}, 1}(\mathrm{kN})^{(2)}$ & $\frac{\delta_{t, 1}}{\delta_{\exp }}$ \\
\hline CP7 & 1,39 & 0,67 & $0,48^{*}$ \\
\hline CP7A & 0,73 & 0,72 & $0,99^{*}$ \\
\hline CP8 & 1,81 & 0,69 & 0,38 \\
\hline CP9 & 1,28 & 0,81 & $0,63^{*}$ \\
\hline CP10 & 2,21 & 0,83 & $0,38^{* *}$ \\
\hline CP11 & 1,43 & 0,73 & 0,51 \\
\hline CP12 & 2,40 & 0,73 & 0,30 \\
\hline CP13 & 0,75 & 0,62 & 0,83 \\
\hline CP14 & 0,62 & 0,60 & 0,97 \\
\hline CP15 & 0,57 & 0,62 & 1,09 \\
\hline CP16 & 0,76 & 0,68 & 0,89 \\
\hline CP17 & 0,99 & 0,70 & 0,71 \\
\hline CP18 & 0,96 & 0,78 & 0,81 \\
\hline CP19 & 1,19 & 0,80 & 0,67 \\
\hline CP20 & 1,15 & 0,70 & 0,61 \\
\hline CP21 & 1,32 & 0,73 & 0,55 \\
\hline CP22 & 0,90 & 0,60 & 0,67 \\
\hline CP23 & 0,89 & 0,69 & 0,78 \\
\hline CP24 & 0,96 & 0,77 & 0,80 \\
\hline CP25 & 1,08 & 0,79 & 0,73 \\
\hline CP26 & 0,93 & 0,70 & 0,75 \\
\hline CP27 & 1,12 & 0,72 & 0,64 \\
\hline \multicolumn{3}{|c|}{ Média } & 0,705 \\
\hline \multicolumn{3}{|c|}{ Desvio Padrão } & 0,195 \\
\hline \multicolumn{3}{|c|}{ Coeficiente de variação } & $27,6 \%$ \\
\hline
\end{tabular}

(1) $\delta_{\text {exp }}$ : deslizamento da ligação na ruptura obtido dos ensaios

(2) $\delta_{t, 1}$ : deslizamento da ligação na ruptura obtido segundo KANEKO (1992)

* Valor não considerado no cálculo da média devido às falhas durante a execução do modelo

** Valor não considerado no cálculo da média devido à ruptura ter ocorrido na peça pré-moldada 


\subsection{Avaliação pelo modelo de KANEKO (1992) modificado para incluir o conector}

A parte do modelo de KANEKO (1992) que descreve a fase de fissuração distribuída é baseada no conceito de bielas e tirantes, aplicado em regiões fissuradas. Essa teoria é baseada em equações de equilíbrio, equações de compatibilidade de deformações e equações constitutivas que representam o comportamento uniaxial dos materiais sob esforços de tração e compressão. Durante o carregamento da estrutura, surgem novas fissuras com inclinações diferentes de modo a equilibrar o carregamento externo. A resistência, normalmente, é alcançada quando a tensão de compressão nas bielas comprimidas, formadas entre fissuras adjacentes, atinge a resistência à compressão do concreto. Essa resistência à compressão normalmente é inferior à resistência uniaxial devido às tensões de tração que agem na direção normal às bielas de compressão ("softening truss model'). Para resolver o equilíbrio de forças na região fissurada, normalmente é empregado um processo iterativo, uma vez que existem mais incógnitas que equações disponíveis. Neste ponto, os autores costumam apresentar diversas metodologias de resolução. No caso do modelo de KANEKO (1992), o autor sugeriu a adoção de um coeficiente de Poisson aparente $\left(v_{\mathrm{a}}=\varepsilon_{\mathrm{c}} / \varepsilon_{\mathrm{t}}\right)$. Usando esse coeficiente e conhecendo $\mathrm{o}$ valor da deformação principal de tração, $\varepsilon_{t}$, é possível obter os valores das tensões e deformações no plano de cisalhamento sem a necessidade de um processo iterativo. Fazendo variar o valor de $\varepsilon_{\mathrm{t}}$, obtém-se uma curva que relaciona a força aplicada na chave com o deslocamento relativo na direção da solicitação, que é calculado a partir das dimensões da chave de cisalhamento.

$O$ fato de se especificar o valor de $\varepsilon_{t}$ significa admitir que a resistência ao cisalhamento é definida pelas tensões de tração que surgem na direção perpendicular às bielas de compressão. Nada impede, entretanto, que o comportamento seja controlado pela deformação principal de compressão, $\varepsilon_{c}$. Tanto é verdade que outros autores, como, por exemplo, HSU et al. (1987), propuseram a resolução do problema a partir de $\varepsilon_{\mathrm{c}}$. Mesmo KANEKO (1992) em seu trabalho analisou esta solução, admitindo $v_{\mathrm{a}}=\varepsilon_{\mathrm{t}} / \varepsilon_{\mathrm{c}}$. Contudo, ele observou que controlando o valor de $\varepsilon_{\mathrm{t}}$ os resultados fornecidos pelo modelo estavam mais próximos dos resultados experimentais de BAKHOUM (1991).

Baseado nessas observações, o modelo de KANEKO (1992) foi novamente empregado para representar os resultados experimentais deste trabalho, porém admitindo conhecido o valor da deformação principal de compressão, $\varepsilon_{c}$, e o coeficiente de Poisson aparente definido por $v_{\mathrm{a}}=\varepsilon_{\mathrm{t}} / \varepsilon_{\mathrm{c}}$. Neste caso, controlar o valor da deformação principal de 
compressão significa admitir que a ruptura acontecerá pelo esmagamento das bielas de compressão. Ao empregar o modelo dessa forma, não faz mais sentido considerar a fase de fissuração discreta. Agora, o comportamento da chave é definido apenas pela fase de fissuração distribuída, e antes que ela se inicie, o concreto apresenta-se no regime elástico. Equacionado o modelo dessa forma, a armadura pode ser diretamente introduzida na formulação, não havendo mais necessidade de considera-la como uma tensão externa. Para tanto, basta introduzir uma parcela na equação de equilíbrio que represente a contribuição da armadura. Para facilitar o problema, a armadura é admitida uniformemente distribuída ao longo do plano de cisalhamento, de modo que na formulação aparece a taxa de armadura.

Os modelos constitutivos uniaxiais para o concreto, simples e reforçado com fibras, submetidos à tração são os mesmos utilizados por KANEKO (1992) e estão mostrados na Figura 2.13 e na Figura 2.14. Na compressão foi empregada, para o concreto sem fibra, uma expressão ligeiramente diferente que considera a redução da resistência à compressão devido às tensões de tração nas bielas comprimidas (MANSUR; ONG (1991)):

$$
\begin{aligned}
& \text { Ramo ascendente: } \quad \sigma_{\mathrm{c}}=\mathrm{f}_{\mathrm{c}}\left[\frac{2 \varepsilon_{\mathrm{c}}}{\varepsilon_{\mathrm{c}, \mathrm{lim}}}-\lambda\left(\frac{\varepsilon_{\mathrm{c}}}{\varepsilon_{\mathrm{c}, \mathrm{lim}}}\right)^{2}\right] \text { se } \varepsilon_{\mathrm{c}} \leq \frac{\varepsilon_{\mathrm{c}, \mathrm{lim}}}{\lambda} \\
& \lambda=\sqrt{0,7-\frac{\varepsilon_{\mathrm{t}}}{\varepsilon_{\mathrm{c}}}} \\
& \text { Ramo descendente: } \sigma_{\mathrm{c}}=\frac{\mathrm{f}_{\mathrm{c}}}{\lambda}\left[1-0,8 \frac{\left(\varepsilon_{\mathrm{c}}-\frac{\varepsilon_{\mathrm{c}, \mathrm{lim}}}{\lambda}\right)}{\left(\varepsilon_{\mathrm{cu} 2}-\frac{\varepsilon_{\mathrm{c}, \mathrm{lim}}}{\lambda}\right)}\right] \text { se } \frac{\varepsilon_{\mathrm{c}, \mathrm{lim}}}{\lambda}<\varepsilon_{\mathrm{c}} \leq \varepsilon_{\mathrm{cu} 2} \\
& \sigma_{\mathrm{c}}=\frac{0,2 \mathrm{f}_{\mathrm{c}}}{\lambda} \text { se } \varepsilon_{\mathrm{c}}>\varepsilon_{\mathrm{cu} 2} \\
& \varepsilon_{\mathrm{c}, \lim }=\frac{2 \mathrm{f}_{\mathrm{c}}}{\mathrm{E}_{\mathrm{c}}} \\
& \varepsilon_{\text {cu2 }}=\frac{0,041-2 \varepsilon_{c, \text { lim }} f_{c}}{f_{c}-6,896}+\varepsilon_{c, \text { lim }}
\end{aligned}
$$

No caso do concreto com fibras, foi empregada a mesma expressão mostrada na Figura 2.14 que não considera a redução da resistência à compressão devido às tensões de tração nas bielas.

Na Tabela 5.6 é mostrada a força última obtida pela aplicação desse modelo aos ensaios de cisalhamento direto com chave na ligação. A razão entre os valores obtidos pelo 
modelo e os valores experimentais apresentou valor médio de 1,055 com desvio padrão de 0,097. Este valor foi obtido considerando todos os ensaios realizados, com exceção dos corpos-de-prova CP7, CP7A e CP9 pelas razões já mencionadas. Considerando apenas os ensaios dos corpos-de-prova sem adição de fibras à ligação, a razão entre os valores obtidos pelo modelo e os valores experimentais apresentou valor médio de 1,117 com desvio padrão de 0,049 . No caso dos ensaios com adição de fibras à ligação, esta mesma razão apresentou valor médio de 0,993 com desvio padrão de 0,095.

As resistências da ligação obtidas com o modelo modificado, em geral, estão mais próximas dos valores experimentais que as obtidas com o modelo original de KANEKO (1992), o que sugere que a ruptura da chave de cisalhamento ocorre pelo esmagamento das bielas de compressão formadas na base da chave.

Com relação ao deslizamento da ligação na ruptura, $\delta_{\mathrm{m}}$, o modelo controlando a deformação principal de compressão forneceu resultados, em média, 50\% inferiores aos experimentais. Este valor é superior ao obtido empregando o modelo com controle da deformação principal de tração. Em parte, isto se deve ao fato de não mais ter sido computado o deslizamento relativo à fissuração discreta. O modelo com controle da deformação de compressão fornece deslizamentos menores que o modelo com controle da deformação de tração por que neste último as deformações de tração são bem maiores que no primeiro caso. Na Figura 5.10 são mostradas as curvas obtidas para os corpos-de-prova CP14 e CP26 pela aplicação do modelo de KANEKO (1992) e pela aplicação do modelo modificado.

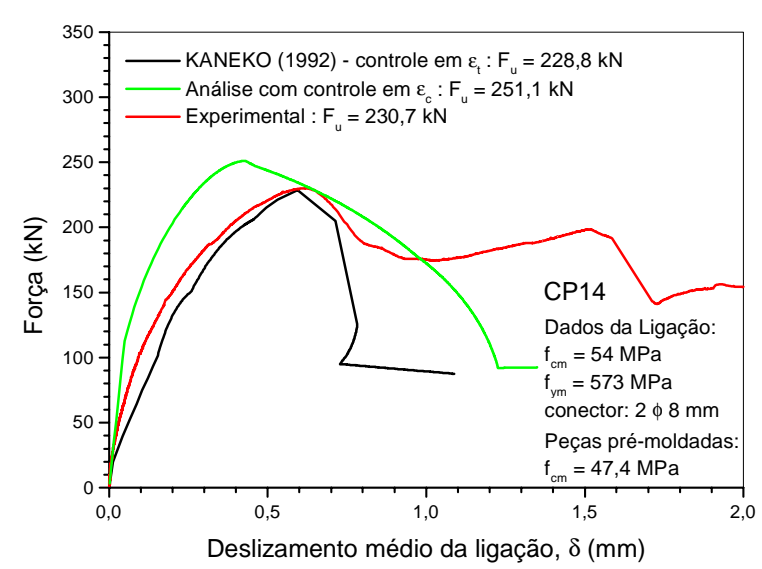

$\mathrm{CP} 14-\mathrm{V}_{\mathrm{f}}=0 \%$

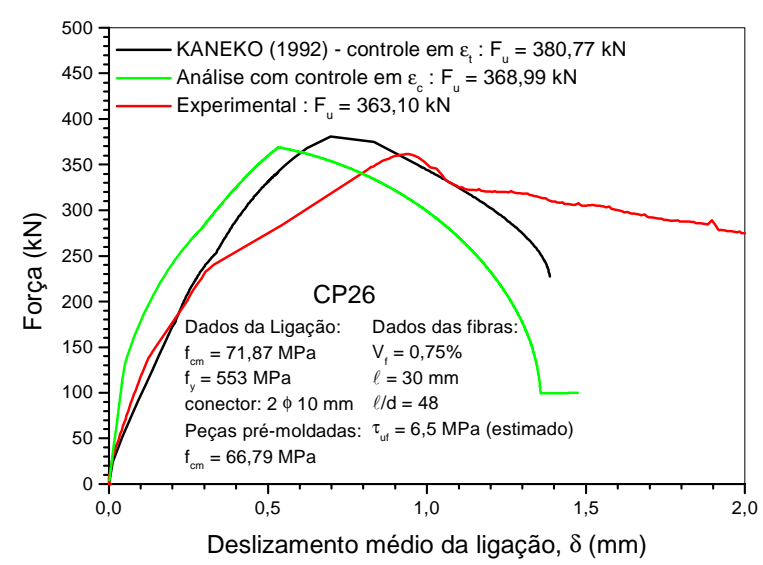

$\mathrm{CP} 26-\mathrm{V}_{\mathrm{f}}=0,75 \%$

Figura 5.10 - Comparação entre o modelo de KANEKO (1992), com controle da deformação principal de compressão, e os resultados experimentais 
Tabela 5.6 - Comparação entre a força última obtida pela aplicação do modelo de KANEKO (1992) modificado para incluir a armadura e os valores experimentais

\begin{tabular}{|c|c|c|c|}
\hline Corpo-de-prova & $\mathrm{F}_{\exp }(\mathrm{kN})^{(1)}$ & $\mathrm{F}_{\mathrm{t}, 1}(\mathrm{kN})^{(2)}$ & $\frac{F_{t, 1}}{F_{\text {exp }}}$ \\
\hline CP7 & 395,60 & 302,70 & $0,765^{*}$ \\
\hline CP7A & 390,50 & 379,20 & $0,971^{*}$ \\
\hline CP8 & 358,30 & 338,17 & 0,944 \\
\hline CP9 & 476,00 & 451,87 & $0,949^{*}$ \\
\hline CP10 & 421,75 & 506,77 & $1,202^{* \star}$ \\
\hline CP11 & 461,90 & 446,53 & 0,967 \\
\hline CP12 & 453,40 & 446,53 & 0,985 \\
\hline CP13 & 250,10 & 271,93 & 1,087 \\
\hline CP14 & 230,70 & 251,15 & 1,089 \\
\hline CP15 & 196,05 & 219,15 & 1,118 \\
\hline CP16 & 286,15 & 332,77 & 1,163 \\
\hline CP17 & 349,40 & 407,78 & 1,167 \\
\hline CP18 & 320,10 & 387,87 & 1,212 \\
\hline CP19 & 519,50 & 477,03 & 0,918 \\
\hline CP20 & 345,30 & 362,53 & 1,050 \\
\hline CP21 & 459,55 & 407,00 & 0,886 \\
\hline CP22 & 259,95 & 273,43 & 1,052 \\
\hline CP23 & 316,55 & 333,47 & 1,053 \\
\hline CP24 & 310,00 & 362,76 & 1,170 \\
\hline CP25 & 345,75 & 399,64 & 1,156 \\
\hline CP26 & 363,10 & 368,99 & 1,016 \\
\hline CP27 & 383,85 & 369,75 & 0,963 \\
\hline \multicolumn{3}{|c|}{ Média } & 1,055 \\
\hline \multicolumn{3}{|c|}{ Desvio Padrão } & 0,097 \\
\hline \multicolumn{3}{|c|}{ Coeficiente de variação } & $9,2 \%$ \\
\hline
\end{tabular}

(1) $F_{\text {exp }}$ : Força última da ligação obtida dos ensaios

(2) $F_{t, 1}$ : Força última da ligação obtida empregando o modelo de KANEKO (1992) modificado para incluir a influência da armadura.

* Valor não considerado no cálculo da média devido às falhas durante a execução do modelo

** Valor não considerado no cálculo da média devido à ruptura ter ocorrido na peça pré-moldada 


\subsubsection{Análise paramétrica do modelo de KANEKO (1992) modificado}

Foi realizado um estudo paramétrico no modelo de KANEKO (1992) modificado com o objetivo de verificar a influência das seguintes variáveis: largura da banda de fissuração $(h)$, resistência à tração do concreto $\left(f_{c t}\right)$ e energia de fratura $\left(G_{\mathrm{f}}\right)$. Para tanto, foram empregadas as características da ligação do corpo-de-prova CP13, ou seja, concreto com resistência à compressão de $54 \mathrm{MPa}$ e conector com $10 \mathrm{~mm}$ de diâmetro. Os demais valores adotados foram: $h=10 \mathrm{~mm}, f_{c t}=0,331 \sqrt{f_{c}}$ e $G_{f}=0,1 \mathrm{~N} / \mathrm{mm}$. Cada uma das variáveis foi alterada, mantendo as demais constantes, de modo a verificar sua influência sobre a resposta do modelo. Os resultados são discutidos a seguir, enquanto na Figura 5.11 são mostrados os gráficos para cada uma das variáveis:

- Largura da banda de fissuração (h)

Foram analisados três valores para a largura da banda de fissuração: $10 \mathrm{~mm}, 20$ $\mathrm{mm}$ e $40 \mathrm{~mm}$. Os resultados mostraram que o aumento de $h$ de $10 \mathrm{~mm}$ para $40 \mathrm{~mm}$ reduziu a resistência em, aproximadamente, 15\%. Com relação ao deslizamento correspondente ao pico de resistência $\left(\delta_{\mathrm{m}}\right)$, houve um aumento de, aproximadamente, $11 \%$.

- Resistência à tração do concreto $\left(f_{c t}\right)$

Foram analisados três valores para a resistência à tração do concreto: 2,43 MPa, 1,46 MPa e 0,97 MPa. Os resultados mostraram que a diminuição de $\mathrm{f}_{\mathrm{ct}}$ de 2,43 MPa para $0,97 \mathrm{MPa}$ reduziu a resistência em, aproximadamente, $12 \%$. Com relação ao deslizamento correspondente ao pico de resistência $\left(\delta_{\mathrm{m}}\right)$, houve um aumento de, aproximadamente, $17 \%$.

- Energia de fratura $\left(G_{f}\right)$

Foram analisados três valores para a Energia de fratura: 0,1 N/mm, 0,2 N/mm e 0,5 $\mathrm{N} / \mathrm{mm}$. Os resultados mostraram que o aumento de $G_{f}$ de $0,1 \mathrm{~N} / \mathrm{mm}$ para $0,5 \mathrm{~N} / \mathrm{mm}$ aumentou a resistência em, aproximadamente, 6\%. Com relação ao deslizamento correspondente ao pico de resistência $\left(\delta_{\mathrm{m}}\right)$, praticamente não houve alteração.

Dessa análise é possível observar que a resposta do modelo de KANEKO (1992), com as modificações efetuadas, é pouco influenciada pela variação destas variáveis. Isto mostra que mesmo com uma estimativa pouco precisa de seus valores, o modelo pode fornecer bons resultados no que diz respeito à avaliação da resistência da ligação com chave de cisalhamento e conector. 
$\mathrm{Na}$ Figura 5.11 também é mostrada a resposta do modelo quando a resistência à compressão do concreto é alterada. Foram analisados três valores: $54 \mathrm{MPa}, 65 \mathrm{MPa}$ e 80 $\mathrm{MPa}$. Os resultados mostraram que o aumento de $\mathrm{f}_{\mathrm{c}}$ de $54 \mathrm{MPa}$ para $80 \mathrm{MPa}$ aumentou a resistência em, aproximadamente, 28\%. Esse aumento foi alcançado acrescendo a resistência à compressão em 48\%. Para se obter aumento equivalente na resistência, só que alterando a resistência à tração do concreto, seria necessário aumenta-la em 168\%. Com relação ao deslizamento correspondente ao pico de resistência $\left(\delta_{m}\right)$, houve um aumento de, aproximadamente, $22 \%$ ao se aumentar a resistência à compressão do concreto. Esses resultados mostram, mais uma vez, que o comportamento da chave de cisalhamento é muito mais influenciado pela resistência à compressão que pela resistência à tração do concreto.

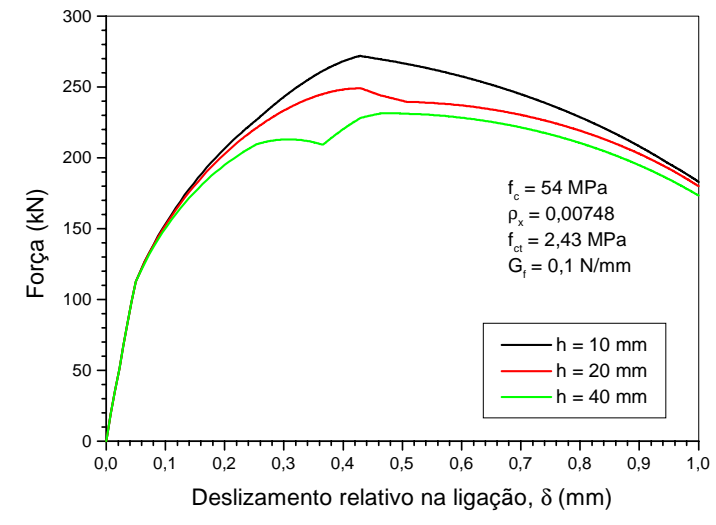

(a) $h$

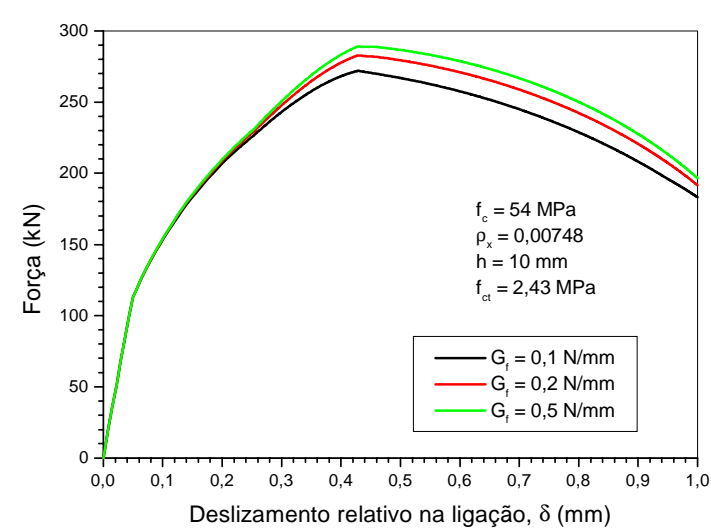

(c) $G_{f}$

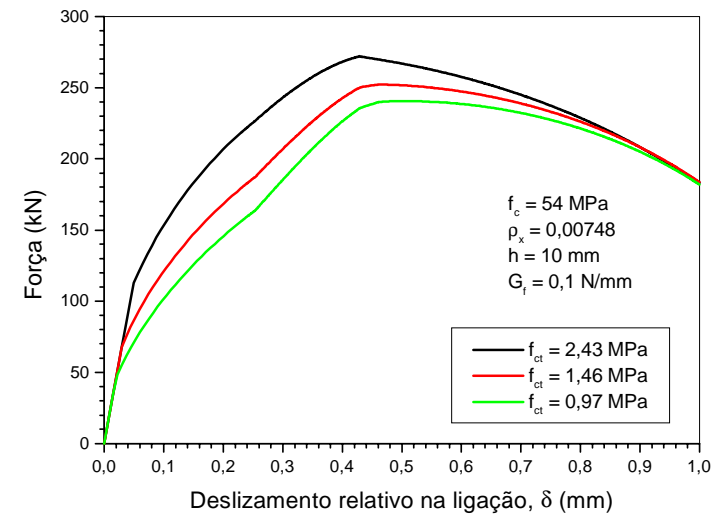

(b) $f_{c t}$

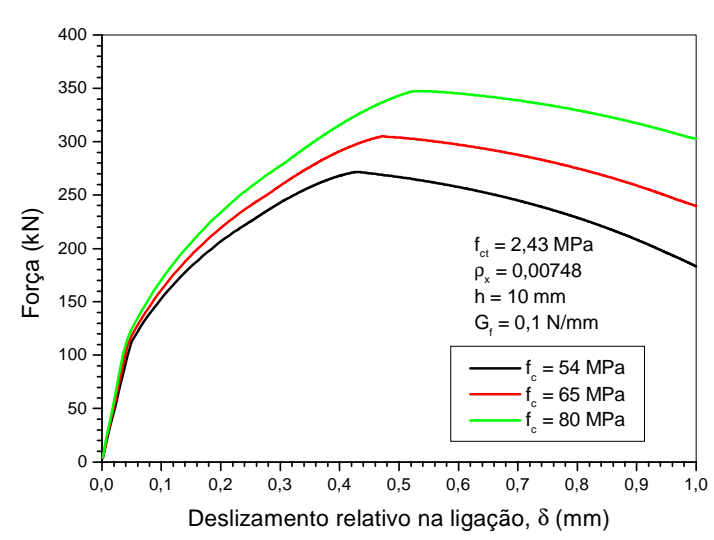

(d) $f_{c}$

Figura 5.11 - Análise paramétrica do modelo de KANEKO (1992) modificado 


\subsection{Avaliação pelo modelo de HSU et al. (1987)}

O modelo de HSU et al. (1987), apresentado no capítulo 2, foi empregado para avaliar o comportamento dos corpos-de-prova sem adição de fibras à ligação. Esse modelo é baseado na idéia da formação de inúmeras fissuras inclinadas no plano de cisalhamento, entre as quais formam-se bielas de compressão, que associadas com as armaduras paralela e normal ao plano de cisalhamento formam um mecanismo resistente aos esforços de cisalhamento.

A formulação desse modelo é idêntica à fase de fissuração distribuída do modelo de KANEKO (1992). A diferença básica reside na equação adicional que os autores propuseram para resolver o problema de existirem mais incógnitas que equações na formulação. Os autores admitiram que em um estágio avançado de carregamento, a formação de inúmeras fissuras concentradas no plano de cisalhamento diminuía a rigidez dessa região e tornavam as tensões uniformemente distribuídas nessa região. Sendo assim, era possível obter uma relação entre a tensão de cisalhamento, $\tau_{x y}$, e a tensão vertical devido à aplicação do carregamento, $\sigma_{y}$, a qual era definida pelo parâmetro $\mathrm{K}$ (Figura 2.17).

Para avaliação do parâmetro $\mathrm{K}$, definido na eq.(2.18), deveria ser empregada a largura da região crítica, $h_{c r}$, e não a largura do corpo-de-prova. Visando justificar essa simplificação, uma vez que é difícil definir o valor de $h_{c r}$, os autores variaram o valor de $K$ entre 1 e 2 e observaram que não houve grande alteração na resposta do modelo, que estava de acordo com os resultados experimentais de HOFBECK et al. (1969).

$\mathrm{Na}$ Figura 5.12 são mostradas fissuras típicas que surgiram na chave de cisalhamento próximo à ruptura da ligação. Observa-se uma semelhança entre esse panorama de fissuração e o admitido por HSU et al. (1987). Portanto, é de se esperar que esse modelo possa representar o comportamento da ligação com chave de cisalhamento.

Inicialmente, é necessária uma simplificação. Nesse modelo, as armaduras normais e paralelas ao plano de cisalhamento são consideradas uniformemente distribuídas na região crítica. No caso das chaves de cisalhamento com conector, isto não acontece. Portanto, para aplicação do modelo, o conector foi substituído por uma taxa de armadura normal ao plano de cisalhamento, sendo a taxa de armadura paralela ao plano tomada igual a zero. 


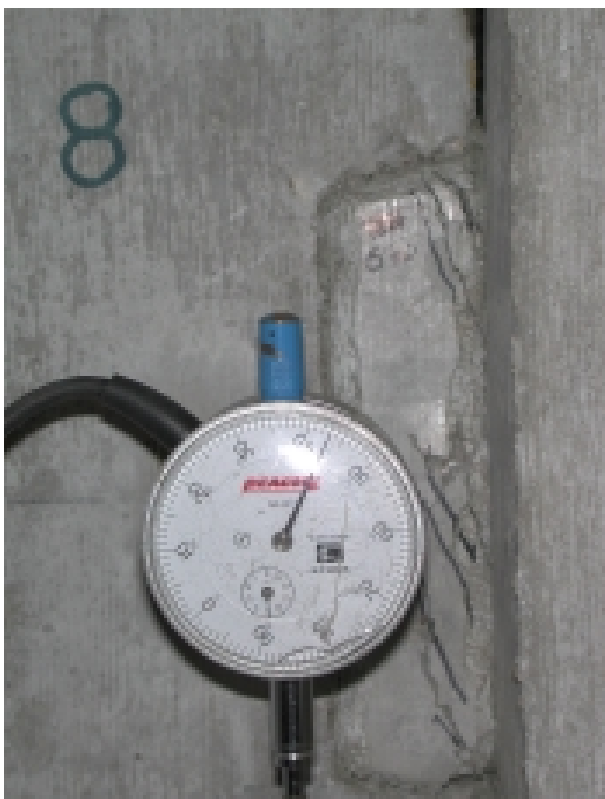

CP26

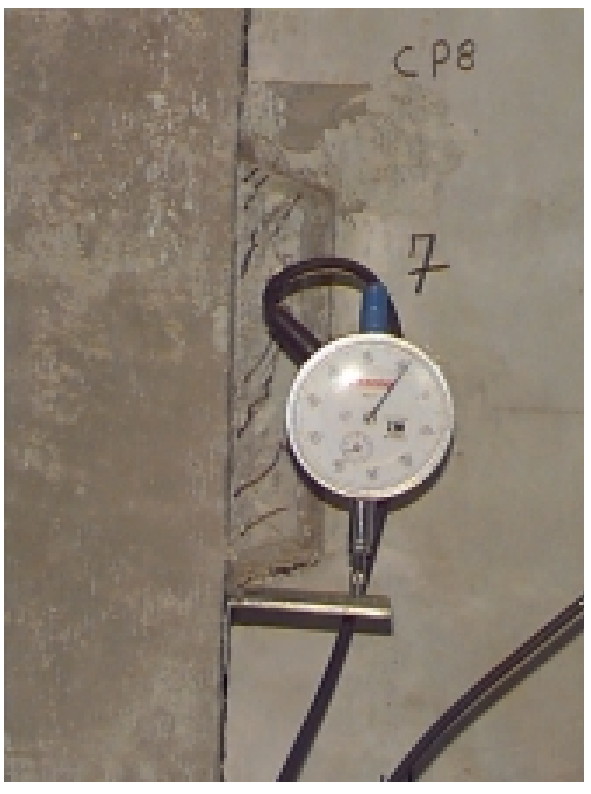

CP8

Figura 5.12 - Panorama de fissuração nas chaves de cisalhamento ensaiadas

Em primeira análise, tomou-se para $K$ o valor unitário. Após a aplicação do modelo aos ensaios de cisalhamento, observou-se que o valor obtido era muito inferior aos experimentais. Procurou-se, então, um valor para esse coeficiente de tal forma que o modelo conseguisse representar os resultados experimentais. Isto foi possível usando a análise numérica no programa ANSYS apresentada no capítulo anterior. Em cada etapa de carregamento, foram calculados os valores médios de $\sigma_{y}$ e $\tau_{x y}$ ao longo da base da chave, e a razão entre estes valores fornecia o valor de $K$ para um determinado carregamento. Repetindo o procedimento ao longa da história de carregamento, foi possível obter uma expressão analítica para o parâmetro $K$. Na Figura 5.13 é mostrada a relação obtida entre o

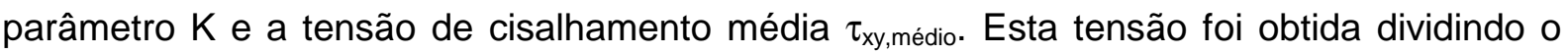
carregamento aplicado na chave $(F)$ pela área do plano de cisalhamento $(A)$.

Observa-se da Figura 5.13 que para carregamentos superiores a 50\% da resistência da chave, o coeficiente $K$ apresenta um valor aproximadamente constante e igual a 2,32. $\mathrm{Na}$ Tabela 5.7 são mostrados os resultados da aplicação do modelo de HSU et al. (1987) com este valor para o coeficiente $K$. Apenas os corpos-de-prova sem fibra na ligação foram analisados. A razão entre a força última obtida pelo modelo e os valores experimentais apresentou valor médio de 0,905 com desvio padrão de 0,140. Nessa tabela também são mostradas as forças obtidas adotando $K=3,5$. Neste caso, a razão entre as resistências apresentou valor médio de 1,036 com desvio padrão de 0,056. Com este último valor de $K$, o modelo representou com boa aproximação as forças últimas medidas nos ensaios. 
Com relação ao deslizamento na ligação, o modelo de HSU et al. (1987) também fornece resultados muito inferiores aos observados nos ensaios (Figura 5.14).

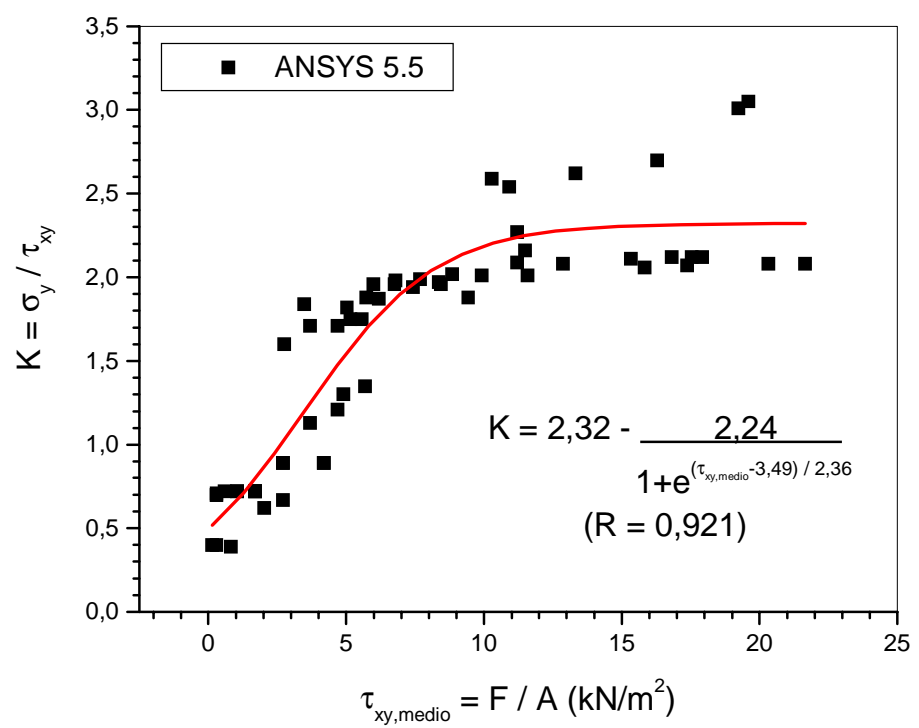

Figura 5.13 - Avaliação do coeficiente $K$ do modelo de HSU et al. (1987) através da simulação numérica

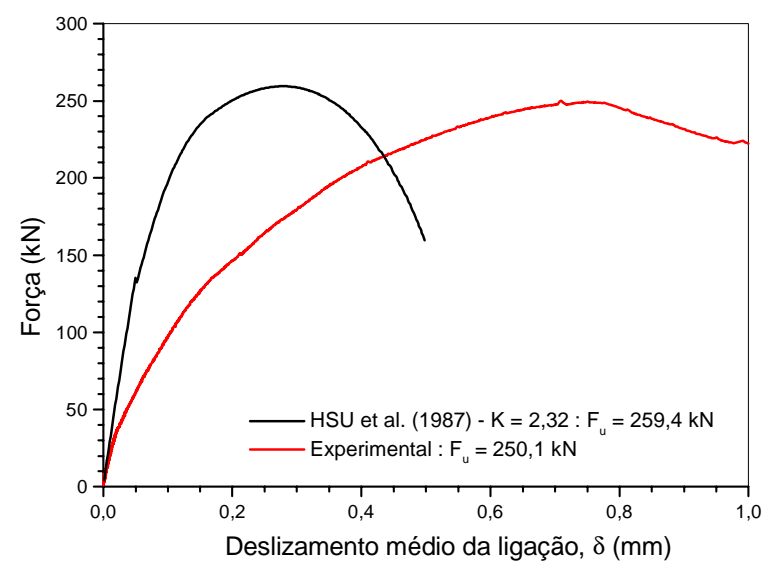

CP13

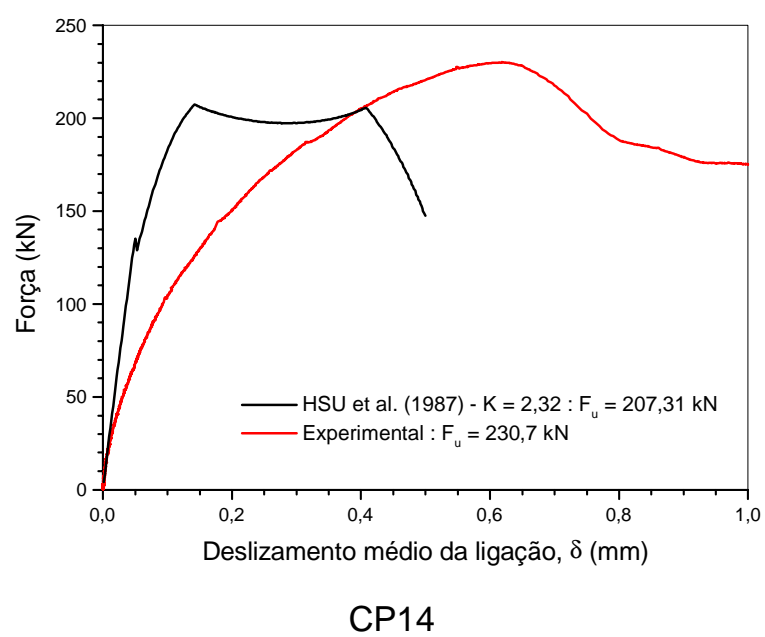

CP14

Figura 5.14 - Comparação entre o modelo de HSU et al. (1987) e os resultados experimentais 
Tabela 5.7 - Comparação entre a força última experimental e a obtida aplicando o modelo de HSU et al. (1987)

\begin{tabular}{|c|c|c|c|c|c|}
\hline Corpo-de-prova & $F_{\text {exp }}(\mathrm{kN})^{(1)}$ & $F_{\mathrm{t}, 1}(\mathrm{kN})^{(2)}$ & $\underline{F}_{\mathrm{t}, 1}$ & $F_{\mathrm{t}, 2}(\mathrm{kN})^{(3)}$ & $\underline{F}_{\mathrm{t}, 2}$ \\
\hline CP7 & 395,60 & 293,50 & $0,742^{*}$ & 278,12 & $0,703^{*}$ \\
\hline CP7A & 390,50 & 366,41 & $0,938^{*}$ & 351,88 & $0,901^{*}$ \\
\hline CP9 & 476,00 & 420,80 & $0,884^{*}$ & 423,99 & $0,891^{*}$ \\
\hline CP13 & 250,10 & 259,41 & 1,037 & 253,60 & 1,014 \\
\hline CP14 & 230,70 & 207,31 & 0,899 & 232,16 & 1,006 \\
\hline CP15 & 196,05 & 138,14 & 0,705 & 192,80 & 0,983 \\
\hline CP16 & 286,15 & 226,00 & 0,790 & 310,61 & 1,085 \\
\hline CP17 & 349,40 & 394,15 & 1,128 & 379,83 & 1,087 \\
\hline CP22 & 259,95 & 265,82 & 1,023 & 250,13 & 0,962 \\
\hline CP23 & 316,55 & 292,53 & 0,924 & 313,13 & 0,989 \\
\hline CP24 & 310,00 & 233,96 & 0,755 & 340,77 & 1,099 \\
\hline CP25 & 345,75 & 306,03 & 0,885 & 380,69 & 1,101 \\
\hline & Média & 0,905 & - & 1,036 \\
\hline Desvio Padrão & & $15,5 \%$ & - & $5,4 \%$ \\
\hline Coeficiente de variação & & & 0,056 \\
\hline
\end{tabular}

(1) $F_{\text {exp }}$ : Força última da ligação obtida dos ensaios

(2) $\mathrm{F}_{\mathrm{t}, 1}$ : Força última da ligação obtida por HSU et al. (1987) empregando $\mathrm{K}=2,32$

(3) $\mathrm{F}_{\mathrm{t}, 2}$ : Força última da ligação obtida por HSU et al. (1987) empregando $\mathrm{K}=3,50$

* Valor não considerado no cálculo da média devido às falhas durante a execução do modelo

\subsection{Alguns comentários sobre a aplicação dos modelos mecânicos}

Os modelos mecânicos de HSU et al. (1987) e KANEKO (1992) conseguiram representar, com relativa precisão, a resistência da ligação obtida experimentalmente. Contudo, eles falharam quanto à representação do deslizamento relativo da ligação. Alguns comentários são necessários para entendimento desse comportamento.

O modelo de KANEKO (1992), como desenvolvido originalmente pelo autor, foi o que forneceu os deslizamentos mais próximos dos experimentais. Isto se deve, principalmente, à primeira fase de fissuração, definida pela formação e propagação de uma fissura discreta. Além disso, na fase de fissuração distribuída, é admitido que a deformação principal de tração controla o processo de propagação das fissuras. O aspecto mais interessante desse modelo é a definição do coeficiente de Poisson aparente, que simplificou 
o processo de resolução do problema. Entretanto, da forma como o modelo foi formulado, ele não pôde ser aplicado aos corpos-de-prova com chave na ligação sem a inclusão de uma tensão normal ao plano de cisalhamento. O problema foi resolvido obtendo a tensão normal a partir da deformação axial do conector no instante da ruptura, sendo mantida constante ao longo do carregamento da chave. Obviamente, esta situação não representa o comportamento real da estrutura, no qual o conector é solicitado à medida que o carregamento aplicado aumenta. Outro problema foi a definição do comprimento da fissura discreta a partir do qual se iniciava a fase de fissuração distribuída. Nos ensaios realizados não foi possível observar a formação dessa fissura e muito menos medir seu comprimento. Dessa forma, a transição foi feita graficamente admitindo um comprimento máximo para a fissura discreta de $140 \mathrm{~mm}$. Novamente, essa consideração não parece fisicamente razoável.

Em seguida, o modelo de KANEKO (1992) foi ligeiramente alterado para incluir o efeito da armadura atravessando o plano de cisalhamento. Essa alteração já havia sido realizada pelo próprio autor em seu trabalho. Contudo, neste trabalho, foram realizadas algumas modificações, como a não consideração da redução da resistência à compressão do concreto das bielas comprimidas para o concreto reforçado com fibras, e a consideração que não mais a deformação principal de tração e sim a deformação principal de compressão controla o processo de propagação e ruptura da chave. Com essas alterações, os resultados do modelo se aproximaram mais dos experimentais que o modelo original de KANEKO (1992), principalmente para os corpos-de-prova com adição de fibras à ligação. $\mathrm{Na}$ Figura 5.15 é mostrada a comparação entre as forças experimental e teórica obtida pelo modelo de KANEKO (1992) modificado.

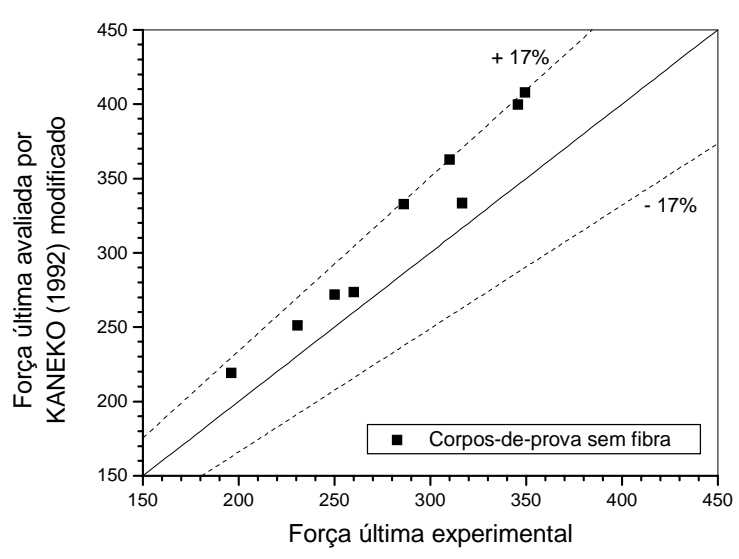

Corpos-de-prova sem fibras na ligação

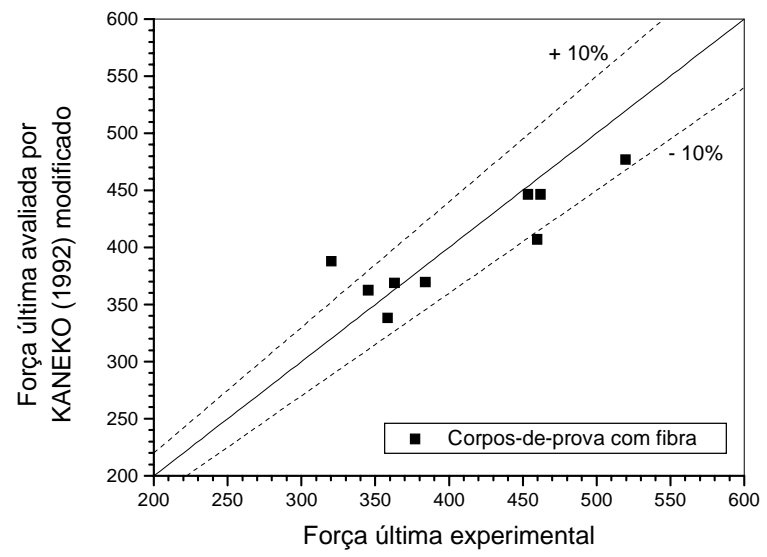

Corpos-de-prova com fibras na ligação

Figura 5.15 - Comparação entre a força última experimental e a obtida segundo o modelo de KANEKO (1992) modificado 
O modelo de HSU et al. (1987) foi aplicado aos ensaios sem adição de fibras à ligação. Basicamente, ele é idêntico à fase de fissuração distribuída do modelo de KANEKO (1992), diferindo apenas nas equações constitutivas do concreto e na introdução de um coeficiente $K$, usado para tornar o sistema de equações do problema determinado. Esse coeficiente foi definido pela razão entre as tensões verticais e de cisalhamento na região crítica e, segundo os autores, variava entre 1 e 2 . Nas análises realizadas pelos autores, foi verificada pequena influência desse coeficiente sobre a resistência final. No presente trabalho, contudo, o emprego desses valores forneceu resultados muito inferiores aos experimentais. Através da análise numérica, verificou-se que o coeficiente $K$ podia atingir valores superiores a 2 , sendo usado o valor de 2,32. Lembrando que esse coeficiente também foi definido pelos autores pela razão entre o comprimento do plano de cisalhamento e a largura do corpo-de-prova ensaiado, a adoção do valor 2,32 implica em admitir $\mathrm{h}=60 \mathrm{~mm}$. Dos ensaios de cisalhamento realizados, foi possível medir a semilargura da região fissurada junto à base da chave. A largura da região crítica $\left(h_{c r}\right)$, admitida igual a duas vezes esse valor, variou entre $25 \mathrm{~mm}$ e $40 \mathrm{~mm}$. Admitindo $h=h_{c r}$, coeficiente $K$ pode variar, então, entre 3,5 e 5,6. Fazendo $K$ variar dentre desse intervalo, não foi observada grande alteração no valor da resistência, sendo que a melhor concordância entre os resultados teóricos e experimentais foi obtida para $K=3,5$ (Figura 5.16). Desta breve discussão, pode-se concluir que não é possível definir um valor único para o coeficiente $K$, que deve ser função da geometria da estrutura. Por exemplo, para os corpos-de-prova de cisalhamento em "S" usados por HOFBECK et al. (1969), K varia entre 1 e 2, enquanto para os corpos-de-prova empregados neste trabalho, com chave de cisalhamento, $\mathrm{K}$ varia entre 2,3 e 5 .

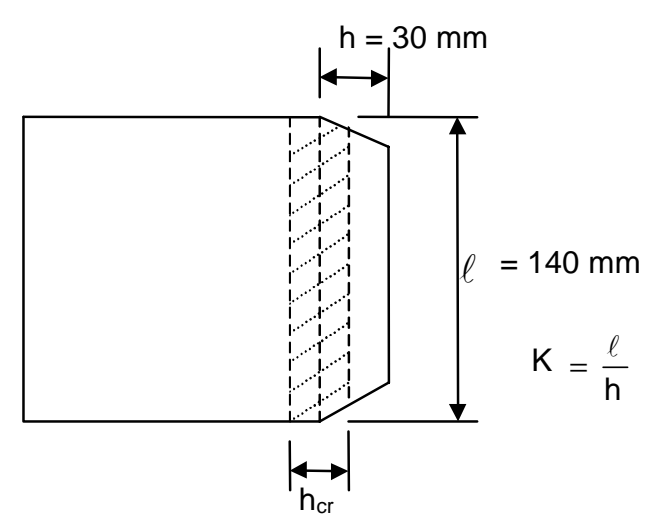

Largura da região crítica $\left(\mathrm{h}_{\mathrm{cr}}\right)$ na chave de cisalhamento

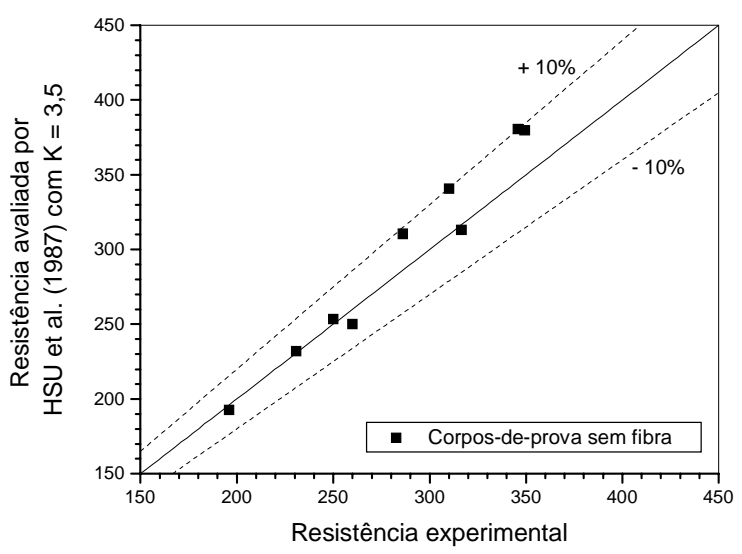

Figura 5.16 - Comparação entre a resistência experimental e a obtida segundo o modelo de HSU et al. (1987) nos corpos-de-prova sem fibras 
Outro ponto interessante a ser observado é o fato dos modelos com controle da deformação principal de compressão melhor representarem a resistência da ligação. Isto ajuda a explicar o fato da adição de fibras aumentar o deslizamento relativo da ligação. Como as fibras tendem a aumentar o valor da deformação limite do concreto, $\varepsilon_{c, l i m}$, isto acarreta, de acordo com os modelos mecânicos, em um aumento do deslizamento relativo da chave para o mesmo nível de carregamento.

Apesar dos modelos mecânicos terem representado bem a resistência da ligação, eles não foram capazes de representar o deslizamento da ligação. Uma das razões para essa divergência é o fato de que os deslizamentos obtidos dos modelos referem-se apenas ao deslocamento da chave de cisalhamento, medido na sua extremidade, enquanto os valores experimentais referem-se ao deslocamento relativo entre as peças pré-moldadas na altura da ligação. Dessa forma, além do deslocamento da chave outros deslocamentos estão incluídos na leitura. Isto pode ser confirmado ao se observar que a melhor aproximação entre os resultados fornecidos pelos modelos e os resultados experimentais ocorreu para o corpo-de-prova CP15, sem conector na ligação e com adesivo epóxi entre a chave e a peça central pré-moldada. A forma de ruptura desse corpo-de-prova será analisada posteriormente. Por enquanto, cabem algumas considerações sobre a maneira como foram obtidos os deslizamentos nos ensaios.

O deslizamento da ligação foi obtido empregando transdutores fixados à peça central pré-moldada e com a haste apoiada em cantoneiras coladas à peça lateral. Dessa forma, o deslocamento medido refere-se ao deslizamento relativo entre as peças prémoldadas na região da ligação. Com o aumento do carregamento na peça central, junto com a fissuração da chave ocorreu a ruptura da aderência entre a chave de cisalhamento e a peça pré-moldada, o que pode ter provocado um pequeno deslizamento relativo entre a peça central e a chave que não foi possível medir. Observou-se dos ensaios, contudo, que esta ruptura ficou restrita à região inferior da chave, não alcançando o conector. Além disso, a inclinação das faces da chave era pequena justamente para evitar a ruptura por deslizamento (Figura 5.17). Desse modo, o acréscimo na leitura dos deslizamentos pode ser admitido pequeno, sendo, portanto, desconsiderado.

A transferência de esforços para a chave de cisalhamento era garantida pela peça central, que, todavia, se deformava por compressão. Como o transdutor foi colado na peça central, na metade da altura da ligação, há um acréscimo nas leituras devido à deformação da peça central logo acima da chave. Esse acréscimo tende a ser tanto maior quanto maior for a diferença entre as resistências à compressão do concreto da chave e do concreto das peças pré-moldadas. Na Figura 5.18 é mostrada uma forma de estimar o acréscimo nas 
leituras devido à deformação da peça central. As forças aplicadas nos corpos-de-prova variaram entre 452 kN e 1100 kN. Admitindo um módulo de elasticidade médio para o concreto pré-moldado de $33 \mathrm{GPa}$, pode-se estimar a valor do acréscimo entre $0,08 \mathrm{~mm}$ e $0,24 \mathrm{~mm}$, o que representa, no máximo, $15 \%$ dos deslizamentos medidos. Mesmo descontando dos deslizamentos médios esta quantidade, os valores experimentais ainda são superiores aos fornecidos pelos modelos mecânicos.

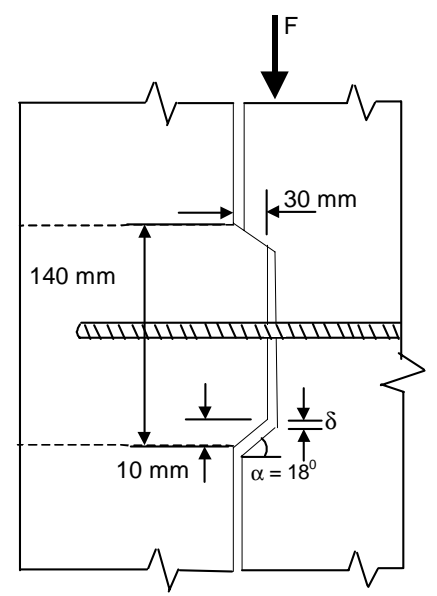

Figura 5.17 - Deslizamento por ruptura da aderência entre a chave de cisalhamento e a peça pré-moldada

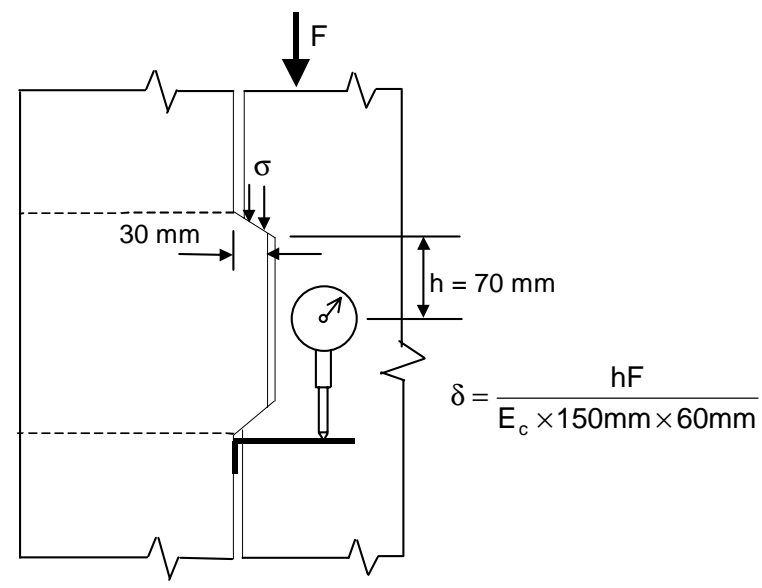

Avaliação do deslizamento devido à deformação da peça pré-moldada na região da ligação

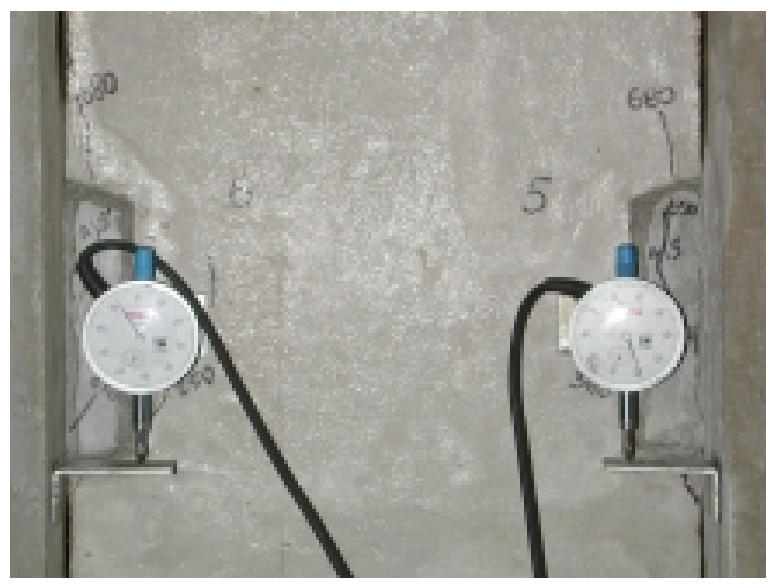

Fissuração na peça pré-moldada antes da ruptura da ligação - CP25

Figura 5.18 - Deslizamento devido à deformação da peça pré-moldada na região da ligação

Outro aspecto que influenciou os deslizamentos fornecidos pelos modelos mecânicos é que nesses modelos a armadura normal ao plano de cisalhamento foi considerada uniformemente distribuída, o que, obviamente, está distante da realidade da 
ligação. Esses modelos assim procedem porque eles derivam de ensaios realizados em painéis de concreto, submetidos a estados planos de tensão, com armadura em forma de malha nas duas direções. Dessa forma, os deslizamentos naturalmente são menores que os obtidos nos ensaios.

Na Figura 5.19 é mostrada a curva que relaciona a força resistida pela ligação com o deslizamento relativo entre as peças pré-moldadas para o corpo-de-prova CP15 sem conector. Como nessa ligação havia um adesivo epóxi entre a chave e a peça pré-moldada, a leitura dos transdutores representa realmente o deslocamento da chave de cisalhamento. Nesta mesma figura também é mostrado o panorama de fissuração da ligação próximo à ruptura. Observa-se que em um nível intermediário de carregamento, antes da ligação atingir a ruptura, houve uma pequena queda de resistência logo recuperada. Isto provavelmente aconteceu pelo deslizamento relativo no plano da fissura principal que surgiu na chave de cisalhamento. Com o aumento do carregamento, surgiram outras fissuras na chave de cisalhamento que resultaram no esgotamento da capacidade resistente da ligação.
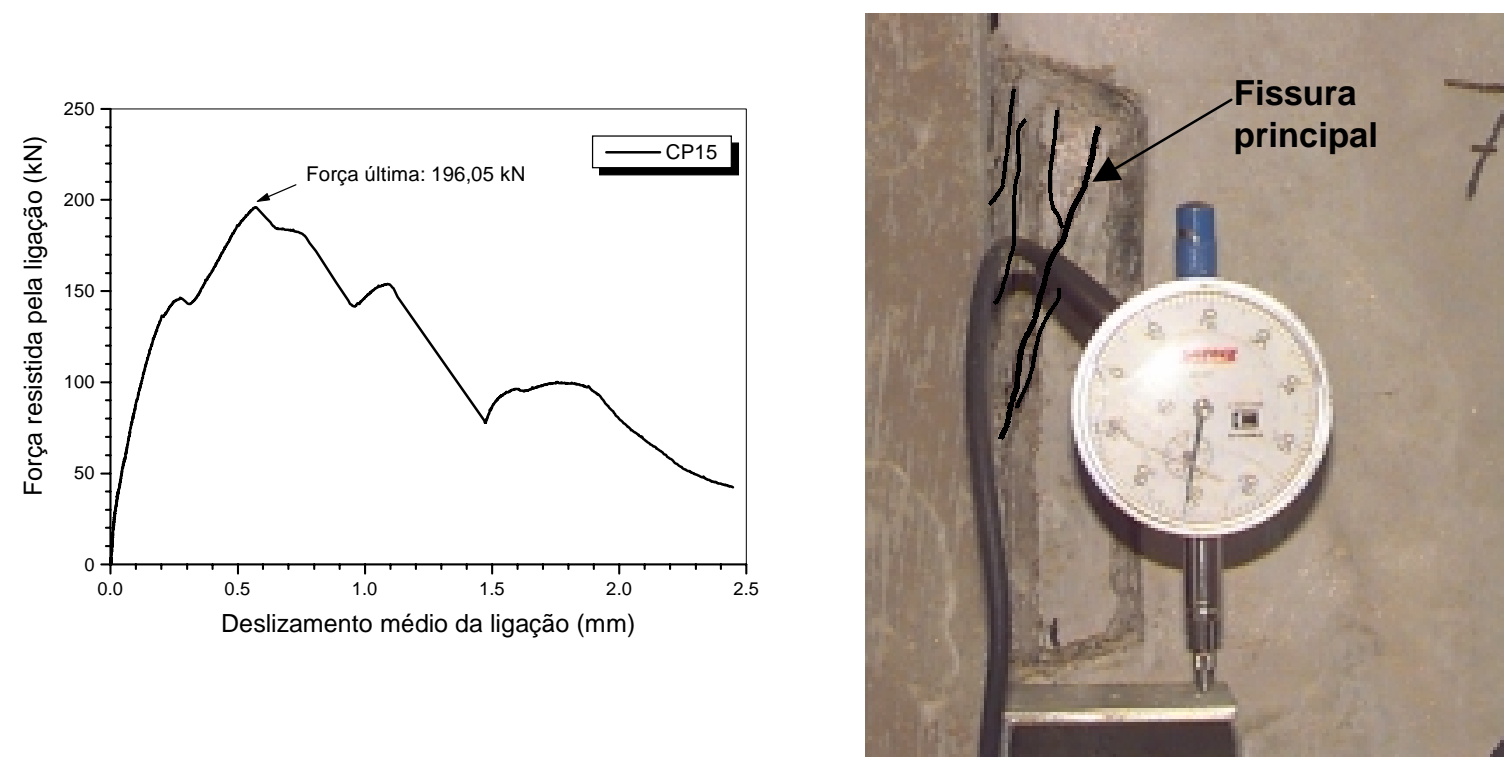

Figura 5.19 - Resultados do corpo-de-prova CP15 ensaiado sem conector

No item 2.1.1 foram mostrados alguns modelos mecânicos desenvolvidos para a representação do comportamento das estruturas com baixa taxa de armadura. A principal diferença desses modelos para os empregados neste capítulo é a consideração do deslizamento no plano da fissura, o que proporciona um aumento na avaliação das deformações das estruturas com baixa taxa de armadura. Dessa forma, esses modelos poderiam melhor representar os deslizamentos das ligações com chave de cisalhamento. 
Contudo o equilíbrio local de tensões na fissura é garantido pelo aumento da tensão na armadura que atravessa o plano da fissura. Sendo assim, eles não podem ser aplicados diretamente à chave de cisalhamento, necessitando de alterações que garantam a transferência de esforços normais à fissura mesmo sem a existência de armadura. Além disso, eles somente são aplicáveis empregando uma ferramenta numérica, como o método dos elementos finitos. Como este assunto foge ao escopo deste trabalho, fica como sugestão para futuros trabalhos a aplicação desses modelos às ligações com chave de cisalhamento e conector.

\subsection{Proposta de um modelo analítico para as chaves de cisalhamento com conector}

Neste item é apresentada um modelo diferente para avaliar o comportamento da ligação com chave de cisalhamento e conector, tomando como base o modelo mecânico desenvolvido por KANEKO (1992). A idéia fundamental desse modelo reside no tratamento separado do concreto e do conector, ou seja, é calculada uma parcela resistente devido apenas ao concreto que é somada com a parcela resistente devido à ação de pino do conector. Dessa forma, o conector não é mais substituído por uma armadura uniformemente distribuída como nos modelos anteriores, sendo sua contribuição calculada separadamente e somada à resistência proporcionada pelo concreto à medida que a ligação se deforma.

\subsubsection{Ação de pino do conector}

A influência do conector no comportamento da ligação pode ser avaliada observando os resultados dos ensaios dos corpos-de-prova CP13, CP14, CP15 e CP22, que estão mostrados na Figura 5.20. Nesses corpos-de-prova, a resistência à compressão do concreto moldado no nicho era praticamente igual em todos eles. Observa-se, nitidamente, que à medida que o diâmetro do conector foi aumentado, também aumentaram a resistência e o deslizamento da ligação. Contudo, a forma da curva, antes da ruptura, foi a mesma em todos os ensaios.

Desses resultados, foi possível obter uma expressão que representasse a ação de pino da armadura. Admitindo que a parcela resistente da ligação devido apenas ao concreto possa ser representada pela resistência do corpo-de-prova CP15, a parcela resistente devido à ação de pino do conector pode ser avaliada subtraindo das resistências alcançadas pelos demais corpos-de-prova a resistência devido ao concreto. Na Figura 5.21 é mostrada a relação entre os valores calculados dessa forma e o quadrado do diâmetro do conector. Realizando uma regressão linear neste gráfico, chegou-se à seguinte expressão: 


$$
F_{d, u}=1,368 \phi_{s}^{2} \sqrt{f_{c m} f_{y}}(N)(R=0,98)
$$

sendo $f_{c m}$ e $f_{y}$ em MPa e $\phi_{s}$ em mm

Essa expressão é muito semelhante à encontrada por VINTZELEOU; TASSIOS (1987), $F_{d, u}=1,3 \cdot \phi_{s}{ }^{2} \cdot \sqrt{f_{c} f_{y}}$, o que justifica sua aplicação, apesar do reduzido número de ensaios.

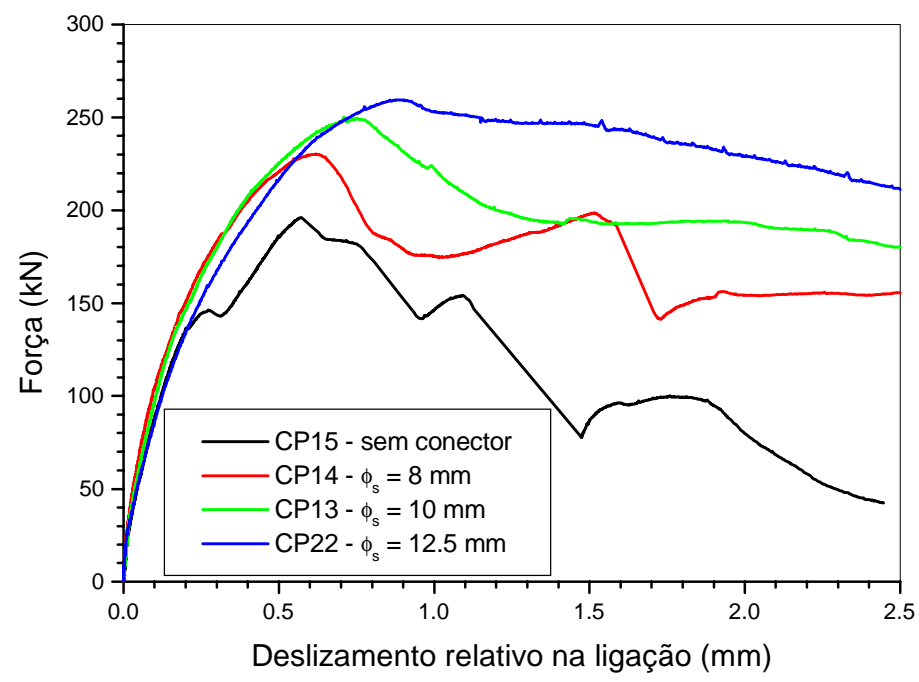

Figura 5.20 - Influência do conector no comportamento da ligação com chave de cisalhamento

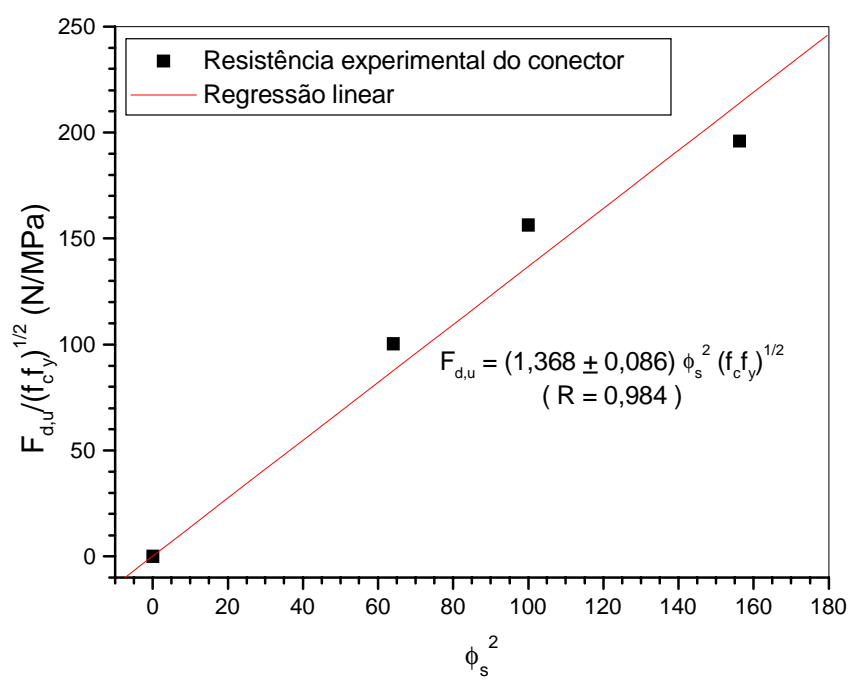

Figura 5.21 - Resistência do conector, por ação de pino da armadura, obtida dos ensaios de cisalhamento direto 
A relação entre a força e o deslocamento da armadura na direção transversal foi obtido do trabalho de SOROUSHIAN et al. (1986). A força resistida pela armadura e seu respectivo deslocamento são função da força última, $F_{d, u}$, e do deslocamento último, $\delta_{d, u} \cdot A$ partir da observação de vários ensaios, os autores sugeriram a seguinte expressão para avaliar o deslocamento último:

$$
\delta_{\mathrm{d}, \mathrm{u}}=2,43 \times 10^{-5} \mathrm{~F}_{\mathrm{d}, \mathrm{u}}+0,24(\mathrm{~mm})
$$

sendo $F_{d, u}$ em N.

A relação entre a força aplicada e o deslocamento da armadura na direção transversal é definido como:

$$
\begin{aligned}
& \mathrm{F}_{\mathrm{d}}=\mathrm{F}_{\mathrm{d}, \mathrm{u}}\left(\frac{\delta_{\mathrm{d}}}{\delta_{\mathrm{d}, \mathrm{u}}}\right)^{0,5} \text { para } \delta_{\mathrm{d}} \leq \delta_{\mathrm{d}, \mathrm{u}} \\
& \mathrm{F}_{\mathrm{d}}=\mathrm{F}_{\mathrm{d}, \mathrm{u}}-\frac{\mathrm{F}_{\mathrm{d}, \mathrm{u}}\left(\delta_{\mathrm{d}}-\delta_{\mathrm{d}, \mathrm{u}}\right)}{\frac{258,06}{\phi_{\mathrm{s}}}-\delta_{\mathrm{d}, \mathrm{u}}} \geq 0,4 \mathrm{~F}_{\mathrm{d}, \mathrm{u}} \text { para } \delta_{\mathrm{d}}>\delta_{\mathrm{d}, \mathrm{u}}
\end{aligned}
$$

\subsubsection{Curva força-deslizamento para o concreto}

A parcela resistente do concreto foi avaliada empregando o modelo de KANEKO (1992) com a modificação apresentada no item 5.3. Neste caso, contudo, foi desconsiderada a existência de armadura transversal ao plano de cisalhamento, uma vez que a parcela resistente devido ao conector foi avaliada pela ação de pino da armadura. As equações constitutivas dos materiais também foram modificadas. Na compressão uniaxial, foi empregada a expressão empírica deduzida no item 3.3, e na tração uniaxial foi empregada uma curva trilinear apresentada por BARROS (1995) para representar o comportamento do concreto com fibras. A seguir são mostradas as expressões empregadas:

Compressão uniaxial:

$$
\sigma_{c}=\frac{f_{c}}{\lambda} \frac{k_{1} \beta \frac{\varepsilon_{c}}{\varepsilon_{c, l i m}}}{k_{1} \beta-1+\left(\frac{\varepsilon_{c}}{\varepsilon_{c, l i m}}\right)^{k_{2} \beta}}
$$




$$
\begin{aligned}
& \lambda=\sqrt{1,3-\frac{\varepsilon_{t}}{\varepsilon_{c}}} \\
& \beta=\frac{1}{1-\frac{f_{c}}{\varepsilon_{c, l i m} E_{c}}} \\
& E_{c}=4576 \sqrt{f_{c}}(M P a) \\
& \varepsilon_{c, \lim }=0,001446 f_{c}^{0,114}+\frac{0,0271 V_{f}^{1,5269}}{f_{c}}
\end{aligned}
$$

Ramo ascendente: $\quad \mathrm{K}_{1}=\mathrm{K}_{2}=1$, se $0<\left|\varepsilon_{\mathrm{c}}\right| \leq \varepsilon_{\mathrm{c}, \mathrm{lim}}$

Ramo descendente: $\quad\left|\varepsilon_{\mathrm{c}}\right|>\varepsilon_{\mathrm{c}, \text { lim }}$

$$
\begin{aligned}
& \mathrm{K}_{1}=8,241 \mathrm{f}_{\mathrm{c}}^{-0,593}, \mathrm{~V}_{\mathrm{f}}=0 \% \\
& \mathrm{~K}_{1}=478,608 \mathrm{f}_{\mathrm{c}}^{-1,593} \mathrm{~V}_{\mathrm{f}}^{0,6577}, 0,75 \% \leq \mathrm{V}_{\mathrm{f}} \leq 2 \% \\
& \mathrm{~K}_{2}=22,500 \mathrm{f}_{\mathrm{c}}{ }^{-0,775}, \mathrm{~V}_{\mathrm{f}}=0 \% \\
& \mathrm{~K}_{2}=34,513 \mathrm{f}_{\mathrm{c}}{ }^{-0,925} \mathrm{~V}_{\mathrm{f}}^{0,368}, 0,75 \% \leq \mathrm{V}_{\mathrm{f}} \leq 2 \%
\end{aligned}
$$

Tração uniaxial:

Concreto simples:

$$
\begin{aligned}
& \sigma_{\mathrm{t}}=\varepsilon_{\mathrm{t}} \mathrm{E}_{\mathrm{c}}, \text { se } 0<\varepsilon_{\mathrm{t}} \leq \varepsilon_{\mathrm{cr}} \\
& \sigma_{\mathrm{t}}=\mathrm{f}_{\mathrm{ct}} \frac{\varepsilon_{\mathrm{tu} 1}-\frac{\varepsilon_{\mathrm{cr}}}{3}-\frac{2}{3} \varepsilon_{\mathrm{t}}}{\varepsilon_{\mathrm{tu} 1}-\varepsilon_{\mathrm{cr}}}, \text { se } \varepsilon_{\mathrm{cr}}<\varepsilon_{\mathrm{t}} \leq \varepsilon_{\mathrm{tu} 1} \\
& \sigma_{\mathrm{t}}=\frac{\mathrm{f} \mathrm{ct}}{3} \frac{\varepsilon_{\mathrm{tu} 2}-\varepsilon_{\mathrm{t}}}{\varepsilon_{\mathrm{tu} 2}-\varepsilon_{\mathrm{tu} 1}}, \text { se } \varepsilon_{\mathrm{tu} 1}<\varepsilon_{\mathrm{t}} \leq \varepsilon_{\mathrm{tu} 2} \\
& \sigma_{\mathrm{t}}=0 \mathrm{se} \varepsilon_{\mathrm{t}}>\varepsilon_{\mathrm{tu} 2} \\
& \varepsilon_{\mathrm{cr}}=\frac{\mathrm{f}_{\mathrm{ct}}}{\mathrm{E}_{\mathrm{c}}}, \varepsilon_{\mathrm{tu} 1}=\varepsilon_{\mathrm{cr}}+\frac{4 \mathrm{G}_{\mathrm{f}}}{5 \mathrm{f}_{\mathrm{ct}} \mathrm{h}}, \varepsilon_{\mathrm{tu} 2}=\varepsilon_{\mathrm{cr}}+\frac{18 \mathrm{G}_{\mathrm{f}}}{5 \mathrm{f}_{\mathrm{ct}} \mathrm{h}} \\
& \mathrm{f}_{\mathrm{ct}}=0,332 \sqrt{\mathrm{f}_{\mathrm{c}}}
\end{aligned}
$$


Concreto reforçado com fibras (Figura 5.22):

$$
\begin{aligned}
\varepsilon_{\mathrm{tu}} & =\mathrm{k}_{4} \frac{\mathrm{G}_{\mathrm{f}}}{\mathrm{f}_{\mathrm{ct}} \mathrm{h}} \\
\mathrm{k}_{4} & =\frac{2}{\xi_{1}+\alpha_{1} \xi_{2}-\alpha_{2} \xi_{1}+\alpha_{2}} \\
\mathrm{f}_{\mathrm{ct}} & =0,332 \sqrt{\mathrm{f}_{\mathrm{c}}}
\end{aligned}
$$

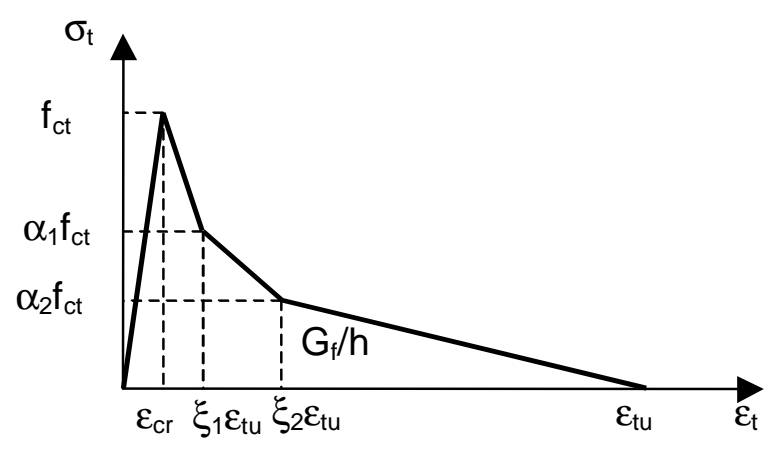

Figura 5.22 - Curva trilinear para representação do concreto à tração

A curva à tração uniaxial do concreto simples é a mesma apresentada no modelo original de KANEKO (1992). Para o concreto reforçado com fibras, optou-se pela curva trilinear apresentada por BARROS (1995), uma vez que ela apresenta um ramo descendente mais próximo da realidade que a curva mostrada no modelo original de KANEKO (1992). Os valores dos parâmetros necessários para a representação do concreto com fibra foram definidos por BARROS (1995) a partir de simulações numéricas em prismas entalhados e submetidos a três pontos de carga,: $\alpha_{1}=0,6, \alpha_{2}=0,2, \xi_{1}=0,004$ e $\xi_{2}=0,35$. Esses valores foram obtidos para concretos reforçados com $60 \mathrm{~kg} / \mathrm{m}^{3}$ de fibras DRAMIX com $30 \mathrm{~mm}$ de comprimento e fator de forma igual a 60. A energia de fratura, $G_{f}$, na curva trilinear é a energia do concreto reforçado com fibras, ao contrário da curva do modelo de KANEKO (1992) na qual a energia empregada refere-se à energia de fratura do concreto simples. No modelo de KANEKO (1992), para caracterizar o concreto com fibras, era necessário o conhecimento da tensão de arrancamento das fibras, valor nem sempre disponível. A energia de fratura do concreto reforçado com fibras, por outro lado, pode ser facilmente obtida a partir da energia de fratura do concreto simples empregando a eq.(3.6) apresentada no capítulo 3. A energia de fratura do concreto simples, por sua vez, pode ser obtida das recomendações do CEB-FIP MC90 (FIB (1999)), por exemplo. 
A largura da região fissurada, definida pelo parâmetro $h$, é de difícil determinação. Nas análises aqui apresentadas, foi empregado o valor de $10 \mathrm{~mm}$.

\subsubsection{Procedimento de solução}

O procedimento de solução pode ser resumido da seguinte forma: (1) escolher um valor para $\varepsilon_{\mathrm{c}}$; (2) calcular $v_{\mathrm{a}}$ a partir do valor de $\varepsilon_{\mathrm{c}}$ calculado no passo anterior ou assumir $v_{\mathrm{a}}$ $=0,2$ no primeiro passo de cálculo (ver item 2.2.1); (3) calcular $\varepsilon_{\mathrm{t}}$ de $v_{\mathrm{a}}=\varepsilon_{\mathrm{t}} / \varepsilon_{\mathrm{c}} ;$ (4) calcular $\lambda$; (5) calcular $\sigma_{\mathrm{t}}$ e $\sigma_{\mathrm{c}}$ a partir do modelo constitutivo do material; (6) obter $\theta$ a partir das equações de equlíbrio com $\sigma_{x}$ conhecido; (7) calcular $\tau_{x y}, \varepsilon_{y}, \gamma_{x y}$ a partir das equações de equilíbrio e das equações de compatibilidade de deformações; (8) escolher um novo valor para $\varepsilon_{\mathrm{c}}$ e repetir o processo. Esse procedimento fornece a resistência proporcionada apenas pelo concreto. Sendo assim, a esse valor somar a resistência devido à ação de pino do conector, que fornecerá a resistência da ligação.

Não foi possível incorporar diretamente o conector no processo incremental usado para obter a parcela resistente do concreto. Em primeira análise, tentou-se resolver o problema admitindo que o deslocamento do conector fosse igual ao deslocamento relativo da chave de cisalhamento. Por esse procedimento, para cada valor adotado para $\varepsilon_{\mathrm{c}}$, calculou-se o deslocamento da chave, $\delta$, que era introduzido na expressão da ação de pino da armadura para obter a resistência do conector. A resistência da ligação era, então, definida pela soma da resistência do concreto com a resistência do conector $\left(F=\tau_{x y} \cdot A_{c}+\right.$ 2. $\left.F_{d}\right)$. Empregando esse procedimento, contudo, a resistência da ligação foi inferior ao valor experimental, uma vez que a parcela resistente do concreto era atingida sempre antes do conector atingir a sua resistência última. Por esta razão, não foi definida uma curva forçadeslizamento para esse modelo. Apenas sugere-se que a resistência da ligação seja avaliada pela soma das parcelas resistentes do concreto e da ação de pino do conector, enquanto o deslizamento da ligação na ruptura foi admitido igual ao deslocamento último do conector $\delta_{\mathrm{d}, \mathrm{u}}$. Novos estudos ainda necessitam serem realizados de modo a melhor esclarecer o trabalho conjunto da chave de cisalhamento com o conector.

\subsubsection{Verificação do modelo}

Este modelo foi aplicado aos corpos-de-prova de cisalhamento direto de modo a verificar sua viabilidade. Na Tabela 5.8 são mostradas a força última e o deslizamento na ruptura obtidos. 
Tabela 5.8 - Comparação entre os resultados obtidos pela aplicação do modelo analítico proposto e os valores experimentais

\begin{tabular}{|c|c|c|c|c|c|c|}
\hline $\begin{array}{c}\text { Corpo-de- } \\
\text { prova }\end{array}$ & $\mathrm{F}_{\exp }(\mathrm{kN})^{(1)}$ & $\mathrm{F}_{\mathrm{t}, 1}(\mathrm{kN})^{(2)}$ & $\underline{\mathrm{F}}_{\mathrm{t}, 1}$ & $\delta_{\exp }(k N)^{(3)}$ & $\delta_{\mathrm{t}, 1}(\mathrm{kN})^{(4)}$ & $\underline{\delta}_{t, 1}$ \\
\hline CP13 & 250,10 & 241,03 & 0,964 & 0,75 & 0,81 & 1,080 \\
\hline CP14 & 230,70 & 224,01 & 0,971 & 0,62 & 0,61 & 0,984 \\
\hline CP15 & 196,05 & 196,57 & 1,002 & 0,57 & 0,26 & 0,456 \\
\hline CP16 & 286,15 & 302,22 & 1,056 & 0,76 & 0,70 & 0,921 \\
\hline CP17 & 349,40 & 356,56 & 1,020 & 0,99 & 1,36 & 1,374 \\
\hline CP22 & 259,95 & 247,73 & 0,953 & 0,90 & 1,09 & 1,211 \\
\hline CP23 & 316,55 & 294,75 & 0,931 & 0,89 & 0,91 & 1,022 \\
\hline CP24 & 310,00 & 330,38 & 1,066 & 0,96 & 0,73 & 0,760 \\
\hline CP25 & 345,75 & 353,17 & 1,021 & 1,08 & 1,01 & 0,935 \\
\hline \multirow{3}{*}{$V_{f}=0 \%$} & \multicolumn{2}{|c|}{ Média } & 0,998 & & & 0,971 \\
\hline & \multicolumn{2}{|c|}{ Desvio Padrão } & 0,047 & & & 0,262 \\
\hline & \multicolumn{2}{|c|}{ Coeficiente de variação } & $4,7 \%$ & & & $27,0 \%$ \\
\hline CP8 & 358,30 & 279,84 & 0,781 & 1,81 & 1,15 & 0,635 \\
\hline CP11 & 461,90 & 347,08 & 0,751 & 1,43 & 1,34 & 0,937 \\
\hline CP18 & 320,10 & 310,73 & 0,971 & 0,96 & 0,71 & 0,740 \\
\hline CP19 & 519,50 & 366,60 & 0,706 & 1,19 & 1,39 & 1,168 \\
\hline CP20 & 345,30 & 302,86 & 0,877 & 1,15 & 0,69 & 0,600 \\
\hline CP21 & 459,55 & 329,78 & 0,718 & 1,32 & 1,27 & 0,962 \\
\hline CP26 & 363,10 & 290,63 & 0,800 & 0,93 & 0,90 & 0,968 \\
\hline CP27 & 383,85 & 301,27 & 0,785 & 1,12 & 0,90 & 0,804 \\
\hline \multirow{3}{*}{$V_{f}>0 \%$} & \multicolumn{2}{|c|}{ Média } & 0,799 & & & 0,852 \\
\hline & \multicolumn{2}{|c|}{ Desvio Padrão } & 0,088 & & & 0,192 \\
\hline & \multicolumn{2}{|c|}{ Coeficiente de variação } & $11,0 \%$ & & & $22,5 \%$ \\
\hline
\end{tabular}

(1) $F_{\text {exp }}$ : Força última da ligação obtida dos ensaios

(2) $\mathrm{F}_{\mathrm{t}, 1}$ : Força última da ligação obtida segundo o modelo analítico proposto.

(3) $\delta_{\text {exp }}$ : deslizamento relativo na ruptura da ligação obtida dos ensaios

(2) $\delta_{t, 1}$ : deslizamento relativo na ruptura da ligação obtida segundo o modelo analítico proposto 
A razão entre a força última obtida pelo modelo e os valores experimentais, para os corpos-de-prova sem adição de fibras, apresentou valor médio de 0,998 com desvio padrão de 0,047 . No caso dos ensaios com adição de fibras à ligação, esta mesma razão apresentou valor médio de 0,799 com desvio padrão de 0,088.

A razão entre os deslizamentos obtidos pelo modelo e os valores experimentais, para os corpos-de-prova sem adição de fibras, apresentou valor médio de 0,971 com desvio padrão de 0,262 . No caso dos ensaios com adição de fibras à ligação, esta mesma razão apresentou valor médio de 0,852 com desvio padrão de 0,192.

Desses resultados, é possível afirmar que o modelo analítico proposto conseguiu avaliar com relativa precisão a resistência da ligação sem fibras. Com relação ao deslizamento na ruptura, em média o modelo conseguiu se aproximar dos resultados experimentais. Houve, porém, uma dispersão muito grande dos resultados, de modo que não é possível afirmar que da maneira como o modelo foi construído ele seja capaz de avaliar o deslizamento da ligação.

Analisando os resultados dos ensaios com adição de fibras à ligação, observa-se que, em média, os resultados avaliados pelo modelo são $20 \%$ inferiores aos observados nos ensaios. É necessário destacar, entretanto, que a expressão usada para avaliar a resistência do conector foi obtida dos ensaios sem adição de fibras. SOROUSHIAN; MIRZA (1991) observaram um aumento na resistência de pino da armadura devido à adição de $2 \%$ de fibras metálicas ao concreto. Apesar dos autores não quantificarem esse aumento, é possível estimar desse trabalho um aumento de $70 \%$ na resistência de pino da armadura. Analisando novamente os ensaios com fibra, porém aumentando a resistência última do conector, $F_{d, u}$, desse valor, chega-se a uma resistência média apenas $10 \%$ inferior aos valores experimentais. Outros autores, como NAAMAN; BACCOUCHE (1995), observaram aumentos de até $250 \%$ na resistência ao cisalhamento do concreto devido à adição de fibras. Nesse trabalho, os autores analisaram um plano de cisalhamento, não fissurado, atravessado por uma barra de aço. Desse modo, a resistência era garantida pelo concreto e pela ação de pino da armadura. Nos ensaios, foram adicionadas ao concreto $5 \%$ de fibras metálicas com relação de forma igual a 100. Infelizmente, os autores não distinguiram a parcela resistente devido ao concreto da parcela devido à ação de pino da armadura, de forma que não foi possível quantificar o aumento da resistência por ação de pino da armadura proporcionado pela adição das fibras.

A partir do que foi exposto até aqui, pode-se concluir que a idéia de separar as parcelas resistentes do concreto e do conector para avaliar a resistência da ligação com 
chave de cisalhamento e conector é razoável. Novos estudos devem ser realizados de modo a confirmar essa análise, bem como para melhor definir o modelo analítico apresentado.

\subsection{Síntese e considerações finais}

Neste capítulo, os resultados dos ensaios de cisalhamento direto com chave de cisalhamento, apresentados no capítulo anterior, foram empregados na determinação de expressões para a representação da curva tensão-deslizamento da ligação com chave, as quais são mostradas no Quadro 5.1. A razão entre a resistência obtida por essas expressões e o valor experimental nos corpos-de-prova sem adição de fibras à ligação apresentou valor médio de 0,999 com desvio padrão de 0,040. No caso dos ensaios com adição de fibras à ligação, essa mesma razão apresentou valor médio de 1,004 com desvio padrão de 0,052 . Analisando a razão entre o deslizamento na ruptura, $\delta_{m}$, obtido pelas expressões empíricas e o valor experimental nos corpos-de-prova sem adição de fibras à ligação, obteve-se um valor médio de 1,005 com desvio padrão de 0,076. No caso dos ensaios com adição de fibras à ligação, essa mesma razão apresentou valor médio de 0,925 com desvio padrão de 0,147. Esses resultados mostram que as expressões desenvolvidas foram capazes de representar com boa precisão o comportamento real da ligação com chave de cisalhamento e conector.

Em seguida, a ligação com chave de cisalhamento foi analisada empregando os modelos mecânicos de KANEKO (1992) e HSU et al. (1987). Os resultados mostraram que a resistência da ligação pode ser avaliada, com boa precisão, por esses modelos, porém os deslizamentos foram sempre inferiores aos obtidos experimentalmente. Analisando os resultados obtidos pelo modelo de KANEKO (1992), verificou-se que a razão entre o valor obtido pelo modelo e o valor experimental nos corpos-de-prova sem adição de fibras à ligação apresentou valor médio de 1,153 com desvio padrão de 0,156. No caso dos ensaios com adição de fibras à ligação, essa mesma razão apresentou valor médio de 1,088 com desvio padrão de 0,060. Esses resultados foram obtidos admitindo que o conector sempre atingia a tensão de escoamento do aço no instante da ruptura.

O modelo de HSU et al. (1987) foi aplicado apenas aos corpos-de-prova sem adição de fibras à ligação. A razão entre a resistência obtida pelo modelo e o valor experimental apresentou valor médio de 1,036 com desvio padrão de 0,056. Esses resultados foram obtidos admitindo $K=3,5$, o que corresponde a uma largura crítica da região fissurada na base da chave igual a $40 \mathrm{~mm}$. 
Quadro 5.1 - Expressões empíricas para representação da ligação com chave de cisalhamento e conector

\begin{tabular}{|c|c|}
\hline \multirow{2}{*}{$\begin{array}{c}\text { Tensão } \\
\text { resistente } \\
\text { última }(\mathrm{MPa})\end{array}$} & $\tau_{\mathrm{u}}=1,270 \sqrt{\mathrm{f}_{\mathrm{cm}}}+0,798 \rho \mathrm{f}_{\mathrm{y}} \leq 1,8 \sqrt{\mathrm{f}_{\mathrm{cm}}}, \mathrm{V}_{\mathrm{f}}=0 \%$ \\
\hline & $\tau_{\mathrm{u}}=1,730 \mathrm{f}_{\mathrm{cm}}{ }^{0,708}\left(\rho \sqrt{\mathrm{f}_{\mathrm{y}}}\right)^{0,415} \leq 2,6 \sqrt{\mathrm{f}_{\mathrm{cm}}}, 0,75 \% \leq V_{\mathrm{f}} \leq 1,50 \%$ e $\rho>0,005$ \\
\hline \multirow{2}{*}{$\begin{array}{l}\text { Deslizamento } \\
\text { relativo na } \\
\text { ruptura }(\mathrm{mm})\end{array}$} & $\delta_{\mathrm{m}}=0,014 \mathrm{f}_{\mathrm{cm}}{ }^{0,572} \phi_{\mathrm{s}}^{0,737}, \mathrm{~V}_{\mathrm{f}}=0 \%$ \\
\hline & $\delta_{\mathrm{m}}=0,0304 \mathrm{f}_{\mathrm{cm}}{ }^{0,572} \phi_{\mathrm{s}}{ }^{0,468} \mathrm{~V}_{\mathrm{f}}{ }^{0,313}, 0,75 \% \leq \mathrm{V}_{\mathrm{f}} \leq 1,50 \%$ \\
\hline \multirow[t]{3}{*}{$\begin{array}{l}\text { Curva tensão- } \\
\text { deslizamento }\end{array}$} & $\frac{\tau}{\tau_{\mathrm{u}}}=\frac{\beta \frac{\delta}{\delta_{\mathrm{m}}}}{\beta-1+\left(\frac{\delta}{\delta_{\mathrm{m}}}\right)^{\beta}}$ \\
\hline & $\delta \leq \delta_{m}: \beta=257,87 \rho \sqrt{f_{c m} f_{y}} \phi_{s}^{-2,318}, 0 \% \leq V_{f} \leq 1,50 \%$ \\
\hline & $\delta>\delta_{\mathrm{m}}: \beta=196,45 \rho \sqrt{\mathrm{f}_{\mathrm{cm}} \mathrm{f}_{\mathrm{y}}} \phi_{\mathrm{s}}^{-2,123}, 0 \% \leq \mathrm{V}_{\mathrm{f}} \leq 1,50 \%$ \\
\hline
\end{tabular}

$\mathrm{f}_{\mathrm{cm}}$ : resistência média à compressão do concreto da ligação

$\mathrm{f}_{\mathrm{y}}$ : resistência de escoamento do aço à tração

$\rho$ : taxa geométrica de armadura na ligação

$\phi_{\mathrm{s}}$ : diâmetro do conector

$V_{f}$ : volume de fibras em porcentagem

Para a aplicação do modelo de KANEKO (1992) à ligação com chave de cisalhamento, foi necessário definir uma tensão externa atuando na direção normal ao plano de cisalhamento da chave. Esse modelo foi, então, modificado incorporando a influência do conector às equações de equilíbrio e de compatibilidade do modelo. Dessa forma, no modelo modificado não havia mais a necessidade de substituir o conector por uma tensão externa. Aplicando esse modelo aos corpos-de-prova sem adição de fibras à ligação, verificou-se que a razão entre o valor obtido pelo modelo e o valor experimental apresentou valor médio de 1,117 com desvio padrão de 0,049. No caso dos ensaios com adição de fibras à ligação, essa mesma razão apresentou valor médio de 0,993 com desvio padrão de 0,095. Comparando esses valores com os obtidos da aplicação do modelo original, observase que o modelo modificado proporcionou uma maior aproximação com os resultados experimentais, principalmente nos corpos-de-prova com fibras na ligação. O deslizamento, contudo, foi bastante inferior aos valores experimentais.

$\mathrm{Na}$ seqüência do capítulo, foram discutidos alguns fatores que influenciaram na medição do deslizamento durante os ensaios, aumentando seu valor. Também foi mostrado que a ligação com chave de cisalhamento, provavelmente, seria mais bem representada por 
modelos que incorporam o deslizamento na fissura. Contudo, esses modelos somente são aplicáveis empregando uma ferramenta numérica, como o método dos elementos finitos. Como este assunto foge ao escopo deste trabalho, fica como sugestão para futuros trabalhos a aplicação desses modelos às ligações com chave de cisalhamento e conector.

Ao final, a ligação foi analisada através de um modelo analítico que separava as parcelas resistentes do concreto e do conector. A resistência do concreto era avaliada empregando o conceito de bielas e tirantes, enquanto a resistência do conector era avaliada pela ação de pino da armadura. Verificou-se que para o caso da ligação sem adição de fibras, a razão entre a força última obtida pelo modelo e os valores experimentais apresentou valor médio de 0,998 com desvio padrão de 0,047. Os deslizamentos da ligação, porém, não foram bem representados por esse modelo. Novos estudos devem ser realizados de modo a confirmar essa forma de separação das parcelas resistentes da ligação, bem como para melhor definir as expressões do modelo analítico apresentado. 


\section{Capítulo 6 - Vigas Compotas com Laje Pré-moldada}

Neste capítulo, são mostrados os resultados dos ensaios realizados em vigas compostas formadas por viga e laje pré-moldadas. A partir desses resultados, foi analisada a influência do espaçamento dos nichos na resistência e na rigidez das vigas. $\mathrm{Na}$ seqüência, são mostrados os resultados obtidos da análise numérica realizada no programa ANSYS, que ampliaram a compreensão do comportamento das vigas compostas com laje pré-moldada. Também é mostrado um exemplo de dimensionamento da ligação entre viga e laje pré-moldadas em uma estrutura típica de ponte rodoviária.

\subsection{Descrição dos ensaios em vigas compostas}

Foram ensaiadas cinco vigas compostas biapoiadas com seção transversal em forma de $\mathrm{T}$ e carregadas com uma força concentrada no meio do vão. As dimensões das vigas compostas eram semelhantes às do programa experimental desenvolvido por ARAUJO (1997), onde as vigas eram pré-moldadas e a laje moldada no local (Figura 6.1).

As vigas compostas ensaiadas neste trabalho eram constituídas por viga e laje prémoldadas. A ligação entre elas era garantida por nichos preenchidos com concreto de alto desempenho e por conectores metálicos formados por vergalhões de aço dobrados em forma de laço. A variável estudada nos ensaios foi o espaçamento dos nichos ao longo do vão das vigas. $\mathrm{Na}$ ligação foram confeccionadas chaves de cisalhamento, e foram empregados conectores com o mesmo diâmetro em todas as vigas. Também foi empregado um único traço para o preenchimento dos nichos em todas as vigas, tendo sido adicionadas $0,75 \%$ de fibras metálicas DRAMIX com $30 \mathrm{~mm}$ de comprimento e fator de forma igual a 48 .

Das cinco vigas ensaiadas, três delas foram submetidas a carregamento monotônico crescente até a ruptura, e uma a carregamento cíclico não reversível. A última viga era monolítica e foi ensaiada sob carregamento monotônico, servindo de referência para a avaliação da influência do espaçamento dos nichos sobre a resistência e sobre a rigidez das vigas compostas (Tabela 6.1). 


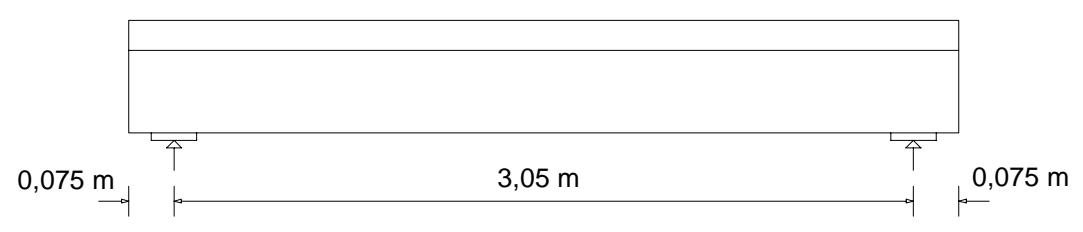

(a) elevação

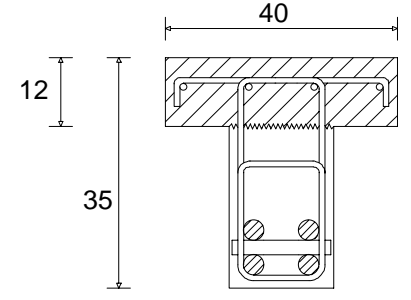

15

Viga 1

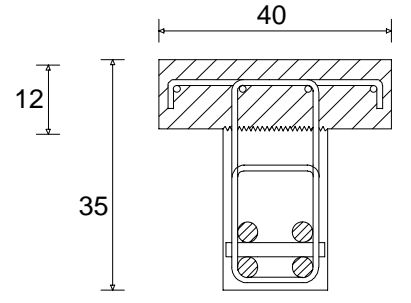

15

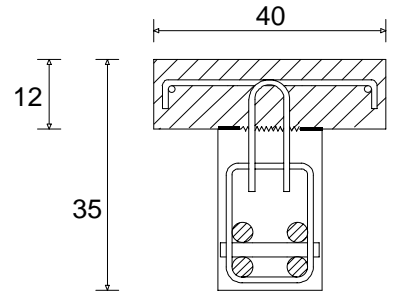

15

Viga 2

Viga 3

dimensões em cm

(b) seções transversais

Figura 6.1 - Principais dimensões das vigas ensaiadas por ARAUJO (1997).

Tabela 6.1 - Relação de ensaios em vigas compostas

\begin{tabular}{|c|c|c|c|}
\hline Viga ensaiada & Carregamento & Superfície da ligação & $\beta$ \\
\hline V1 & Monotônico & Viga monolítica & ${ }^{*}$ \\
\hline V2 & Monotônico & Chave de cisalhamento & 0,48 \\
\hline V3 & Monotônico & Chave de cisalhamento & 0,31 \\
\hline V4 & Monotônico & Chave de cisalhamento & 0,22 \\
\hline V5 & Cíclico não reversível & Chave de cisalhamento & 0,31 \\
\hline
\end{tabular}

- $\beta$ : relação entre a área de transferência de esforços de cisalhamento e a área total da interface em uma viga composta.

- No caso das vigas com chave de cisalhamento, foi empregado o traço 2, definido no capítulo 2, com $0,75 \%$ de fibras DRAMIX.

* Na viga monolítica não há uma interface previamente definida, dessa forma o parâmetro $\beta$ não foi definido.

O objetivo deste estudo foi analisar a influência do espaçamento dos nichos no comportamento à flexão das vigas compostas. Dessa forma, foram adotados três espaçamentos para os nichos: $28 \mathrm{~cm}$, o que correspondia a uma área de contato responsável pela transferência de tensões entre a viga e a laje igual a $48 \%$ da área da 
interface; $42 \mathrm{~cm}$, o que correspondia a $31 \%$ da área da interface; e $56 \mathrm{~cm}$, o que correspondia a $22 \%$ da área da interface (Figura 6.2, Figura 6.3, Figura 6.4). As dimensões dos nichos eram as mesmas empregadas nos ensaios de cisalhamento direto. A viga e a laje pré-moldadas foram confeccionadas com o mesmo traço empregado na confecção das peças pré-moldadas dos corpos-de-prova de cisalhamento direto, enquanto para 0 preenchimento dos nichos foi empregado o traço 2 com $0,75 \%$ de fibras metálicas DRAMIX. Esses traços foram mostrados e analisados no capítulo 2.

As dimensões das vigas ensaiadas eram inferiores às dimensões reais de vigas empregadas na construção de pontes. Apesar disso, o tamanho dos nichos não diferem muito das dimensões dos nichos empregados na construção de pontes compostas. Além disso, a ligação entre a viga e a laje é solicitada a cisalhamento direto. Sendo assim, esses ensaios são representativos com relação ao comportamento real das ligações. Quanto a outras solicitações, como, por exemplo, o cisalhamento na viga pré-moldada, os resultados aqui obtidos não podem ser diretamente extrapolados para as estruturas reais.

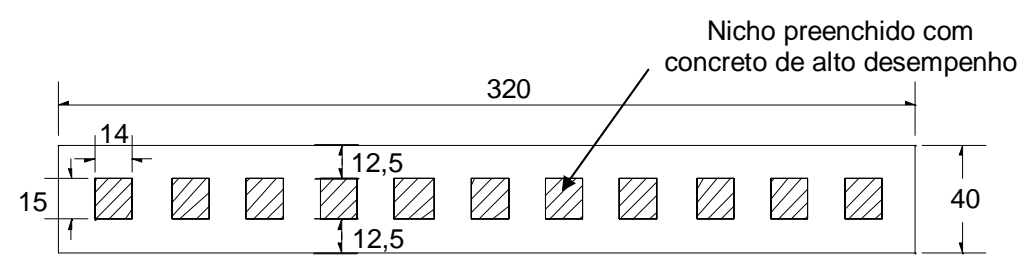

Vista superior
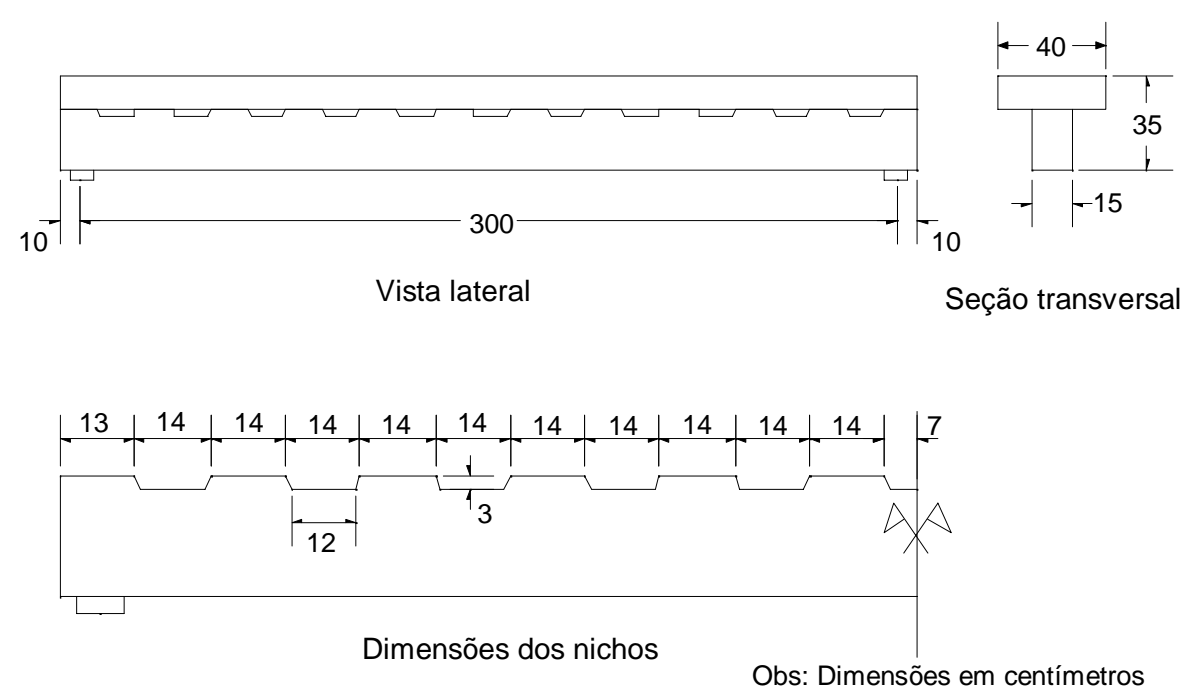

Figura 6.2 - Dimensões da viga com espaçamento entre chaves de $28 \mathrm{~cm}$ (V2). 

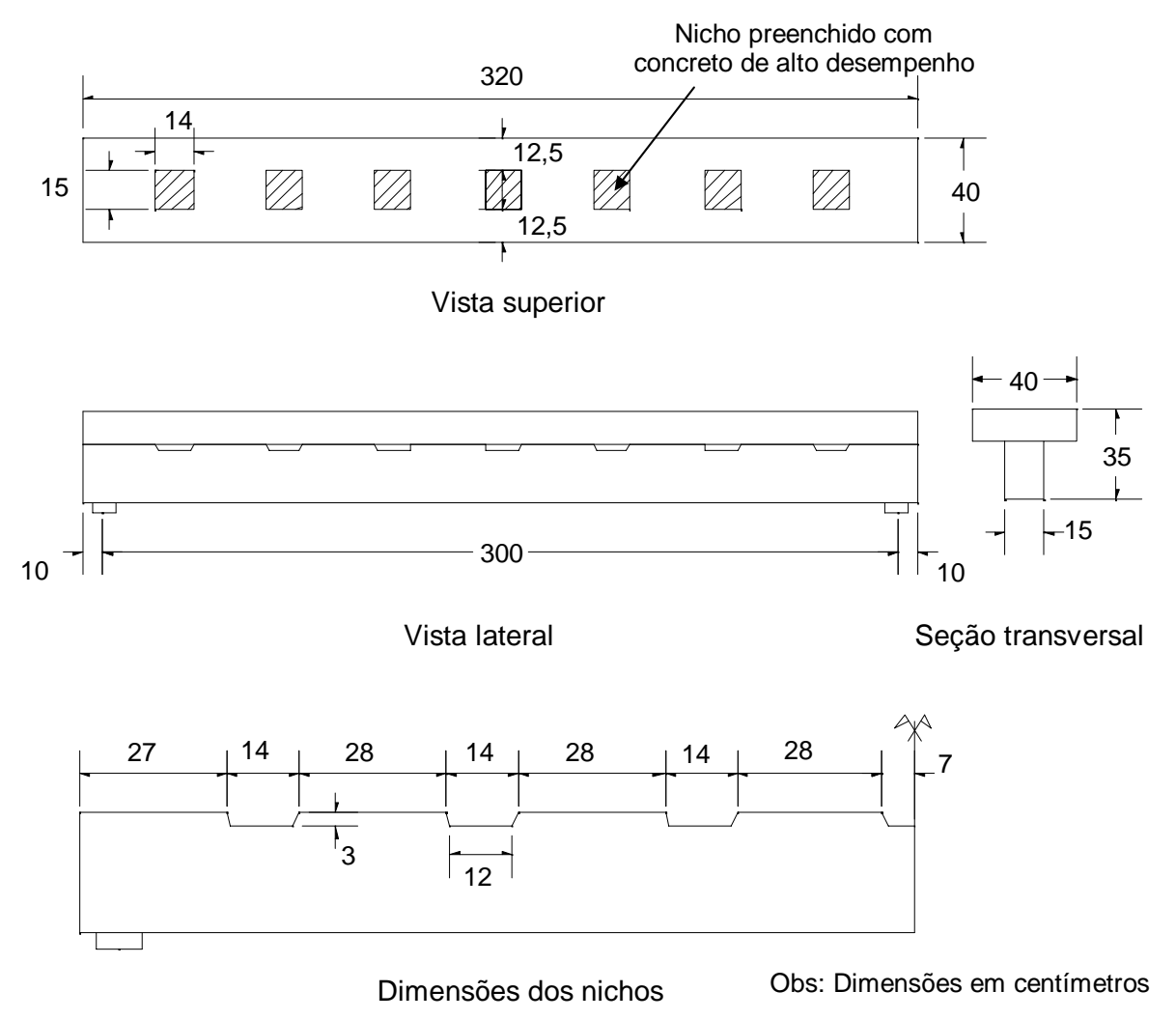

Figura 6.3 - Dimensões da viga com espaçamento entre chaves de 42 cm (V3 e V5).

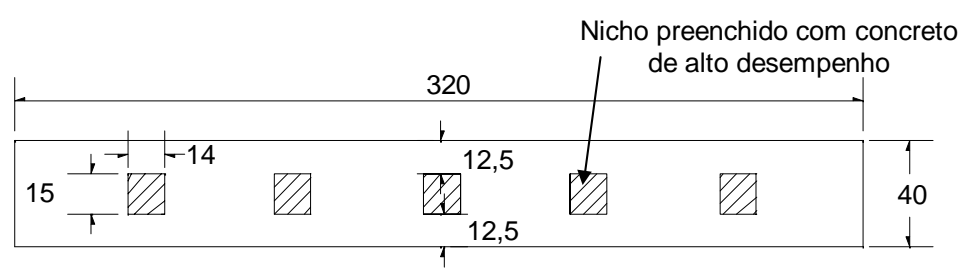

Vista superior
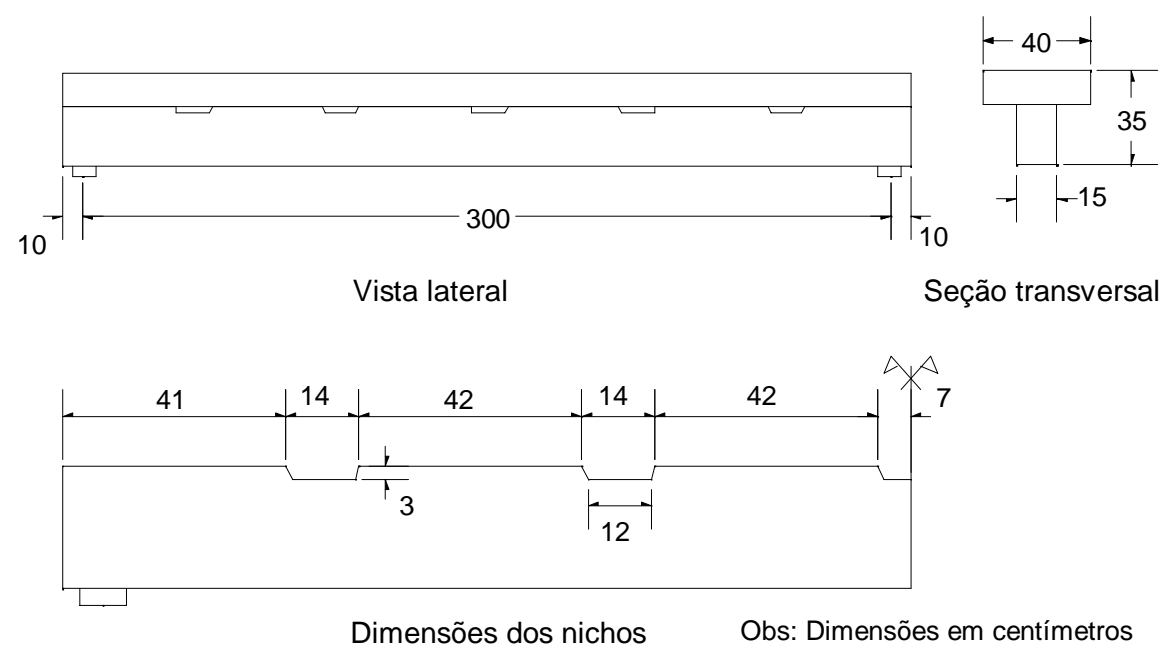

Figura 6.4 - Dimensões da viga com espaçamento entre chaves de $56 \mathrm{~cm}$ (V4). 
$\mathrm{Na}$ Figura 6.5, na Figura 6.6 e na Figura 6.7 é mostrada a armação das vigas compostas enquanto na Figura 6.8 é mostrada a armação da viga monolítica.
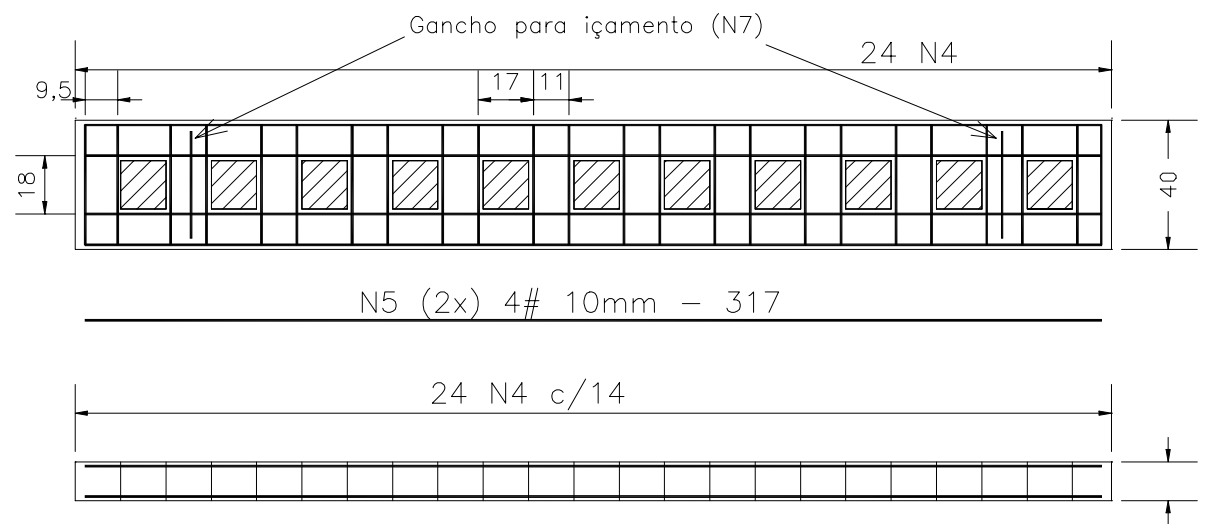

Laje pre-moldada
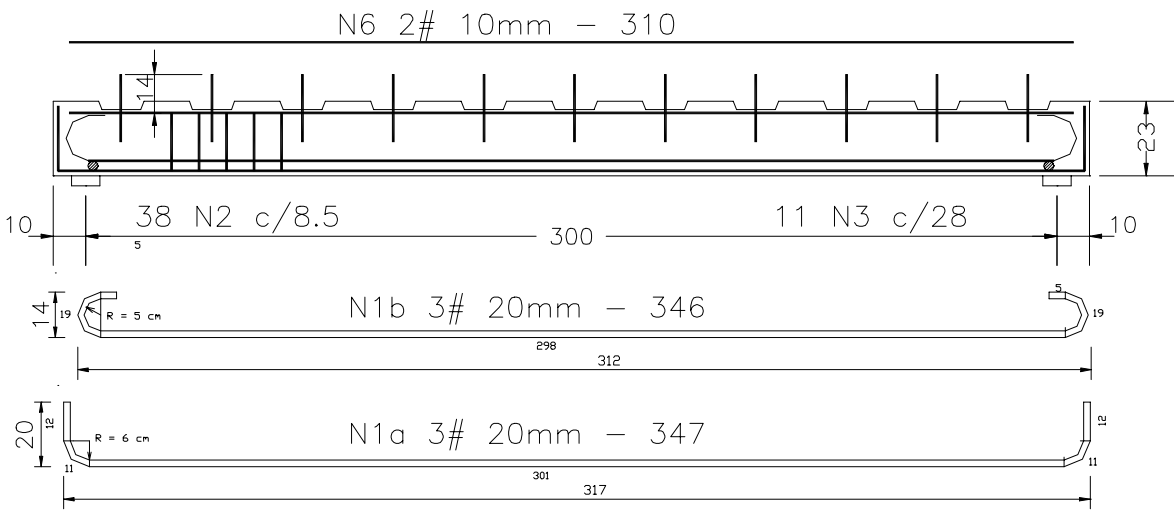

\section{Viga pre-moldada}
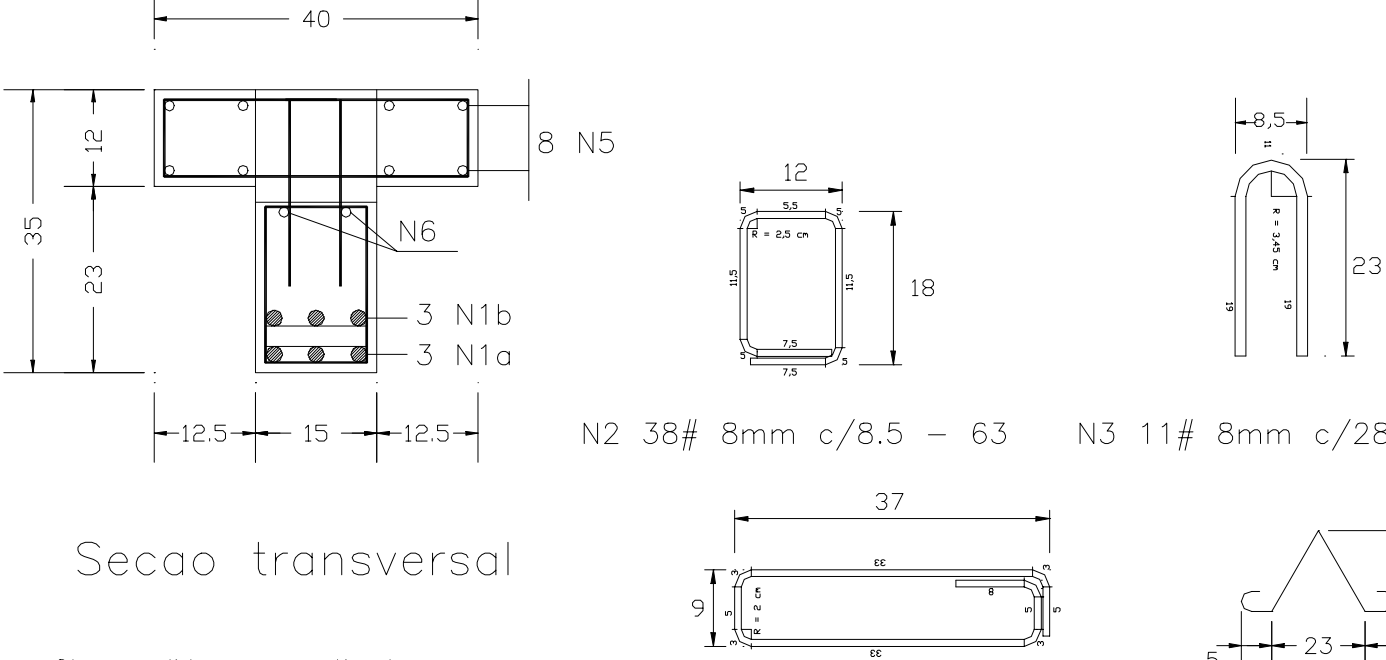

Secao transversal

Obs: medidas em centimetro

N4 24\# $8 \mathrm{~mm} \mathrm{c/14-104}$

Figura 6.5 - Armadura da viga com espaçamento entre nichos de $28 \mathrm{~cm}$ (V2). 

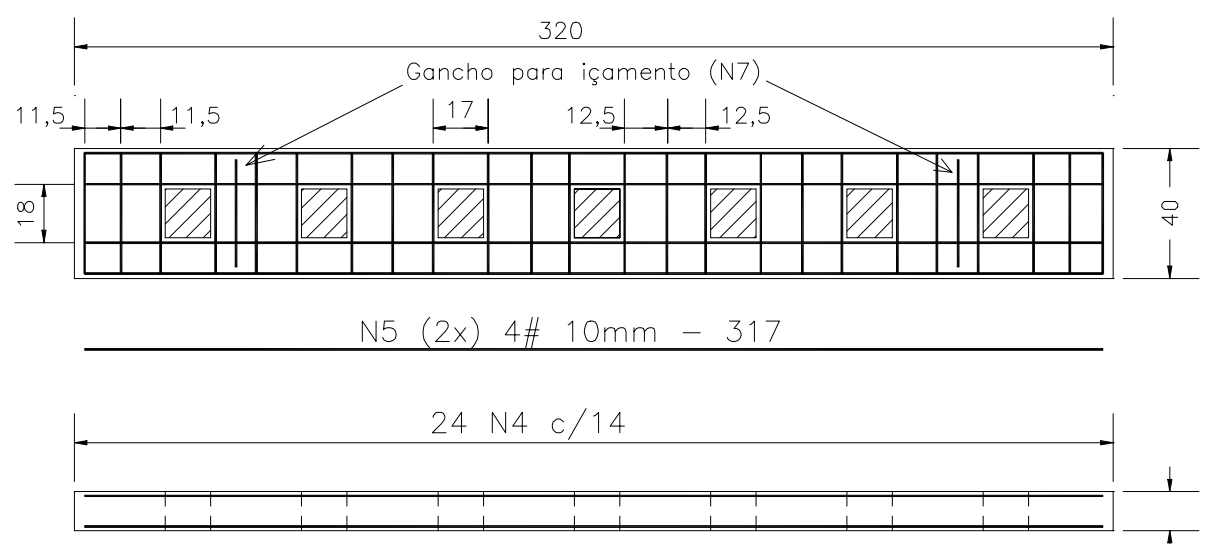

Laje pre-moldada

N6 $2 \# 10 \mathrm{~mm}-310$
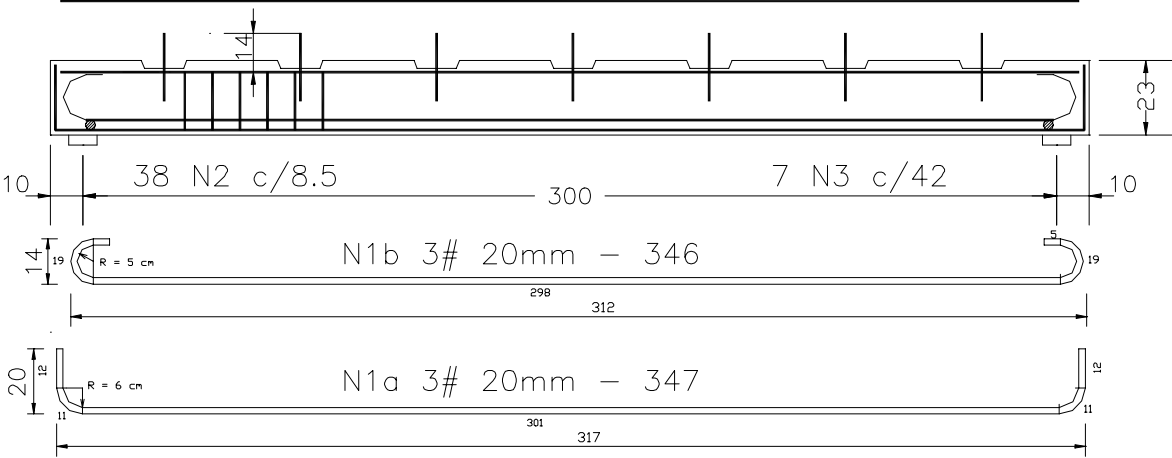

Viga pre-moldada

$+40 \longrightarrow$

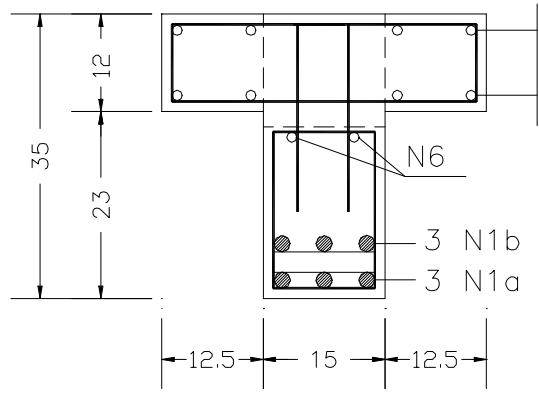

Secao transversal

Obs: medidas em centimetro

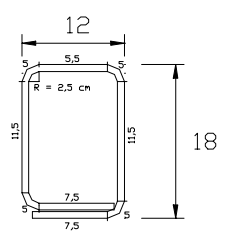

N2 38\# $8 \mathrm{~mm} \mathrm{c} / 8.5-63 \quad \mathrm{~N} 311 \# 8 \mathrm{~mm} \mathrm{c/28}-49$

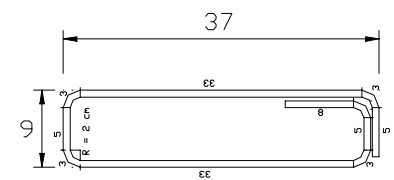

N4 24\# $8 \mathrm{~mm} \mathrm{c/14-104}$
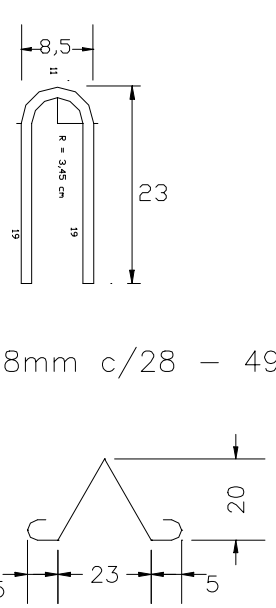

N7 2\# $6.3 \mathrm{~mm}-65$

Figura 6.6 - Armadura da viga com espaçamento entre nichos de $42 \mathrm{~cm}$ (V3 e V5). 

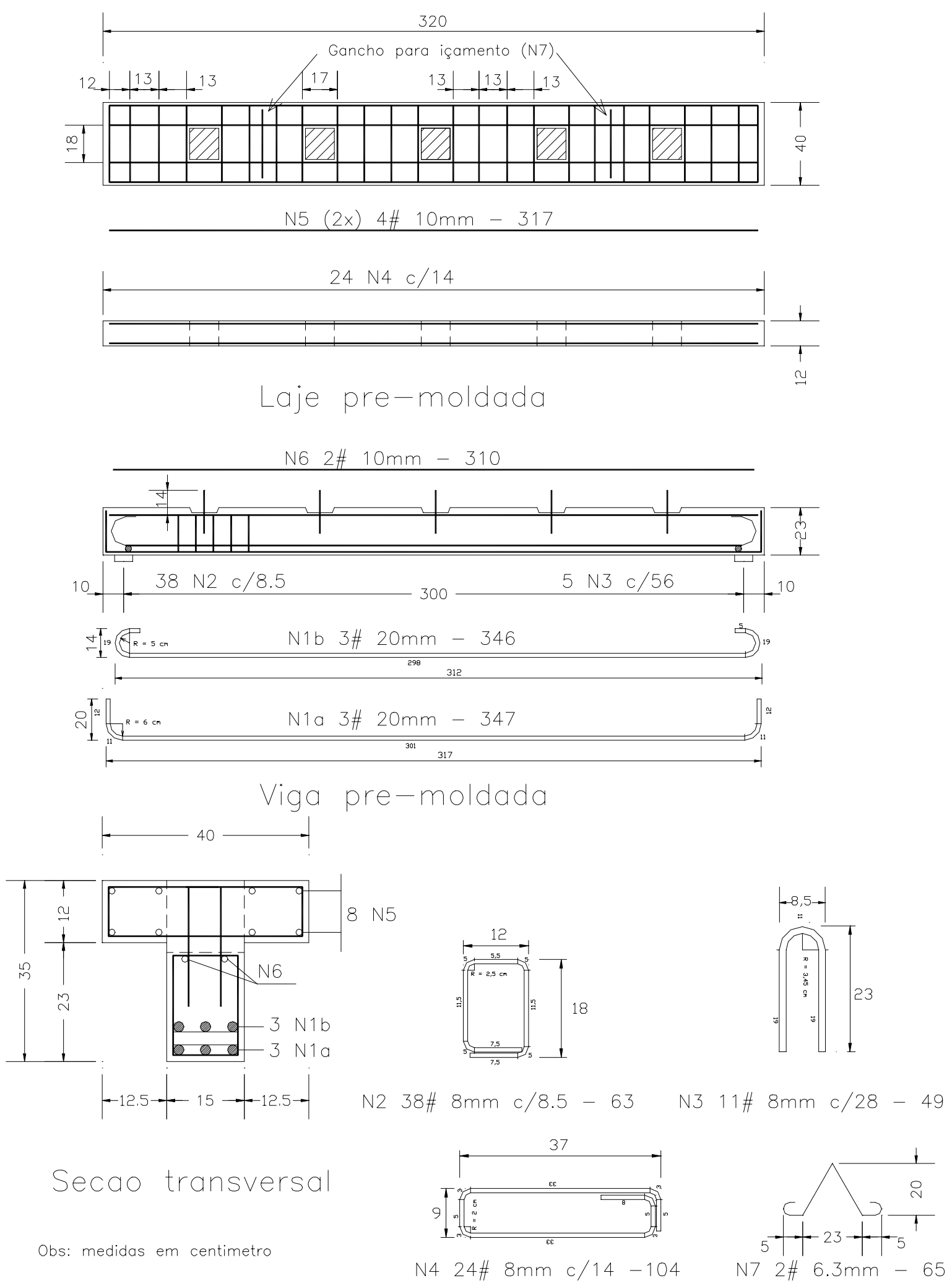

Figura 6.7 - Armadura da viga com espaçamento entre nichos de 56 cm (V4). 

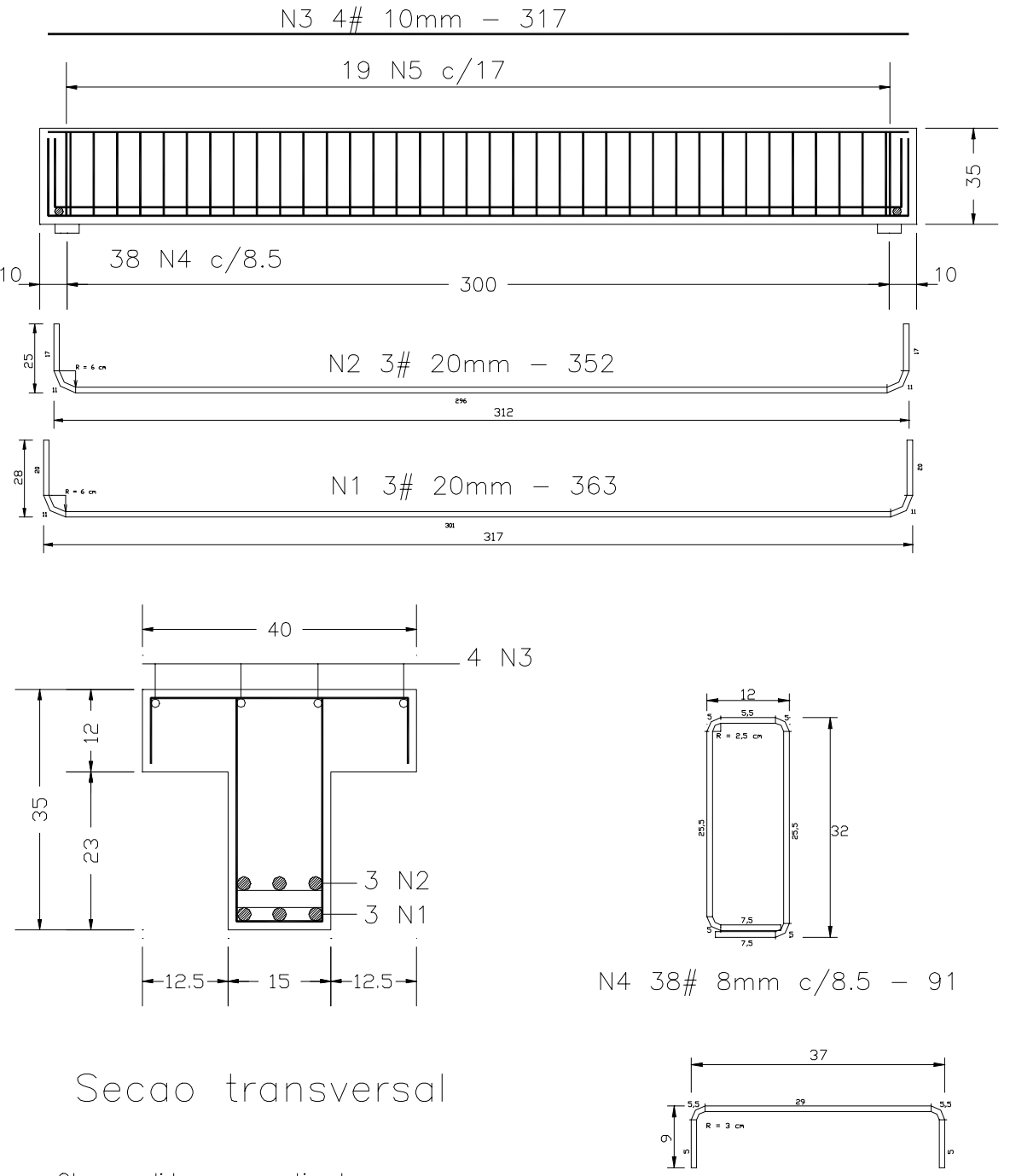

Figura 6.8 - Armadura da viga monolítica (V1).

\subsubsection{Confecção das vigas}

As vigas compostas foram moldadas em duas etapas com a finalidade de simular 0 comportamento de estruturas compostas formadas por viga e laje pré-moldadas. $\mathrm{Na}$ primeira etapa foi moldada a viga, deixando-se exposto parte do conector, e a laje com os nichos (Figura 6.9). A viga e a laje foram moldadas com o mesmo traço, porém o concreto de cada uma delas foi misturado separadamente. Após dois dias de cura, a laje foi desmoldada e posicionada sobre a viga pré-moldada. Na superfície superior da viga, que ficaria em contato com a laje, foi passada uma fina camada de graxa de modo a evitar o atrito entre as peças pré-moldadas. Depois de posicionada a laje, e antes da concretagem do nicho, este foi calafetado de modo a evitar a fuga de nata para fora da região da ligação, o que poderia alterar os resultados de resistência da ligação. 


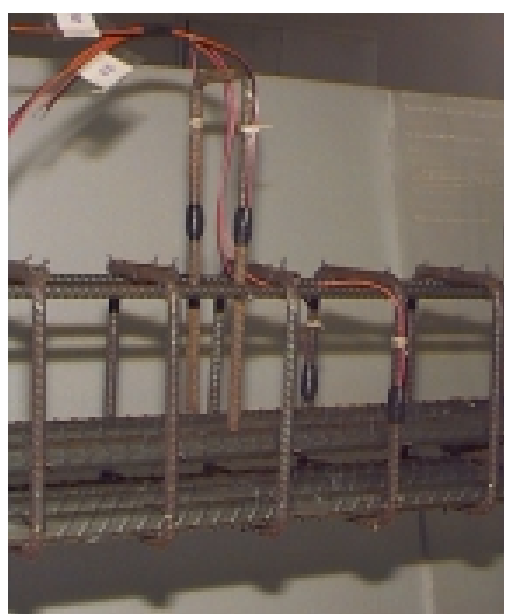

(a) Instrumentação do conector

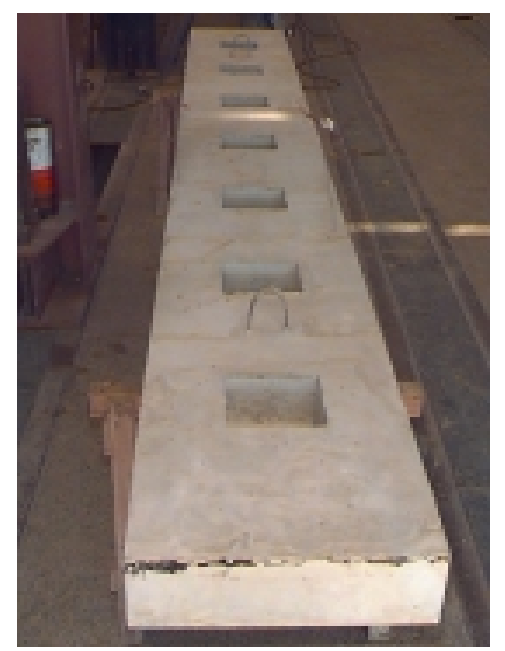

(d) Laje pré-moldada com nichos

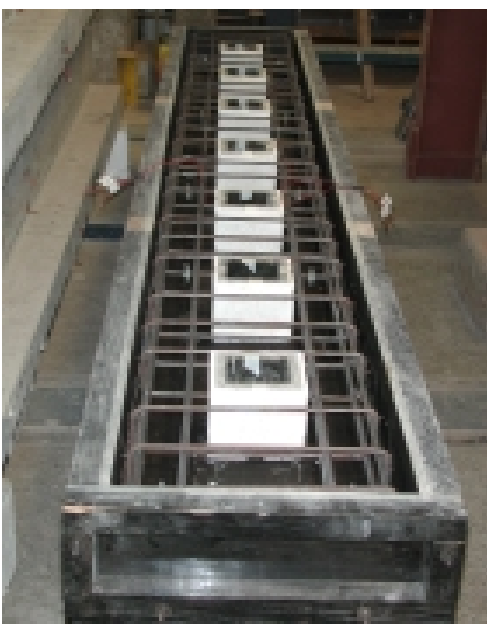

(b) Fôrma da laje pré-moldada

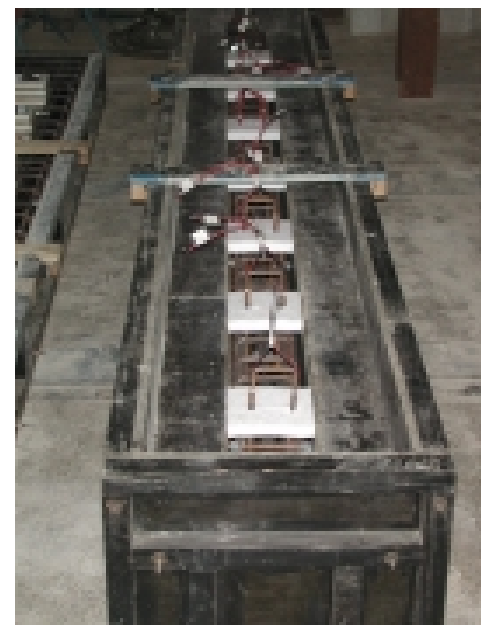

(c) Fôrma da viga pré-moldada

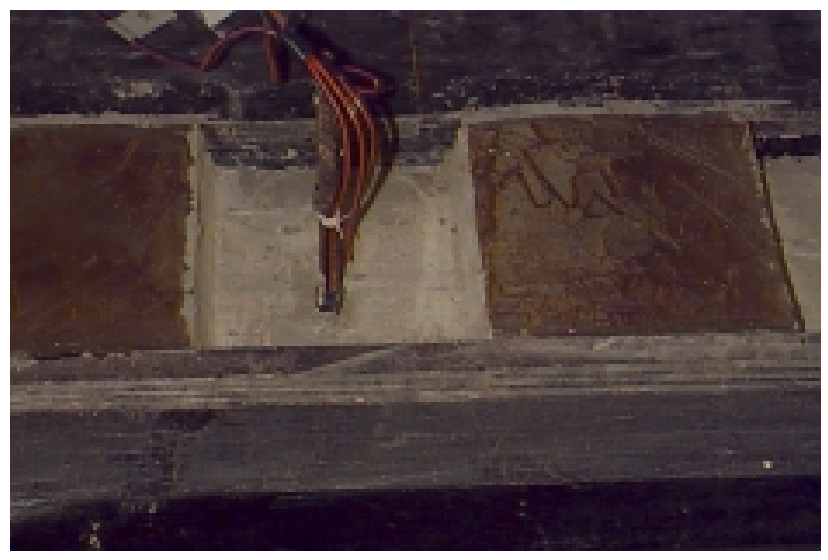

(e) Face superior da viga pré-moldada com chave de cisalhamento e conector - superfície engraxada para evitar atrito

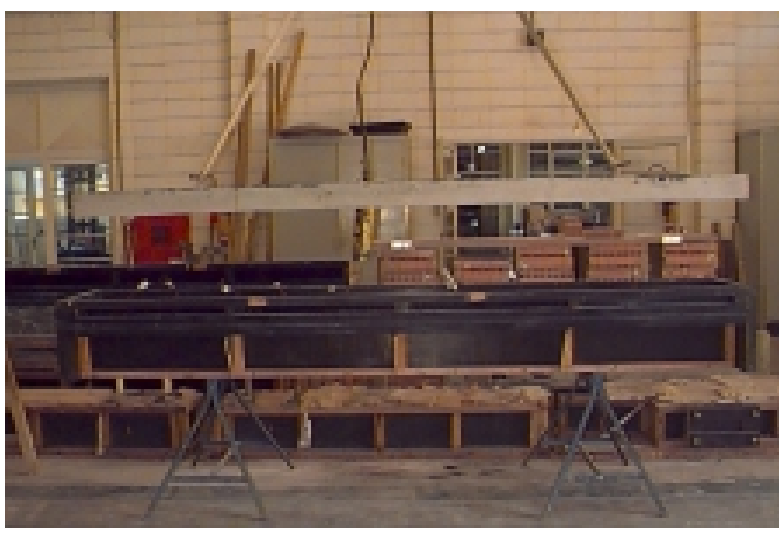

(f) Posicionamento da laje pré-moldada sobre a viga pré-moldada

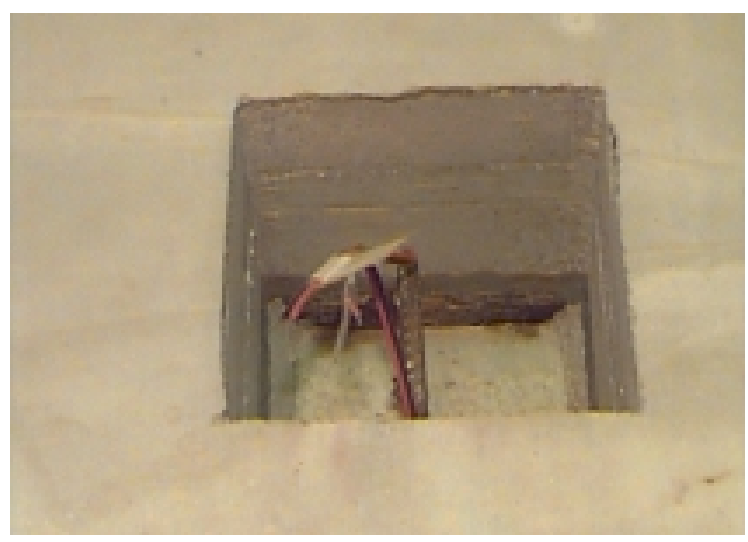

(g) Nicho antes da concretagem

Figura 6.9 - Confecção das vigas compostas 
No terceiro dia foi executada a ligação empregando concreto de alto desempenho. Antes do lançamento do concreto nos nichos, porém, a superfície de contato entre os dois concretos foi limpa com ar comprimido para retirar impurezas e partículas soltas. Em seguida, ela foi umedecida, evitando que ficasse água livre que provocaria redução na resistência do concreto moldado no nicho. A ligação foi mantida sob cura durante quatro dias. Após esse período, a viga composta foi desmoldada e posicionada no pórtico de reação para ensaio. O cronograma típico de moldagem das vigas compostas é mostrado na Figura 6.10.

\begin{tabular}{|c|l|l|l|l|l|l|l|l|l|l|l|}
\hline Serviço & Seg. & Ter. & Qua & Qui. & Sex. & Sab. & Dom & Seg. & Ter. & Qua & Qui. \\
\hline $\begin{array}{c}\text { Moldagem da viga, da laje e } \\
\text { dos corpos-de-prova }\end{array}$ & & & & & & & & & & & \\
\hline $\begin{array}{c}\text { Desmoldagem da laje e } \\
\text { posicionamento sobre a viga }\end{array}$ & & & & & & & & & & & \\
\hline $\begin{array}{c}\text { Montagem da viga composta, } \\
\text { preenchimento dos nichos e } \\
\text { moldagem dos corpos-de- } \\
\text { prova }\end{array}$ & & & & & & & & & & \\
\hline $\begin{array}{c}\text { Desmoldagem da viga } \\
\text { composta e posicionamento } \\
\text { no pórtico de reação }\end{array}$ & & & & & & & & & & & \\
\hline $\begin{array}{c}\text { Ensaio da viga e ruptura dos } \\
\text { corpos-de-prova }\end{array}$ & & & & & & & & & & & \\
\hline
\end{tabular}

Figura 6.10 - Cronograma de moldagem das vigas compostas.

No caso da viga monolítica, ela foi moldada em etapa única, sendo o ensaio realizado sete dias depois.

$\mathrm{Na}$ Tabela 6.2 são mostradas as principais propriedades mecânicas do concreto empregado na confecção das vigas. Essas propriedades foram obtidas no mesmo dia dos ensaios das respectivas vigas. Nessa data, o concreto das peças pré-moldadas estava com dez dias, e o concreto da ligação estava com sete dias. A resistência média à compressão foi obtida a partir do ensaio de três corpos-de-prova cilíndricos com dimensões de $100 \mathrm{~mm} x$ $200 \mathrm{~mm}$. A resistência média à tração indireta foi obtida a partir do ensaio de compressão diametral também em três corpos-de-prova cilíndricos com dimensões de $100 \mathrm{~mm} \times 200$ $\mathrm{mm}$. O módulo de elasticidade foi obtido a partir do ensaio de compressão em dois corposde-prova cilíndricos com dimensões de $100 \mathrm{~mm}$ x 200 mm, empregando dois extensômetros elétricos de resistência colados em duas geratrizes opostas do corpo-de-prova.

A armadura de flexão foi ensaiada à tração direta com o objetivo de determinar a tensão de escoamento do aço. Os resultados mostraram um nítido patamar de escoamento 
do material, a partir do qual foi obtida a tensão média de escoamento de $700 \mathrm{MPa}$. A tensão de ruptura do aço foi superior a $900 \mathrm{MPa}$.

Tabela 6.2 - Resistência e módulo de elasticidade do concreto empregado nas vigas

\begin{tabular}{|c|c|c|c|c|c|c|c|c|c|}
\hline \multirow{2}{*}{$\begin{array}{c}\text { Viga } \\
\text { ensaiada }\end{array}$} & \multicolumn{3}{|c|}{ Viga pré-moldada (MPa) } & \multicolumn{3}{|c|}{ Laje pré-moldada (MPa) } & \multicolumn{3}{|c|}{ Nicho (MPa) } \\
\hline & $f_{c m}$ & $\mathrm{f}_{\mathrm{ctm}, \mathrm{sp}}$ & $E_{c m}$ & $f_{c m}$ & $\mathrm{f}_{\mathrm{ctm}, \mathrm{sp}}$ & $E_{c m}$ & $\mathrm{f}_{\mathrm{cm}}$ & $f_{c t m, s p}$ & $E_{c m}$ \\
\hline $\mathrm{V} 1$ & 52,92 & 4,03 & 37.800 & - & - & - & - & - & - \\
\hline V2 & 53,93 & 3,92 & 36.600 & 51,46 & 3,94 & 41.250 & 70,75 & 6,82 & 40.750 \\
\hline V3 & 59,76 & 4,57 & 37.050 & 61,28 & 4,62 & 38.850 & 81,07 & 7,73 & 44.700 \\
\hline V4 & 55,45 & 4,23 & 38.050 & 50,05 & 4,03 & 38.850 & 80,89 & 7,85 & 39.150 \\
\hline V5 & 56,13 & 3,87 & * & 55,43 & 4,17 & * & 82,18 & 7,44 & * \\
\hline
\end{tabular}

*Valor não avaliado

\subsubsection{Instrumentação}

As vigas compostas foram instrumentadas para a medição do deslizamento relativo entre a viga e a laje, para a medição dos deslocamentos verticais e para a medição da deformação na armadura. $O$ deslizamento relativo entre a viga e a laje foi medido através de transdutores fixados à laje por meio de cantoneiras de alumínio e com a haste apoiada em uma cantoneira fixada à viga. Os deslocamentos verticais foram medidos em três pontos: no meio do vão e a um quarto do vão de cada lado da viga.

Para a medição das deformações nas armaduras, foram colados extensômetros elétricos uniaxiais, modelo KFG-5 da KYOWA. Eles foram colados nas barras da armadura longitudinal, no meio do vão, para medição das deformações devido à flexão, e em dois estribos contidos na viga pré-moldada, para medição da deformação devido ao esforço cortante. Também foram colados extensômetros em todos os conectores na altura da interface entre a viga e a laje pré-moldada, de modo semelhante ao realizado nos ensaios de cisalhamento direto. No concreto, foram colados extensômetros elétricos uniaxiais, modelo KFG-10, no meio do vão de modo a medir as deformações de compressão devido à flexão da viga composta.

Da Figura 6.11 à Figura 6.14 é mostrada a instrumentação realizada em todas as vigas ensaiadas. Nessas figuras, é mostrada a numeração dos transdutores e dos extensômetros elétricos. Os resultados dos ensaios, mostrados na seqüência, estão referenciados a essa numeração. 


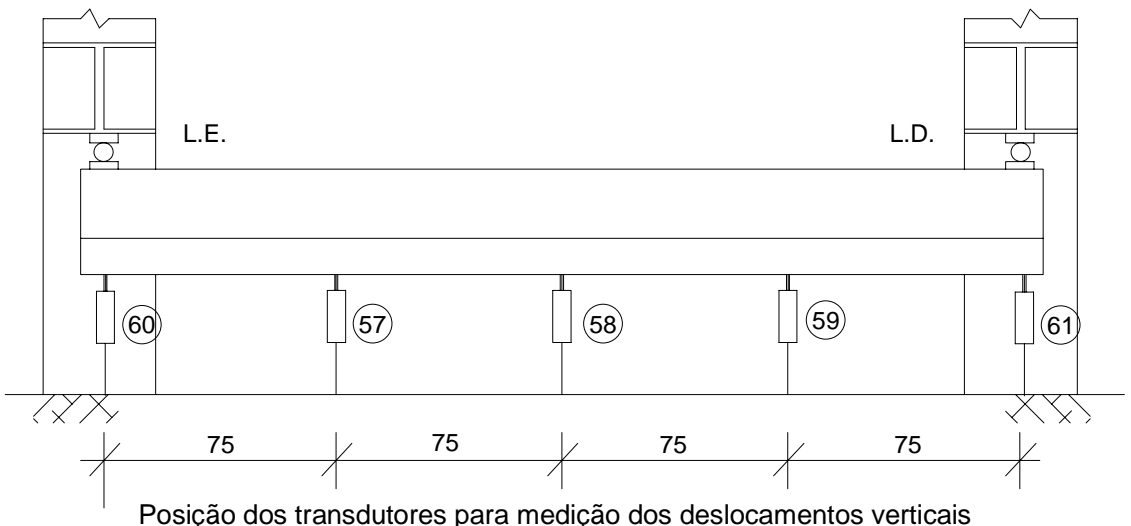

Posição dos transdutores para medição dos deslocamentos verticais

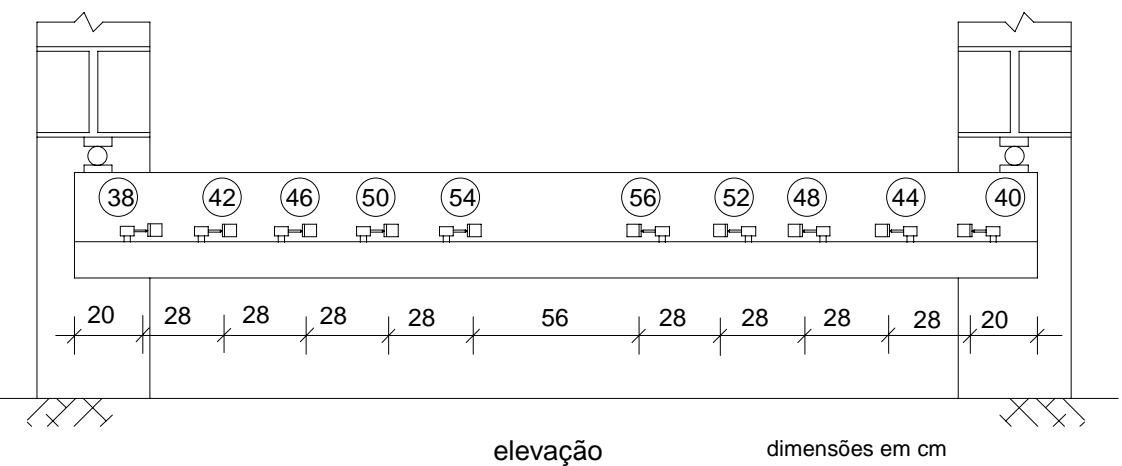

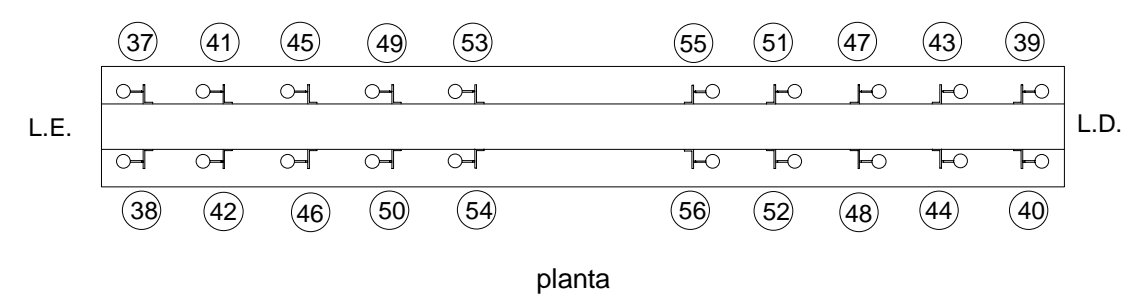

Posição dos transdutores para medição do deslizamento relativo entre a mesa e a alma

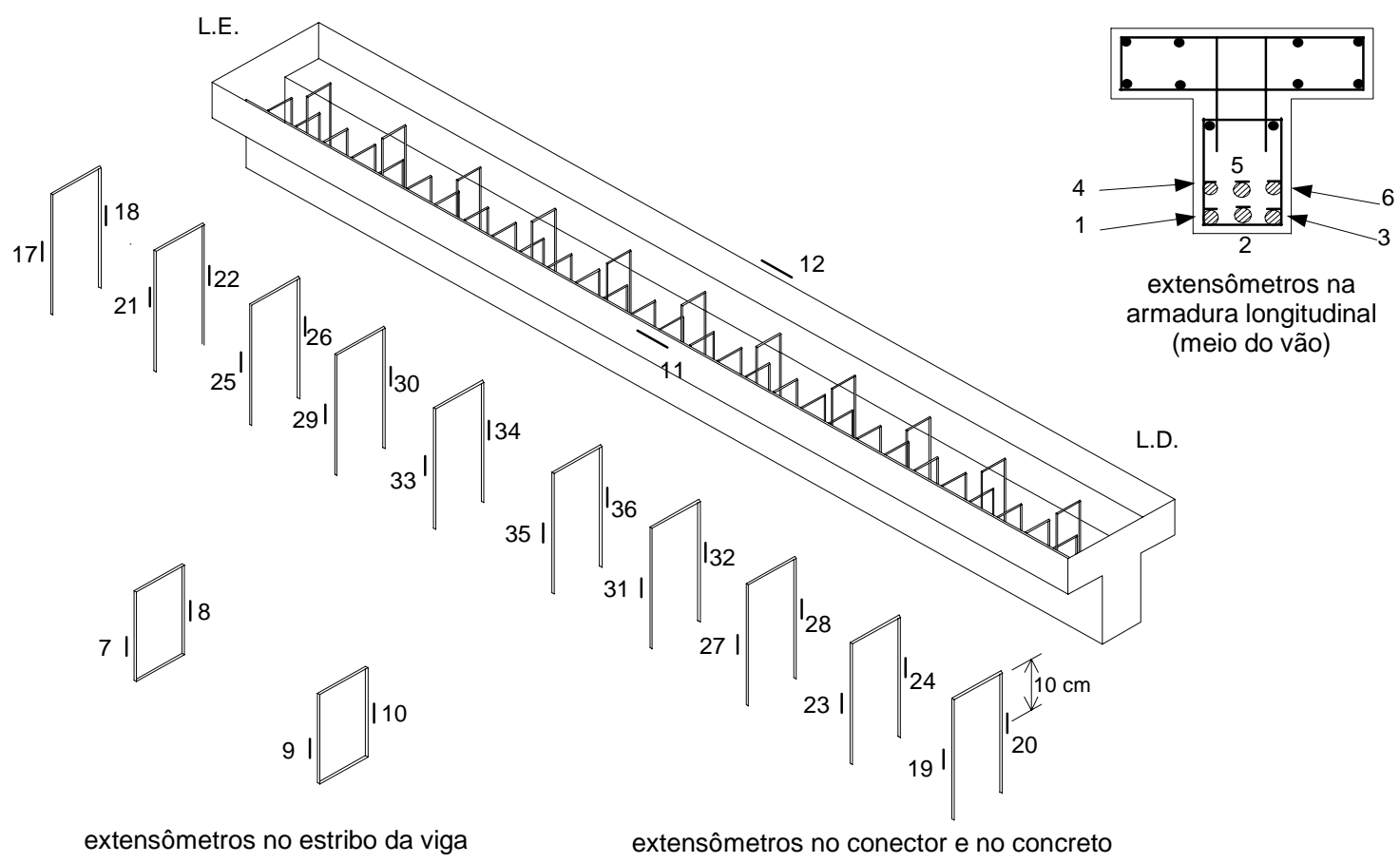

Figura 6.11 - Instrumentação da viga V2 com nichos espaçados de $28 \mathrm{~cm}$. 


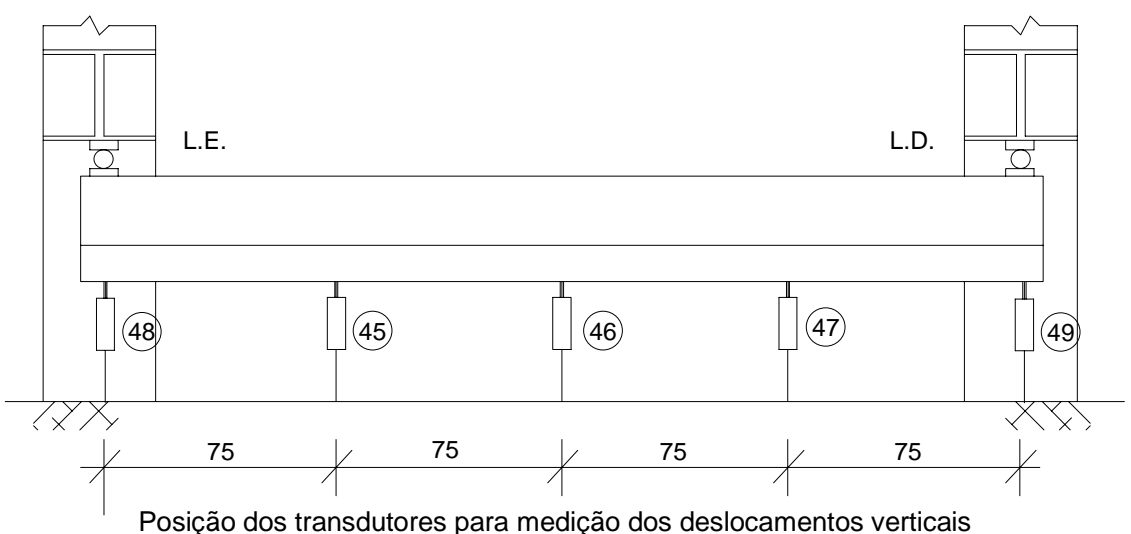

Posição dos transdutores para medição dos deslocamentos verticais

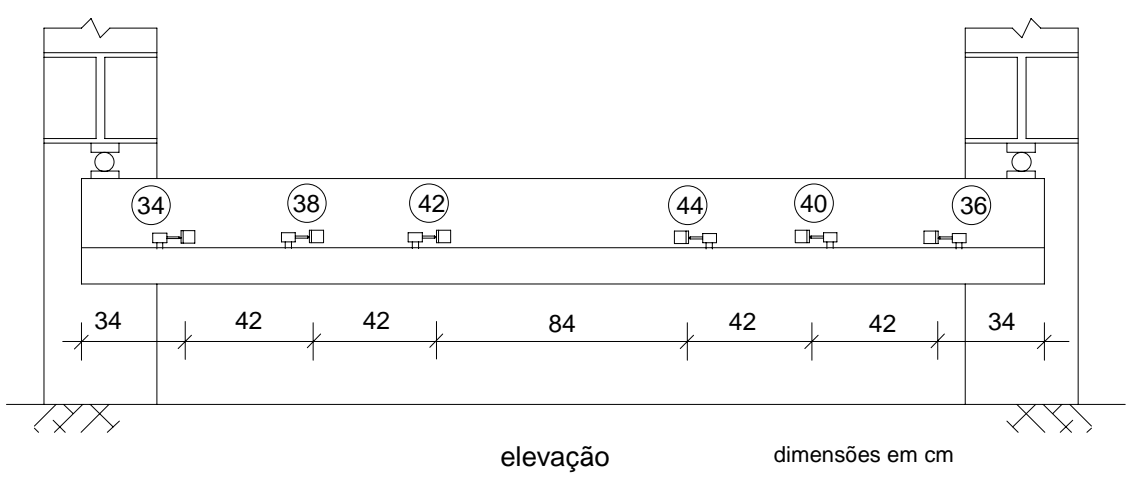

\begin{tabular}{|c|c|c|c|c|c|c|}
\hline & (33) & (37) & (41) & (43) & (39) & (35) \\
\hline \multirow{4}{*}{ L.E. } & $\mathrm{OH}_{1}$ & $\mathrm{OH}$ & $\mathrm{OH}$ & to & 1. & 10 \\
\hline & & & & & & \\
\hline & $\mathrm{OH}$ & $O=$ & O & 7-O & to & To \\
\hline & (34) & (38) & (42) & (44) & (40) & (36) \\
\hline
\end{tabular}

Posição dos transdutores para medição do deslizamento relativo entre a mesa e a alma

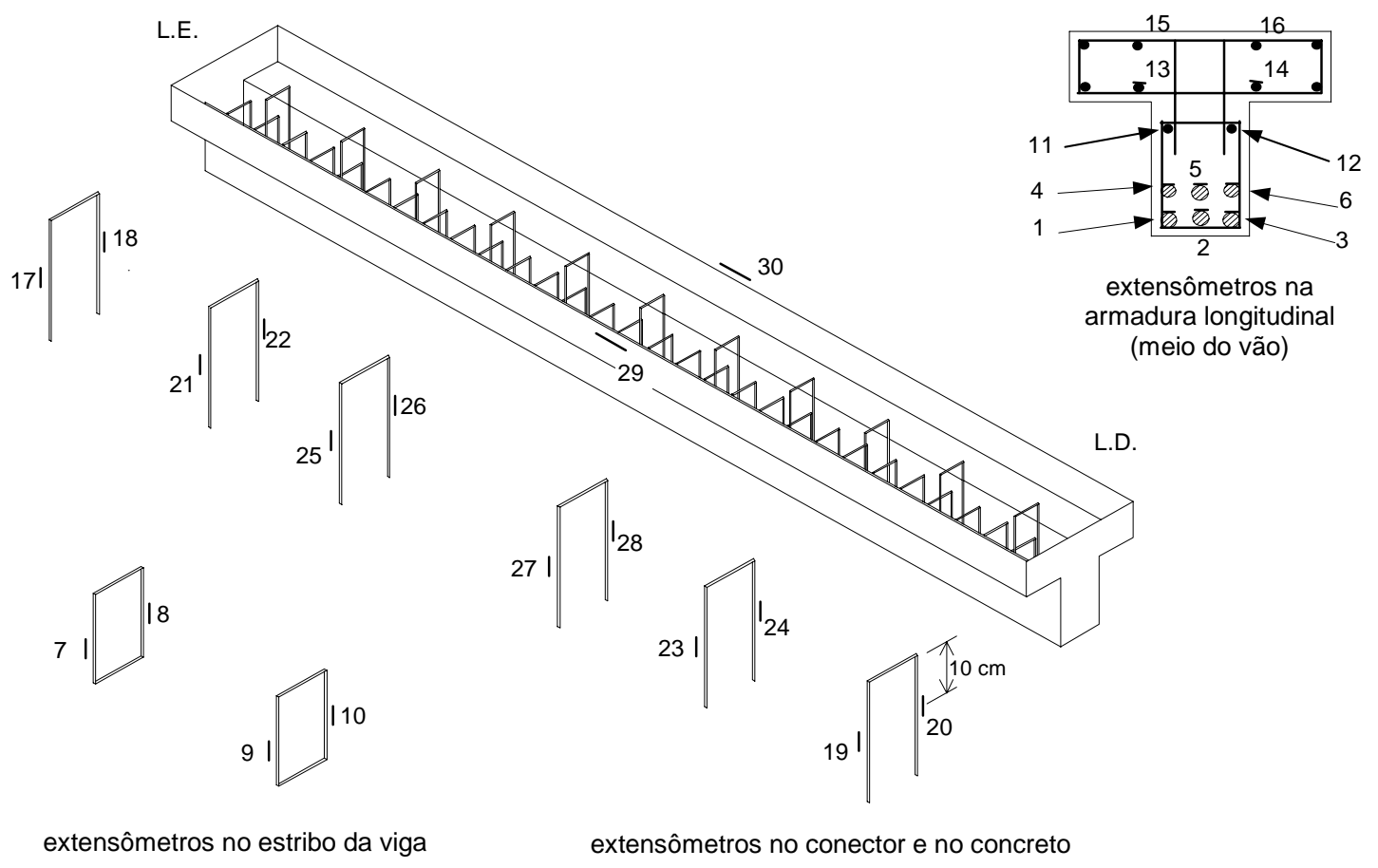

Figura 6.12 - Instrumentação das vigas V3 e V5 com nichos espaçados de $42 \mathrm{~cm}$. 


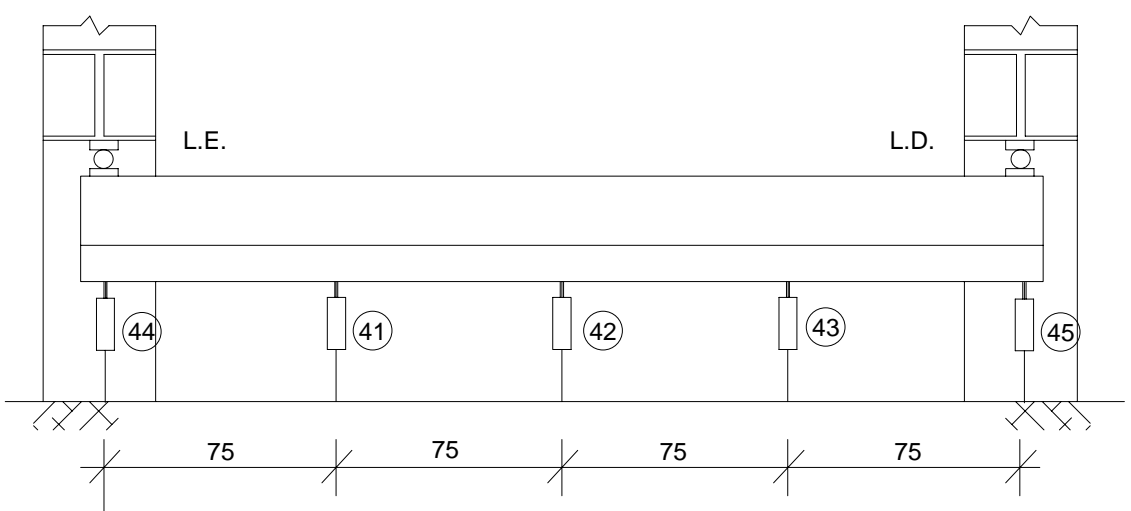

Posição dos transdutores para medição dos deslocamentos verticais
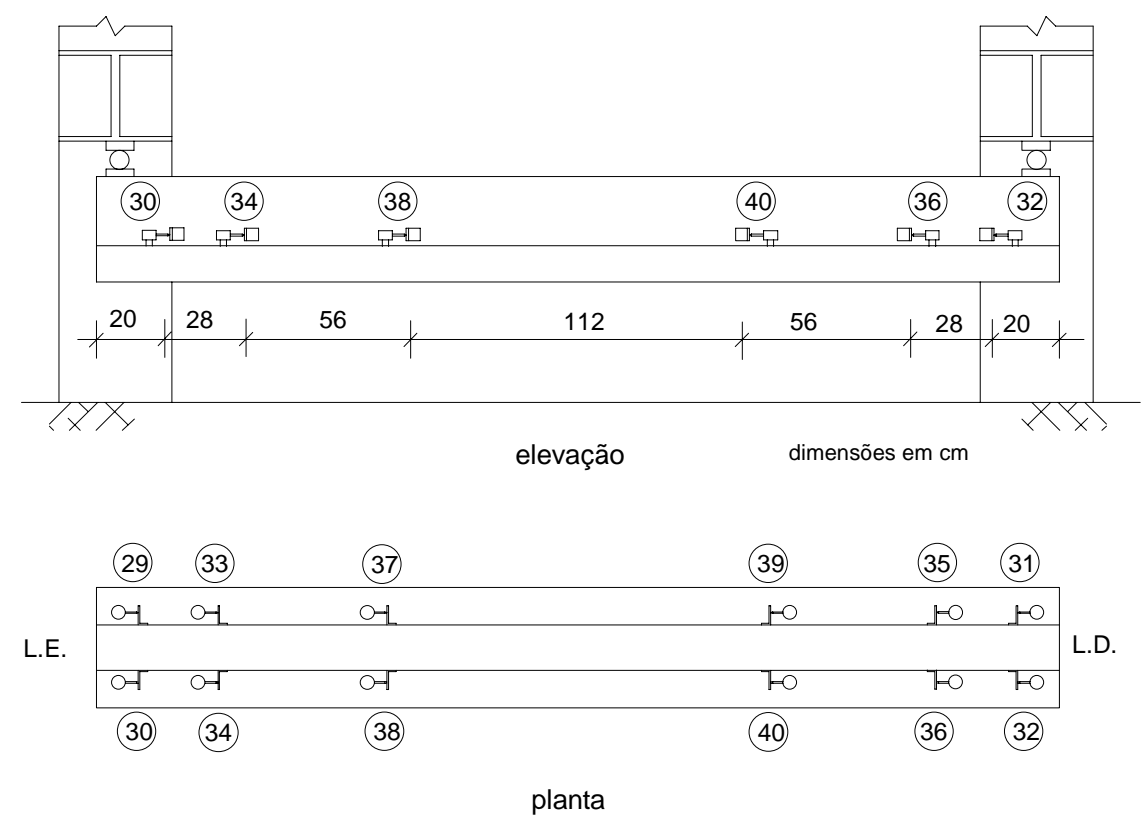

Posição dos transdutores para medição do deslizamento relativo entre a mesa e a alma

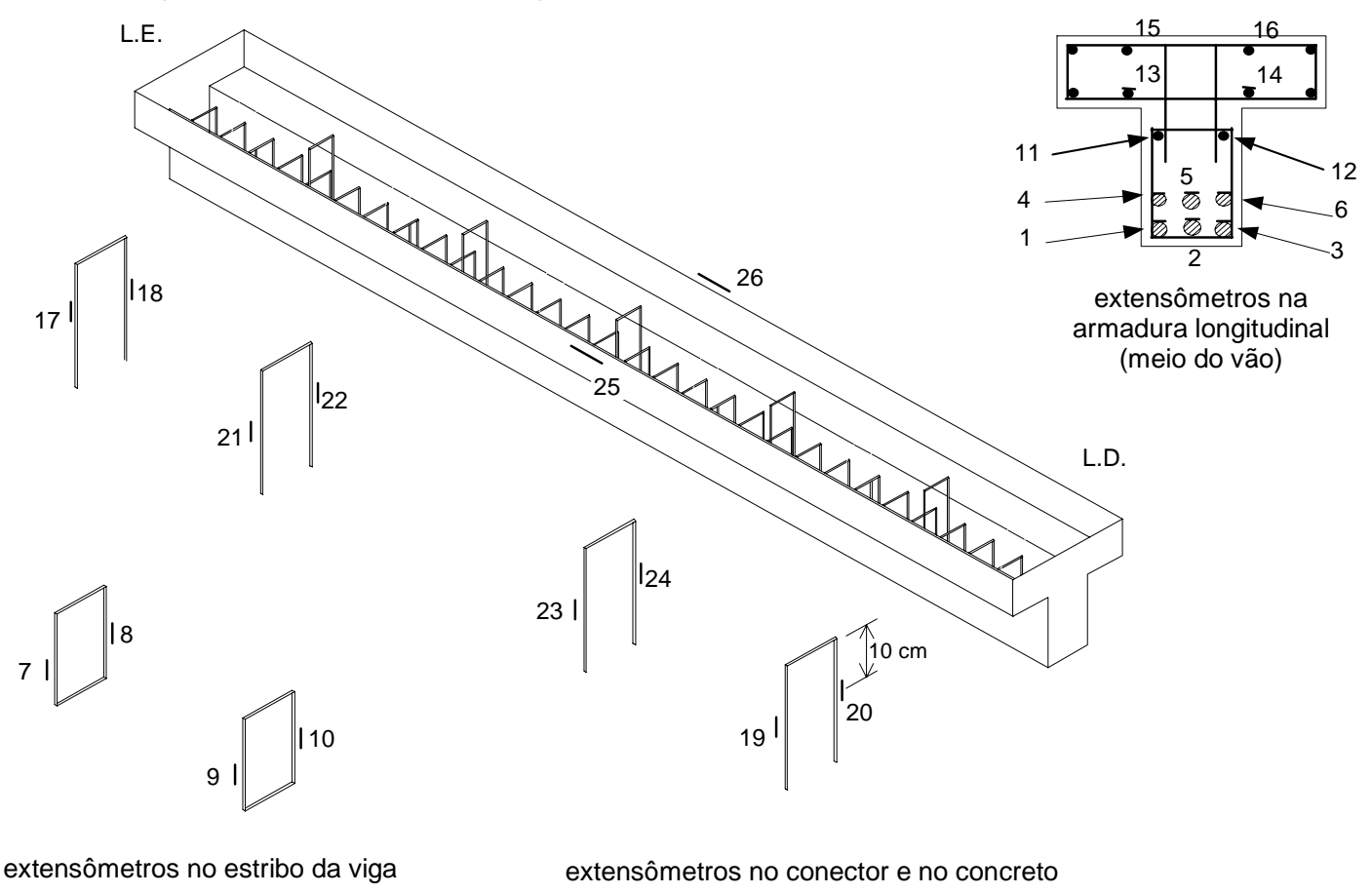

Figura 6.13 - Instrumentação da viga V4 com nichos espaçados de $56 \mathrm{~cm}$ 


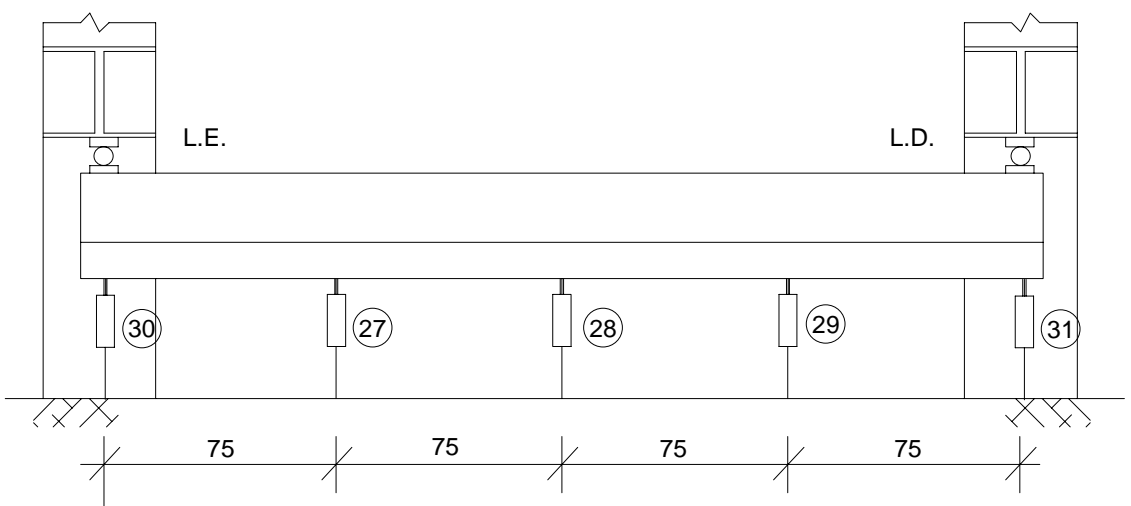

Posição dos transdutores para medição dos deslocamentos verticais
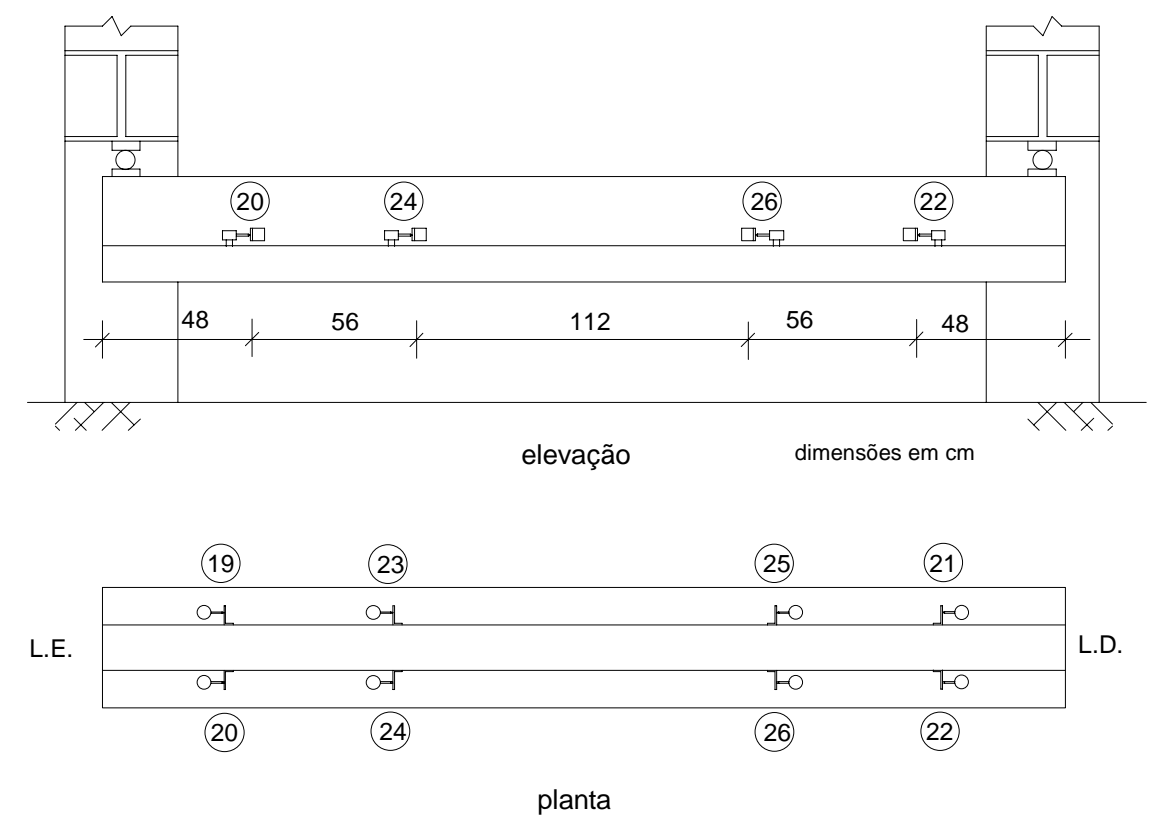

Posição dos transdutores para medição do deslizamento relativo entre a mesa e a alma

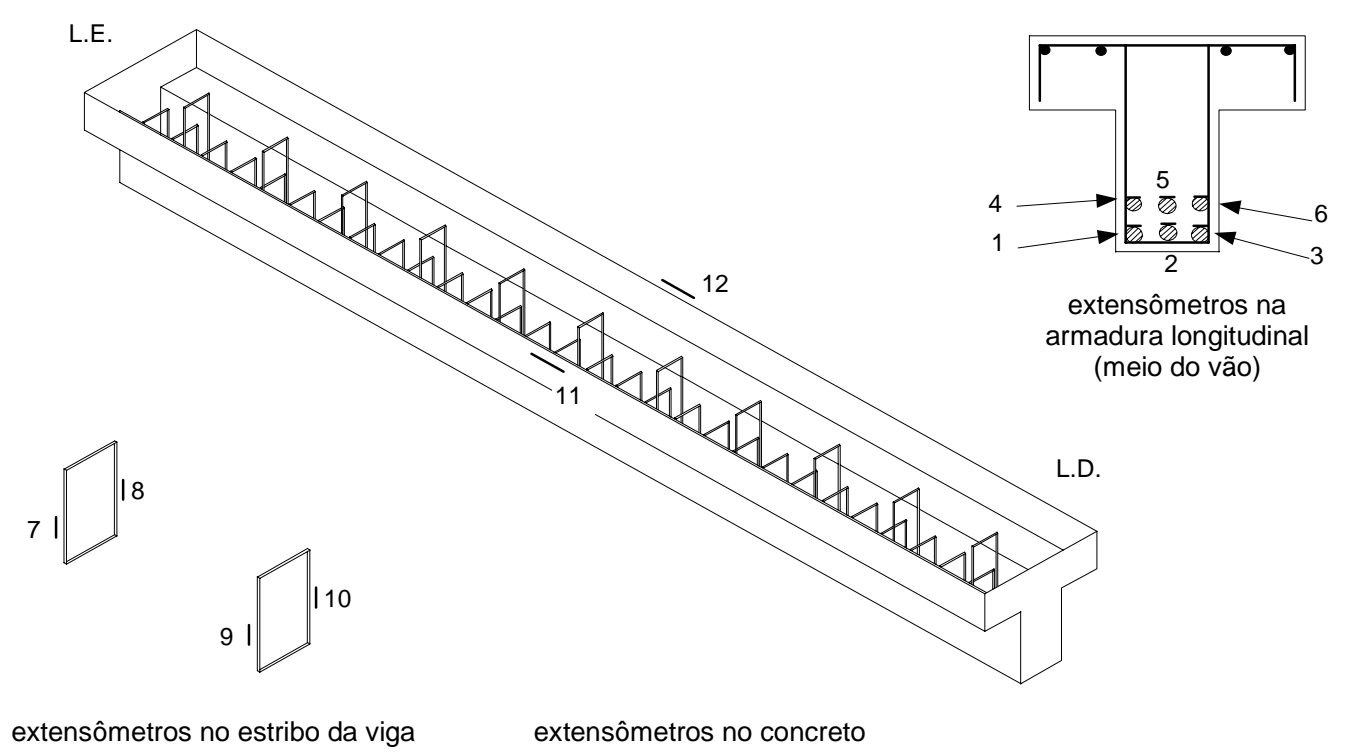

Figura 6.14 - Instrumentação da viga V1 monolítica 


\subsubsection{Execução dos ensaios}

Os ensaios nas vigas compostas foram realizados sete dias após a execução da ligação. No caso da viga monolítica, o ensaio foi realizado sete dias após a concretagem da viga. A realização do ensaio após um período tão reduzido de cura somente foi possível devido ao emprego de cimento de alta resistência inicial na preparação do concreto.

Os ensaios com carregamento monotônico foram realizados com controle de força, empregando um atuador hidráulico acoplado a uma célula de carga, ambos com capacidade de 1000 kN, e dois pórticos de reação. As vigas foram ensaiadas em posição invertida, ou seja, com a face superior da laje voltada para baixo, conforme ilustrado na Figura 6.15, e foram solicitadas por uma força concentrada no meio do vão. O carregamento foi aplicado com incrementos de $10 \mathrm{kN}$, sendo as leituras registradas pelo sistema de aquisição de dados System 4000 disponível no laboratório. O panorama de fissuração das vigas também foi observado durante os ensaios de modo a analisar a sua forma de ruptura.

O ensaio da viga $\mathrm{V} 5$, com carregamento cíclico não reversível, foi realizado com controle de deslocamento empregando um atuador servo-controlado INSTRON com capacidade de $500 \mathrm{kN}$. Foram adotadas duas velocidades de carregamento durante o ensaio. $\mathrm{Na}$ etapa de carregamento, a velocidade adotada foi de $0,075 \mathrm{~mm} / \mathrm{s}$, enquanto no descarregamento a velocidade foi de $0,10 \mathrm{~mm} / \mathrm{s}$. A viga foi descarregada sem, contudo, solicitá-la no outro sentido. O objetivo desse ensaio era verificar se a resistência e a rigidez da viga composta sofriam alguma diminuição quando ela era submetida a carregamentos sucessivos. Dessa forma, as amplitudes adotadas na etapa de carregamento eram inferiores à resistência à flexão da viga. Foram adotadas três amplitudes: 30\%, 50\% e 75\% da força última da viga, que era conhecida pelo ensaio da viga V3.

Para cada amplitude, foram realizados vinte ciclos completos de carga e descarga. A escolha do número de ciclos foi feita, como nos ensaios de cisalhamento direto, admitindo que a perda de rigidez da viga estaria estabilizada antes de vinte ciclos de carga. Após o termino do carregamento cíclico, a viga foi levada à ruptura aplicando o carregamento de modo contínuo a uma velocidade de $0,03 \mathrm{~mm} / \mathrm{s}$.

Na Figura 6.16 é mostrado o esquema do carregamento cíclico adotado. O período de cada ciclo dependia da amplitude do carregamento. No primeiro nível de carregamento, cada ciclo durava, em média, 120 segundos. Esse período era maior nos níveis maiores de carregamento. 


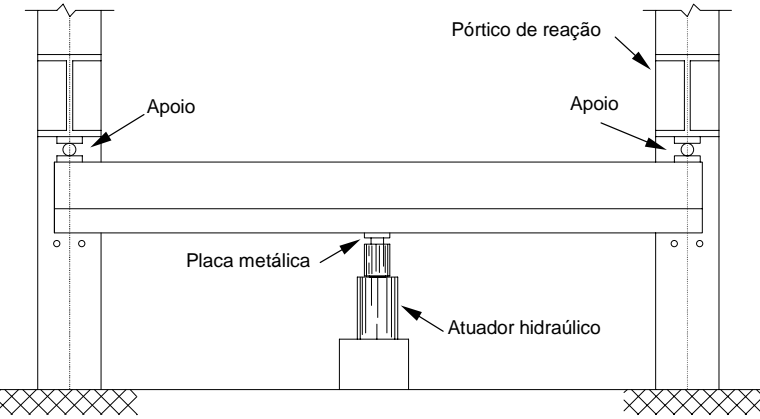

Esquema de carregamento

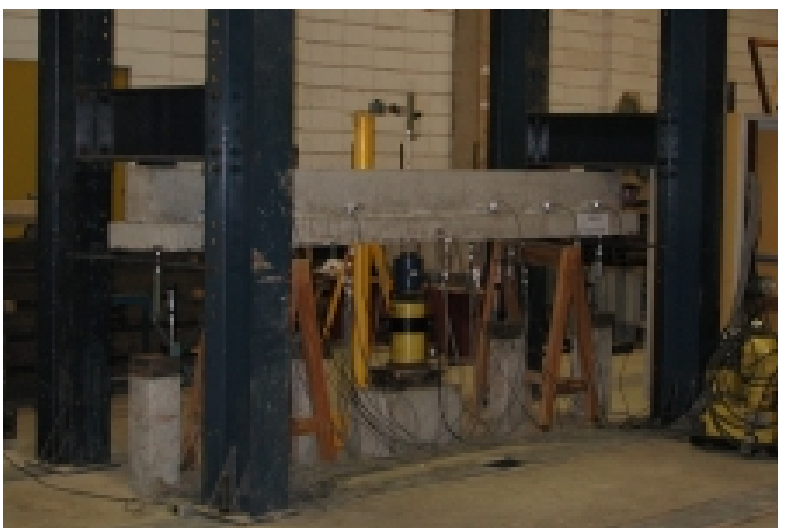

Figura 6.15 - Ensaio das vigas compostas submetidas a carregamento monotônico.

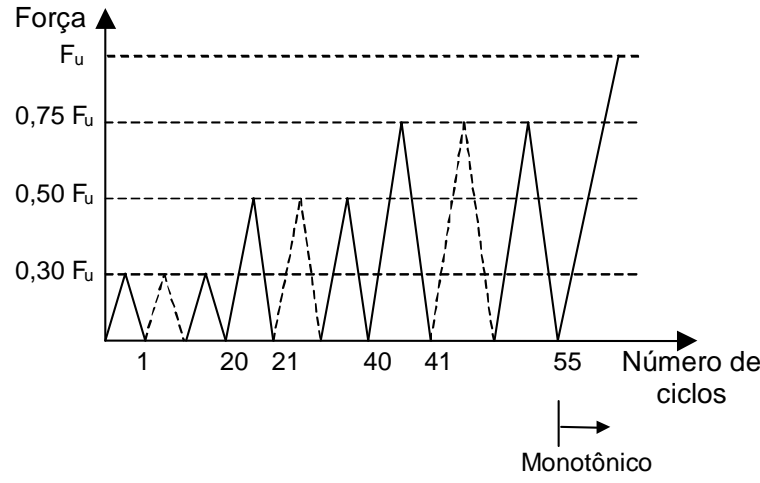

(a) Esquema de carregamento

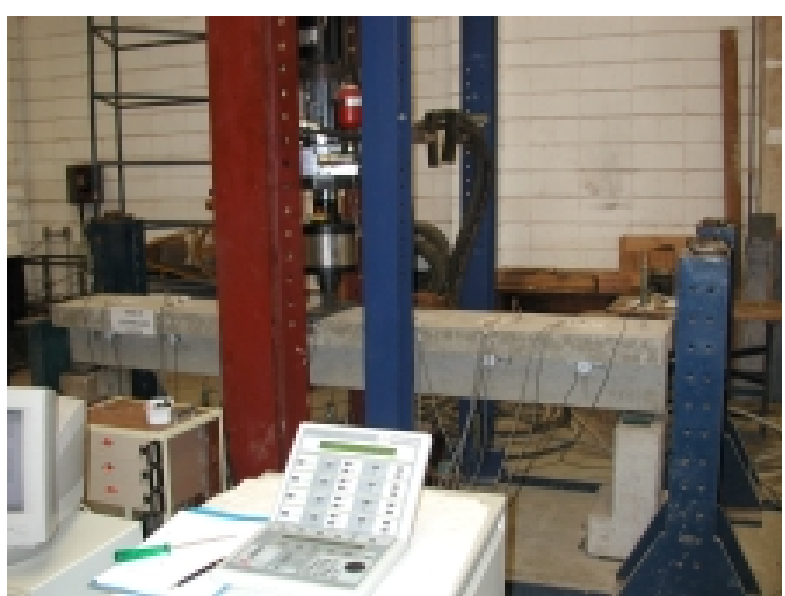

(b) Viga posicionada para ensaio

Figura 6.16 - Ensaio da viga composta submetida a carregamento cíclico

\subsection{Resultados dos ensaios}

\subsubsection{Vigas submetidas a carregamento monotônico}

\subsubsection{Resistência e rigidez à flexão}

$\mathrm{Na}$ Tabela 6.3 é mostrada a máxima força resistida pelas vigas submetidas a carregamento monotônico. Também são mostrados os resultados de duas vigas compostas ensaiadas por ARAUJO (1997). Essas vigas eram constituídas por uma viga pré-moldada e pela laje moldada no local, tendo as mesmas dimensões das vigas estudadas neste trabalho. 
Tabela 6.3 - Força máxima resistida pelas vigas ensaiadas

\begin{tabular}{|c|c|c|c|c|}
\hline Viga ensaiada & $\beta$ & Viga $-\mathrm{f}_{\mathrm{cm}}(\mathrm{MPa})$ & Laje $-\mathrm{f}_{\mathrm{cm}}(\mathrm{MPa})$ & Força última $(\mathrm{kN})$ \\
\hline Monolítica-V1 & - & 52,92 & - & 437,0 \\
\hline Laje pré-moldada-V2 & 0,48 & 53,93 & 51,46 & 429,8 \\
\hline Laje pré-moldada-V3 & 0,31 & 59,76 & 61,28 & 324,5 \\
\hline Laje pré-moldada-V4 $^{\text {Laje moldada no }}$ & 0,22 & 55,45 & 50,05 & 290,5 \\
\hline local $^{*}$ & 1,00 & 48,60 & 39,80 & 419,9 \\
\cline { 2 - 5 } & 1,00 & 42,84 & 41,50 & 389,2 \\
\hline
\end{tabular}

${ }^{*}$ Resultados obtidos por ARAUJO (1997)

Na Figura 6.17 é mostrada a relação entre a máxima força resistida pelas vigas e o parâmetro $\beta$, definido pela relação entre a área da interface responsável pela transferência de esforços e a área total da interface. Nas vigas com laje pré-moldada, esse parâmetro é definido pela relação entre a área total dos nichos e a área da interface, enquanto nas vigas com laje moldada no local ele é igual à unidade, uma vez que neste caso a transferência de esforços de horizontais é feita por toda a interface. Dessa figura, observa-se que à medida que se aumenta o espaçamento dos nichos, a capacidade resistente da viga diminui. Os resultados mostraram que uma redução de 35\% da área responsável pela transferência de esforços pela interface resultou em uma redução de $24 \%$ da capacidade resistente da viga. De modo semelhante, uma redução de $54 \%$ da área da interface resultou em uma redução de $32 \%$ da capacidade resistente da viga. Por outro lado, a garantia de transferência de esforços por $48 \%$ da interface, proporcionou uma capacidade resistente para a viga muito próxima à observada na viga monolítica com as mesmas dimensões. Comparando com as vigas compostas com laje moldada no local, observou-se que a solução em laje prémoldada foi capaz de garantir o mesmo nível de resistência à viga composta, desde que garantida uma área mínima de transferência de esforços pela interface. Esses resultados foram obtidos a partir de ensaios com chave de cisalhamento na ligação entre a viga e laje pré-moldada, devendo ser confirmados para outros tipos de ligação.

A curva força versus deslocamento vertical no meio do vão das vigas compostas é mostrada na Figura 6.18. Observa-se que a curva da viga com $\beta=0,48$ é muito semelhante à curva da viga monolítica. De igual modo, ela também é muito semelhante à curva das vigas com laje moldada no local. Isso mostra que essa viga apresentou um comportamento muito próximo ao de uma viga monolítica. 


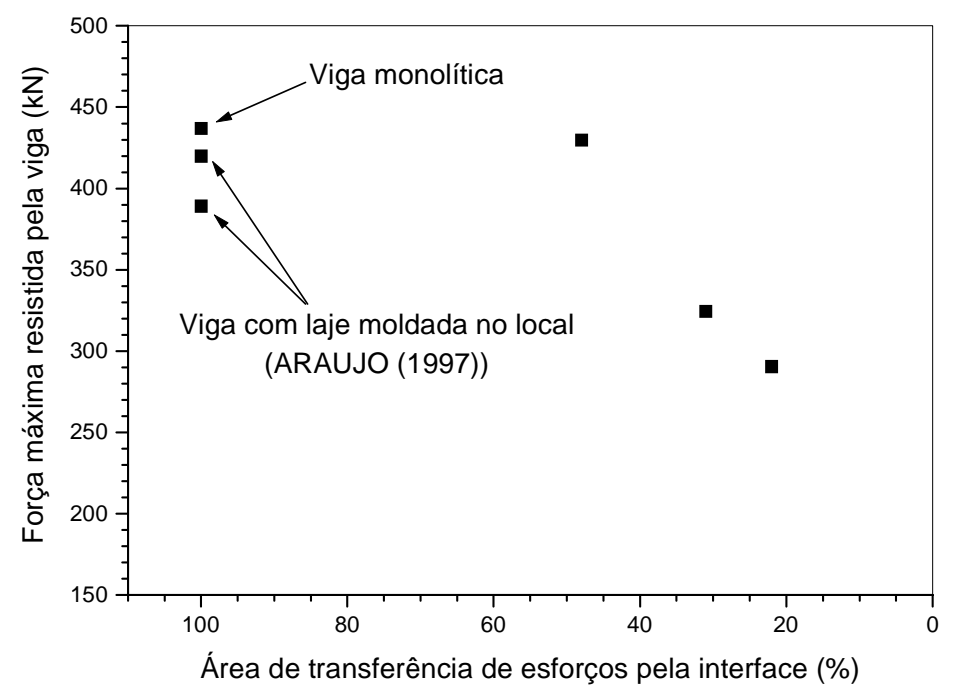

Figura 6.17 - Relação entre a força máxima resistida pela viga e a área de transferência de esforços pela interface
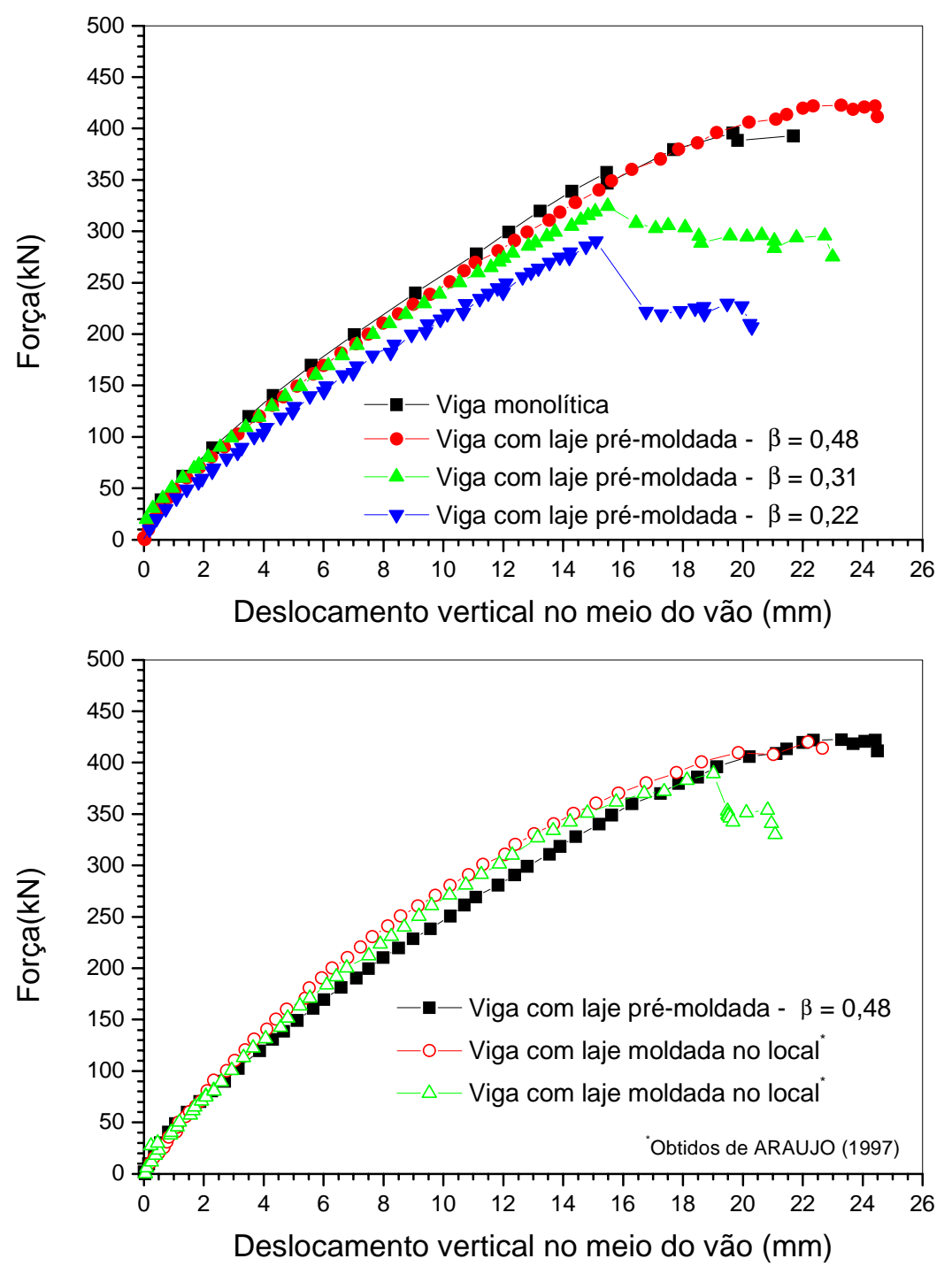

Figura 6.18 - Curva força versus deslocamento vertical nas vigas compostas. 
Dessa figura, também é possível observar uma redução na rigidez da viga à medida que o espaçamento dos nichos aumenta. Por exemplo, tomando a rigidez secante para uma força aplicada de, aproximadamente, $290 \mathrm{kN}$, a redução da área de transferência de esforços de $48 \%$ para $22 \%$ resultou em uma redução de $18 \%$ no valor da rigidez. Isto mostra que a rigidez da viga também é influenciada pelo espaçamento dos nichos, sendo sua redução tanto mais significativa quanto mais espaçados forem os nichos. Essas observações foram feitas a partir de ensaios com chave de cisalhamento na ligação entre a viga e laje pré-moldada, devendo ser verificada para outros tipos de ligação.

\subsubsection{Configuração das fissuras e forma de ruptura das vigas}

No item anterior, foi verificado que a viga V2, com os nichos espaçados de $28 \mathrm{~cm}$, apresentou comportamento semelhante ao da viga monolítica. Essa mesma conclusão pode ser obtida analisando a forma de ruptura das vigas.

A ruptura da viga monolítica ocorreu pelo esmagamento do concreto na face superior da viga. Naquele momento, toda a armadura de flexão também atingiu a tensão de escoamento do aço. A ruptura da viga V2 foi muito semelhante. Durante o seu carregamento, foram observadas várias fissuras de flexão que surgiram na face inferior da viga pré-moldada e prolongaram-se na direção da laje à medida que o carregamento foi incrementado. Próximo à força de ruptura da viga, as fissuras prolongaram-se até a região inferior da laje pré-moldada, reduzindo a região comprimida e culminando no esmagamento do concreto. Naquele momento, toda a armadura de flexão também atingiu a tensão de escoamento do aço. Na Figura 6.19 é mostrado o panorama de fissuração após o término do ensaio dessas vigas. Nota-se que a viga composta apresenta um número maior de fissuras inclinadas na viga pré-moldada que a viga monolítica, havendo uma maior concentração delas junto às chaves. Isto pode ser explicado pelo fato da transferência de esforços pela interface ser feita de forma discreta. Dessa forma, há uma maior concentração de tensões nas regiões próximas às chaves. Nessa figura também são mostradas as deformações médias de tração na armadura principal de flexão e as deformações de compressão na face superior da viga composta. Observa-se comportamento muito semelhante entre a viga monolítica e a viga composta com laje prémoldada, o que confirma que a viga composta com os nichos espaçados de $28 \mathrm{~cm}$ aproximou-se muito bem do comportamento da viga monolítica. Na Figura 6.20 é mostrado o panorama de fissuração de uma viga composta com laje moldada no local ensaiada por ARAUJO (1997). Comparando com a viga V2, observa-se uma nítida modificação na fissuração da viga quando a ligação foi feita de forma discreta, apesar de ambas apresentarem resistências semelhantes. 


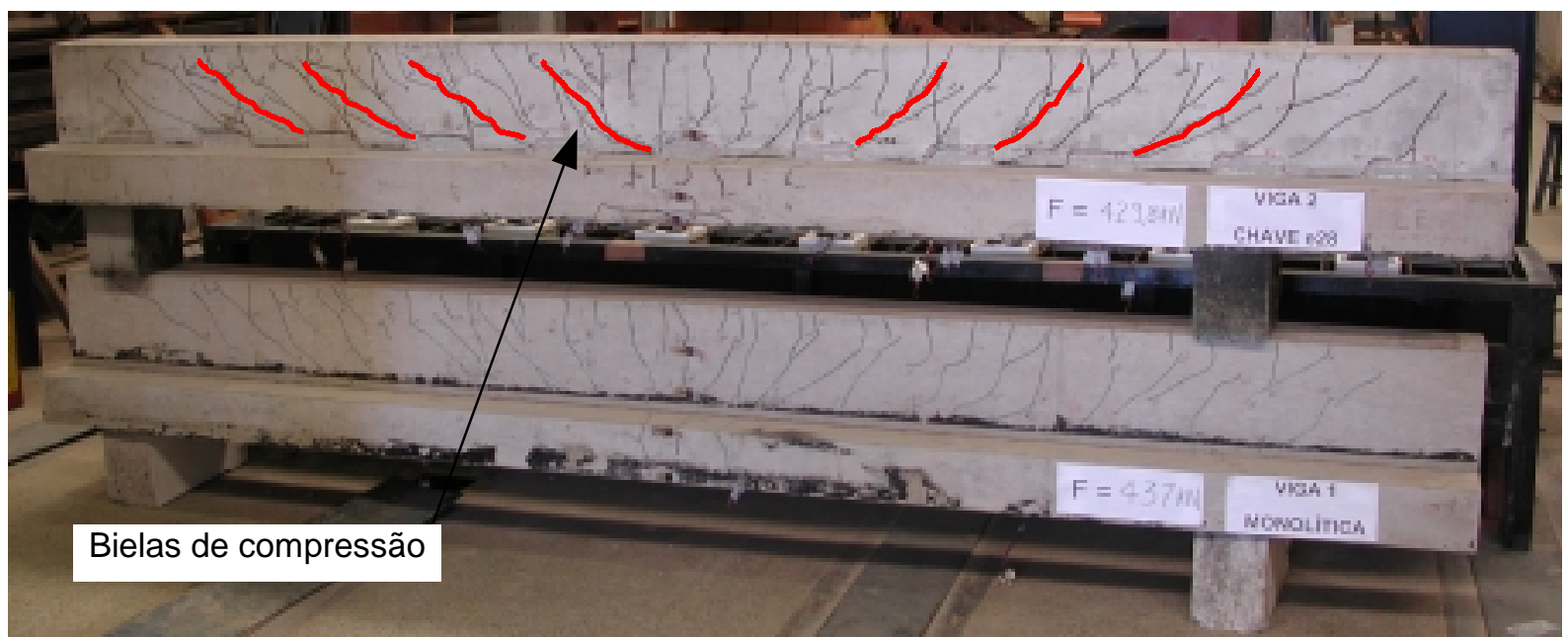

(a) Panorama de fissuração após a ruptura

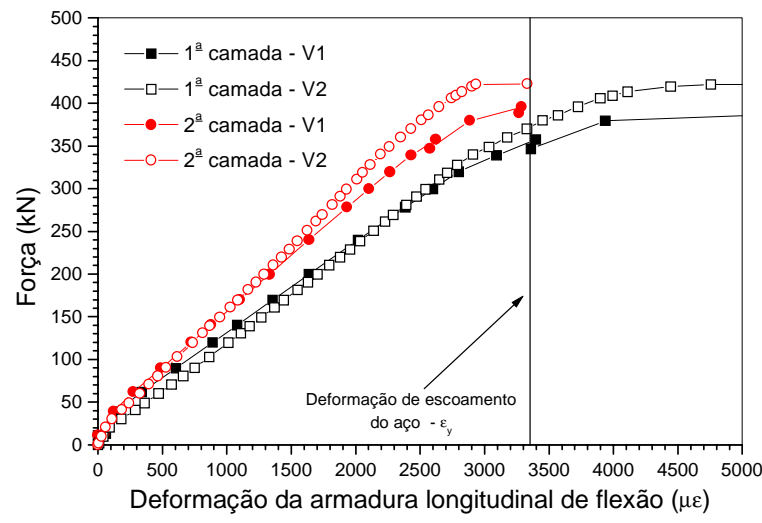

(b) Deformação na armadura principal de flexão

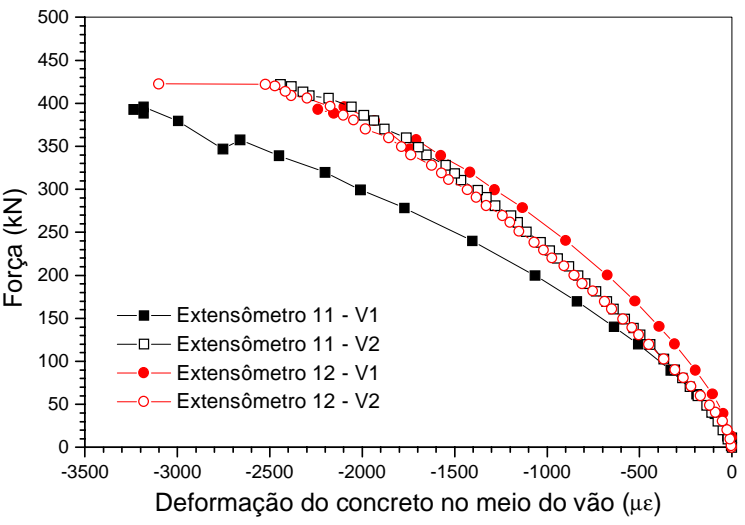

(c) Deformação na face superior da viga

Figura 6.19 - Comparação entre os comportamentos à flexão das vigas monolítica - V1 - e com chave de cisalhamento - V2

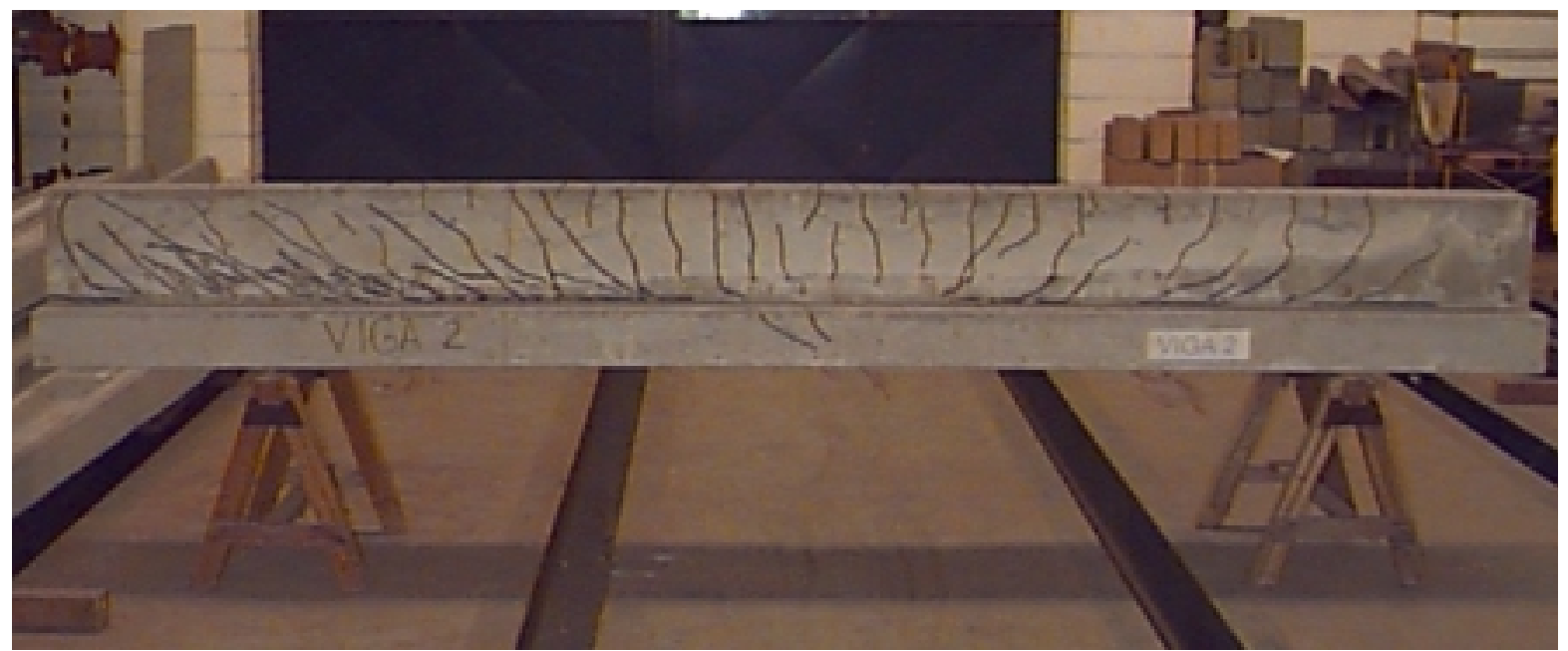

Figura 6.20 - Panorama de fissuração de uma viga composta com laje moldada no local (ARAUJO (1997)). 
A ruptura da viga $V 3$, com os nichos espaçados de $42 \mathrm{~cm}$, ocorreu devido ao esgotamento da capacidade resistente de umas das ligações entre a viga e a laje prémoldadas. No momento em que a viga atingiu sua máxima força, a armadura principal de flexão não havia atingido a tensão de escoamento do aço. Também não foi observada a ruptura do concreto na face superior da viga composta. Ao mesmo tempo em que houve a ruptura da ligação, também foi observada a ruptura do concreto da viga pré-moldada junto à chave de cisalhamento. Isto provavelmente ocorreu devido à tendência de redistribuição dos esforços entre os nichos após a ruptura do primeiro nicho. Contudo, devido ao baixo número de nichos, teve ter ocorrido uma concentração de tensões na viga pré-moldada que resultou na ruptura do concreto antes de haver a redistribuição de esforços. Essa concentração de tensões pôde ser observada desde o início do ensaio. Nas etapas iniciais de carregamento, foram observadas simultaneamente fissuras de flexão na face inferior da viga pré-moldada e fissuras na região da viga pré-moldada junto às chaves de cisalhamento. À medida que o carregamento era incrementado, tanto as fissuras de flexão quanto as fissuras na região da ligação prolongavam-se na direção do interior da viga pré-moldada. As fissuras de flexão não alcançaram a face inferior da laje pré-moldada no meio do vão. Esta somente veio a fissurar nas etapas finais de carregamento, provavelmente pela flexão independente entre a viga e a laje. Quanto às fissuras que se originaram na região da ligação, elas estenderamse até a face inferior da viga pré-moldada (Figura 6.21 e Figura 6.22).

$A$ ruptura da viga $V 4$, com os nichos espaçados de $56 \mathrm{~cm}$, foi semelhante à ruptura da viga V3. A máxima força da viga composta foi alcançada quando ocorreu a ruína de uma das ligações entre a viga e laje pré-moldadas. Também não foi observado escoamento da armadura principal de flexão nem ruptura do concreto na face superior da viga composta. Foi observada pouca fissuração devido à flexão da viga, e as fissuras que surgiram no meio do vão não atingiram a face inferior da laje pré-moldada. Esta veio a fissurar próximo à ruptura da viga composta, porém de modo menos intenso que o observado na viga V3. Após a ruptura da ligação, foi observado um rápido aumento do deslizamento relativo da interface e do deslocamento vertical da viga composta com brusca redução na força aplicada. Nessa viga, aparentemente, não havia nichos em quantidade suficiente para promover uma redistribuição de esforços pela interface. Dessa forma, rompida a primeira ligação, a viga composta passou a se comportar como duas vigas independentes. Também foi observada a formação de uma fissura prematura na viga pré-moldada entre os nichos, de modo semelhante ao da viga V3. Contudo, essa fissura surgiu depois de atingida a máxima força resistida pela viga composta, e deve ter sido ocasionada pelo excessivo deslizamento entre a viga e a laje pré-moldadas. 


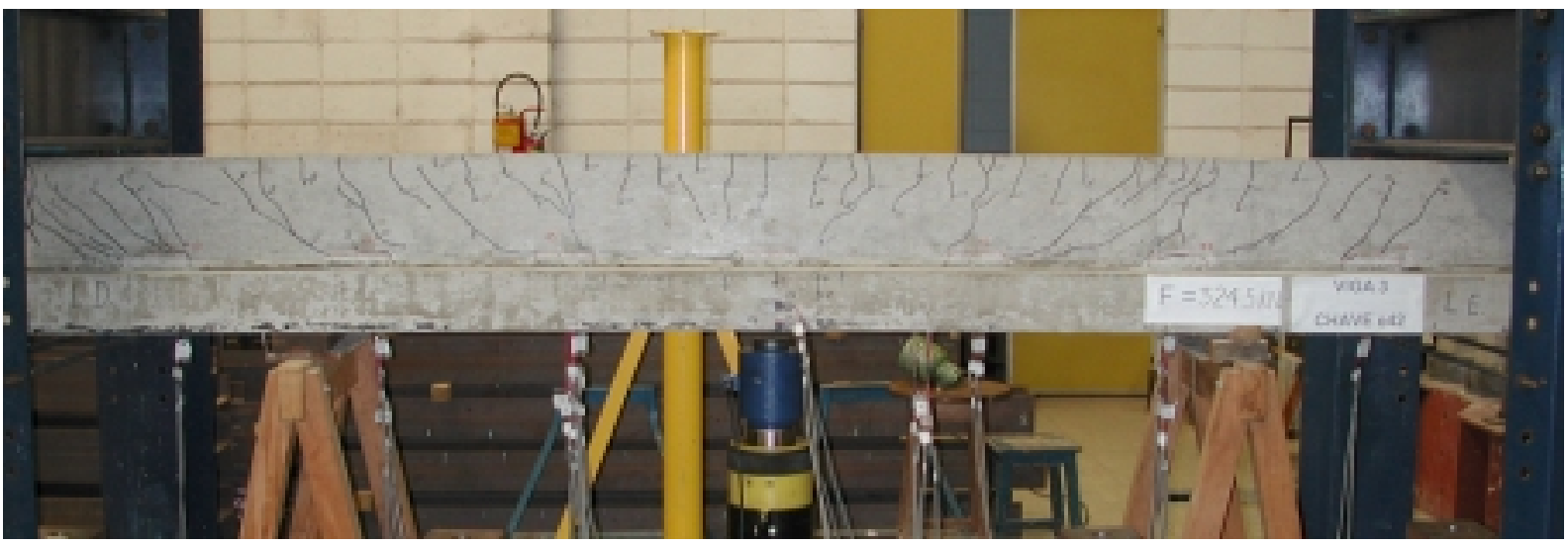

(a) Panorama de fissuração da V3 após a ruptura

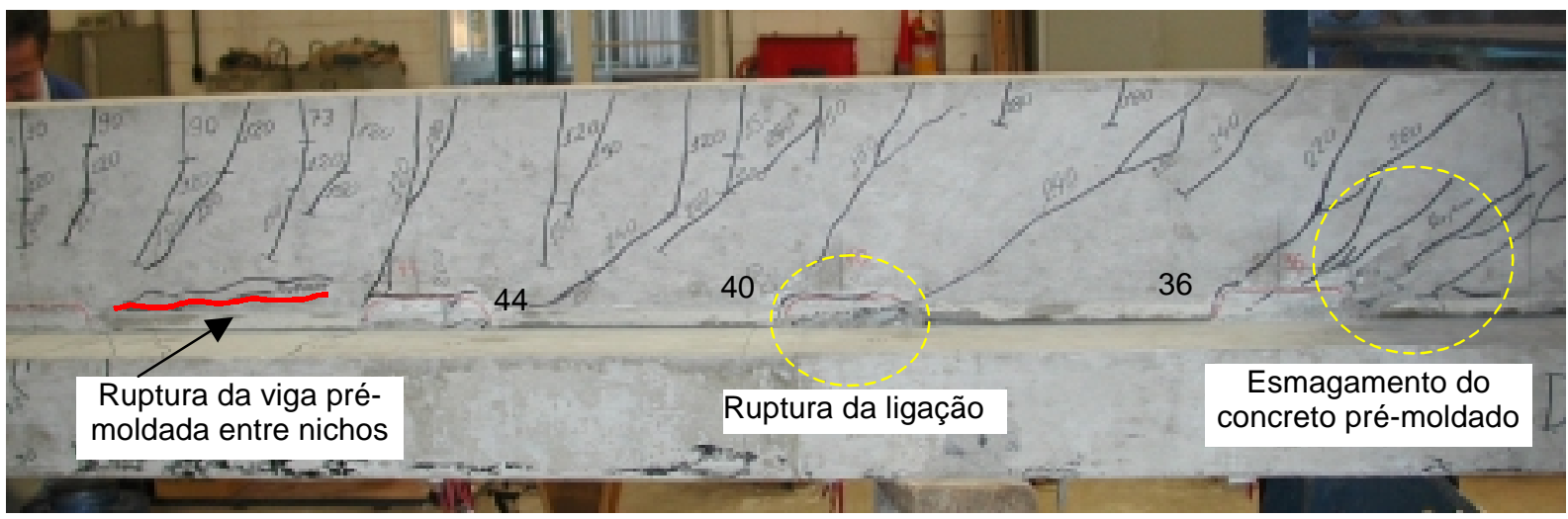

(b) Detalhe da V3 mostrando a ruptura da ligação e do concreto pré-moldado

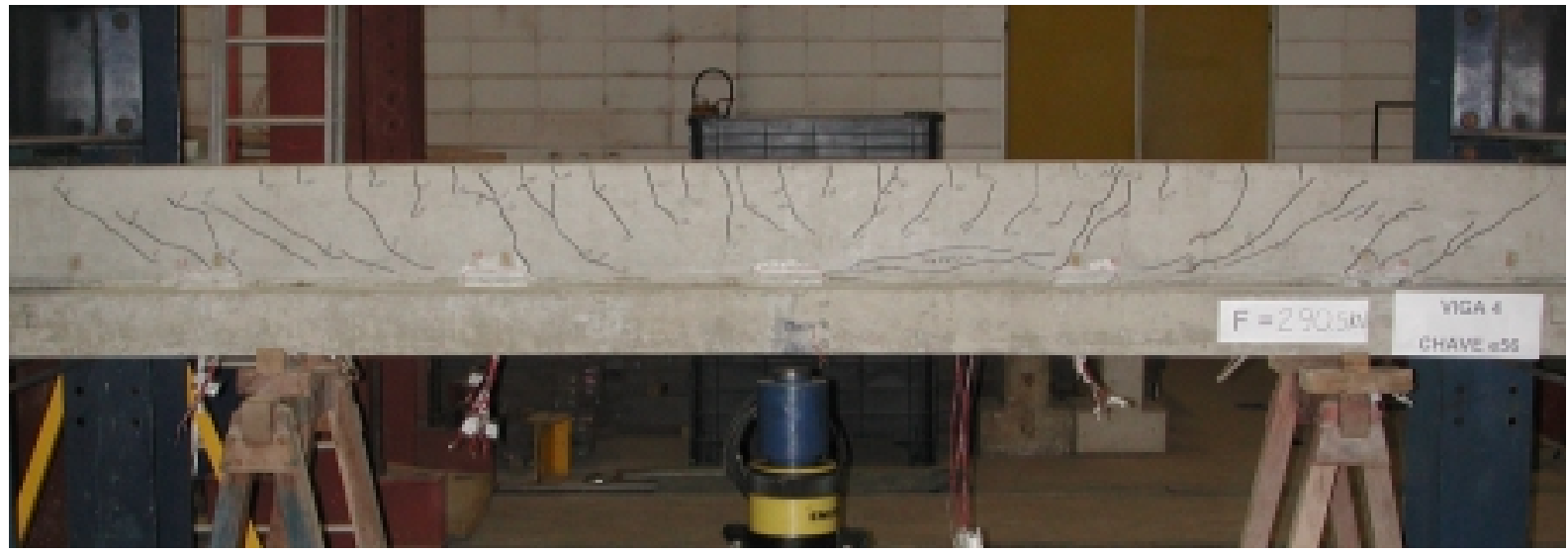

(c) Panorama de fissuração da V4 após a ruptura

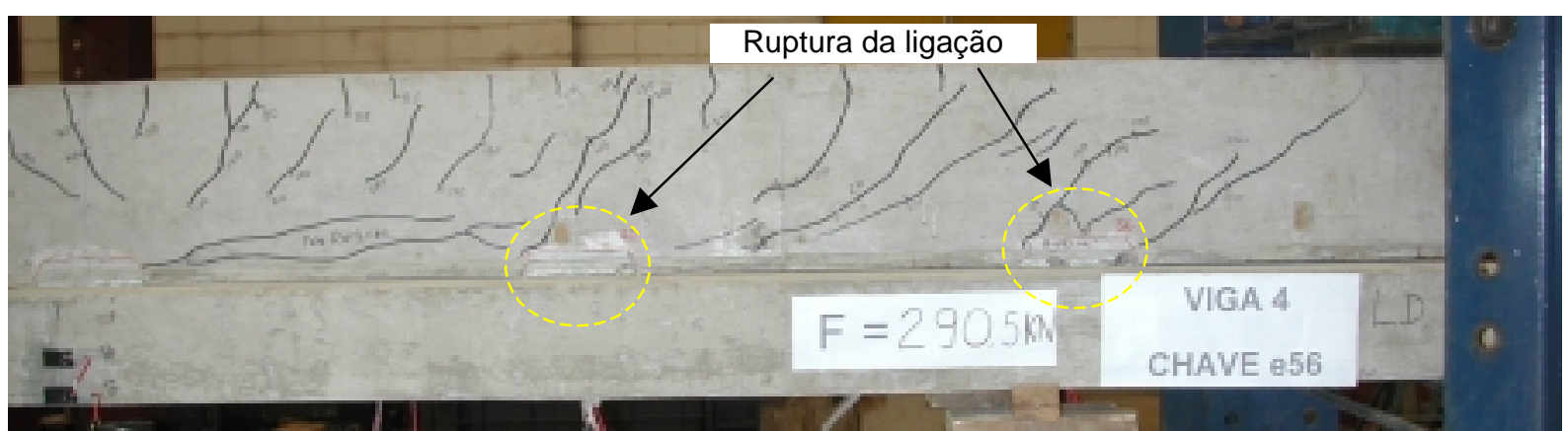

(d) Detalhe da V4 mostrando a ruptura da ligação

Figura 6.21 - Forma de ruptura das vigas compostas V3 e V4 

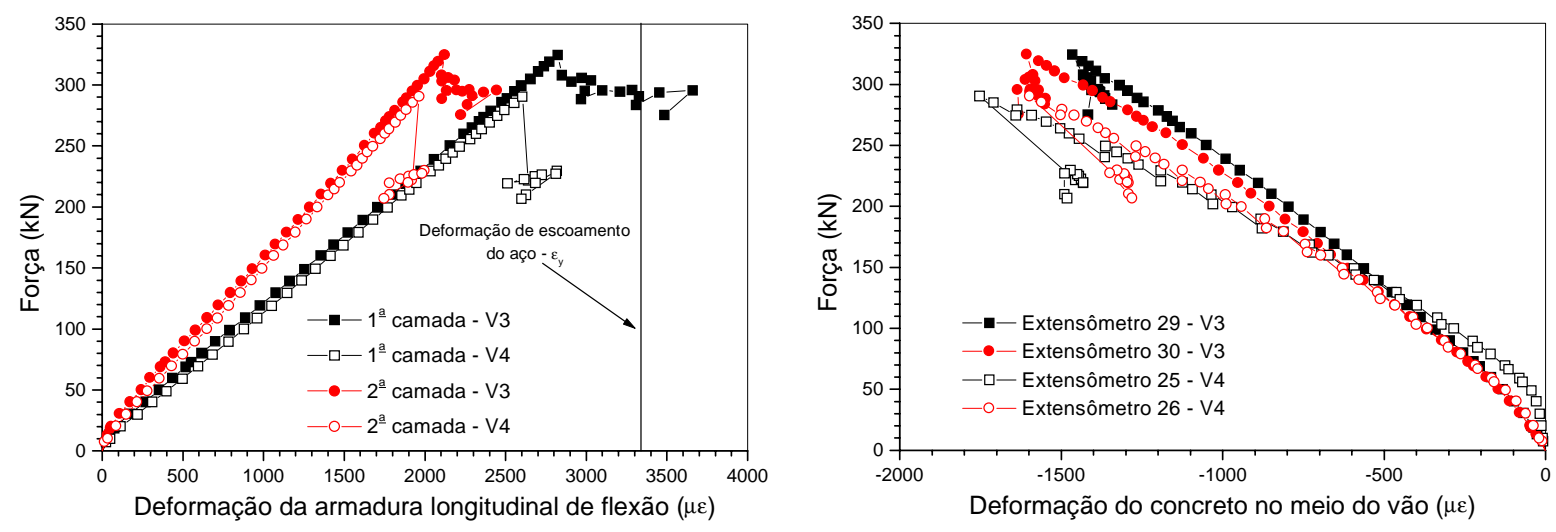

Figura 6.22 - Comparação entre os comportamentos à flexão das vigas compostas V3 e V4

A forma como as vigas V3 e V4 romperam sugere que, nessas vigas, o número de nichos era inferior ao necessário para garantir a transferência integral de tensões pela interface, enquanto na viga V2 o número de nichos era suficiente para fazer a viga composta comportar-se como uma viga monolítica. Essas observações também podem ser obtidas analisando a tensão de cisalhamento na interface entre a viga e a laje prémoldadas.

Nas vigas compostas, uma da formas de avaliar a tensão de cisalhamento na interface consiste em calcular as resultantes dos esforços normais na seção transversal da viga, e prover a transferência desses esforços pela interface. A tensão de cisalhamento média é avaliada entre as seções de momento máximo, positivo ou negativo, e momento nulo. Nesse trecho, a força transmitida pela interface é igual à resultante de compressão na seção de momento máximo, uma vez que na seção de momento nulo a resultante de compressão é nula. A tensão na interface pode, portanto, ser avaliada por (Figura 6.23):

$$
\tau=\frac{F_{\text {int }}}{b \cdot a_{v}}=\frac{A_{c 2} \cdot 0,85 \cdot f_{c d}}{b \cdot a_{v}} \leq \frac{A_{s} \cdot f_{y d}+A_{p} \cdot \sigma_{p d}}{b \cdot a_{v}}
$$

$F_{\text {int }}:$ força na interface

$A_{c 2}$ : área comprimida da seção transversal acima da interface

$A_{s}$ : área de aço da armadura passiva

$A_{p}$ : área de aço da armadura ativa

$\mathrm{f}_{\mathrm{cd}}$ : resistência de cálculo à compressão do concreto

$\mathrm{f}_{\mathrm{yd}}$ : resistência de cálculo do aço

b : largura da interface;

$a_{v}$ : comprimento sobre o qual são transferidas as tensões de cisalhamento horizontais, isto é, a distância entre os pontos de momento máximo e momento nulo;

$\sigma_{p d}$ : tensão na armadura de protensão; 


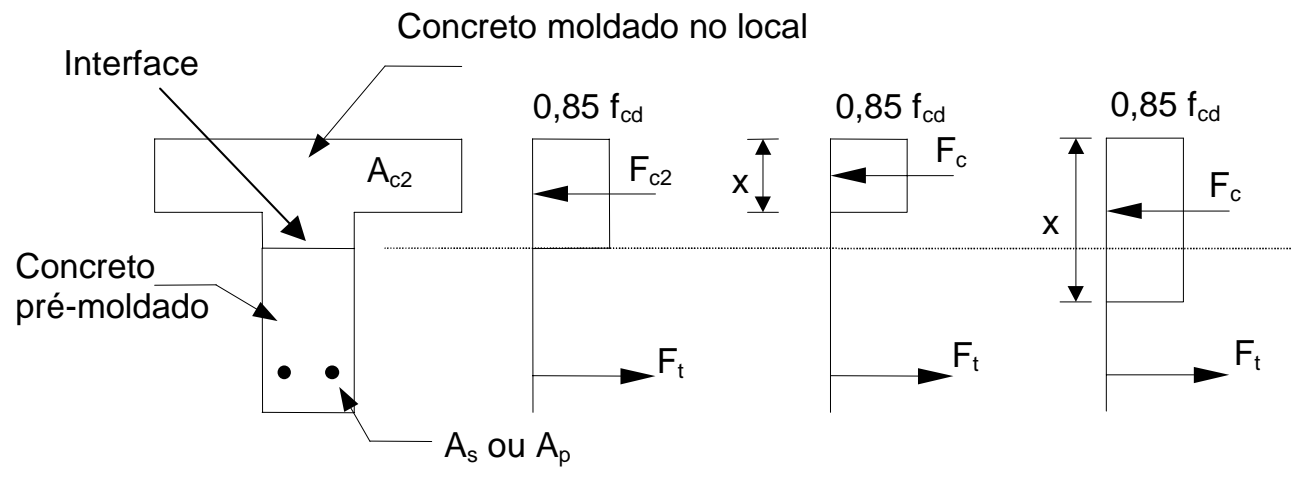

Caso 1

Caso 2

$$
\begin{aligned}
\text { Caso 1: } F_{\mathrm{c} 2}>F_{\mathrm{c}} & \text { Caso 2: } & F_{\mathrm{c} 2}<F_{c} \\
F_{\text {int }} & =F_{c}=F_{t} & F_{i n t}=F_{c 2}<F_{t}
\end{aligned}
$$

Sendo $F_{c}$ : resultante de compressão na seção composta

$\mathrm{F}_{\mathrm{c} 2}$ : resultante de compressão na seção de concreto acima da interface

$F_{t}$ : resultante de tração na armadura de flexão

$F_{\text {int }}$ : força transmitida pela interface

Figura 6.23 - Avaliação da tensão na interface por equilíbrio de forças

No momento da ruptura da viga V2 a linha neutra da seção composta encontrava-se acima da interface. Dessa forma, a tensão de cisalhamento na interface pode ser obtida através da deformação das barras longitudinais, o que resultou em uma tensão igual a 5,5 $\mathrm{MPa}$. A força aplicada em cada nicho foi avaliada dividindo a força total transmitida pela interface pelo número de nichos existentes, o que resultou em uma força de $264 \mathrm{kN}$. Empregando a eq.(5.2b), deduzida no capítulo 5, obteve-se uma resistência estimada para cada ligação igual a 293 kN. Este valor é superior à solicitação na ligação, o que comprova que os nichos foram capazes de garantir o trabalho conjunto da viga e da laje prémoldadas, permitindo que o comportamento da viga composta se aproximasse do comportamento da viga monolítica.

$\mathrm{Na}$ viga V3, foi realizado um procedimento ligeiramente diferente. Aplicando novamente a eq.(5.2b), obteve-se uma resistência estimada para cada ligação igual a 323 kN. Como foram dispostos 3 nichos em cada metade do vão, a resistência total da interface valia 969 kN, o que resultava em uma tensão resistente para interface de 4,04 MPa. Este valor é inferior à tensão solicitante obtida na viga V2, o que mostra que esta viga não poderia alcançar a mesma força máxima que a viga V2. Usando a deformação da armadura de flexão, chega-se a uma tensão máxima solicitante na interface da viga V3 igual a 3,98 $\mathrm{MPa}$. Esse valor é praticamente igual à tensão resistente da interface, o que comprova que a ruptura dessa viga ocorreu pelo esgotamento da capacidade resistente das ligações. 
Procedendo de modo semelhante com a viga V4, obteve-se uma resistência estimada para cada ligação igual a 322 kN, o que resultava em uma tensão resistente para a interface de 2,7 MPa. Como esse valor é inferior à solicitação que surgiu na viga V2, novamente conclui-se que essa viga não poderia se comportar como uma viga monolítica, sendo sua resistência à flexão definida pela capacidade resistente das ligações.

\subsubsection{Deslizamento relativo na interface e deformação dos conectores}

Na Figura 6.24 é mostrado o deslizamento relativo na interface ao longo do vão das vigas compostas ensaiadas. A partir dessa figura, é possível visualizar a seqüência de ruptura da viga. No caso da viga $V 2$, nota-se que o deslizamento na interface foi aproximadamente constante ao longo do vão até um carregamento correspondente a $40 \%$ da máxima força resistida pela viga composta. A partir desse carregamento, as ligações situadas próximas a um quarto do vão apresentaram maiores deslizamentos que as demais ligações. No momento da ruptura da viga, as ligações próximas aos apoios apresentavam menores deslizamentos que as demais ligações, indicando que elas ainda não haviam esgotado sua capacidade resistente. Nas vigas V3 e V4 o deslizamento na interface ao longo do vão foi aproximadamente constante até a ruptura da viga, que aconteceu pelo esgotamento da capacidade resistente das ligações na interface.

Essas observações sobre a seqüência de ruptura das vigas compostas também podem ser verificadas pela Figura 6.25, na qual é mostrada a deformação dos conectores nas ligações mais solicitadas das vigas V2, V3 e V4. Por essa figura, observa-se que na viga V2 apenas os conectores das ligações intermediárias atingiram a tensão de escoamento do aço antes da ruptura da viga. Os demais conectores apresentavam deformações menores que a correspondente ao escoamento do aço, o que indica que essas ligações ainda possuíam uma reserva de resistência. Nas vigas V3 e V4, as deformações dos conectores foram aproximadamente iguais em todas as ligações, e a máxima força resistida pela viga composta foi alcançada no momento em que os conectores atingiram o escoamento do aço. Esses resultados novamente confirmam que na viga V2 o número de nichos foi suficiente para que a viga composta se comportasse como uma viga monolítica, enquanto nas demais vigas o baixo número de nichos limitou a capacidade resistente da viga composta. 


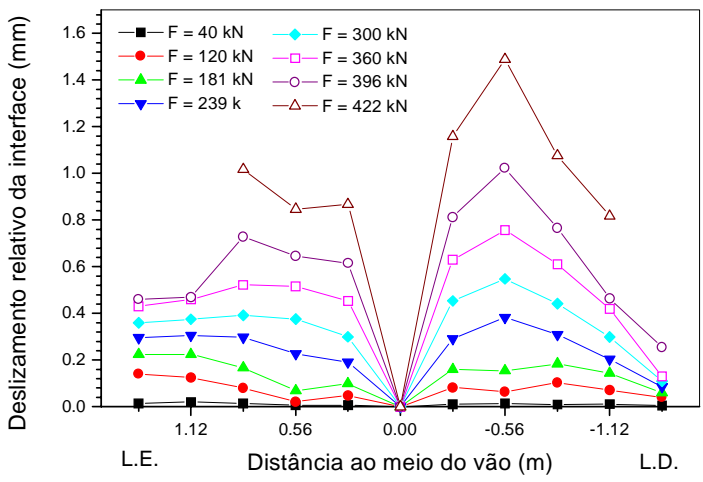

(a) Viga composta V2

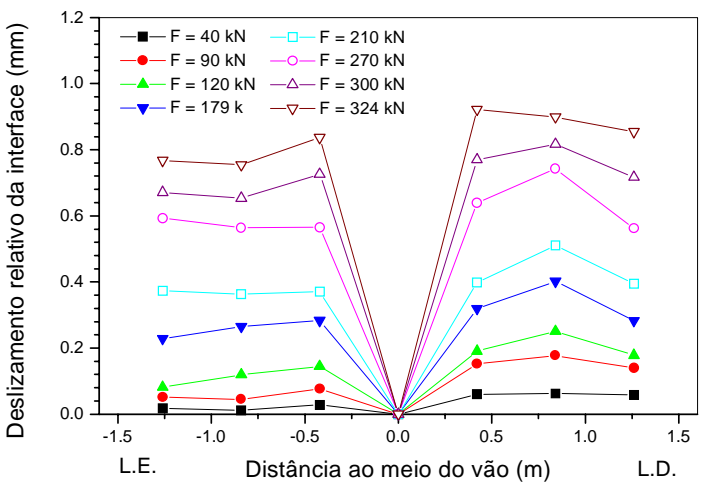

(c) Viga composta V3

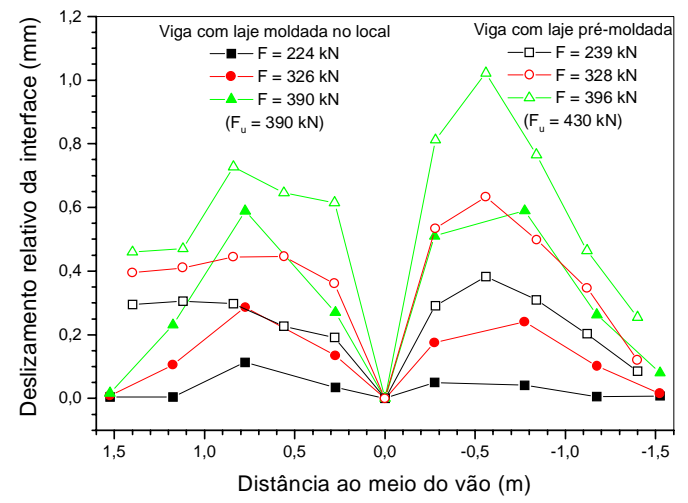

(b) Viga composta V2 e viga com laje moldada no local (ARAUJO (1997))

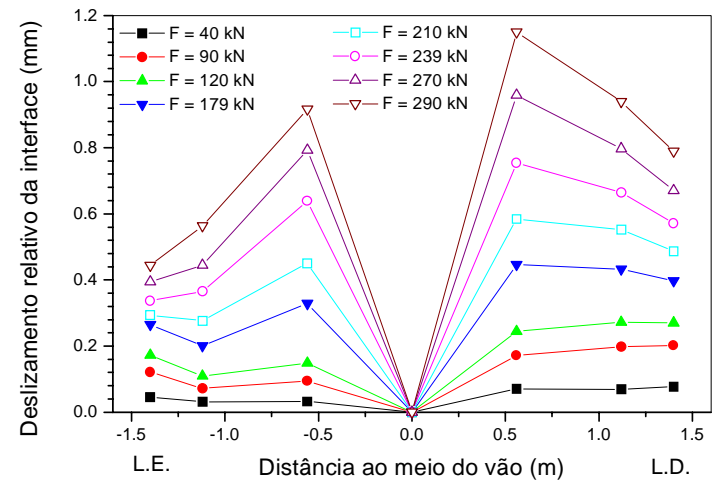

(d) Viga composta V4

Figura 6.24 - Deslizamento relativo na interface das vigas compostas

$\mathrm{Na}$ Figura 6.24b os deslizamentos na interface da viga V2 são comparados com os deslizamentos na interface de uma viga composta com laje moldada no local, ensaiada por ARAUJO (1997), com as mesmas dimensões das vigas ensaiadas neste trabalho. É possível notar que os deslizamentos na viga composta com laje pré-moldada foram superiores aos deslizamentos na viga com laje moldada no local. Isto se deve ao fato que na viga composta com laje pré-moldada houve uma concentração de tensões próxima à região da ligação com conseqüente aumento da fissuração na viga pré-moldada. Como o deslizamento relativo foi medido entre a viga e a laje pré-moldadas, esse aumento na fissuração da viga pré-moldada poder ter resultado em maiores deslizamentos. Essa análise serve para confirmar que alguns limites propostos para as vigas com laje moldada no local não se aplicam às vigas com laje pré-moldada, como, por exemplo, a definição da ruptura da viga composta quando o deslizamento da interface atinge o limite de 0,5 mm (ARAUJO (1997) e PATNAIK (1992)). 


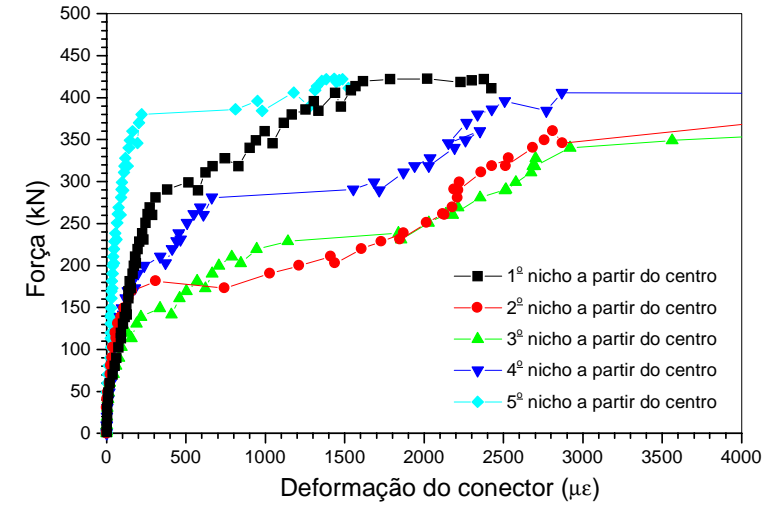

(a) Viga composta V2

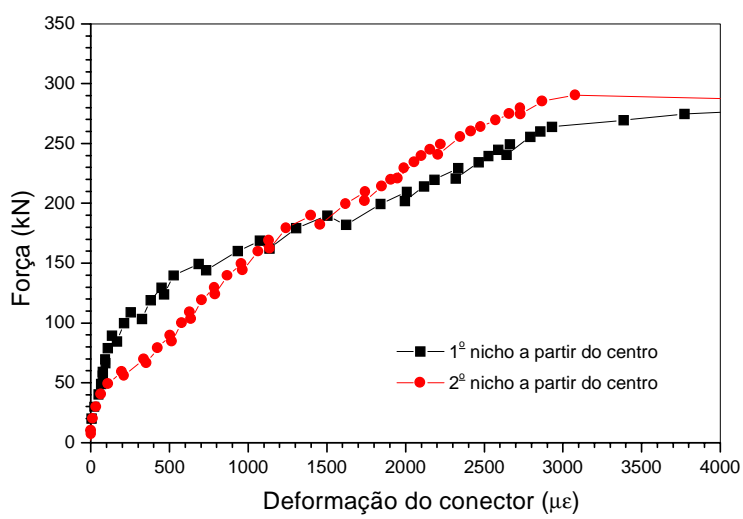

(c) Viga composta V4

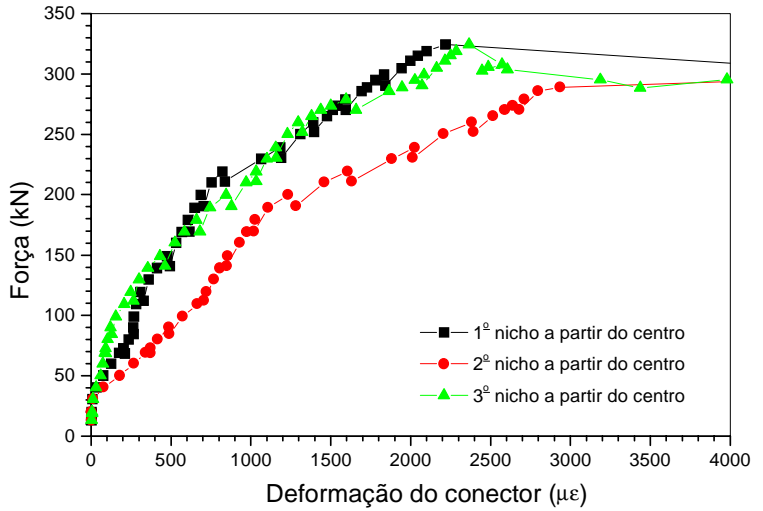

(b) Viga composta V3

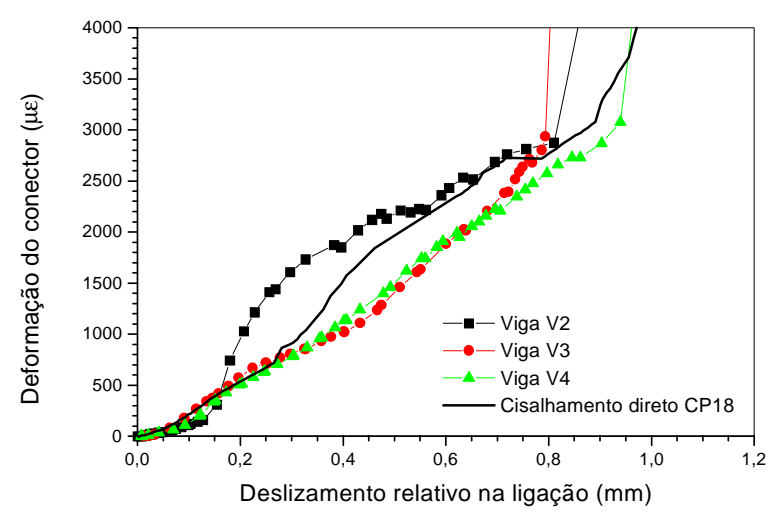

(d) Deformação do conector na ligação das vigas e no corpo-de-prova de cisalhamento direto CP18

Figura 6.25 - Deformação nos conectores das vigas compostas

Na Figura 6.25d é mostrada a deformação do conector em função do deslizamento relativo entre a viga e a laje na ligação mais solicitada das vigas V2, V3 e V4. Também é mostrada a deformação do conector obtida a partir do ensaio de cisalhamento direto no corpo-de-prova com ligação semelhante à empregada nas vigas compostas. Observa-se que todas as curvas apresentam aspecto semelhante, de modo que é possível afirmar que o ensaio de cisalhamento direto realizado neste trabalho foi adequado para caracterizar o comportamento da ligação entre viga e laje pré-moldadas. Tal afirmação também pode ser confirmada pela Figura 6.26 na qual o comportamento da ligação nas vigas V3 e V5 é comparado com os resultados do ensaio de cisalhamento direto do corpo-de-prova CP18. A força resistida por cada ligação da viga pode ser avaliada empregando a seguinte expressão aproximada:

$$
F_{\text {lig }}=\frac{1}{n} \tau A_{n}=\frac{1}{n} \frac{V}{0,9 b d} A_{n}
$$

sendo $V$ o esforço cortante, $b$ a largura da interface, $d$ a altura útil da viga composta, $A_{n} a$ área do nicho e $n$ o número de nichos dispostos na interface. Pelo fato da viga ensaiada ser 
biapoiada com uma força concentrada no meio do vão, o esforço cortante era constante ao longo do vão da viga. Dessa forma, a força transmitida pela interface foi dividida uniformemente entre os nichos. A eq.(6.2), a rigor, é válida apenas para seções fissuradas com a linha neutra acima da interface. Contudo, calculando a força transmitida pela interface através do equilíbrio de forças horizontais (eq.(6.1)) e comparando com os resultados da eq.(6.2), os valores da expressão simplificada diferiram em 12\%, no máximo.

Dessa figura é possível observar que, geralmente, a resposta da ligação na viga composta coincide bem com a resposta obtida do ensaio de cisalhamento direto. Esta conclusão é importante para validar a análise numérica apresentada na seqüência deste capítulo. Outro ponto a se notar do ensaio da viga V5, realizada com controle de deslocamento, é que a queda de resistência da ligação na região pós-pico foi menos acentuada que no ensaio de cisalhamento direto. Isto aconteceu porque rompida a primeira ligação ainda existiam outras ligações que não haviam rompido e que garantiram uma certa resistência residual para a viga.

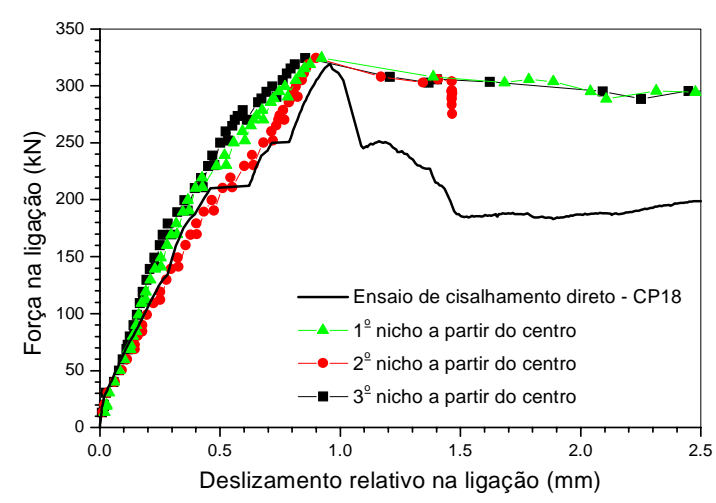

(a) Viga composta V3

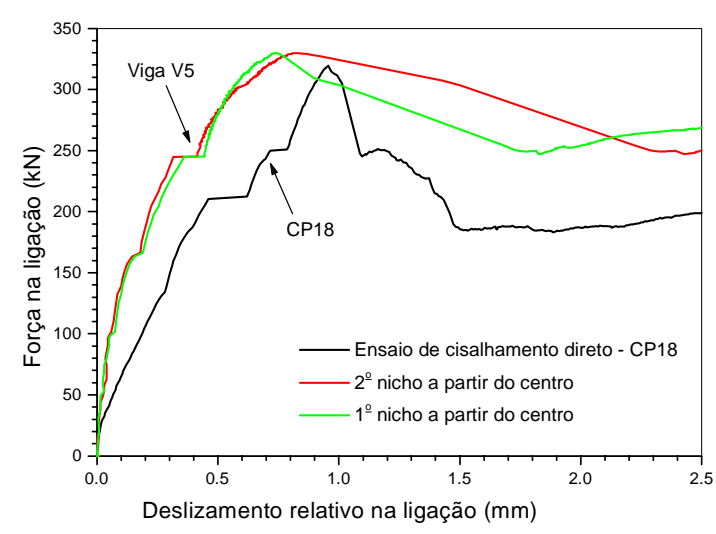

(c) Viga composta V5

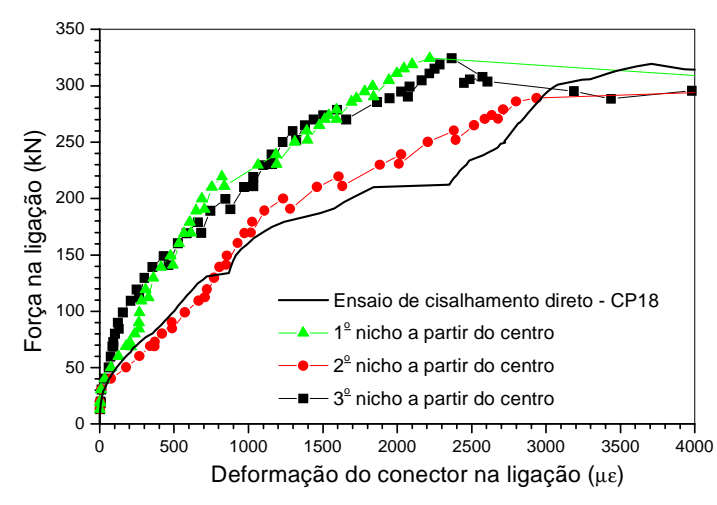

(b) Viga composta V3

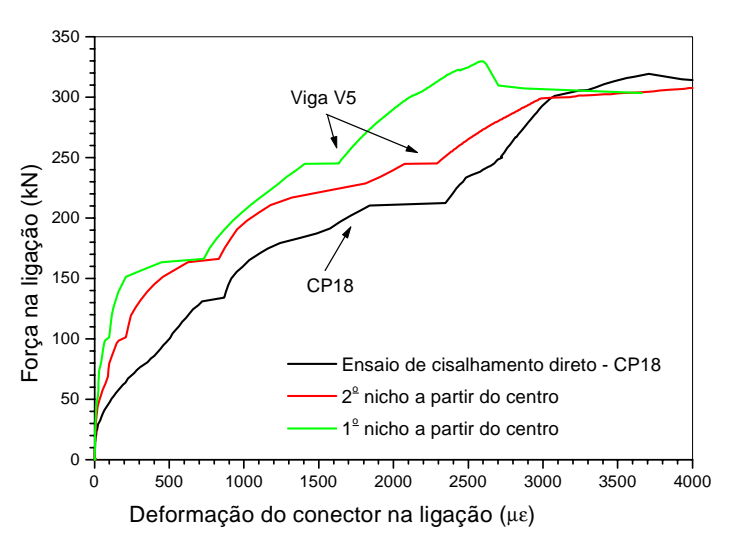

(d) Viga composta V5

Figura 6.26 - Comparação do comportamento da ligação nas vigas compostas V3 e V5 com os resultados do ensaio de cisalhamento direto 


\subsubsection{Momento fletor resistente}

Na Figura 6.27 é mostrada a deformação da seção transversal no meio do vão das vigas compostas V3 e V4. Esses diagramas foram obtidos a partir da leitura dos extensômetros elétricos colados nas armaduras longitudinais posicionadas na viga e na laje pré-moldadas (Figura 6.12, Figura 6.13). Para o seu traçado, foi admitido igualdade de deformações do concreto e da armadura. Por essa figura fica evidente que a viga e a laje pré-moldadas apresentaram um trabalho conjunto até o momento da ruptura das ligações na interface, após o qual passaram a trabalhar de forma independente. Também é possível observar que apesar delas trabalharem em conjunto, não houve uma interação completa entre elas devido ao baixo número de ligações dispostas na interface. Desse modo, mesmo para baixos níveis de carregamento na viga composta, a armadura inferior da laje prémoldada apresentou tensões de tração. Como conseqüência, a seção transversal na viga fletida não era plana.

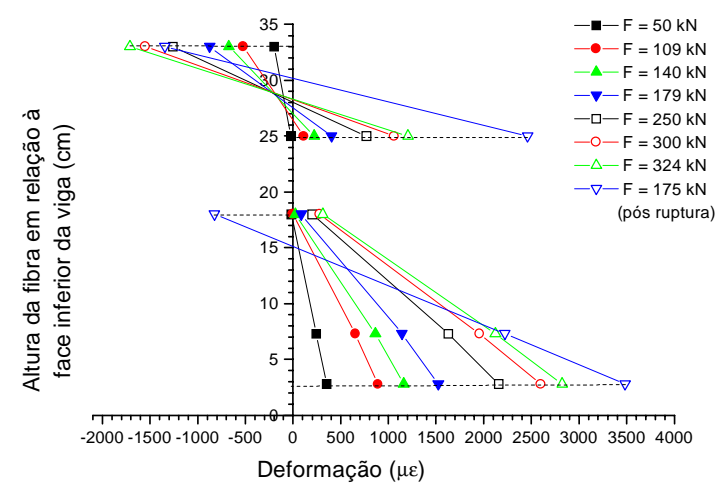

(a) Viga composta V3

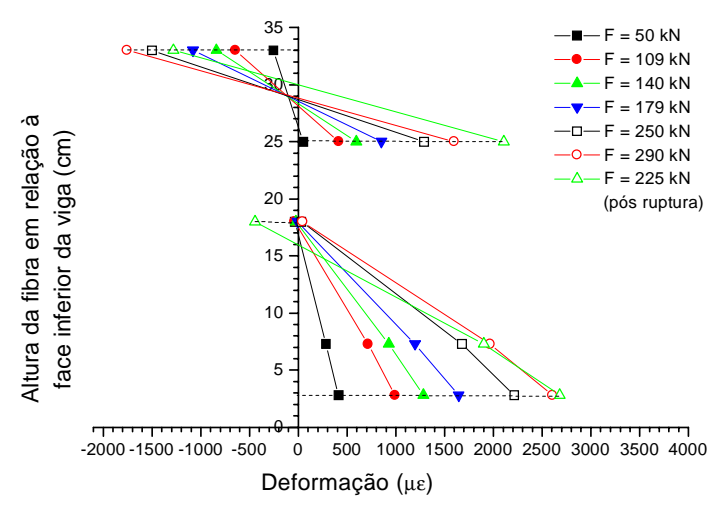

(b) Viga composta $\mathrm{V} 4$

Figura 6.27 - Deformação na seção do meio do vão das vigas compostas

Existem na literatura alguns trabalhos que avaliam o momento resistente em vigas compostas, formadas por viga metálica e laje de concreto moldada no local, quando há baixa quantidade de conectores na interface. Dentre eles, citam-se os trabalhos de OEHLERS; SVED (1995) e SERACINO et al. (2001). Outro trabalho que apresenta uma formulação para avaliação do momento resistente em vigas compostas é o de LAM et al. (2000) $)^{\text {a }}$. Nesse último trabalho, os autores estudaram o comportamento de vigas compostas formadas por viga metálica e laje alveolar de concreto. A expressão recomendada por esses autores foi ligeiramente modificada de modo a substituir a parcela resistente devido à viga metálica pela da viga pré-moldada de concreto, o que resultou nas seguintes expressões: 


$$
\begin{aligned}
& M_{\text {comp }}=F_{t}\left(d_{1}+h_{L}-\frac{F_{t}}{F_{c}} \frac{h_{L}}{2}\right) \text {, linha neutra na laje }\left(F_{c 2}>F_{t}\right) \\
& M_{\text {comp }}=F_{t} d_{1}+F_{c 2} \frac{h_{L}}{2}-\left(F_{t}-F_{c 2}\right) \frac{0,8 x-h_{L}}{2} \text {, linha neutra na viga }\left(F_{c 2}<F_{t}\right)(6
\end{aligned}
$$

sendo $M_{\text {comp }}$ o momento resistente da seção composta, $F_{t}$ a resultante de tração na armadura de flexão, $F_{c 2}$ a resultante de compressão na seção de concreto acima da interface, $d_{1}$ a distância do centro de gravidade da armadura de flexão até a interface da viga composta, $h_{L}$ a altura da laje e $x$ a altura da linha neutra (Figura 6.23). A resultante de compressão $F_{c 2}$ é calculada admitindo que o concreto da laje esteja plastificado, o que resulta em um diagrama de tensões retangular. Dessa forma tem-se:

$$
F_{c 2}=0,68 f_{c} b_{f} h_{L}
$$

Nessa expressão, $\mathrm{f}_{\mathrm{c}}$ e $b_{f}$ são a resistência à compressão do concreto e a largura colaborante da laje pré-moldada, respectivamente. A eq.(6.3) é válida se a resistência da interface for suficiente para garantir o trabalho conjunto da viga e da laje pré-moldadas no estado limite último. Caso contrário, o momento resistente da seção composta pode ser avaliado por:

$$
M_{\text {comp }}=F_{\text {int }} d_{1}+F_{\text {int }}\left(h_{L}-\frac{F_{\text {int }}}{F_{c 2}} \frac{h_{L}}{2}\right)
$$

sendo $F_{\text {int }}$ a resistência da interface, que pode ser obtida multiplicando a resistência ao cisalhamento da ligação pelo número de nichos dispostos na interface da viga composta.

$\mathrm{Na}$ Tabela 6.4 é mostrado o momento resistente da seção do meio do vão das vigas compostas avaliado pelas expressões anteriores. Nas vigas ensaiadas, a distância do centro de gravidade da armadura de flexão à interface valia $18 \mathrm{~cm}$. De modo geral, houve uma boa aproximação entre o momento calculado e o valor obtido dos ensaios. Na viga V2, o momento resistente foi calculado pela eq.(6.3a), uma vez que a quantidade de nichos era suficiente para garantir o trabalho conjunto da viga e da laje até a ruptura da viga composta. A resultante de tração foi obtida admitindo que toda a armadura de flexão atingia a tensão de escoamento do aço antes da ruptura da viga composta. Procedendo dessa forma, o momento resistente calculado foi apenas 3,5\% superior ao valor experimental. Nas vigas $\mathrm{V} 3$ e V4, o momento resistente foi calculado pela eq.(6.5), uma vez que nessas vigas a quantidade de nichos era inferior à necessária para garantir o trabalho conjunto da viga e da laje. A resistência da interface $\left(F_{\text {int }}\right)$ foi obtida calculando a resistência da ligação pela eq.(5.2b) e multiplicando esse valor pelo número de nichos existentes na interface. 
Procedendo assim, o momento resistente calculado na viga V3 foi $8 \%$ superior ao valor experimental, e o momento resistente calculado na viga $\mathrm{V} 4$ foi $18 \%$ inferior ao valor experimental. A resistência da interface também foi calculada a partir da resultante de tração na armadura de flexão, obtida das deformações medidas no. Neste caso, o momento resistente, calculado pela eq.(6.5), foi de $259,1 \mathrm{kN}$.m para a viga $\mathrm{V} 3$ e de $242,1 \mathrm{kN} . \mathrm{m}$ para a viga V4. Esses valores foram $6,5 \%$ e $11 \%$ superiores aos valores experimentais das vigas V3 e V4, respectivamente. Analisando esses resultados, percebe- se que não houve grande alteração no valor do momento resistente da viga V3, o que mostra que nessa viga a avaliação da resistência da interface pela eq.(5.2b) foi adequada. No caso da viga V4, porém, houve um sensível aumento do momento resistente, o que sugere que a resistência da ligação nessa viga era superior ao valor estimado pela eq.(5.2b), ou então que outros fatores influenciaram na resistência à flexão da viga composta. Uma possível explicação seria que, com os nichos mais espaçados, houve uma maior deformação da armadura inferior da laje pré-moldada, o que poderia ter aumentado o momento resistente da seção composta.

Tabela 6.4 - Avaliação do momento resistente das vigas compostas

\begin{tabular}{|c|c|c|c|c|}
\hline Viga & $M_{\text {exp }}(k N . m)^{(1)}$ & $f_{c}(\mathrm{MPa})^{(2)}$ & $M_{\text {comp }}(k N . m)^{(3)}$ & $M_{\text {comp }} / M_{\exp }$ \\
\hline V2 & 322,35 & 51,46 & 333,50 & 1,035 \\
\hline V3 & 243,38 & 61,28 & 262,50 & 1,079 \\
\hline V4 & 217,88 & 50,05 & 178,20 & 0,818 \\
\hline
\end{tabular}

(1) $M_{\text {exp }}$ : momento resistente no meio do vão das vigas obtido dos ensaios

(2) $f_{c}$ : resistência à compressão do concreto da laje pré-moldada

(3) $M_{\text {comp }}$ : momento resistente da seção do meio do vão avaliado pela eq.(6.3), pela eq.(6.4) e pela eq.(6.5)

Com os resultados obtidos até aqui, não é possível definir com precisão uma metodologia simples para avaliar a resistência à flexão das vigas compostas com laje prémoldada. Apesar disso, a eq.(6.3), a eq.(6.4) e a eq.(6.5) ficam como sugestão para uma primeira avaliação da resistência das vigas compostas. A resistência da ligação pode ser avaliada de acordo com as expressões empíricas deduzidas no capítulo 5 ou pelos modelos mecânicos também apresentados no mesmo capítulo.

\subsubsection{Viga submetida a carregamento cíclico}

A viga V5 foi ensaiada com carregamento cíclico com o objetivo de verificar seu comportamento sob a ação de carregamentos repetidos. Na Figura 6.28 é mostrada a 
variação da rigidez secante relativa da viga nos três níveis de carregamento empregados. A rigidez secante foi obtida dividindo a força no final de cada ciclo de carregamento pela respectiva flecha no meio do vão. Em seguida, os valores obtidos foram divididos pela rigidez do primeiro ciclo de carregamento, obtendo-se, assim, a rigidez relativa. Procedendo dessa forma, é possível comparar diretamente a perda de rigidez nos três níveis de carregamento. Observa-se que houve uma perda de rigidez da viga com o aumento do número de ciclos. Essa perda foi tanto maior quanto maior foi o nível de carregamento aplicado. Em primeira aproximação, pode-se afirmar que para um nível de carregamento igual a $30 \%$ da resistência da viga, ocorre uma redução de cerca de $6 \%$ na rigidez da viga composta após vinte ciclos de carregamento. Essa perda sobe para $8 \%$ e $10 \%$ quando o nível de carregamento é elevado para $50 \%$ e $75 \%$ da resistência da viga composta, respectivamente. Observa-se, também, uma tendência de estabilização da rigidez após vinte ciclos de carregamento.

Na Figura 6.29 é mostrada a variação da rigidez secante da ligação entre a viga e a laje pré-moldadas em função do número de ciclos de carregamento. Essa rigidez foi definida pela razão entre a força resistida pela ligação e o deslizamento relativo entre a viga e a laje na região da ligação. $O$ deslizamento relativo foi obtido diretamente das leituras dos transdutores fixados à viga pré-moldada. A força resistida pela ligação foi estimada a partir da eq.(6.2). Essa expressão fornece valores ligeiramente diferentes dos obtidos pela eq.(6.1), porém a comparação dos resultados é feita empregando a rigidez secante relativa, o que elimina eventuais erros na avaliação da força.

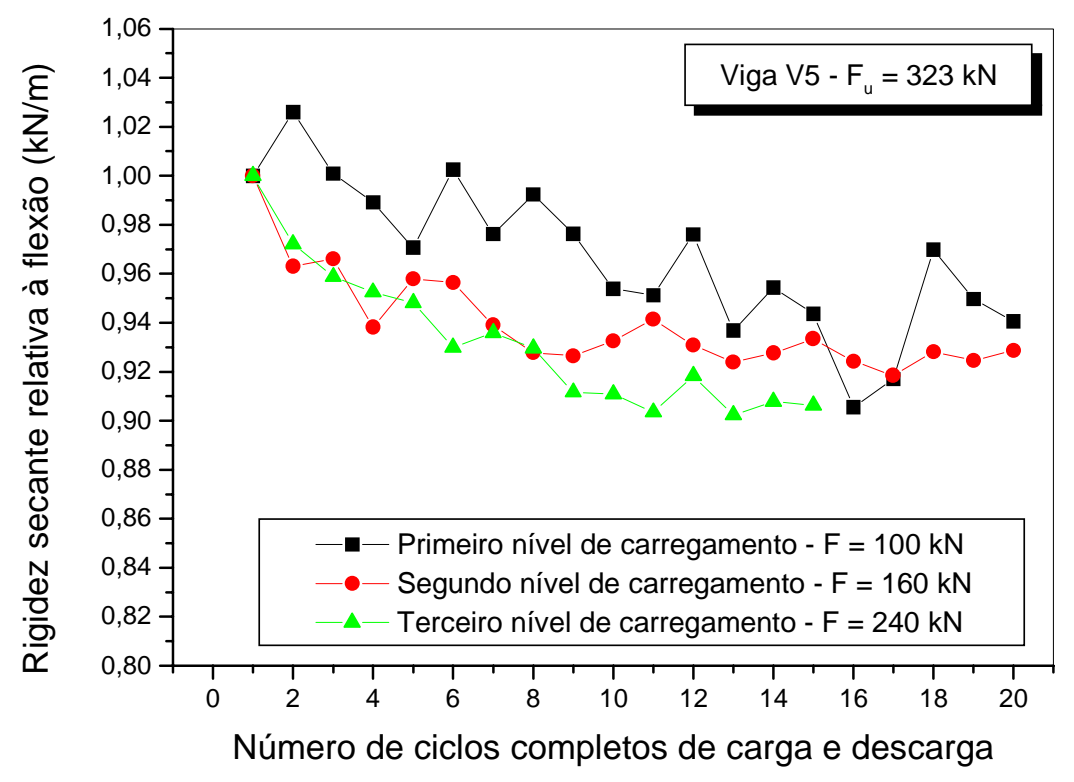

Figura 6.28 - Variação da rigidez à flexão da viga V5 submetida a carregamento cíclico 
Os resultados mostrados na Figura 6.29 referem-se às ligações mais solicitadas na interface da viga, nas quais houve ruptura da chave de cisalhamento. As demais ligações foram menos solicitadas, apresentando, portanto, menor perda de rigidez. Dessa figura, observa-se que, geralmente, houve uma diminuição da rigidez da ligação com o aumento do número de ciclos. A perda de rigidez foi maior quanto maior foi o nível do carregamento aplicado. Desses resultados foi possível quantificar uma redução de até $19 \%$ na rigidez da ligação quando foram aplicados vinte ciclos de carregamento a um nível de $30 \%$ da resistência da viga composta. Essa perda subiu para até $22 \%$ quando o nível de carregamento foi elevado para $75 \%$ da resistência da viga composta. Observou-se, também, uma tendência de estabilização da rigidez após vinte ciclos de carregamento. Deve-se notar, contudo, que houve uma grande dispersão dos resultados relativos ao primeiro nível de carregamento. Isto deve ter acontecido devido aos baixos valores de deslizamento registrados na ligação neste nível de carregamento, que estavam próximos dos valores mínimos possíveis de serem medidos com os transdutores usados.
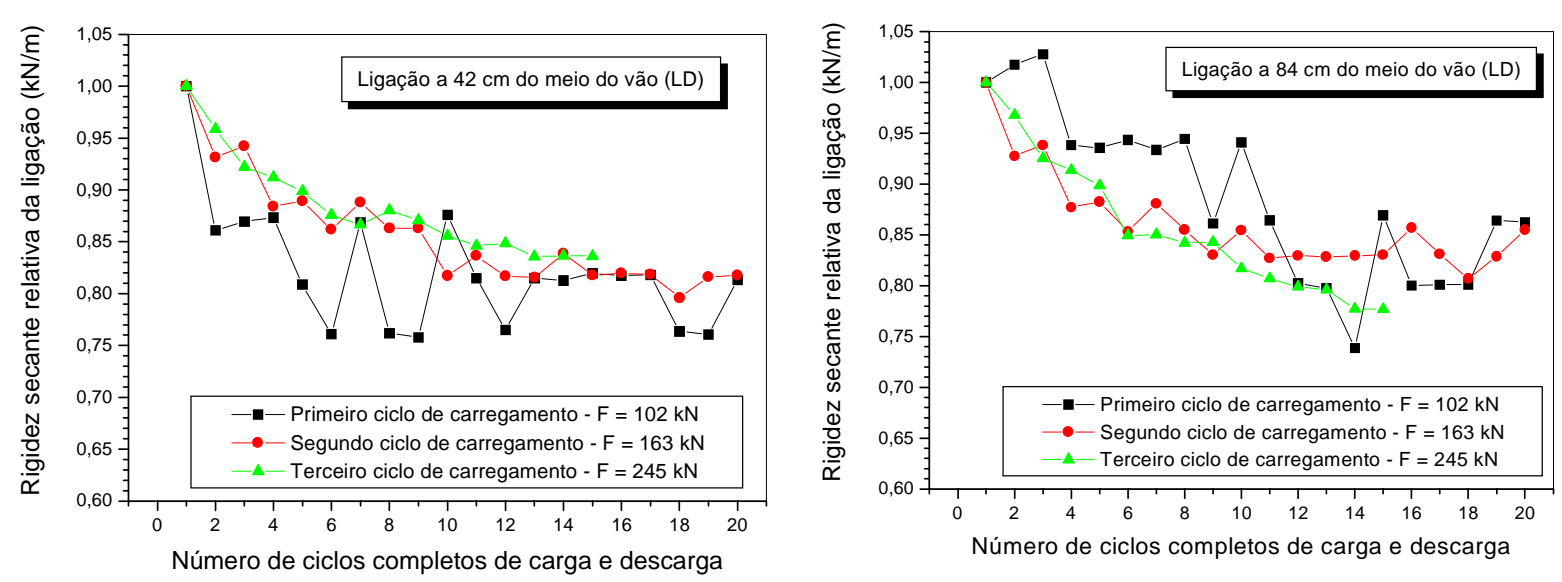

Figura 6.29 - Variação da rigidez da ligação da viga V5 submetida a carregamento cíclico

É interessante notar que a perda de rigidez à flexão da viga composta foi muito inferior à perda de rigidez da ligação. Isto se deve ao fato de que nem todas as ligações apresentaram o mesmo nível de redução da rigidez. De fato, a solicitação não é igual em todas as ligações, variando de acordo com o nível de carregamento imposto à viga composta. No caso da viga V5, as duas ligações mais próximas ao meio do vão foram as mais solicitadas, enquanto as ligações próximas aos apoios somente foram solicitadas próximo à ruptura da viga. Além disso, a solicitação foi maior em um dos lados da viga, de modo que a ruptura ocorreu pelo esgotamento da capacidade resistente das ligações em apenas um dos lados da viga. Sendo assim, a solicitação nas demais ligações foi menor e, consequentemente, sua perda de rigidez devido ao carregamento cíclico também foi menor. 
Após o término do ensaio cíclico, a viga V5 foi levada à ruptura pela aplicação de um carregamento monotônico crescente. A máxima força que essa viga resistiu foi de $323 \mathrm{kN}$. Esse valor é praticamente igual à força máxima resistida pela viga V3, ensaiada sob carregamento monotônico (Tabela 6.3). Isto mostra que a aplicação do carregamento cíclico não alterou a resistência da viga composta. Esse comportamento era esperado, uma vez que foi observado dos ensaios de cisalhamento direto que a aplicação de um pequeno número de ciclos, com baixa intensidade, não altera a resistência da ligação.

Quanto à forma de ruptura, a viga V5 alcançou sua capacidade resistente máxima no momento em que as duas primeiras ligações, próximas do meio do vão, romperam por cisalhamento do concreto da chave. Naquele instante, os conectores dessas ligações também atingiram a tensão de escoamento do aço. Como havia poucas ligações na interface, não foi possível a redistribuição de esforços entre os nichos, o que resultou no deslizamento crescente entre a viga e a laje pré-moldadas com redução da força aplicada na viga composta. A armadura de flexão não atingiu a tensão de escoamento do aço, e não foi observada a ruptura do concreto na face superior da viga composta. O panorama de fissuração foi semelhante ao da viga V3 (Figura 6.30).

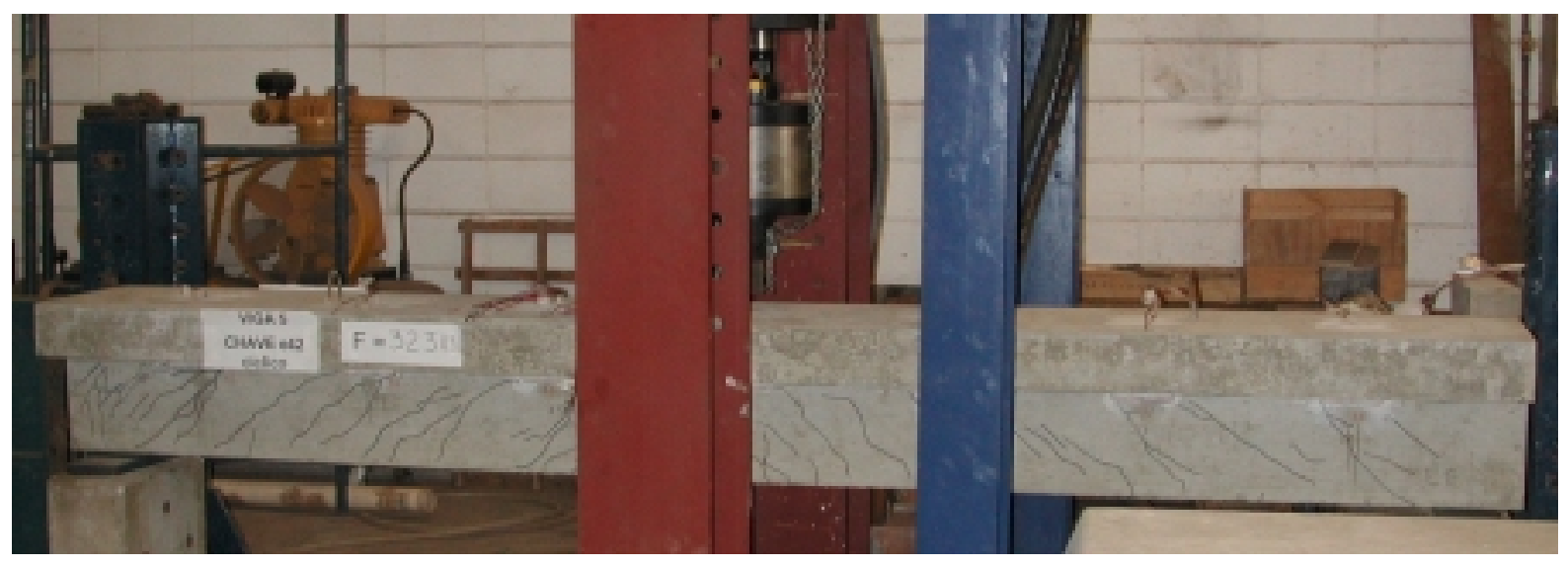

Figura 6.30 - Panorama de fissuração da V5 após a ruptura

\subsection{Análise numérica das vigas compostas com laje pré-moldada}

Foi realizada a simulação numérica das vigas ensaiadas sob carregamento monotônico empregando o programa comercial ANSYS, baseado no método dos elementos finitos. O objetivo inicial foi obter um modelo numérico que representasse com fidelidade 0 comportamento experimental dessas vigas. A partir daí, foi possível estender a análise numérica de modo a verificar a influência sobre o comportamento da viga composta da alteração do tipo de ligação empregada entre a viga e a laje pré-moldadas. 
Foram realizadas duas modelagens diferentes. Na primeira modelagem, a ligação foi modelada de modo explícito, ou seja, a chave de cisalhamento e o conector foram modelados separadamente. Além disso, foi considerada a diferença existente entre as resistências do concreto pré-moldado e do concreto moldado no nicho. Com essa modelagem, foi possível verificar a influência do espaçamento dos nichos sobre a forma de ruptura da viga composta.

Na segunda modelagem, a ligação foi substituída por uma mola com comportamento não linear, cujo comportamento foi calibrado com os resultados dos ensaios de cisalhamento direto. Com essa modelagem, foi possível analisar a influência de outros tipos de ligação sobre o comportamento da viga composta.

Cada uma das modelagens apresentou vantagens e desvantagens que serão discutidas posteriormente. De modo geral, ambas as modelagens conseguiram representar com boa aproximação os resultados experimentais.

\subsubsection{Modelagem 1}

Nesta modelagem, a viga e a laje pré-moldadas, bem como os nichos, foram modelados com o elemento SOLID65 disponível na biblioteca de elementos do ANSYS. Esse elemento é constituído por oito nós com três graus de liberdade em cada nó (translação nas três direções ortogonais). O conector foi modelado separadamente empregando um elemento de viga com resistência ao cisalhamento (BEAM23). Os estribos da viga pré-moldada e da laje pré-moldada foram modelados empregando um elemento de barra com capacidade de resistir a esforços de tração e de compressão (LINK8). A armadura principal de flexão foi modelada empregando, também, o elemento SOLID65.

Para o aço foi admitido um comportamento elastoplástico perfeito, e para o concreto pré-moldado foi adotado o modelo CONCRETE disponível no ANSYS. Esse modelo é o mesmo empregado na simulação dos corpos-de-prova de cisalhamento, sendo que suas propriedades foram discutidas no item 4.4. A armadura principal de flexão foi admitida uniformemente distribuída nos elementos dispostos na face inferior da viga pré-moldada. Suas propriedades mecânicas foram modificadas em função do volume do elemento, sendo a tensão de escoamento e o módulo de elasticidade definidos como:

$$
f_{y, \bmod }=\frac{A_{s}}{A_{c}} f_{y} \text { e } E_{s, \text { mod }}=\frac{A_{s}}{A_{c}} E_{s}
$$


onde $A_{s}$ é a área total de aço, $A_{c}$ é a área do elemento no qual a armadura foi distribuída, $\mathrm{f}_{\mathrm{y}}$ é a tensão de escoamento do aço e $E_{s}$ o módulo de elasticidade do aço.

Para representar o comportamento mecânico do concreto moldado nos nichos, foi empregado o modelo de Drucker Prager. Os parâmetros desse modelo foram definidos como $c=\mathrm{f}_{\mathrm{c}} \backslash 4$ e $\phi=37^{\circ}$, onde $\mathrm{c}$ é a coesão do material e $\phi$ o ângulo de atrito interno (PROENÇA (1988)). As propriedades dos materiais, necessárias para a definição dos modelos constitutivos, foram obtidas da caracterização dos materiais empregados nos ensaios das vigas compostas. O módulo de elasticidade do concreto foi tomado com apenas $50 \%$ do valor medido nos ensaios. Procedeu-se assim pelo fato de se desejar comparar os resultados numéricos com os resultados experimentais próximos à ruptura. Nesse momento, o módulo de elasticidade real é menor que o módulo tangente inicial. Como o programa não permite a atualização do valor do módulo de elasticidade, optou-se por tomá-lo reduzido desde o início do processo numérico.

Na Figura 6.31 é mostrada a modelagem empregada na simulação das vigas V2 , V3 e V4. Devido à simetria existente, apenas um quarto da viga foi modelado. Na Figura 6.32 os resultados da simulação numérica são comparados com os resultados experimentais. A máxima força resistida pela viga V2 a partir da simulação numérica foi de $451,2 \mathrm{kN}$, valor apenas 5\% superior ao obtido experimentalmente. No caso da viga $\mathrm{V} 3$, a máxima força numérica foi de $318,4 \mathrm{kN}$, e na viga V4 foi de $254,9 \mathrm{kN}$. Esses valores foram $2 \%$ e $12 \%$ inferiores aos resultados experimentais, respectivamente. Em todas as simulações, o processo numérico foi interrompido devido à instabilidade da matriz de rigidez, que ocorreu devido à formação de um mecanismo na estrutura. Esse comportamento está de acordo com a forma de ruptura observada nas vigas V3 e V4, nas quais a ruptura ocorreu na ligação entre a viga e a laje pré-moldadas.

Além da resistência da viga, é possível observar da Figura 6.32 que a resposta força - deslocamento no meio do vão também foi muito próxima da obtida experimentalmente. Apenas na viga V2 houve uma diferença maior próximo à ruptura da viga. Isto ocorreu porque nessa viga a ruptura se deu pelo esmagamento do concreto na face superior da viga, situação que não é bem representada pelo elemento constitutivo empregado na simulação do concreto (modelo CONCRETE). Apesar disso, pode-se afirmar que a simulação numérica com esta modelagem foi capaz de representar com boa precisão os resultados experimentais. Outras comparações entre os resultados numéricos e experimentais são mostradas no Apêndice D. Cabe apenas ressaltar que esses resultados são válidos apenas para a modelagem mostrada na Figura 6.31, uma vez que os resultados da simulação são diretamente influenciados pelo tamanho da malha adotada. 


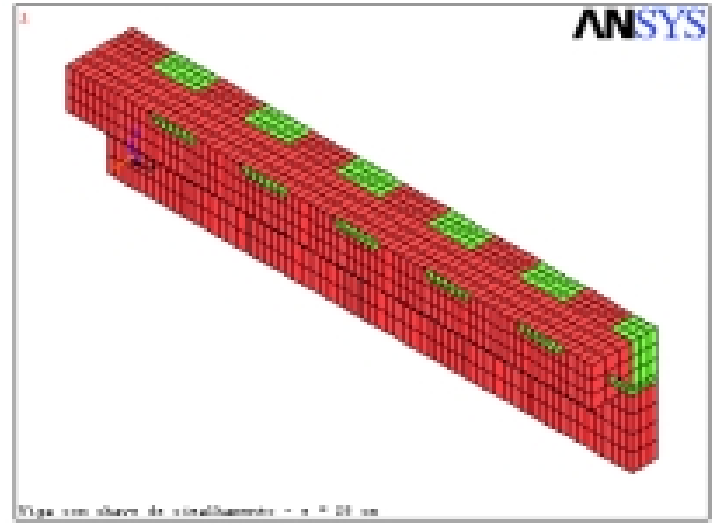

Perspectiva da viga composta com nichos espaçados de $28 \mathrm{~cm}$ (V2)

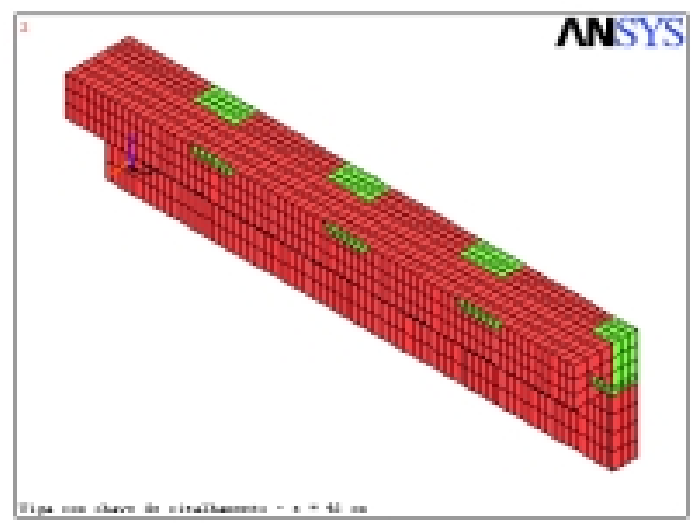

Perspectiva da viga composta com nichos espaçados de $42 \mathrm{~cm}(\mathrm{~V} 3)$

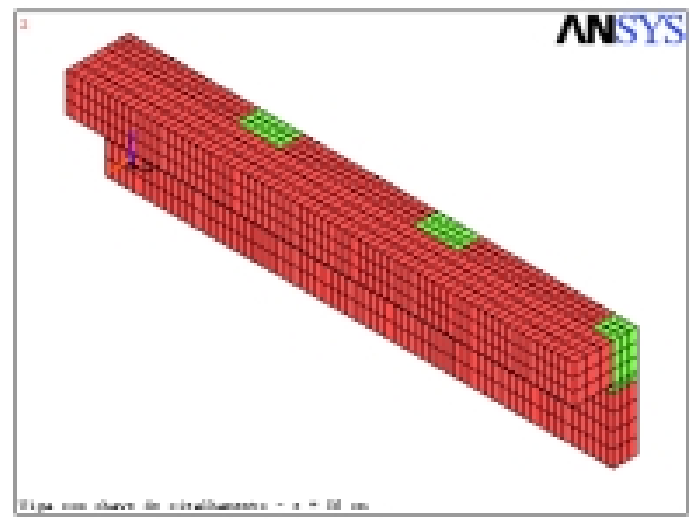

Perspectiva da viga composta com nichos espaçados de $56 \mathrm{~cm}$ (V4)

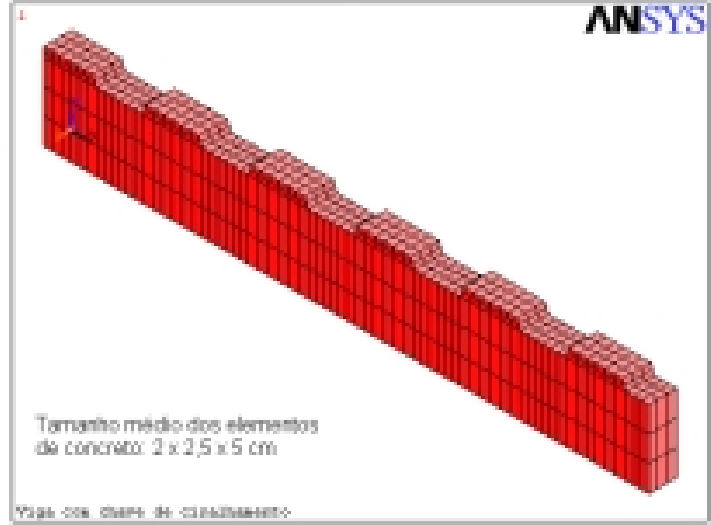

Perspectiva da viga pré-moldada mostrando as chaves de cisalhamento - V2

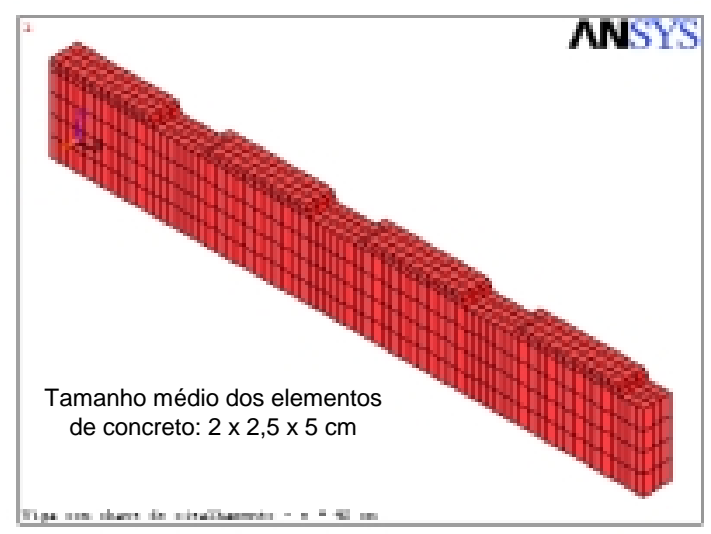

Perspectiva da viga pré-moldada mostrando as chaves de cisalhamento - V3

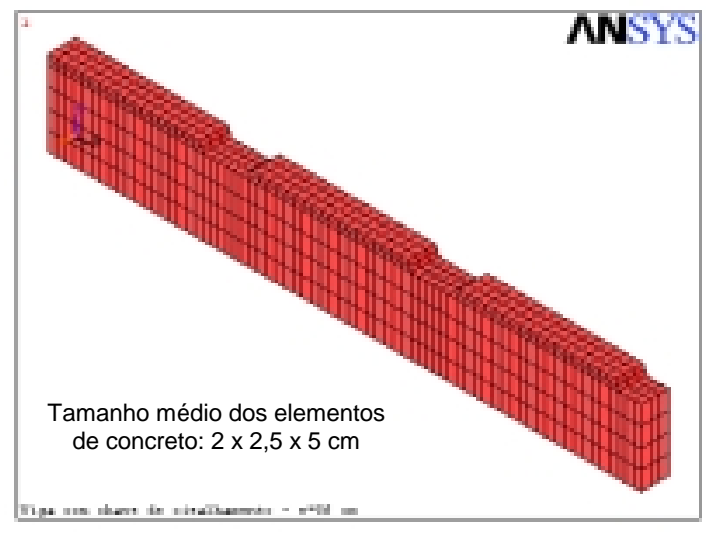

Perspectiva da viga pré-moldada mostrando as chaves de cisalhamento - V4

Figura 6.31 - Discretização das vigas compostas V2, V3 e V4 


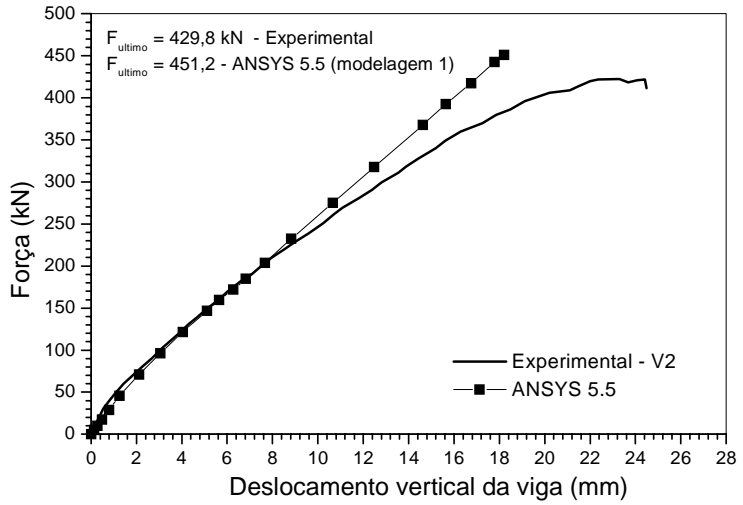

(a) Viga V2

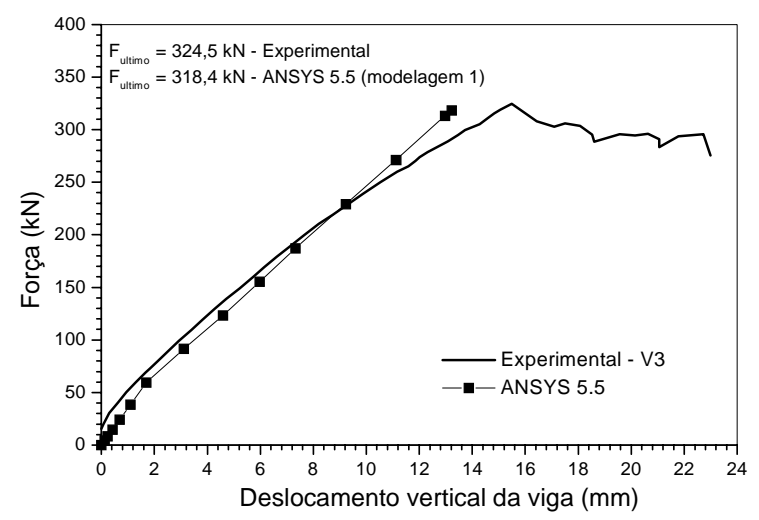

(b) Viga V3

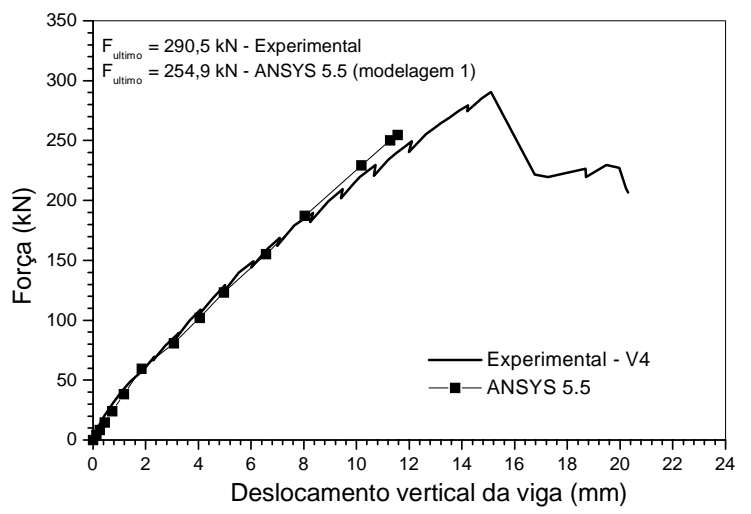

(a) Viga V4

Figura 6.32 - Comparação entre os deslocamentos verticais no meio do vão obtidos da simulação numérica e os resultados experimentais

A simulação numérica realizada possibilitou a confirmação de alguns resultados observados nos ensaios das vigas compostas. Na Figura 6.33 é mostrado o panorama de fissuração na viga e na laje pré-moldadas obtido da simulação numérica, enquanto na Figura 6.34 são mostradas as deformações principais de tração na viga pré-moldada em uma etapa intermediária de carregamento. Dessas figuras, é possível observar que em todas as vigas houve a formação de uma região intensamente fissurada ligando os nichos à face inferior da viga pré-moldada, o que pode caracterizar a formação de uma biela de compressão. Na viga V2, houve uma maior fissuração por flexão da viga pré-moldada que nas vigas V3 e V4. Outra observação interessante é que na viga V2 apareceram fissuras na face inferior da laje pré-moldada para níveis de carregamento próximos à ruptura, enquanto nas vigas V3 e V4 essas fissuras surgiram nas fases iniciais de carregamento. $O$ comportamento observado nas vigas V3 e V4 está de acordo com o observado nos ensaios, nos quais percebeu-se que as fissuras de flexão da viga pré-moldada não atingiram a laje pré-moldada, que porém apresentou fissuras de flexão na face inferior. Nessas vigas, além da fissuração da laje no meio do vão, surgiu outra fissura de flexão mais afastada do meio 
do vão próximo à ruptura da viga composta. Na viga 4 a primeira fissura de flexão na face inferior da laje foi observada no mesmo nível de carregamento em que surgiram as primeiras fissuras de flexão na viga pré-moldada. Esses resultados confirmam que a quantidade de nichos nas vigas V3 e V4 era inferior à necessária para que houvesse uma colaboração completa entre a viga e a laje pré-moldadas no estado limite último, acarretando em uma maior deformabilidade da viga composta e em uma diminuição da sua resistência à flexão.

A principal vantagem da simulação numérica empregando esta modelagem foi a possibilidade de verificar as regiões de concentração de tensões. Dessa forma, verificou-se o surgimento de bielas de compressão na viga pré-moldada, devido à transferência de esforços pela interface da laje para a viga, que necessitam ser analisadas no projeto com viga e laje pré-moldadas. Por outro lado, foi observado que a solicitação nos conectores foi muito inferior à observada nos ensaios. Além disso, o concreto moldado nos nichos foi simulado com um modelo constitutivo que não permitiu a consideração da fissuração do concreto. Sendo assim, essa modelagem não permitiu analisar, por exemplo, a influência do diâmetro do conector e da resistência do concreto da ligação sobre a resistência à flexão das vigas compostas. Por essas razões, no item seguinte é mostrada uma segunda modelagem, empregada para analisar a influência de outros tipos de ligação na interface entre a viga e a laje pré-moldadas.

\subsubsection{Modelagem 2}

Nesta modelagem, a simulação foi realizada empregando um modelo tridimensional devido à limitação do programa em possuir um modelo com fissuração dispersa aplicável apenas em um elemento finito de forma cúbica. Devido à simetria, foi analisado apenas um quarto da viga. Para o concreto da viga pré-moldada e para o concreto da laje pré-moldada foram admitidas características idênticas, sendo tomado, para efeito de simulação, as propriedades mecânicas obtidas do ensaio do concreto empregado na confecção da laje pré-moldada. Na Figura 6.35 é mostrada a discretização empregada na simulação das vigas compostas. 


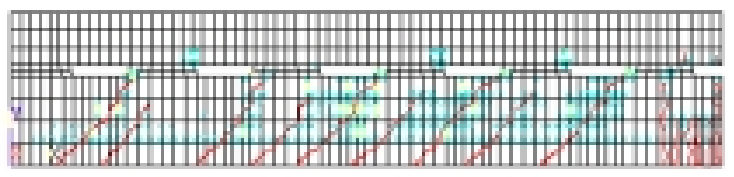

$\mathrm{F}=1722 \mathrm{kN}$

(a) Viga V2

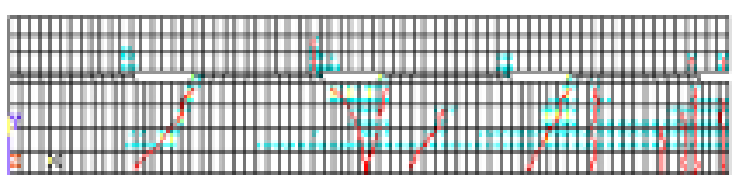

$\mathrm{F}=123,4 \mathrm{kN}$

(c) Viga V3

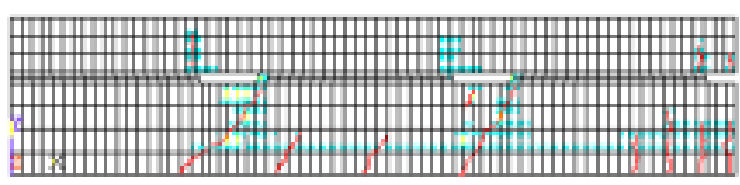

$\mathrm{F}=123 . \mathrm{kN}$

(e) Viga V4

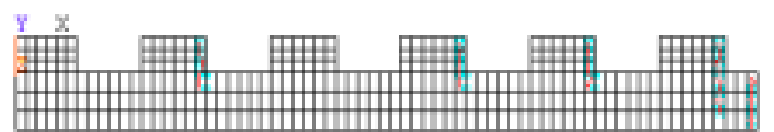

$F=172,2 \mathrm{kN}$

(b) Vista superior da laje pré-moldada - V2

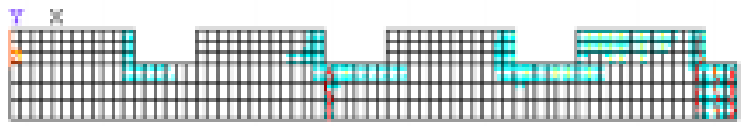

$F=313,2 \mathrm{kN}$

(d) Vista superior da laje pré-moldada - V3

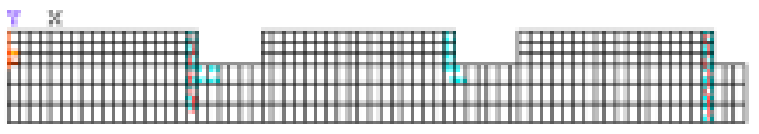

$\mathrm{F}=60,9 \mathrm{kN}$

(f) Vista superior da laje pré-moldada - V4

Figura 6.33 - Panorama de fissuração das vigas compostas segundo análise numérica
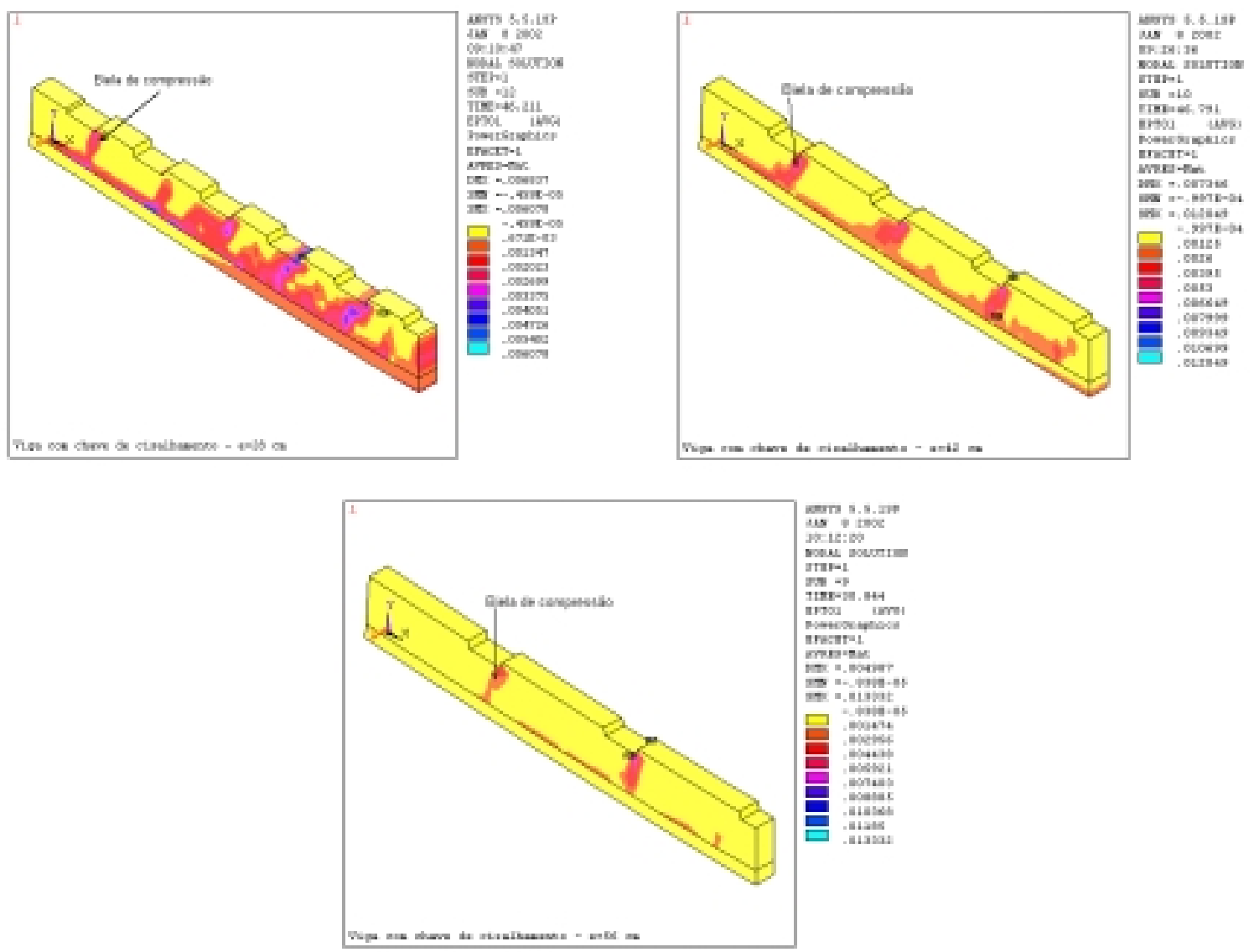

Figura 6.34 - Deformação principal de tração nas vigas pré-moldadas segundo a análise numérica 


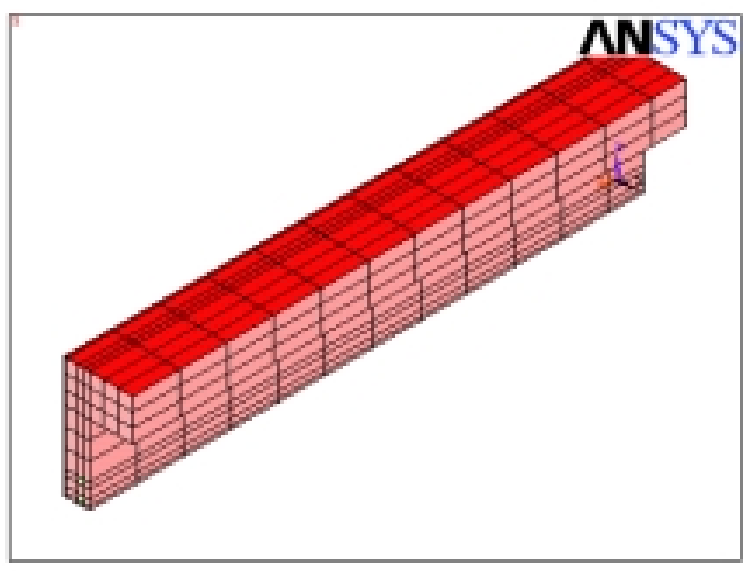

(a) perspectiva

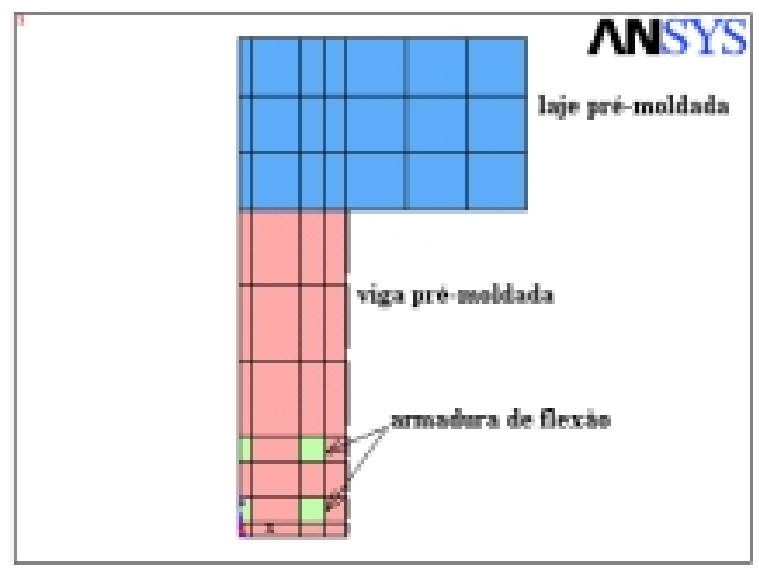

(b) seção transversal

Figura 6.35 - Discretização das vigas compostas com laje pré-moldada.

Ao contrário da modelagem anterior, em que a ligação com chave de cisalhamento foi modelada com elementos sólidos, nesta modelagem a transferência de esforços pela interface entre a viga e a laje foi garantida por dois elementos disponíveis na biblioteca do ANSYS, ou seja, CONTAC52 e COMBIN39. O elemento CONTAC52 é um elemento de contato, definido a partir de dois nós não coincidentes, que permite a transferência de tensões tangenciais entre dois nós segundo a teoria do atrito de Coulomb. Essa característica, contudo, não foi utilizada na modelagem, sendo o elemento empregado apenas para evitar a penetração da laje na viga durante a flexão da viga composta. $O$ elemento COMBIN39 foi utilizado para simular a transferência de esforços pela interface entre a viga e a laje através das ligações discretas. Esse elemento é formado por uma mola com comportamento não-linear, sendo a curva que relaciona a força resistida pelo elemento com o seu respectivo deslocamento obtida a partir da curva média da ligação do corpo-deprova de cisalhamento direto CP18, mostrada no capítulo 4. Nesse corpo-de-prova, as características da ligação eram muito semelhantes às características da ligação empregada nos ensaios das vigas compostas. Na Figura 6.36 são mostradas a curva de resistência do elemento CONBIN39 e o seu posicionamento na interface entre a viga e a laje prémoldadas ao longo do vão da viga. Nessa figura é mostrada a modelagem da viga V2. As demais vigas foram modeladas da mesma forma, apenas alterando o número e o posicionamento das molas na interface para corresponder à posição das ligações nas vigas V3 e V4. 


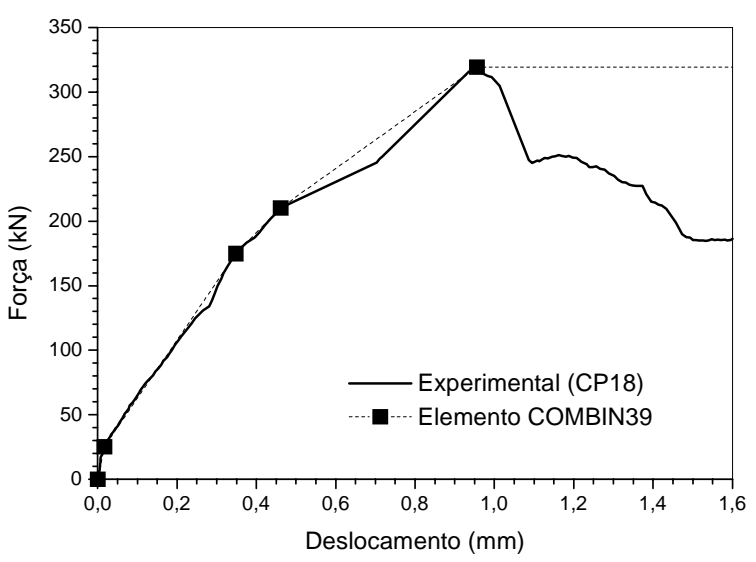

(a) Curva força-deslocamento do elemento COMBIN39

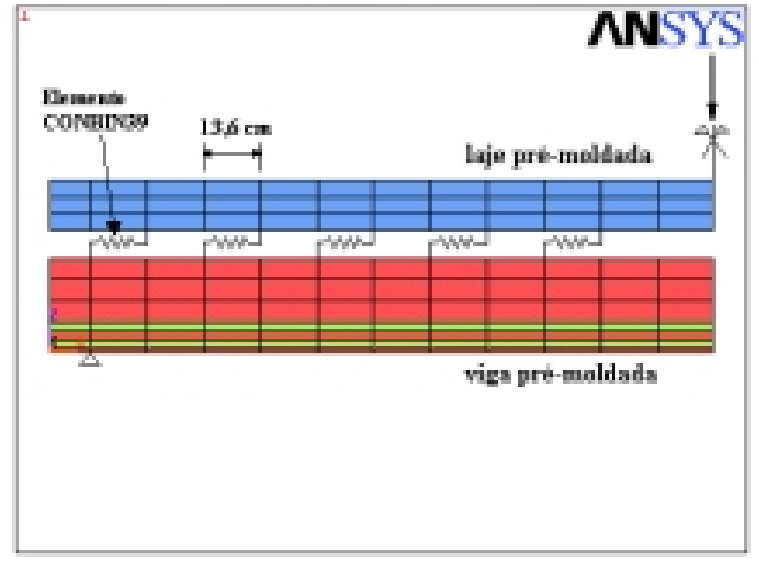

(b) Posicionamento do elemento CONBIN39 na interface - V2

Figura 6.36 - Modelagem da transferência de esforços pela interface da viga composta com laje pré-moldada.

O concreto foi modelado usando um elemento sólido com três graus de liberdade por nó (SOLID65). Para representar o comportamento físico do concreto, foi empregado o modelo constitutivo CONCRETE disponível no ANSYS. A armadura de flexão da viga também foi modelada pelo elemento SOLID65, empregando um modelo constitutivo elastoplástico perfeito. Neste caso, porém, os elementos foram dispostos nas mesmas posições em que a armadura encontrava-se na viga durante o ensaio (Figura 6.35b). As suas dimensões foram definidas de modo que a área da seção transversal do elemento fosse igual à área da seção transversal das barras de flexão. As propriedades mecânicas necessárias à definição do modelo elastoplástico foram obtidas do ensaio de tração uniaxial do aço. O restante da armadura da viga e da laje foi modelada por um elemento de barra resistente à tração e à compressão (LINK8), também admitindo comportamento elastoplástico perfeito para o material. O módulo de elasticidade do concreto, assim como na modelagem anterior, foi tomado igual a $50 \%$ do módulo tangente inicial.

A viga monolítica foi modelada de forma semelhante à viga com laje pré-moldada, apenas modificando as propriedades do concreto, que também foram obtidas experimentalmente. Neste caso, a viga e a laje foram unidas, não sendo portanto utilizados os elementos que modelaram a interface da viga composta.

Na Figura 6.37 o deslocamento vertical no meio do vão obtido da modelagem numérica é comparado com o deslocamento experimental. Observa-se que os valores numéricos estão muito próximos dos valores experimentais, inclusive no que diz respeito à máxima força resistida pela viga. No caso da viga monolítica, obteve-se uma força máxima 
de 420,0 kN, o que representa uma diferença de apenas 4\% com relação ao valor experimental. Para a viga V2, a força máxima numérica foi de $431,4 \mathrm{kN}$, valor apenas $0,4 \%$ superior ao experimental. A viga $\mathrm{V} 3$ foi a que apresentou maior divergência em relação aos resultados experimentais, com uma força máxima numérica de $381,8 \mathrm{kN}$, o que representa um valor $17 \%$ superior ao experimental. Na viga $\mathrm{V} 4$, a força máxima numérica de $282,8 \mathrm{kN}$ é apenas $3 \%$ inferior à resistência experimental. Nessas simulações, o processo numérico foi interrompido quando uma das ligações atingiu a resistência máxima definida para o elemento CONBIN39, estando de acordo com a forma de ruptura observada nas vigas V3 e V4. Na simulação da viga V2, contudo, a força que provocou a ruptura da ligação entre a viga e a laje foi superior à resistência experimental da viga. Para corrigir esse resultado, as deformações na amadura foram limitadas à deformação de escoamento do aço, e as deformações no concreto foram limitadas ao valor de 0,35\%. Com esses limites, o valor da força máxima numérica da viga $\mathrm{V} 2$ ficou próximo do valor experimental.

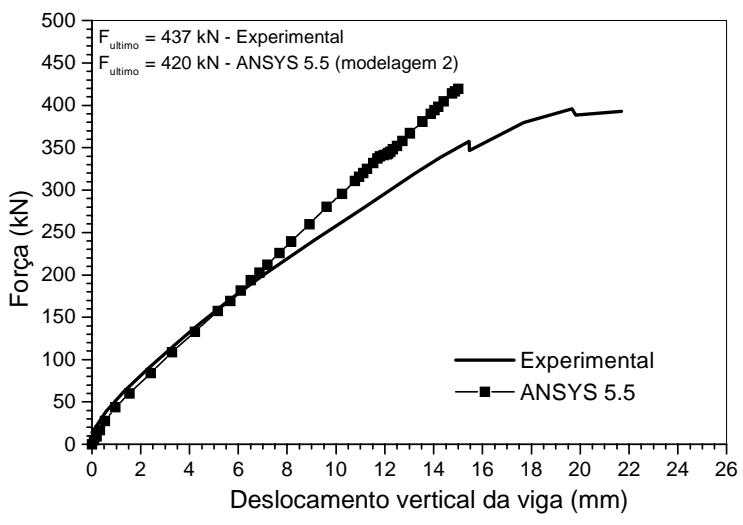

(a) Viga monolítica - V1

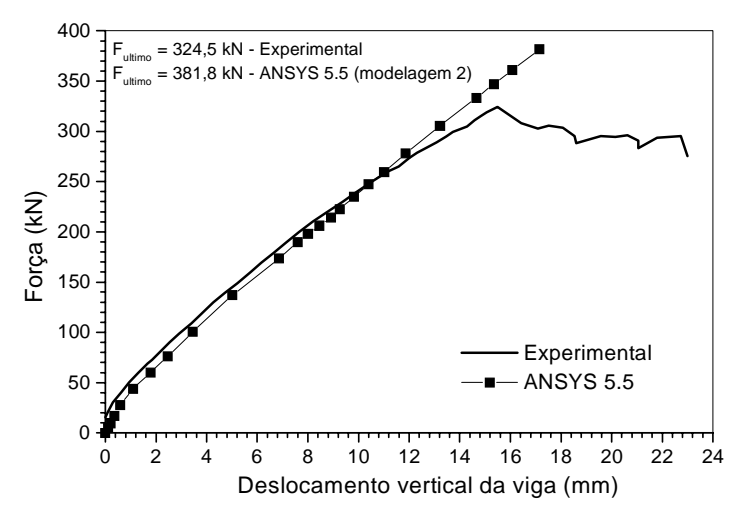

(c) Viga composta - V3

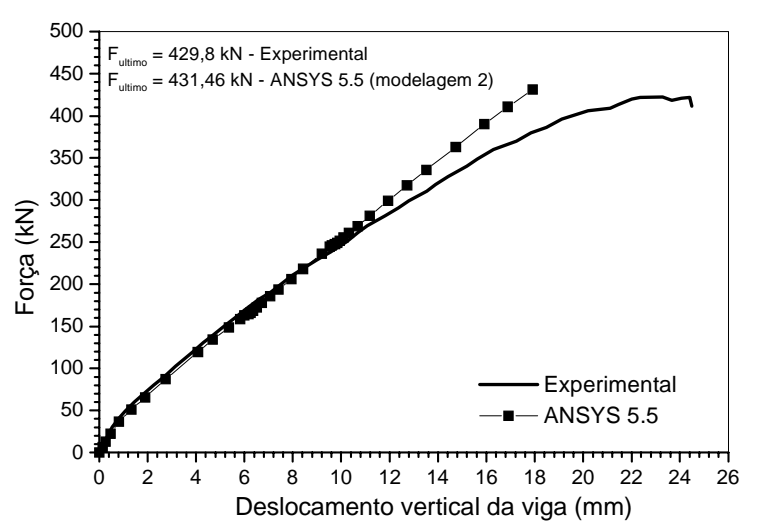

(b) Viga composta - V2

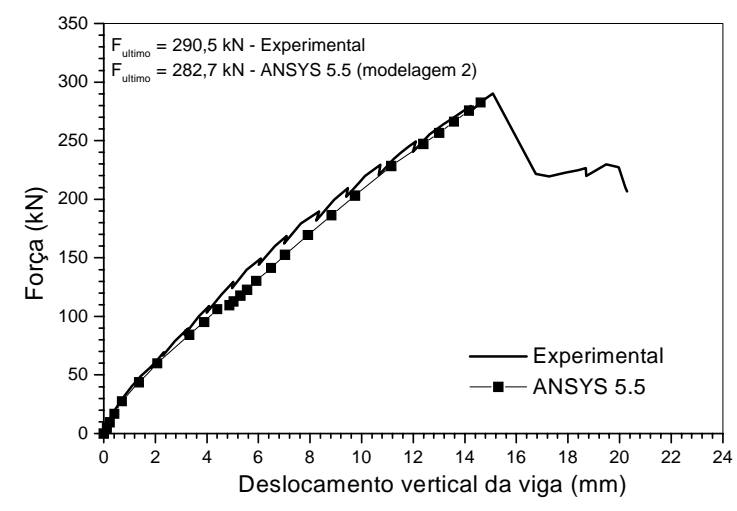

(d) Viga composta - V4

Figura 6.37 - Comparação entre o deslocamento vertical no meio do vão obtido da simulação numérica e o deslocamento experimental 
A partir desses resultados, é possível afirmar que a modelagem numérica adotada foi capaz de representar com boa fidelidade o comportamento observado nos ensaios das vigas. Outras comparações entre os resultados numéricos e experimentais são mostradas no Apêndice D.

A possibilidade de empregar outros tipos de ligação na interface entre a viga e a laje pré-moldadas foi a principal vantagem da simulação numérica com esta modelagem. Uma vez que a ligação é definida apenas por um elemento, para que outros tipos de ligação sejam considerados, basta modificar a curva de resistência desse elemento. A desvantagem é que não foi possível observar o panorama de fissuração na viga composta à medida que o carregamento era incrementado, uma vez que a chave de cisalhamento na viga pré-moldada não foi modelada.

\subsubsection{Influência do tipo de ligação na interface entre a viga e a laje pré-moldadas}

A partir da modelagem 2 foi possível analisar a influência de outros tipos de ligação na interface entre a viga e a laje pré-moldadas. Essa modelagem foi especialmente útil quando a ruptura da viga composta se dava pela ruptura da ligação na interface. Quando a ruptura ocorria por compressão do concreto na face superior da viga, essa modelagem tendia a fornecer valores de resistência superiores aos reais. Para corrigir esse efeito, foi adotado um limite máximo para as deformações do concreto e da armadura principal de flexão, de maneira semelhante ao realizado na modelagem da viga V2.

Foram analisados três tipos de ligação: ligação com superfície plana e lisa, ligação com superfície plana e rugosa, e ligação com chave de cisalhamento sem adição de fibras. A curva utilizada para representar o comportamento da ligação plana e lisa foi obtida do corpo-de-prova de cisalhamento direto CP2, enquanto a curva para representar a ligação plana e rugosa foi obtida do corpo-de-prova CP3 e a curva para representar a ligação com chave de cisalhamento sem fibras foi obtida do corpo-de-prova CP14. Nos corpos-de-prova CP3 e CP14, o diâmetro do conector era de $8 \mathrm{~mm}$, enquanto no corpo-de-prova CP2 o conector era de $12,5 \mathrm{~mm}$. (Figura 6.38).

Na Tabela 6.5 é mostrada a máxima força resistida pela viga composta, a partir da simulação numérica, para os três tipos de ligação. Também são mostrados os resultados obtidos no item anterior a partir da simulação das vigas compostas com chave de cisalhamento e fibras na ligação. Além desses valores, é mostrada a máxima força resistida pela viga monolítica e a máxima força resistida apenas pela viga pré-moldada. 


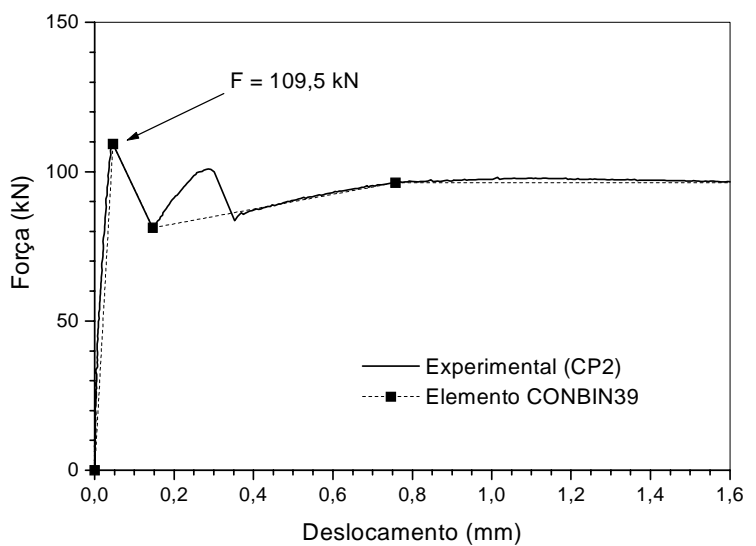

(a) Ligação com superfície plana e lisa

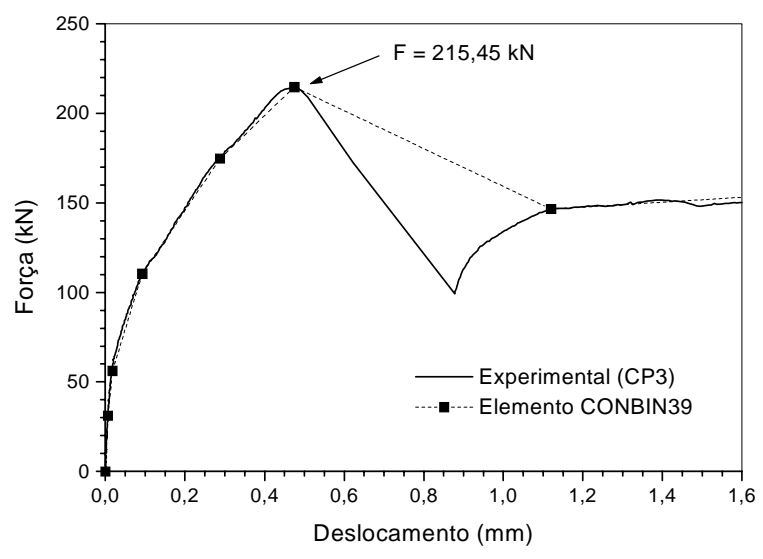

(b) Ligação com superfície plana e rugosa

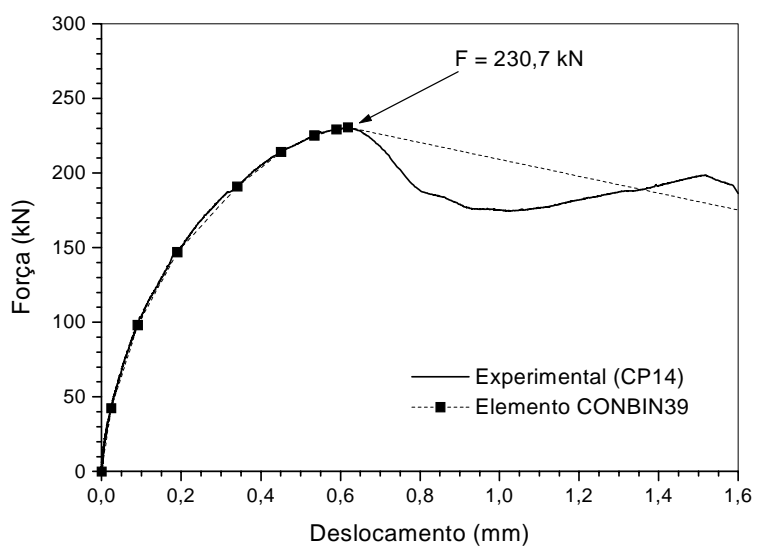

(c) Ligação com chave de cisalhamento sem fibra

Figura 6.38 - Curvas força versus deslocamento do elemento COMBIN39 nos casos de ligação plana com superfícies lisa e rugosa, e ligaçao com chave sem fibra

Na Figura 6.39 é mostrada a curva força versus deslocamento vertical no meio do vão para os três tipos de ligação considerados, e na Figura 6.40 é mostrada a curva força versus deslocamento vertical no meio do vão para os três espaçamentos de nichos apresentados na Tabela 6.5.

Analisando os resultados da viga com os nichos espaçados de $28 \mathrm{~cm}$, observa-se que a substituição da ligação com chave de cisalhamento e fibras por outra com chave de cisalhamento sem fibras proporcionou à viga composta resistir à mesma força. Ao ser substituída pela ligação plana e rugosa, houve uma perda de apenas $3 \%$ na força máxima resistida pela viga composta, porém a adoção da superfície plana e lisa reduziu em 33\% a força máxima resistida pela viga composta. 
Tabela 6.5 - Força máxima alcançada pelas vigas compostas em função do tipo de ligação na interface (obtido da simulação numérica)

\begin{tabular}{|c|c|c|c|}
\hline Tipo de ligação & $\begin{array}{l}\text { Espaçamento dos } \\
\text { nichos }(\mathrm{cm})\end{array}$ & $\mathrm{F}_{\mathrm{u}}(\mathrm{kN})^{(1)}$ & $\mathrm{F}_{\mathrm{F}_{\mathrm{u}, \mathrm{pre}}}{ }^{(2)}$ \\
\hline \multirow{3}{*}{ Plana e lisa } & 28 & 289,99 & 2,19 \\
\hline & 42 & 236,42 & 1,79 \\
\hline & 56 & 170,78 & 1,29 \\
\hline \multirow{3}{*}{ Plana e rugosa } & 28 & 418,56 & 3,16 \\
\hline & 42 & 299,58 & 2,26 \\
\hline & 56 & 223,42 & 1,69 \\
\hline \multirow{3}{*}{$\begin{array}{c}\text { Chave de } \\
\text { cisalhamento sem } \\
\text { fibras }\end{array}$} & 28 & 433,48 & 3,28 \\
\hline & 42 & 333,80 & 2,52 \\
\hline & 56 & 246,44 & 1,86 \\
\hline \multirow{3}{*}{$\begin{array}{c}\text { Chave de } \\
\text { cisalhamento com } \\
0,75 \% \text { de fibras }\end{array}$} & 28 & 431,36 & 3,26 \\
\hline & 42 & 381,76 & 2,89 \\
\hline & 56 & 282,72 & 2,14 \\
\hline $\begin{array}{c}\text { Apenas viga pré- } \\
\text { moldada }\end{array}$ & - & 132,25 & 1,00 \\
\hline Viga monolítica & - & 419,64 & 3,17 \\
\hline
\end{tabular}

(1) $F_{\mathrm{u}}$ : máxima força de convergência obtida da simulação numérica

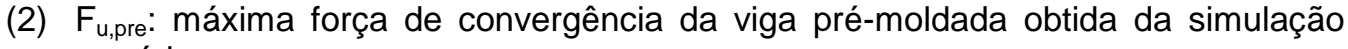
numérica

Analisando os resultados da viga com os nichos espaçados de $42 \mathrm{~cm}$, observa-se que a substituição da ligação com chave de cisalhamento e fibras por outra com chave de cisalhamento sem fibras reduziu a máxima força resistida pela viga composta em $13 \%$. Ao ser substituída pela ligação plana e rugosa, houve uma redução de $22 \%$, enquanto a adoção da superfície plana e lisa reduziu em 38\% a máxima força resistida pela viga composta. Nessas análises, a forma de ruptura da viga composta foi ligeiramente diferente da observada na simulação da viga com os nichos espaçados de $28 \mathrm{~cm}$. A ruptura ocorreu na ligação entre a viga e a laje pré-moldadas, sendo que a armadura de flexão não atingiu a tensão de escoamento do aço e o concreto na fibra mais comprimida manteve-se no regime elástico. A ligação situada mais próxima ao meio do vão foi a primeira a romper-se. Quando essa ligação atingiu a resistência do elemento CONBIN39, as outras ligações atingiram a resistência do elemento logo em seguida, não permitindo nenhuma redistribuição de esforços entre as ligações. 
Analisando os resultados da viga com os nichos espaçados de $56 \mathrm{~cm}$, observa-se que a substituição da ligação com chave de cisalhamento e fibras por outra com chave de cisalhamento sem fibras reduziu a máxima força resistida pela viga composta em $13 \%$. Ao ser substituída pela ligação plana e rugosa, houve uma redução de $21 \%$, enquanto a adoção da superfície plana e lisa reduziu em $40 \%$ a máxima força resistida pela viga composta. Nessas análises, a forma de ruptura da viga composta foi semelhante à observada na simulação da viga com os nichos espaçados de $42 \mathrm{~cm}$. No caso da ligação plana e lisa, quando a máxima força resistida pela viga foi alcançada, os deslizamentos relativos na interface eram superiores a $2 \mathrm{~mm}$.

Observando os valores de força última das vigas compostas mostrados na Tabela 6.5 e discutidos nos parágrafos anteriores, percebe-se que houve uma redução da força última das vigas compostas ao substituir a ligação empregado nos ensaios por outras menos resistentes (chave de cisalhamento sem fibra, plana rugosa e plana lisa). O nível de redução foi semelhante nas vigas com os nichos espaçados de $42 \mathrm{~cm}$ e $56 \mathrm{~cm}$, que foi superior ao nível de redução observado na viga com os nichos espaçados de $28 \mathrm{~cm}$. Nas vigas com os nichos mais espaçados a força última da viga composta foi definida pela resistência da ligação. Sendo assim, era esperado que uma redução na resistência da ligação proporcionasse uma redução de mesma proporção na força última da viga composta. Contudo, o que se viu foi uma redução menor que o esperado. Por exemplo, a resistência da ligação com chave de cisalhamento sem fibra era $28 \%$ menor que a resistência da ligação com chave de cisalhamento e 0,75\% de fibras. De igual maneira, as resistências das ligações rugosa e lisa eram 33\% e 66\% menores que a resistência da ligação com chave de cisalhamento e fibras. Os percentuais de redução da força última das vigas compostas, porém, foram inferiores a esses valores. Isto sugere que outros fatores influenciaram no comportamento à flexão das vigas compostas com baixa quantidade de conectores na ligação. Talvez o grande espaçamento entre os nichos permitiu que a viga e a laje se deformassem de modo mais independente, o que resultou em maiores deformações na armadura inferior da laje pré-moldada. Se isto aconteceu, pode ter surgido um momento resistente adicional na laje devido à maior deformação da armadura de flexão da laje.

Com relação à rigidez da viga composta, a alteração da ligação na interface entre a viga e a laje pré-moldadas, independente do espaçamento dos nichos, não apresentou grande influência sobre os resultados. Apenas quando foi adotada a ligação plana e lisa houve uma sensível redução na rigidez da viga composta (Figura 6.39). Essa redução ocorreu, contudo, apenas após a ruptura da ligação. 

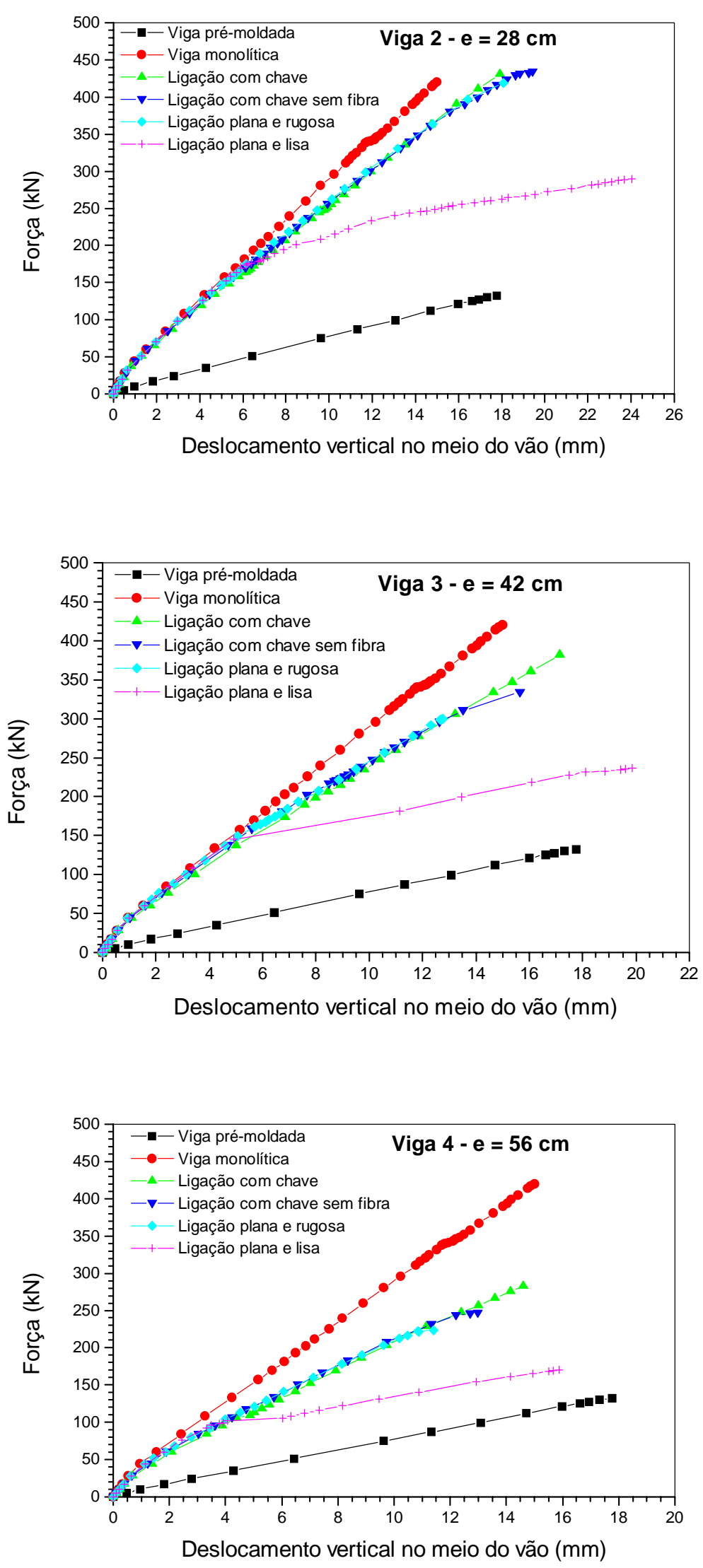

Figura 6.39 - Deslocamento vertical no meio do vão das vigas compostas para vários tipos de ligação na interface (obtido da simulação numérica) 
A influência do espaçamento dos nichos pode ser melhor visualizada na Figura 6.40, onde cada tipo de ligação é analisada separadamente. Observa-se que há uma relação direta entre a força última da viga composta e a resistência da ligação empregada na interface, ou seja, a resistência da viga composta diminui à medida que se diminui a resistência da ligação. Na Figura $6.40 d$ é mostrada a relação da razão entre a força última da viga composta e a força última apenas da viga pré-moldada $\left(F_{u} / F_{u, p r e}\right)$ com 0 espaçamento dos nichos. Essa razão identifica o quanto viga e laje pré-moldadas trabalham em conjunto, e possui um limite máximo definido pela razão entre a força última da viga monolítica e a força última da viga pré-moldada. Observa-se que a redução da força última da viga composta com o aumento no espaçamento dos nichos foi aproximadamente linear, apresentando uma perda média de $41 \%$ quando o espaçamento passou de $28 \mathrm{~cm}$ para 56 $\mathrm{cm}$. Essa perda foi mais acentuada na viga com a ligação plana e rugosa (47\%) e menos acentuada na viga com a ligação com chave de cisalhamento e fibras (34\%).

Da Figura 6.40 também é possível observar uma nítida redução na rigidez da viga a medida em que se aumenta o espaçamento dos nichos. Analisando a rigidez secante, por exemplo, para uma força aplicada de $160 \mathrm{kN}$ pode-se quantificar a variação da rigidez da viga. Na viga composta onde a ligação entre a viga e laje era realizada com chave de cisalhamento sem fibras, a rigidez secante da viga, com os nichos espaçados de $28 \mathrm{~cm}$, foi $8 \%$ inferior à rigidez da viga monolítica. Quando o espaçamento dos nichos foi aumentado para $42 \mathrm{~cm}$ e $56 \mathrm{~cm}$, a rigidez secante foi $8 \%$ e 25\% inferior à rigidez da viga monolítica, respectivamente. No caso da viga composta com a ligação plana e rugosa, a rigidez secante da viga, com os nichos espaçados de $28 \mathrm{~cm}$, foi $7 \%$ inferior à rigidez da viga monolítica. Quando o espaçamento dos nichos foi aumentado para $42 \mathrm{~cm}$ e $56 \mathrm{~cm}$, a rigidez secante foi $7 \%$ e $27 \%$ inferior à rigidez da viga monolítica, respectivamente. De modo semelhante, na viga composta com a ligação plana e lisa, a rigidez secante da viga com os nichos espaçados de $28 \mathrm{~cm}$ foi $5 \%$ inferior à rigidez da viga monolítica. Quando 0 espaçamento dos nichos foi aumentado para $42 \mathrm{~cm}$ e $56 \mathrm{~cm}$, a rigidez secante foi $22 \%$ e $60 \%$ inferior à rigidez da viga monolítica, respectivamente. Desses resultados, é possível observar que no nível de carregamento analisado as vigas compostas nas quais a ligação entre a viga e a laje pré-moldadas foi realizada com chave de cisalhamento apresentaram a mesma rigidez que as vigas com superfície plana e rugosa. Por outro lado, com a superfície plana e lisa, houve uma maior perda de rigidez da viga composta quando comparada com uma viga monolítica de mesmas dimensões. 


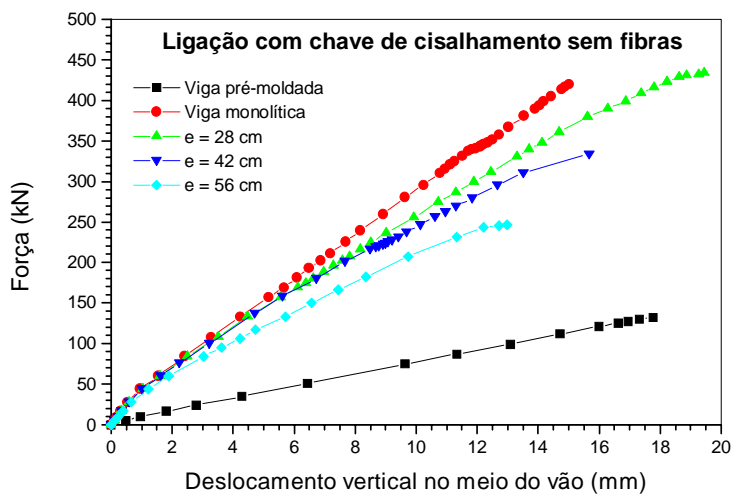

(a)

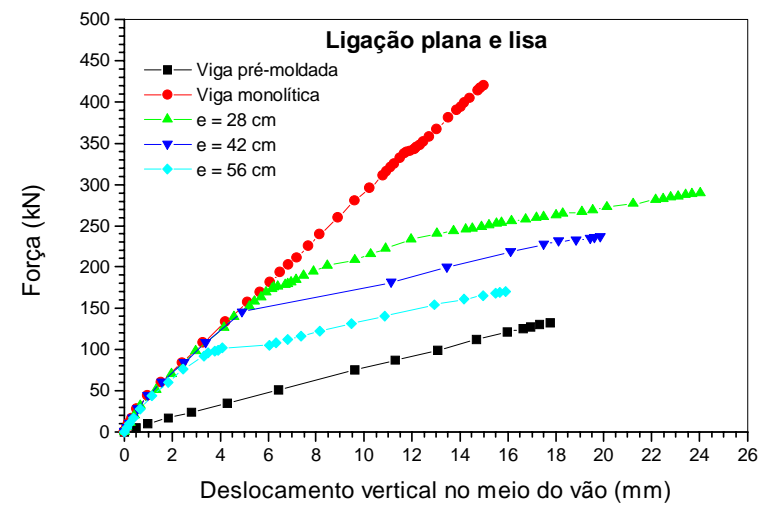

(c)

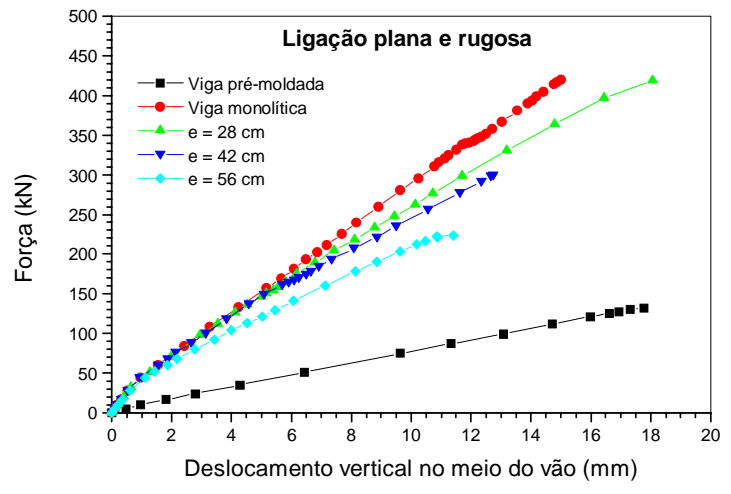

(b)

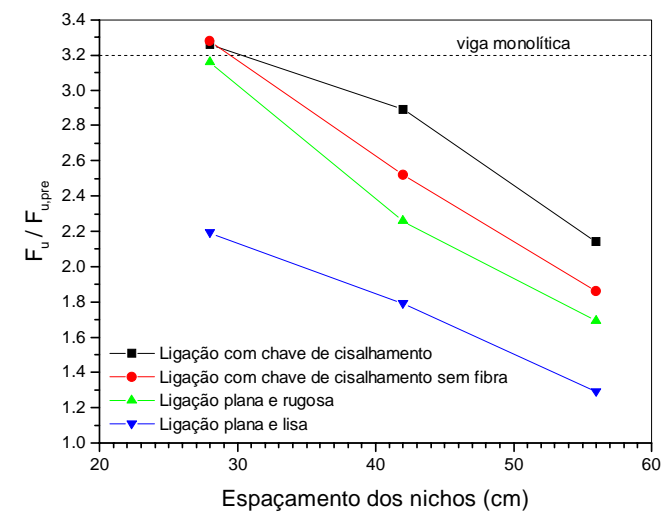

(d)

Figura 6.40 - Influência do espaçamento dos nichos na resistência da viga composta (obtido da simulação numérica)

A adição de fibras ao concreto da ligação proporciona um aumento na resistência da ligação e também um maior deslizamento relativo entre as peças pré-moldadas, como foi observado nos ensaios de cisalhamento direto. Com o objetivo de verificar a influência da deformabilidade da ligação sobre o comportamento da viga composta, foi novamente simulada a viga cuja ligação era constituída por chave de cisalhamento, sem adição de fibras, e nichos espaçados de $56 \mathrm{~cm}$, porém com os deslizamentos majorados em $30 \%$. Os resultados mostraram pouca influência da deformabilidade da ligação sobre o comportamento da viga composta. Houve um pequeno aumento de $2 \%$ na força última da viga e um aumento de $8 \%$ no deslocamento no meio do vão. O aumento na força última foi proporcionado pela maior deformação da armadura de flexão e do concreto na face superior da viga, o que resultou em um aumento do momento resistente da seção. Esse mesmo procedimento foi aplicado à viga composta com nichos espaçados de $28 \mathrm{~cm}$ e chave de cisalhamento sem fibra. Neste caso, praticamente não houve alteração no valor do deslocamento no meio do vão. Foi observada, também, uma pequena redução de $5 \%$ no valor da força última da viga composta. 
Estes últimos resultados mostram que a resistência da ligação tem uma influência muito mais significativa sobre o comportamento da viga composta que a deformabilidade da ligação. Portanto, uma estimativa, mesmo que pouco precisa, da curva de resistência da ligação não deve alterar de modo significativo os resultados obtidos para a viga composta. Além disso, a deformabilidade da ligação somente é importante quando não há uma colaboração completa da laje na resistência da seção composta, o que normalmente ocorre quando os nichos são muito espaçados. Existem algumas formulações, desenvolvidas para a associação de viga metálica com laje alveolar de concreto, que avaliam a perda de rigidez de vigas compostas com baixa taxa de transferência de esforços pela interface (LAM et al. $\left.(2000)^{a}\right)$. Para o caso de viga e laje pré-moldadas, entretanto, este problema ainda não foi completamente equacionado.

\subsection{Exemplo de aplicação}

A seguir é apresentado um exemplo prático de associação de viga pré-moldada com laje pré-moldada. Trata-se da estrutura típica de uma ponte rodoviária da classe 45 . Ela é constituída por sete vãos simplesmente apoiados de $30 \mathrm{~m}$ de comprimento cada, e possui uma largura total de $14 \mathrm{~m}$. A superestrutura é formada por cinco longarinas de concreto, pré-moldadas e protendidas, quatro transversinas, sendo duas de apoio e duas intermediárias, e a laje moldada no local. Cada vão foi tratado isoladamente, ou seja, não foi admitida continuidade do tabuleiro. Originalmente essa estrutura foi dimensionada com laje moldada no local. Para efeito de exemplificação, a laje foi admitida pré-moldada com as mesmas dimensões da laje moldada no local. Na Figura 6.41 são mostrados alguns detalhes da geometria dessa ponte.

O objetivo desse exemplo é mostrar a aplicação das expressões deduzidas ao longo desse trabalho usadas na avaliação da resistência da ligação entre viga e laje prémoldadas. Para tanto, inicialmente é necessário o conhecimento dos esforços na interface provenientes do carregamento externo, que são função do esquema construtivo adotado. Para essa ponte, a seqüência de construção adotada pode ser assim resumida:

- Execução da infra-estrutura formada por tubulões executados com auxílio de ar comprimido.

- Execução dos pilares e das travessas ligando-os.

- Execução das vigas pré-moldadas no canteiro e transporte para o local de utilização após 20 dias de sua concretagem ( $\left.f_{c k}=30 \mathrm{MPa}\right)$. Aos 14 dias, realização de parte da protensão conforme disposto no projeto. O transporte é realizado com auxílio de 
guindastes ou pórticos de rolamento, sendo o içamento realizado por dois pontos conforme disposto no projeto. A montagem das vigas sobre as travessas é realizada com auxílio de treliças.

- Execução das transversinas moldadas no local.

- Execução da laje do tabuleiro, também moldada no local, utilizando pré-lajes. Essas pré-lajes servem de forma para o lançamento do concreto e ficam incorporadas ao tabuleiro, contribuindo na sua resistência às solicitações.

- Após a cura do concreto da laje, realização do restante da protensão das longarinas. Essa protensão é prevista para ser realizada 56 dias após a moldagem das vigas pré-moldadas.

- Colocação do asfalto e demais componentes da ponte.

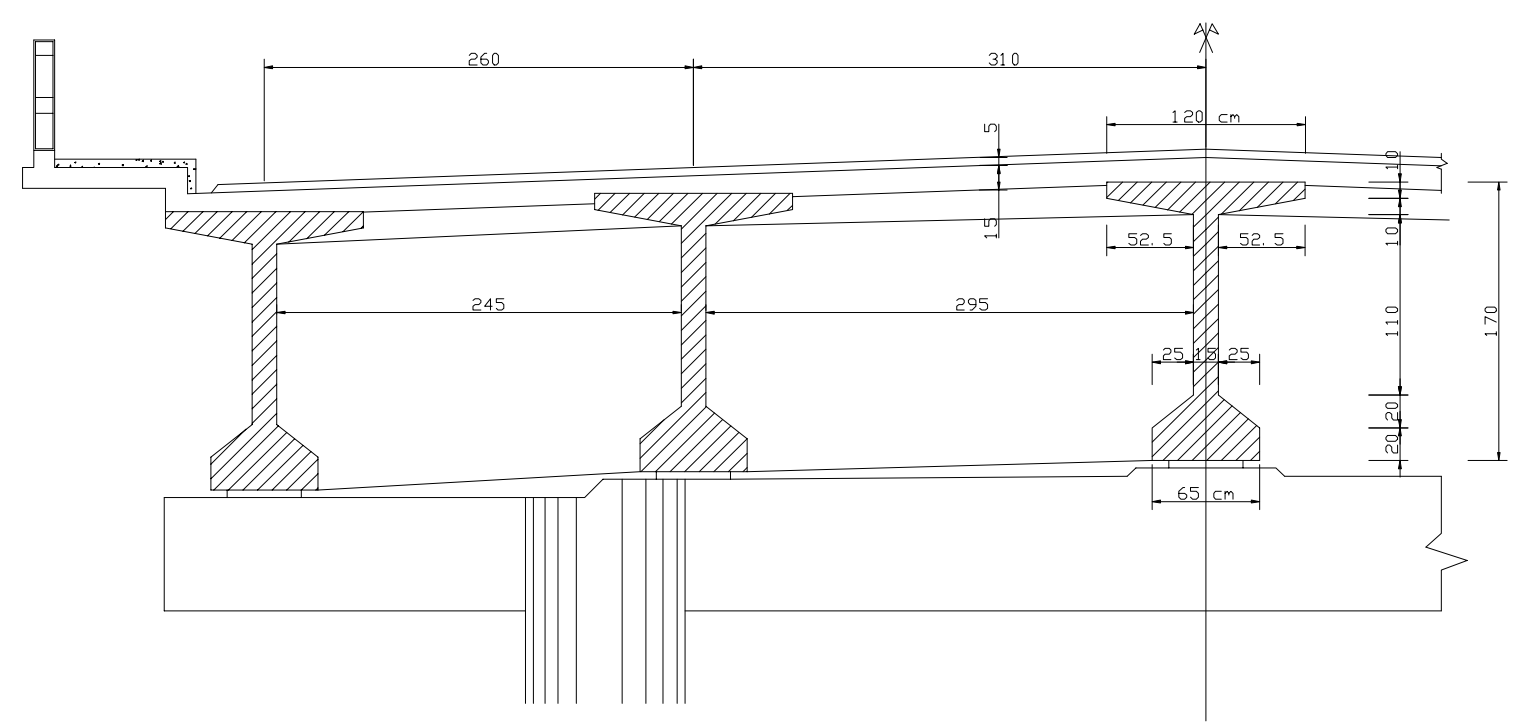

(a) Seção transversal do tabuleiro

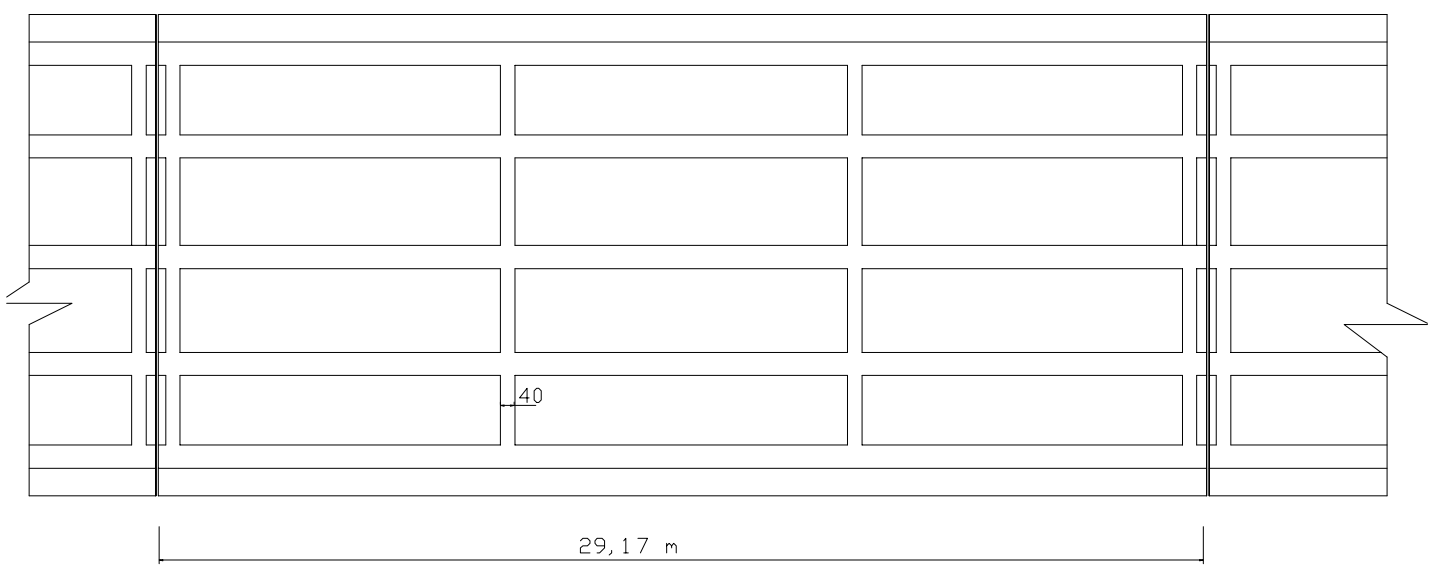

(b) Vista inferior do tabuleiro

Figura 6.41 - Estrutura típica de ponte rodoviária com tabuleiro em grelha formada por vigas pré-moldadas de concreto 
Essa seqüência construtiva é típica de uma estrutura composta com laje moldada no local, porém é perfeitamente compatível com uma estrutura com laje pré-moldada. A única alteração é na execução do tabuleiro, que passa a ser constituído pelas longarinas, transversinas e laje pré-moldada de concreto. Após a colocação das longarinas e execução das transversinas, os painéis de concreto são apoiados sobre as longarinas, e a ligação é realizada através do preenchimento dos nichos com concreto de alto desempenho. Neste processo construtivo, as transversinas são desligadas da laje para facilitar a execução do tabuleiro. A segunda fase de protensão nas longarinas é feita após o concreto do nicho alcançar a resistência necessária para garantir a transferência de esforços pela interface. De acordo com essa seqüência, os esforços que atuam na seção composta são a segunda fase de protensão da longarina, o peso próprio dos elementos acessórios $\left(g_{3}\right)$ e 0 carregamento móvel (q). Esses são os esforços que devem ser transferidos pela interface. Neste exemplo, são considerados apenas os esforços provenientes do peso próprio e do carregamento móvel. Os esforços provenientes da segunda fase de protensão agem em sentido contrário aliviando a solicitação na interface. Por simplicidade, eles foram desconsiderados.

Os esforços solicitantes nas longarinas foram obtidos empregando o trem-tipo da NBR-7188 (1984), e o dimensionamento e detalhamento da longarina foram realizados seguindo as recomendações da NBR-7187 (1986) e da NBR-7197 (1987). Na Tabela 6.6 são apresentados os esforços nas seções intermediárias das longarinas (central, intermediária e de extremidade) para os carregamentos $g_{1}$ (peso próprio da viga prémoldada), $g_{2}$ (peso próprio da laje e das transversinas), $g_{3}$ (peso próprio do revestimento e do guarda-corpo) e móvel. Na Tabela 6.7 são apresentados os esforços cortantes nas seções intermediárias das longarinas (central, intermediária e de extremidade) para os carregamentos $g_{1}, g_{2}, g_{3}$ e móvel (Figura 6.42). Esses esforços foram obtidos do sistema construtivo com laje moldada no local. No caso do sistema construtivo com laje prémoldada, a flange superior da viga pré-moldada foi reduzida para melhor apoiar a laje. Apesar disso, não houve alteração significativa nos esforços devido ao peso próprio, de modo que foram empregados no exemplo os valores calculados a partir do sistema construtivo com laje moldada no local. 
Tabela 6.6 - Momento fletor nas longarinas (kN.m).

\begin{tabular}{|c|c|c|c|c|c|c|}
\hline Seção & 0 & 1 & 2 & 3 & 4 & 5 \\
\hline \multicolumn{7}{|c|}{ Viga central } \\
\hline$M_{g 1}$ & 1495 & 1436 & 1256 & 957 & 538 & 0 \\
\hline$M_{g 2}$ & 1915 & 1838 & 1608 & 1225 & 689 & 0 \\
\hline$M_{g 3}$ & 510 & 490 & 429 & 327 & 184 & 0 \\
\hline$M_{q}$ & 2354 & 2258 & 1975 & 1450 & 853 & 0 \\
\hline \multicolumn{7}{|c|}{ Viga intermediária } \\
\hline$M_{g 1}$ & 1495 & 1436 & 1256 & 957 & 538 & 0 \\
\hline $\mathrm{M}_{\mathrm{g} 2}$ & 1765 & 1695 & 1483 & 1130 & 635 & 0 \\
\hline $\mathrm{M}_{\mathrm{g} 3}$ & 510 & 490 & 429 & 327 & 184 & 0 \\
\hline$M_{q}$ & 2672 & 2563 & 2240 & 1665 & 970 & 0 \\
\hline \multicolumn{7}{|c|}{ Viga da extremidade } \\
\hline$M_{g 1}$ & 1495 & 1436 & 1256 & 957 & 538 & 0 \\
\hline $\mathrm{M}_{\mathrm{g} 2}$ & 1606 & 1542 & 1349 & 1028 & 578 & 0 \\
\hline$M_{g 3}$ & 510 & 490 & 429 & 327 & 184 & 0 \\
\hline $\mathrm{M}_{\mathrm{q}}$ & 3143 & 3014 & 2634 & 1973 & 1142 & 0 \\
\hline
\end{tabular}

Tabela 6.7 - Esforço cortante nas longarinas (kN).

\begin{tabular}{|c|c|c|c|c|c|c|}
\hline Seção & 0 & 1 & 2 & 3 & 4 & 5 \\
\hline \multicolumn{7}{|c|}{ Viga central } \\
\hline $\mathrm{V}_{\mathrm{g} 1}$ & 0 & 41,0 & 82,0 & 123,1 & 164,1 & 205,1 \\
\hline $\mathrm{V}_{\mathrm{g} 2}$ & 0 & 52,5 & 105,0 & 157,6 & 210,1 & 262,6 \\
\hline $\mathrm{V}_{\mathrm{g} 3}$ & 0 & 14,0 & 28,0 & 42,0 & 56,0 & 70,0 \\
\hline $\mathrm{V}_{\mathrm{q}}$ & 106 & 141,9 & 182,4 & 227,4 & 277,1 & 331,2 \\
\hline \multicolumn{7}{|c|}{ Viga intermediária } \\
\hline $\mathrm{V}_{\mathrm{g} 1}$ & 0 & 41,0 & 82,0 & 123,1 & 164,1 & 205,1 \\
\hline $\mathrm{V}_{\mathrm{g} 2}$ & 0 & 48,4 & 96,8 & 145,3 & 193,7 & 242,1 \\
\hline $\mathrm{V}_{\mathrm{g} 3}$ & 0 & 14,0 & 28,0 & 42,0 & 56,0 & 70,0 \\
\hline $\mathrm{V}_{\mathrm{q}}$ & 129,0 & 169,6 & 214,9 & 264,8 & 319,4 & 378,3 \\
\hline \multicolumn{7}{|c|}{ Viga da extremidade } \\
\hline $\mathrm{V}_{\mathrm{g} 1}$ & 0 & 41,0 & 82,0 & 123,1 & 164,1 & 205,1 \\
\hline $\mathrm{V}_{\mathrm{g} 2}$ & 0 & 44,0 & 88,1 & 132,2 & 176,2 & 220,3 \\
\hline $\mathrm{V}_{\mathrm{g} 3}$ & 0 & 14,0 & 28,0 & 42,0 & 56,0 & 70,0 \\
\hline $\mathrm{V}_{\mathrm{q}}$ & 158,0 & 205,8 & 258,8 & 316,6 & 379,3 & 446,8 \\
\hline
\end{tabular}




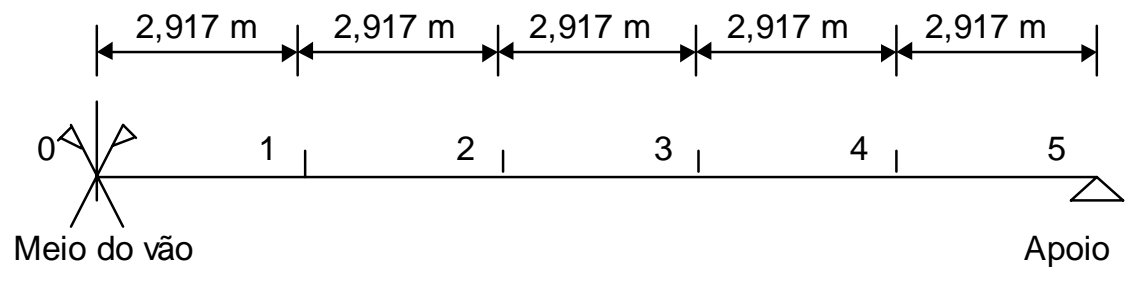

Figura 6.42 - Posição das seções de cálculo nas longarinas.

Na Figura 6.43 é mostrada a armadura de protensão dimensionada para as longarinas dessa ponte. Foi empregado o aço CP 190 RB com tensão de escoamento característica $\left(f_{\text {pyk }}\right)$ igual a $1710 \mathrm{MPa}$. Foram dimensionados 8 cabos com área nominal $\left(A_{p}\right)$ de $592,2 \mathrm{~mm}^{2}$ e bainha com diâmetro externo ( $\left.\phi_{\text {ext }}\right)$ de $55 \mathrm{~mm}$. Foram adotados em cada cabo seis cordoalhas com 7 fios cada $(12,7 \mathrm{~mm})$. A ancoragem adotada para os cabos era do tipo Freyssinet para 6 cordoalhas de $\phi=12,7 \mathrm{~mm}$ com cunhas individuais. Os cabos de 4 a 8 foram dimensionados para serem protendidos na viga pré-moldada ainda no canteiro, enquanto os cabos de 1 a 3 foram dimensionados para serem protendidos na seção composta após a efetivação da ligação entre a viga e a laje.

Os esforços na interface viga-laje foram avaliados empregando a seguinte expressão simplificada:

$$
\tau=\frac{V}{0,9 b d}
$$

sendo $V$ o esforço cortante, $b$ a largura da interface e $d$ a altura útil da viga composta. Essa expressão é função do esforço cortante na seção. Sendo assim, os esforços na interface seguem uma distribuição semelhante ao do esforço cortante ao longo do vão. Na Tabela 6.8 é mostrada a tensão de cisalhamento na interface em cada uma das seções de cálculo da longarina. A viga da extremidade foi adotada para o dimensionamento da ligação por representar a situação de maior solicitação. Para a largura da interface, foi adotado o valor de $18 \mathrm{~cm}$. Diferente da solução com laje moldada no local em que os esforços são transmitidos por toda a superfície superior da viga pré-moldada, na solução com laje prémoldada os esforços são transmitidos pelas ligações discretas ao longo do vão. Dessa forma, a largura da interface foi definida igual à largura do nicho, que, por sua vez, foi admitida aproximadamente igual à largura da alma da viga pré-moldada. A altura útil da viga composta, $1,73 \mathrm{~m}$, foi obtida a partir da distribuição da armadura no meio do vão, sendo admitida constante ao longo do vão. Os valores mostrados na Tabela 6.8 foram obtidos dos esforços nas seções de cálculo. Para efeito de detalhamento, esses valores foram admitidos constantes entre duas seções de cálculo adjacentes. 


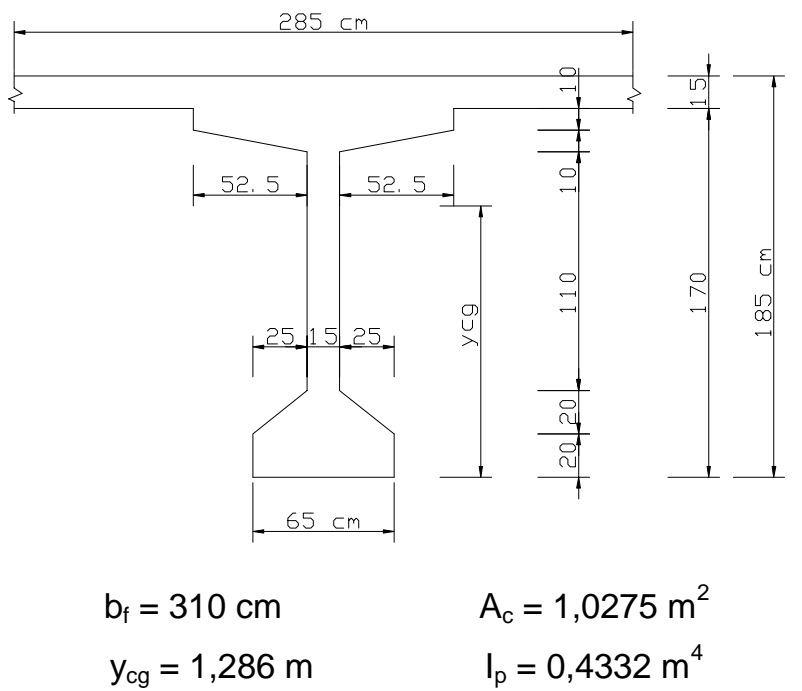

(a) Seção transversal composta: Viga central

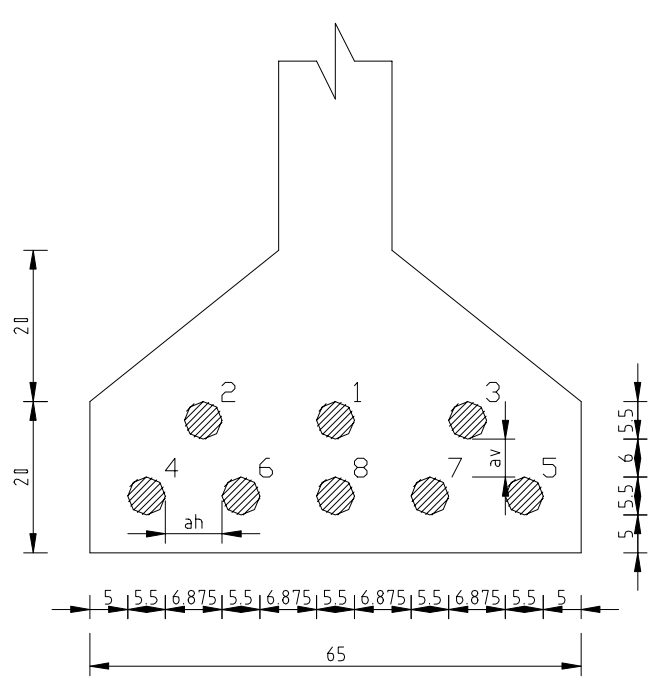

(b) Disposição dos cabos na seção transversal $\left(d^{\prime}=12,1 \mathrm{~cm}\right)$

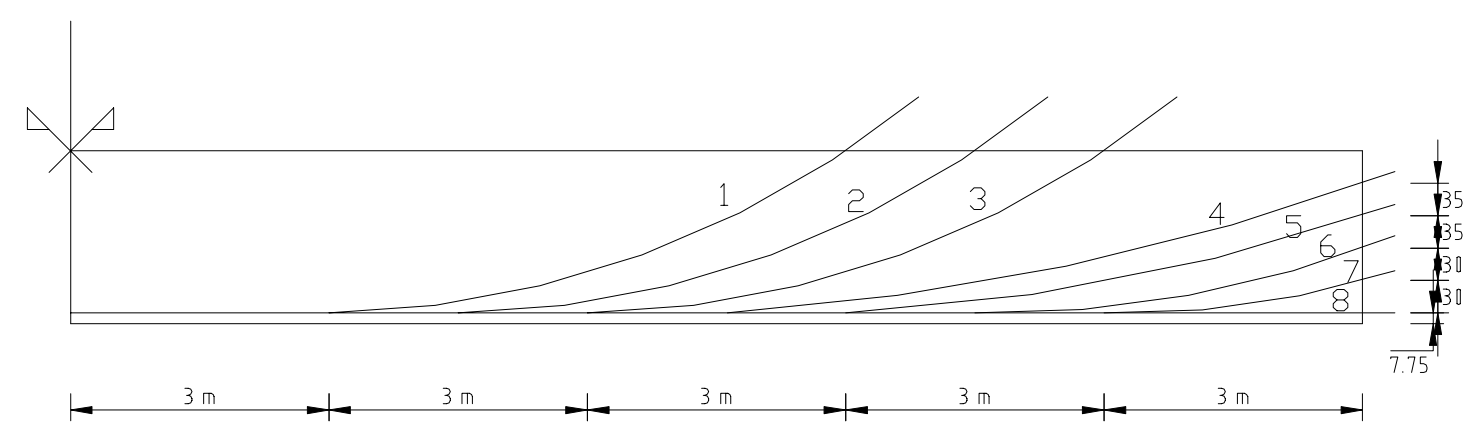

\begin{tabular}{|c|c|}
\hline cabo & ângulo (graus) \\
\hline 1 & 29 \\
\hline 2 & 29 \\
\hline 3 & 29 \\
\hline 4 & 19,1 \\
\hline 5 & 17,6 \\
\hline 6 & 14,9 \\
\hline 7 & 11,3 \\
\hline 8 & 0 \\
\hline
\end{tabular}

(c) Disposição dos cabos ao longo do vão

Figura 6.43 - Disposição da armadura protendida nas longarinas

Tabela 6.8 - Tensão de cisalhamento na interface da viga de extremidade

\begin{tabular}{|c|c|c|c|c|c|c|}
\hline Seção & 0 & 1 & 2 & 3 & 4 & 5 \\
\hline $\mathrm{V}_{\mathrm{g} 3}(\mathrm{kN})$ & 0 & 14,0 & 28,0 & 42,0 & 56,0 & 70,0 \\
\hline $\mathrm{V}_{\mathrm{q}}(\mathrm{kN})$ & 158,0 & 205,8 & 258,8 & 316,6 & 379,3 & 446,8 \\
\hline$\tau\left(\mathrm{kN} / \mathrm{m}^{2}\right)$ & 563,8 & 784,3 & 1023,3 & 1279,5 & 1553,2 & 1844,0 \\
\hline $\mathrm{F}_{\text {lig }}(\mathrm{kN})$ & 76,1 & 105,9 & 138,2 & 172,7 & 209,7 & 226,1 \\
\hline
\end{tabular}

$\mathrm{F}_{\text {lig }}$ : solicitação em cada ligação na interface obtida por $\mathrm{F}_{\text {lig }}=\tau \times b \times e$, sendo $e=75 \mathrm{~cm} 0$ espaçamento entre os nichos e $b=18 \mathrm{~cm}$ a largura da interface. 
Definida a solicitação na interface, o próximo passo consistiu na escolha do tipo de ligação e do espaçamento dos nichos na interface. Há várias maneiras de dimensionar a ligação. Neste trabalho, optou-se por inicialmente adotar o espaçamento e as dimensões dos nichos, e a partir daí definir o diâmetro do conector, a resistência do concreto e o tipo de ligação que garantisse à ligação uma resistência superior à solicitação na interface. A escolha inicial do espaçamento e das dimensões dos nichos foi feita com o intuito de padronizar a laje pré-moldada, o que facilitaria a sua produção em série. Foi adotado um espaçamento de $75 \mathrm{~cm}$ entre nichos, o que significa colocar, aproximadamente, quatro nichos entre seções de cálculo. Dessa forma, cada painel de laje poderia ter, por exemplo, $300 \mathrm{~cm}$ de largura, e o comprimento do painel ficaria limitado pela capacidade de carga dos equipamentos disponíveis para içamento. Quanto às dimensões do nicho, uma delas foi adotada aproximadamente igual à largura da alma da viga pré-moldada. A outra dimensão foi adotada também com $18 \mathrm{~cm}$, uma vez que nos resultados de ensaios disponíveis as duas dimensões do nicho eram sempre próximas, não havendo comprovação experimental que as expressões empíricas deduzidas possam ser diretamente aplicadas em nichos com outras relações entre os lados.

Na Tabela 6.8 também é mostrada a força que cada ligação, entre duas seções de cálculo adjacentes, deve resistir. Essa força foi obtida multiplicando a tensão de cisalhamento na interface em cada seção de cálculo pela largura da interface e pelo espaçamento entre nichos. No caso do trecho próximo ao apoio, compreendido entre as seções 4 e 5 , o esforço cortante foi reduzido em função do efeito de arco que surge no apoio. Esse efeito, que transmite diretamente as tensões de cisalhamento da interface para o apoio, foi observado nos ensaios das vigas compostas, onde se percebeu que os nichos mais próximos aos apoios foram pouco solicitados. Dessa forma, a tensão de cisalhamento usada no cálculo da força transmitida para a ligação $\left(\tau=1674,5 \mathrm{kN} / \mathrm{m}^{2}\right)$ foi aquela da seção situada a $1,70 \mathrm{~m}$ do apoio. Essa distância foi definida igual à altura da viga pré-moldada.

Conhecida a solicitação nas ligações entre a viga e a laje pré-moldadas, foi definido o tipo de ligação e a resistência do concreto moldado nos nichos. $O$ aço escolhido para os conectores foi o CA 50-A com $\mathrm{f}_{\mathrm{yk}}=500 \mathrm{MPa}$. Adotando ligação com chave de cisalhamento e adicionando $0,75 \%$ de fibras ao concreto, a resistência da ligação pode ser avaliada pela eq. (5.2b), que foi rescrita como :

$$
F_{\text {lig }}=A_{n} \tau_{u}=A_{n}\left(1,730 f_{c k}^{0,708}\left(\rho \sqrt{f_{y k}}\right)^{0,415}\right) \leq A_{n} 2,6 \sqrt{f_{c k}} \operatorname{com} \rho>0,005
$$


Nessa expressão, as resistências médias do concreto e do aço foram substituídas por seus valores característicos. A resistência de cálculo da ligação foi obtida dividindo as resistências características dos materiais pelos coeficientes de ponderação das resistências $\left(\gamma_{c}=1,4\right.$ e $\left.\gamma_{s}=1,15\right)$. Além desses coeficientes, foram introduzidos outros dois coeficientes, $\gamma_{2}$ e $\phi$, que levam em consideração a redução de resistência proporcionada pela fadiga do material e a probabilidade de falha da eq.(5.2b), respectivamente. As estruturas de pontes são submetidas a milhões de ciclos de carregamento e descarregamento durante sua vida útil, sendo fundamental o dimensionamento dos elementos estruturais ao fenômeno de fadiga. Não há resultados experimentais para a definição da redução da resistência dessa ligação por fadiga. Sendo assim, esse fenômeno foi levado em consideração, de forma simplificada, dividindo a resistência estática da ligação pelo coeficiente $\gamma_{2}=1,2$.

O coeficiente $\phi$ leva em consideração a probabilidade de falha da eq.(5.2b), isto é, a probabilidade da resistência da ligação ser inferior ao valor calculado pela expressão empírica. Para se obter um valor para esse coeficiente, foi empregado o conceito de índice de confiabilidade $(\beta)$ que representa a margem de segurança de um evento ter sucesso, ou seja, indica quão longe determinada configuração de carregamento ou resistência de uma estrutura está de seu estado limite (CASTRO (1997)). O índice de confiabilidade é calculado a partir da probabilidade de falha do evento, neste caso, definida pelo fato da resistência avaliada pela expressão empírica ser superior à resistência experimental da ligação. Como não se dispõe de resultados experimentais em quantidade suficiente para definir a curva de probabilidade, foi admitido que a resistência da ligação segue uma distribuição normal (Figura 6.44). Na Tabela 6.9 estão mostrados os valores do índice de confiabilidade em função da probabilidade de falha assumida (Figura 6.44b).

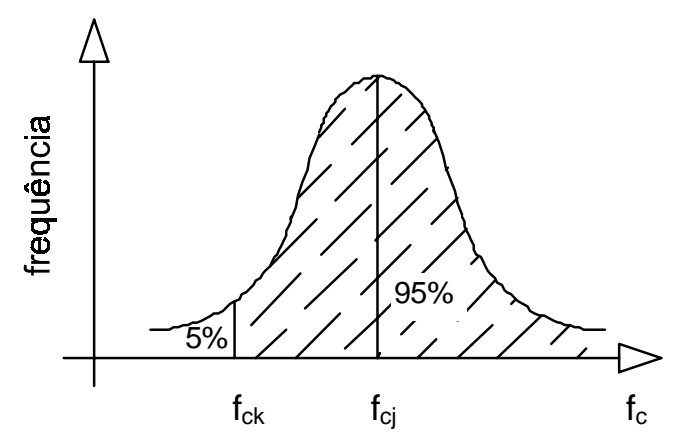

(a) curva normal para determinação da resistência característica do concreto à compressão

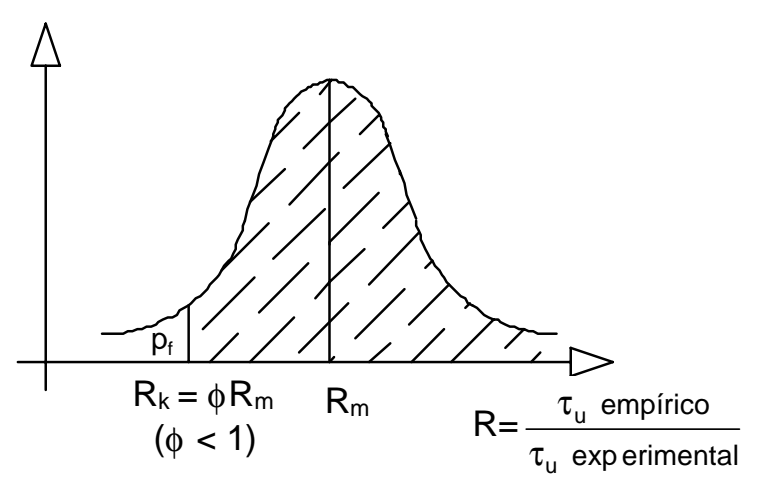

(b) curva normal para determinação de coeficientes de minoração

Figura 6.44 - Curva normal de distribuição de freqüências. 
Se for desejado que a resistência da ligação avaliada pela eq.(5.2b) tenha uma probabilidade de $95 \%$ de ser igual ou menor que os valores reais obtidos de ensaios $\left(p_{f}=\right.$ $5 \%$ ), o coeficiente de minoração da resistência a ser aplicado é calculado por (CASTRO (1997)):

$$
\phi=1-\beta . \delta
$$

sendo $\beta=1,65\left(p_{\mathrm{f}}=5 \%\right)$ e $\delta=S / M$ o coeficiente de variação. S e $M$ são o desvio padrão e a média, respectivamente, da relação entre a resistência calculada pela equação empírica e os resultados obtidos dos ensaios (Tabela 5.1). Do item 5.1 sabe-se que $S=0,052$ e $M=$ 1,004 , logo $\phi=0,91$. Esse valor é próximo ao recomendado na norma norueguesa $(\phi=0,83)$ para a determinação da resistência característica de peças de concreto ensaiadas em laboratório, e pode ser obtido pela eq.(6.9) usando $\delta=0,1$ e $\beta=1,7$ (JONSSON (1996)). Na Figura 6.45 é novamente mostrada a regressão realizada para obtenção da eq.(5.2b), porém mostrando também os valores previstos com a equação minorada pelo coeficiente $\phi$. Nota-se que com esse coeficiente, a curva prevista pela equação empírica ficou abaixo de todos os resultados experimentais.

Tabela 6.9 - Índices de confiabilidade $(\beta)$

\begin{tabular}{|c|c|}
\hline probabilidade de falha assumida $\left(\mathrm{p}_{\mathrm{f}}\right)$ & índice de confiabilidade $(\beta)$ \\
\hline $10 \%$ & 1,28 \\
\hline $5 \%$ & 1,65 \\
\hline $1 \%$ & 2,33 \\
\hline $0,1 \%$ & 3,10 \\
\hline
\end{tabular}

A resistência de cálculo da ligação com chave de cisalhamento e fibras pode, portanto, ser avaliada por :

$$
F_{\text {lig,d }}=A_{n} \phi \frac{1}{\gamma_{2}} \tau_{u, d}=A_{n} \phi \frac{1}{\gamma_{2}}\left(1,730\left(\frac{f_{c k}}{\gamma_{c}}\right)^{0,708}\left(\rho \sqrt{\frac{f_{y k}}{\gamma_{s}}}\right)^{0,415}\right) \leq A_{n} \phi \frac{1}{\gamma_{2}} 2,6 \sqrt{\frac{f_{c k}}{\gamma_{c}}}
$$

Adotando um conector de $12,5 \mathrm{~mm}$ em cada nicho, tem-se $\rho=0,0076$. Igualando a eq.(6.10) com a solicitação de cálculo da seção 4, por exemplo, obtêm-se a resistência necessária ao concreto moldado nos nichos:

$$
\gamma_{\mathrm{f}} F_{\text {lig }}=A_{n} \phi \frac{1}{\gamma_{2}}\left(1,730\left(\frac{f_{c k}}{\gamma_{c}}\right)^{0,708}\left(\rho \sqrt{\frac{f_{y k}}{\gamma_{s}}}\right)^{0,415}\right) \leq A_{n} \phi \frac{1}{\gamma_{2}} 2,6 \sqrt{\frac{f_{c k}}{\gamma_{c}}}
$$




$$
\begin{aligned}
& 1,4 \times 209,7 \times 10^{-3}=0,18 \times 0,18 \times 0,91 \times \frac{1}{1,2}\left(1,730\left(\frac{f_{c k}}{1,4}\right)^{0,708}\left(0,0076 \sqrt{\frac{500}{1,15}}\right)^{0,415}\right) \\
& f_{c k} \cong 65 \mathrm{MPa}
\end{aligned}
$$

Com essa resistência para o concreto e o conector de $12,5 \mathrm{~mm}$, é facilmente verificado que os limites da eq.(6.8) e da eq.(6.10) também são satisfeitos. No trecho da interface situado entre as seções 4 e 5 , essa ligação é insuficiente para resistir à solicitação. Neste caso, foram mantidas as dimensões do nicho e a resistência do concreto e foi adicionado mais um conector de $8 \mathrm{~mm}$ que ficará posicionado junto com o conector de 12,5 $\mathrm{mm}$. Procedendo assim, a resistência de cálculo da ligação passou para 345,2 kN, valor superior à solicitação de cálculo nesse trecho $(1,4 \times 266,1=316,5 \mathrm{kN})$. Essa solução foi adotada com a finalidade de aproximar, o máximo possível, a resistência da ligação da solicitação na interface, sem preocupação com a padronização de projeto. Nos demais trechos, a ligação com chave de cisalhamento e conector de $12,5 \mathrm{~mm}$ resiste com folga à solicitação na interface. Pode-se, então, adotar essa ligação no restante da viga, ou adotar ligações menos resistentes à medida que se caminha para o meio do vão. A solução a ser adotada é particular de cada projetista, devendo ser levada em consideração a padronização do projeto.

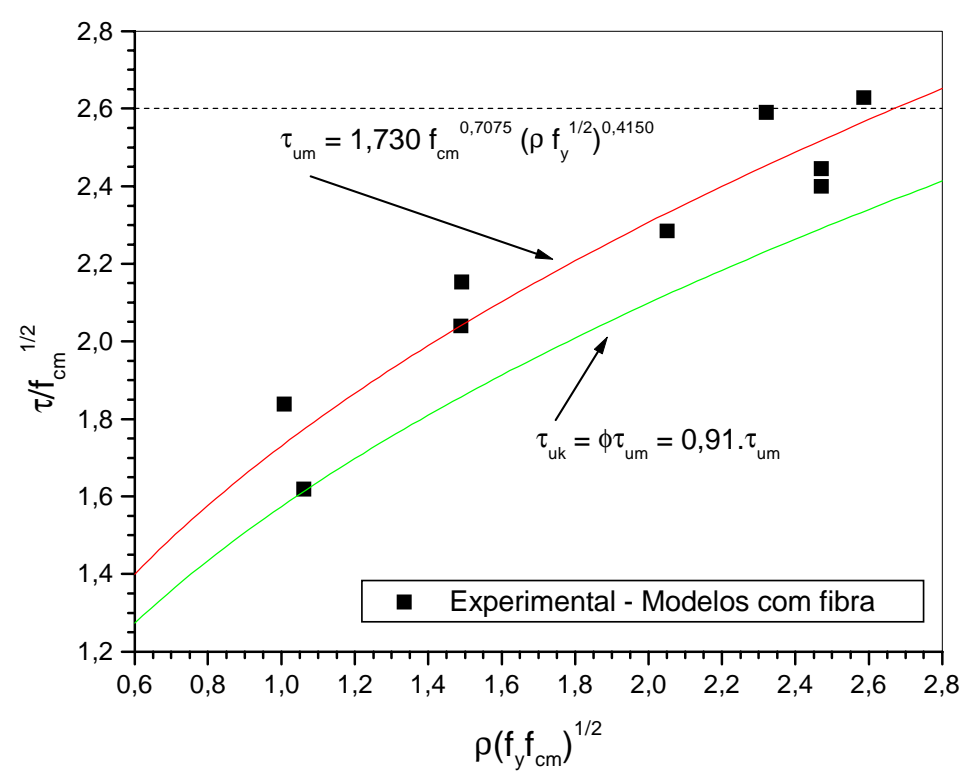

Figura 6.45 - Resistência da ligação com chave de cisalhamento e fibras por equações empíricas

Com o objetivo de permitir comparações, são mostradas na Tabela 6.10 as resistências de algumas ligações variando o diâmetro do conector e o tipo de ligação. A 
resistência do concreto moldado no nicho não foi alterada. No caso da ligação com chave de cisalhamento e fibras, se o limite $\rho>0,005$ não for satisfeito, deve-se empregar a eq.(5.1b) na avaliação da resistência, a qual foi obtida dos ensaios sem adição de fibras à ligação. Esse limite foi introduzido devido ao fato de não ter sido realizado nenhum ensaio com ligação sem conector. Na Figura 6.46 é mostrada a avaliação da resistência da ligação empregando a eq.(5.1b) e a eq.(5.2b). Também é mostrada uma expressão alternativa para a ligação com chave de cisalhamento e fibras. Essa expressão foi obtida por regressão linear nos resultados dos ensaios de cisalhamento direto, porém apresentou um índice de correlação menor que o da eq.(5.2b). Se o limite $\rho>0,005$ não for satisfeito, ela pode ser extrapolada para as regiões com baixa taxa de armadura e usada como alternativa para avaliar a resistência da ligação com fibras.

Tabela 6.10 - Resistência de vários tipos de ligação viga-laje

\begin{tabular}{|c|c|c|c|c|c|}
\hline Ligação & $\begin{array}{l}\text { Volume de } \\
\text { fibras (\%) }\end{array}$ & $\begin{array}{l}\text { Diâmetro } \\
\text { do conector } \\
(\mathrm{mm})\end{array}$ & $\begin{array}{l}\text { Método de } \\
\text { cálculo }\end{array}$ & $\begin{array}{l}\text { Resistência de } \\
\text { cálculo da ligação } \\
\text { - } F_{\text {lig,d }}(\mathrm{kN})\end{array}$ & Observações \\
\hline \multirow{6}{*}{$\begin{array}{l}\text { Chave de } \\
\text { cisalhamento }\end{array}$} & \multirow{3}{*}{0,75} & $\begin{array}{c}1 \phi 12,5 \\
\rho=0,00759\end{array}$ & $\begin{array}{l}\text { eq.(5.2b) } \\
\text { Figura } 6.46\end{array}$ & 299,5 & \multirow{6}{*}{$\begin{array}{c}f_{c k}=65 \mathrm{MPa} e \\
\text { nichos com } 18 \mathrm{~cm} \\
\times 18 \mathrm{~cm}\end{array}$} \\
\hline & & $\begin{array}{c}1 \phi 10 \\
\rho=0,00485\end{array}$ & $\begin{array}{c}\text { eq.(1) } \\
\text { Figura } 6.46\end{array}$ & 278,4 & \\
\hline & & $\begin{array}{c}1 \phi 8 \\
\rho=0,00310\end{array}$ & $\begin{array}{c}\text { eq.(1) } \\
\text { Figura } 6.46\end{array}$ & 253,3 & \\
\hline & \multirow{3}{*}{-} & $\begin{array}{c}1 \phi 12,5 \\
\rho=0,00759\end{array}$ & $\begin{array}{l}\text { eq.(5.1b) } \\
\text { Figura } 6.46\end{array}$ & 277,3 & \\
\hline & & $\begin{array}{c}1 \phi 10 \\
\rho=0,00485\end{array}$ & $\begin{array}{l}\text { eq.(5.1b) } \\
\text { Figura } 6.46\end{array}$ & 253,9 & \\
\hline & & $\begin{array}{c}1 \phi 8 \\
\rho=0,00310\end{array}$ & $\begin{array}{l}\text { eq.(5.1b) } \\
\text { Figura } 6.46\end{array}$ & 239,1 & \\
\hline \multirow{5}{*}{ Plana rugosa } & \multirow{5}{*}{-} & $1 \phi 12,5$ & \multirow{5}{*}{$\begin{array}{c}\text { Modelo de } \\
\text { TASSIOS; } \\
\text { VINTZELEOU } \\
\text { (1990) - item } 4.3\end{array}$} & 178,8 & \multirow{3}{*}{$\begin{array}{c}\mathrm{f}_{\mathrm{ck}}=30 \mathrm{MPa} \mathrm{e} \\
\text { nichos com } 18 \mathrm{~cm} \\
\times 18 \mathrm{~cm}\end{array}$} \\
\hline & & $2 \phi 12,5$ & & 243,4 & \\
\hline & & $2 \phi 10$ & & 197,9 & \\
\hline & & $1 \phi 12,5$ & & 265,5 & \multirow{2}{*}{$\begin{array}{c}f_{c k}=30 \mathrm{MPa} \text { e } \\
\text { nichos com } 25 \mathrm{~cm} \\
\times 25 \mathrm{~cm}\end{array}$} \\
\hline & & $2 \phi 12,5$ & & 350,4 & \\
\hline Plana lisa & - & $1 \phi 12,5$ & \multirow{2}{*}{$\begin{array}{l}\text { Interpolação no } \\
\text { gráfico da Figura } \\
4.12 \\
\tau=1,477+0,035 \frac{f_{c k}}{\gamma_{c}}\end{array}$} & 100,5 & $\begin{array}{c}\mathrm{f}_{\mathrm{ck}}=65 \mathrm{MPa} \text { e } \\
\text { nichos com } 18 \mathrm{~cm} \\
\times 18 \mathrm{~cm}\end{array}$ \\
\hline Plana lisa & - & $1 \phi 12,5$ & & 193,9 & $\begin{array}{c}\mathrm{f}_{\mathrm{ck}}=65 \mathrm{MPa} \text { e } \\
\text { nichos com } 25 \mathrm{~cm} \\
\times 25 \mathrm{~cm}\end{array}$ \\
\hline
\end{tabular}




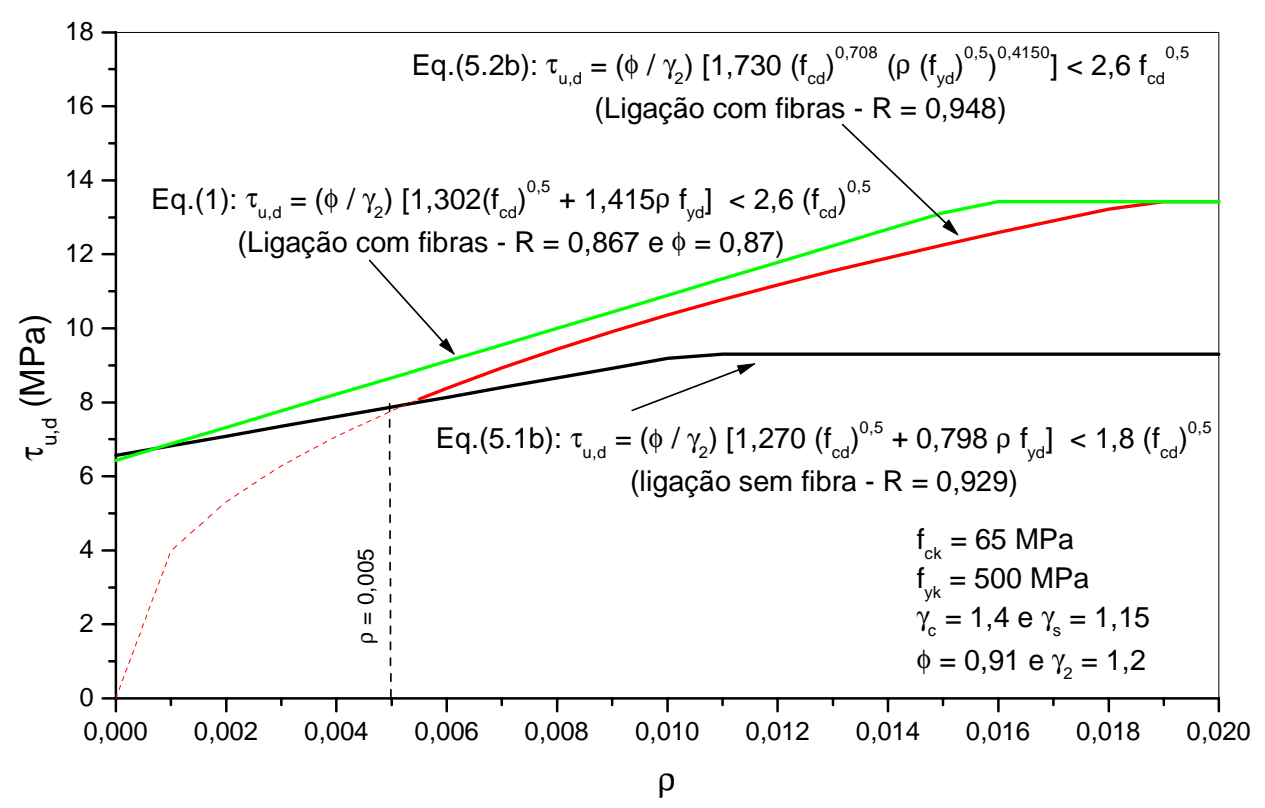

Figura 6.46 - Resistência da ligação com chave de cisalhamento em função da taxa de armadura

Na Figura 6.47 é mostrado um detalhamento possível para garantir a transferência dos esforços pela interface entre a viga e a laje pré-moldadas. Nessa figura, é mostrado, em forma de diagrama, a solicitação e a resistência de cálculo da interface admitindo a existência de quatro nichos entre as seções de cálculo. Esse detalhamento foi realizado visando atender apenas à distribuição de esforços pela interface ao longo do vão da viga. Em um projeto real, deve-se levar em consideração, também, a padronização da ligação. Nessa mesma figura também são mostrados uma perspectiva do tabuleiro com os nichos e um detalhe da viga pré-moldada. Esta teve suas dimensões modificadas em função da laje ser pré-moldada, isto é, a flange superior da viga pré-moldada foi reduzida pelo fato de que a laje não é mais moldada no local.

O dimensionamento aqui realizado empregou alguns conceitos de segurança das estruturas adotados pelas normas brasileiras e européias. Esse procedimento, dito semiprobabilístico por incluir conceitos de probabilidade juntamente com relações determinísticas, tem sido empregado com freqüência nas análises das estruturas em estados limites últimos. Como conseqüência de ser um processo semiprobabilístico, nem sempre é possível avaliar o nível de segurança da estrutura. Outras normas, como as americanas, adotam um conceito diferente de dimensionamento. Nelas as solicitações em serviço são comparadas diretamente com as resistências que, por sua vez, são reduzidas por um coeficiente único. Dessa forma, esse coeficiente pode ser admitido como um coeficiente de segurança global, servindo para estimar o nível de segurança da estrutura. Esse último conceito foi aplicado à seção 4 para avaliar o nível de segurança introduzido à 
ligação. Para tanto, admite-se inicialmente que os valores mostrados na Tabela 6.7 sejam as solicitações reais a que a estrutura será submetida. A resistência real da ligação pode ser obtida da eq.(5.2b) empregando as propriedades médias dos materiais. Nessa equação foi aplicado apenas o coeficiente $\gamma_{2}$. A resistência da ligação vale, portanto:

$$
\begin{aligned}
& f_{c m}=f_{c k}+3,5=68,5 \mathrm{MPa} \\
& F_{\text {lig }}=0,18 \times 0,18 \times \frac{1}{1,2}\left(1,73 \times 68,5^{0,708} \times\left(\frac{2 \times 1,23}{18 \times 18} \times \sqrt{500}\right)^{0,415}\right) \times 1000=446,1 \mathrm{kN}
\end{aligned}
$$

O coeficiente de segurança global da ligação, $\Phi$, pode ser estimada como:

$$
\Phi=\frac{446,1}{209,7}=2,13
$$

Para finalizar o exemplo, verificou-se o estado limite último por solicitações normais. No projeto foram adotados 8 cabos com 6 cordoalhas de 12,7 mm (área nominal de 98,7 $\mathrm{mm}^{2}$ ) em cada cabo. O aço de protensão empregado foi o CP $190 \mathrm{RB}$ com $\mathrm{f}_{\text {pyd }}=1487 \mathrm{MPa}$. Dessa forma, a resultante de tração na armadura ativa vale $F_{t d}=7045 \mathrm{kN}$. A resultante de compressão na seção composta foi estimada pela eq.(6.4). No caso da viga central, a resultante de compressão vale:

$$
F_{c d}=0,68 f_{c d} b_{f} h_{L}=0,68 \times \frac{30}{1,4} \times 3,10 \times 0,15 \times 1000=6776 \mathrm{kN}
$$

$\mathrm{Na}$ expressão anterior, $f_{\mathrm{cd}}$ é a resistência de cálculo do concreto da laje $\left(f_{\mathrm{ck}}=30\right.$ $\mathrm{MPa}), b_{f}$ é a largura da laje colaborante e $h_{\llcorner}$é a espessura da laje. Como a resultante de compressão é menor que a resultante de tração, a linha neutra da seção composta encontra-se abaixo da interface. Para que a laje e a viga trabalhem em conjunto no estado limite último, é necessário que a resultante de compressão na laje $\left(F_{c d}\right)$ seja integralmente transmitida pela interface. Empregando a distribuição de tensões mostrada na Figura 6.47a, a resistência da interface $\left(F_{\text {int,d }}\right)$ vale:

$$
F_{\text {int,d }}=345,2 \times 4+299,5 \times 4+278,4 \times 4+253,3 \times 8=5719 \mathrm{kN}<F_{c d}
$$

Logo, não é possível considerar colaboração completa da viga e da laje na avaliação do momento resistente da seção composta, sendo o momento resistente estimado pela eq.(6.5):

$$
M_{\text {comp }, d}=F_{i n t, d} d_{1}+F_{i n t, d}\left(h_{L}-\frac{F_{i n t, d}}{F_{c d}} \frac{h_{L}}{2}\right)
$$




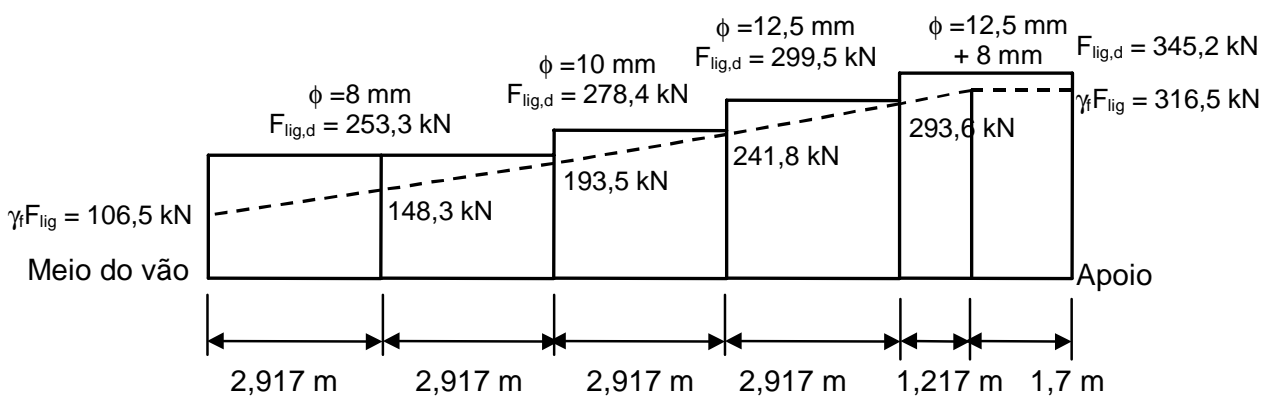

Ligação com chave de cisalhamento Dimensões dos nichos : $18 \mathrm{~cm} \times 18 \mathrm{~cm}$

Espaçamento dos nichos: $75 \mathrm{~cm}$

Resistência do concreto moldado no nicho: $\mathrm{f}_{\mathrm{ck}}=65 \mathrm{MPa}$

Volume de fibras: $0,75 \%$

Obs: Esse detalhamento foi realizado visando atender apenas à distribuição de esforços pela interface ao longo do vão da viga. Em um projeto real, deve-se levar em consideração, também, a padronização da ligação.

(a) Diagrama de solicitação e resistência da interface ao longo do vão
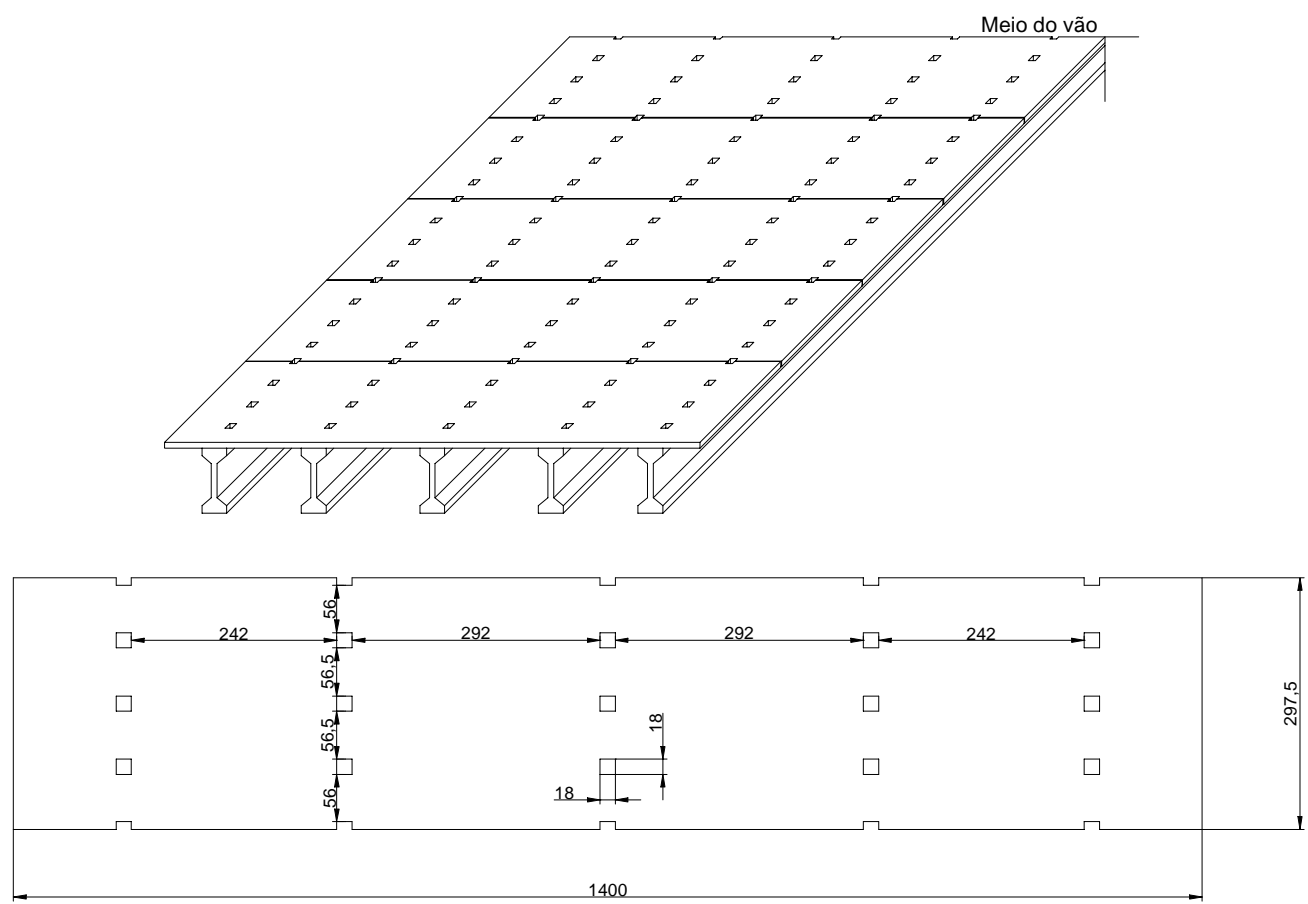

Vista superior do painel de laje

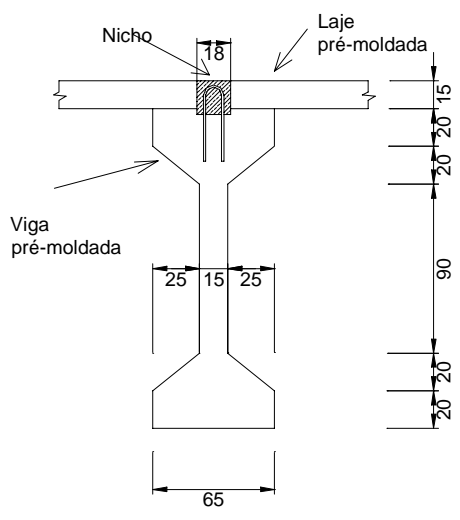

Vista frontal da viga pré-moldada com nicho

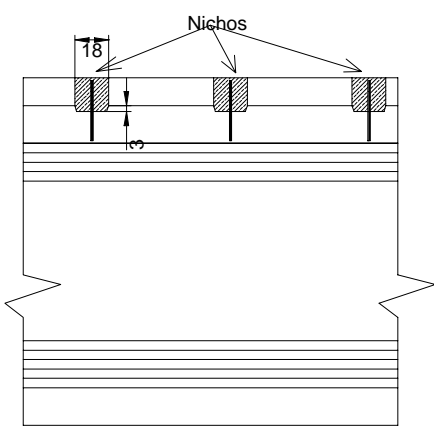

Vista lateral da viga pré-moldada com nichos

(b) Detalhes do tabuleiro com laje pré-moldada (dimensões em centímetros)

Figura 6.47 - Tabuleiro de ponte com viga e laje pré-moldadas 


$$
M_{c o m p, d}=5719 \times(1,73-0,15)+5719\left(0,15-\frac{5719}{6776} \times \frac{0,15}{2}\right)=9532 \mathrm{kN} \cdot \mathrm{m}
$$

O momento solicitante de cálculo no meio do vão da viga central vale:

$$
M_{d}=1,4 \times 6274=8784 \mathrm{kN} \cdot \mathrm{m}<\mathrm{M}_{\text {comp }, \mathrm{d}}
$$

Logo, conclui-se que a seção está segura quanto ao estado limite último por solicitações normais. Com relação à viga de extremidade, procedeu-se de modo idêntico. A resultante de compressão na laje vale:

$$
F_{c d}=0,68 f_{c d} b_{f} h_{L}=0,68 \times \frac{30}{1,4} \times 1,825 \times 0,15 \times 1000=3989 \mathrm{kN}
$$

Esse valor é inferior à resultante de tração, de modo que a linha neutra encontra-se abaixo da interface. Empregando as dimensões da viga pré-moldada mostrada na Figura 6.47b, a posição da linha neutra foi facilmente obtida igualando as resultantes de tração e de compressão na seção composta $(x=0,503 \mathrm{~m})$. Como a resultante de compressão na laje é inferior à resistência da interface, o momento resistente foi calculado considerando colaboração completa da laje no estado limite último pela eq.(6.3b):

$$
\mathrm{M}_{\text {comp }, \mathrm{d}}=7045 \times(1,73-0,15)+3989 \times \frac{0,15}{2}-(7045-3989) \frac{0,8 \times 0,503-0,15}{2}=11045 \mathrm{kN} \cdot \mathrm{m}
$$

O momento solicitante de cálculo no meio do vão da viga de extremidade vale:

$$
M_{d}=1,4 \times 6754=9456 \mathrm{kN} \cdot \mathrm{m}<\mathrm{M}_{\text {comp }, \mathrm{d}}
$$

Logo, conclui-se que essa seção também está segura quanto ao estado limite último por solicitações normais.

\subsection{Síntese e considerações finais}

Neste capítulo, foram mostrados os resultados dos ensaios realizados nas vigas compostas formadas por viga e laje pré-moldadas. Foram ensaiadas quatro vigas submetidas a carregamento monotônico, sendo três vigas compostas com laje pré-moldada e uma viga monolítica, todas com as mesmas dimensões. Nas vigas compostas, a ligação entre as peças pré-moldadas foi realizada empregando chave de cisalhamento e adicionando fibras ao concreto moldado nos nichos. A variável analisada nesses ensaios foi o espaçamento dos nichos ao longo da viga. A partir dos resultados verificou-se uma 
diminuição da capacidade resistente da viga composta com o aumento do espaçamento dos nichos. Em termos quantitativos, quando os nichos foram espaçados de $28 \mathrm{~cm}$ ( $\beta=48 \%$ ) a capacidade resistente da viga composta foi apenas $2 \%$ inferior à observada na viga monolítica. Por outro lado, quando o espaçamento dos nichos foi aumentado para $42 \mathrm{~cm}$ ( $\beta$ $=31 \%$ ) a capacidade resistente da viga composta foi $26 \%$ inferior à observada na viga monolítica. De modo semelhante, quando o espaçamento dos nichos foi aumentado para 56 $\mathrm{cm}(\beta=22 \%)$, a capacidade resistente da viga composta foi $34 \%$ inferior à observada na viga monolítica. Com relação à rigidez na flexão, observou-se que na viga com nichos espaçados de $28 \mathrm{~cm}$, a deformação era a mesma da viga monolítica. O aumento no espaçamento dos nichos, entretanto, reduziu a rigidez da viga composta. Por exemplo, quando o espaçamento dos nichos foi aumentado para $56 \mathrm{~cm}$ houve uma redução de até $18 \%$ no valor da rigidez secante.

Analisando a forma de ruptura das vigas, observou-se que na viga com os nichos espaçados de $28 \mathrm{~cm}$ a ruptura ocorreu pelo esmagamento do concreto na face superior da viga. Quando o espaçamento dos nichos foi aumentado, a capacidade resistente da viga composta foi definida pela ruptura da ligação entre a viga e a laje pré-moldadas, o que mostra que nessas vigas o número de nichos era inferior ao necessário para garantir a transferência integral de tensões pela interface no estado limite último.

Comparando as vigas com laje pré-moldada com as vigas com laje moldada no local ensaiadas por ARAUJO (1997), observou-se que a solução com laje pré-moldada e nichos espaçados de $28 \mathrm{~cm}$ garantiu à viga composta a mesma resistência alcançada pela solução com concreto moldado no local. O panorama de fissuração dessas vigas, entretanto, foi bem diferente. Foram observadas concentrações de tensões na viga pré-moldada junto à ligação da viga composta com laje pré-moldada que devem ser considerados no projeto. Além disso, foi observado que alguns limites propostos para as vigas com laje moldada no local não se aplicam às vigas com laje pré-moldada, como, por exemplo, a definição da ruptura da viga composta quando o deslizamento da interface atingir o limite máximo de 0,5 mm (ARAUJO (1997) e PATNAIK (1992)).

Foi observado, também, que o mecanismo de transferência de esforços da laje para a viga na solução com laje pré-moldada é diferente do mecanismo proposto para a solução com laje moldada no local. Nas vigas compostas com laje pré-moldada, a transferência de esforços pela interface deu-se por cisalhamento direto na ligação. Como conseqüência dessa observação, foram apresentadas algumas expressões simplificadas para avaliação do momento resistente das vigas compostas com laje pré-moldada baseadas em trabalhos 
com viga metálica e laje alveolar de concreto. Essas expressões foram deduzidas considerando a resistência ao cisalhamento da ligação entre a viga e a laje que, por sua vez, pode ser avaliada pelas expressões empíricas ou pelos modelos mecânicos apresentados no capítulo 5 .

Além dos ensaios com carregamento monotônico, foi realizado o ensaio de uma viga composta submetida a carregamento cíclico não reversível. Foram aplicados à viga três níveis de carregamento, e em cada nível foram realizados vinte ciclos completos de carga e descarga. Foi observada uma perda de rigidez da viga devido à repetição do carregamento. Essa perda foi tanto maior quanto maior foi o nível do carregamento aplicado. Em primeira aproximação, pode-se afirmar que para um nível de carregamento igual a $30 \%$ da resistência da viga, após vinte ciclos de carregamento ocorre uma redução de cerca de $6 \%$ na rigidez da viga composta. Essa perda sobe para $8 \%$ e $10 \%$ quando o nível de carregamento é elevado para $50 \%$ e $75 \%$ da resistência da viga composta, respectivamente. Foi observada, também, uma tendência de estabilização da rigidez após vinte ciclos de carregamento.

Após o término do ensaio cíclico, essa viga foi levada à ruptura pela aplicação de um carregamento monotônico crescente. Não foi observada redução na força máxima resistida pela viga devido ao carregamento cíclico. Esse comportamento era esperado, uma vez que foi observado nos ensaios de cisalhamento direto que a aplicação de um pequeno número de ciclos, com baixa intensidade, não altera a resistência da ligação.

Na seqüência, foram mostrados os resultados obtidos da análise numérica realizada no programa ANSYS, que ampliaram a compreensão do comportamento das vigas compostas com laje pré-moldada. Foram empregadas duas modelagens. $\mathrm{Na}$ primeira modelagem, os nichos e o conector foram modelados de modo explícito. A partir dessa modelagem foi possível visualizar as regiões de concentração de tensões na viga prémoldada devido à transferência discreta de esforços da laje para a viga pré-moldada.

$\mathrm{Na}$ segunda modelagem, a ligação entre a viga e a laje foi substituída por um elemento uniaxial com comportamento não linear. Dessa modelagem foi possível analisar a influência de outros tipos de ligação na interface entre a viga e a laje pré-moldadas. Foram analisados quatro tipos de ligação: ligação com superfície plana e lisa, ligação com superfície plana e rugosa, ligação com chave de cisalhamento sem fibras, e ligação com chave de cisalhamento e fibras. A curva utilizada para representar o comportamento dessas ligações foi obtida a partir dos resultados dos ensaios de cisalhamento direto. A desvantagem dessa modelagem é que não foi possível observar o panorama de fissuração 
na viga composta à medida que o carregamento era incrementado, uma vez que a chave de cisalhamento na viga pré-moldada não foi modelada.

Os resultados da simulação numérica mostraram uma redução da força última das vigas compostas à medida que a ligação entre a viga e a laje foi substituída por outras menos resistentes. Na viga com os nichos espaçados de $28 \mathrm{~cm}$, observou-se que a substituição da ligação com chave de cisalhamento e fibras por outra com chave de cisalhamento sem fibras proporcionou à viga composta resistir à mesma força. Ao ser substituída pela ligação plana e rugosa, houve uma perda de apenas 3\% na força última da viga composta, porém a adoção da superfície plana e lisa reduziu em $33 \%$ a força última da viga composta. Os baixos níveis de redução nas ligações com chave de cisalhamento e rugosa foram possíveis por que após a primeira ligação romper houve uma redistribuição de esforços entre as demais ligações.

Nas vigas com os nichos espaçados de $42 \mathrm{~cm}$ e $56 \mathrm{~cm}$, a capacidade resistente da viga foi definida pela resistência ao cisalhamento da ligação. Sendo assim, era esperado, nessas vigas, uma redução da força última proporcional à redução na resistência da ligação. Contudo, o que se viu foi uma redução menor que o esperado. Por exemplo, a resistência da ligação com chave de cisalhamento sem fibra era $28 \%$ menor que a resistência da ligação com chave de cisalhamento e 0,75\% de fibras. De igual maneira, as resistências das ligações rugosa e lisa eram 33\% e 66\% menores que a resistência da ligação com chave de cisalhamento e fibras. A redução observada na força última da viga composta com os nichos espaçados de $42 \mathrm{~cm}$, quando a ligação com chave de cisalhamento e fibras foi substituída pelas ligações com chave de cisalhamento sem fibra, rugosa e lisa, foi de $13 \%, 22 \%$ e $38 \%$, respectivamente. Na viga com os nichos espaçados de $56 \mathrm{~cm}$, a redução da força última foi semelhante. Isto sugere que outros fatores influenciaram no comportamento à flexão das vigas compostas com baixa quantidade de conectores na ligação. Talvez o grande espaçamento entre os nichos permitiu que a viga e a laje se deformassem de modo mais independente, o que resultou em maiores deformações na armadura inferior da laje pré-moldada. Se isto aconteceu, pode ter surgido um momento resistente adicional na laje devido à maior deformação da armadura de flexão da laje.

Com relação à rigidez da viga composta, a alteração da ligação na interface entre a viga e a laje pré-moldadas não apresentou grande influência sobre os resultados. Apenas quando foi adotada a ligação plana e lisa houve uma sensível redução na rigidez da viga composta. Essa redução ocorreu, contudo, apenas após a ruptura da ligação. 
A partir dos resultados da segunda modelagem, também foi analisada a influência do espaçamento dos nichos sobre o comportamento da viga composta. Observou-se que a redução da força última da viga composta com o aumento no espaçamento dos nichos foi aproximadamente linear, apresentando uma perda média de $41 \%$ quando o espaçamento passou de $28 \mathrm{~cm}$ para $56 \mathrm{~cm}$. Essa perda foi mais acentuada na viga com a ligação plana e rugosa $(47 \%)$ e menos acentuada na viga com a ligação com chave de cisalhamento e fibras (34\%). Com relação à rigidez da viga composta, foi observada uma nítida redução em seu valor na medida em que se aumentou o espaçamento dos nichos.

Também foi analisada a influência da deformabilidade da ligação sobre o comportamento da viga composta. Os resultados mostraram que a deformabilidade da ligação tem pouca influência sobre o comportamento da viga composta. Apenas na viga com os nichos espaçados de $56 \mathrm{~cm}$ foi observado um pequeno acréscimo de $8 \%$ na deformação da viga no meio do vão. Portanto, uma estimativa, mesmo que pouco precisa, da curva de resistência da ligação não deve alterar de modo significativo os resultados obtidos para a viga composta.

Diante dos resultados da análise numérica, verificou-se a complexidade da interação entre o comportamento da ligação viga-laje e a resposta à flexão da viga composta. Por essa razão, não foram definidos critérios específicos para o projeto das vigas compostas com laje pré-moldada. Por outro lado, ficou claro que a ligação com chave de cisalhamento proporcionou um bom desempenho à viga composta, enquanto a ligação com superfície plana e lisa reduziu substancialmente a força última da viga composta. Ao que parece, o fator principal no dimensionamento da interface das vigas compostas é a resistência da ligação. A deformabilidade da ligação assume um papel secundário, sendo importante em outras análises como, por exemplo, nas deformações impostas pela variação de temperatura.

No final do capítulo foi mostrado um exemplo de dimensionamento da interface entre viga e laje pré-moldadas em uma estrutura típica de ponte rodoviária classe 45 . O objetivo foi mostrar uma aplicação prática das expressões deduzidas ao longo deste trabalho. Essa ponte foi originalmente dimensionada com longarinas pré-moldadas e laje moldada no local. No exemplo, a laje foi substituída por outra de concreto pré-moldado com as mesmas dimensões originais, e foram usados os esforços do projeto original. Os resultados mostraram que é possível empregar a solução com laje pré-moldada a partir da escolha adequada da ligação entre a viga e a laje pré-moldadas. No caso desse exemplo, foram empregadas ligações com chave de cisalhamento que permitiram, inclusive, a colaboração completa da laje na avaliação do estado limite último por solicitações normais. 


\section{Capítulo 7 - Considerações Finais e Conclusão}

\subsection{Considerações finais}

Neste trabalho, foi estudada a associação de viga pré-moldada de concreto com laje também pré-moldada de concreto. Nesse tipo de estrutura, a transferência de tensões de cisalhamento pela interface apresenta um papel importante, uma vez que a contribuição da laje na resistência da seção composta ao momento fletor depende do nível de resistência da interface. A ligação empregada entre a viga e a laje consistia de conectores metálicos associados com concreto moldado no local. Os conectores eram formados por vergalhões de aço dobrados em forma de laço e ancorados na viga pré-moldada. A região do conector que ficava externo à viga era inserida em nichos previamente executados na laje prémoldada, sendo a ligação realizada pelo preenchimento dos nichos com concreto de alto desempenho.

O objetivo deste trabalho foi caracterizar a ligação viga-laje pré-moldadas e analisar o comportamento à flexão das vigas compostas com laje pré-moldada, comparando-as com as vigas compostas com laje moldada no local. Para alcançar esse objetivo, foi empregada uma metodologia baseada em investigação experimental associada com análises numéricas e comparação com modelos mecânicos. Os resultados obtidos ao final do trabalho foram satisfatórios.

A investigação experimental da ligação foi realizada empregando ensaios de cisalhamento direto e ensaios em vigas compostas. O corpo-de-prova empregado nos ensaios de cisalhamento direto foi originalmente definido para estudar a resistência ao cisalhamento de ligações em vigas compostas com viga metálica e laje de concreto moldado no local. Posteriormente, ele também foi aplicado por outros autores para avaliar a resistência ao cisalhamento de ligações entre viga metálica e laje pré-moldada de concreto. No caso de ligações entre viga e laje pré-moldada de concreto, ele foi empregado por MALITE; TAKEYA (1996). No presente trabalho, esses corpos-de-prova tiveram suas 
dimensões modificadas e foram empregados para analisar vários tipos de ligações, tendo fornecido resultados satisfatórios. Por ser um ensaio relativamente simples, foi possível realizar um número razoável de ensaios, e a partir daí propor expressões para avaliar o comportamento das ligações com chave de cisalhamento. Novos ensaios ainda necessitam ser realizados para caracterizar outros tipos de ligação.

A partir dos ensaios de cisalhamento direto com carregamento cíclico não reversível foi possível avaliar a perda de rigidez da ligação com chave à medida em que o carregamento foi repetido. Essa análise é particularmente importante nas estruturas de pontes submetidas a milhões ciclos de carga e descarga ao longo de sua vida útil. Evidentemente, os resultados aqui obtidos não podem ser diretamente aplicados, uma vez que nessas estruturas as ligações estão submetidas ao fenômeno de fadiga. Entretanto, eles sugerem que as fibras podem melhorar o comportamento das ligações quando submetidas ao fenômeno de fadiga.

Os ensaios de vigas à flexão foram úteis para entender o comportamento das vigas compostas com laje pré-moldada. Os resultados mostraram que a resistência à flexão da viga composta está diretamente relacionada com a resistência ao cisalhamento da interface. O dimensionamento adequado da interface pode garantir que a viga composta com laje prémoldada se comporte como uma viga monolítica. De igual forma, ela também pode apresentar comportamento semelhante ao de vigas compostas com laje moldada no local, apresentando-se, assim, como uma alternativa viável ao sistema com laje moldada no local, principalmente nos casos onde se deseja uma redução no tempo de execução da obra.

A metodologia empregada no desenvolvimento do trabalho mostrou-se satisfatória. A análise numérica empregando programas comerciais baseados no método dos elementos finitos foi útil no sentido de ampliar as análises realizadas pela investigação experimental. Contudo, nem sempre a análise com o emprego de programas comerciais é capaz de representar com fidelidade as respostas experimentais. Essa ferramenta, extremamente útil, deve ser empregada com critério, observando suas limitações, principalmente quando forem empregados programas comerciais.

A comparação dos resultados experimentais com modelos mecânicos existentes na literatura serviu para verificar em que situações esses modelos podem representar o comportamento da ligação. Dessa forma, eles se mostram como uma alternativa eficiente na avaliação da resistência da ligação, o que é de fundamental importância para o dimensionamento da interface das vigas compostas. Os modelos existentes, porém, não representaram bem o deslizamento relativo da ligação. Dessa forma, buscou-se propor um 
modelo analítico que pudesse representar melhor a ligação com chave de cisalhamento e conector. Para tanto, foi realizado um estudo de traço que resultou em uma expressão para avaliação do comportamento à compressão do concreto simples e reforçado com fibras. $O$ comportamento da ligação foi admitido como definido pela deformação da chave de cisalhamento associada com a ação de pino do conector. Infelizmente, o modelo analítico proposto mostrou-se eficiente apenas na avaliação da resistência da ligação sem fibras. Além disso, não foi possível encontrar uma forma simples de acoplar a deformação do conector com a deformação da chave de cisalhamento. Novos estudos ainda necessitam ser realizados para melhor definir esse modelo, principalmente no que diz respeito à avaliação conjunta das deformações do concreto simples e do conector.

No final do capítulo seis foi mostrado um exemplo de dimensionamento da interface entre viga e laje pré-moldadas em uma estrutura típica de ponte rodoviária classe 45 . 0 objetivo foi mostrar uma aplicação prática das expressões deduzidas ao longo deste trabalho. Essa ponte foi originalmente dimensionada com longarinas pré-moldadas e laje moldada no local. No exemplo, a laje foi substituída por outra de concreto pré-moldado com as mesmas dimensões originais, e foram usados os esforços do projeto original. Os resultados mostraram que é possível empregar a solução com laje pré-moldada a partir da escolha adequada da ligação entre a viga e a laje pré-moldadas. O exemplo também permitiu ilustrar o processo de dimensionamento da interface de uma viga composta empregando as equações obtidas dos ensaios para avaliação da resistência da ligação com chave de cisalhamento (eq.(5.1b) e eq.(5.2b)). Além disso, foram mostradas as resistências de diversos tipos de ligação que podem ser empregadas na interface entre viga e laje prémoldadas. No caso desse exemplo, foram empregadas ligações com chave de cisalhamento que permitiram, inclusive, a colaboração completa da laje na avaliação do estado limite último por solicitações normais.

\subsection{Conclusões}

As principais conclusões obtidas deste trabalho são:

a) Com relação ao comportamento do concreto reforçado com fibras, verificou-se que a adição de até 2,0\% de fibras metálicas com fator de forma igual a 48 não alterou a resistência à compressão do concreto. Foi verificado um aumento de até $80 \%$ na resistência à tração na flexão do concreto devido à adição de $2,0 \%$ de fibras. Também foi verificado um aumento nos índices de tenacidade devido à adição de fibras. A energia de fratura do concreto simples, medida a partir de ensaios de flexão sob três pontos de 
carga, apresentou um valor muito próximo do recomendado pelo CEB-FIP MC90 (FIB (1999)). A adição de fibras ao concreto em um volume superior a 0,75\% aumentou de forma significativa a energia de fratura do material. Os corpos-de-prova com 2,0\% de fibras, por exemplo, apresentaram uma energia mais de cinqüenta vezes maior que a energia dos corpos-de-prova sem fibras. A partir dos ensaios de compressão axial com deformação controlada, foi possível verificar a influência das fibras na ductilidade do material empregando o conceito de tenacidade relativa. Novamente, foi verificado um aumento na energia devido à adição das fibras. Desses ensaios também foi proposta uma expressão para o traçado da curva tensão-deformação do concreto comprimido, que se mostrou coerente com os resultados experimentais.

b) Quando comparadas às fibras de maiores fatores de forma, as fibras empregadas neste trabalho mostraram-se menos eficientes. Os resultados obtidos indicam, contudo, que o emprego de um volume de fibras maior que o usual é capaz de melhorar o comportamento do concreto de alta resistência de forma satisfatória.

c) A partir dos resultados dos ensaios de cisalhamento direto, verificou-se que a confecção da chave de cisalhamento na ligação aumentou em $250 \%$ a resistência da ligação, quando comparada a uma ligação com superfície plana e lisa. A garantia de rugosidade na superfície de contato aumentou em 165\% a resistência da ligação, também comparada com a superfície lisa. Esses valores foram obtidos dos ensaios com conector de $10 \mathrm{~mm}$ e com um concreto moldado no nicho de resistência igual a $50 \mathrm{MPa}$.

d) A resistência da ligação com chave de cisalhamento foi influenciada pela resistência do concreto moldado no nicho, pelo diâmetro do conector e pela adição de fibras ao concreto da ligação. $O$ aumento da resistência à compressão do concreto moldado no nicho de $50 \mathrm{MPa}$ para $100 \mathrm{MPa}$ aumentou a resistência da ligação em 35\%, em média. Verificou-se, porém, que quando a resistência à tração do concreto da ligação era muito superior à resistência à tração da peça pré-moldada, a ruína da ligação ocorria pela ruptura do concreto pré-moldado. Foi observado, também, um aumento de $62 \%$ na resistência da ligação quando o diâmetro do conector passou de $8 \mathrm{~mm}$ para $12,5 \mathrm{~mm}$. A adição de fibras ao concreto moldado nos nichos proporcionou um aumento de até $37 \%$ na resistência da ligação, porém sua maior contribuição foi no aumento da energia absorvida até a ruptura da ligação, devido ao aumento do deslizamento relativo da ligação antes da ruptura.

e) Dos ensaios de cisalhamento direto sob carregamento cíclico não reversível observou-se que as ligações sem fibras apresentaram uma perda de rigidez, ao final de vinte ciclos, 
de $25 \%$. A adição de fibras ao concreto moldado no nicho reduziu essa perda para $15 \%$. Esses resultados foram obtidos para um nível de solicitação correspondente a $40 \%$ da resistência da ligação. Em níveis mais altos de solicitação, também foi observada uma menor perda de rigidez da ligação devido à adição de fibras.

f) A ligação com superfície plana e rugosa foi avaliada pelo modelo analítico de TASSIOS; VINTZELEOU (1990), modificado pela proposição de um novo limite para o deslizamento relativo da interface. Os resultados mostraram-se coerentes com os obtidos experimentalmente, o que indica que esse modelo pode ser capaz de avaliar o comportamento desse tipo de ligação. Novos ensaios, porém, necessitam serem realizados para confirmar essa afirmação.

g) A simulação numérica dos corpos-de-prova com chave de cisalhamento, realizada no programa ANSYS, não representou de modo adequado o comportamento observado nos ensaios, apesar da força última numérica estar, em média, próxima da resistência da ligação medida nos ensaios. A maior discrepância entre os resultados foi verificada na avaliação do deslizamento último da ligação. A pouca representatividade do deslizamento da ligação pode ser devido ao modelo constitutivo empregado na representação do concreto. Nesse modelo, não foi possível a inclusão da energia de fratura como um parâmetro do material, de modo que a resposta ficou dependente da malha empregada. O emprego de uma malha mais refinada aumentou os deslizamentos relativos na ligação, porém a máxima força de convergência foi reduzida. Por outro lado, nos corpos-de-prova com superfície plana, lisa ou rugosa, a simulação numérica mostrou-se adequada na representação do comportamento da ligação.

h) Os resultados dos ensaios de cisalhamento direto com chave de cisalhamento foram empregados na determinação de uma expressão analítica para a representação da curva tensão-deslizamento da ligação com chave (eq.(5.1), eq.(5.2), eq.(5.3), eq.(5.4), eq.(5.5), eq.(5.8) e eq.(5.9)). A razão entre a resistência obtida por essa expressão e o valor experimental nos corpos-de-prova sem adição de fibras à ligação apresentou um valor médio de 0,999 com desvio padrão de 0,040. No caso dos ensaios com adição de fibras à ligação, essa mesma razão apresentou valor médio de 1,004 com desvio padrão de 0,052. A curva tensão-deslizamento da ligação prevista pela expressão analítica mostrou-se coerente com os resultados experimentais em todas as comparações.

i) A ligação com chave de cisalhamento foi analisada empregando os modelos mecânicos de KANEKO (1992) e HSU et al. (1987). Os resultados mostraram que a resistência da 
ligação pode ser avaliada, com boa precisão, por esses modelos, porém os deslizamentos foram sempre inferiores aos obtidos experimentalmente.

j) O modelo de KANEKO (1992) foi modificado incorporando o conector às equações de equilíbrio e de compatibilidade. Analisando os resultados obtidos, observou-se que os valores de resistência da ligação com fibras avaliados pelo modelo modificado aproximaram-se mais dos valores obtidos experimentalmente que os obtidos pelo modelo original. Os deslizamentos, contudo, foram bastante inferiores aos valores experimentais.

k) A partir dos resultados dos ensaios das vigas compostas, verificou-se uma diminuição da capacidade resistente da viga composta com o aumento do espaçamento dos nichos. Quando os nichos foram espaçados de $28 \mathrm{~cm}$ ( $\beta=48 \%$ ) a capacidade resistente da viga composta foi apenas $2 \%$ inferior à observada na viga monolítica. Por outro lado, quando o espaçamento dos nichos foi aumentado para $42 \mathrm{~cm}(\beta=31 \%)$, a capacidade resistente da viga composta foi $26 \%$ inferior à observada na viga monolítica. De modo semelhante, quando o espaçamento dos nichos foi aumentado para $56 \mathrm{~cm}(\beta=22 \%)$, a capacidade resistente da viga composta foi $34 \%$ inferior à observada na viga monolítica. Com relação à rigidez na flexão, observou-se que na viga com nichos espaçados de $28 \mathrm{~cm}$, a deformação era a mesma da viga monolítica. O aumento no espaçamento dos nichos, entretanto, reduziu a rigidez da viga composta. Por exemplo, quando o espaçamento dos nichos foi aumentado para $56 \mathrm{~cm}$ houve uma redução de até $18 \%$ no valor da rigidez secante. Esses resultados mostram que a viga com os nichos espaçados de $28 \mathrm{~cm}$ apresentou um comportamento muito próximo ao da viga monolítica de mesmas dimensões.

I) Comparando as vigas com laje pré-moldada com as vigas com laje moldada no local ensaiadas por ARAUJO (1997), observou-se que a solução com laje pré-moldada e nichos espaçados de $28 \mathrm{~cm}$ garantiu à viga composta a mesma resistência alcançada pela solução com concreto moldado no local. O panorama de fissuração dessas vigas, entretanto, foi bem diferente. Foram observadas concentrações de tensões na viga prémoldada junto à ligação na viga composta com laje pré-moldada que devem ser considerados no projeto. Além disso, foi observado que alguns limites propostos para as vigas com laje moldada no local não se aplicam às vigas com laje pré-moldada, como, por exemplo, a definição da ruptura da viga composta quando o deslizamento da interface atingir o limite máximo de $0,5 \mathrm{~mm}$. 
m)Do ensaio da viga composta submetida a carregamento cíclico não reversível, foi observada uma perda de rigidez da viga com a repetição do carregamento. Essa perda foi tanto maior quanto maior foi o nível do carregamento aplicado. Em primeira aproximação, pode-se afirmar que para um nível de carregamento igual a $30 \%$ da resistência da viga, após vinte ciclos de carregamento ocorre uma redução de cerca de $6 \%$ na rigidez da viga composta. Essa perda sobe para $8 \%$ e $10 \%$ quando o nível de carregamento é elevado para $50 \%$ e $75 \%$ da resistência da viga composta, respectivamente. Não foi observada redução na força máxima resistida pela viga devido ao carregamento cíclico.

n) Os resultados obtidos da análise numérica das vigas compostas empregando o programa ANSYS mostraram uma redução da força última das vigas à medida que a ligação entre a viga e a laje foi substituída por outras menos resistentes. Na viga com os nichos espaçados de $28 \mathrm{~cm}$, devido à redistribuição de esforços entre as ligações na interface, foi observada uma redução significativa na força última apenas quando foi empregada a ligação plana e lisa (redução de $33 \%$ em relação à força última da viga monolítica). Nas vigas com os nichos espaçados de $42 \mathrm{~cm}$ e $56 \mathrm{~cm}$, a capacidade resistente da viga foi definida pela resistência ao cisalhamento da ligação. A redução observada na força última da viga composta com os nichos espaçados de $42 \mathrm{~cm}$, quando a ligação com chave de cisalhamento e fibras foi substituída pelas ligações com chave de cisalhamento sem fibra, rugosa e lisa, foi de $13 \%, 22 \%$ e $38 \%$, respectivamente. Na viga com os nichos espaçados de $56 \mathrm{~cm}$, a redução da força última foi semelhante. Esses níveis de redução, porém, foram inferiores aos níveis de redução da resistência ao cisalhamento da ligação. Isso sugere que outros fatores influenciaram no comportamento à flexão das vigas compostas com baixa quantidade de conectores na ligação.

o) Com relação à rigidez da viga composta, a alteração da ligação na interface entre a viga e a laje pré-moldadas não apresentou grande influência sobre os resultados. Apenas quando foi adotada a ligação plana e lisa houve uma sensível redução na rigidez da viga composta. Essa redução ocorreu, contudo, apenas após a ruptura da ligação.

p) A partir dos resultados da simulação numérica, também foi analisada a influência do espaçamento dos nichos sobre o comportamento da viga composta. Observou-se que a redução da força última da viga composta com o aumento no espaçamento dos nichos foi aproximadamente linear, apresentando uma perda média de $41 \%$ quando 0 espaçamento passou de $28 \mathrm{~cm}$ para $56 \mathrm{~cm}$. Essa perda foi mais acentuada na viga com a ligação plana e rugosa (47\%) e menos acentuada na viga com a ligação com chave de 
cisalhamento e fibras (34\%). Com relação à rigidez da viga composta, foi observada uma nítida redução em seu valor na medida em que se aumentou o espaçamento dos nichos.

q) Verificou-se, ainda, a partir da simulação numérica que a deformabilidade da ligação entre a viga e a laje teve pouca influência sobre o comportamento da viga composta. Apenas na viga com os nichos espaçados de $56 \mathrm{~cm}$ foi observado um pequeno acréscimo de $8 \%$ na deformação da viga no meio do vão. Portanto, uma estimativa, mesmo que pouco precisa, da curva de resistência da ligação não deve alterar de modo significativo os resultados obtidos para a viga composta.

\subsection{Sugestões para trabalhos futuros}

Obviamente, um único trabalho não é capaz de esgotar qualquer assunto no campo da ciência, constituindo-se, antes de tudo, em pequenas contribuições para o conhecimento humano. Dentro desse espírito, o presente trabalho fornece indicações sobre o comportamento e aplicação da ligação viga-laje e abre novos campos de estudo, uma vez que além de certezas ele também gera indagações que ainda necessitam ser respondidas. Ficam aqui, portanto, registradas algumas sugestões para trabalhos futuros no sentido de ampliar o conhecimento da ligação entre viga e laje pré-moldadas:

- Realização de novos ensaios de cisalhamento direto para quantificar a resistência ao cisalhamento das ligações planas com superfície rugosa. Isto torna-se necessário uma vez que neste trabalho foram realizados poucos ensaios com este tipo de ligação, tendo sido mostrado apenas indicações sobre o seu comportamento. Acredita-se que devido ao seu grande potencial de aplicação, essa ligação merece modelos específicos para avaliação de seu comportamento.

- Realização de novos ensaios de cisalhamento direto sob carregamento monotônico para: (i) verificar a relação entre as dimensões do nicho e a resistência da ligação; (ii) quantificar a influência do volume de fibras na resistência da ligação, uma vez que devido ao número reduzido de ensaios realizados não foi possível incluir o volume de fibras na equação empírica de avaliação da resistência da ligação; (ii) quantificar a influência de outras fibras metálicas sobre a resistência da ligação. Isto torna-se necessário uma vez que os ganhos de resistência proporcionados pelas fibras empregadas neste trabalho foram inferiores aos observados em outros trabalhos. Talvez a relação entre o comprimento da fibra e a largura da chave de cisalhamento influencie a resistência final da ligação. Neste trabalho, tanto as fibras quanto a chave possuíam a 
mesma dimensão $(30 \mathrm{~mm})$. Provavelmente, se forem empregadas fibras mais curtas e com fator de forma maior que 48, haverá uma melhor "costura" das fissuras na base da chave, o que resultará em maiores ganhos de resistência para a ligação.

- Realização de ensaios de cisalhamento direto com carregamento cíclico reversível para caracterizar o comportamento da ligação nas regiões dos tabuleiros de pontes onde há inversão no sinal do carregamento.

- Avaliação da resistência à fadiga da ligação entre viga e laje pré-moldadas. Esses ensaios podem ser realizados em corpos-de-prova de cisalhamento direto ou em vigas compostas.

- Verificação do comportamento da ligação entre viga e laje pré-moldadas ao longo do tempo devido às diferentes características entre o concreto pré-moldado e o concreto moldado no nicho.

- Realização de simulações numéricas para avaliação do comportamento da ligação com chave de cisalhamento submetida a carregamentos cíclicos. Existem algumas teorias baseadas na mecânica do dano que podem ser aplicadas com sucesso na avaliação da rigidez e da resistência da ligação após um grande número de ciclos (Driemeier (1995), LA BORDERIE (1991)). Algumas dessas teorias, contudo, ainda necessitam de ferramentas para possibilitar sua aplicação à ligação entre viga e laje pré-moldadas. 


\section{Referências Bibliográficas}

ABDUL-WAHAB, H.M.S. (1992). Strength of vertical joints with steel fiber reinforced concrete in large panel structures. ACI Structural Journal, v.89, n.4, p.367-374, JulyAugust.

ABDUL-WAHAB, H.M.S. (1989). Strength of reinforced concrete corbels with fibers. $\mathrm{ACl}$ Structural Journal, v.86, n.1, p.60-66, January-February.

ABDUL-WAHAB, H.M.S. (1986). An experimental investigation of vertical castellated joints between large concrete panels. Structural Engineer, v.64B, n.4, p.93-99, December.

ACI Committee 363 (1994). State-of-the-art Report on High-strength Concrete (ACI 363R92). ACI Manual of Concrete Practice, part 1, materials and general properties of concrete. American Concrete Institute, Detroit.

ALI, M.A.; WHITE, R.N. (1999). Enhanced Contact Model for Shear Friction of Normal and High-Strength Concrete. ACI Structural Journal, v.96, n.3, p.348-360, May-June.

ALLOS, A.E. (1989). Shear transfer in fibre reinforced concrete. In: SWAMY, R.N.; BARR, B.. Fibre reinforced cements and concretes: Recent developments. Elsevier Applied Science. p.146-156.

ALMEIDA, L.R. (1982). Parabolóides elípticos - monolíticos e pré-moldados - sobre base retangular. São Carlos. Dissertação (Mestrado). Escola de Engenharia de São Carlos, Universidade de São Paulo.

AL-TAAN, S.A. ; EZZADEEN, N.A. (1995). Flexural analysis of reinforced fibrous concrete members using the finite element method. Computers \& Structures, v.56, n. 6, p.10651072.

AMERICAN CONCRETE INSTITUTE - ACI (1989). Building code requirements for reinforced concrete (ACl 318M-89). Detroit, American Concrete Institute.

AMERICAN SOCIETY FOR TESTING AND MATERIALS - ASTM (1992). Standard Test Method for Flexural Toughness and First-Crack Strength of Fiber-Reinforced Concrete (Using Beam With Third-Point Loading). (ASTM C 1018 -92).

ANNAMALAI, G.; BROWN JR., R.C. (1990). Shear-transfer behavior of post-tensioned grouted shear-key connections in precast concrete-framed structures. ACI Structural Journal, v.87, n.1, p.53-59, January-February.

ANSYS RELEASE 5.5.1 (1998). Basic Analysis Procedures Guide. $3^{\text {rd }}$ Edition. SAS IP, Inc. ${ }^{\odot}$ 
ARAUJO, D.L. (1997). Cisalhamento na interface entre concreto pré-moldado e concreto moldado no local em elementos submetidos à flexão. São Carlos. Dissertação (Mestrado). Escola de Engenharia de São Carlos, Universidade de São Paulo.

ARAUJO, D.L.; EL DEBS, M.K. (2000). Avaliação do comportamento à flexão de viga prémoldada de concreto associada com laje moldada no local pelo método dos elementos finitos. In: JORNADAS SUL-AMERICANAS DE ENGENHARIA ESTRUTURAL, 29, Uruguai. Montevideo : Instituto de Estructuras y Transporte/ Faculdad de Ingeniería, Universidad de la República/ASAIE, 2000. [CD-ROM]

ASHOUR, S.A. ; HASANAIN, G.S. ; WAFA, F.F. (1992). Shear behavior of high-strength fiber reinforced concrete beams. ACl Structural Journal, v.89, n.2, p.176-184, MarchApril.

ASSOCIAÇÃO BRASILEIRA DE NORMAS TÉCNICAS (1984). NBR-7188 - Carga móvel em ponte rodoviária e passarela de pedestre). Rio de Janeiro.

ASSOCIAÇÃO BRASILEIRA DE NORMAS TÉCNICAS - ABNT (1985). NBR 9062 - Projeto e execução de estruturas de concreto pré-moldado. Rio de Janeiro.

ASSOCIAÇÃO BRASILEIRA DE NORMAS TÉCNICAS (1986). NBR-7187 - Projeto e execução de pontes de concreto armado e protendido. Rio de Janeiro.

ASSOCIAÇÃO BRASILEIRA DE NORMAS TÉCNICAS (1987). NBR-7197 - Projeto de estruturas de concreto protendido. Rio de Janeiro.

ASSOCIAÇÃO BRASILEIRA DE NORMAS TÉCNICAS - ABNT (1991). NBR-5733 - Cimento Portland de alta resistência inicial. Rio de Janeiro.

BAKHOUM, M.M. (1991). Shear behavior and design of joints in precast concrete segmental bridges. PhD thesis, Massachusetts Institute of Technology, Cambridge, Mass.

BALAGURU, P.N.; SHAH, S.P. (1992). Fiber reinforced cement composites. McGraw-Hill International Editions, New York.

BARROS, J.A.O.; FIGUEIRAS, J.A. (1999). Flexural Behavior of SFRC: Testing and Modeling. Journal of Materials in Civil Engineering, v.11, n.4, p.331-339, November.

BARROS, J.A.O. (1995). Comportamento do Betão Reforçado com Fibras: Análise Experimental e Simulação Numérica. Porto, Portugal. Dissertação de Doutoramento em Engenharia Civil. Faculdade de Engenharia, Universidade do Porto.

BASS, R.A.; CARRASQUILLO, R.L.; JIRSA, J.O. (1989). Shear transfer across new and existing concrete interfaces. ACl Structural Journal, v.86, n.4, p.383-393, July-August.

BENTUR, A.; MINDESS, S. (1990). Fibre reinforced cementitious composites. Elsevier Applied Science, London.

BIRKELAND, P.W.; BIRKELAND, H.W. (1966). Connections in precast concrete construction. Journal of American Concrete Institute, Proceedings, v.63, n.3, p.345-367, March.

BRITISH STANDARDS INSTITUTION - BSI (1979). Steel, concrete and composite bridges. Part 5: code of practice for design of composite bridges. (BS 5400: Part 5: 1979). 
CARREIRA, D.J.; CHU, K. (1985). Stress-strain relationship for plain concrete in compression. Journal of the American Concrete Institute, Proceedings, v.82, n.6, p.797-804, November-December.

CASTRO, L.A. (1997). Análise da segurança no projeto de estruturas: método dos estados limites. São Carlos. Dissertação (Mestrado) - Escola de Engenharia de São Carlos Universidade de São Paulo.

CATELLI JR., C.A. (2000). Determinação de propriedades mecânicas de concreto com fibras de aço. São Carlos. Relatório Técnico (Iniciação Científica). Escola de Engenharia de São Carlos, Universidade de São Paulo.

COMITE EURO-INTERNATIONAL DU BETON (1991). CEB-FIP model code 1990. Bulletin d'information, n.203-205.

CHAKRABARTI, S.C.; NAYAK, G.C.; PAUL, D.K. (1988). Shear characteristics of cast-inplace vertical joints in story-high precast wall assembly. ACI Structural Journal, v.85, n.1, p.30-45, January-February.

CHO, S. ; LEE, L. (2000). Rotating and Fixed Angle Crack Models in Beams Without Transverse Reinforcement. ACl Structural Journal, v.97, n.5, p.757-764, SeptemberOctober.

DAVIES, G.; ELLIOTT, K.S.; OMAR, W. (1990). Horizontal diaphragm action in precast concrete floors. The Structural Engineer, v.68, n.2, p.25-33, 23 January.

DE BORST, R. (1989). Analysis of spurious kinematic modes in finite element analysis of strain-softening concrete. IN: Cracking and Damage: Strain localization and Size Effect, eds. J. Mazars, Z.P. Bazant, Elsevier Applied Science, London and New York, p.335-345.

DEI POLI, S.; DI PRISCO, M.; GAMBAROVA, P.G. (1992). Shear response, deformations, and subgrade stiffness of a dowel bar embedded in concrete. ACI Structural Journal, v.89, n.6, p.665-675, November-December.

DRIEMEIER, L. (1995). Considerações sobre a fadiga em metais e o comportamento do concreto sob solicitação cíclica. São Carlos. Dissertação (Mestrado). Escola de Engenharia de São Carlos, Universidade de São Paulo.

EL DEBS, M.K. (2000). Concreto pré-moldado: fundamentos e aplicações. São Carlos: Escola de Engenharia de São Carlos, Universidade de São Paulo.

ELMORSI, M. ; KIANOUSH, M.R. ; TSO, W.K. (1998). Nonlinear analysis of cyclically loaded reinforced concrete structures. ACl Structural Journal , v.95, n.6, p.725-739, November-December.

EZELDIN, A.S.; BALAGURU, P.N. (1992). Normal and High-Strength Fiber-Reinforced Concrete under Compression. Journal of Materials in Civil Engineering, v.4, n.4, p.415429, November.

FANG, I.K. ; WU, J.Y. (1994). Shear behavior of fiber-reinforced HPC deep beams. In: HIGH-PERFORMANCE CONCRETE, Proceedings, p.523-543, ACI International Conference. Singapore. 
FATTUHI, N.I. (1987). SFRC corbel tests. ACl Structural Journal, v.84, n.2, p.119-123, March-April.

FAUCHART, J.; CORTINI, P. (1972). Étude expérimentale de joints horizontaux entre panneaux préfabriqués pour murs de batiments. Annales de L'Institut Technique du Batiment et des Travaux Publics, n.300, p.86-103, Decembre.

FÉDÉRATION INTERNATIONALE DE BÉTON - FIB (1999). Structural concrete textbook on behavior, design and performance. Updated knowledge of the CEB/FIP Model Code 1990, v.1. International Federation for Structural Concrete (FIB), Switzerland.

FÉDÉRATION INTERNATIONALE DE LA PRÉCONTRAINTE - FIP (1999). Practical design of structural concrete. SETO, London.

FEDERATION INTERNATIONALE DE LA PRECONTRAINTE - FIP (1982). Shear at the interface of precast and in situ concrete: guide to good practice.

FENWICK, R.C.; PAULAY, T. (1968). Mechanisms of shear resistance of concrete beams. Journal of the Structural Division, Proceedings, v.94, n.ST10, p.2325-2350, October.

FOERSTER, H.R.; RIZKALLA, S.H.; HEUVEL, J.S. (1989). Behavior and design of shear connections for loadbearing wall panels. PCI Journal, v.34, n.1, p.102-119, JanuaryFebruary.

FROSCH, R.J. (1999). Panel Connections for Precast Concrete Infill Walls. ACI Structural Journal, v.96, n.4, July-August.

FURLAN JR.,S. (1995). Vigas de concreto com taxas reduzidas de armadura de cisalhamento: influência do emprego de fibras curtas e de protensão. São Carlos. Tese (Doutorado) - Escola de Engenharia de São Carlos - Universidade de São Paulo.

GUPTA, A. ; RANGAN, B.V. (1998). High-strength concrete (HSC) structural walls. ACl Structural Journal, v.95, n.2, p.194-204, March-April.

HARAJLI, M.H. ; SALLOUKH, K.A. (1997). Effect of fibers on developments / splice strength of reinforcing bars in tension. ACI Materials Journal, v.94, n.4, p.317-324, July-August.

HILLERBORG, A. (1985). The theoretical basis of a method to determine the fracture energy $\mathrm{G}_{\mathrm{f}}$ of concrete. Matériaux et Constructions, v.18, n.106, p.291-296.

HOFBECK, J.A.; IBRAHIM, I.O.; MATTOCK, A.H. (1969). Shear transfer in reinforced concrete. Journal of the American Concrete Institute, Proceedings, v.66, n.2, p.119128, February.

HSU; L.S.; HSU, C.T.T. (1994). Stress-Strain Behavior of Steel-Fiber High-Strength Concrete under Compression. ACl Structural Journal, v.91, n.4. p.448-457, JulyAugust.

HSU, T.T.C.; MAU, S.T.; CHEN, B. (1987). Theory of shear transfer strength of reinforced concrete. ACI Structural Journal, v.84, n.2, p.149-160, March-April.

HWANG, S. J.; YU, H. W.; LEE, H. J. (2000). Theory of Interface Shear Capacity of Reinforced Concrete. Journal of Structural Engineering, v.126, n. 6, p.700-707, June. 
IMAM, M. ; VANDEWALLE, L. ; MORTELMANS, F. (1995). Shear-moment analysis of reinforced high strength concrete beams containing steel fibres. Canadian Journal of Civil Engineering, v.22, n.3, p.462-470, June.

IMAM, M. ; VANDEWALLE, L. ; MORTELMANS, F. (1994). Shear capacity of steel fiber high-strength concrete beams. In: HIGH-PERFORMANCE CONCRETE, Proceedings, p.227-241, ACI International Conference. Singapore.

ISSA, M.A.; YOUSIF, A.A.; ISSA, M.A. (2000). Experimental Behavior of Full-Depth Precast Concrete Panels for Bridge Rehabilitation. ACI Structural Journal, v.97, n.3, May-June.

ISSA, M.A. ; YOUSIF, A.A. ; ISSA, M.A. ; KASPAR, I.I. ; KHAYYAT, S.Y. (1998). Analysis of full depth precast concrete bridge deck panels. PCI Journal, v.43, n.1, p.74-85, January-February.

JELIC, I. ; PAVLOVIC, M.N. ; KOTSOVOS, M.D. (1999). A study of dowel action in reinforced concrete beams. Magazine of Concrete Research, v.51, n.2, p.131-141, April.

JIMENEZ, R.; WHITE, R.N.; GERGELY, P. (1982). Cyclic shear and dowel action models in R/C. Journal of the Structural Division, Proceedings, v.108, n.ST5, p.1106-1123, May.

JIURI, T. ; CHAOBIN, H. ; KAIJIAN, Y. ; YONGCHENG, Y. (1992). Seismic behavior and shear strength of framed joint using steel-fiber reinforced concrete. Journal of Structural Engineering, v.118, n.2, p.341-358, February.

JONSSON, E. (1996). Design on the basis of testes. Betonwerk und Fertigteil-Technik, v.62, n.1, p.162-174, January.

KANEKO, Y. ; MIHASHI, H. (1999). Analytical study on the cracking transition of concrete shear key. Materials and Structures / Matériaux et Constructions, v.32, p.196-202, April.

KANEKO, Y.; CONNOR, J.J.; TRIANTAFILLOU, T.C.; LEUNG, C.K. (1993 ${ }^{\mathrm{a}}$. Fracture mechanics approach for failure of concrete shear key I: theory. Journal of Engineering Mechanics, v.119, n.4, p.681-700, April.

KANEKO, Y.; CONNOR, J.J.; TRIANTAFILLOU, T.C.; LEUNG, C.K. (1993 ${ }^{\mathrm{b}}$ ). Fracture mechanics approach for failure of concrete shear key II: verification. Journal of Engineering Mechanics, v.119, n.4, p.701-719, April.

KANEKO, Y. (1992). Modeling of shear-off failure of concrete: Fracture mechanics approach. PhD thesis, Massachusetts Institute of Technology, Cambridge, Mass.

KARIHALOO, B. (1995). Fracture mechanics and structural concrete. Concrete design and construction series, Longman, Edinburgh, England.

KHALOO, A.R.; KIM, N. (1997). Influence of concrete and fiber characteristics on behavior of steel fiber reinforced concrete under direct shear. ACI Materials Journal, v.94, n.6, p.592-601, November-December.

LA BORDERIE, C. (1991). Phenomenes unilateraux dans un materiau endommageable: modelisation et application a l'analyse de structures en beton. These de Doctorat de l'universite Paris 6. E.N.S. de Cachan/ C.N.R.S./ Université Paris 6, Paris, France. 
LACOMBE, G.; POMMERET, M. (1974). Les joints structuraux dans les constructions en grands panneaux prefabriques. Annales de L'Institut Technique du Batiment et des Travaux Publics, n.314, p.114-144, Fevrier.

LAM, D.; ELLIOTT, K.S.; NETHERCOT, D.A. (2000)ㄹ. Designing composite steel beams with precast concrete hollow-core slabs. Proceedings of the Institutional Engineering Structures \& Buildings, n.140, p.139-149, May.

LAM, D.; ELLIOTT, K.S.; NETHERCOT, D.A. (2000) $)^{b}$ Experiments on composite steel beams with precast concrete hollow core floor slabs. Proceedings of the Institutional Engineering Structures \& Buildings, n.140, p.127-138, May.

LAM, D.; ELLIOTT, K.S.; NETHERCOT, D.A. (2000) ${ }^{c}$. Parametric study on composite steel beams with precast concrete hollow core floor slabs. Journal of Constructional Steel Research, n.54, p.283-304.

LAM, D. ; ELLIOT, K.S. ; NETHERCOT, D.A. (1998). Push-off tests on shear studs with hollow-cored floor slabs. The Structural Engineer, v.76, n.9, p.167-174, 5 May 1998.

LI, V.C. ; WARD, R. ; HAMZA, A.M. (1992). Steel and synthetic fibers as shear reinforcement. ACI Materials Journal, v.89, n.5, p.499-508, September-October.

MALITE, M.; TAKEYA, T. ; SANTOS NETTO, P. (1997). Ensaios em conectores de cisalhamento viga-laje para tabuleiro de pontes. In: Reunião do IBRACON: Reunião Comemorativa de 25 anos do IBRACON, 39, v. 1, p. 181-196. São Paulo : IBRACON.

MALITE, M.; TAKEYA, T. (1996). Ensaios em conectores de cisalhamento viga-laje para tabuleiro de pontes (construtora MARNA Ltda). São Carlos, Departamento de Engenharia de Estruturas. EESC-USP. (Relatório técnico)

MALITE, M. (1993). Análise do comportamento estrutural de vigas mistas aço-concreto constituídas por perfis de chapa dobrada. São Carlos. Tese (Doutorado). Escola de Engenharia de São Carlos, Universidade de São Paulo.

MANGAT, P.S.; HALABI, W. (1996). Steel-fibre-reinforced high strength concrete corbels: test results and analysis. The Structural Engineer, v.74, n.23-24, p.412-422, 10 December.

MANSUR, M.A. ;CHIN, M.S ; WEE, T.H. (1999). Stress-Strain Relationship of High-Strength Fiber Concrete in Compression. Journal of Materials in Civil Engineering, v.11, n.1, p.21-29, February.

MANSUR, M.A. ; WEE, T.H. ; CHIN, M.S. (1995). Derivation of the complete stress-strain curves for concrete in compression. Magazine of Concrete Research, v.47, n.173, p.285-290, December.

MANSUR, M.A.; ONG, K.C.G. (1991). Behavior of Reinforced Fiber Concrete Deep Beams in Shear. ACl Structural Journal, v.88, n.1, p.98-105, January-February.

MARTÍN-PÉREZ, B. (1995). A study of the mechanical response of reinforced concrete to cyclic shear reversals. Master thesis, Department of Civil Engineering, University of Toronto. 
MARTÍN-PÉREZ; PANTAZOPOULOU (2001). Effect of bond, aggregate interlock and dowel action on the shear strength degradation of reinforced concrete. Engineering Structures, v.23, p.214-227.

MAST, R.F. (1968). Auxiliary reinforcement in concrete connections. Journal of the Structural Division, ASCE, v.94, n.ST6, p.1485-1504, June.

MATTOCK, A.H. (2001). Shear Friction and High-Strength Concrete. ACl Structural Journal, v.98, n.1, p.50-59, January- February.

MATTOCK, A.H. (1994). Comments of "Horizontal shear strength of composite concrete beams with a rough interface". PCI Journal, v.39, n.5, p.106-108, September-October. /paper by R.E. Loov. A.K. Patnaik, PCl Journal, v.39, n.1, p.48-69, January-February.

MATTOCK, A.H. (1988). Comments of "Influence of concrete strength and load history on the shear friction capacity of concrete members". PCI Journal, v.33, n.1, p.166-168, January-February. /paper by J. Walraven, et al., PCl Journal, v.32, n.1, p.66-84, January-February.

MATTOCK, A.H. (1981). Cyclic shear transfer and type of interface. Journal of the Structural Division, proceedings of ASCE, v.107, n.ST10, p.1945-1964, October.

MILLARD, S.G.; JOHNSON, R.P. (1984). Shear transfer across cracks in reinforced concrete due to aggregate interlock and to dowel action. Magazine of Concrete Research, v.36, n.126, p.9-21, March.

NAAMAN, A.E.; BACCOUCHE, M.R. (1995). Shear response of dowel reinforced SIFCON. ACI Structural Journal, v.92, n.5, p.587-596, September-October.

NATARAJA, M.C.; DHANG, N.; GUPTA, A.P. (1999). Stress-strain curves for steel-fiber reinforced concrete under compression. Cement \& Concrete Composites, v.21, p.383390.

OEHLERS, D.J.; SVED, G. (1995). Composite Beams with Limited-Slip-Capacity Shear Connectors. Journal of Structural Engineering, v.121, n.6, p.932-938, June.

PARAMASIVAM, P. ; TAN, K.H. ; MURUGAPPAN, K. (1995). Finite element analysis of partially prestressed steel fiber concrete beams in shear. Advanced Cement Based Materials, v.2, n.6, p.231-239, November.

PATNAIK, A.K. (2001). Behavior of Composite Concrete Beams with Smooth Interface. Journal of Structural Engineering, v.127, n.4, p.359-366, April.

PATNAIK, A.K.. (1992). Horizontal shear strength of composite concrete beams with a rough interface. Ph.D. Thesis, University of Calgary, Calgary, Canada.

PROENÇA, S.P.B. (1988). Sobre modelos matemáticos do comportamento não-linear do concreto: análise crítica e contribuições. São Carlos. Tese (Doutorado). Escola de Engenharia de São Carlos, Universidade de São Paulo.

PRUIJSSERS, A.F. (1988). Theoretical and experimental analysis of the behavior of cracked concrete under monotonic and cyclic shear loading. Heron, v.33, n.4, 72p.

RILEM TC 148-SSC: STRAIN SOFTENING OF CONCRETE - TEST METHODS FOR COMPRESSIVE SOFTENING (2000). Test method for measurement of the strain- 
softening behavior of concrete under uniaxial compression. Materials and Structures, v.33, p.347-351, July.

RILEM (1985). Draft Recommendation, 50-FMC Committee Fracture Mechanics of Concrete. Determination of the fracture energy of mortar and concrete by means of three-point bend tests on notched beams. Matériaux et Constructions, v.18, n.106, p.285-290.

RULE, W.K. ; ROWLANDS, R.E. (1992). Predicting behavior of cyclically loaded RC structures. Journal of Structural Engineering, v.118, n.2, p.603-616, February.

SERACINO,R.; OEHLERS, D.J.; YEO, M.F. (2001). Partial-interaction flexural stresses in composite steel and concrete bridge beams. Engineering Structures, v.23, p.11861193.

SERRETTE, R.L.; RIZKALLA, S.H.; ATTIOGBE, E.K.; HEUVEL, J.S. (1989). Multiple shear key connections for precast shear wall panels. PCI Journal, v.34, n.2, p.104-120, March-April.

SHAH, S.P. ; SWARTZ, S.E. ; OUYANG, C. (1995). Fracture mechanics of concrete: applications of fracture mechanics to concrete, rock and other quasi-brittle materials. JOHN WILEY \& SONS, INC., United States of America.

SHIM, C.S.; LEE, P.G.; CHANG, S.P. (2001). Design of shear connection in composite steel and concrete bridges with precast decks. Journal of Constructional Steel Research, v.57, p.203-219.

SIMÕES, L.C. (1998). Um modelo constitutivo para concreto com fibras. Rio de Janeiro. Dissertação (Mestrado). Pontifícia Universidade Católica do Rio de Janeiro.

SOROUSHIAN, P.; MIRZA, F. (1991). Effects of fiber reinforcement on cyclic behavior of dowel bars. Journal of Structural Engineering, v.117, n.3, p.822-828, March.

SOROUSHIAN, P.; OBASEKI, K.; BAIYASI, M.I ; EL-SWEIDAN, B.; CHOI, K. (1988). Inelastic cyclic behavior of dowel bars. ACl Structural Journal, v.85, n.1, p.23-29, January-February.

SOROUSHIAN, P.; OBASEKI, K.; ROJAS, M.; NAJM, H.S. (1987). Behavior of bars in dowel action against concrete cover. ACl Structural Journal, v.84, n.2, p.170-176, MarchApril.

SOROUSHIAN, P.; OBASEKI, K.; ROJAS, M.C.; SIM, J. (1986). Analysis of dowel bars acting concrete core. ACl Journal, Proceedings, v.83, n.4, p.642-649, July-August.

SOUBRA, K.S.; WIGHT, J.K.; NAAMAN, A.E. (1993). Cyclic response of fibrous cast-inplace connections in precast beam-column subassemblages. ACl Structural Journal, v.90, n.3, p.316-323, May-June.

SOUDKI, K.A.; WEST, J.S.; RIZKALLA, S.H.; BLACKETT, B. (1996). Horizontal connections for precast concrete shear wall panels under cyclic shear loading. PCl Journal, v.41, n.3, p.64-79, May-June.

SOUDKI, K.A.; RIZKALLA, S.H.; LEBLANC, B. (1995). Horizontal connections for precast concrete shear walls subjected to cyclic deformations part 1: mild steel connections. PCl Journal, v.40, n.4, p.78-96, July-August. 
SWAMY, R.N.; JONES, R.; CHIAM, A.T.P. (1993). Influence of steel fibers on the shear resistance of lightweight concrete I-beams. ACl Structural Journal, v.90, n.1, p.103114 , January-February.

SWAMY, R.N.; BAHIA, H.M. (1979). Influence of fiber reinforcement on the dowel resistance to shear. ACl Journal, Proceedings, v.76, n.2, p.327-355, February.

TAERWE, L.R. (1992). Influence of steel fibers on strain-softening of high-strength concrete. ACI Materials Journal, v.89, n.1, p.54-60, January-February.

TAN, K.H.; MURUGAPPAN, K.; PARAMASIVAM, P. (1993). Shear behavior of steel fiber reinforced concrete beams. ACl Structural Journal, v.90, n.1, p.3-11, JanuaryFebruary.

TAN, K.H. ; MANSUR, M.A. (1990). Shear transfer in reinforced fiber concrete. Journal of Materials in Civil Engineering, v.2, n.4, p.202-214, November.

TASSIOS, T.P. ; VINTZELEOU,E.N. (1990). Shear crack stability along a precast reinforced concrete joint. In: CARPINTERI, A., ed. Applications of fracture mechanics to reinforced concrete. Essex, Elsevier Applied Science. p.365-486.

TASSIOS,T.P.; VINTZELEOU, E.N. (1987). Concrete-to-concrete friction. Journal of Structural Engineering, ASCE, v.113, n.4, p.832-849, April.

TSOUKANTAS, S.G.; TASSIOS, T.P. (1989). Shear resistance of connections between reinforced concrete linear precast elements. ACI Structural Journal, v.86, n.3, p.242249, May-June.

VALLE, M.; BÜYÜKÖZTÜRK, O. (1993). Behavior of fiber reinforced high-strength concrete under direct shear. ACI Materials Journal, v.90, n.2, p.122-133, March-April.

VALLUVAN, R.; KREGER, M.E.; JIRSA, J.O. (1999). Evaluation of ACI 318-95 ShearFriction Provisions. ACl Structural Journal, v.96, n.4, p.473-481, July-August.

VASCONEZ, R.M. ; NAAMAN, A.E. ; WIGHT, J.K. (1998). Behavior of HPFRC connections for precast concrete frames under reversed cyclic loading. PCI Journal, v.43, n.6, p.5871, November-December.

VECCHIO, F.J.; LAI, D.; SHIM, W. ; NG, J. (2001). Disturbed Stress Field Model for Reinforced Concrete: Validation. Journal of Structural Engineering, v.127, n.4, p.350358, April.

VECCHIO, F.J. (2001). Disturbed Stress Field Model for Reinforced Concrete: Implementation. Journal of Structural Engineering, v.127, n.1, p.12-20, January.

VECCHIO, F.J. (2000). Disturbed Stress Field Model for Reinforced Concrete: Formulation. Journal of Structural Engineering, v.126, n.9, p.1070-1077, September.

VECCHIO, F.J. ; COLLINS, M.P. (1986). The modified compression-field theory for reinforced concrete elements subjected to shear. Journal of the American Concrete Institute, Proceedings, v.83, n.2, p.219-231, March-April.

VINTZELEOU, E.N.; TASSIOS, T.P. (1990). Eccentric dowels loaded against core of concrete sections. Journal of Structural Engineering, v.116, n.10, p.2621-2633, October. 
VINTZELEOU, E.N. ; TASSIOS, T.P. (1987). Behavior of dowels under cyclic deformations. ACI Structural Journal, v.84, n.1, p.18-30, January-February.

YAMANE, T. ; TADROS, M.K. ; BADIE, S.S. ; BAISHYA, M.C. (1998). Full depth precast, prestressed concrete bridge deck system. PCl Journal, v.43, n.3, p.50-66, May-June.

WALRAVEN, J.; STROBAND, J. (1994). Shear friction in high-strength concrete. In: HIGHPERFORMANCE CONCRETE, Proceedings, p.311-330, ACI International conference, Singapore.

WALRAVEN, J.C. ; REINHARDT, H.W. (1981). Theory and experiments on the mechanical behavior of cracks in plain and reinforced concrete subject to shear loading. Heron, v.26, n.1A, 68p.

ZILCH, K. ; REINECKE, R. (2000). Capacity of shear joints between high-strength precast elements and normal-strength cast-in-place decks. In: International Symposium of High Performance Concrete: The economical solution for durable bridges and transportation structures. PCI / FHWA / FIB. Proceedings, 25-27 September, Orlando, Florida, USA. Edited by Precast / Prestressed Concrete Institute. 


\title{
Apêndice A - Resultados dos Ensaios de Cisalhamento Direto
}

\author{
Neste apêndice são mostrados todos os resultados obtidos dos ensaios de \\ cisalhamento. Também são mostrados os resultados obtidos da simulação numérica no \\ programa ANSYS.
}

\section{A.1. Deslizamento relativo na ligação}

A seguir são apresentados os deslizamentos relativos na ligação medidos durante o ensaio. Também são apresentados os deslizamentos médios da ligação corrigidos em função da rotação das peças laterais. Essa correção foi realizada, a partir da leitura dos relógios posicionados na parte inferior do corpo-de-prova, pela seguinte expressão:

$$
\begin{aligned}
\delta_{\text {médio }}= & \frac{\delta_{\text {transdutor } 5}+\delta_{\text {transdutor } 6}+\delta_{\text {transdutor } 7}+\delta_{\text {transdutor } 8}}{4}+ \\
& 0,4 \frac{\delta_{\text {transdutor } 9}+\delta_{\text {transdutor 10 }}+\delta_{\text {transdutor } 11}+\delta_{\text {transdutor } 12}}{4}
\end{aligned}
$$

Os transdutores de 5 a 8 foram empregados para medir o deslizamento relativo entre as peças pré-moldadas na região da ligação, e os transdutores de 9 a 12 foram empregados para medir o afastamento entre as peças pré-moldadas na parte inferior do corpo-de-prova. O coeficiente 0,4 que aparece na expressão $A .1$ foi obtido a partir da posição dos transdutores fixados no corpo-de-prova. Por esta expressão, se as peças prémoldadas se afastarem, a leitura dos transdutores horizontais será positiva e será adicionada uma parcela de deslocamento aos transdutores verticais. Essa parcela é positiva porque com o giro da peça lateral, a cantoneira sobre a qual a haste do transdutor vertical está apoiada sofre um movimento de corpo rígido para baixo. De igual forma, se as peças laterais se aproximarem, será subtraída uma parcela devido ao movimento da cantoneira para cima. Esta última situação ocorreu em alguns ensaios devido às falhas de posicionamento da peça lateral sobre a peça central durante a confecção do corpo-de- 
prova. Na Figura A.1 é mostrada a numeração dos transdutores e o seu posicionamento durante os ensaios.

Da Figura A.2 até a Figura A.29 são mostradas as curvas obtidas para todos os ensaios.

Vista superior

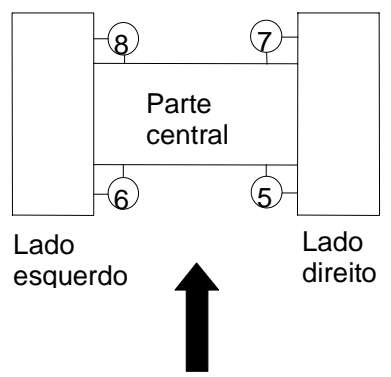

Frente
Vista de frente

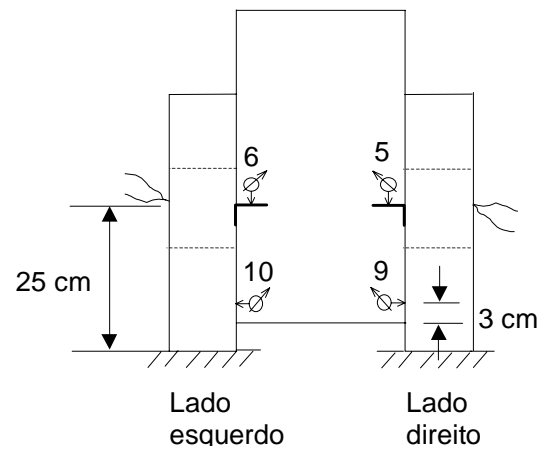

Vista de trás

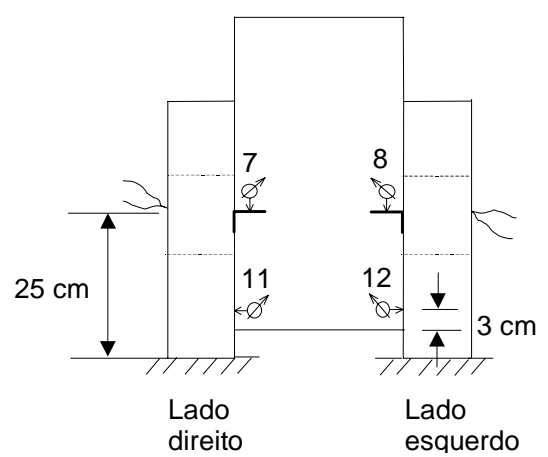

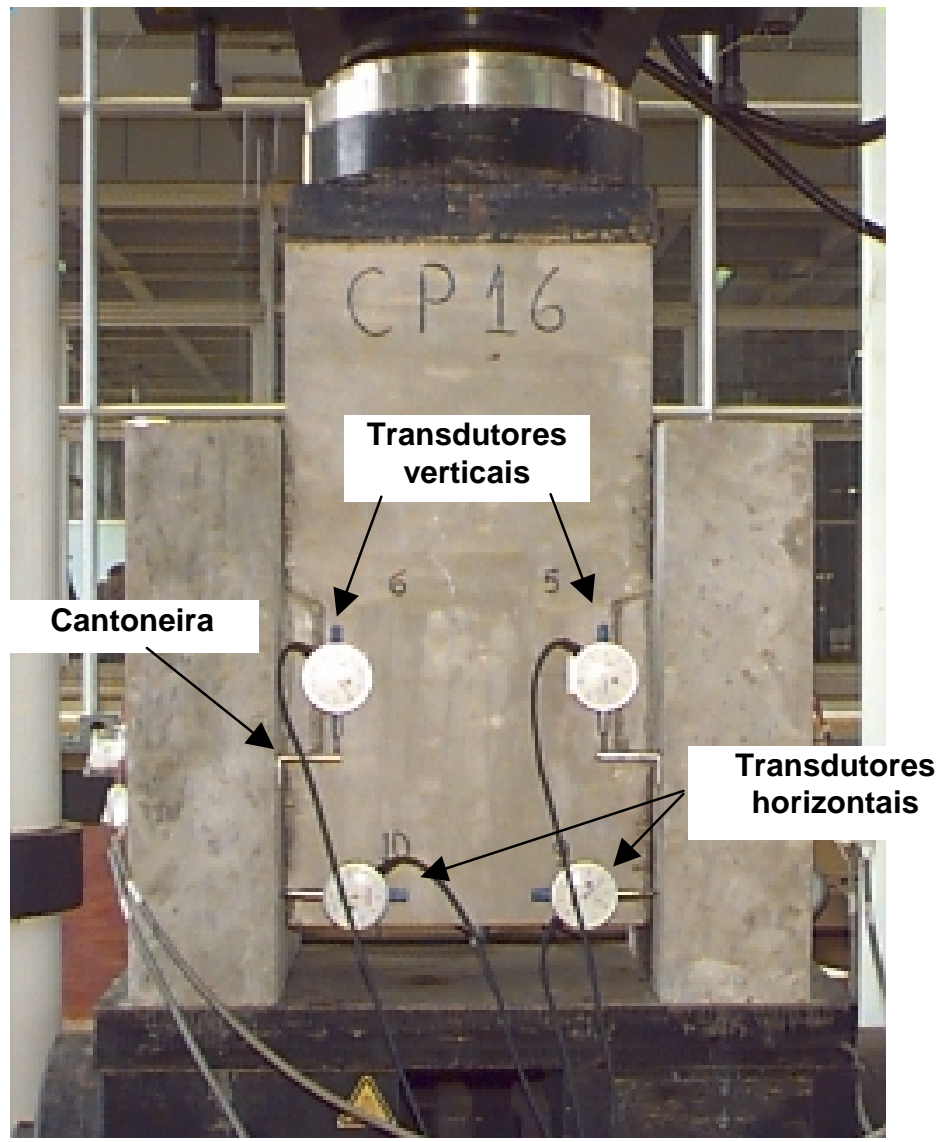

Figura A.1 - Posição dos transdutores no ensaio de cisalhamento direto. 

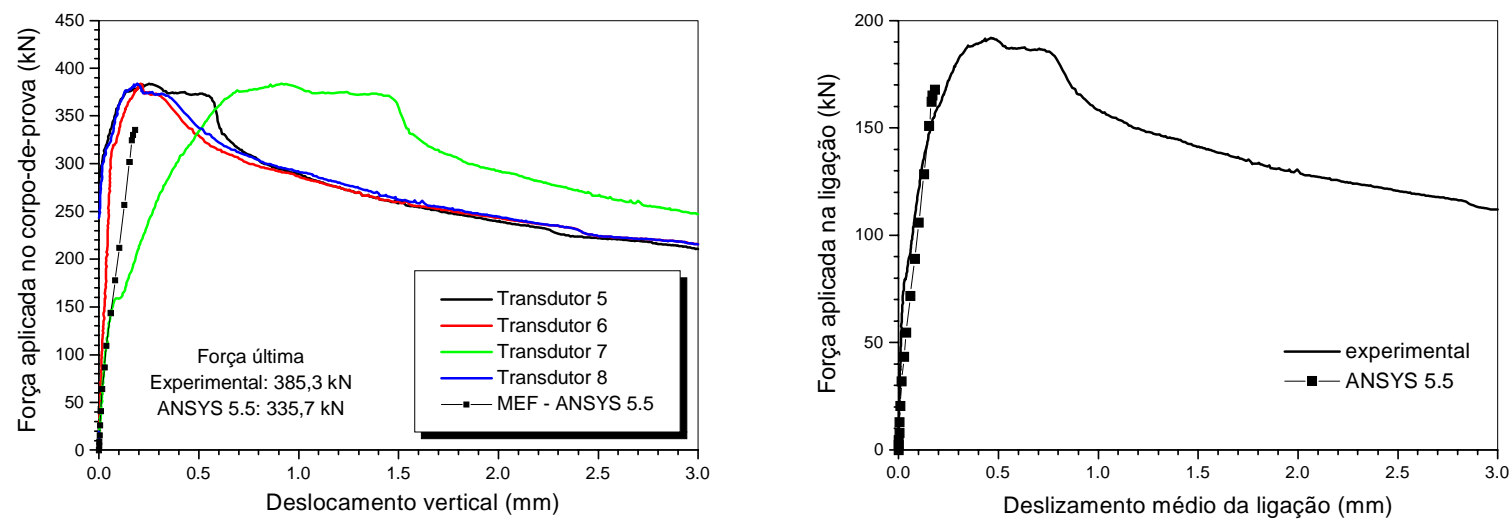

Figura A.2 - Deslizamento relativo na ligação do corpo-de-prova CP1
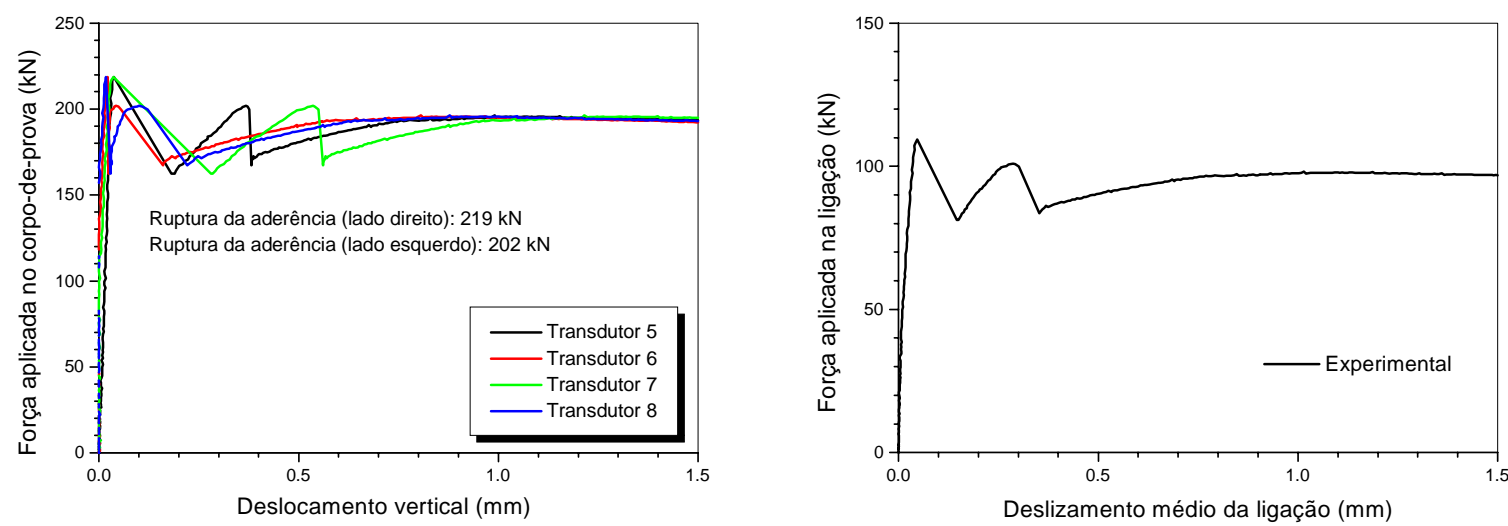

Figura A.3 - Deslizamento relativo na ligação do corpo-de-prova CP2
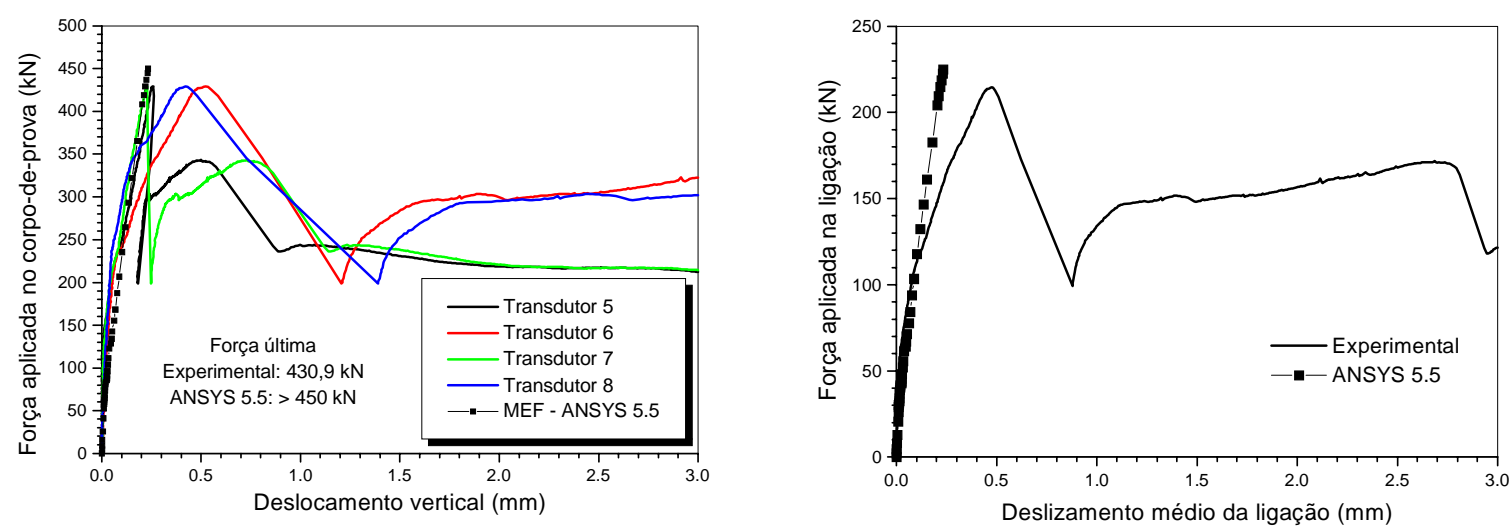

Figura A.4 - Deslizamento relativo na ligação do corpo-de-prova CP3 

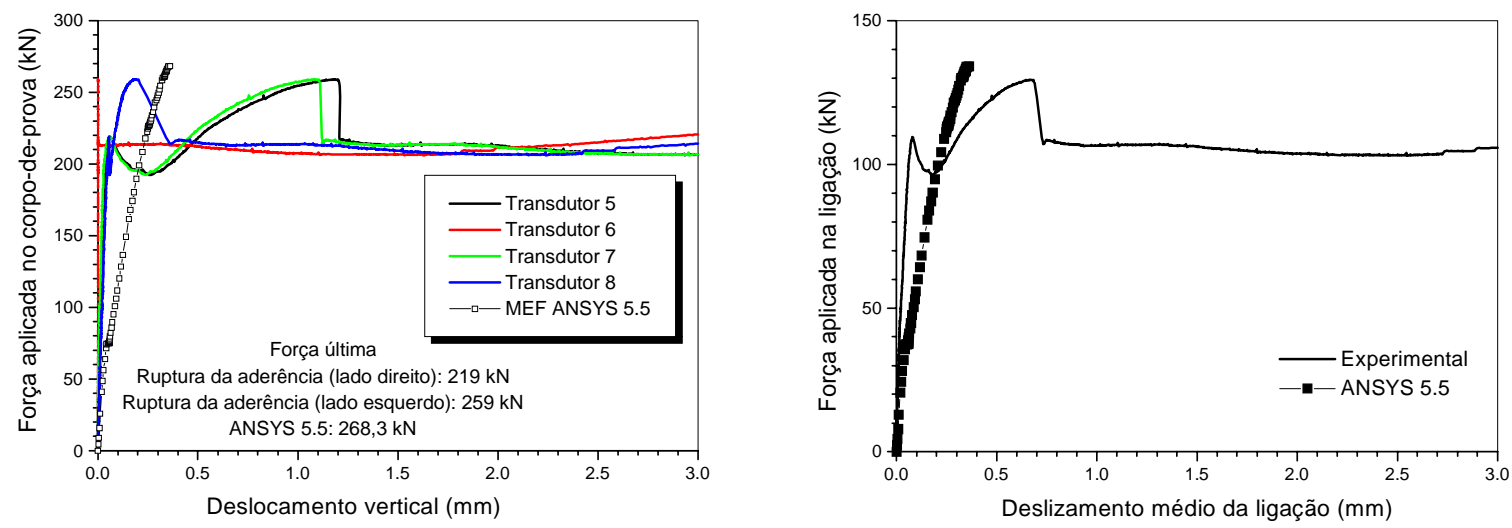

Figura A.5 - Deslizamento relativo na ligação do corpo-de-prova CP4
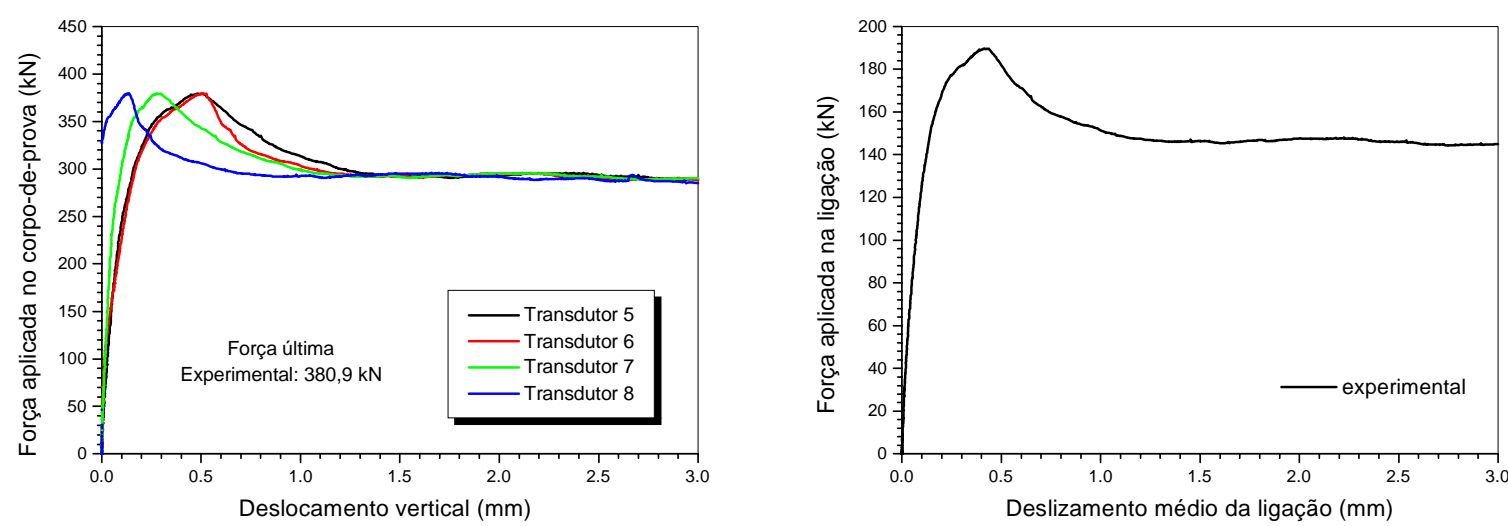

Figura A.6 - Deslizamento relativo na ligação do corpo-de-prova CP5
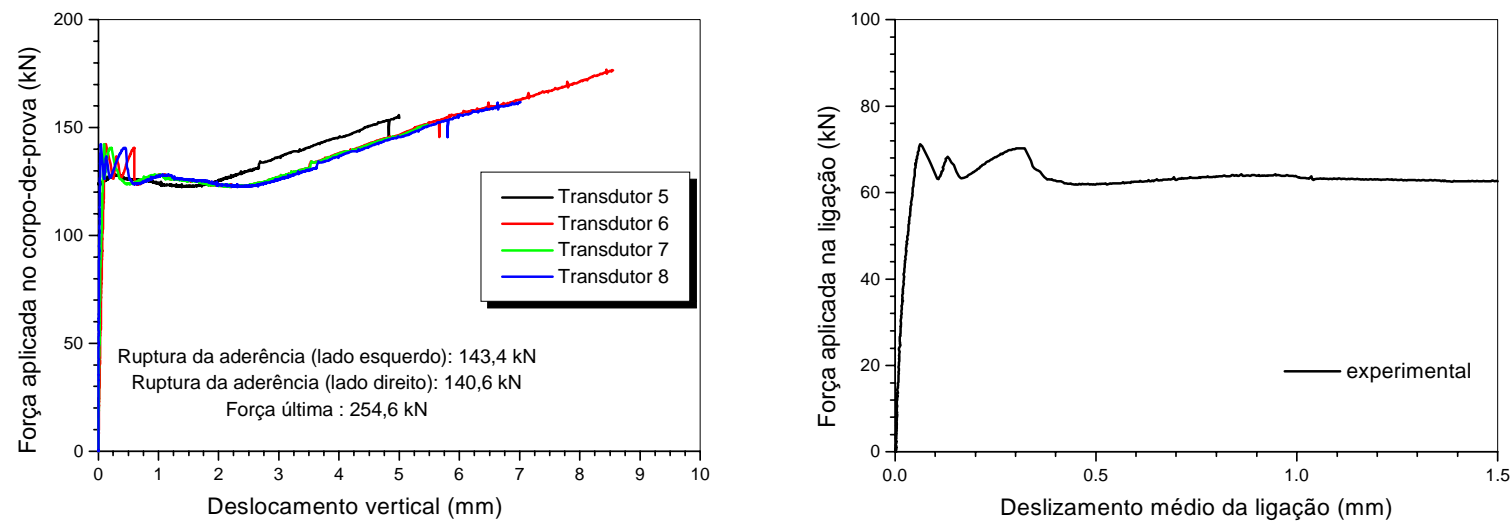

Figura A.7 - Deslizamento relativo na ligação do corpo-de-prova CP6 

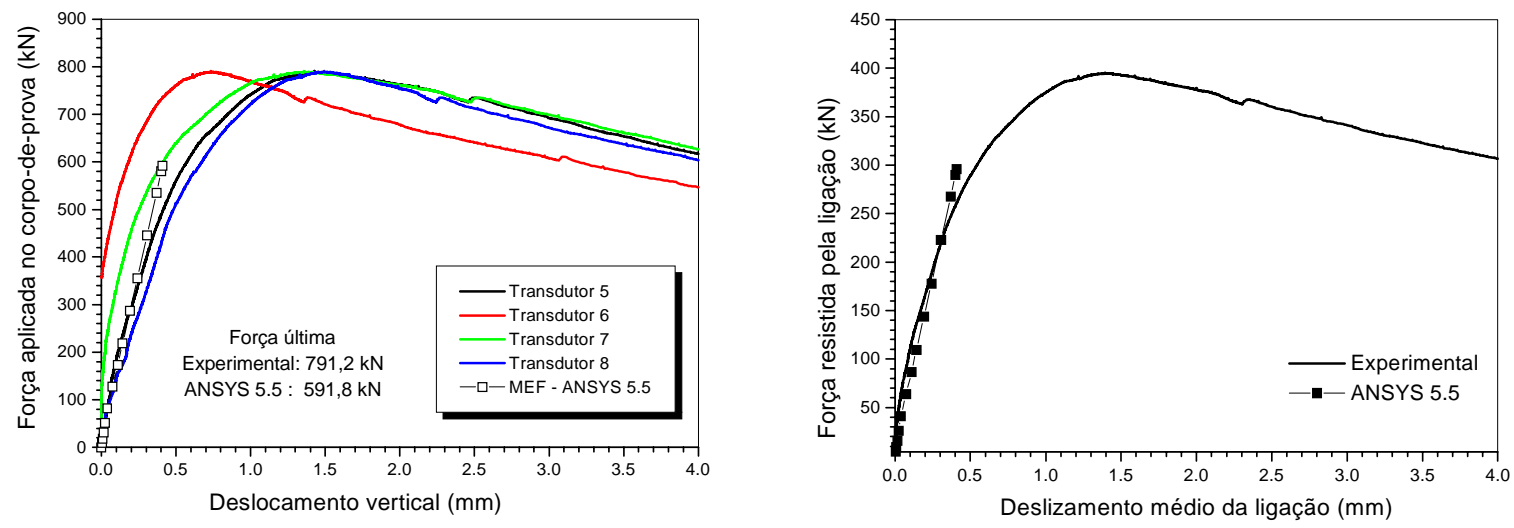

Figura A.8 - Deslizamento relativo na ligação do corpo-de-prova CP7
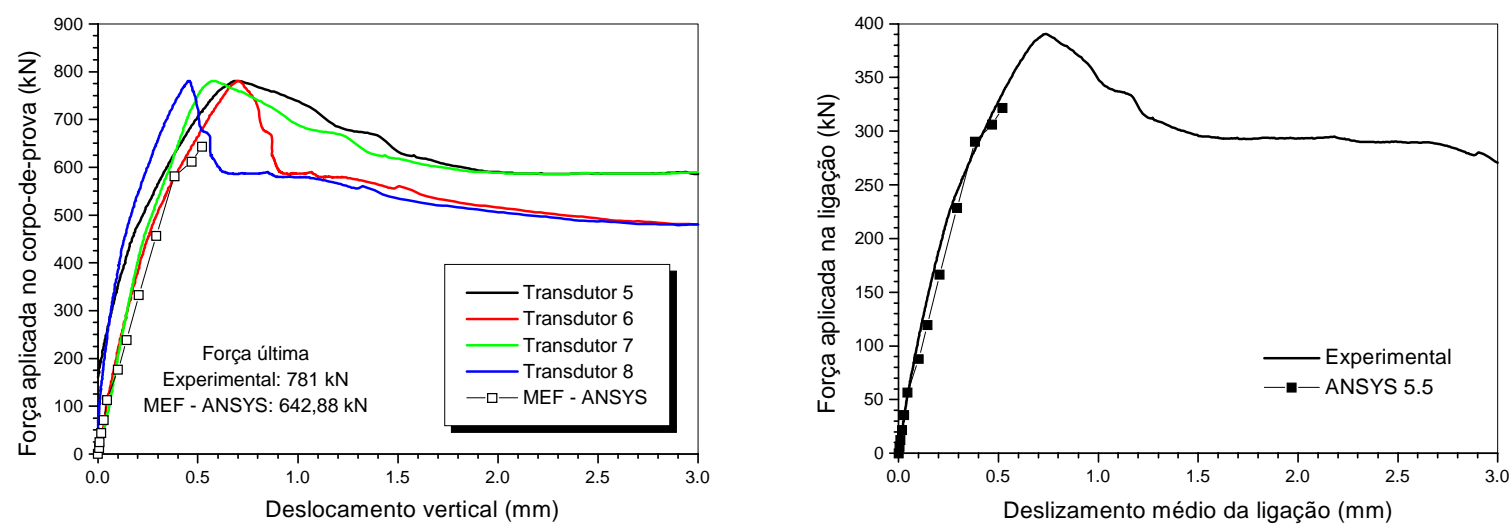

Figura A.9 - Deslizamento relativo na ligação do corpo-de-prova CP7A
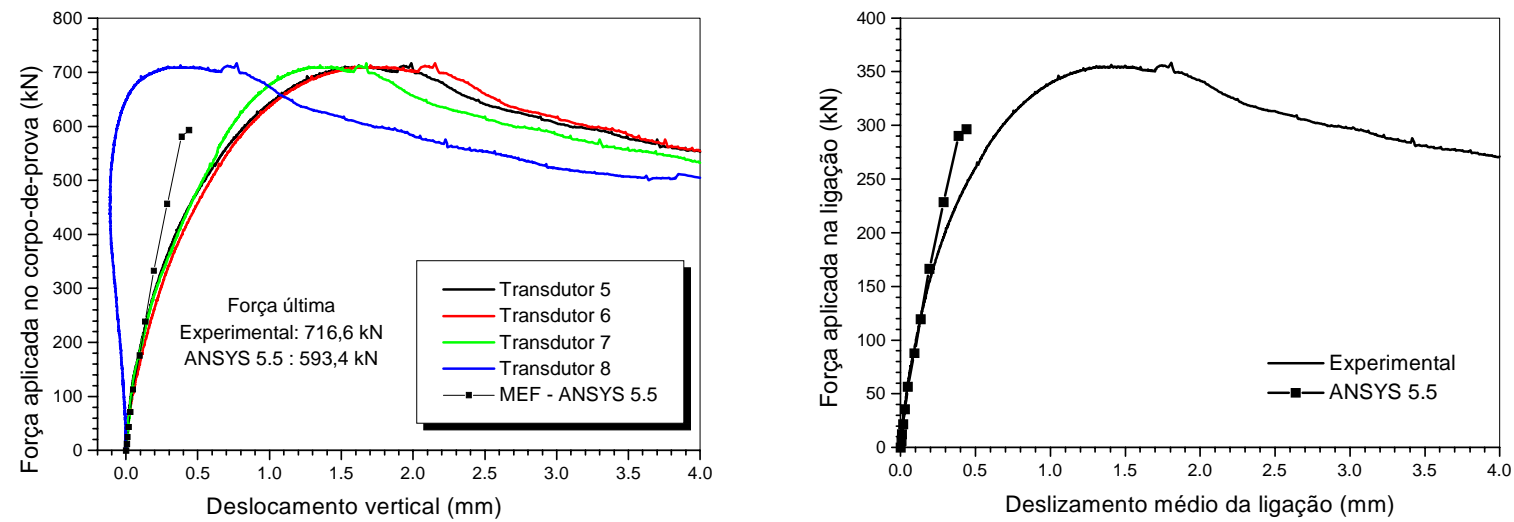

Figura A.10 - Deslizamento relativo na ligação do corpo-de-prova CP8 

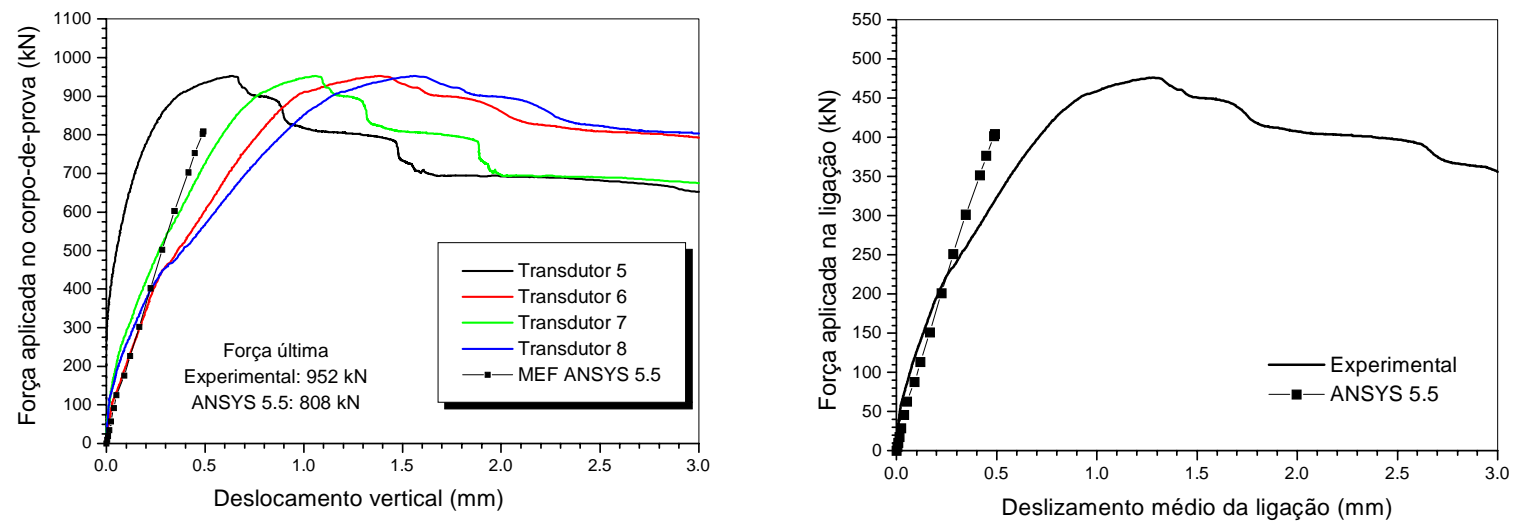

Figura A.11 - Deslizamento relativo na ligação do corpo-de-prova CP9
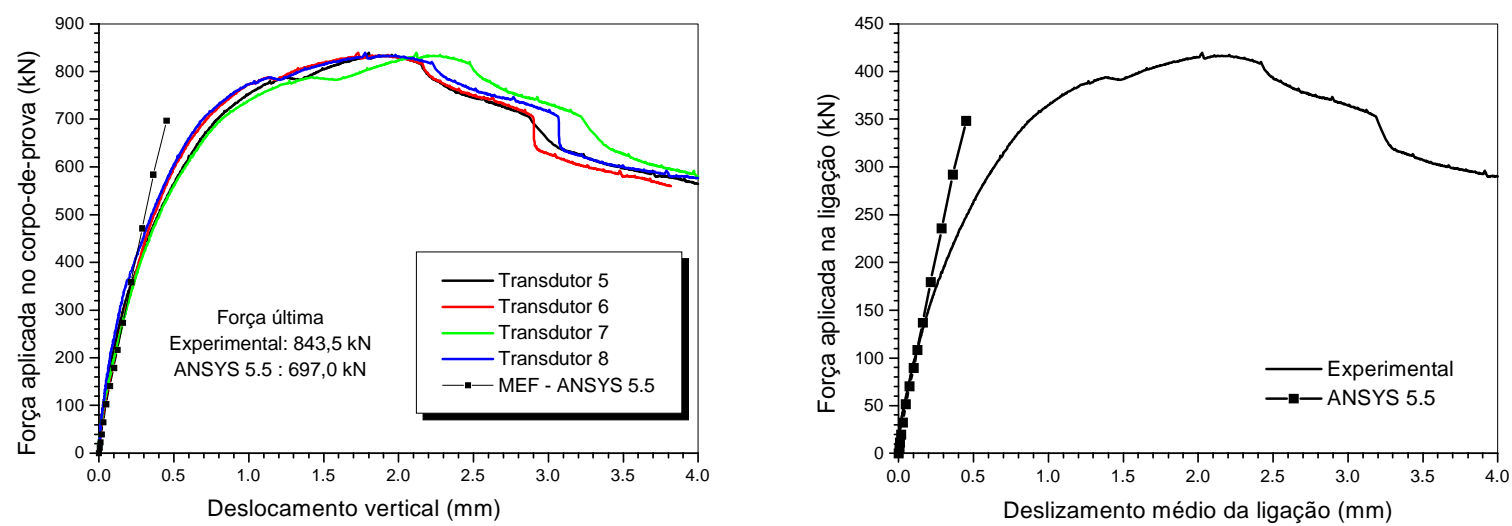

Figura A.12 - Deslizamento relativo na ligação do corpo-de-prova CP10
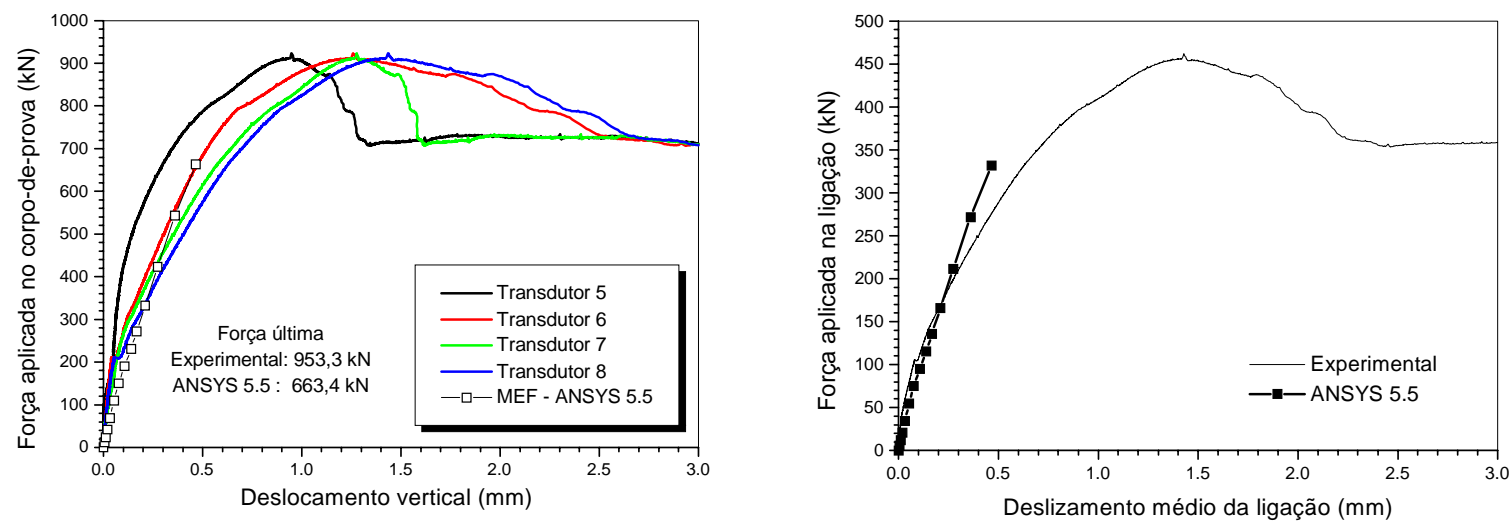

Figura A.13 - Deslizamento relativo na ligação do corpo-de-prova CP11 

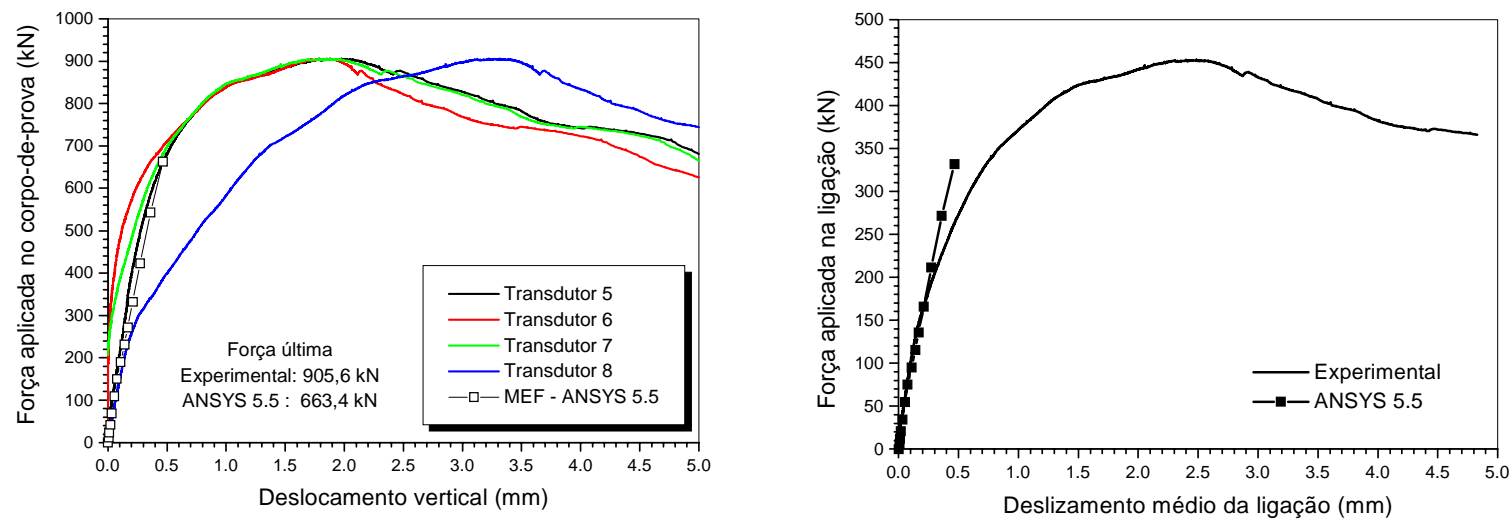

Figura A.14 - Deslizamento relativo na ligação do corpo-de-prova CP12
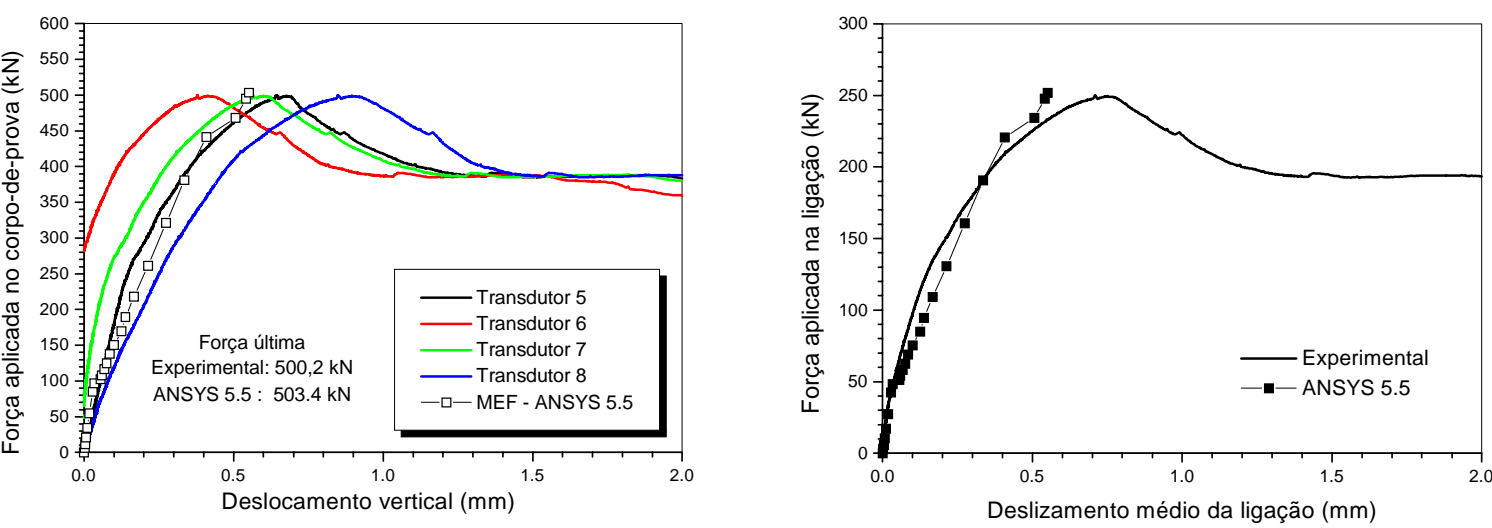

Figura A.15 - Deslizamento relativo na ligação do corpo-de-prova CP13
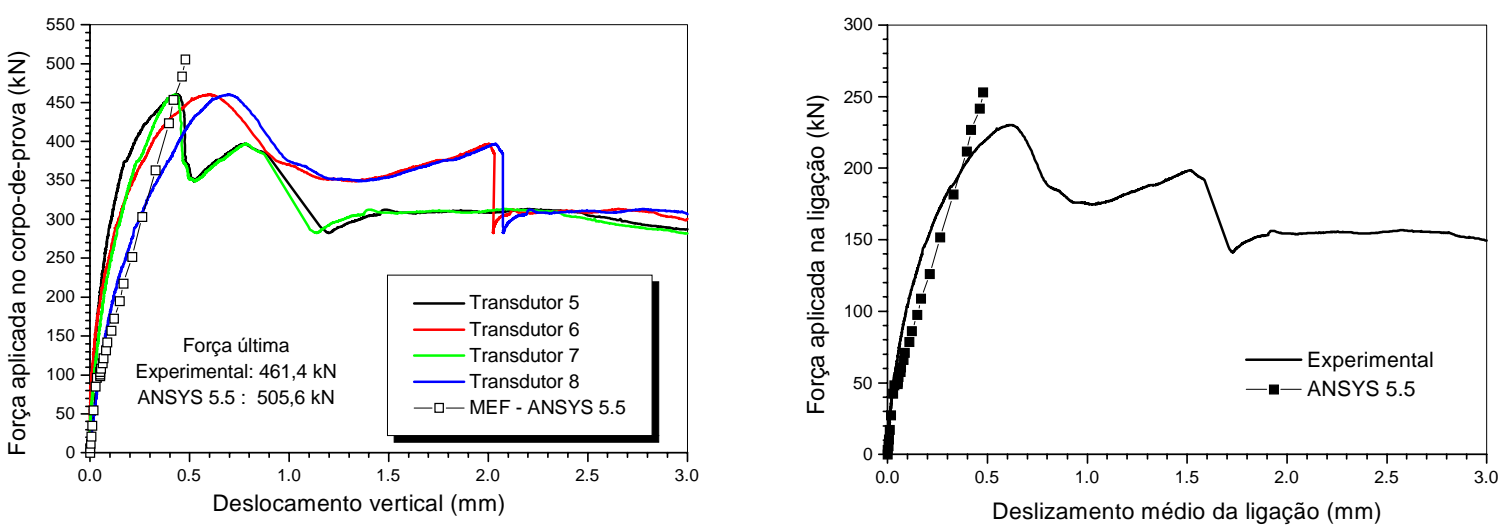

Figura A.16 - Deslizamento relativo na ligação do corpo-de-prova CP14 

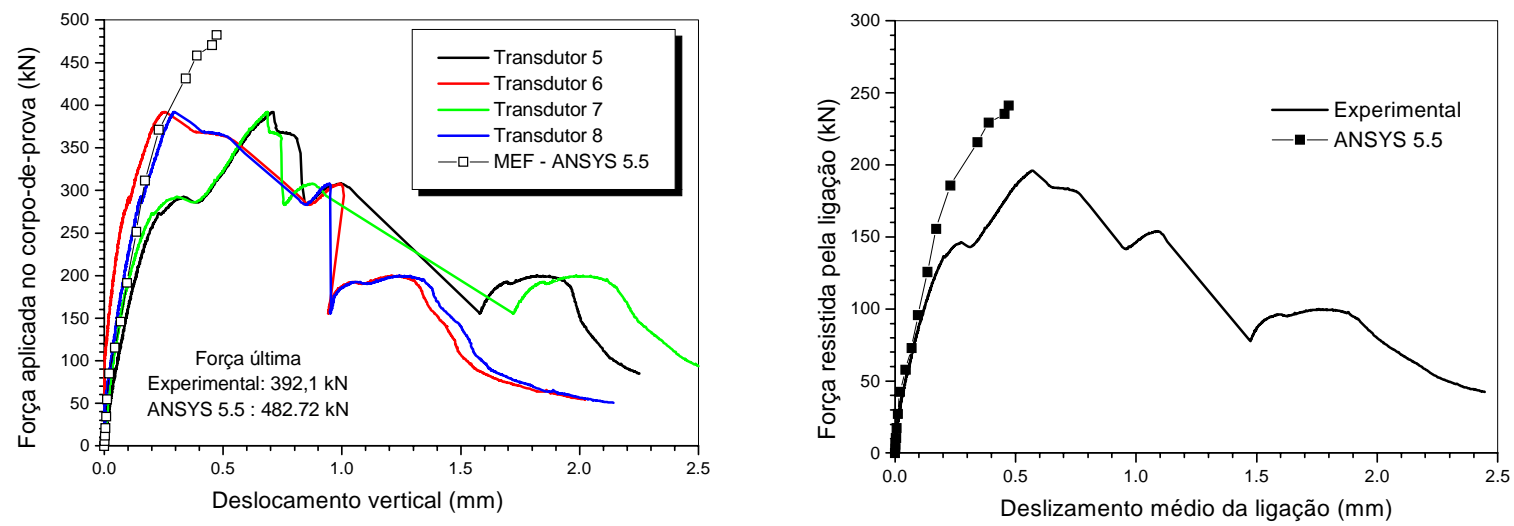

Figura A.17 - Deslizamento relativo na ligação do corpo-de-prova CP15
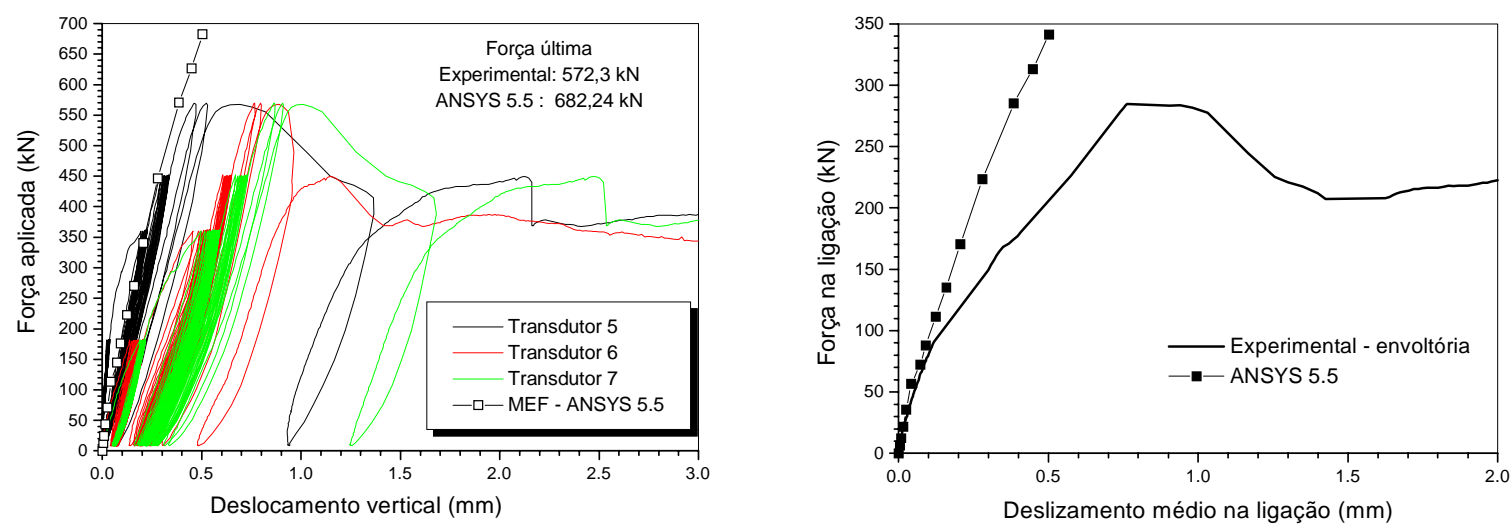

Figura A.18 - Deslizamento relativo na ligação do corpo-de-prova CP16
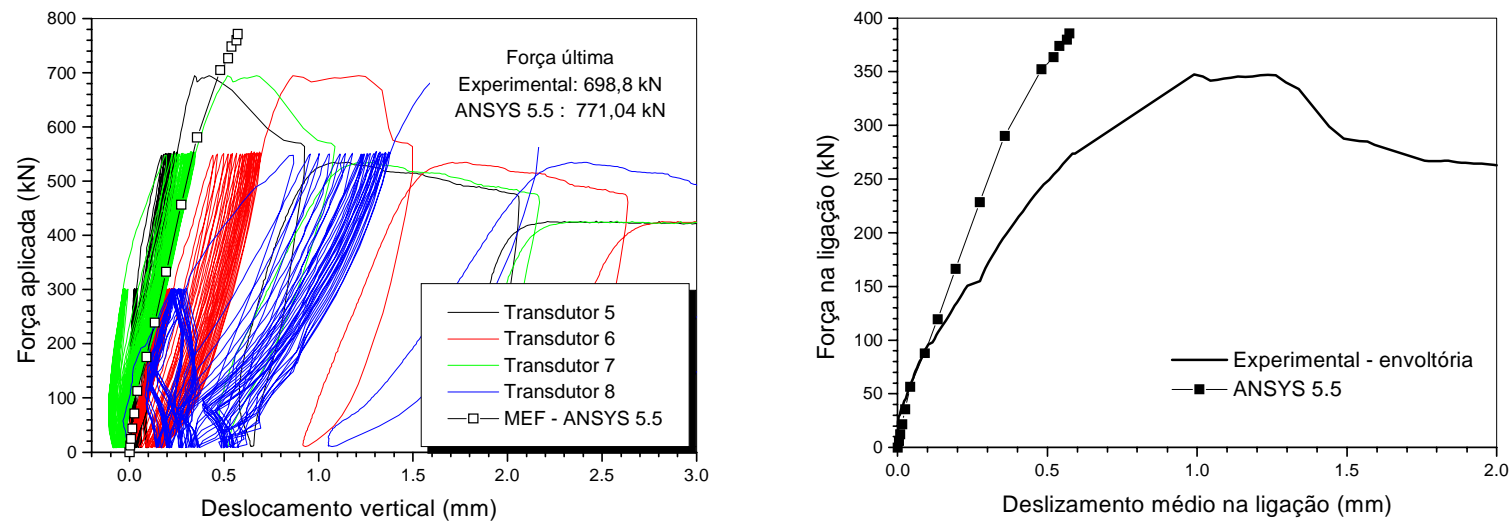

Figura A.19 - Deslizamento relativo na ligação do corpo-de-prova CP17 

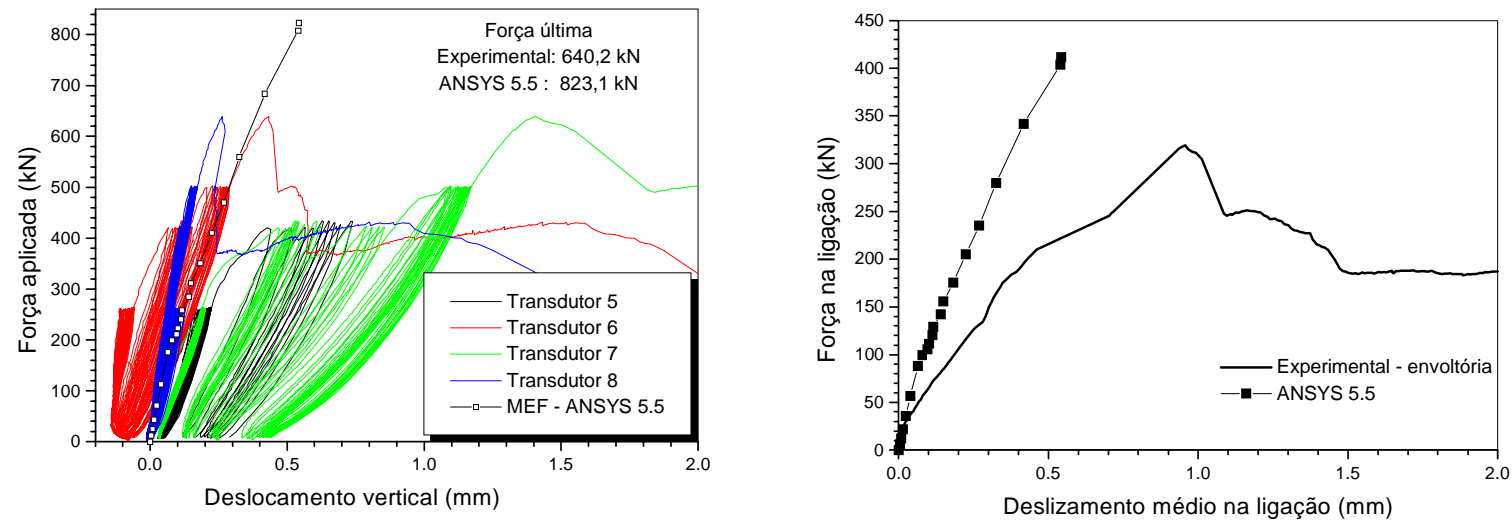

Figura A.20 - Deslizamento relativo na ligação do corpo-de-prova CP18
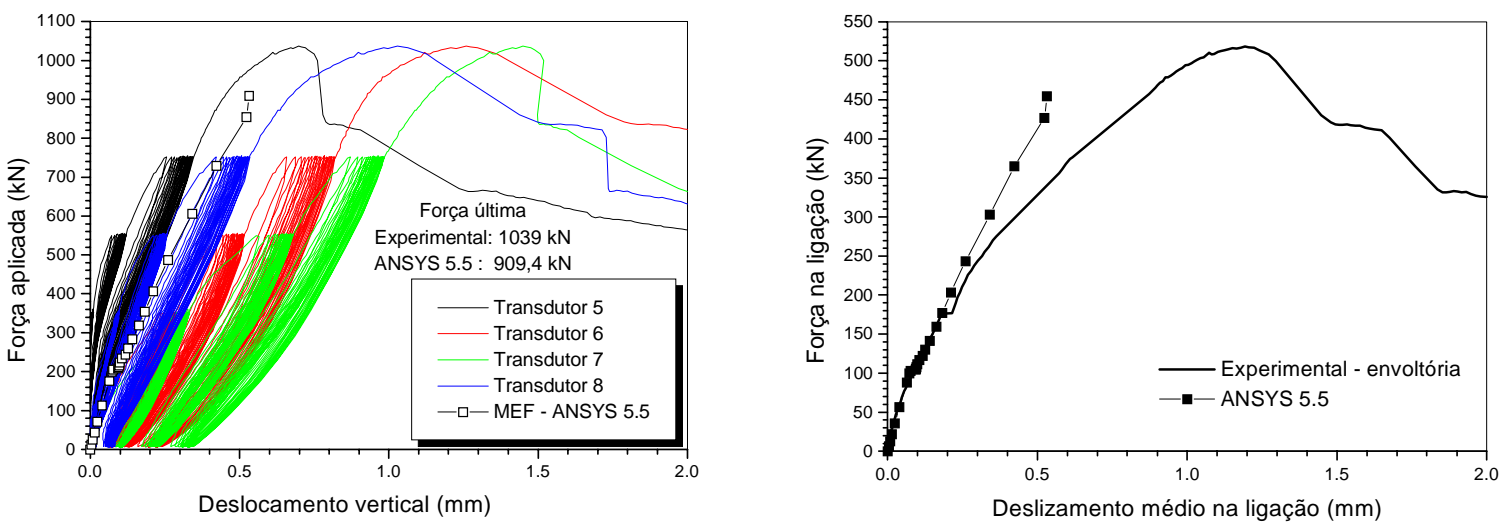

Figura A.21 - Deslizamento relativo na ligação do corpo-de-prova CP19
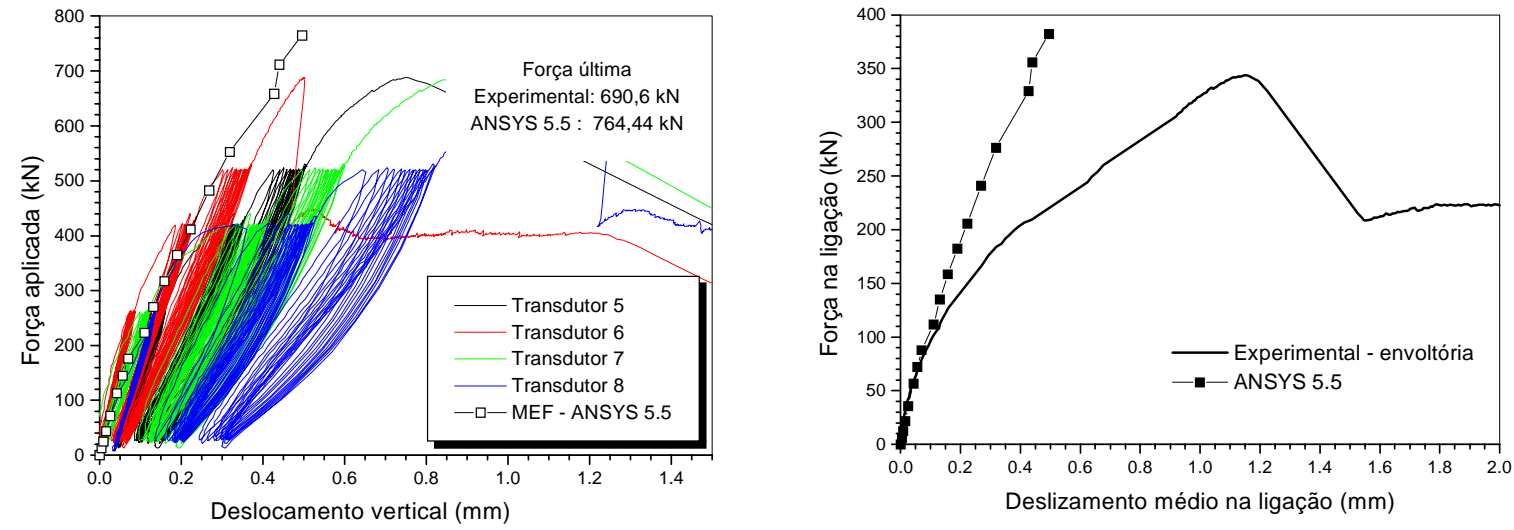

Figura A.22 - Deslizamento relativo na ligação do corpo-de-prova CP20 

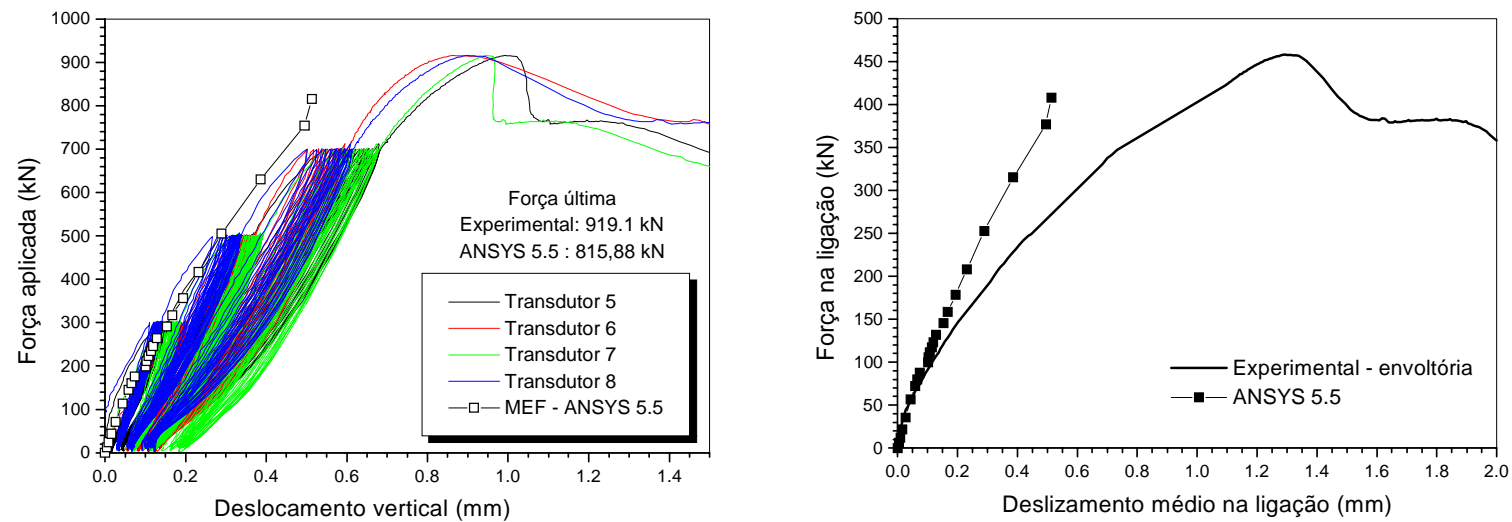

Figura A.23 - Deslizamento relativo na ligação do corpo-de-prova CP21
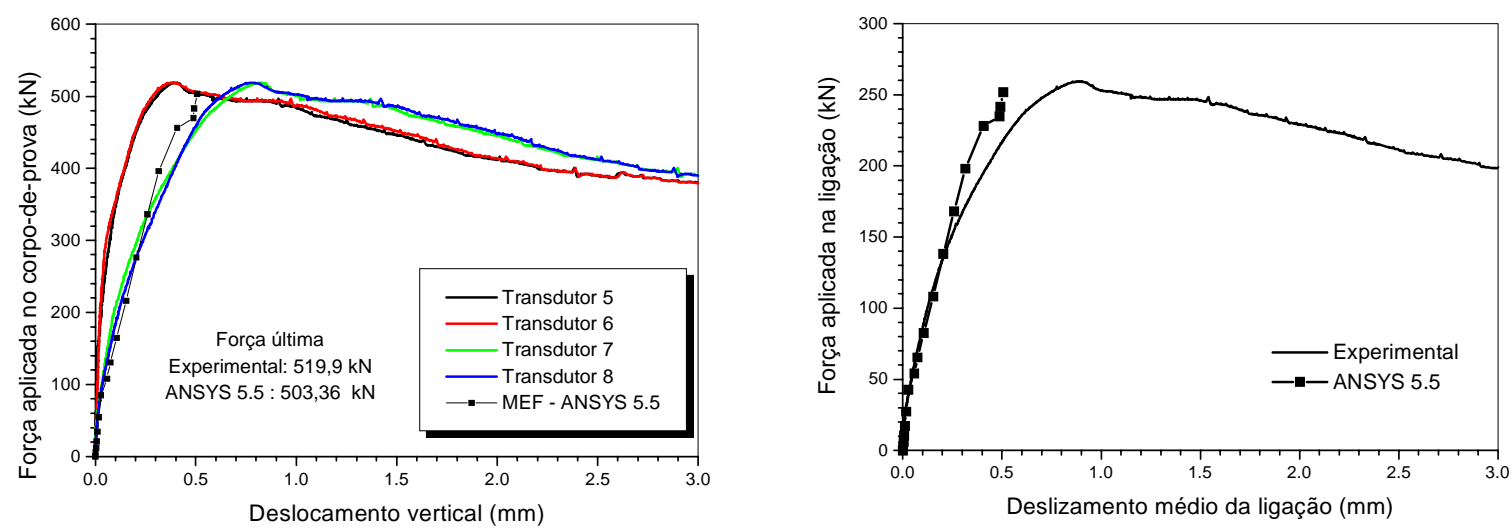

Figura A.24 - Deslizamento relativo na ligação do corpo-de-prova CP22
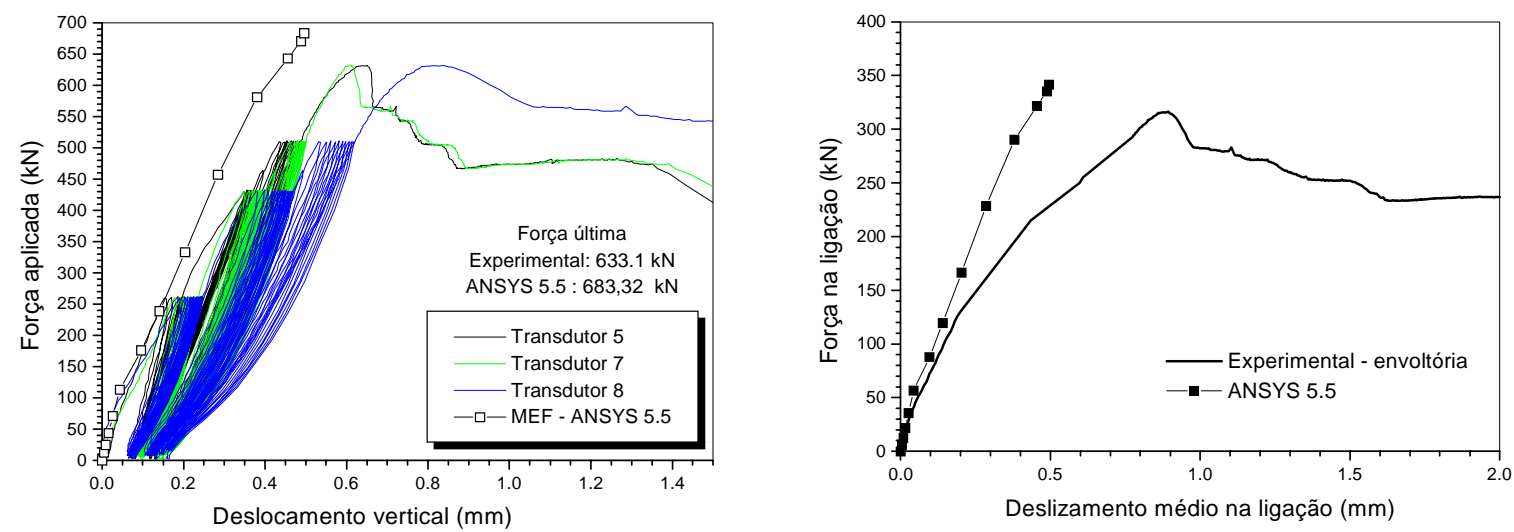

Figura A.25 - Deslizamento relativo na ligação do corpo-de-prova CP23 

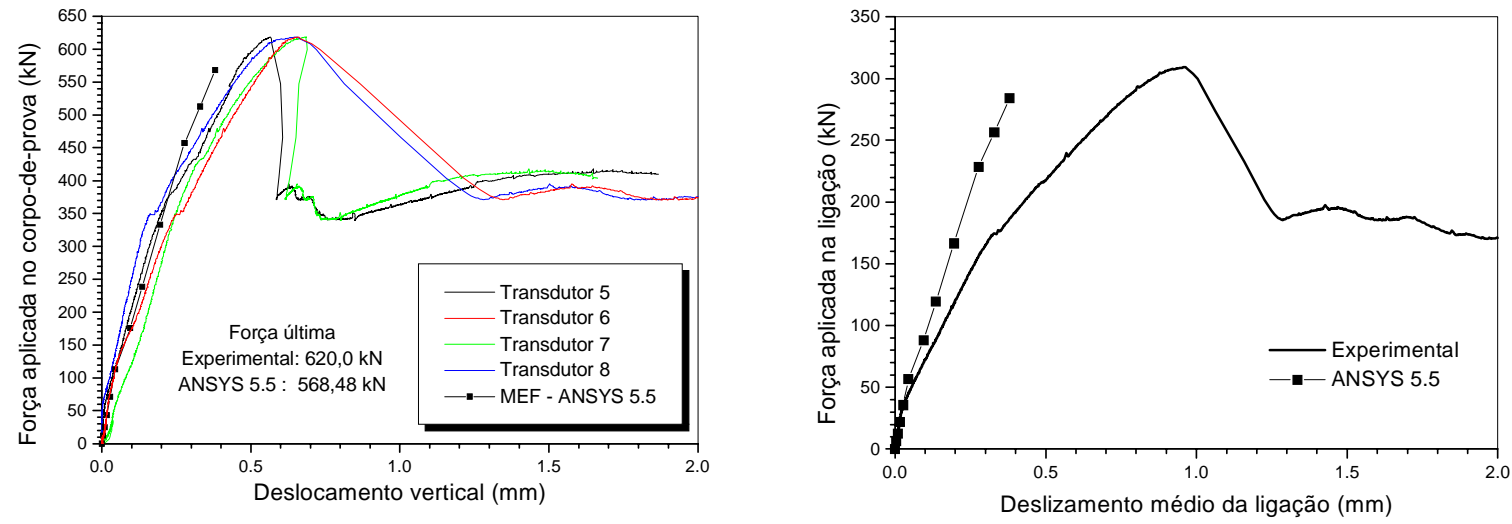

Figura A.26 - Deslizamento relativo na ligação do corpo-de-prova CP24
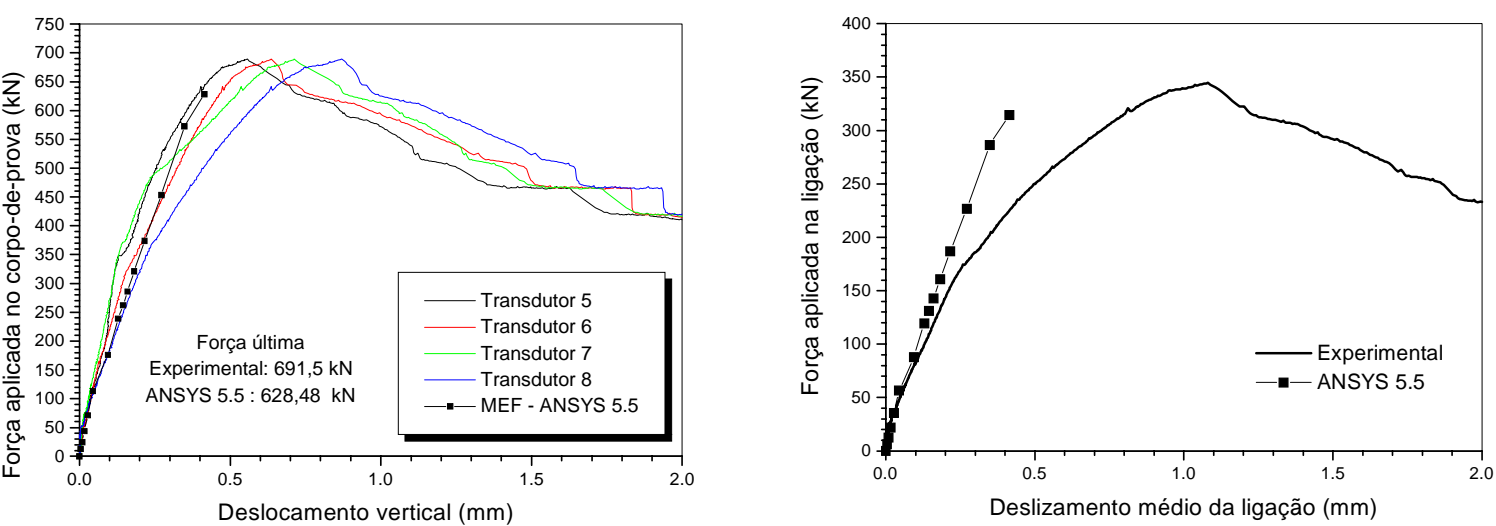

Figura A.27 - Deslizamento relativo na ligação do corpo-de-prova CP25
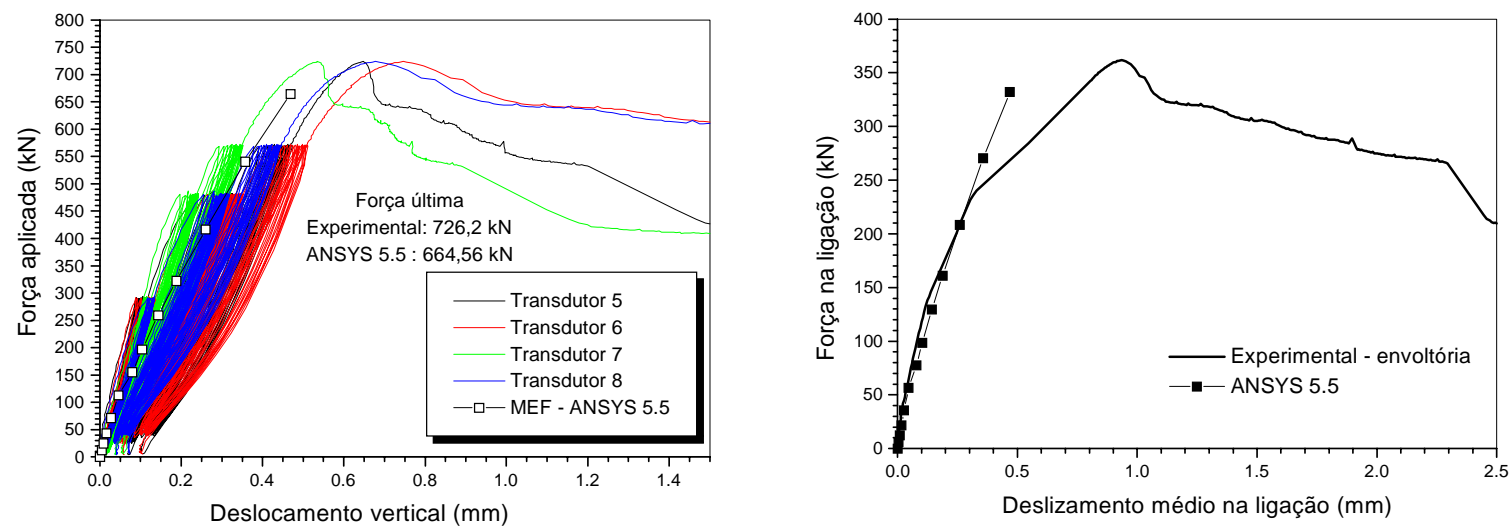

Figura A.28 - Deslizamento relativo na ligação do corpo-de-prova CP26 

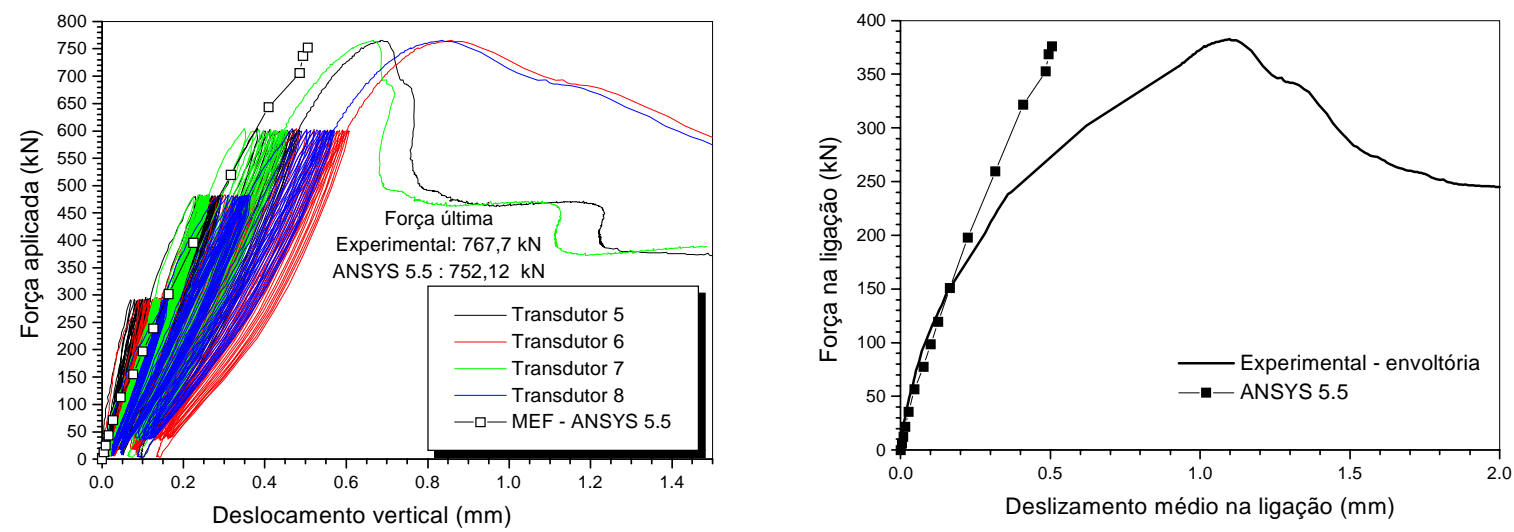

Figura A.29 - Deslizamento relativo na ligação do corpo-de-prova CP27

\section{A.2. Deformação no conector}

A seguir são apresentados os resultados obtidos dos extensômetros elétricos sobre a deformação do conector em todos os ensaios de cisalhamento realizados.

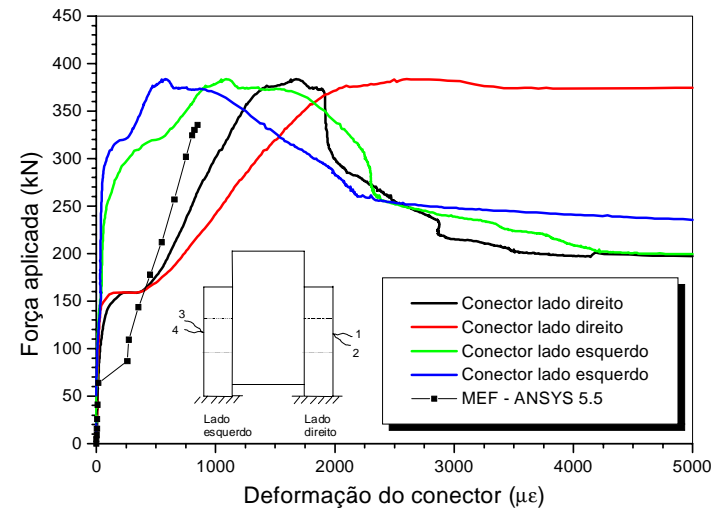

CP1

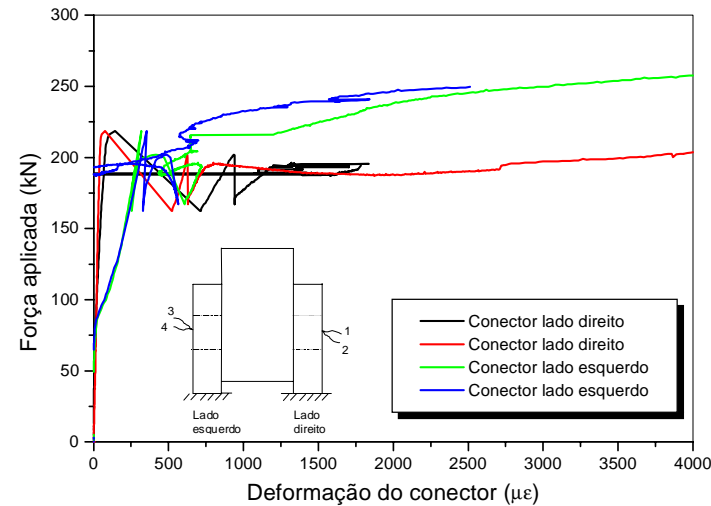

CP2

Figura A.30 - Deformação do conector nos corpos-de-prova CP1 e CP2 


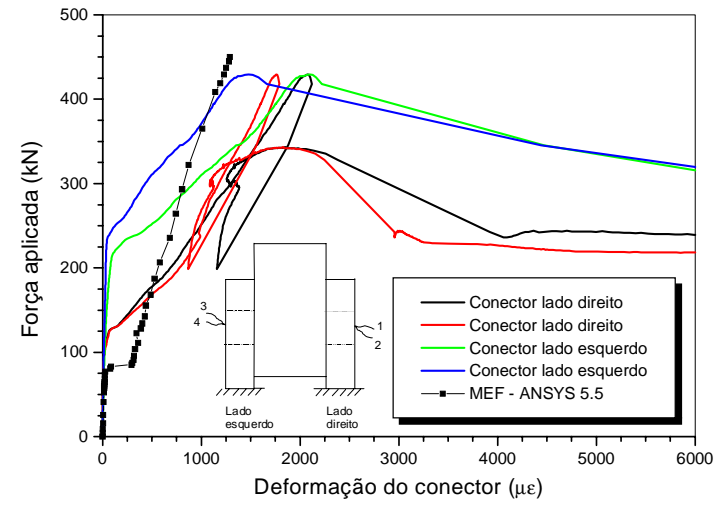

CP3

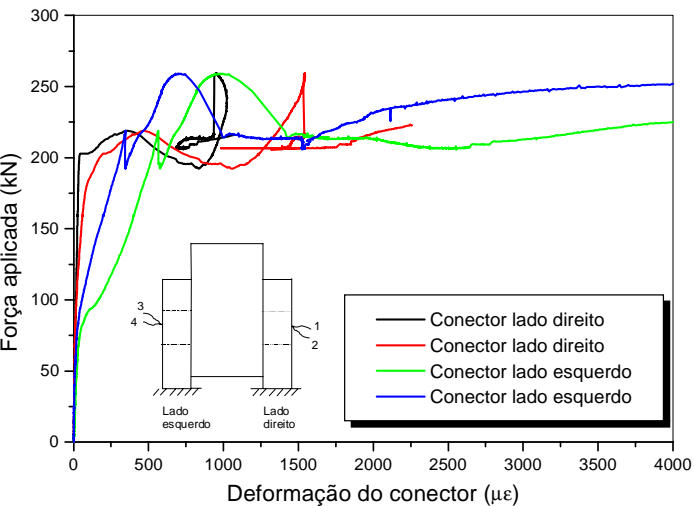

CP4

Figura A.31 - Deformação do conector nos corpos-de-prova CP3 e CP4

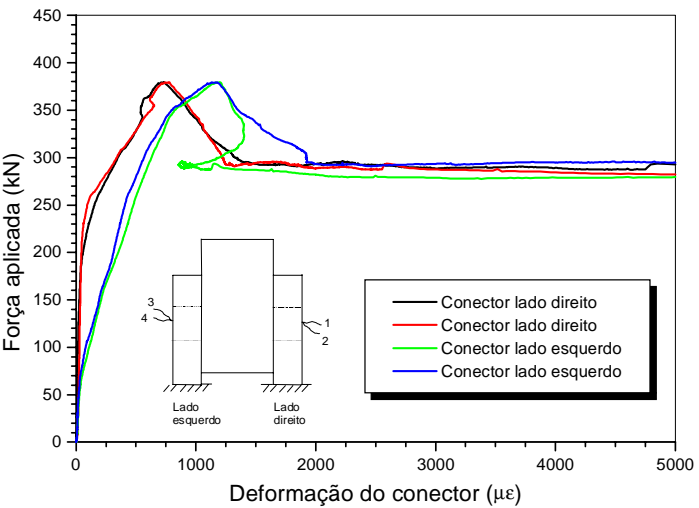

CP5

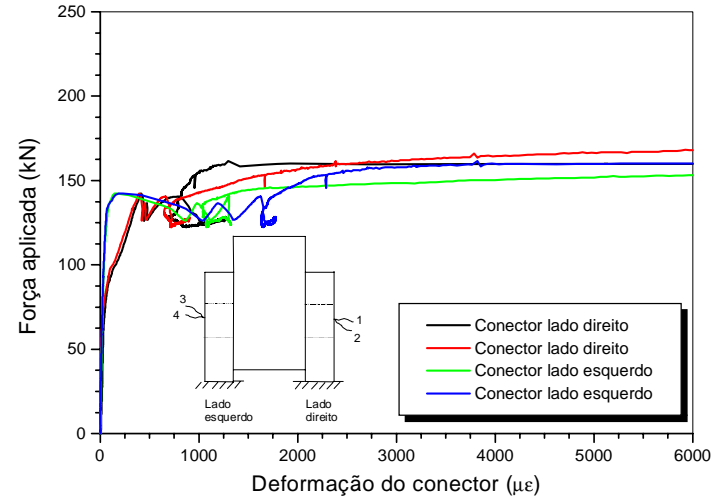

CP6

Figura A.32 - Deformação do conector nos corpos-de-prova CP5 e CP6

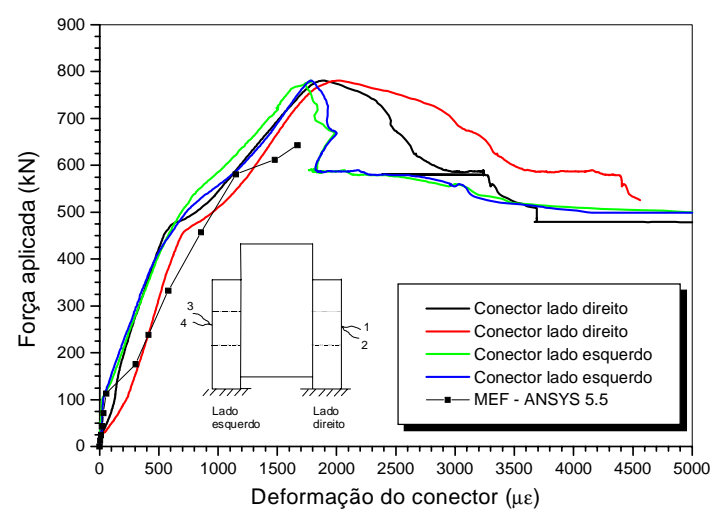

CP7A

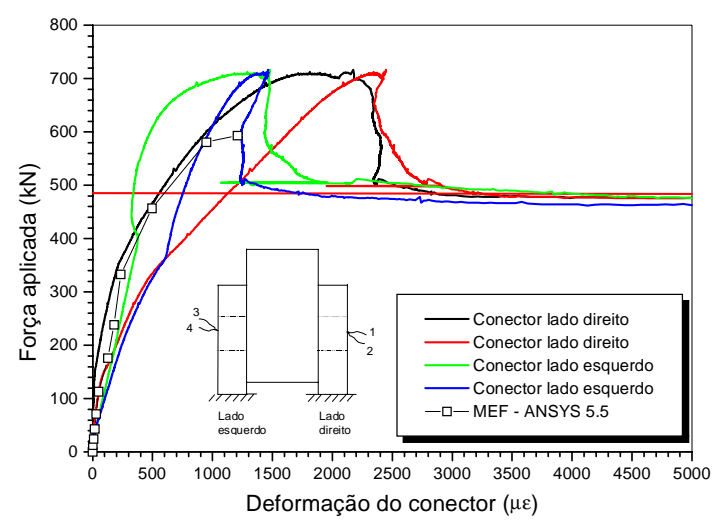

CP8

Figura A.33 - Deformação do conector nos corpos-de-prova CP7A e CP8 


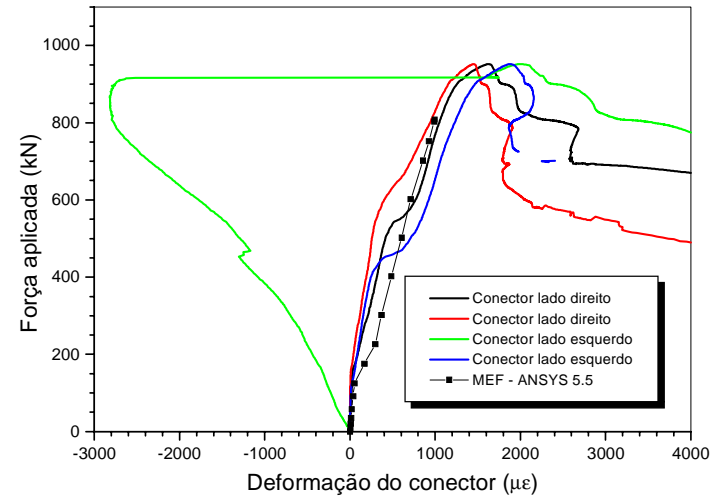

CP9

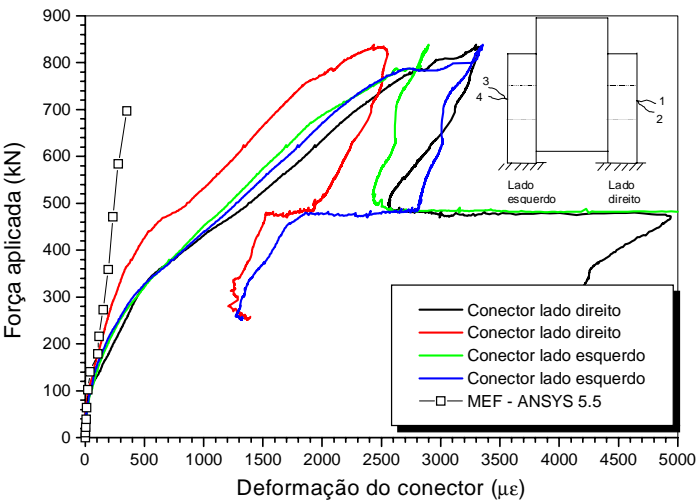

CP10

Figura A.34 - Deformação do conector nos corpos-de-prova CP9 e CP10

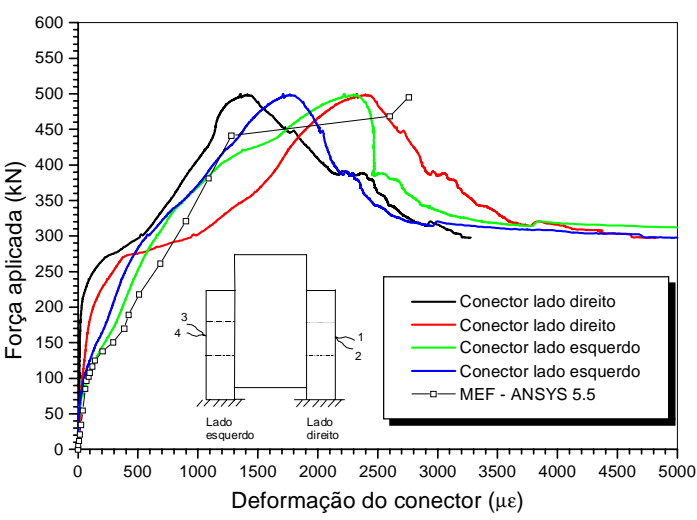

CP13

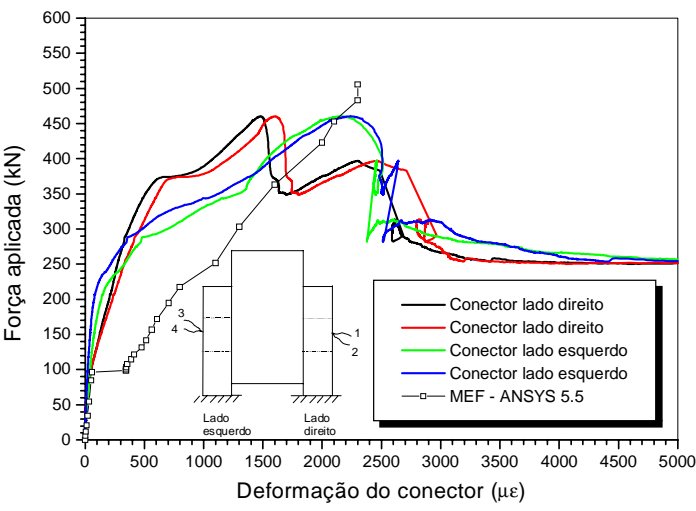

CP14

Figura A.35 - Deformação do conector nos corpos-de-prova CP13 e CP14

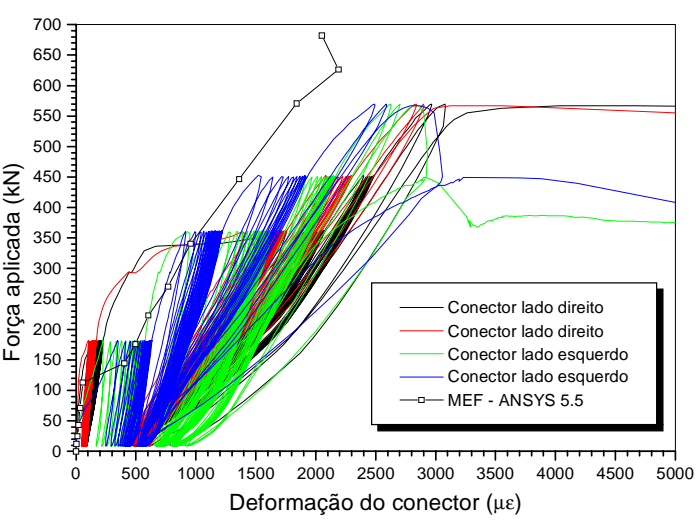

CP16

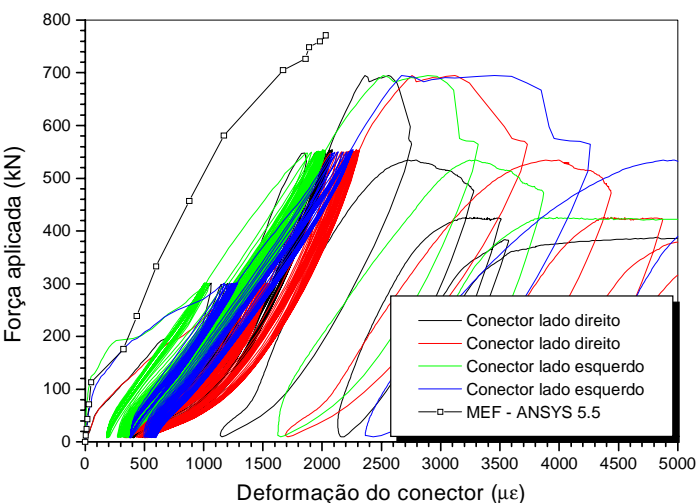

CP17

Figura A.36 - Deformação do conector nos corpos-de-prova CP16 e CP17 


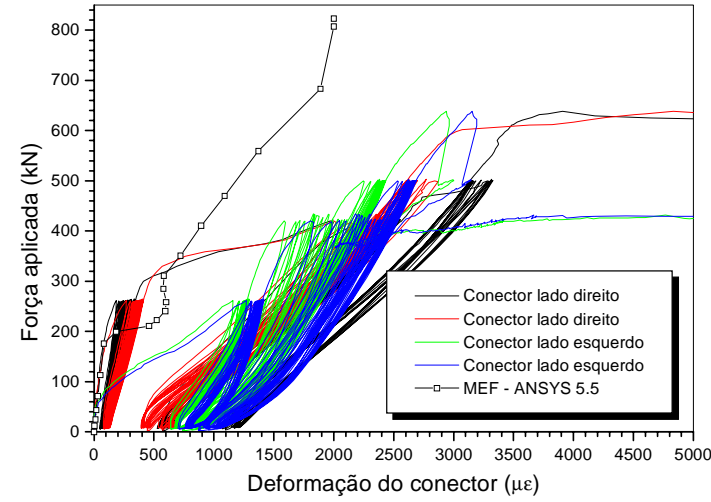

CP18

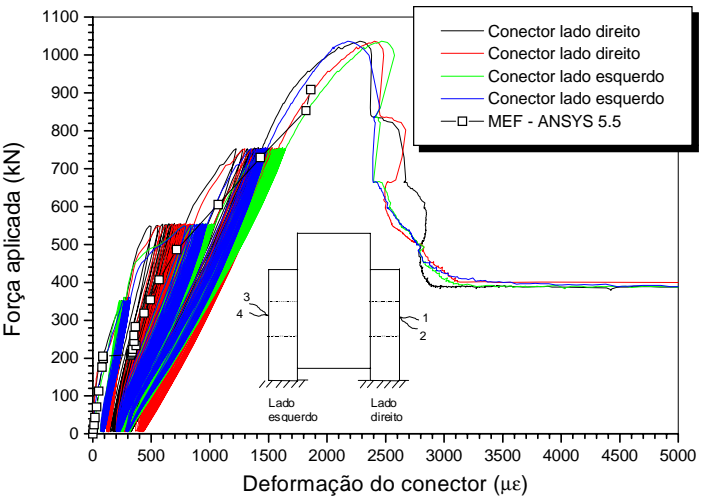

CP19

Figura A.37 - Deformação do conector nos corpos-de-prova CP18 e CP19

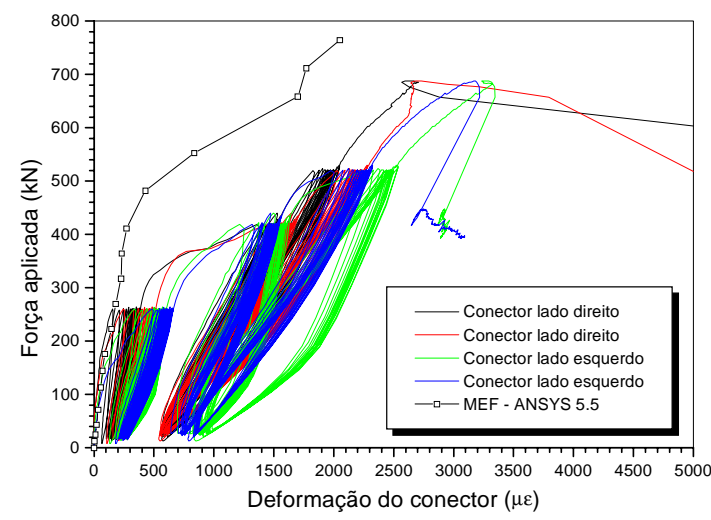

CP20

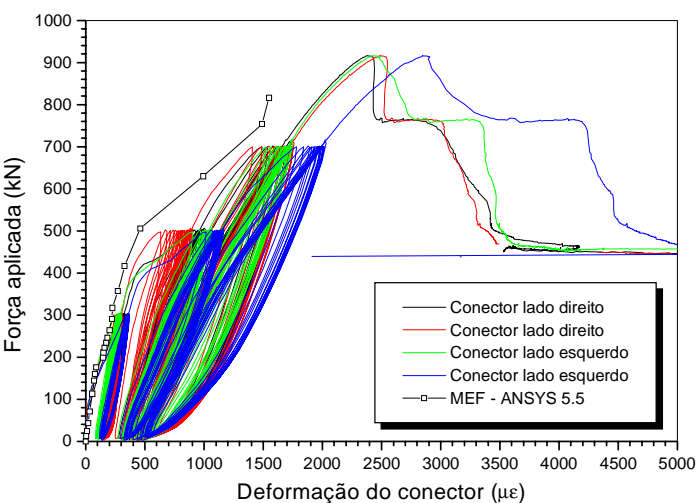

CP21

Figura A.38 - Deformação do conector nos corpos-de-prova CP20 e CP21

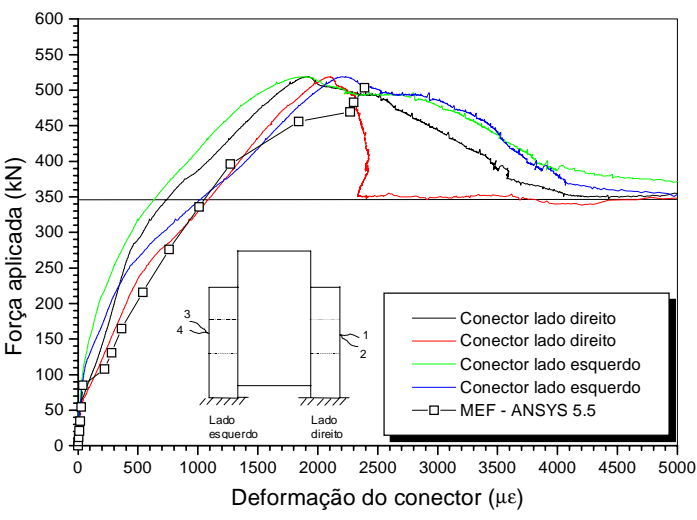

CP22

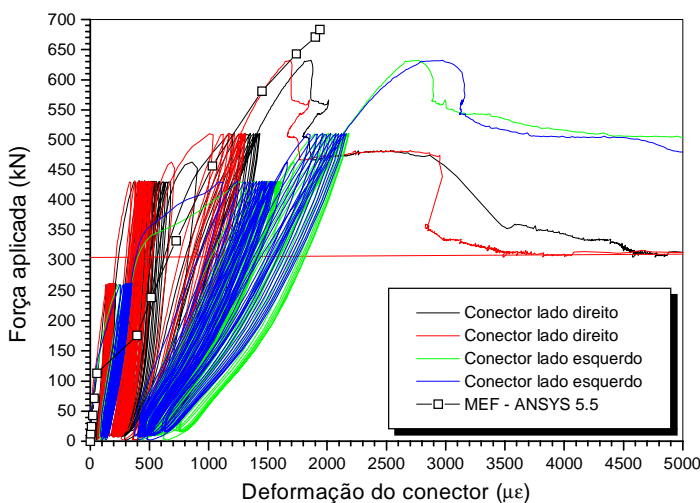

CP23

Figura A.39 - Deformação do conector nos corpos-de-prova CP22 e CP23 


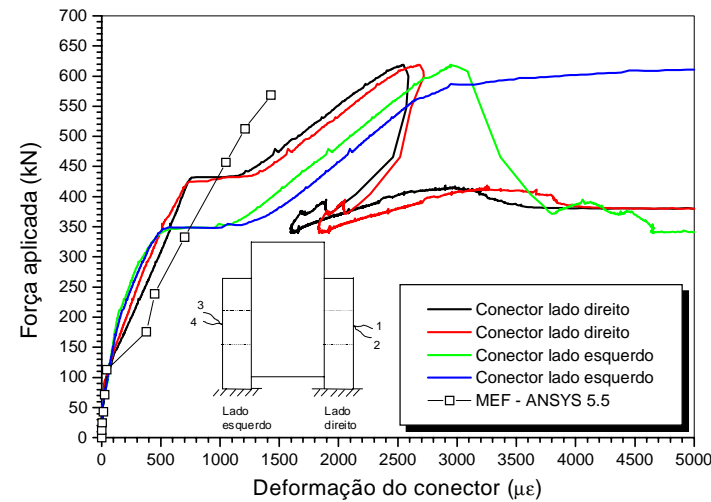

CP24

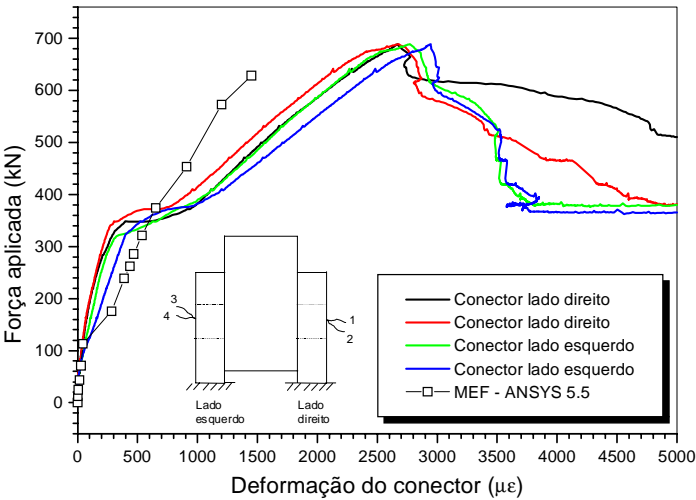

CP25

Figura A.40 - Deformação do conector nos corpos-de-prova CP24 e CP25

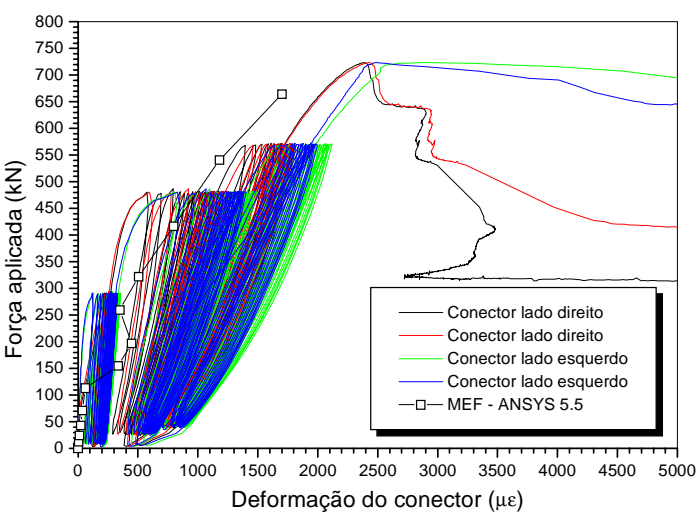

CP26

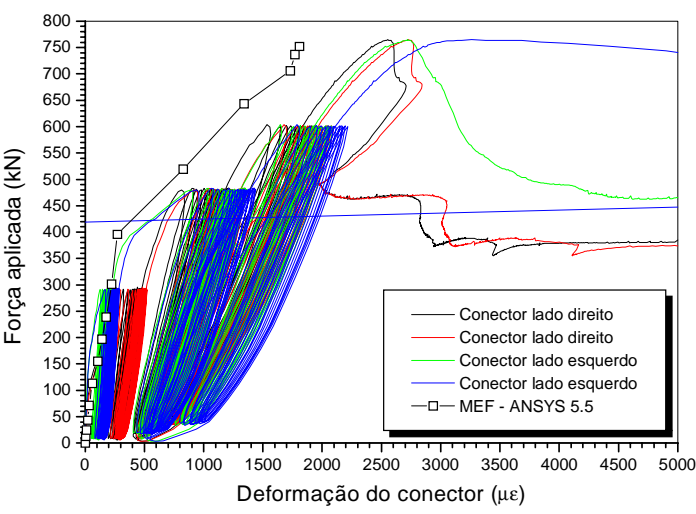

CP27

Figura A.41 - Deformação do conector nos corpos-de-prova CP26 e CP27

\section{A.3. Deformação nos estribos}

A seguir são apresentados os resultados obtidos dos extensômetros elétricos sobre a deformação nos estribos do corpo-de-prova de cisalhamento CP13. Pelo nível de deformação apresentado por essas leituras, pode-se afirmar que estes estribos foram pouco solicitados durante o carregamento do corpo-de-prova. 


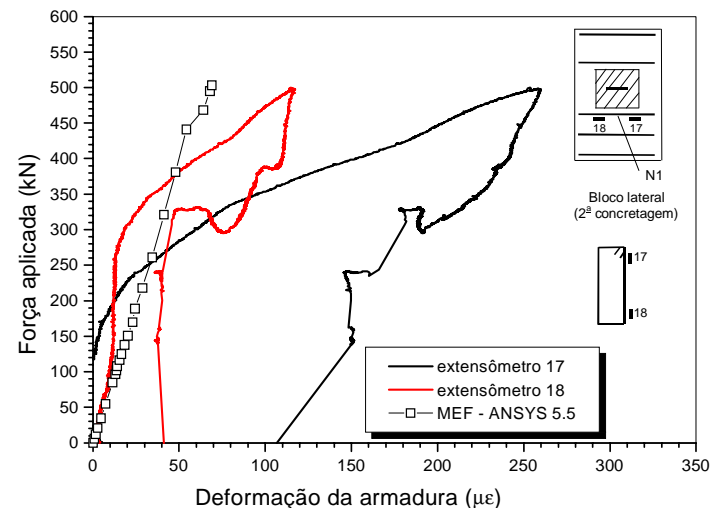

Peça pré-moldada lateral

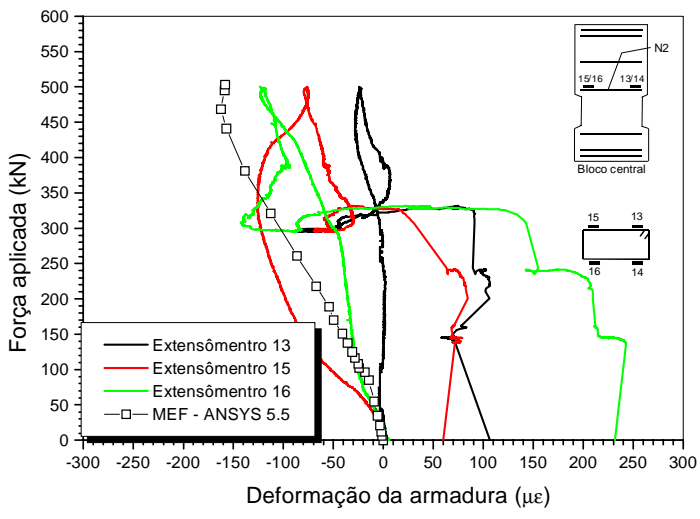

Peça pré-moldada central

Figura A.42 - Deformação dos estribos no corpo-de-prova CP13 


\section{Apêndice B - Comparação da Expressão Analítica com os Resultados dos Ensaios de Cisalhamento Direto}

A seguir são apresentados os gráficos obtidos da aplicação da expressão analítica desenvolvido no capítulo 5 deste trabalho a todos os ensaios de cisalhamento realizados com chave na ligação.
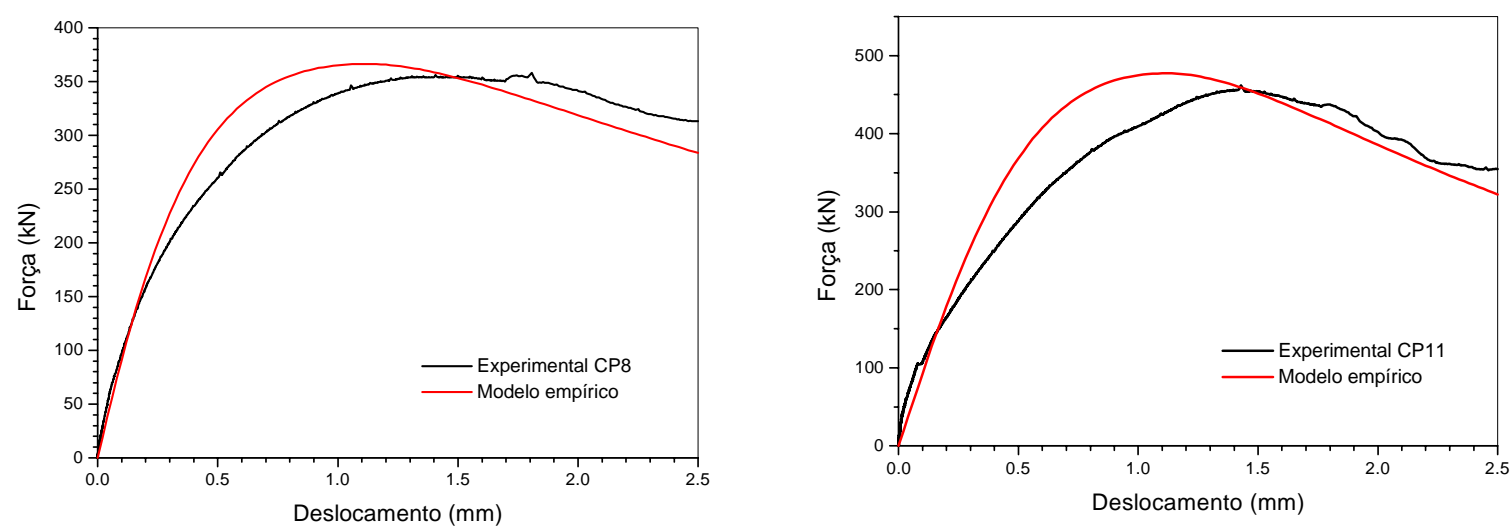

CP8

CP11

Figura B.1 - Comparação da expressão analítica com os resultados experimentais dos corpos-de-prova CP8 e CP11

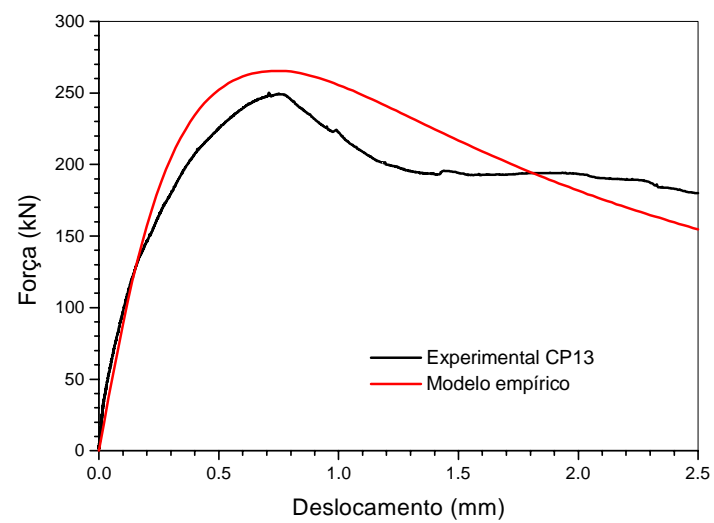

CP13

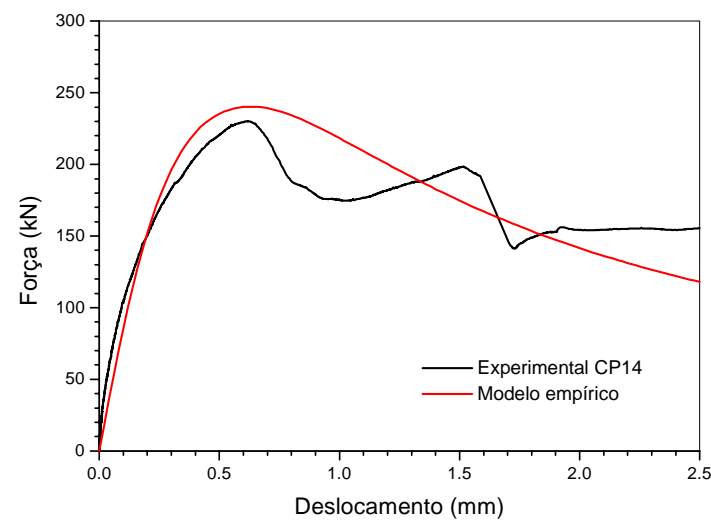

CP14

Figura B.2 - Comparação da expressão analítica com os resultados experimentais dos corpos-de-prova CP13 e CP14 


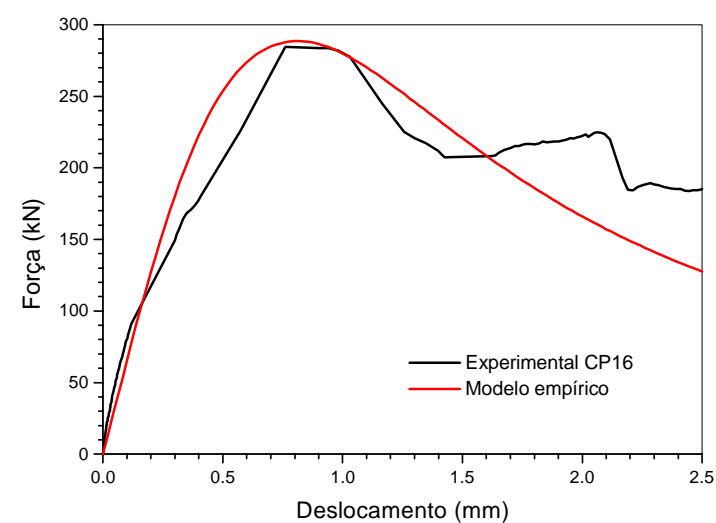

CP16

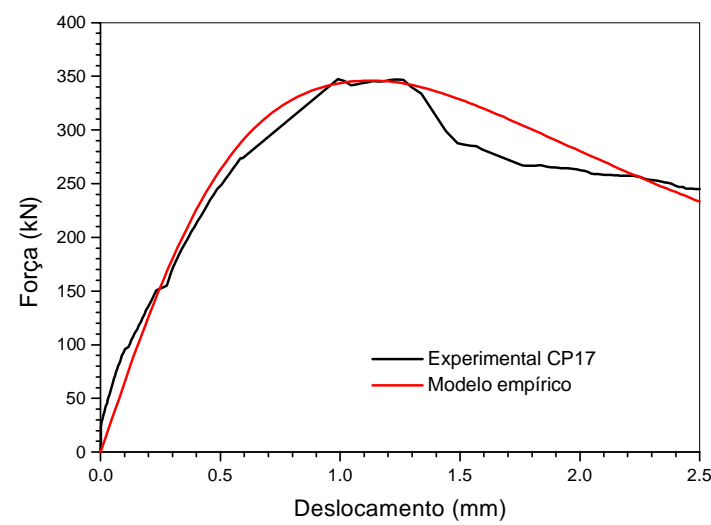

CP17

Figura B.3 - Comparação da expressão analítica com os resultados experimentais dos corpos-de-prova CP16 e CP17

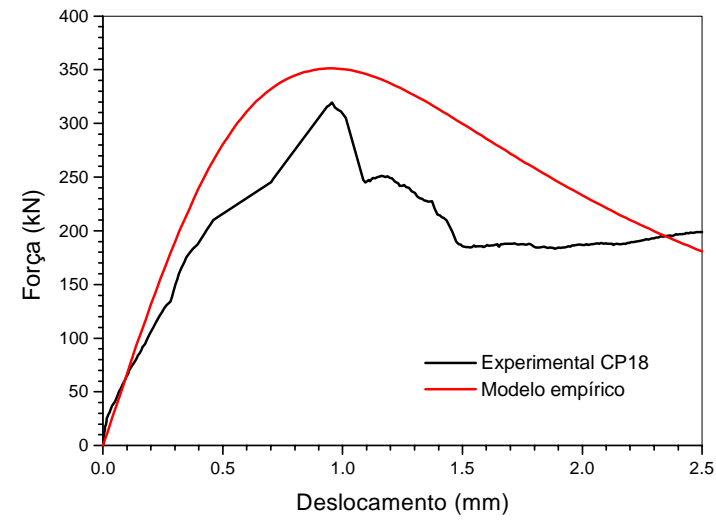

CP18

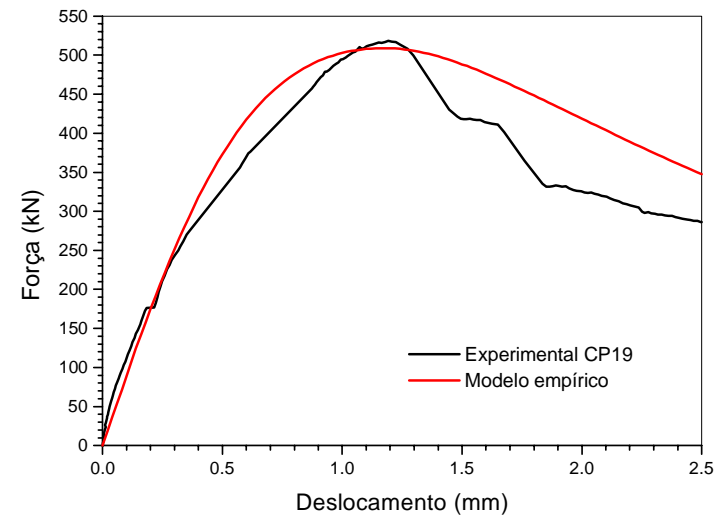

CP19

Figura B.4 - Comparação da expressão analítica com os resultados experimentais dos corpos-de-prova CP18 e CP19

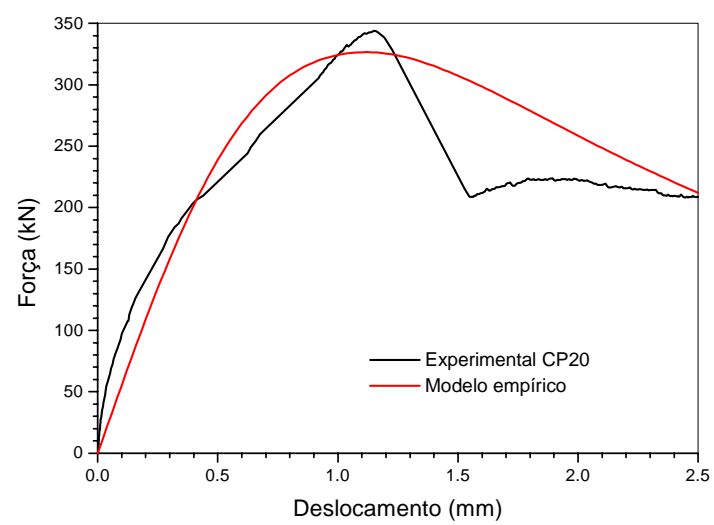

CP20

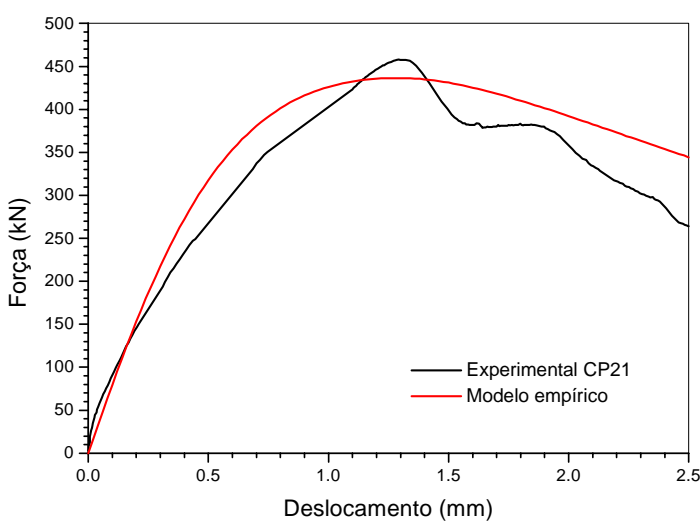

CP21

Figura B.5 - Comparação da expressão analítica com os resultados experimentais dos corpos-de-prova CP20 e CP21 


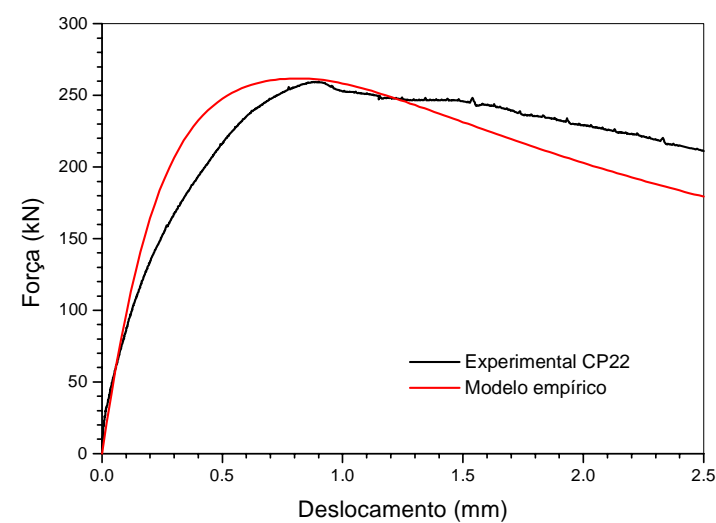

CP22

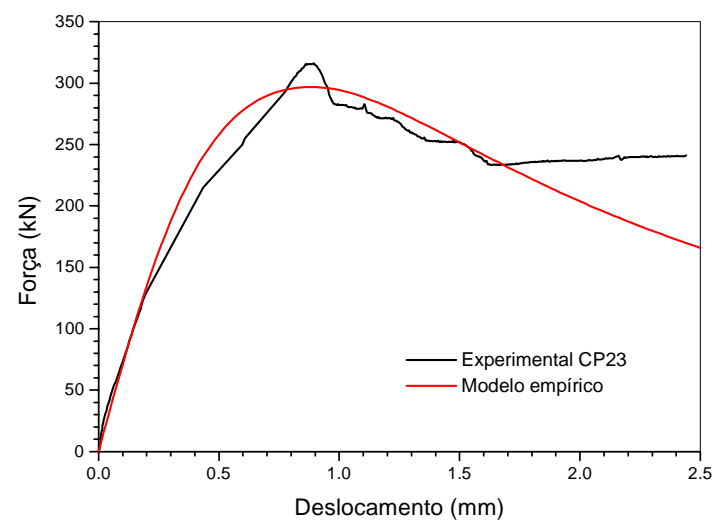

CP23

Figura B.6 - Comparação da expressão analítica com os resultados experimentais dos corpos-de-prova CP22 e CP23

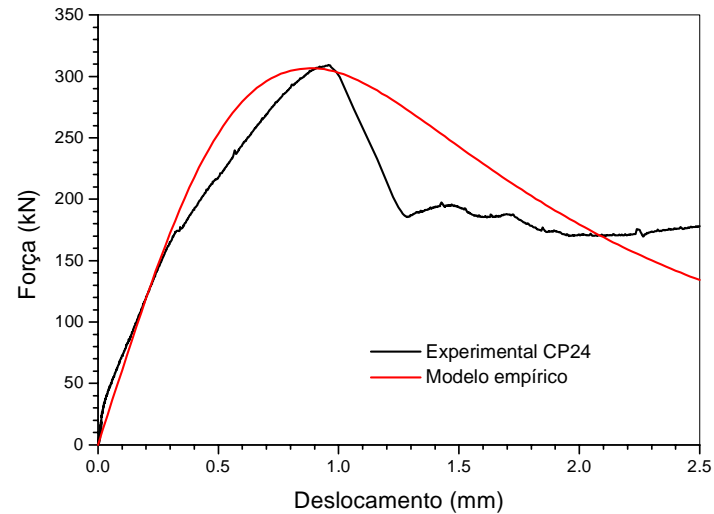

CP24

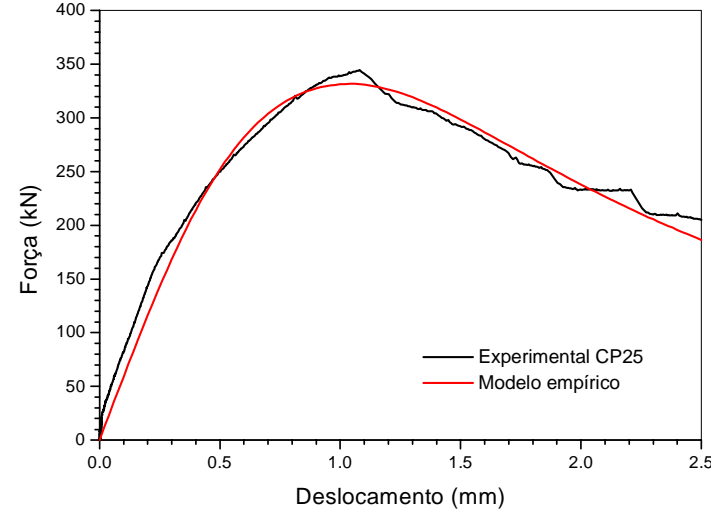

CP25

Figura B.7 - Comparação da expressão analítica com os resultados experimentais dos corpos-de-prova CP24 e CP25

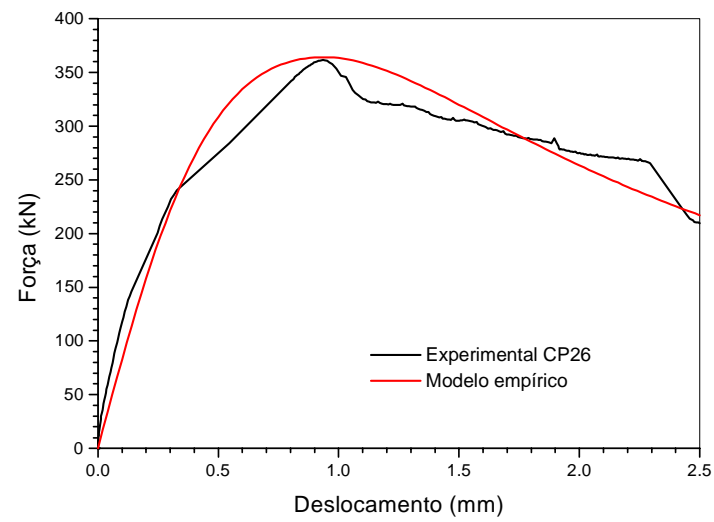

CP26

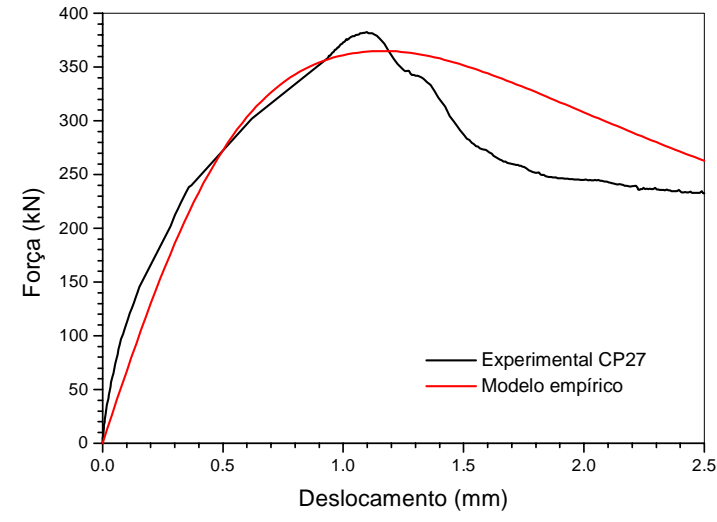

CP27

Figura B.8 - Comparação da expressão analítica com os resultados experimentais dos corpos-de-prova CP26 e CP27 


\section{Apêndice C - Comparação do Modelo Mecânico de KANEKO (1992) com os Resultados dos Ensaios de Cisalhamento Direto}

A seguir são apresentados os gráficos obtidos da aplicação do modelo de KANEKO (1992) em todos os ensaios de cisalhamento direto realizados com chave na ligação.

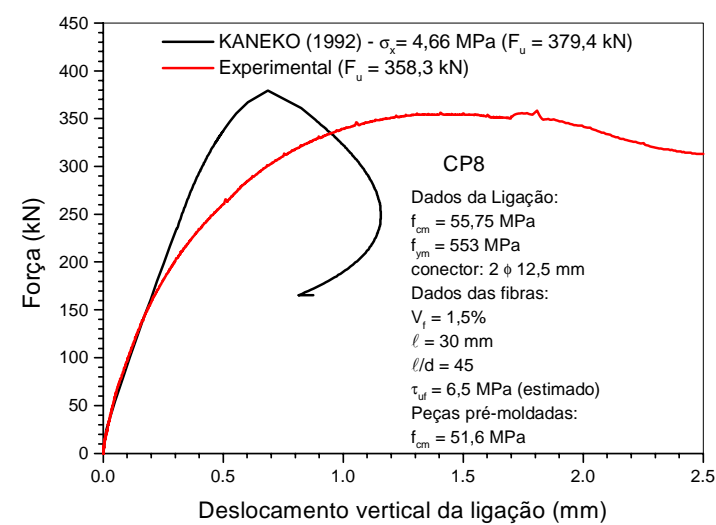

CP8

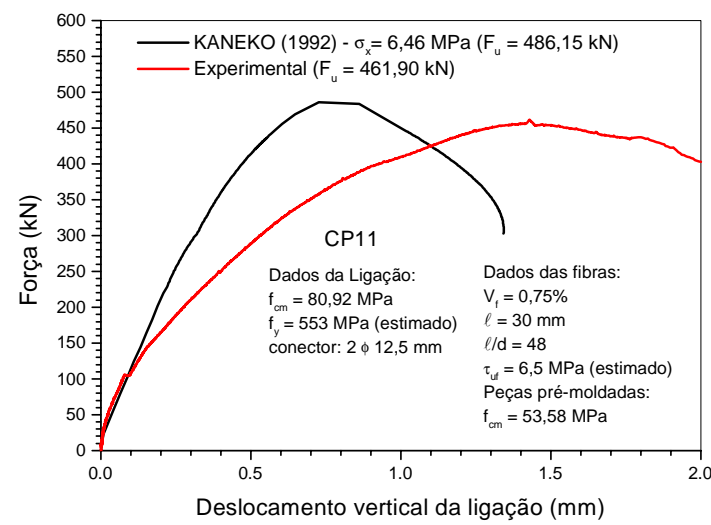

CP11

Figura C.1 - Comparação do modelo de KANEKO (1992) com os resultados experimentais dos corpos-de-prova CP8 e CP11

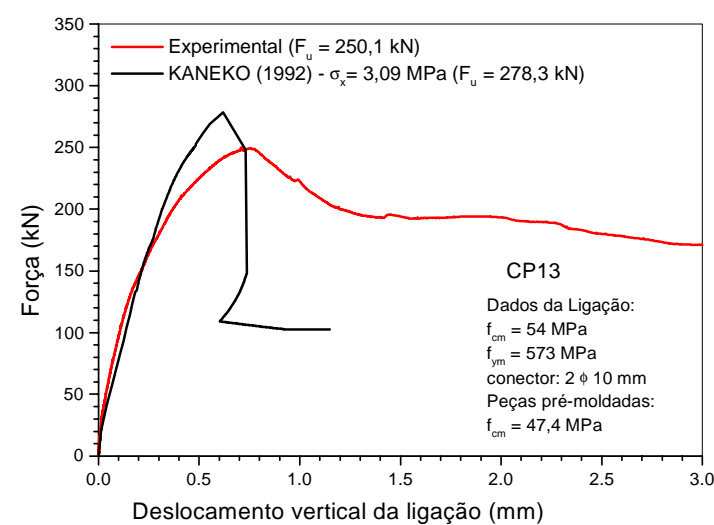

CP13

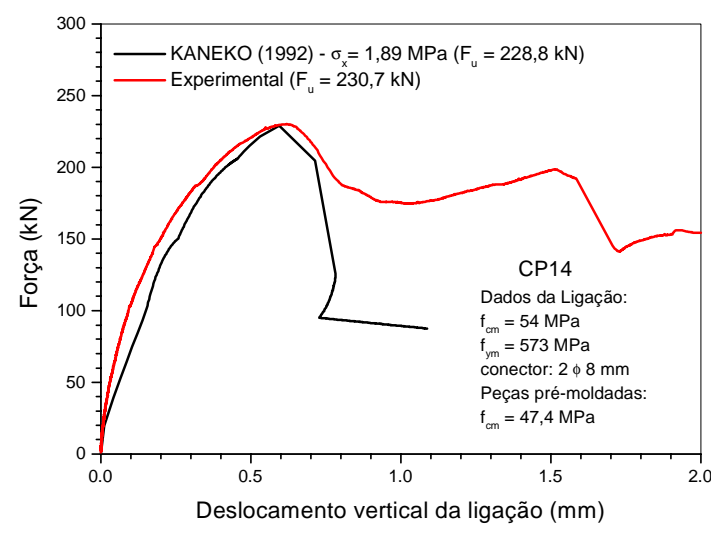

CP14

Figura C.2 - Comparação do modelo de KANEKO (1992) com os resultados experimentais dos corpos-de-prova CP13 e CP14 


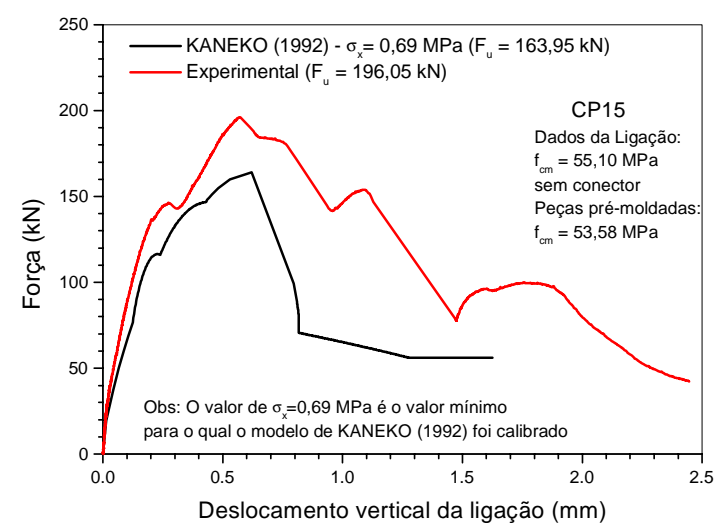

CP15

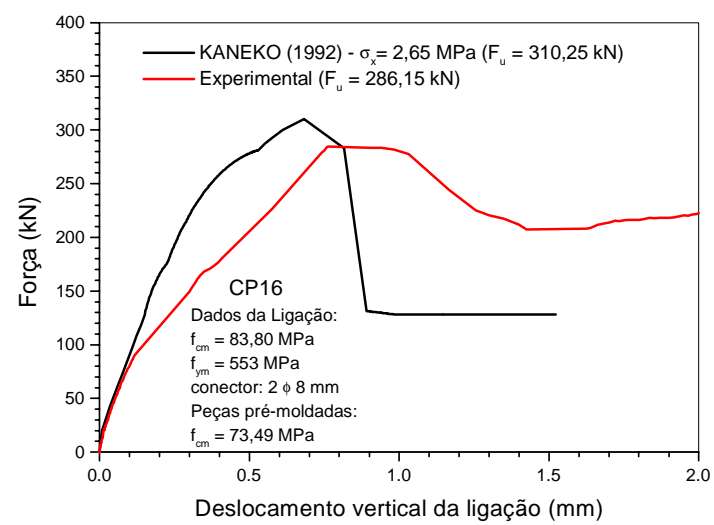

CP16

Figura C.3 - Comparação do modelo de KANEKO (1992) com os resultados experimentais dos corpos-de-prova CP15 e CP16

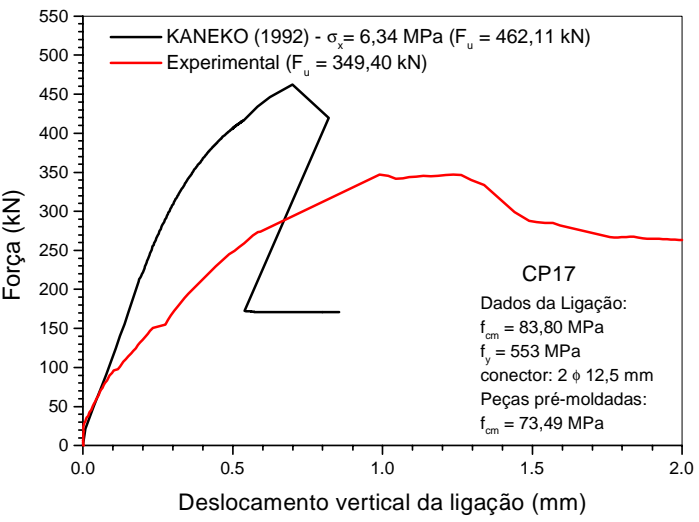

CP17

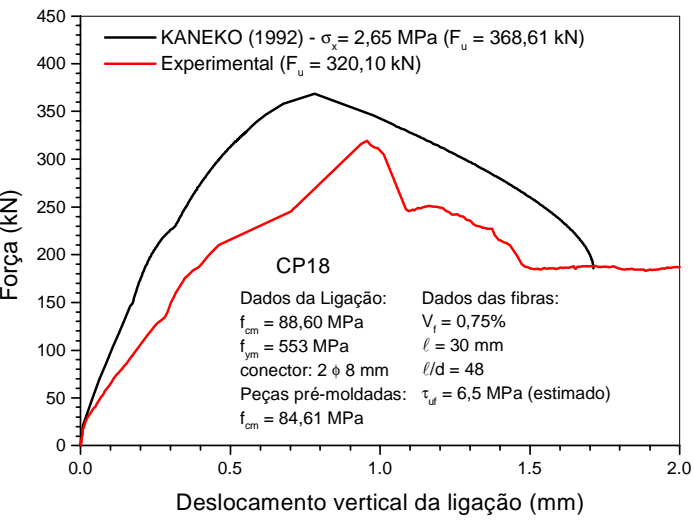

CP18

Figura C.4 - Comparação do modelo de KANEKO (1992) com os resultados experimentais dos corpos-de-prova CP17 e CP18

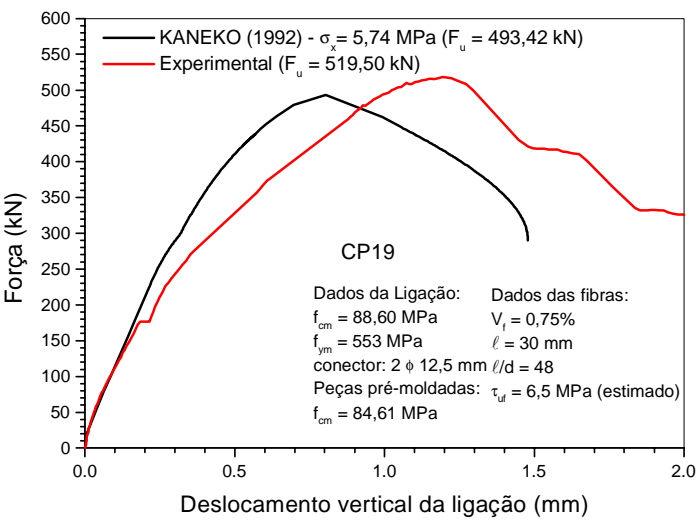

CP19

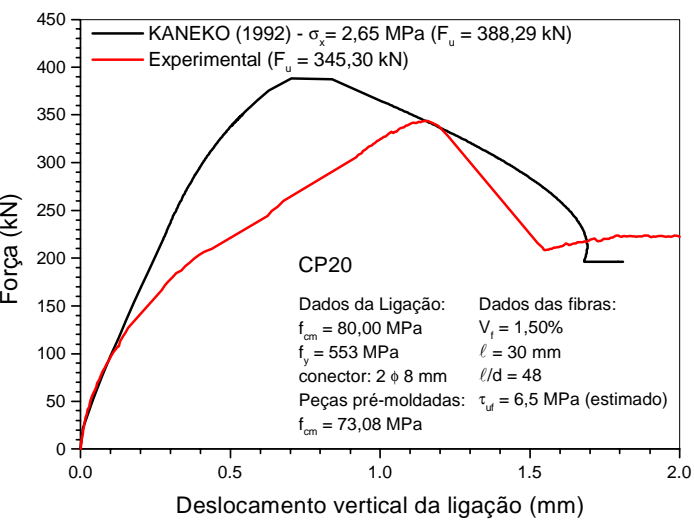

CP20

Figura C.5 - Comparação do modelo de KANEKO (1992) com os resultados experimentais dos corpos-de-prova CP19 e CP20 


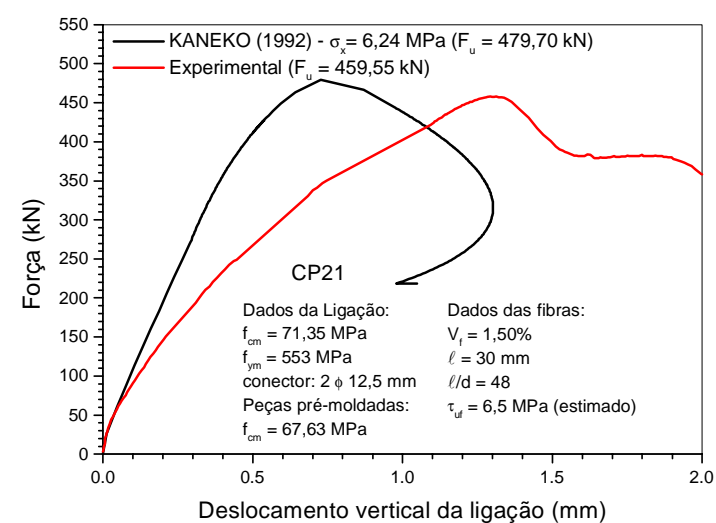

CP21

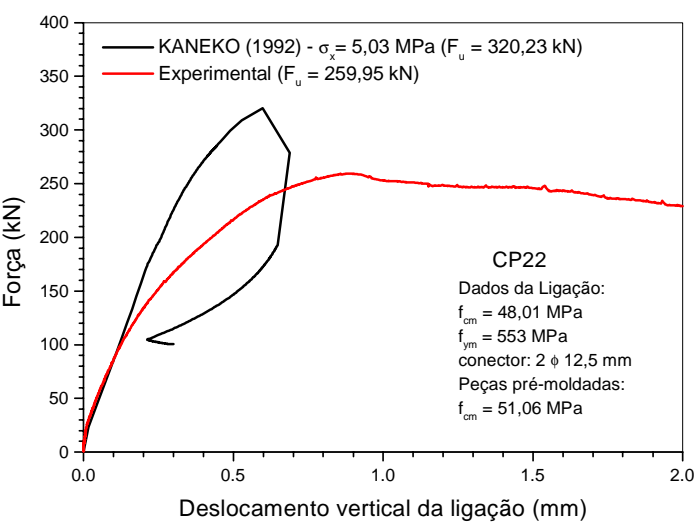

CP22

Figura C.6 - Comparação do modelo de KANEKO (1992) com os resultados experimentais dos corpos-de-prova CP21 e CP22

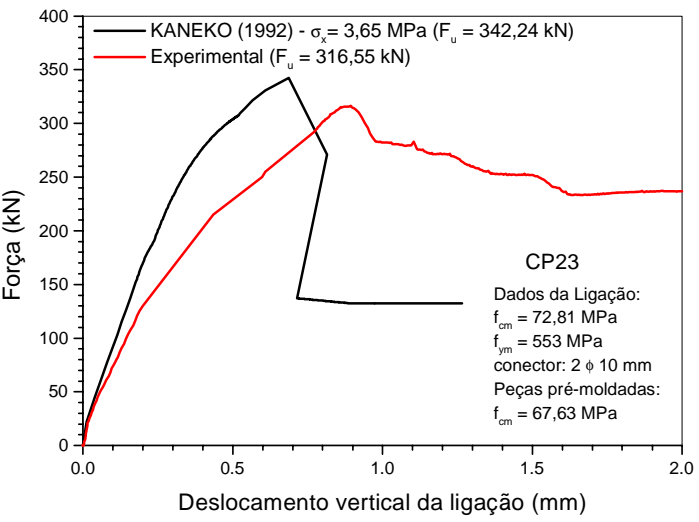

CP23

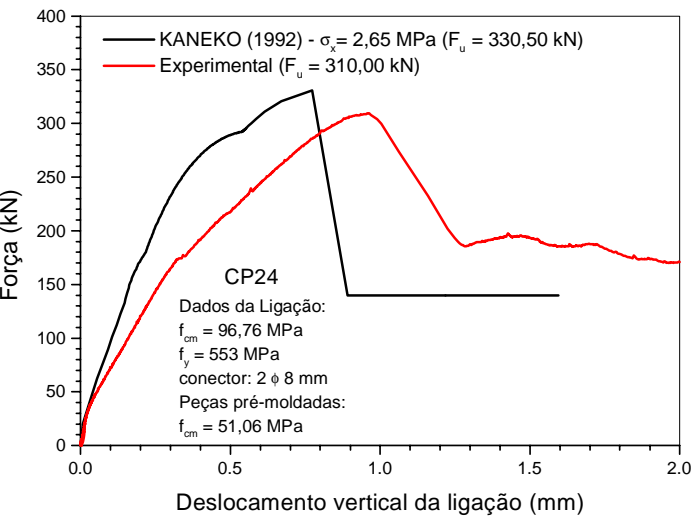

CP24

Figura C.7 - Comparação do modelo de KANEKO (1992) com os resultados experimentais dos corpos-de-prova CP23 e CP24

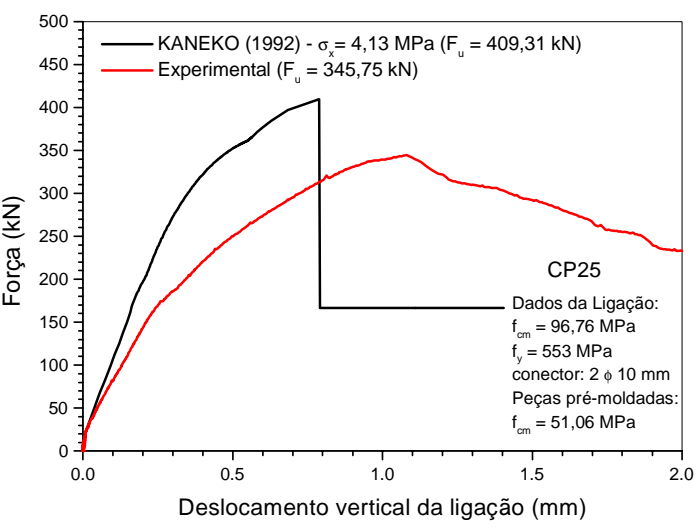

CP25

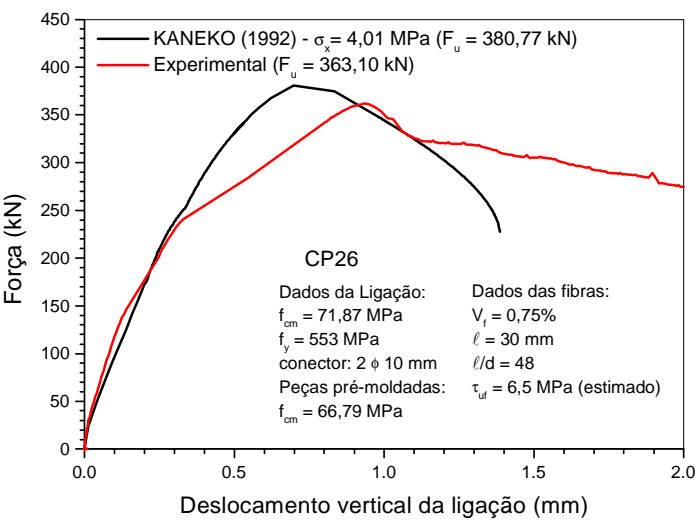

CP26

Figura C.8 - Comparação do modelo de KANEKO (1992) com os resultados experimentais dos corpos-de-prova CP25 e CP26 


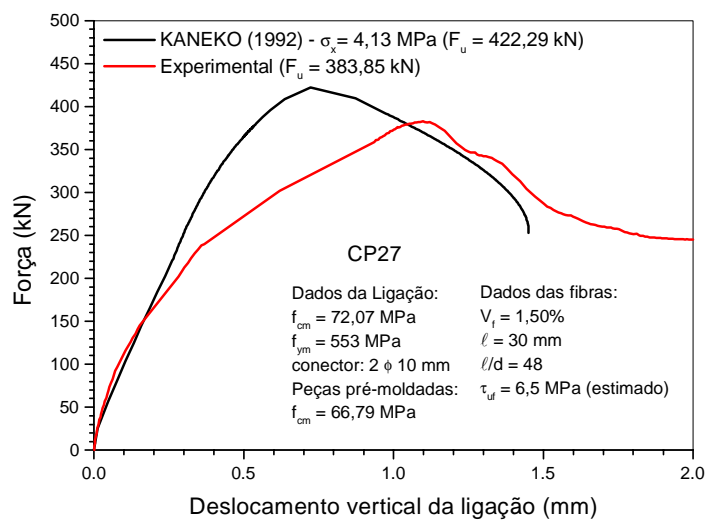

CP27

Figura C.9 - Comparação do modelo de KANEKO (1992) com os resultados experimentais do corpo-de-prova CP27 


\section{Apêndice D - Resultados dos Ensaios nas Vigas Compostas}

Neste apêndice são mostrados todos os resultados obtidos dos ensaios das vigas compostas analisadas no capítulo 6. Também são mostrados os resultados obtidos da simulação numérica no programa ANSYS.

\section{D.1. Viga 1 : monolítica}
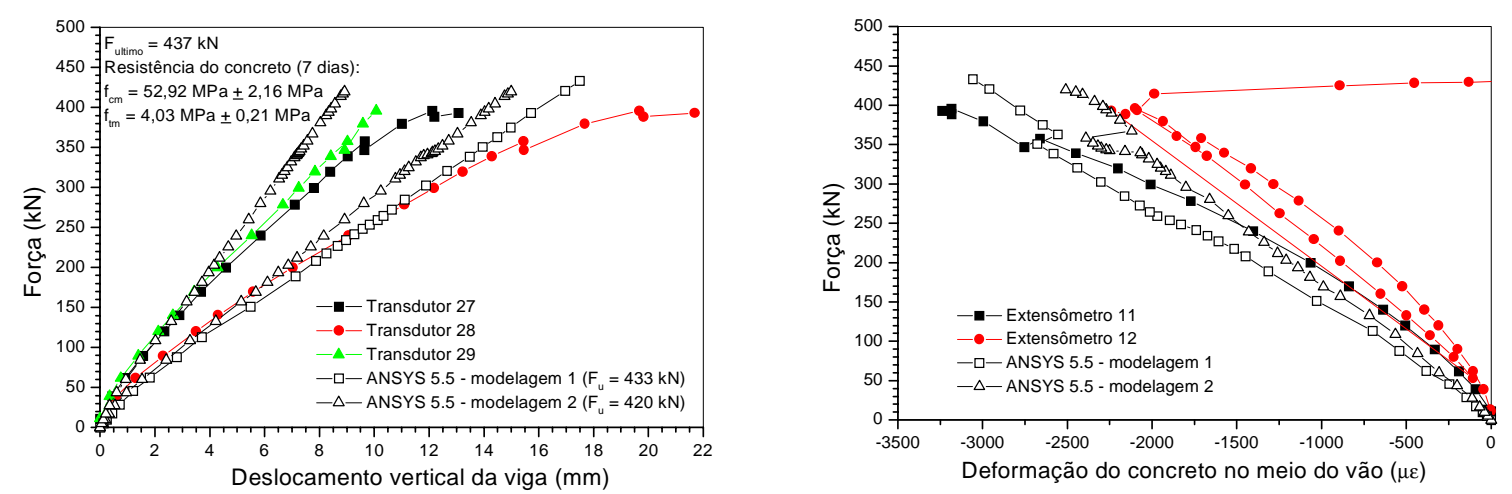

Figura D.1 - Flecha e deformação no concreto
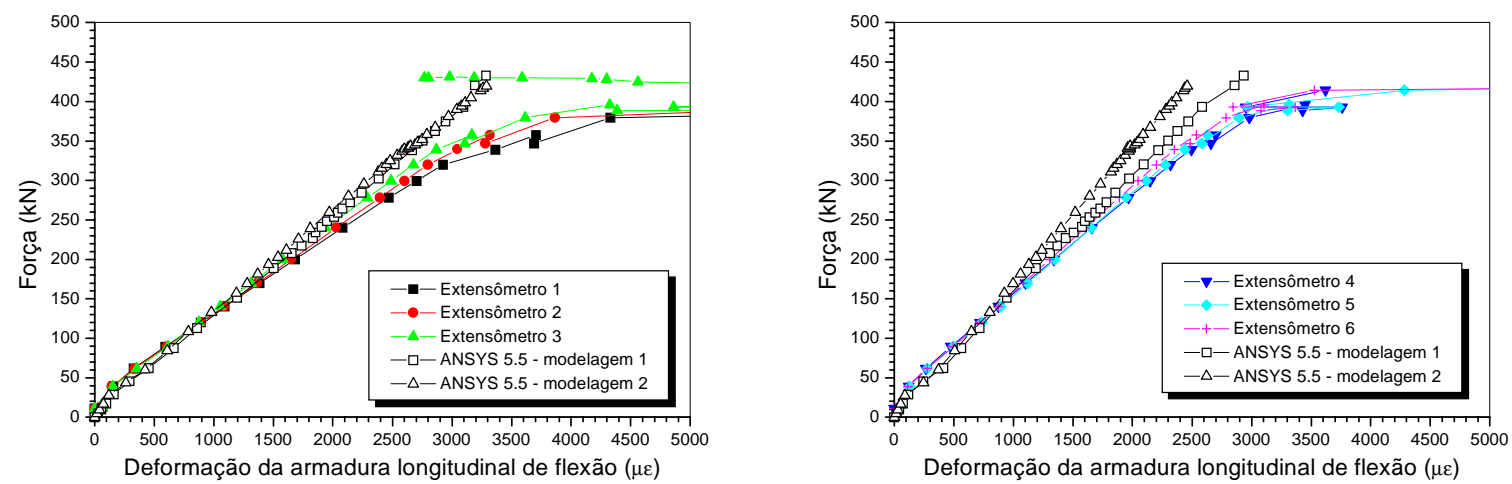

Figura D.2 - Deformação na armadura longitudinal de flexão 

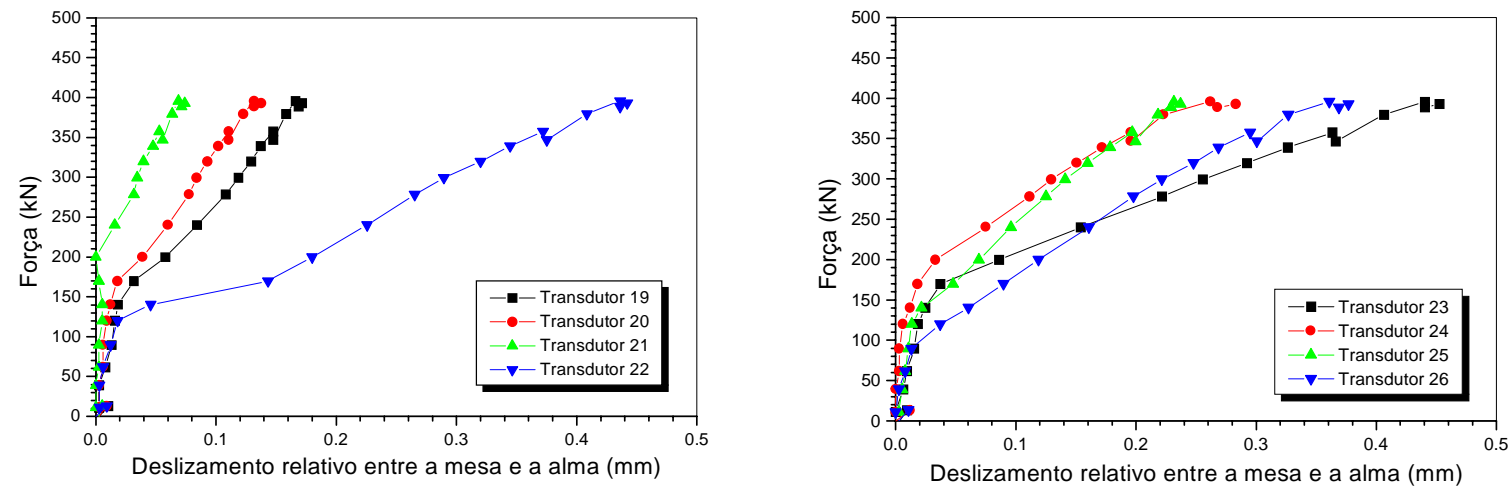

Figura D.3 - Transdutores horizontais

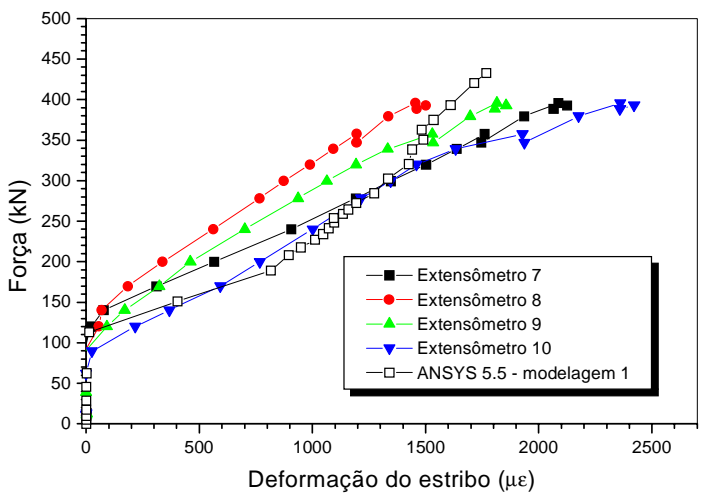

Figura D.4 - Deformação no estribo

\section{D.2. Viga 2 : Laje pré-moldada com nichos espaçados de $28 \mathrm{~cm}$}
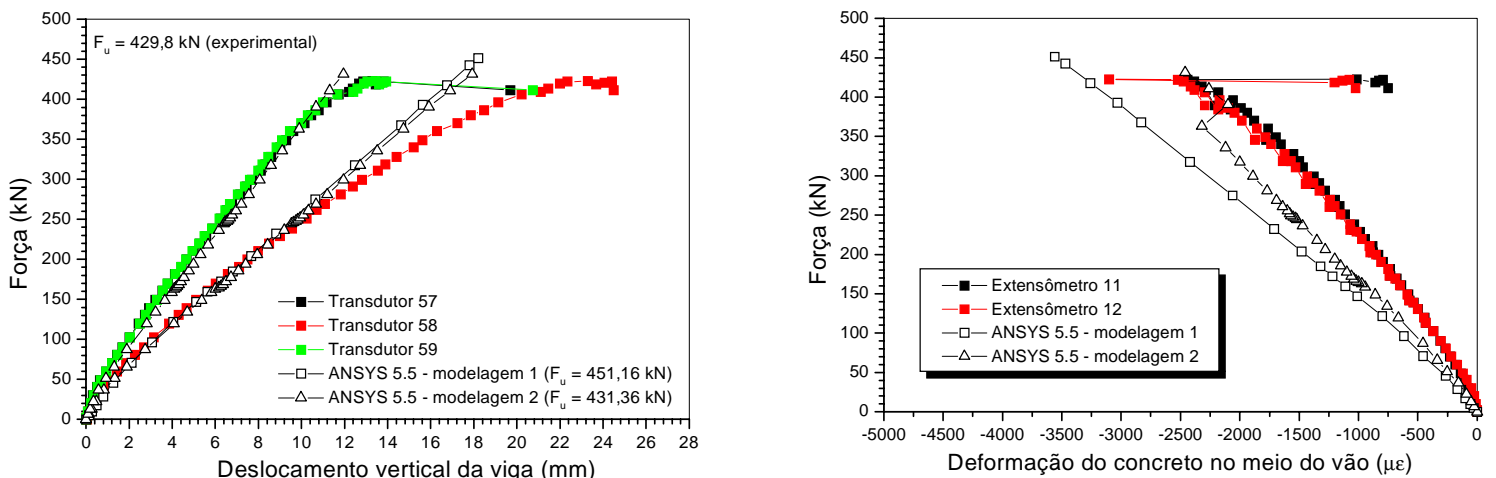

Figura D.5 - Flecha e deformação no concreto 

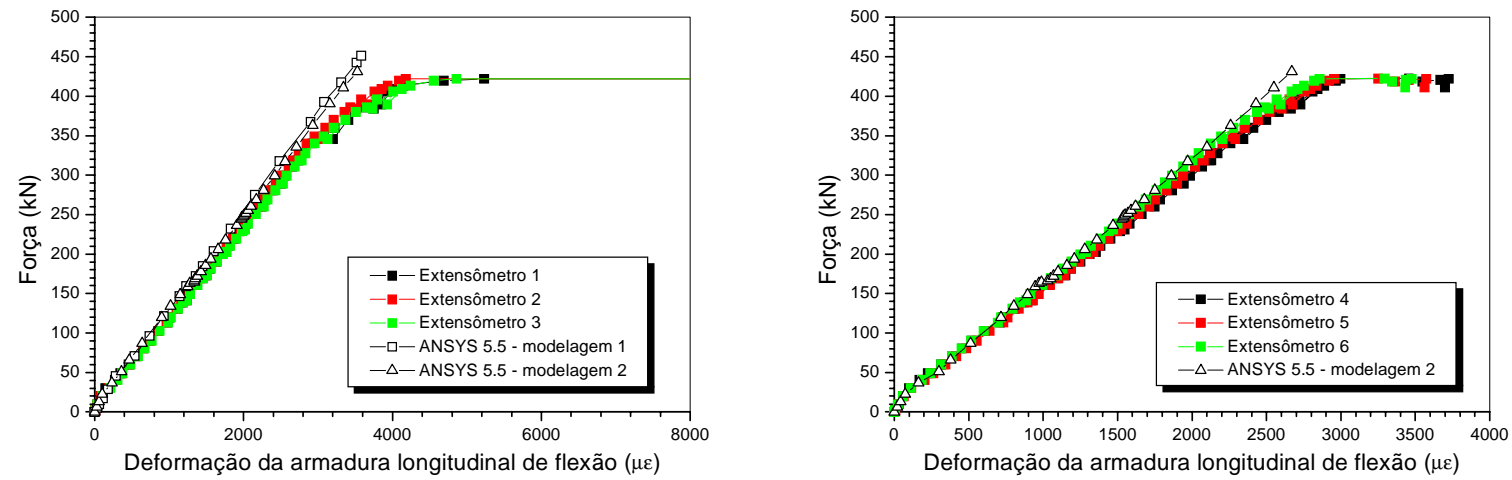

Figura D.6 - Deformação na armadura longitudinal de flexão
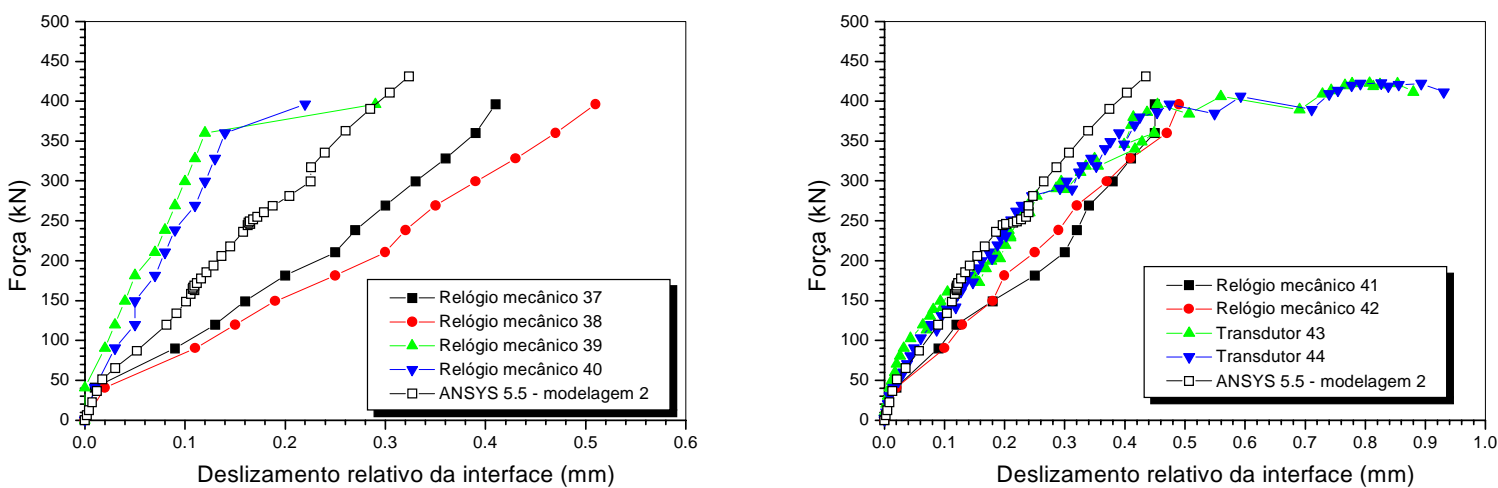

Figura D.7 - Deslizamento relativo entre a viga e a laje pré-moldadas
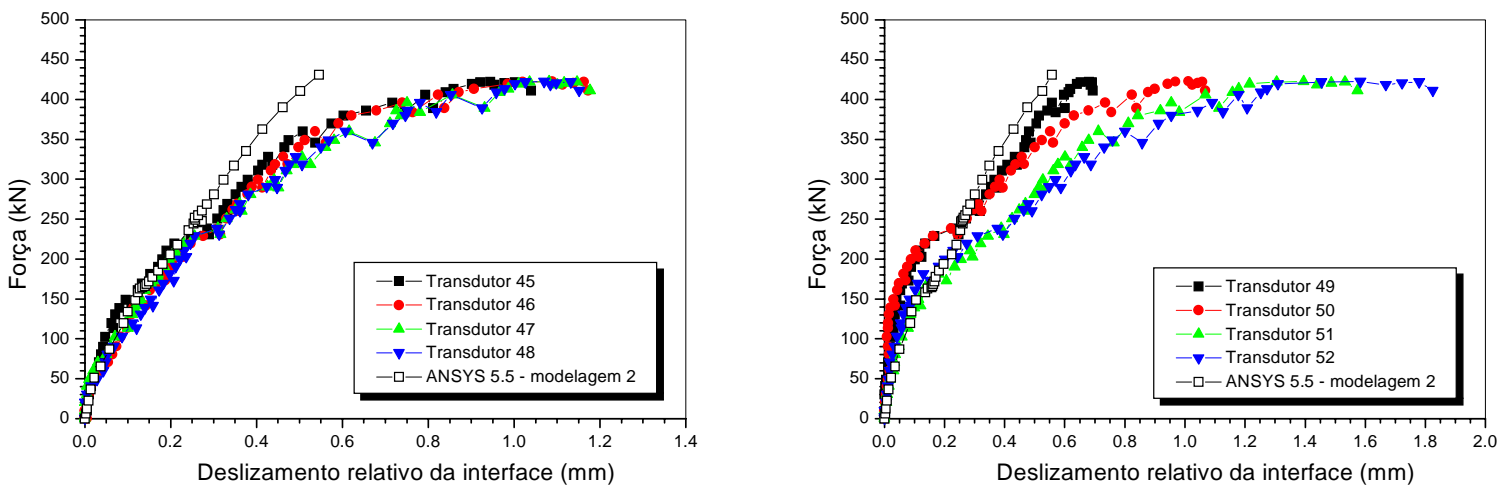

Figura D.8 - Deslizamento relativo entre a viga e a laje pré-moldadas 

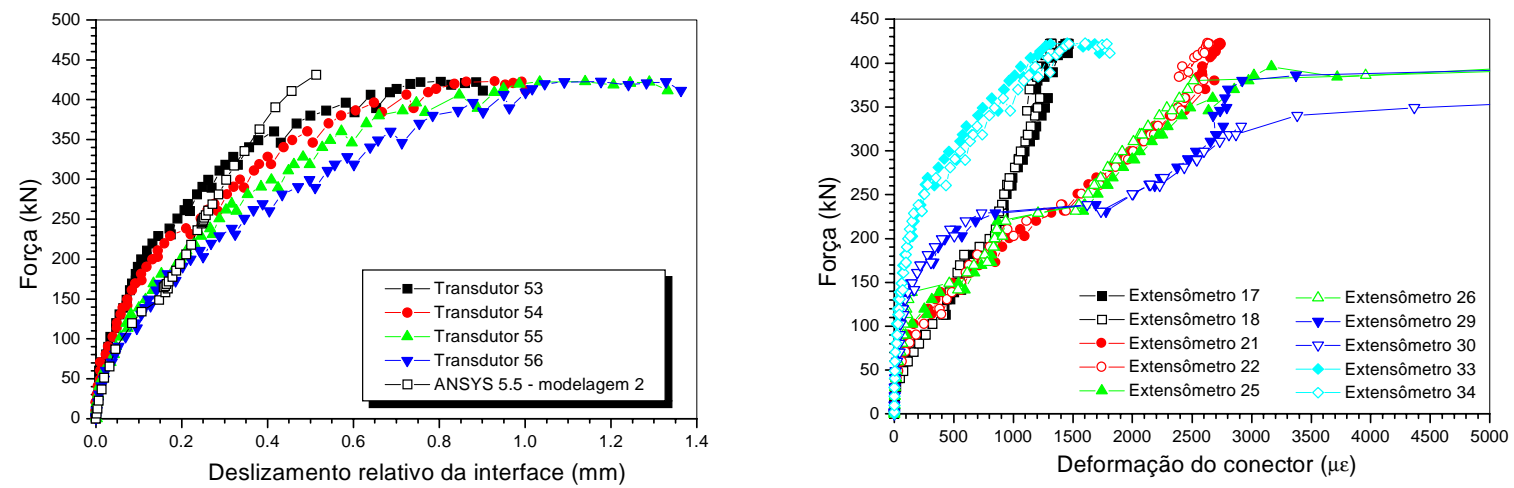

Figura D.9 - Deslizamento relativo na entre a viga e a laje pré-moldadas e deformação nos conectores
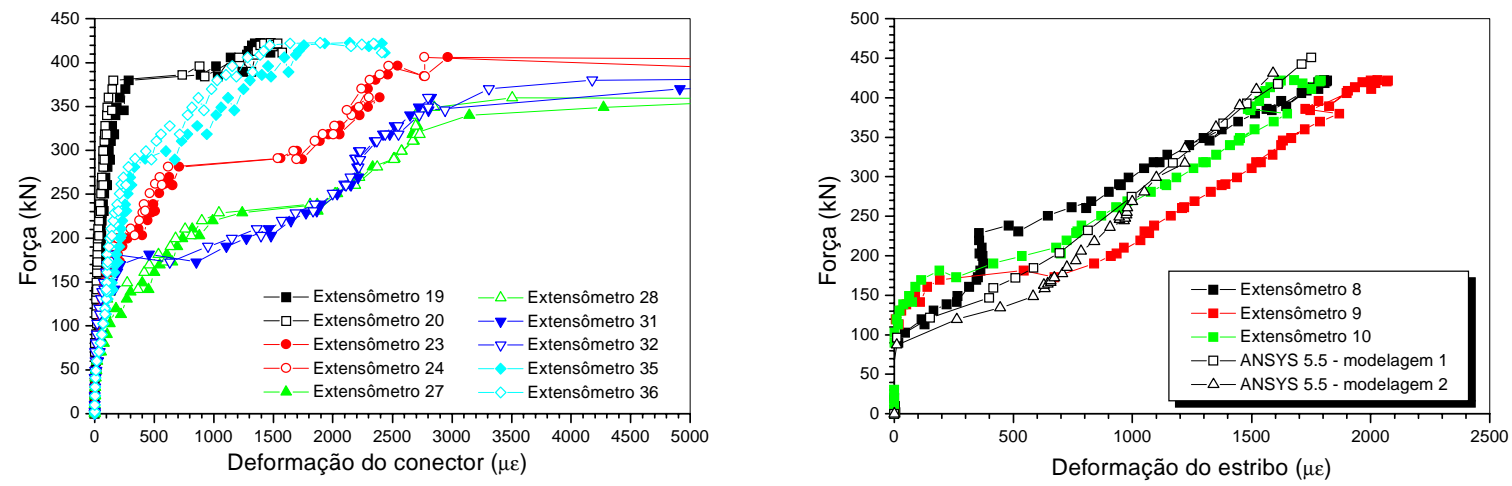

Figura D.10 - Deformação nos conectores e nos estribos da viga pré-moldada

\section{D.3. Viga 3 : Laje pré-moldada com nichos espaçados de $42 \mathrm{~cm}$}
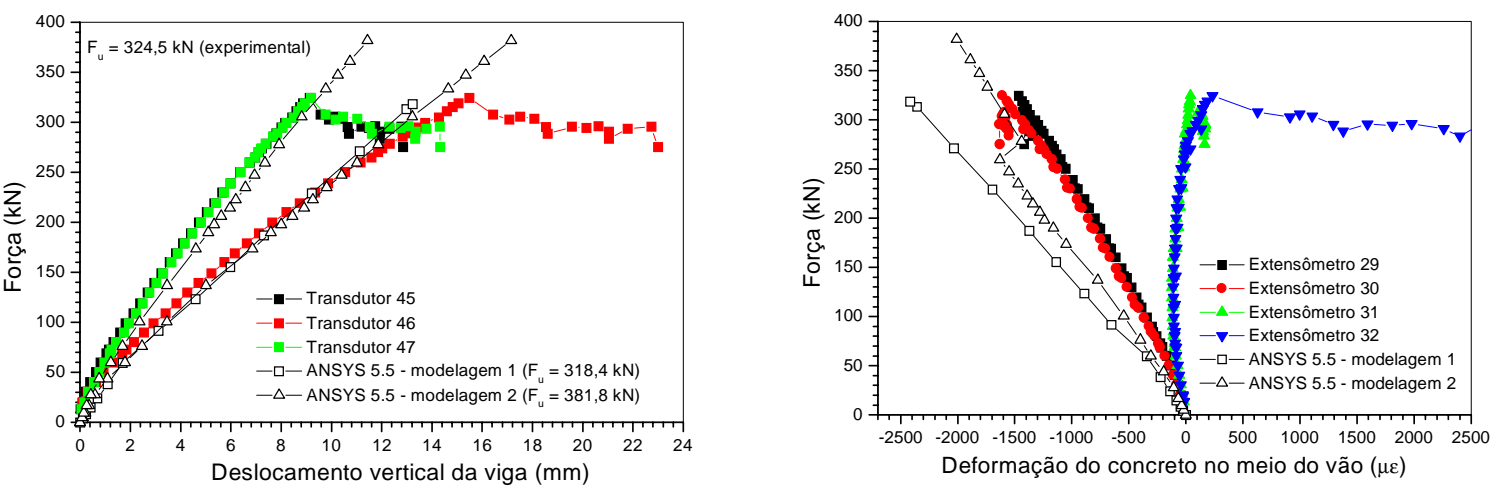

Figura D.11 - Flecha e deformação no concreto 

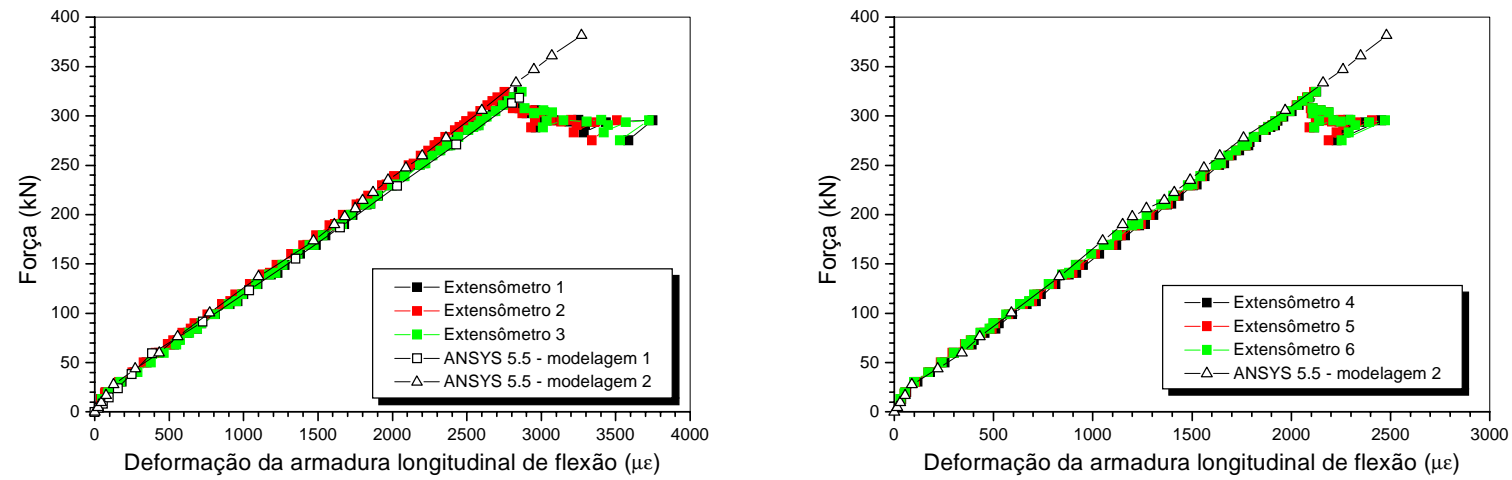

Figura D.12 - Deformação na armadura longitudinal de flexão
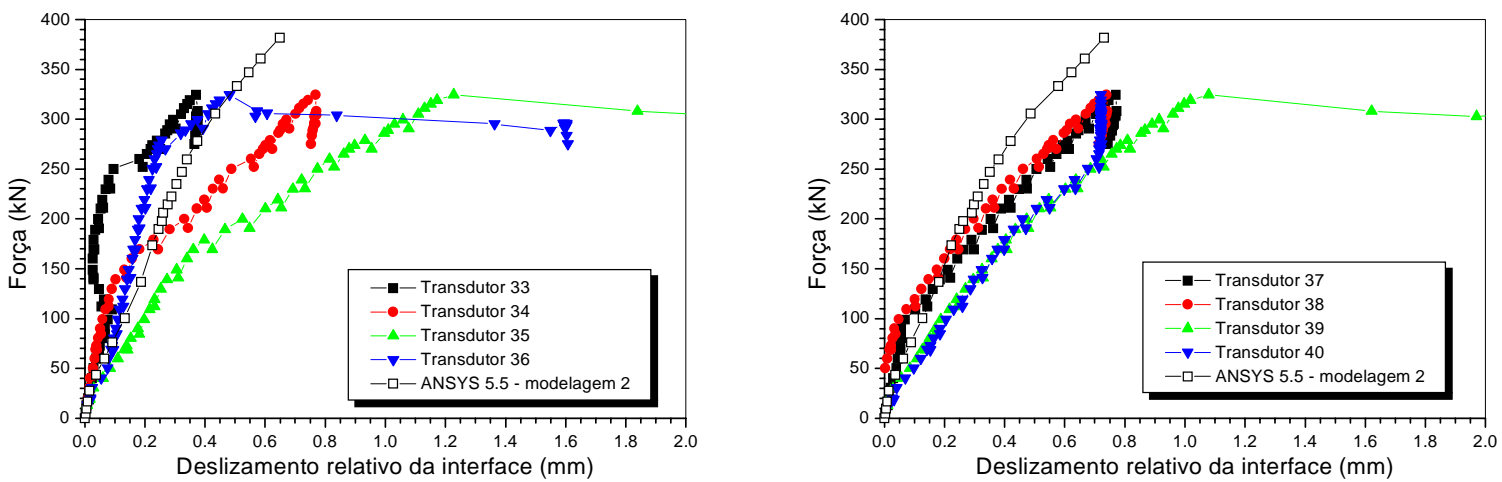

Figura D.13 - Deslizamento relativo entre a viga e a laje pré-moldadas
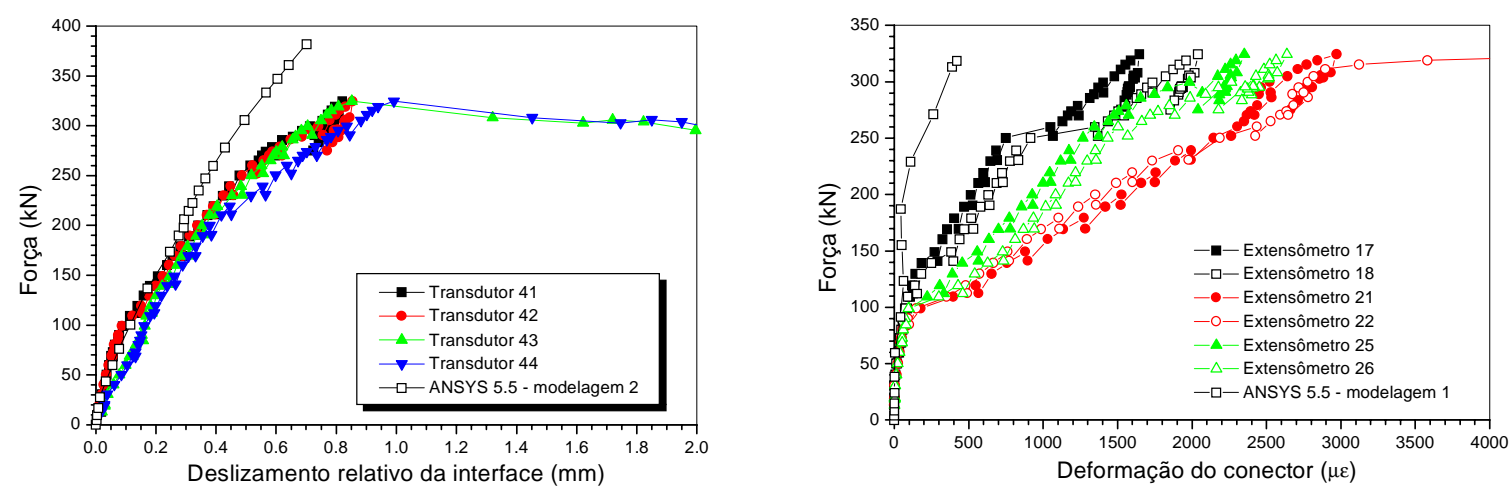

Figura D.14 - Deslizamento relativo entre a viga e a laje pré-moldadas e deformação nos conectores 

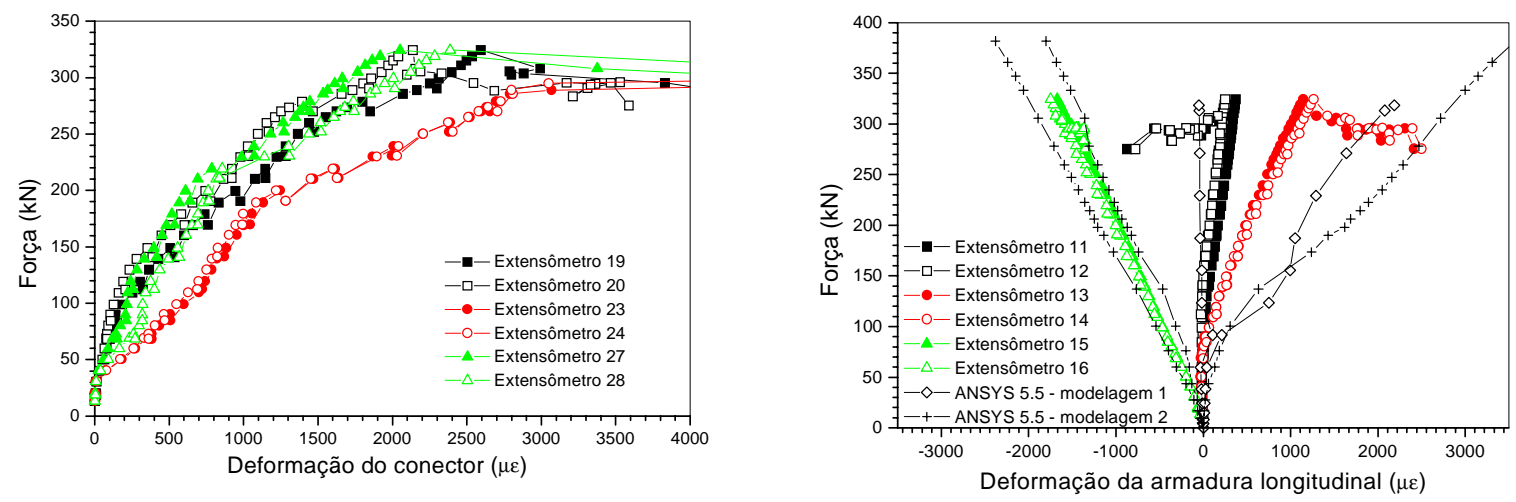

Figura D.15 - Deformação nos conectores e na armadura longitudinal

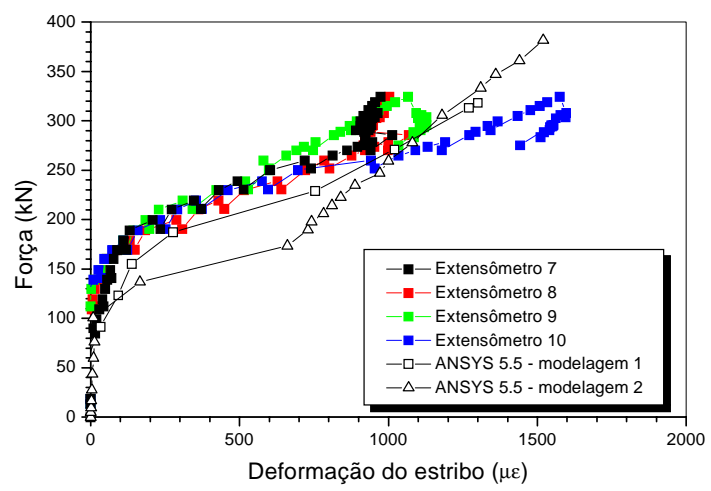

Figura D.16 - Deformação nos estribos da viga pré-moldada

\section{D.4. Viga 4 : Laje pré-moldada com nichos espaçados de $56 \mathrm{~cm}$}
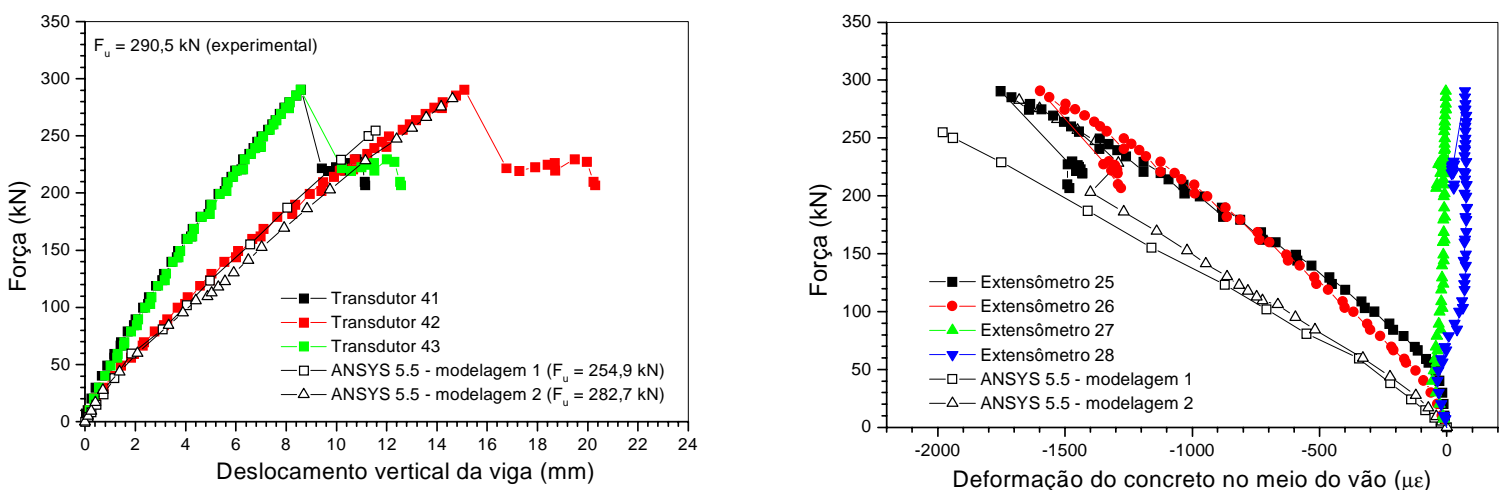

Figura D.17 - Flecha e deformação no concreto 

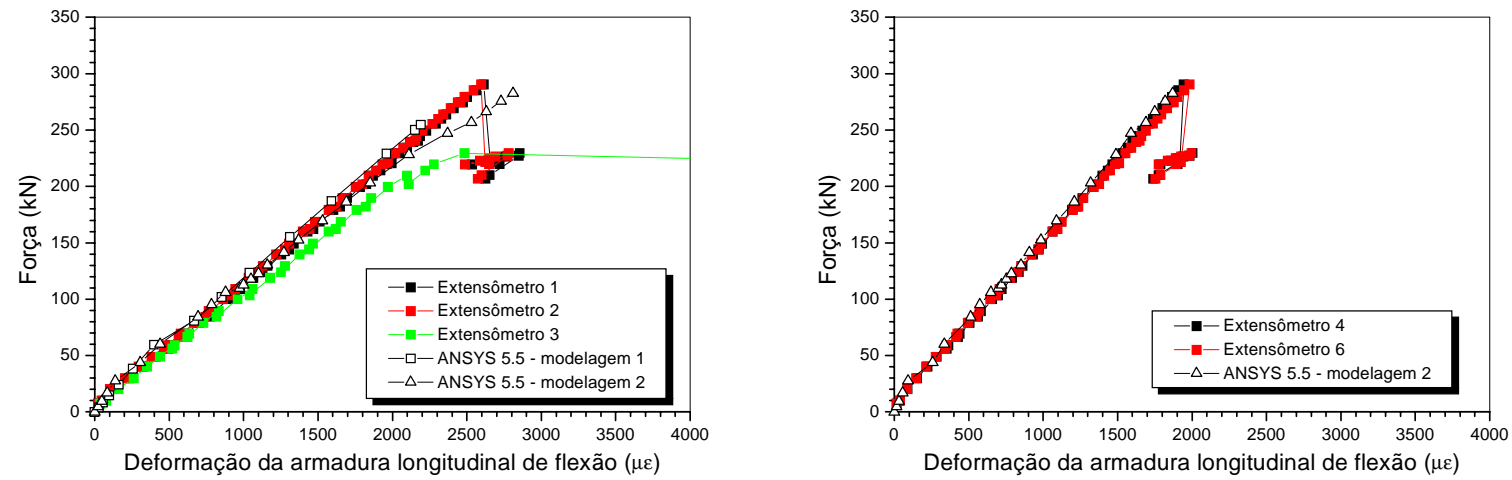

Figura D.18 - Deformação na armadura longitudinal de flexão
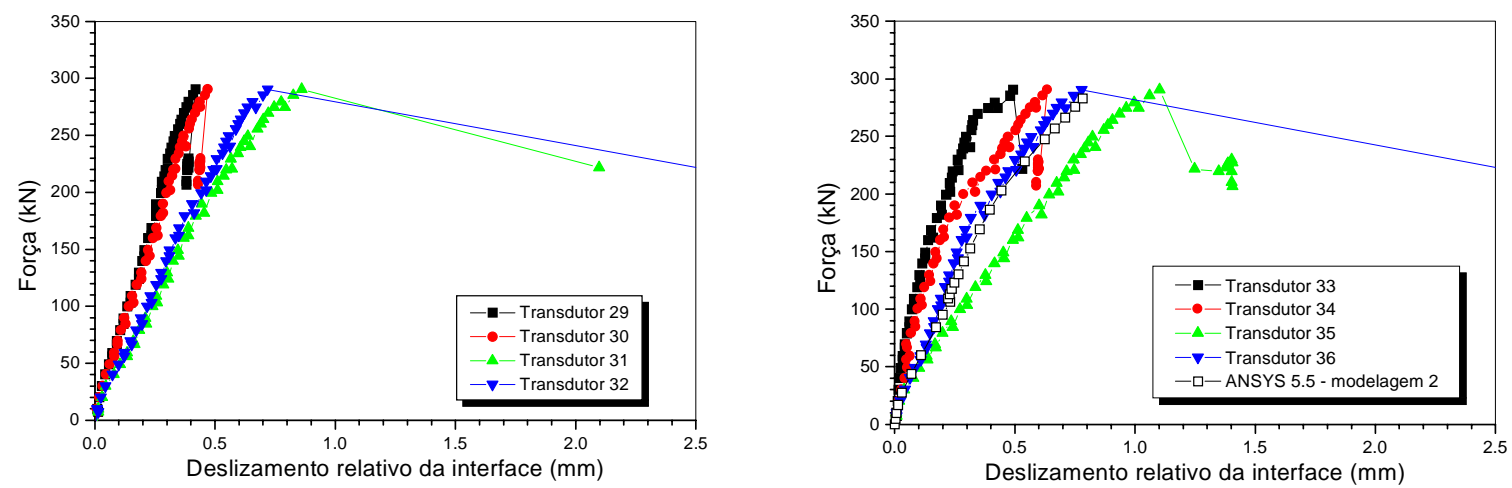

Figura D.19 - Deslizamento relativo entre a viga e a laje pré-moldadas
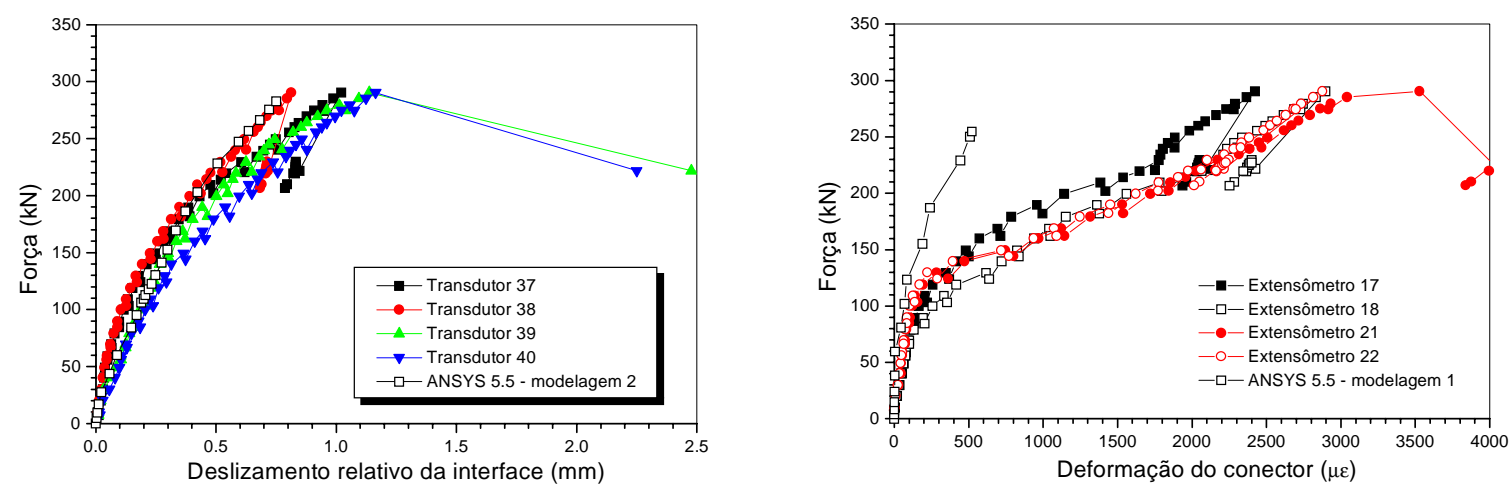

Figura D.20 - Deslizamento relativo entre a viga e a laje pré-moldadas e deformação nos conectores 

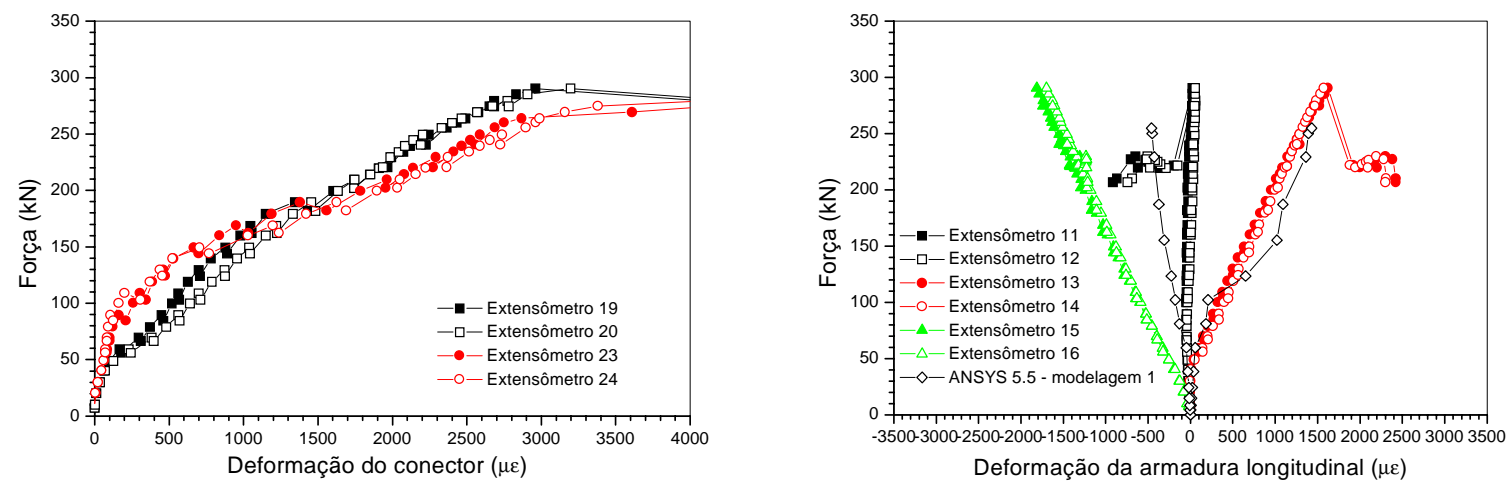

Figura D.21 - Deformação nos conectores e na armadura longitudinal

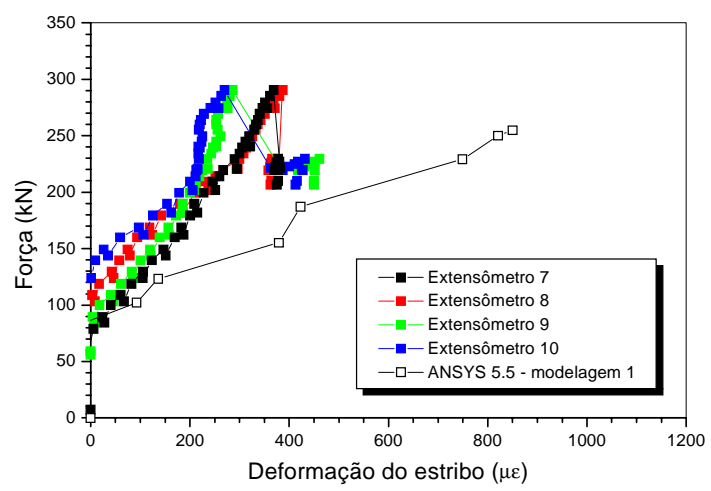

Figura D.22 - Deformação nos estribos da viga pré-moldada

\section{D.5. Viga 5 : Laje pré-moldada com nichos espaçados de $42 \mathrm{~cm}$ (carregamento cíclico)}
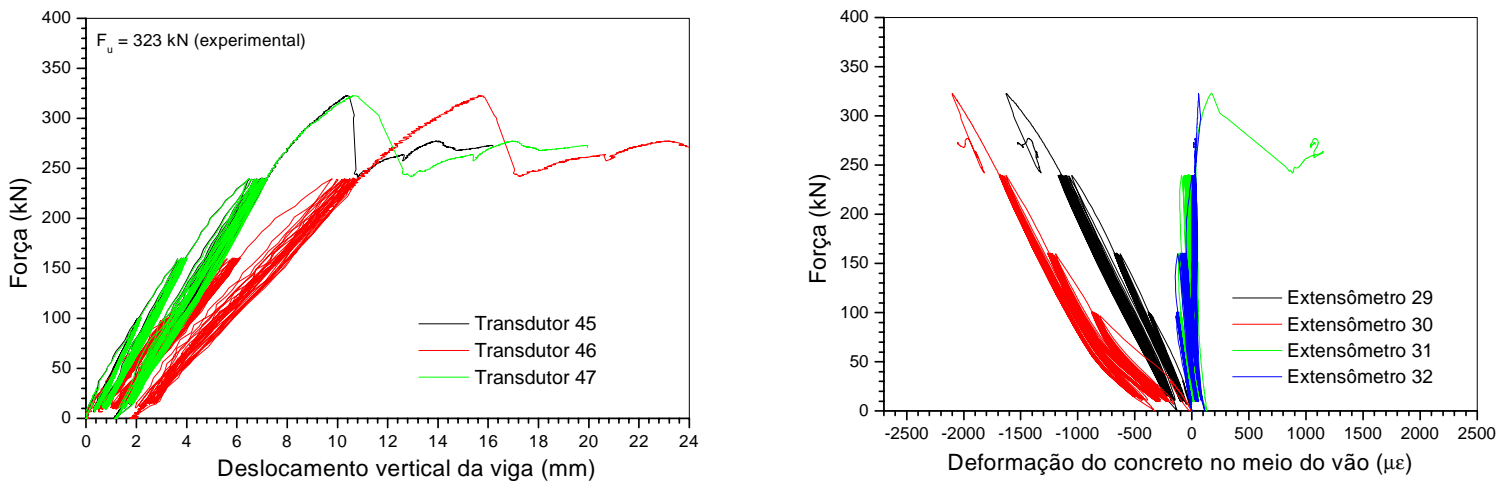

Figura D.23 - Flecha e deformação no concreto 

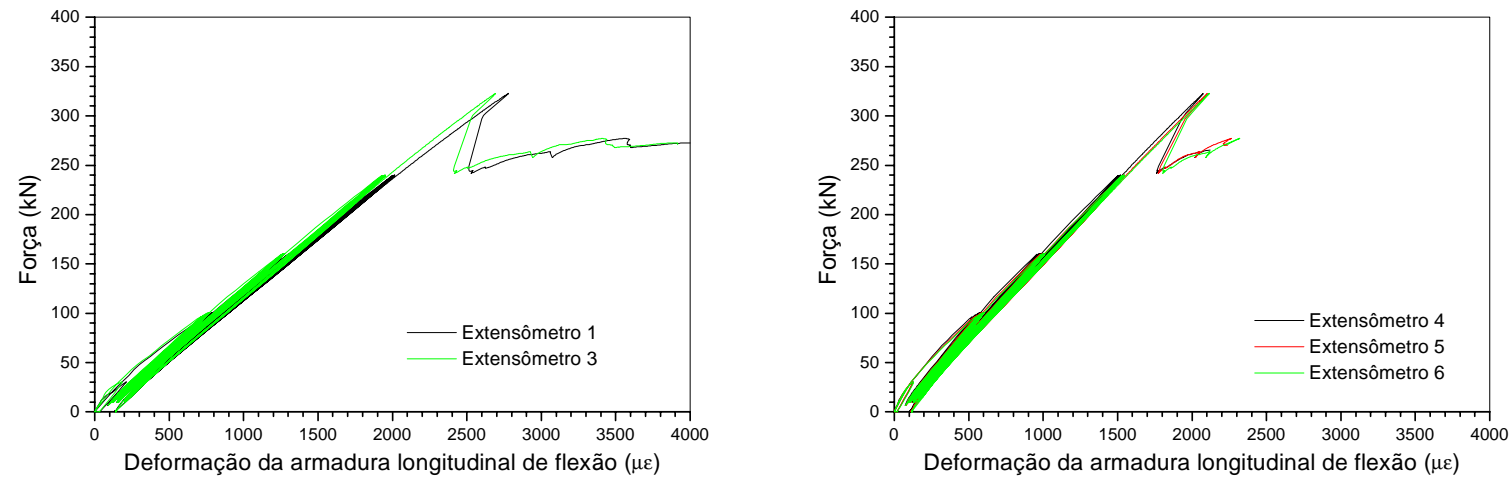

Figura D.24 - Deformação na armadura longitudinal de flexão
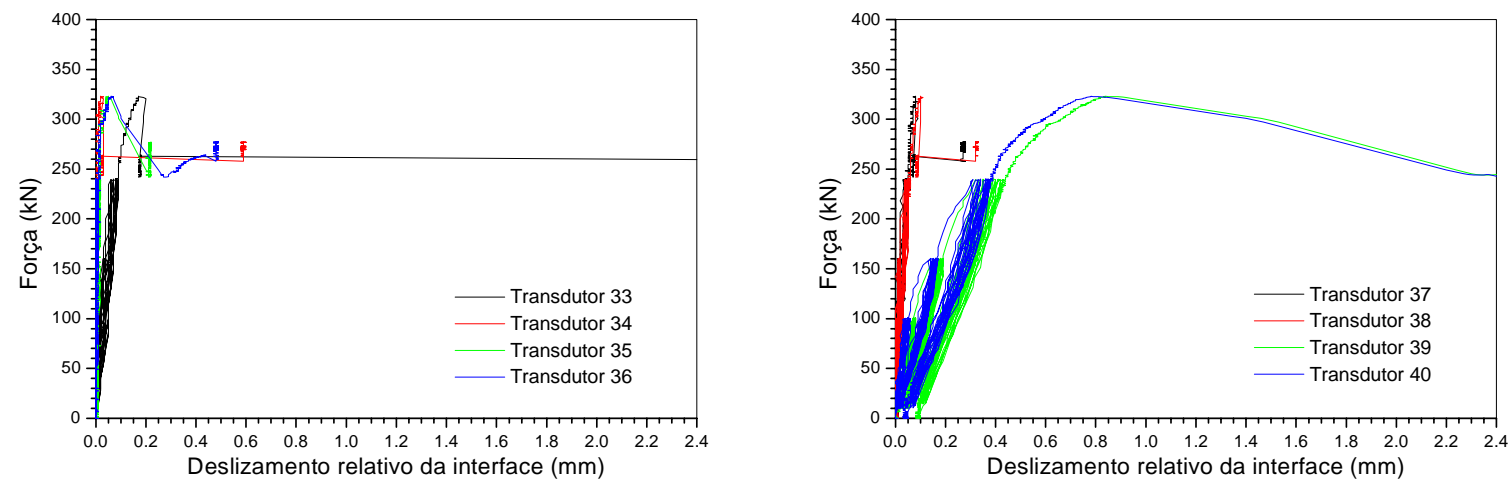

Figura D.25 - Deslizamento relativo entre a viga e a laje pré-moldadas
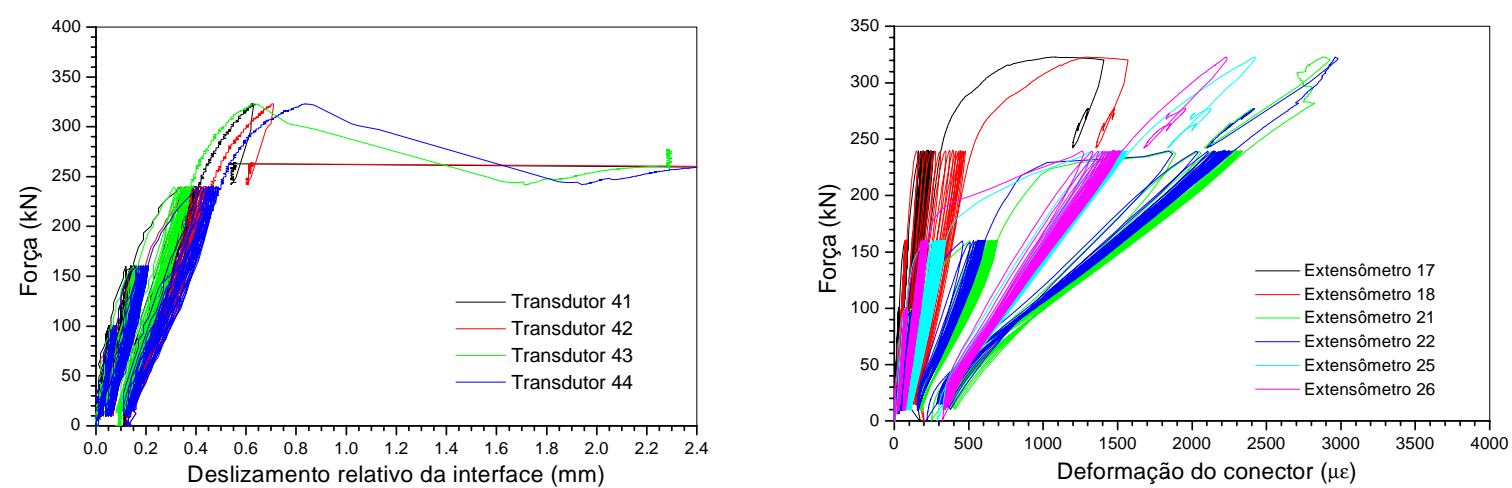

Figura D.26 - Deslizamento relativo entre a viga e a laje pré-moldadas e deformação nos conectores 

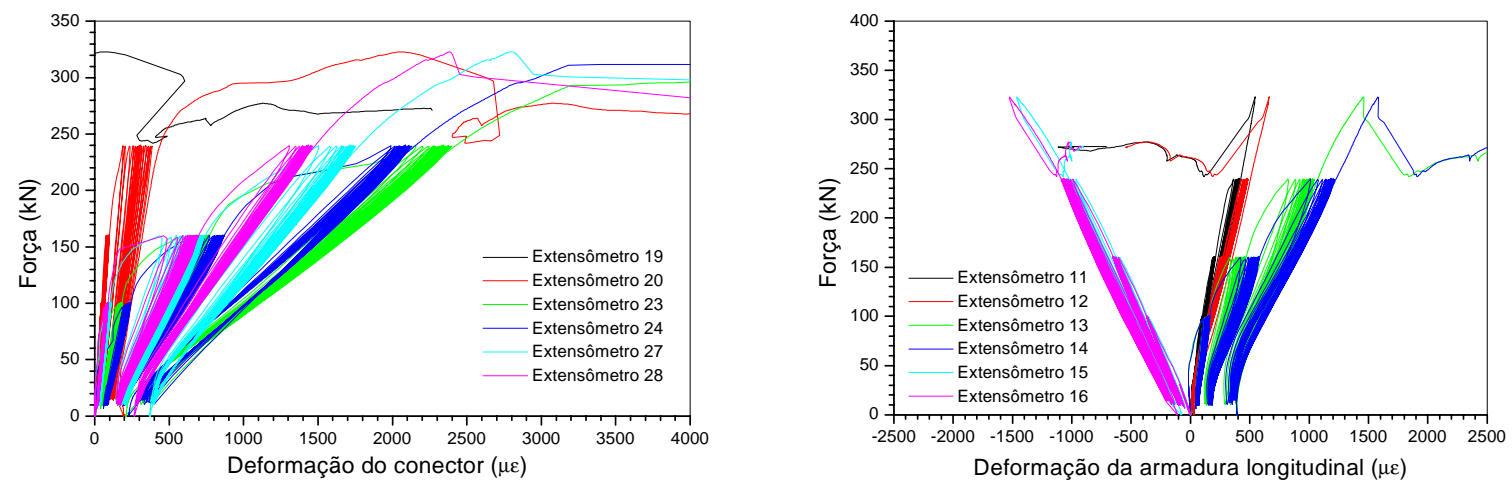

Figura D.27 - Deformação nos conectores e na armadura longitudinal

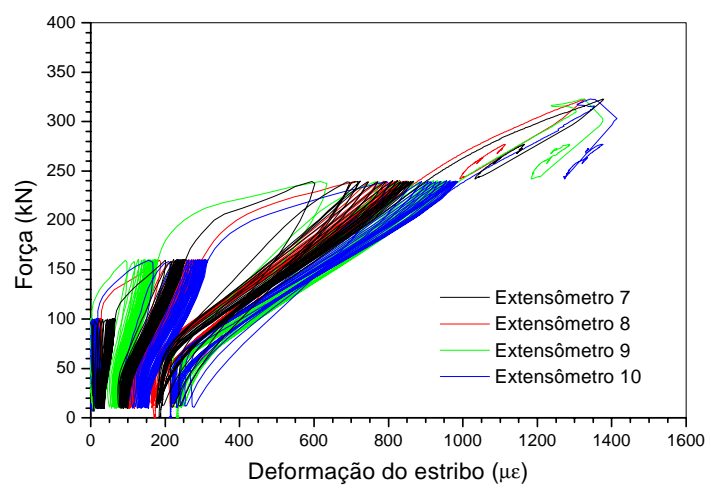

Figura D.28 - Deformação nos estribos da viga pré-moldada 